Fall 1992

\title{
1992 Miracle Yearbook
}

\section{Cedarville College}

Follow this and additional works at: https://digitalcommons.cedarville.edu/yearbooks

Part of the Higher Education Commons, Organizational Communication Commons, and the Public Relations and Advertising Commons

\section{Recommended Citation}

Cedarville College, "1992 Miracle Yearbook" (1992). Yearbooks. 9.

https://digitalcommons.cedarville.edu/yearbooks/9

This Book is brought to you for free and open access by DigitalCommons@Cedarville, a service of the Centennial Library. It has been accepted for inclusion in Yearbooks by an authorized administrator of DigitalCommons@Cedarville. For more information, please contact digitalcommons@cedarville.edu. 


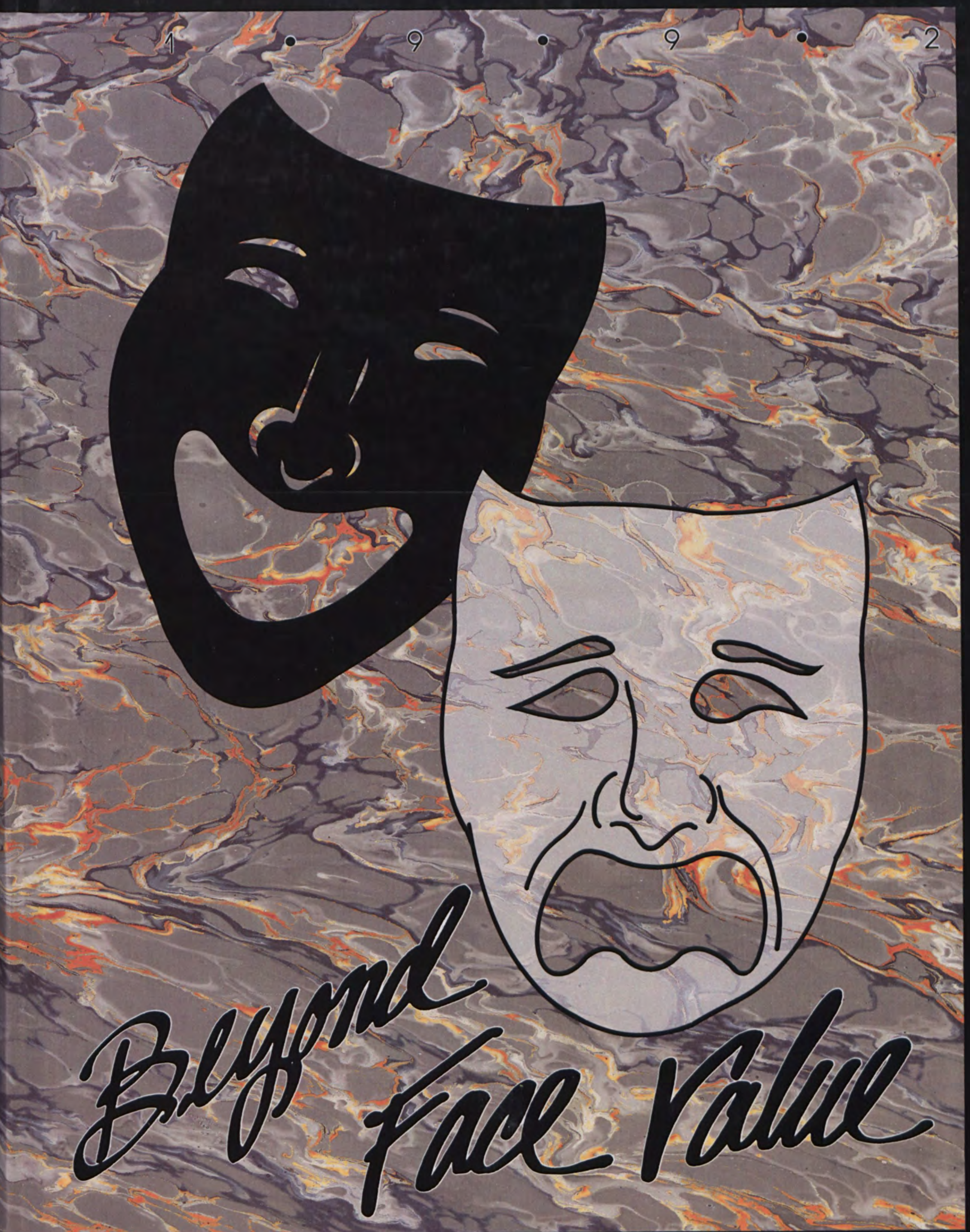




\section{Featuring:}

The Plans Behind the Progress

President Dixon's "State of the Academics . . . . . . . . 2 College" address and a closeup look at each academic department.

Burdens that Build Bridges

Personal accounts of the com-

Ministries . . . . . . . 26 munity ministries and a look at what's new in MIS.

Friendships Through the Frenzy

Student Life . . . . . . 58

The Effort Behind the Excellence

Fine Arts .........106

A Testimony Amidst Triumph

Sports ..........126

Products of His Plan

Seniors .........156

Sacrifices for Success

Organizations ......196
Spring break photos, a peek into the lives of married students and all of the old favorites.

Behind-the-scenes photos of private lessons and rehearsals.

A guest author from the crosscountry team who presents sports as a ministry.

Junior/Senior Banquet, Commencement, and some extraspecial memories.

An article on each organization demonstrating the hard work and sacrifices that have gone into each one. 


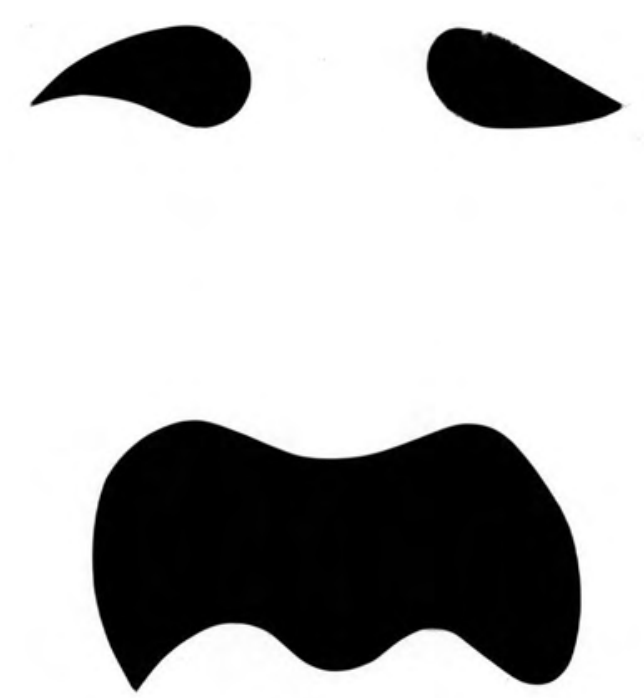
Beyond Face Value 1992 Miracle Cedarville Callege Cedaruille, Ohia Valume 39 


\section{STATE OF THE COLLEGE}

\section{Dr. Paul Dixon}

President

October 18,1991

Truly as we think of Cedarville College, the LORD be magnified, not the trustees, not the president, not the administration, the faculty, the staff, the graduates, the students, those who send in the financial support; above everything else as David said -- let the LORD be magnified.

Our theme for this academic year is "Seizing a World of Opportunity" -- that's a tremendous challenge for all of us individually and certainly institutionally.

We rejoice in the blessing of God in the academic quality of the students choosing to come and to complete their education at Cedarville. But beyond the academic quality, I am impressed with the spirit of our student body. The potential is phenomenal for God and I'm thankful, so very thankful, that they chose and that God led for them to be a part of the Cedarville College family. Students want to get an education that is based on the Word of God; if they are going to go to a Christian school, and want legitimate credentials, they want something that has some integrity behind it. They want to be able to go out and say with pride, "I was adequately prepared to serve my God and to serve the people of the world in my particular discipline."

We put the addition onto Alford last January to facilitate not only the needs of the music department but also to help drama; we've completed the track and we're told it's one of the finest tracks for any college or university in the state. To think that a school like Cedarville can have a facility like this with the latest in equipment. God has blessed us and we're so thankful for those who provide the funds that make this possible.

We are enjoying immense blessing and have tremendous accountability before our Creator... a theological responsibility and a moral responsibility. If we are going to seize our world of opportunity for Christ, we must do it according to truth -- God's truth.

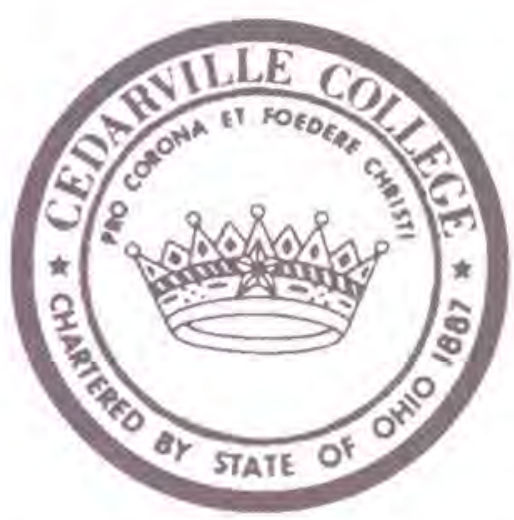




\section{Seeking God's Face \\ Day of Prayer, May 7, 1992}

Woohoo! We get out of a whole morning of classes! What? We have to get up at $8 \mathrm{am}$, miss breakfast, and sign in at three different meetings?! What is the Day of Prayer, and why does Cedarville's administration plan one every quarter?

The Day of Prayer has been a tradition at Cedarville for many years. Its purpose is to allow the college family to focus on prayer and to remindthem to be in a constant state of prayer (I Thessalonians 5:17). Dr. Dixon said our Day of Prayer also helps show support to those with special needs, especially students with unsaved parents.

Sometimes, such as last year during Desert Shield, the Day of Prayer has a special focus. Other times we focus on special needs of the college family; students and professors give testimonies about how prayer has affected their lives. It is awesome, and sometimes almost frightening, to hear about the incredible power of God and what faith in Him can accomplish.

Following is a list of ideas that can help us to maintain variety and continue focusing on prayer throughout the year.

1 . Write out prayers, especially praises.

2. Read prayers that are in the Bible.

3 . Write requests in a notebook; then when answers come, write them in also.

4. Pick a different topic to pray for each day.

5. Just praise and thank God once in a while.

6. Pray especially for people with whom you don't get along (Matthew 5:44; Luke 6:28).

7. Pray out loud.

8. Write down one praise and one request each day.

-Jim Foster
Pastor Green leads the student body in prayer on the Day of Prayer.

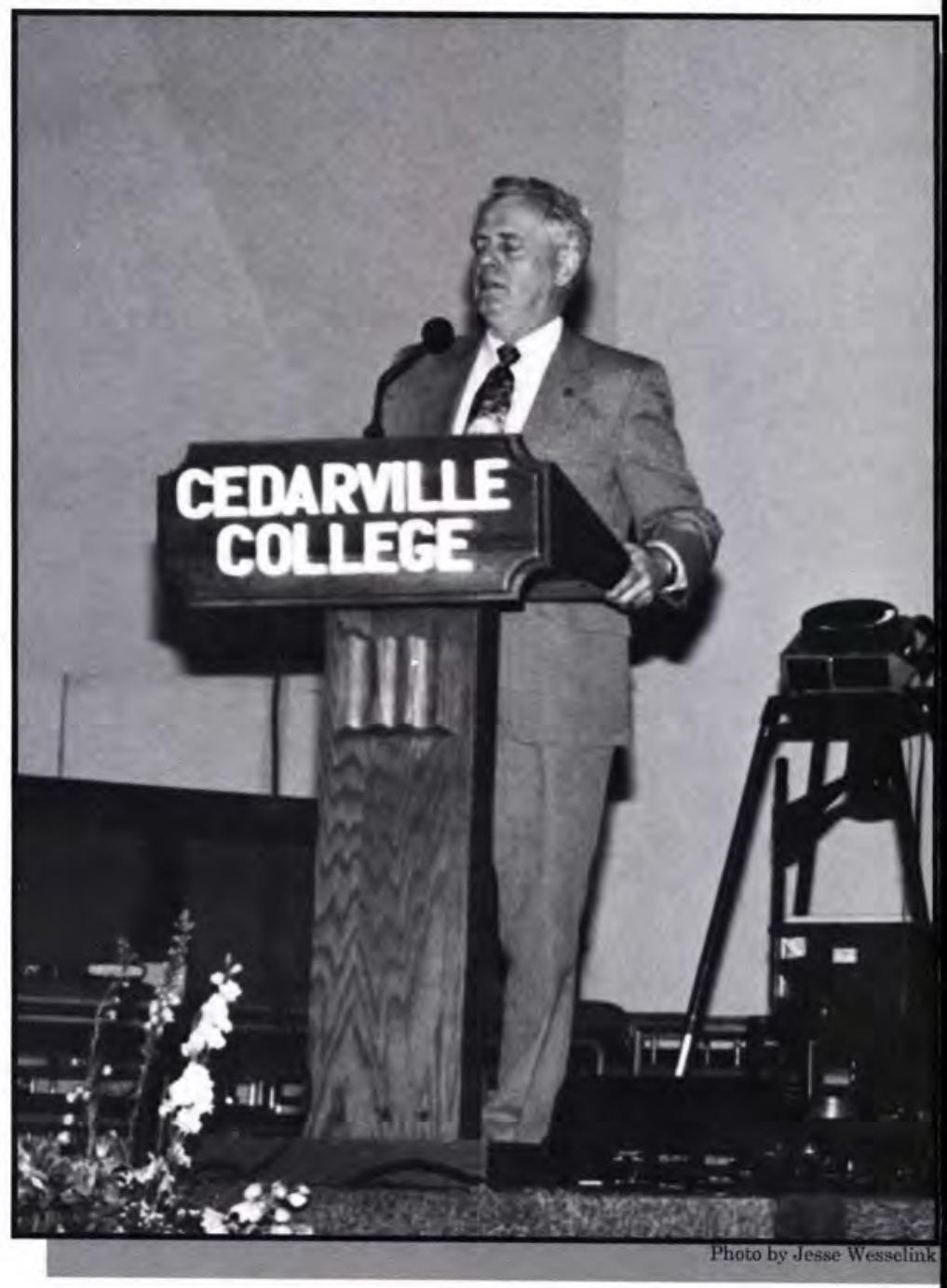

The Day of Prayer is honored by all as these students prepare to pray for our nation.

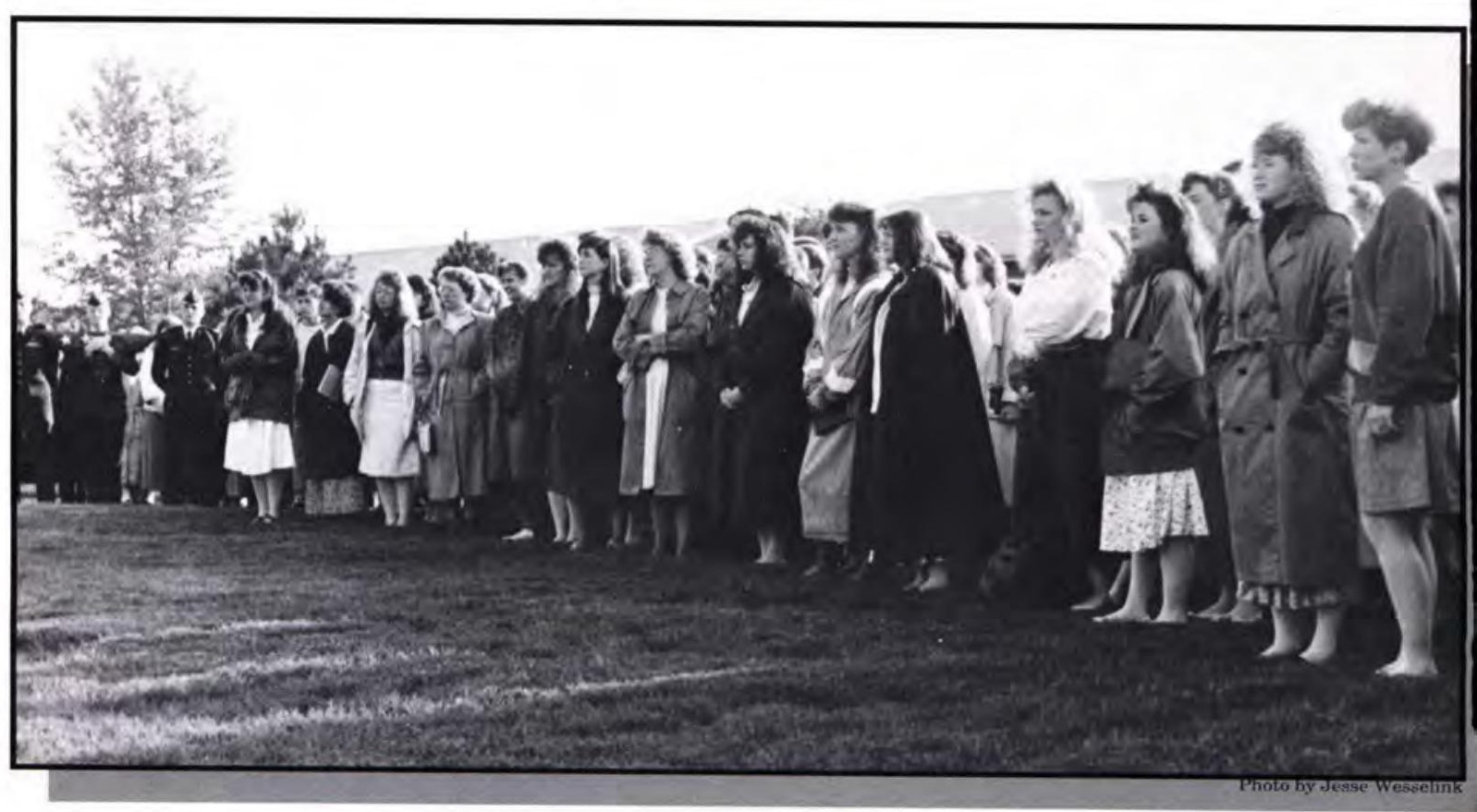




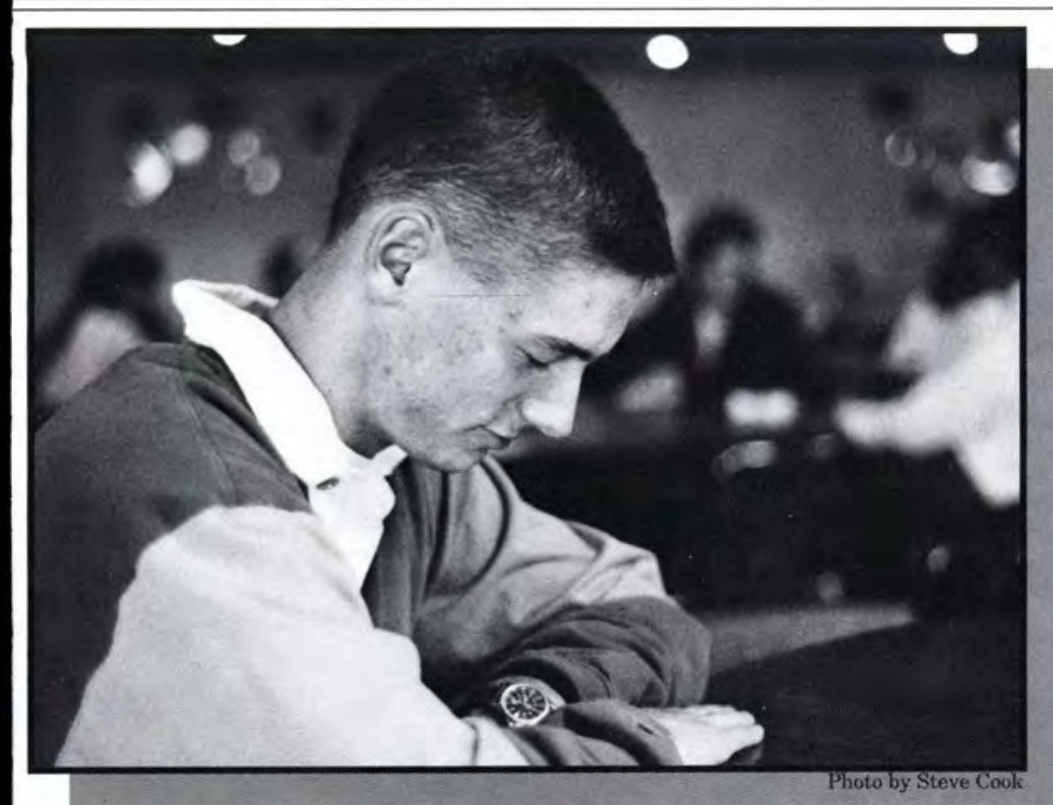

Devon Berry takes time out for prayer.

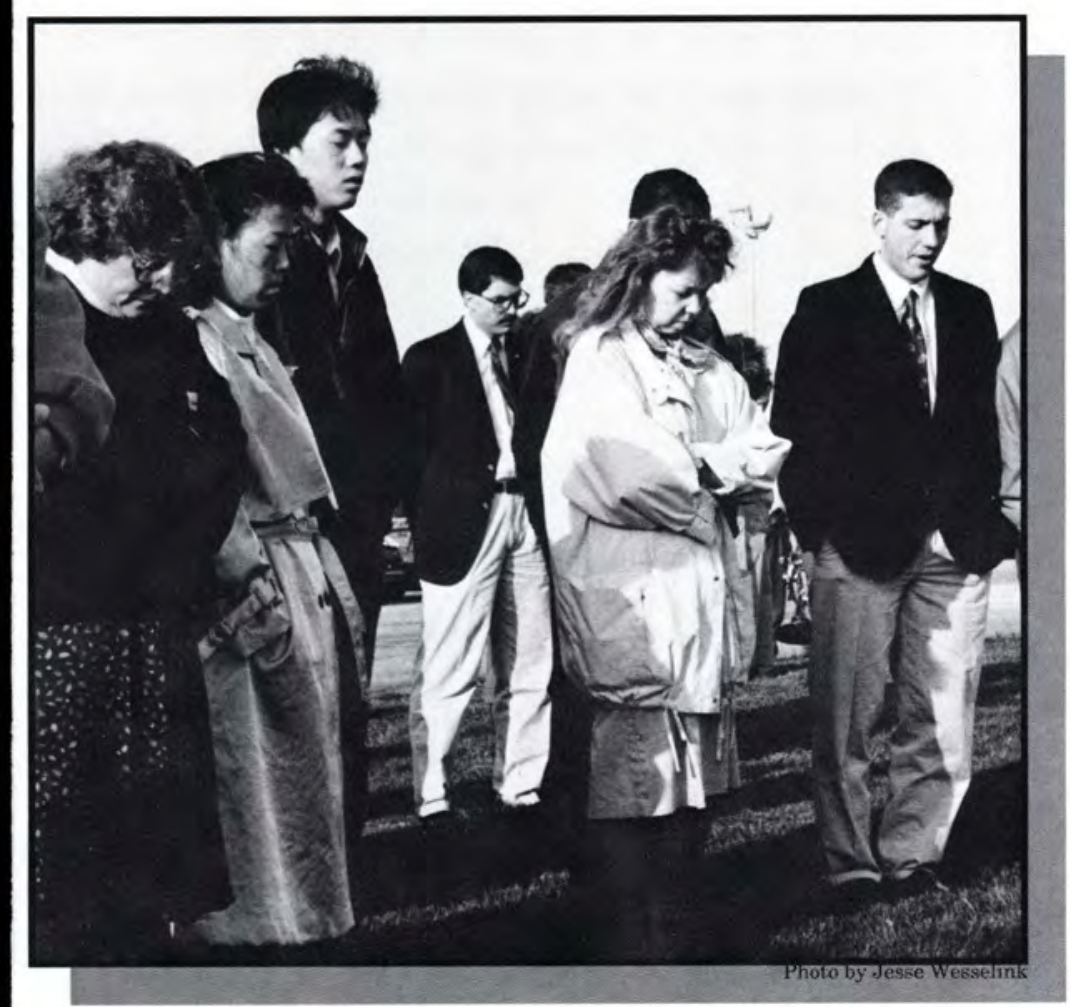

Students gather at the flagpole for a prayer of dedication.

During the Day of Prayer, Dr. Durham focuses the attention on missions.
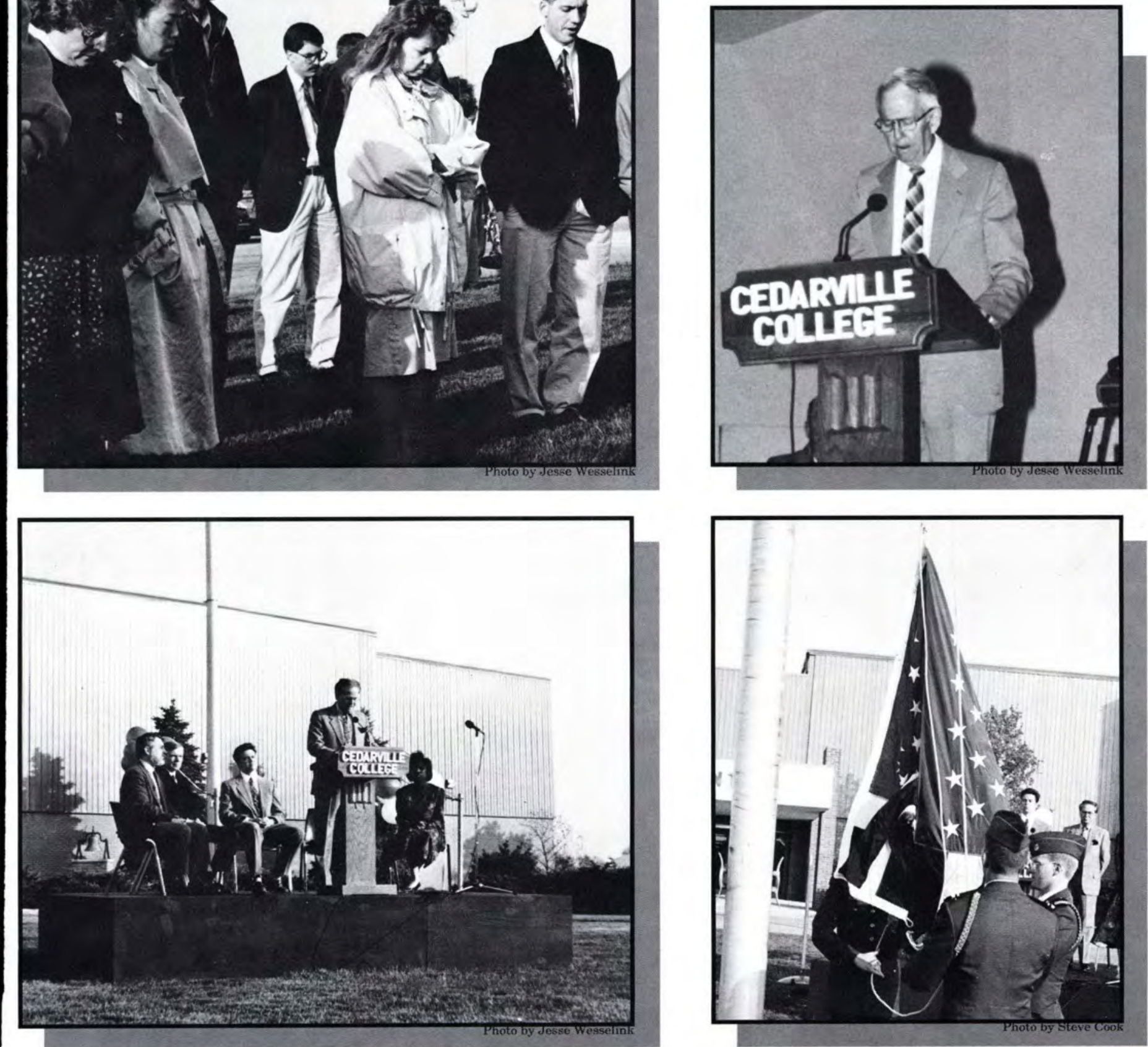

Jeading in prayer, Dr. Dixon focuses on the state of our country.

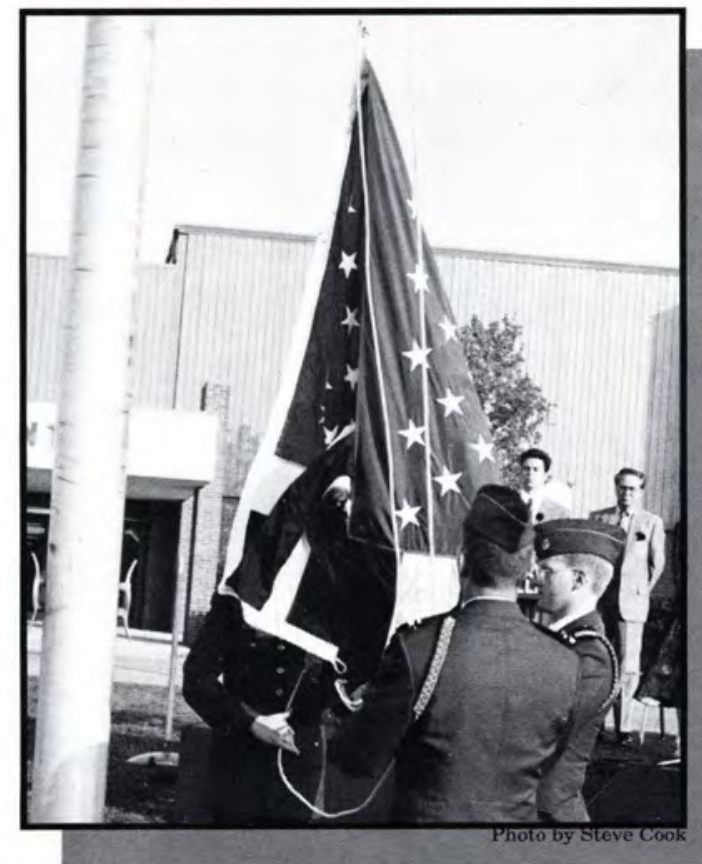

A ceremonial flag raising is performed by the Cedarville ROTC members. 


\section{Faces of Excellence Who's Who}

Out of nearly two thousand students at Cedarville College, forty-nine were inducted this year into the national Who's Who Among American Colleges and Universities. Requirements for induction include excellent academic performance, demonstration of leadership ability, and involvement in extra-curricular activities. Each year these students minister to the rest of the student body in a special spring quarter chapel service.
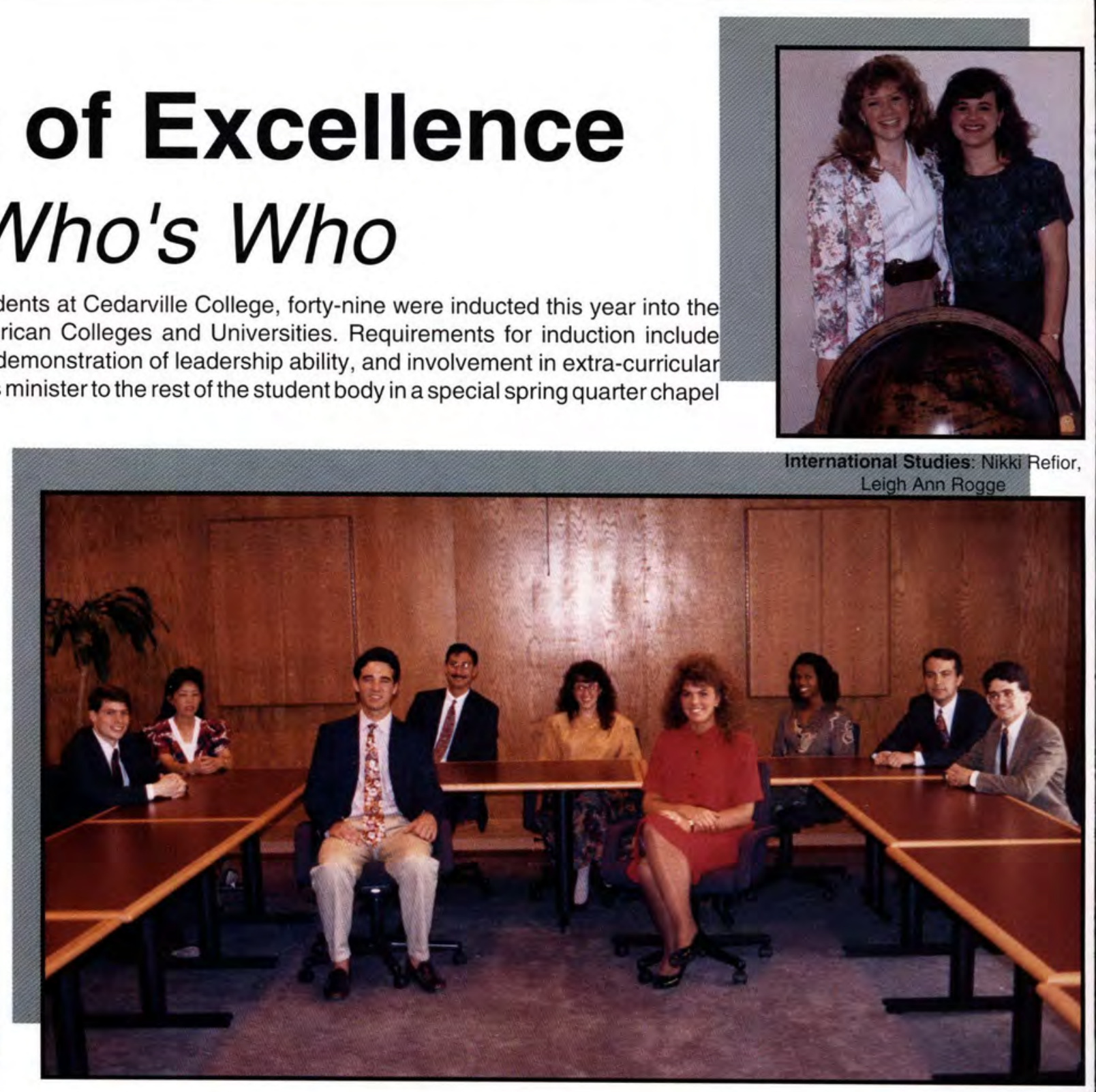

Psychology: Becky Taylor, Michael Ortlieb (not pictured)

Business Administration: John Neill, Joan Zhuang, Andrew Kesier, Stefan Tarapchak, Laurel Born, Diane Rank, Kelly Scott, Mark Miller, Brian Guinther
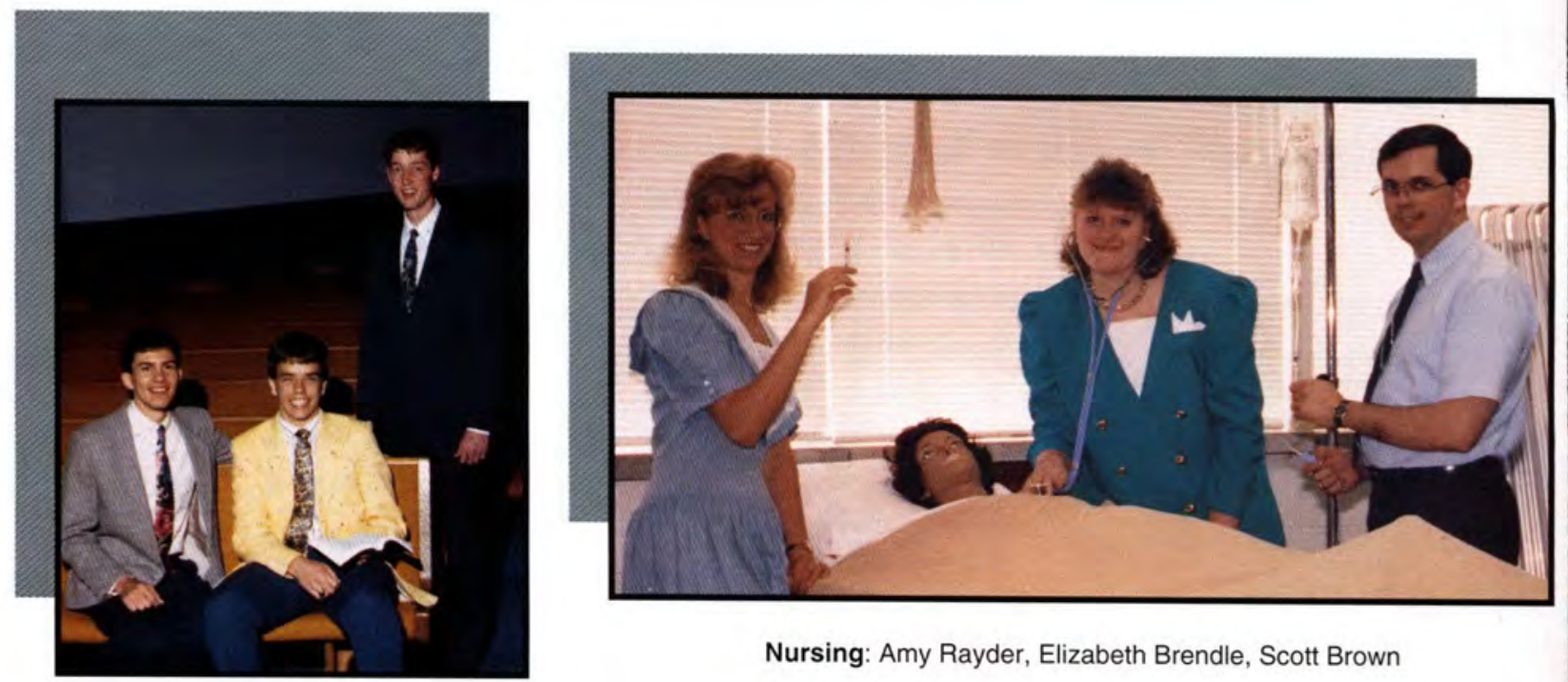

Nursing: Amy Rayder, Elizabeth Brendle, Scott Brown

Bible: Brian Phipps, Benjamin Brown, Andrew Rhind 


\section{Preparing For}

\section{Tomorrow}

\section{Computer Network Plan Announced For 1992-93}

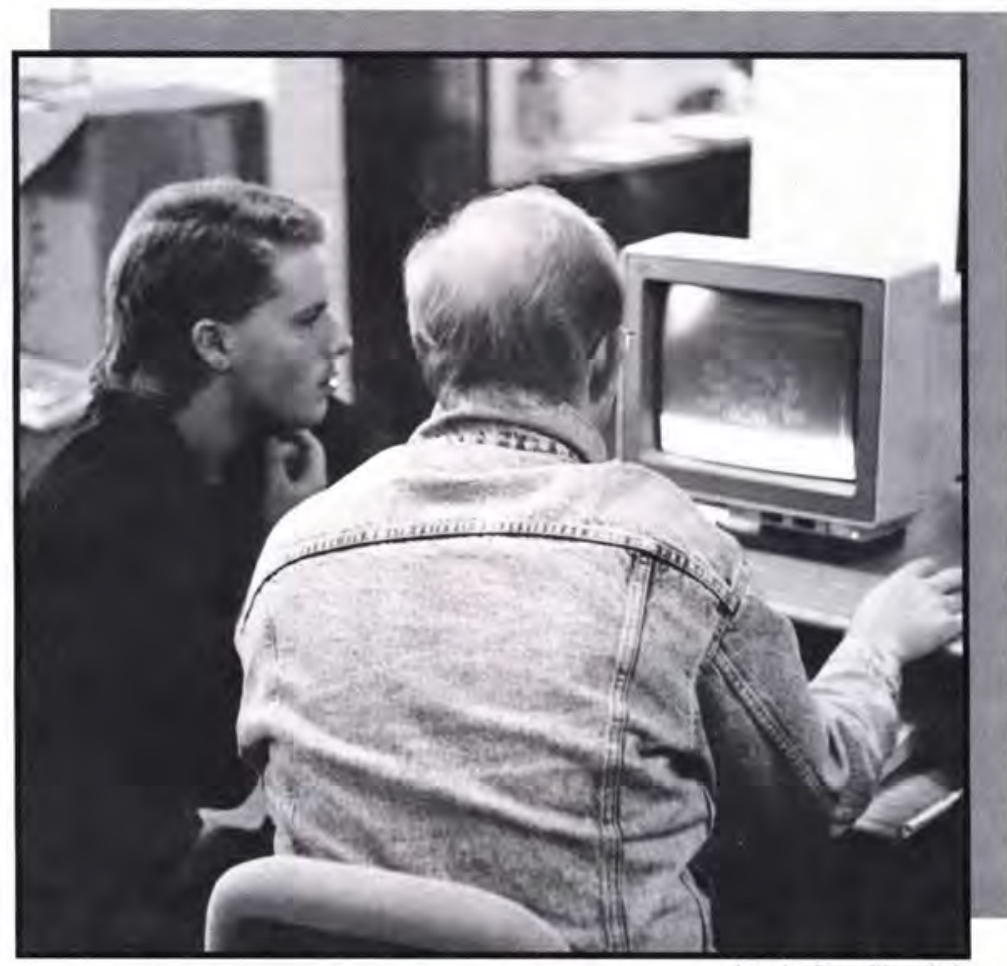

photo by Jesse Wesselink Exploring the future of Cedarville College, Scott Baker and Jeff Zwart experiment with the new system.

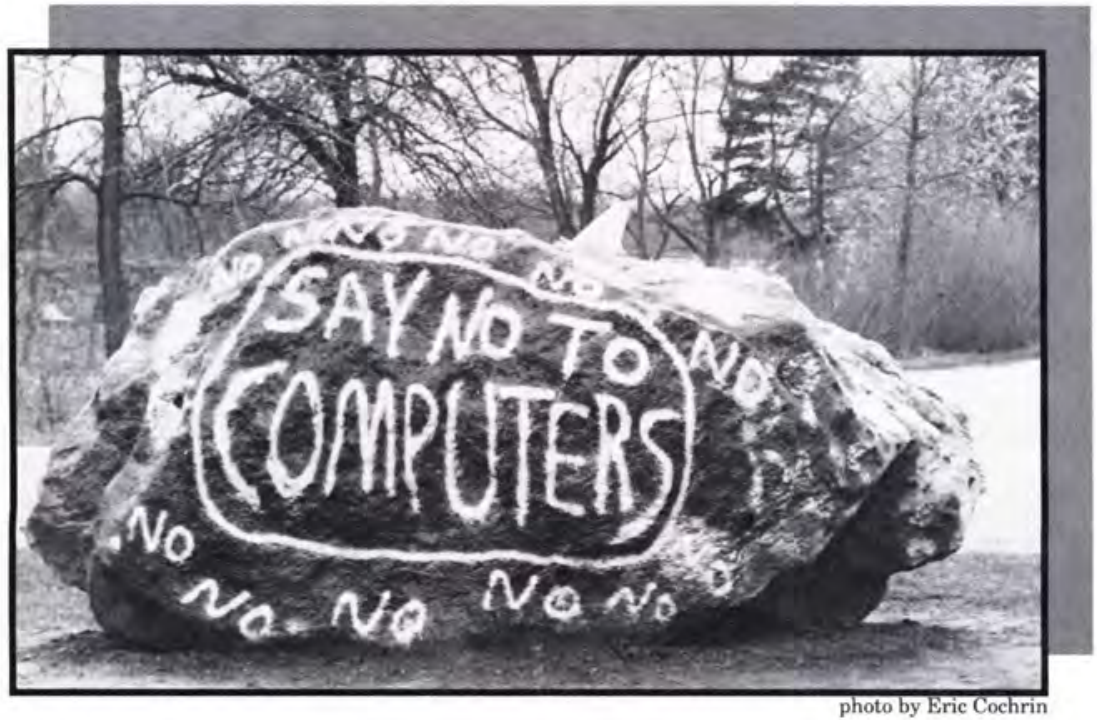

$\sqrt[4]{8}$ Academics
Cedarville College and IBM announced this year their new status as Network Showcase Partners. Cedarville will place IBM PS/ 2 's in nearly every dorm room, giving students access to a network which will link the entire campus. IBM will help make the network possible with significant donations of equipment. An independent Christian college with 2,000 students, Cedarville has: over 1,600 students in residence halls on its southwestern Ohio campus.

Phase 1 of the network to be in plat has fall, will connect 300 student rooms with the computer center, classrooms, the colleges library, faculty and staff offiees, and other student rooms. Every network compute hili have access to advanced word processing, spreadsheet database, graphics, and research software. The network will use IBM's LANkit technology, and the computer company plans to bring fisitors from industry and higher education to the Ohio campus. $=2$ The Campus-wide Networking Showcase will show how IBM's networking technology ean enable and enhance Local Area Network administration and management.

Dr. Paul Dixon, President of Cedarville College, says, "This network will provide new ways for us to meet our educational mission and objectives in a world which increasingly

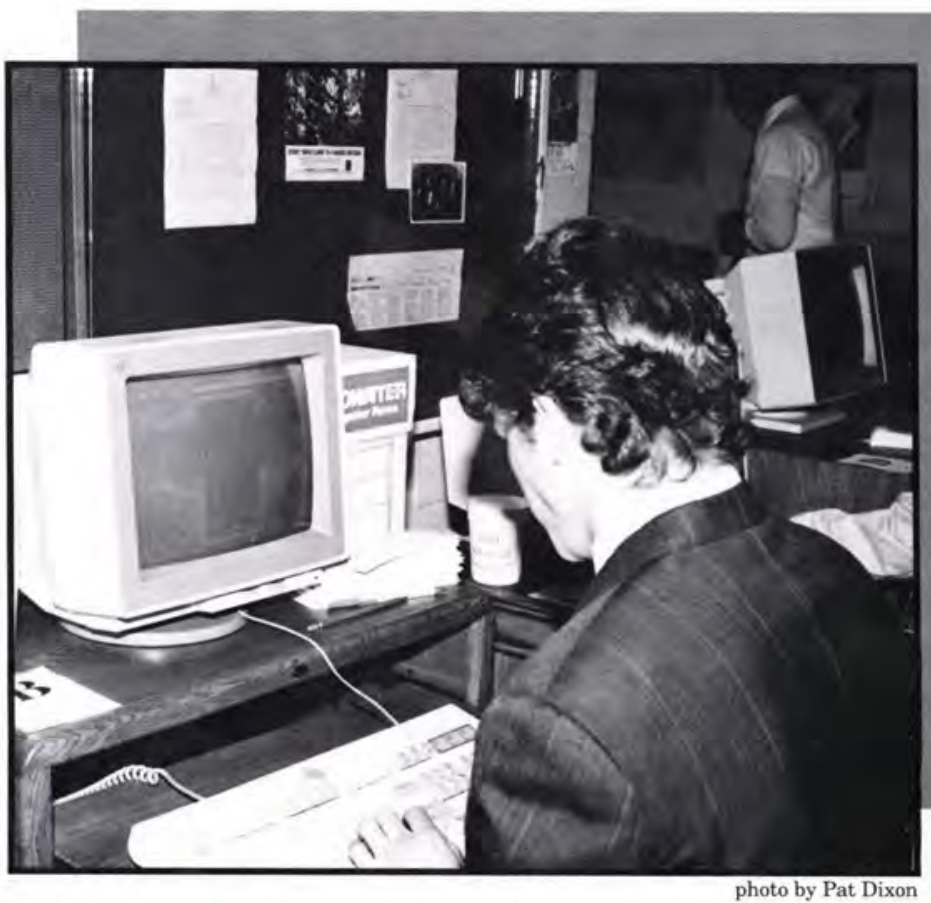

Personal computing takes place in the C.C. lobby as Will Orser takes advantage of I.B.M.'s display. 
requires computer literacy. Few colleges are providing this amount of hands-on experience, so Cedarville graduates will have an advantage as they go into future work and ministry."

Over the next few years, IBM PS/2 computers, color monitors, and dot matrix printers will be installed in the rest of the dorm =rooms on campus. Until then, students from those dormitories and off-campus students will have access to the network through several computer labs. Laser printers will also be available in those labs.

Some faculty will begin training to use the network for instructional purposes this summer.

Dr Duane-Wood, Cedarville's academic vicepresident, says,WThe campus-wide network will enhance the elose faculty-student interaction characteristie of a Cedarvilie education. Faculty will be able to give assighmentsand present basic information on the - computer network so they can spend more elass time on analysis and evaluation. Students will also have a more immediate means to communicate with professors via 24-hour electronic mail. The network will dramatically improve the teaching-learning process at Cedarville."

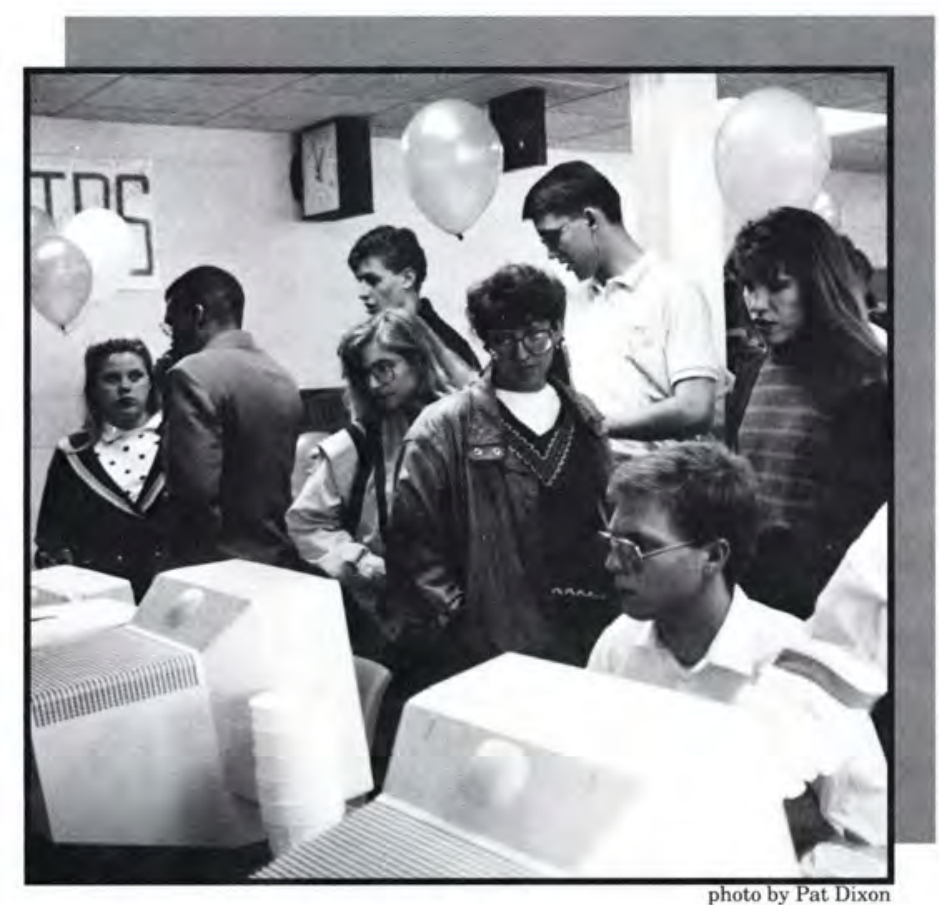

The Computer Network is the point of interest as students examine both hardware and software.

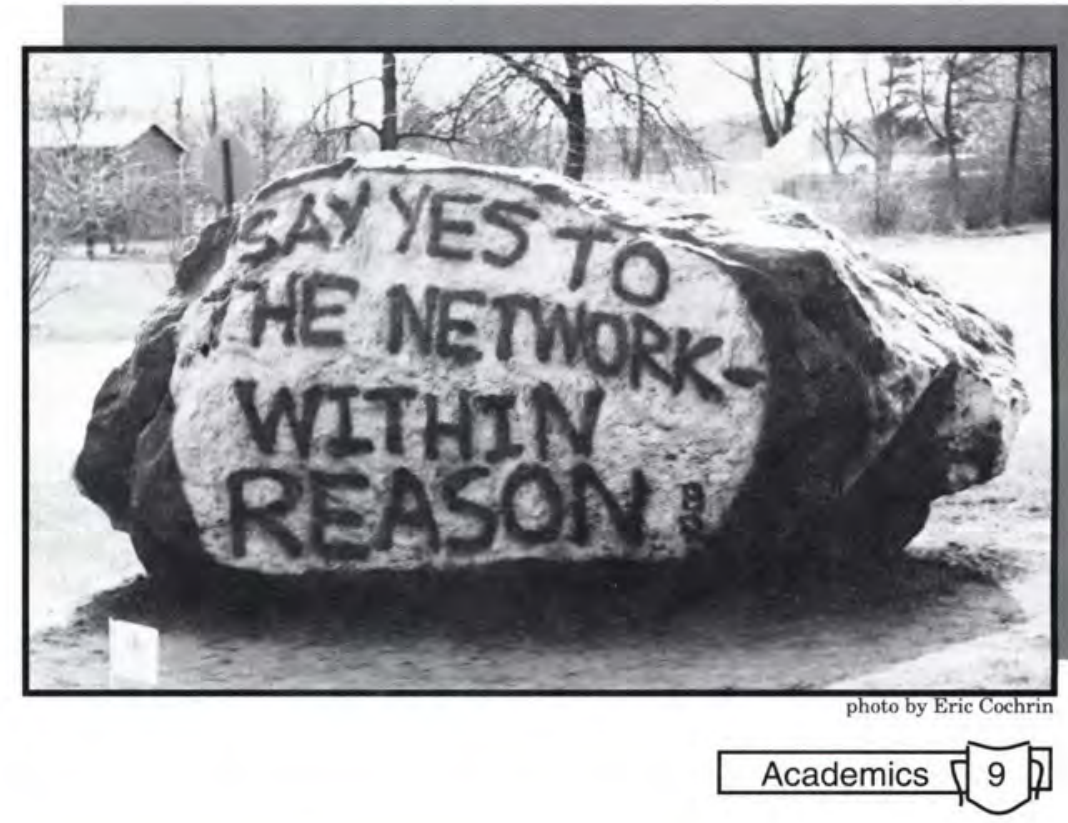




\section{Giving Honor Where It's Due}

\section{Honors Day 1992}

While there are many aspects to any one student's life at Cedarville, all students are involved in academics. Honors Day, held this year on May 1, 1992 , is the day when those who have made significant academic achievements are honored for their diligent study. Honors Day is also a day for the student body to thank one special staff and faculty member by presenting the Faculty and Staff Member of the Year awards. This year's Faculty Member of the Year was Dr. Pamela Diehl. And Mrs. Susan Faulkner was named Staff Member of the Year.

Dr. Bartholomew chairmen of the Language and Literature Department, presents Cinnamon Brown with the Edith Hart Milner Award.

A gracious acceptance shows on the face of Heather Fulton as she accepts her Alumni

Scholarship Award in Physical Education from Dr. Diehl.

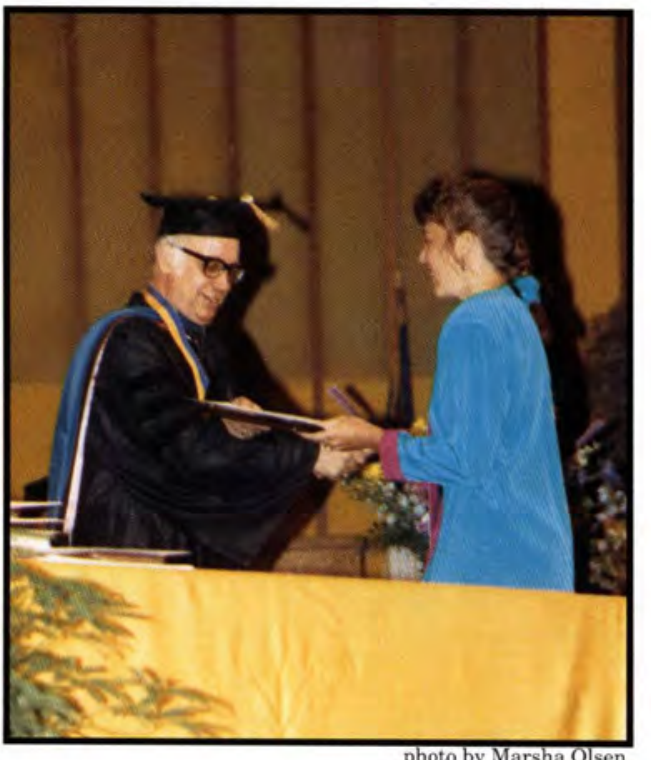

Chairman of the Social Sciences and History Department, Dr. Murdoch presents Bruce Mc Kanna with the Alumni Scholarship Award in Social Sciences and History.

\section{Dr. James Phipps,} chairman of the Communication Arts Department, presents Matthew Moore with the Rietveld Fine Arts Award.

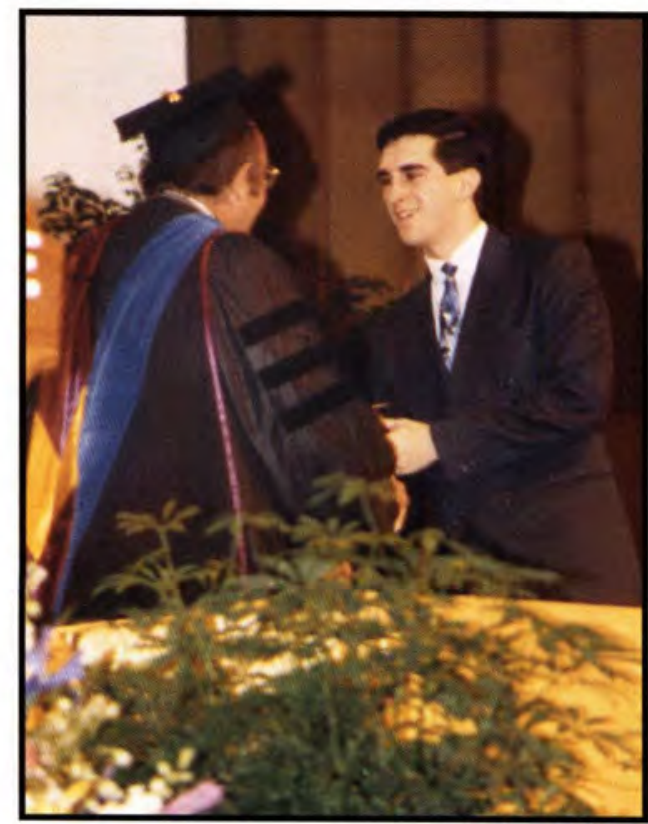

photo by Marsha Olsen
Dr. Dixon addresses the audience at the Honors Day ceremony.
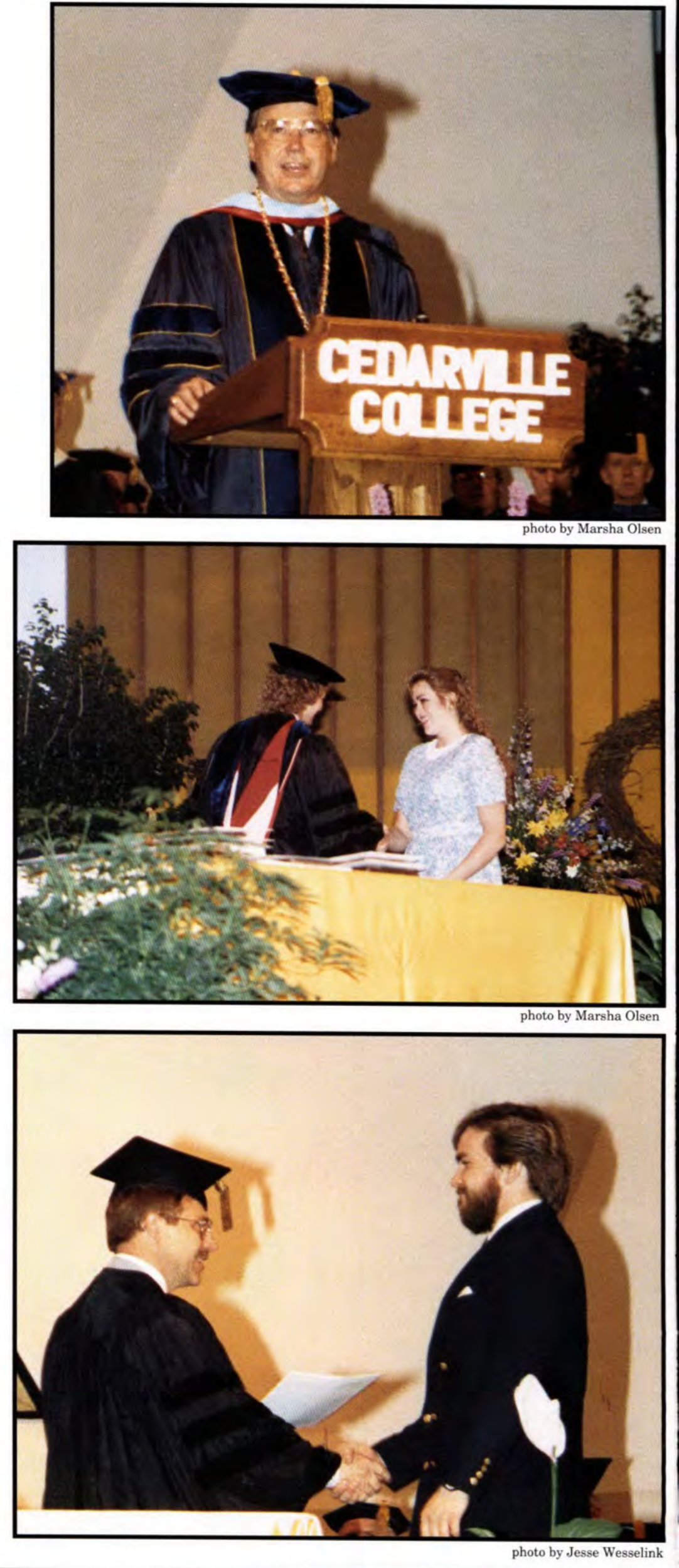
Dr. Gromacki, Chairman of the Department of Biblical Education, presents Brian Phipps with the Arthur Franklin Williams Award.

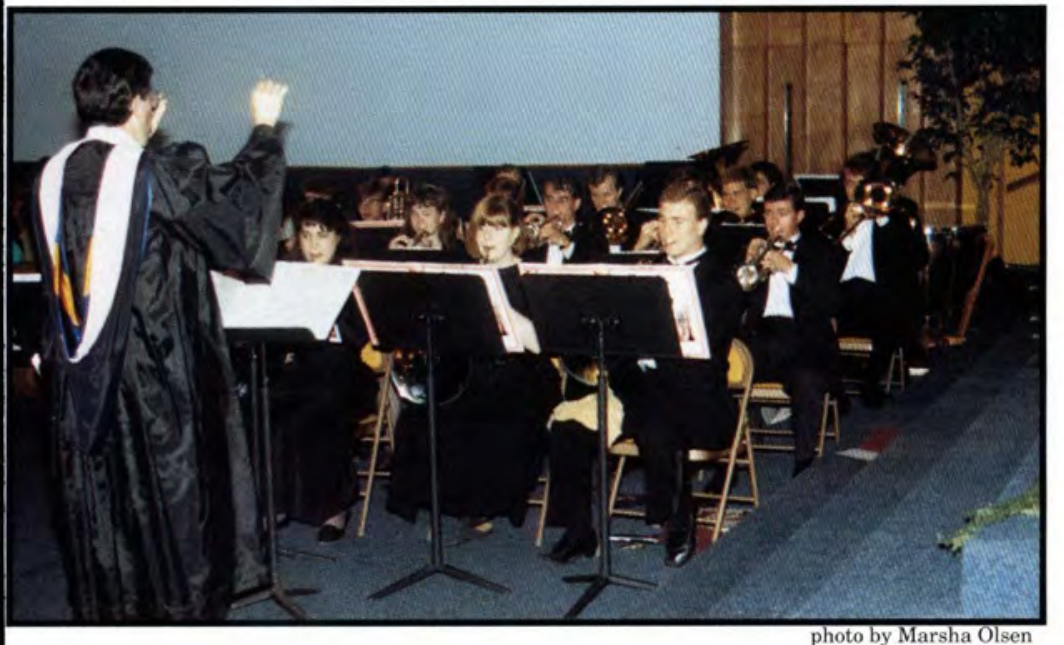

Angela Mouser, President of the Student Academic Advisory

Board, presents Dr. Pam Diehl with the Faculty Member of the

Year Award.
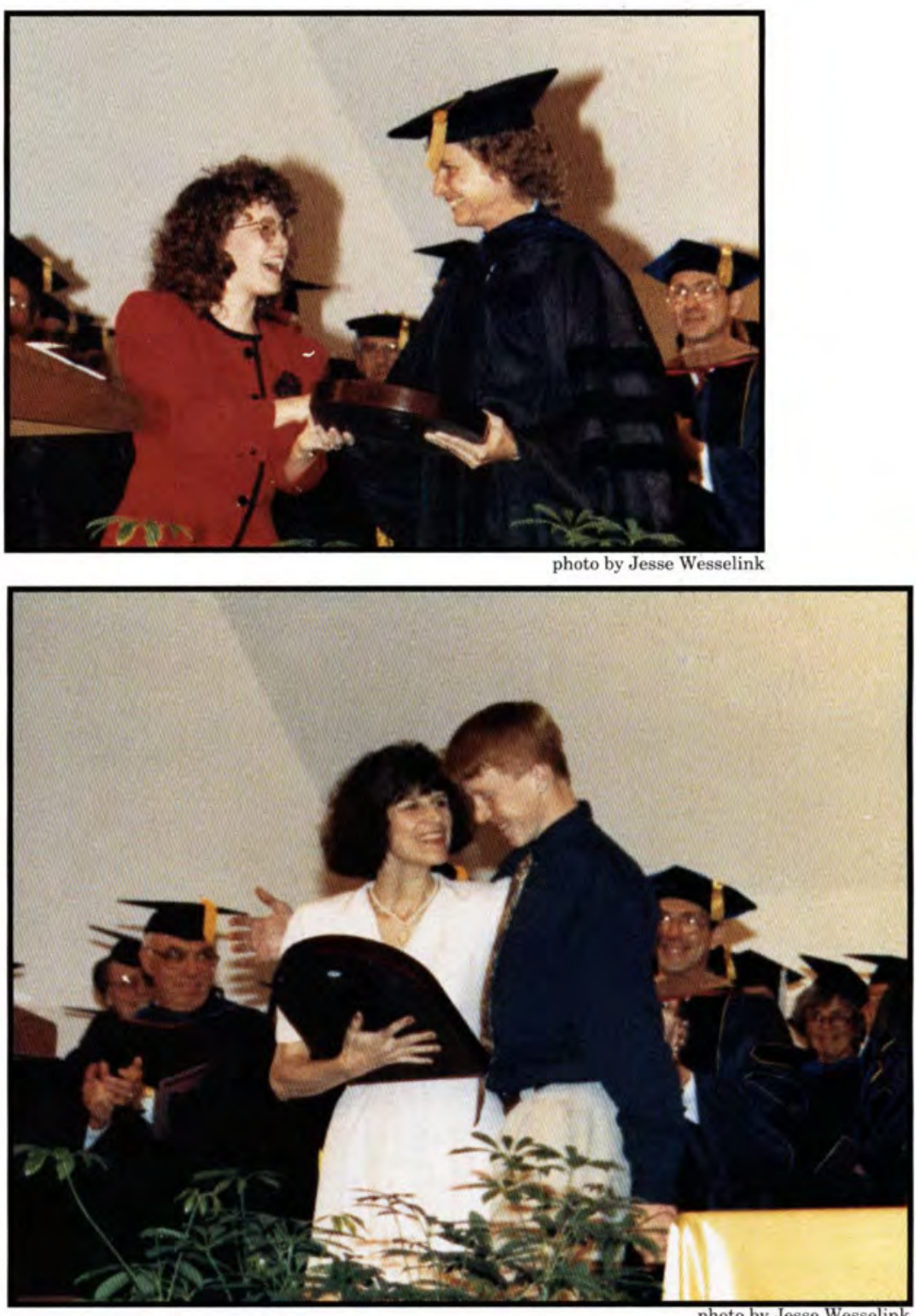

photo by Marsha Olsen

Mrs. Susan Faulkner, Secretary to fargis

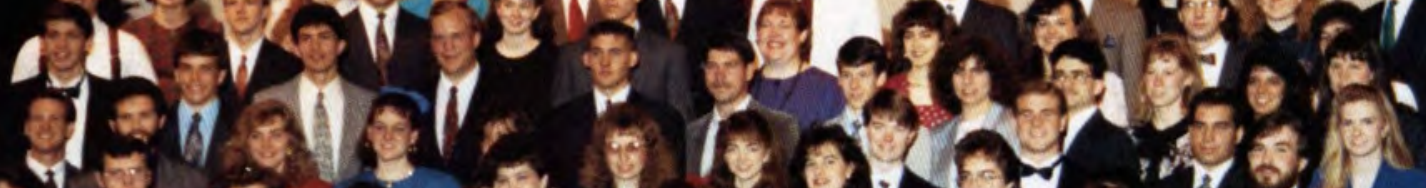

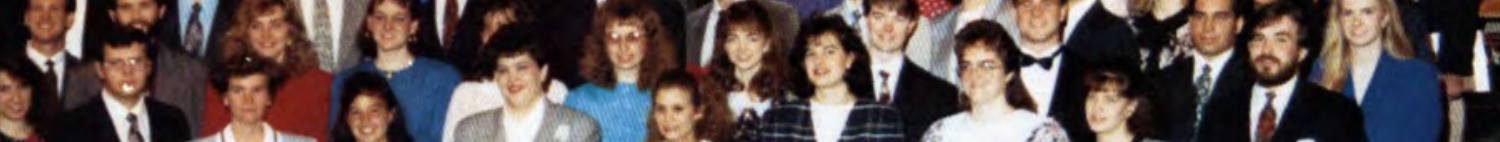
(2)

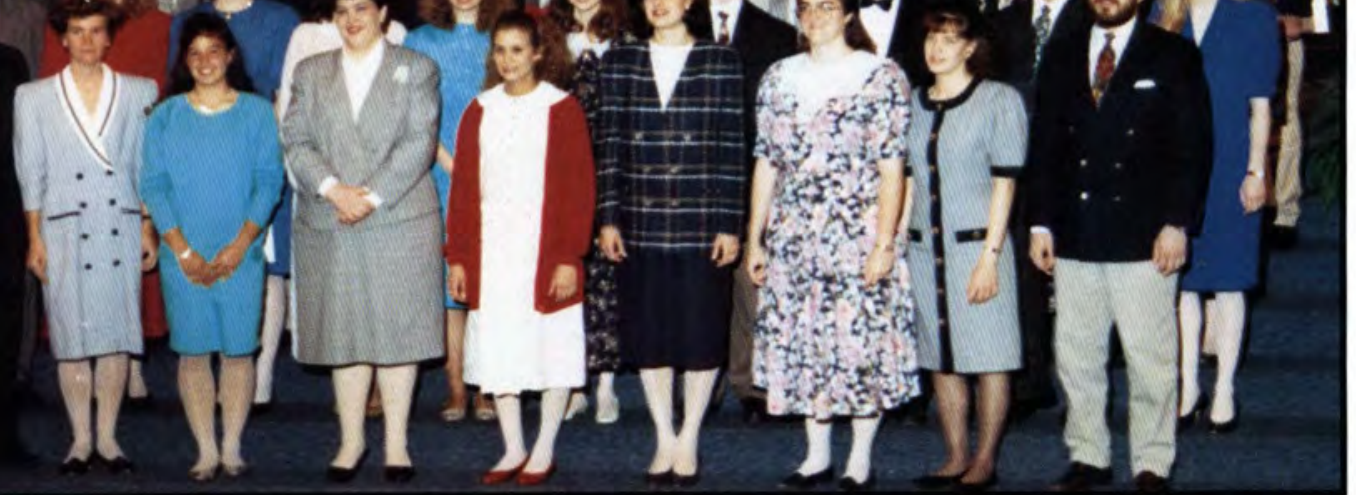

the Academic Vice President, was presented with the Staff Member of the Year Award by her son, Reid Faulkner.

The Honors Day Award recipients. 


\section{Biblical Education}

The faculty are a vital part of Cedarville College. This year the Bible Department has been blessed with two new faculty members, Dr. Cheryl Fawcett and Mr. Chris Miller.

Dr. Fawcett received her B.R.E. from Baptist Bible College, Clarks Summit, Pennsylvania; M.A. from Wheaton College, Wheaton, Illinois; and Ed.D. from Trinity Evangelical Divinity School.

Mr. Miller graduated from Word of Life Bible Institute, received a B.A. from Tennessee Temple, a Th.M. from Grace Theological Seminary, and is currently working on his Doctorate of Theology degree from Dallas Theological Seminary.

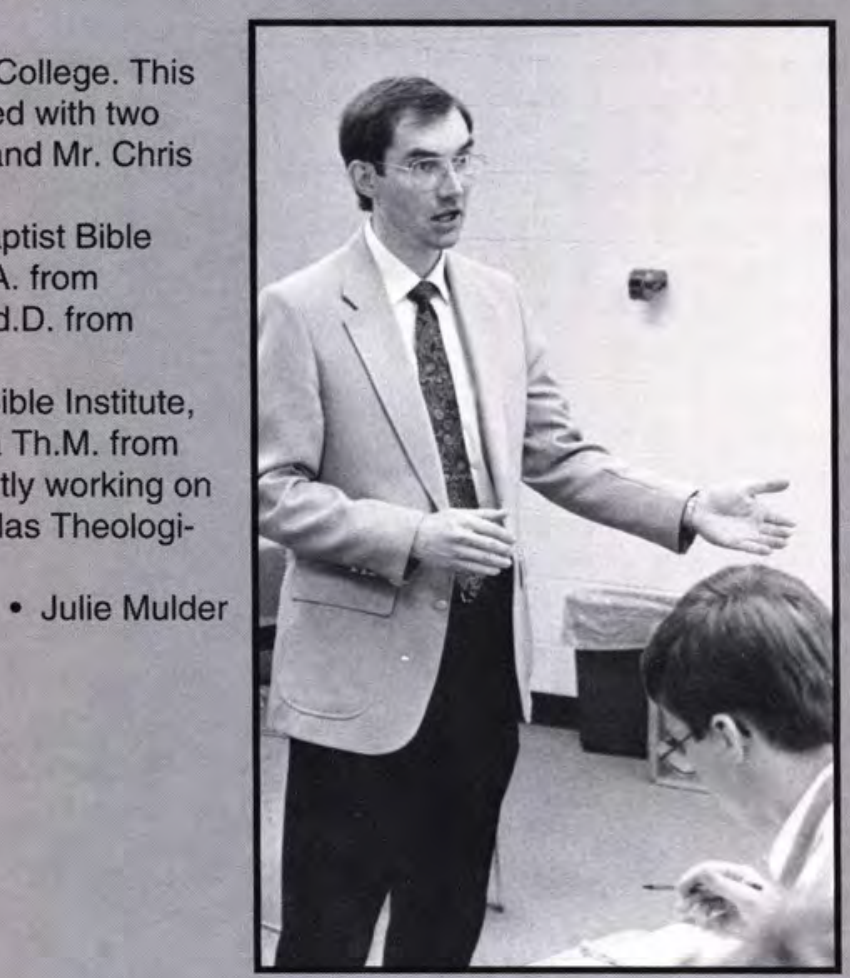

New faculty member Mr. Chris Miller.

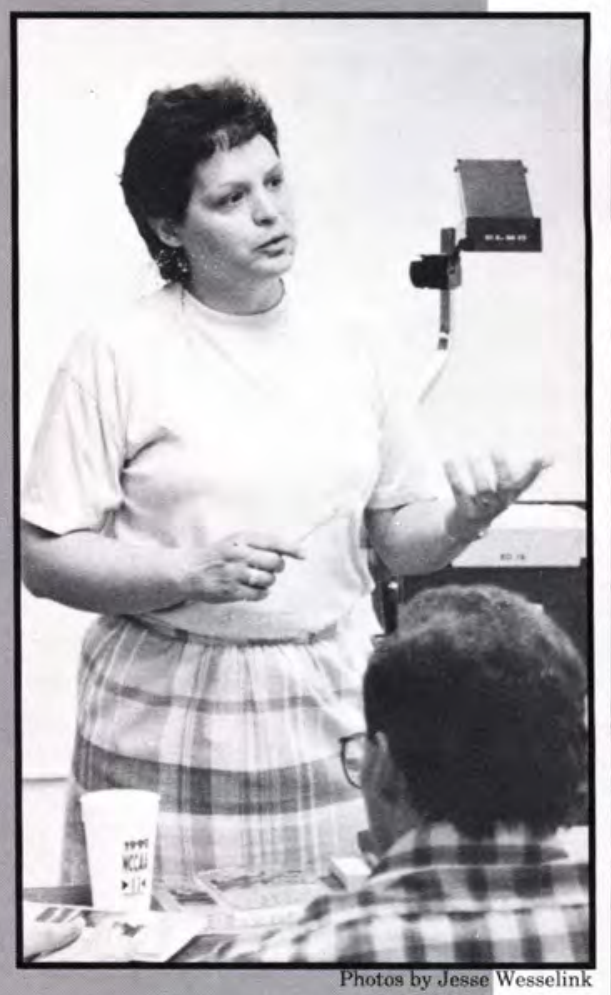

New faculty member Cheryl Fawcett.

\section{Business Administration}

As the business communities of the world become independent and free, new and exciting opportunities emerge for the message of reconciliation which God has given. "Seizing a World of Opportunity" has been chosen as the Cedarville College theme for the 1991-1992 academic year. God has opened many doors of ministry in eastern Europe and the USSR; Dr. Richard Baldwin, Associate Professor of Management, was an invited lecturer at the Foreign Language Institute in Gorky, Russia.

Through a Russian translator, Dr. Baldwin addressed 25-30 production managers on basic business practices in the U.S.A., international business, and Japanese management principles. He became part of the global focus which the Business Department has adopted this year.

Through Dr. Baldwin and other faculty, the Business Department hopes to seize each of the opportunities in which God would have them involved for the sake of the gospel.

\section{-Meredith Clements}

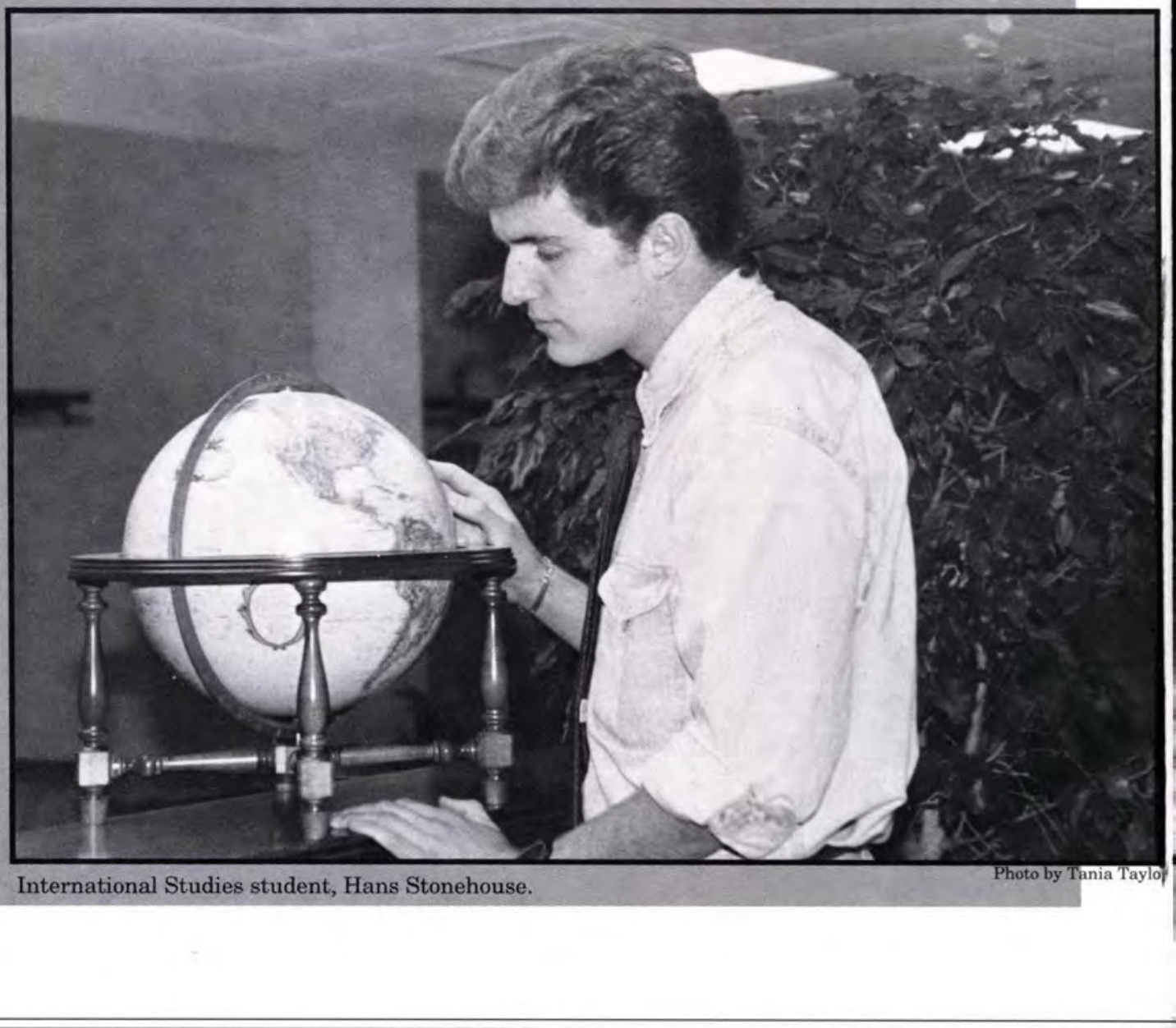




\section{Cedarville College Administration}

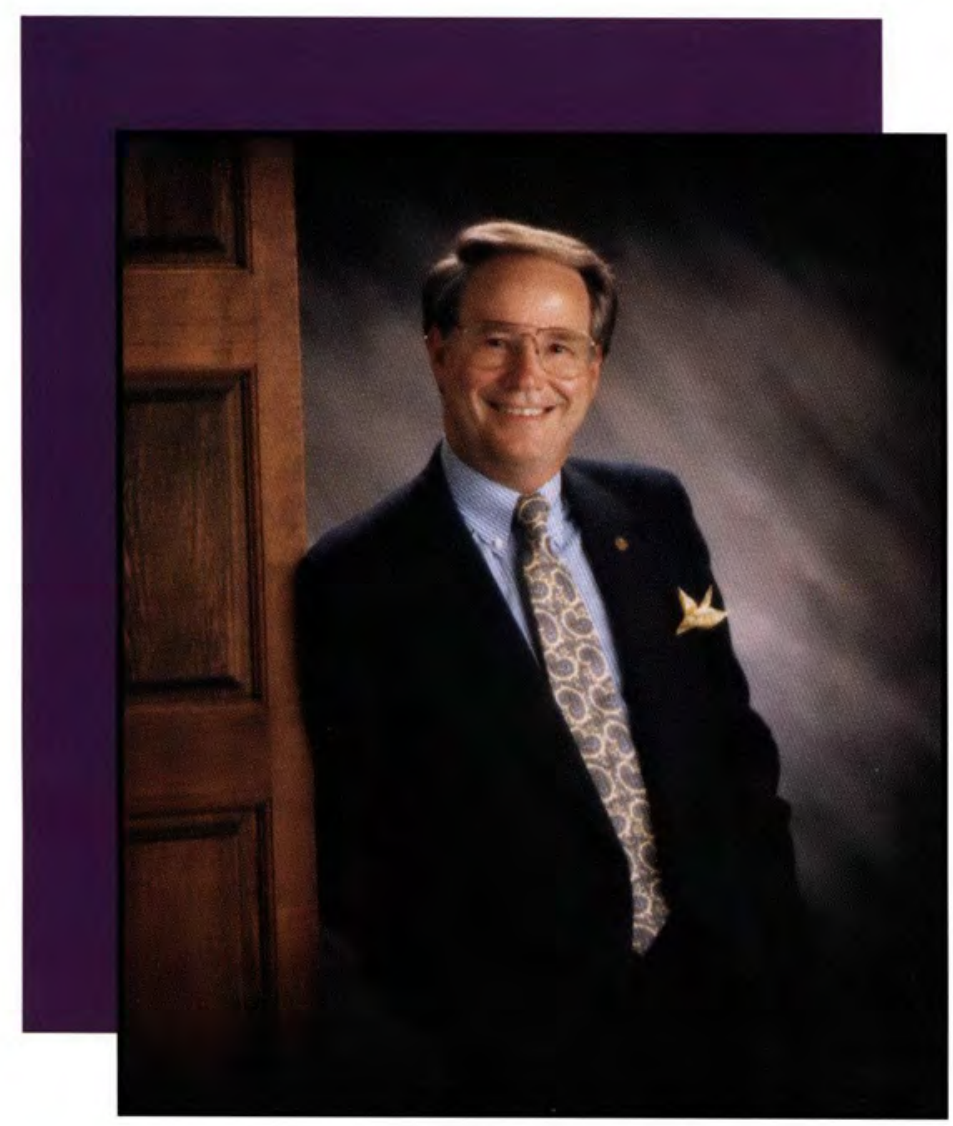

Dr. Paul Dixon

President

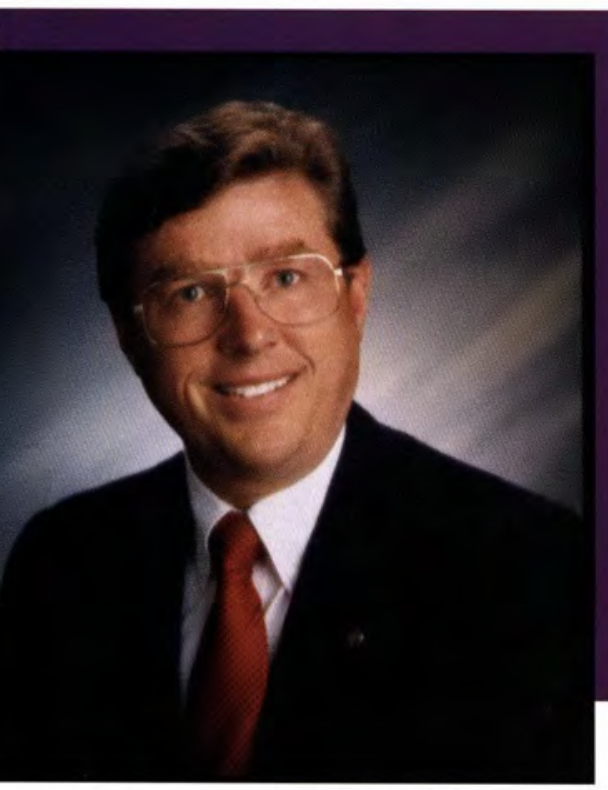

John Anglea

Vice President for Business

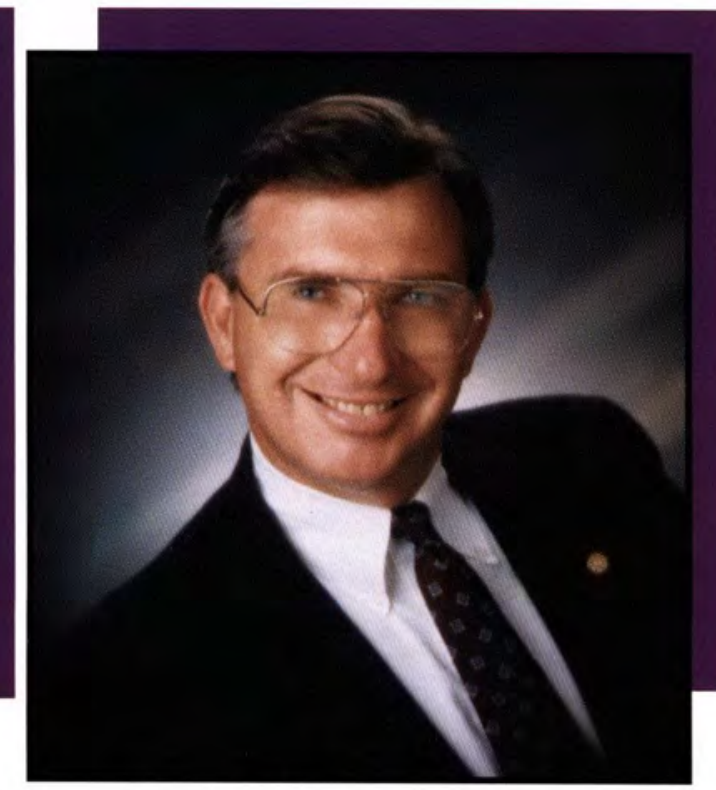

Dr. Martin Clark

Vice President For Development

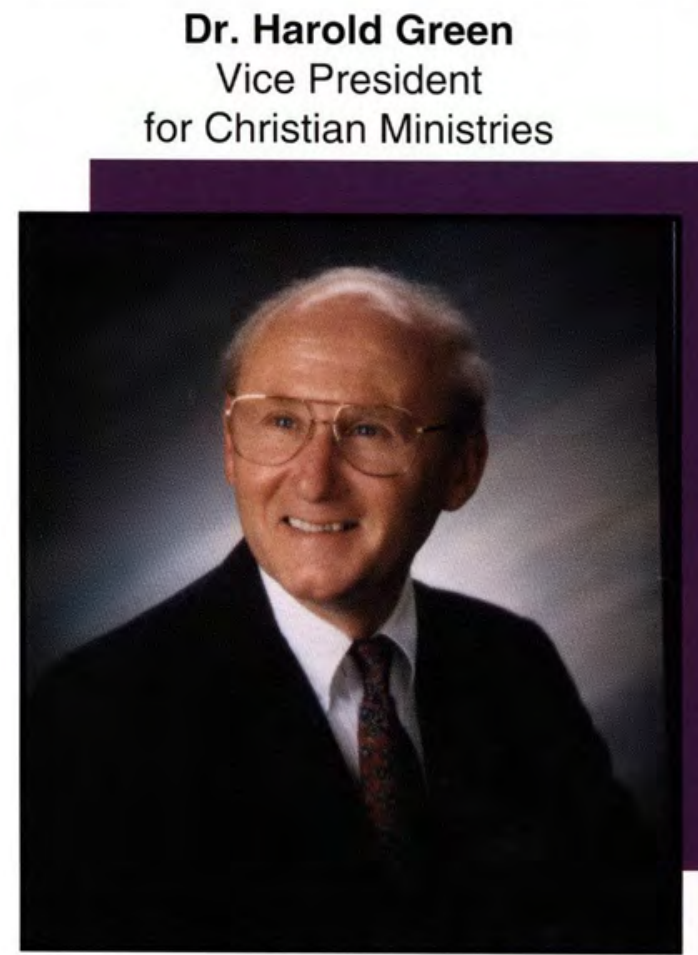

Donald Rickard

Vice President for Student Services

Vice President

or Christian Ministries

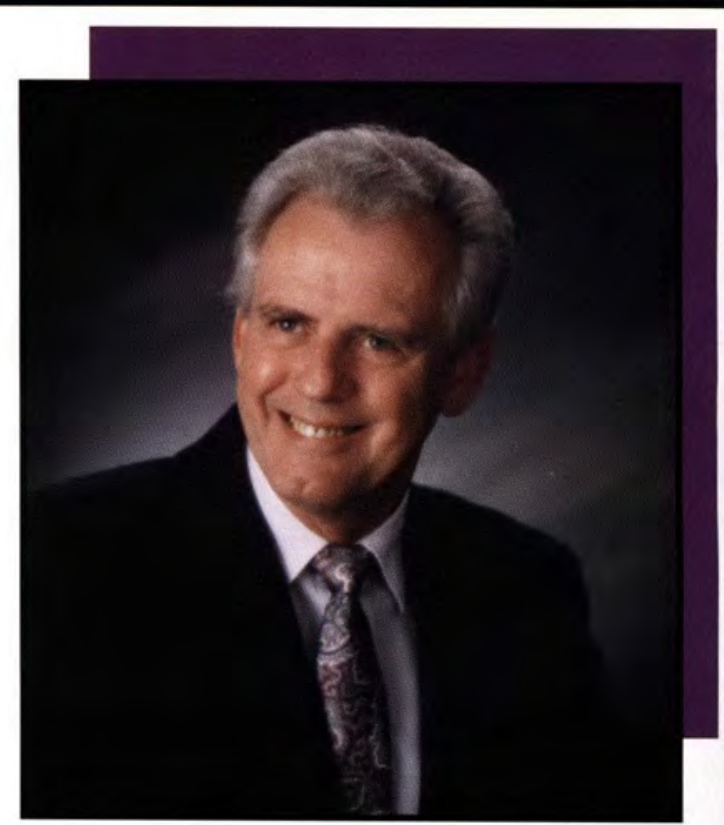

\section{Dr. Harold Green}

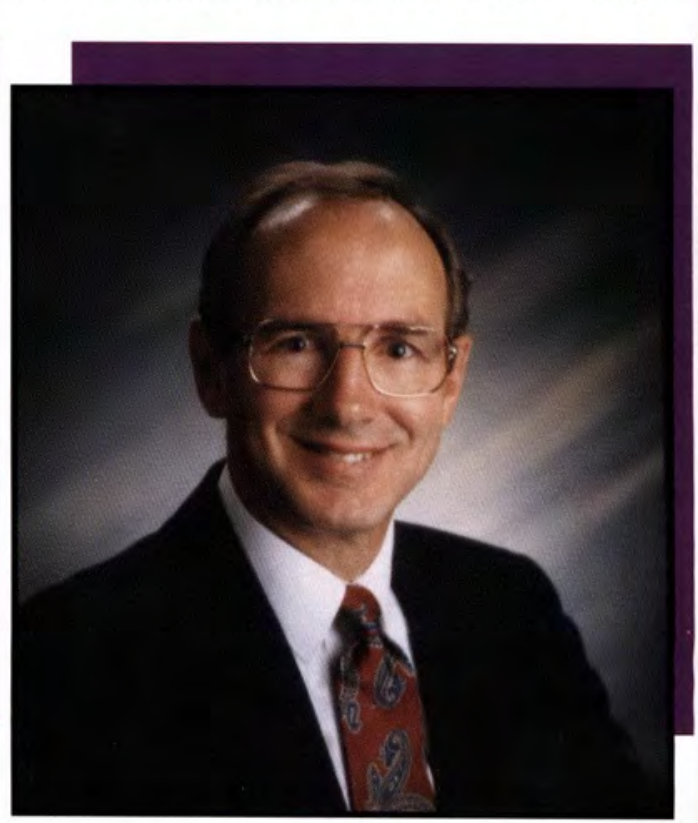

Dr. Duane Wood

Academic Vice President 


\section{Board of Trustees}
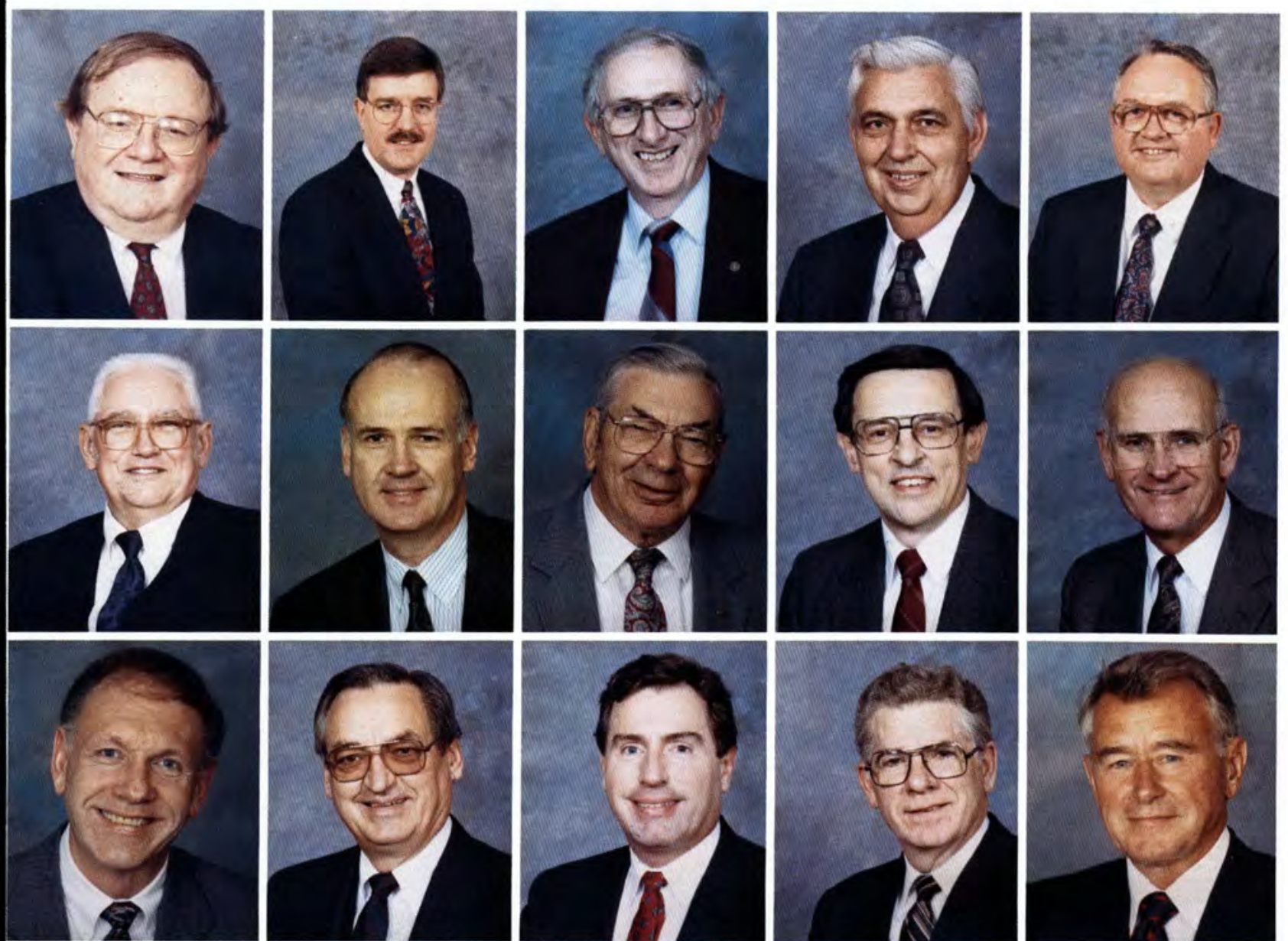

Dr. Eugene Apple

Rev. William Bernhard Mr. Francis Bresson Mr. Gilbert Brueckner Mr. James Carraher
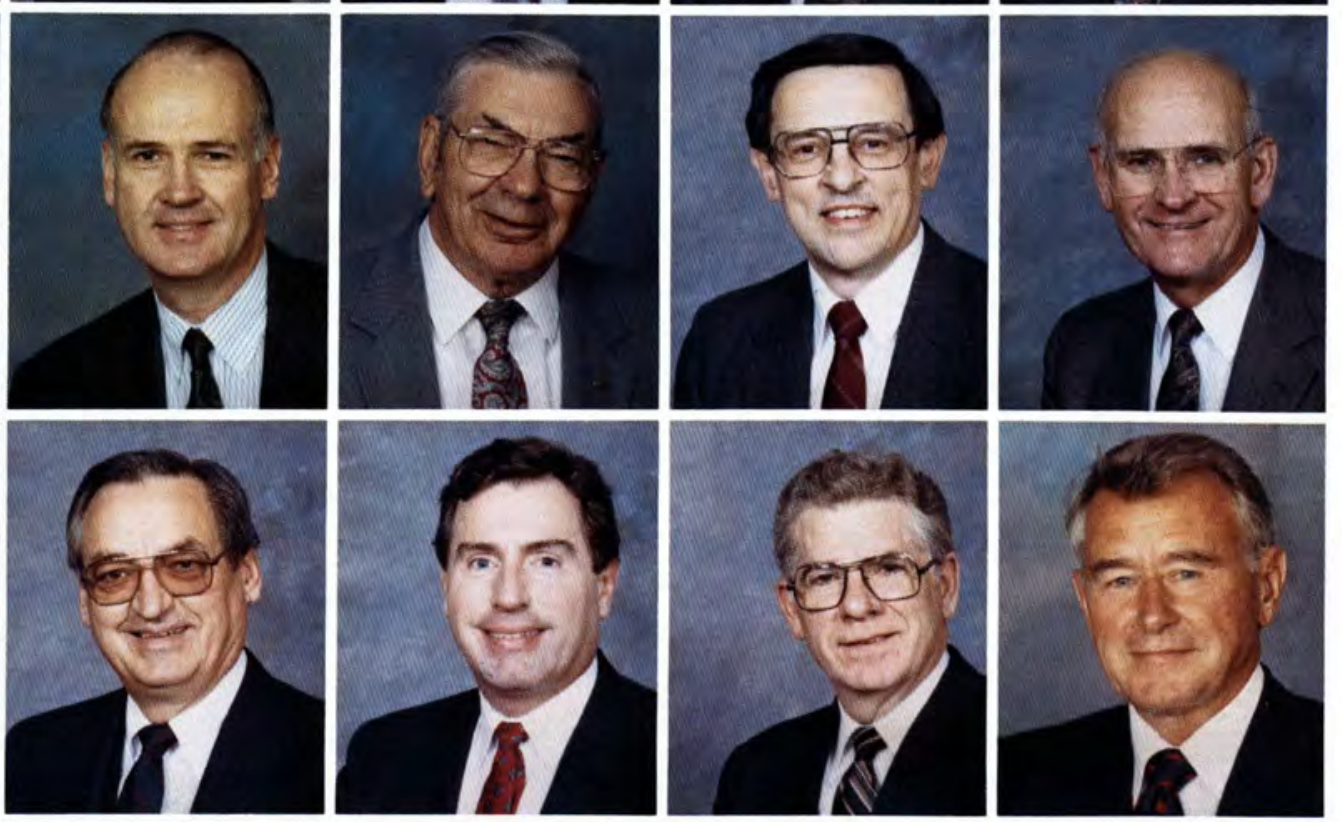

\section{Dr. Jack Cline}

Rev. William Commons Mr. George Engelmann

Rev. Larry Fetzer

Rev. Joseph Godwin

Rev. David Graham

Mr. Glenn Guenin

Rev. James Henniger

Dr. Jack Jacobs

Mr. Eugene Miller
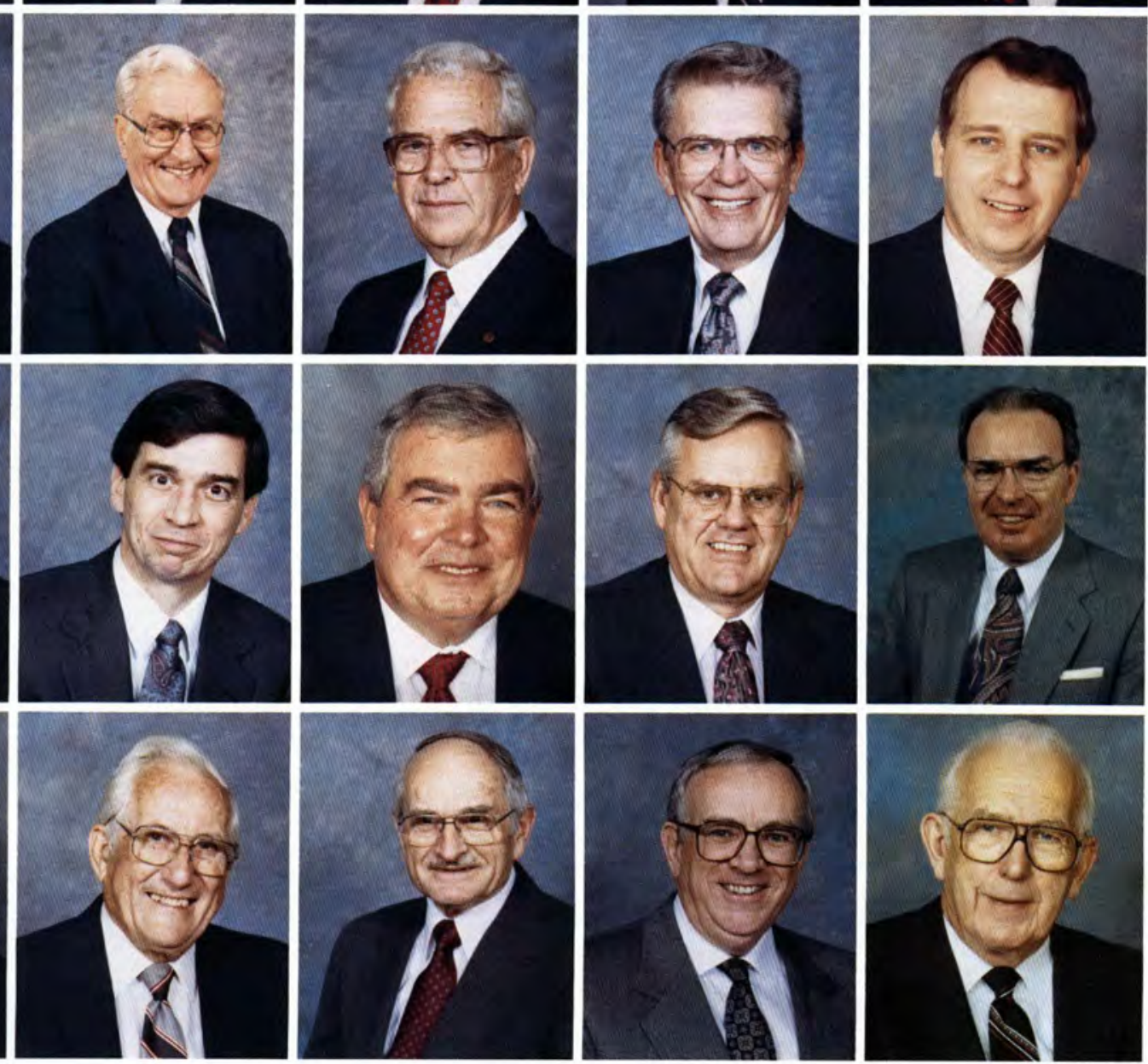

Dr. James Misirian

Mr. Dale Murphy

Mr. George O'Bryon

Rev. Irwin Olson

Rev. Randy Patten

Rev. Lynn Rogers

Rev. William Rudd Mr. Bill Smith

Mr. Albert Stevens

Dr. Paul Tassell

\section{Dr. Donald Tyler}

Rev. Earl Umbaugh

Dr. Paul Vernier

Dr. Thomas Younger

Dr. James T. Jeremiah Chancellor 


\section{Engineering}

Practical experience that begins the first year, field trips, presentations from professionals, hands on projects, and designs that are entered in competitions, professors who are experienced engineers and desire to integrate their curriculum with Biblical principles, Cedarville's Engineering emphasizes these objectives. Engineering is a new and expanding major. Each year more students come, and new faculty are added. The most significant addition is the new engineering and nursing facility. This addition "will contain the latest in equipment and instructional technology." A Computer Aided Design (CAD) Laboratory is already in use, helping students complete assignments and design projects. The Engineering Department trains students to tackle twenty-first century problems from a Christian perspective.

- Jim Foster

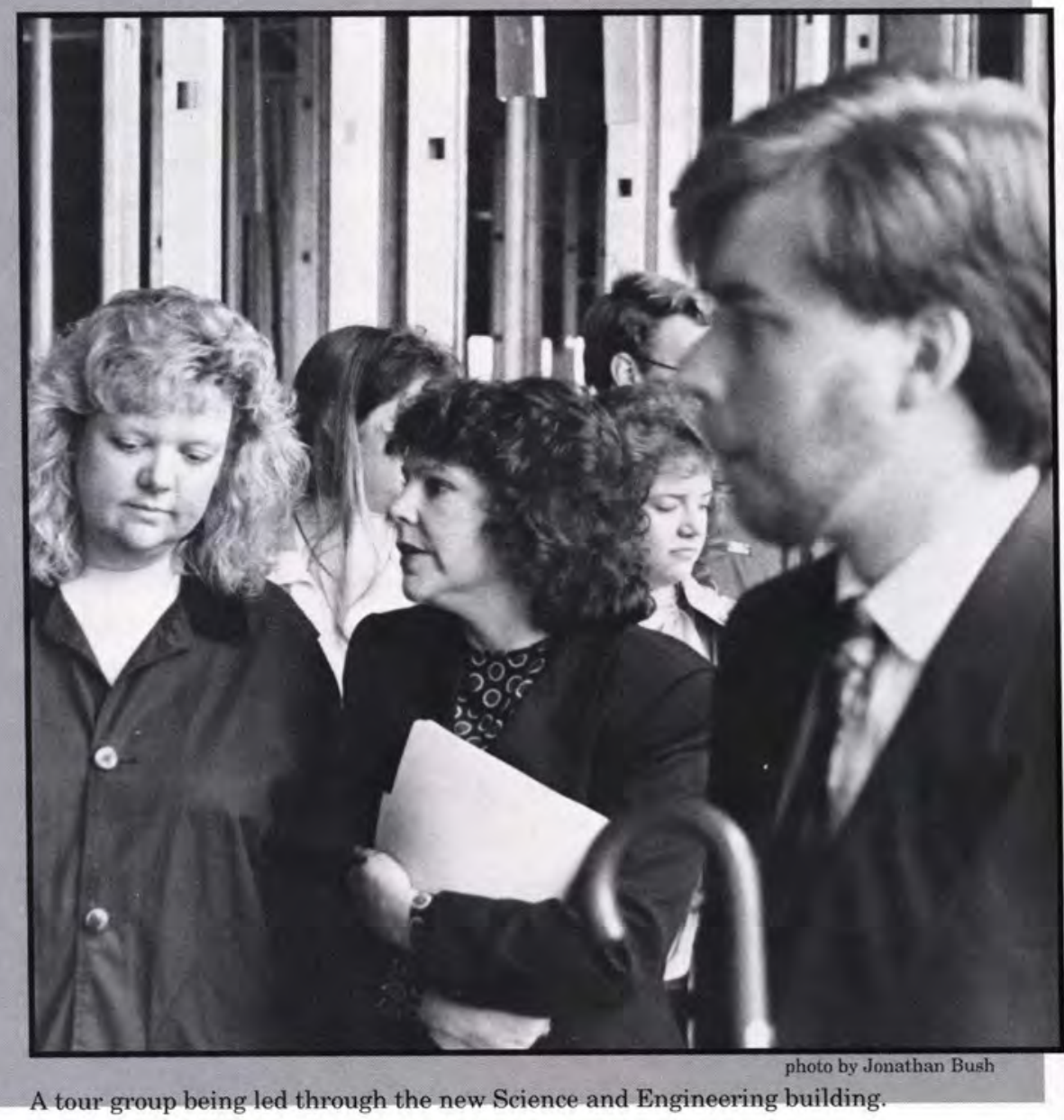

\section{Health and Physical}

Education

The Department of Health and Physical Education is focusing on service by reaching out to people who are in either emotional or physical pain and by demonstrating God's love to them. A highlight of the year was the awarding of Dr. Diehl with Faculty Member of the Year. Her life exemplifies the concepts of thinking of others and seeking to meet their needs through service and prayer.

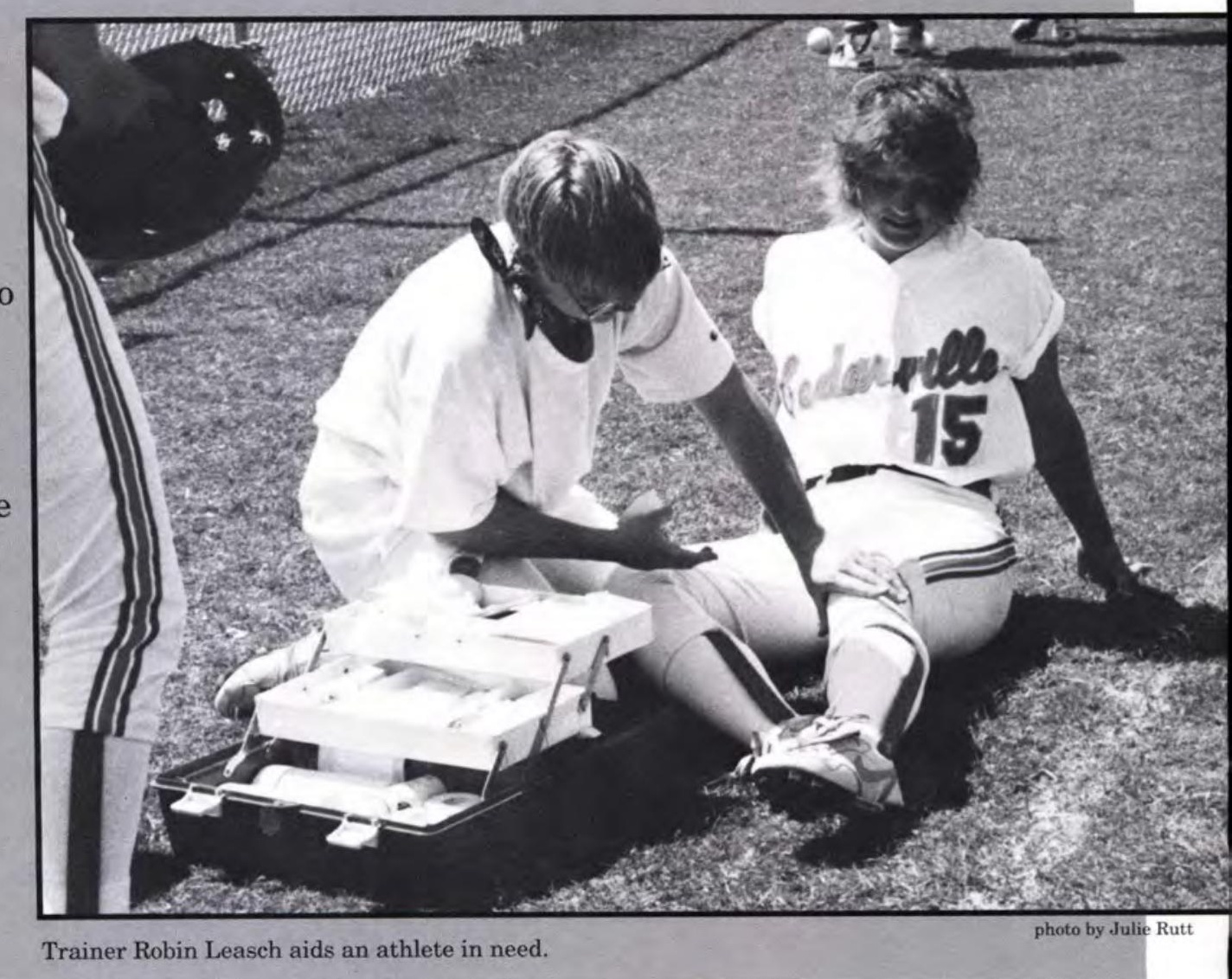




\section{Nursing}

Dr. Alyn wants to focus on nursing as a ministry, not just as a profession. A nurse is responsible for many roles medically, socially, and spiritually. She/he can exemplify the love of God through administering medicine, encouraging the patient in physical therapy, sharing in the joy of a newborn, and listening with the heart to a patient. The nurse must balance her/his life-style with both people and technology. She/he also must properly interact with doctors, patients, the patient's environment, and other peers. Cedarville College prepares each student properly to carry out her or his responsibilities as a future nurse and warrior of God.

\section{-Janet Payne}

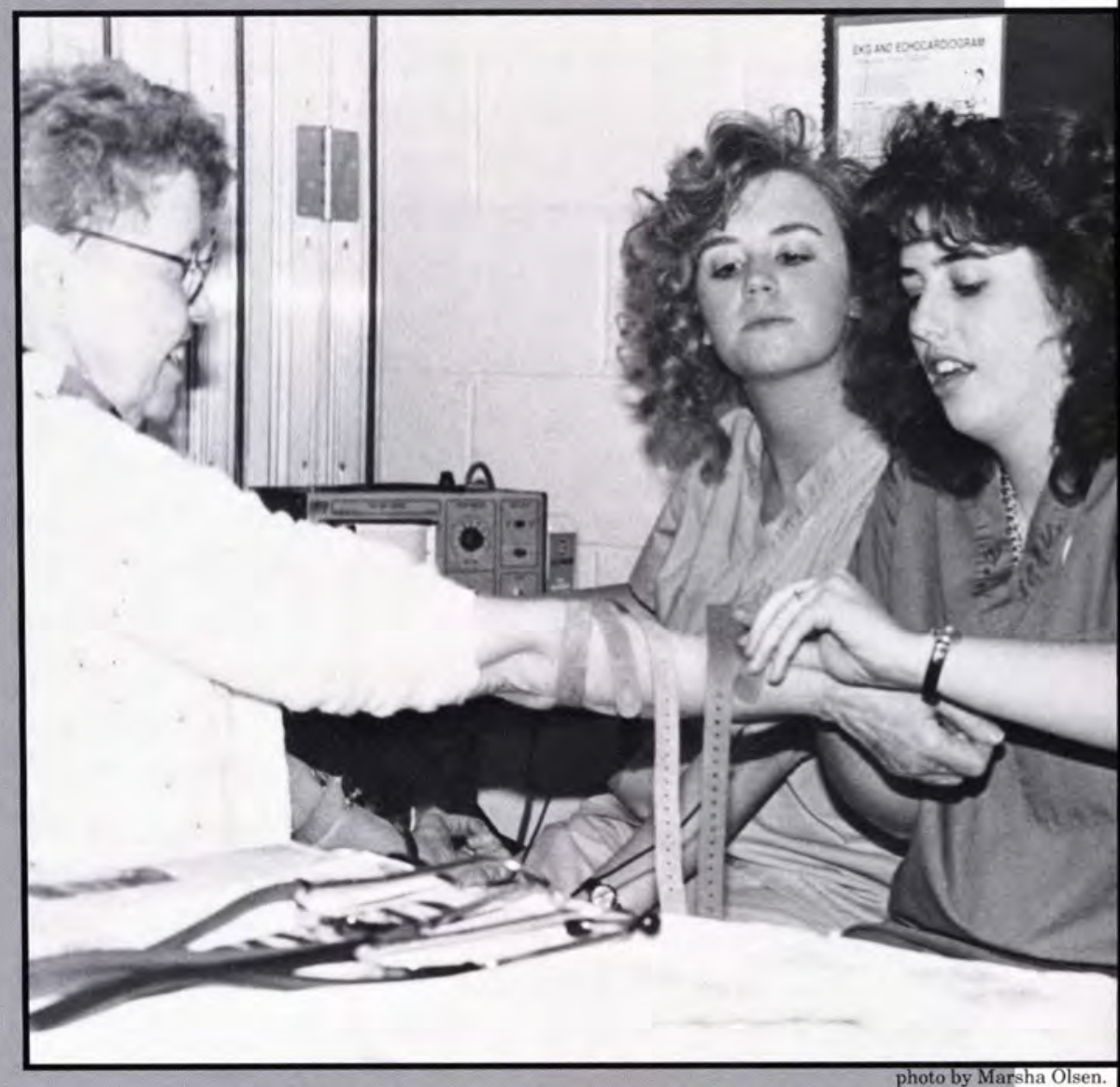

Melissa Henry and Beth Lutz do an ECG on a "patient" at the Health Fair.

\section{Psychology}

Few students know about the changes the Psychology Department has undergone within the past year. First of all, an Applied Psychology major has been added to the curriculum. This new major allows the Psychology student to branch out into other related areas within five emphases: Counseling, Child/Family Studies, Gerontology, Health, and Industrial/Organizational. Another addition to the department is Dr. Chi-En-Hwang, the first woman to belong to the department. Dr. Hwang studied at the University of Iowa after leaving her home in Taiwan in 1977. She then spent two years in Hong Kong before returning to the United States to teach at the University of Houston. The most interesting aspect of Dr. Hwang is her name, which means "Grace of God." She is often asked about it and finds her name to be an effective tool in witnessing. With these two additions, the rather small Psychology Department is making significant progress.

-Karla Warnken

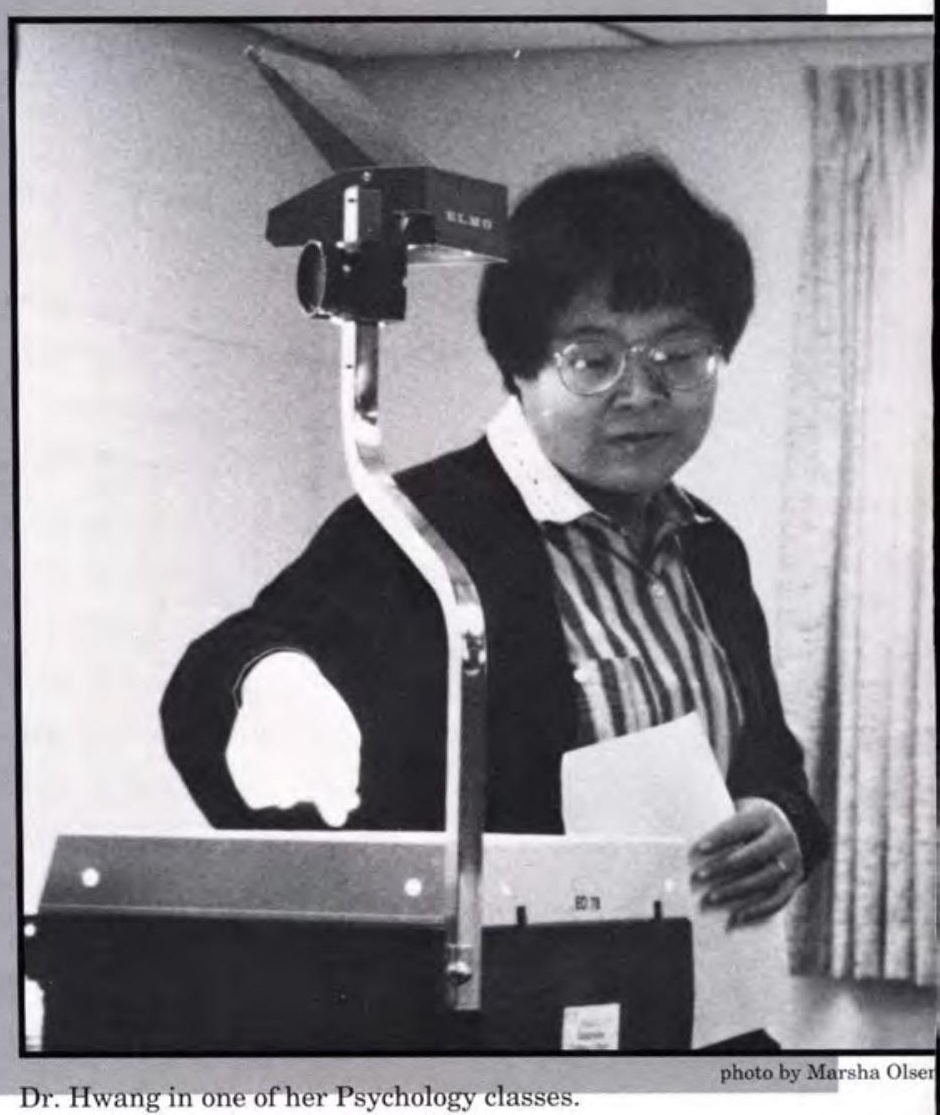




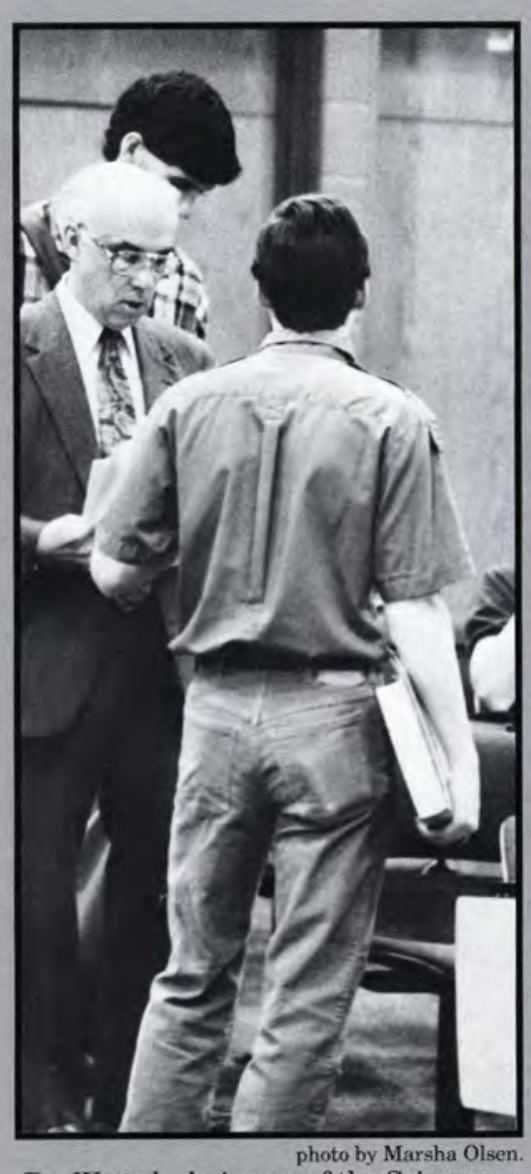

\section{$\underline{\text { Science and Mathematics }}$}

Dr. Wetzel is excited about the changes in the Science and Math Department. Four new professors are coming next year; one will be the first full-time female faculty member in the department. Two of the new professors will be filling new positions, one in biology and one in math. A new trigonometry based physics course may also be added. The department is also trying to add some younger professors, as well as keep up their high percentage of those with doctorates.

More obvious to students will be the change in the building where the Science and Math Department is housed. The old science center has been almost completely renovated. Air conditioning, sprinklers, new carpeting and paint have given it a more modern look. Rebricking the science center helps it match the motif of Cedarville's campus.

The addition of the new facility is probably the most exciting change on campus. Dr. Wetzel, who chaired the committee that planned the new building, said faculty and student lounges, twelve new classrooms, and another computer center will make it possible for every one to take advantage of it. The Science and Math Department will benefit from professors offices, two biology labs, a physical science lab, and a geology lab. Cedarville's Science and Math Department is leading the way in preparing students to face 21 st century challenges and technology.

- Jim Foster

Dr. Wetzel, chairman of the Science and Math Department.

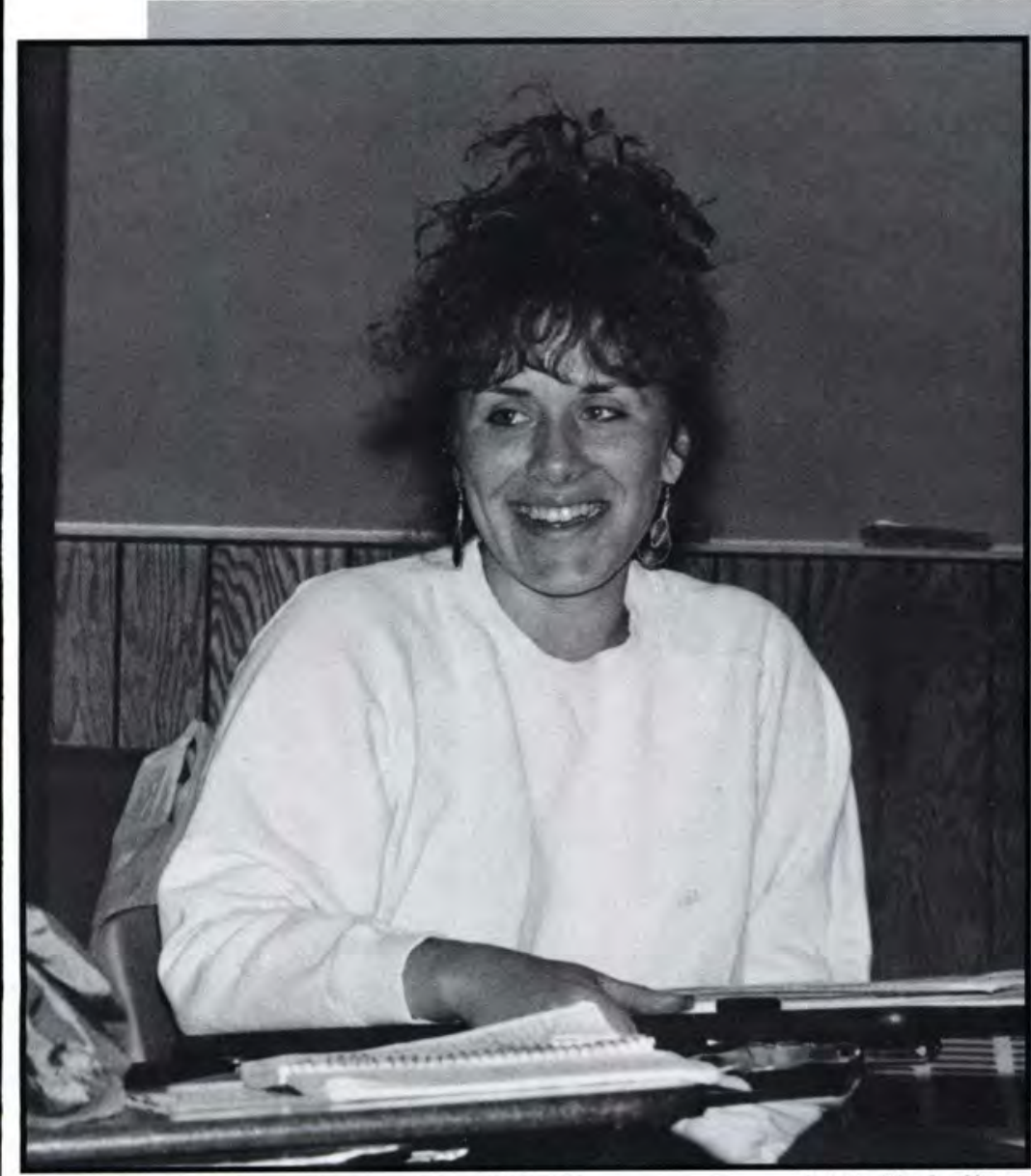

\section{$\underline{\text { Social Sciences and History }}$}

Major changes are under way in the Department of Social Science and History for the 1992-93 academic year. Perhaps the greatest is the addition of the social work major. Recognizing the immediate need for Christian social workers, the department has made the effort to have all coursework in place for the fall. Along with this change, the department has added a new faculty member, Miss Cynthia Sutter.

- Mindy Boone 


\section{Cedarville College}

\section{Administration}

Patricia Ashby, M.L.S. Janice Bosma, M.L.S. Lynn Brock, M.L.S

Stephen Brown, M.L.S. Sandra Entner, M.S.

Clifford Johnson, D.Ed. Judy Johnson, M.L.S. Ruth Martin, M.L.S. David Ormsbee, B.A. Jon Purple, M.Ed.

Carl Ruby, M.A. Biblical Education

Robert Gromacki, Th.D. Chair

Richard Blumenstock, Th.M. David Drullinger, D.Min. Floyd Elmore, Th.D.

Daniel Estes, Ph.D. Jack Riggs, Th.D.

David Warren, Th.M.

Business Administration

Ronald Walker, D.B.A. Chair

Richard Baldwin, Ph.D.

Jeff Fawcett, M.B.A.

Charles Hartman, M.B.A Marinus Hazen, M.B.A. Walter Hoffmann, M.B.A. Martha Johnson, M.A.

Betty Orme, M.S. Kenneth St. Clair, M.S., C.P.A. Galen Smith, M.S.

Sarah Smith, Ph.D. Communication Arts James Phipps, Ph.D. Chair

Michael J. Lopez, Ph.D. Kurt Moreland, M.A. Education

Merlin Ager, Ph.D. Chair

Sue Baker, D.Ed. Philip Bassett, Ph.D.
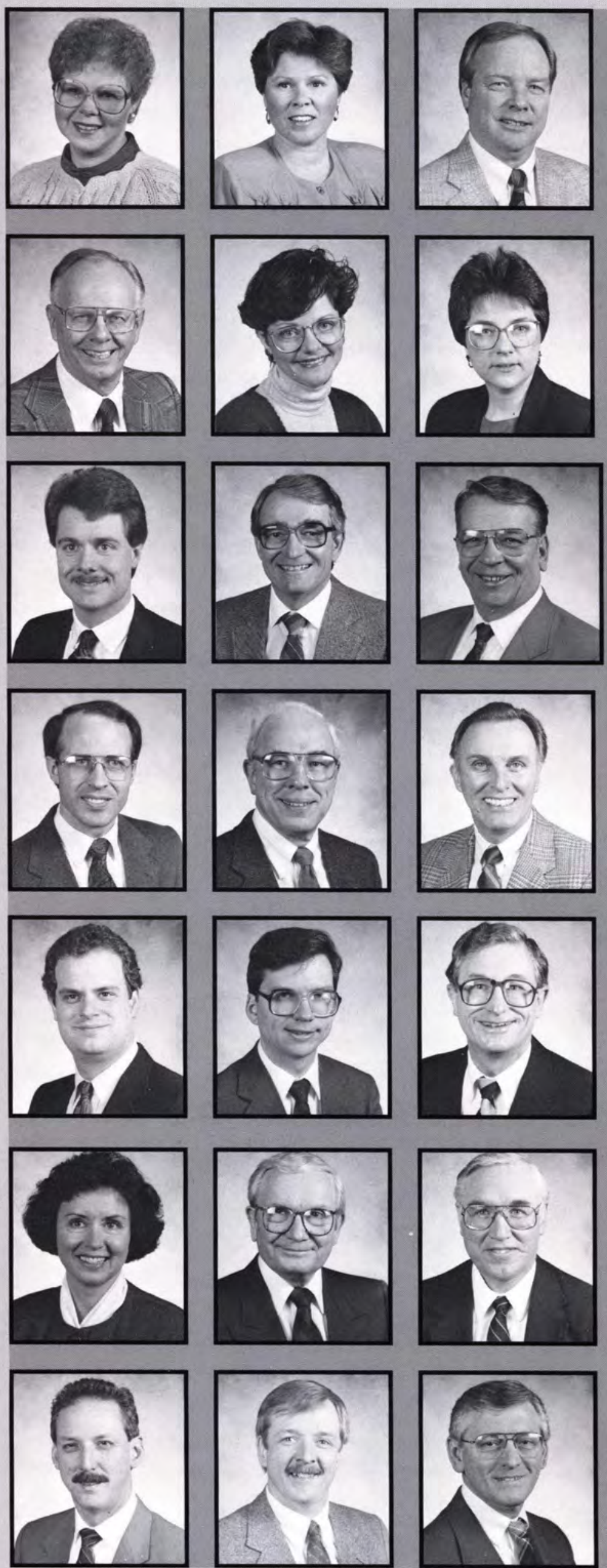
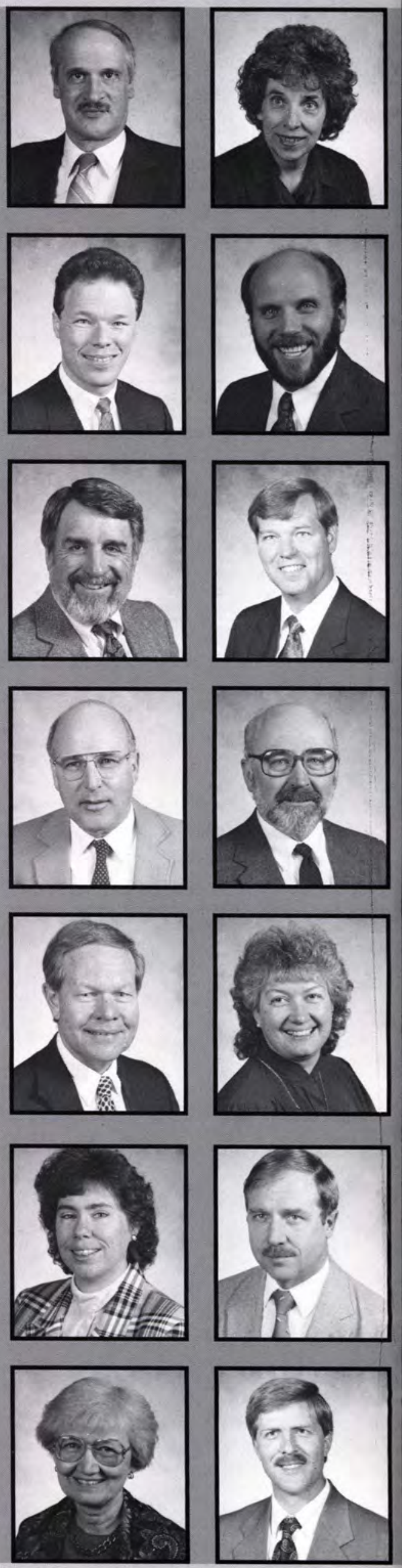
Kimberly Holliday, M.S.N. Margaret Ingalls, M.S.N.

Sandra Pratt, B.S.N.

\section{Psychology}

Stanley Ballard, Ph.D., Chair Science and Mathematics Daniel Wetzel, Ph.D., Chair

Donald Baumann, Ph.D. Edwin Braithwaite, Ph.D. Leroy Eimers, Ph.D. Dennis Flentge, Ph.D. Larry Helmick, Ph.D.

Wilbur Kirtland, M.S. Douglas Miller, Ph.D. John Silvius, Ph.D. John Whitmore, B.S.

Social Science and History Murray J. Murdock, Ph.D. Chair

Joseph Halsey, Ph.D. Robert Parr, Ph.D. Kevin Sims, Ph.D. Cynthia Sutter, M.S.W.
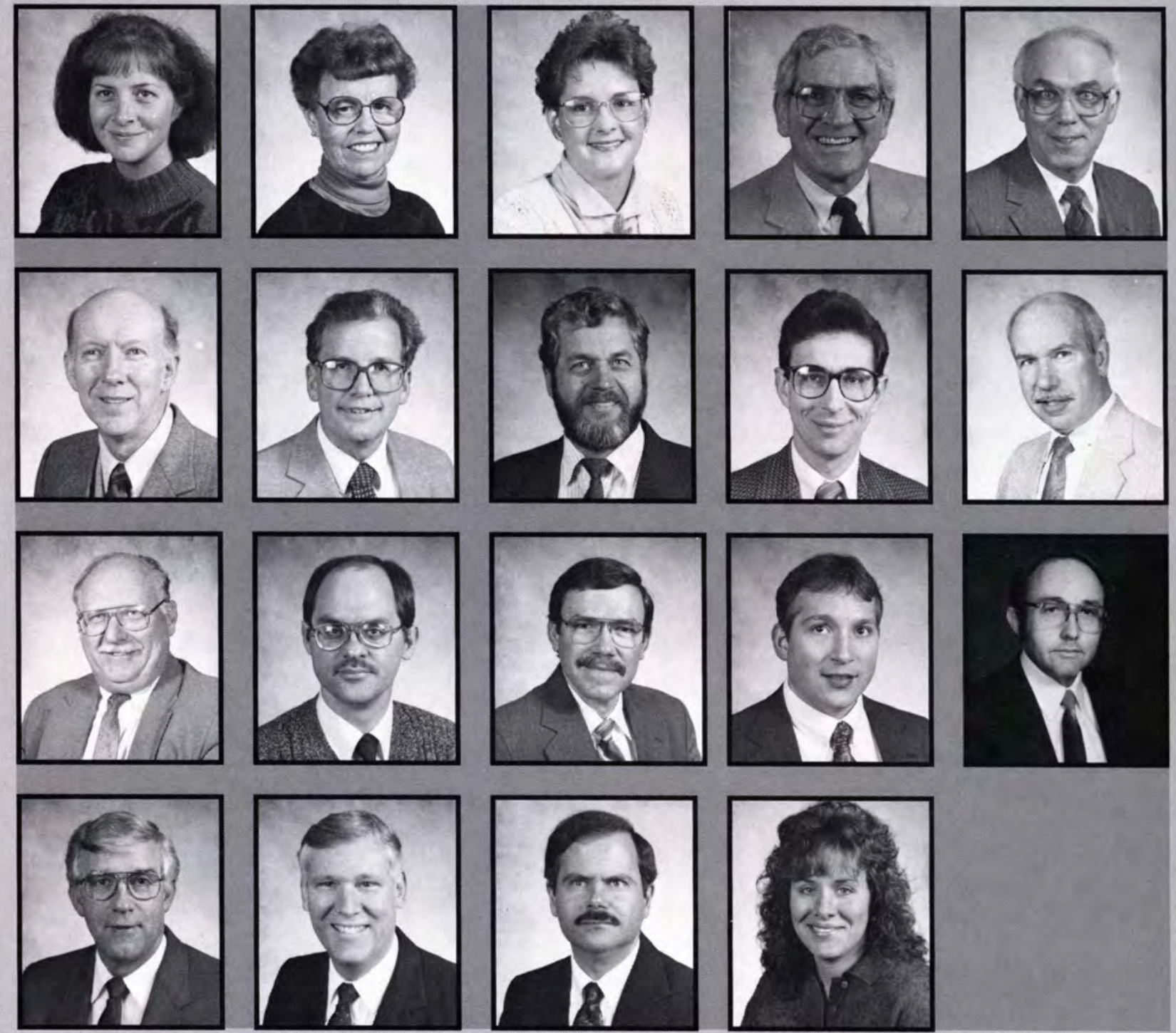

Kenneth St. Clair

(1959-1992)

Kenneth and Ida St. Clair arrived on the Cedarville College scene in 1959. They came to the college so that Mr. St. Clair could set up the Department of Business. He later became chairman and taught business courses until this year's retirement. For twenty five years of his tenure he was Vice President for Business.

Coupled with his teaching and administrative duties have been several other church and community responsibilities: director of the Institute for Christian Ministries Management, board member of Baptist Mid Missions, active church member, and former clerk-treasurer of the Village of Cedarville.

-Cliff Johnson

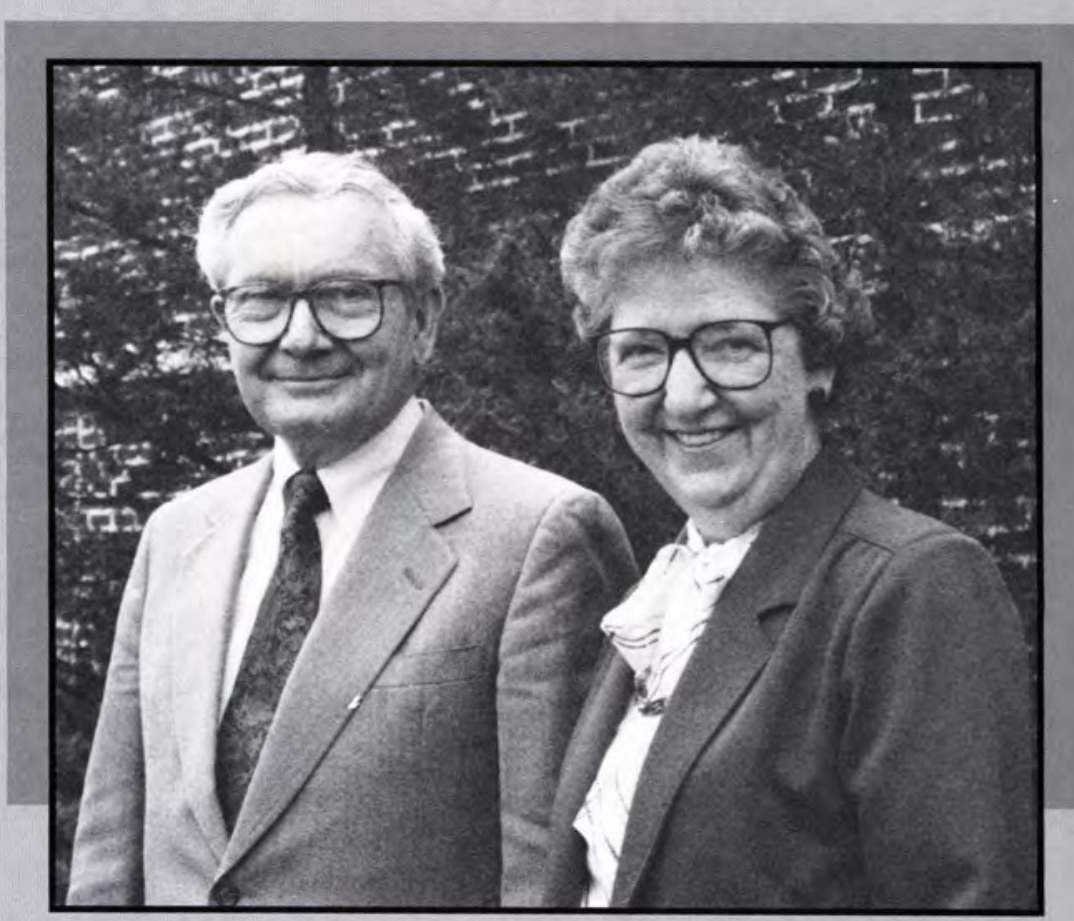




\section{Cedarville College \\ Staff}
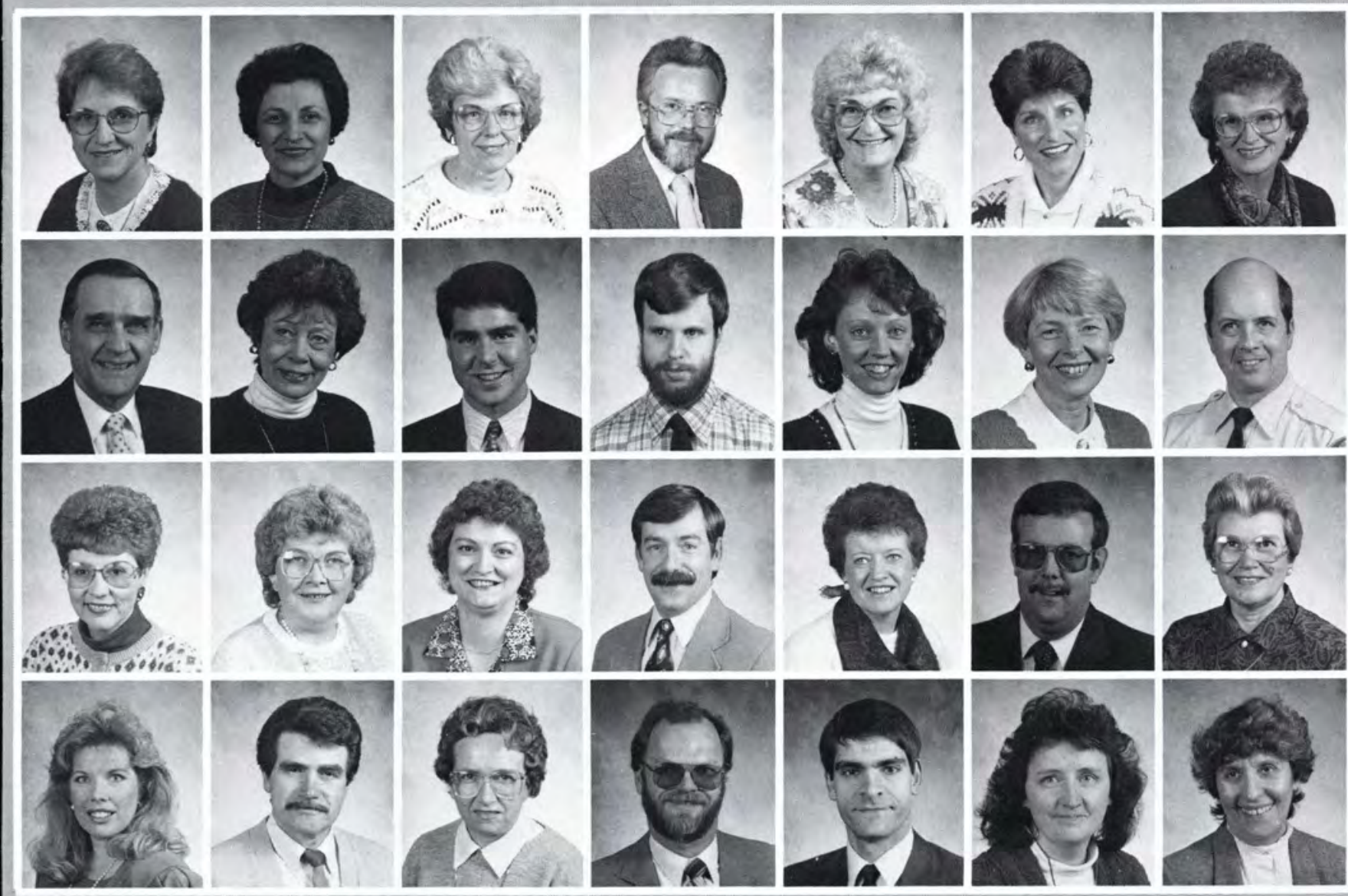
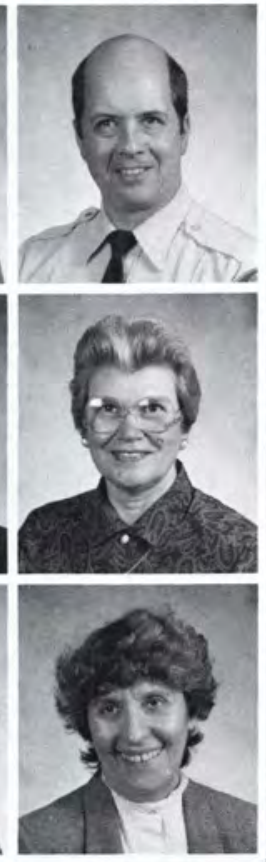

Ruth Ager

Frances Andrews

Mary Auckland

Ronald Bader

Barbara Baise

Louann Baise

Martha Baldwin

Robert Beikert Sr.

Grace Beikert

Jeff Beste

Brian Blair

Carol Bliss

Helen Blumenstock Jim Bowersox

Connie Bradds

Margaret Burrichter

Deborah Cagwin

Jack Campbell

Fran Campbell

Thomas Cannon

Alberta Carr

Diane Cornish

Ronald Coy

Sherry Coy

Jeff Cunningham

Tim Danube

Cynthia Davis

Norma Deranek

\section{Betty Bertschinger}

(1966-1992)

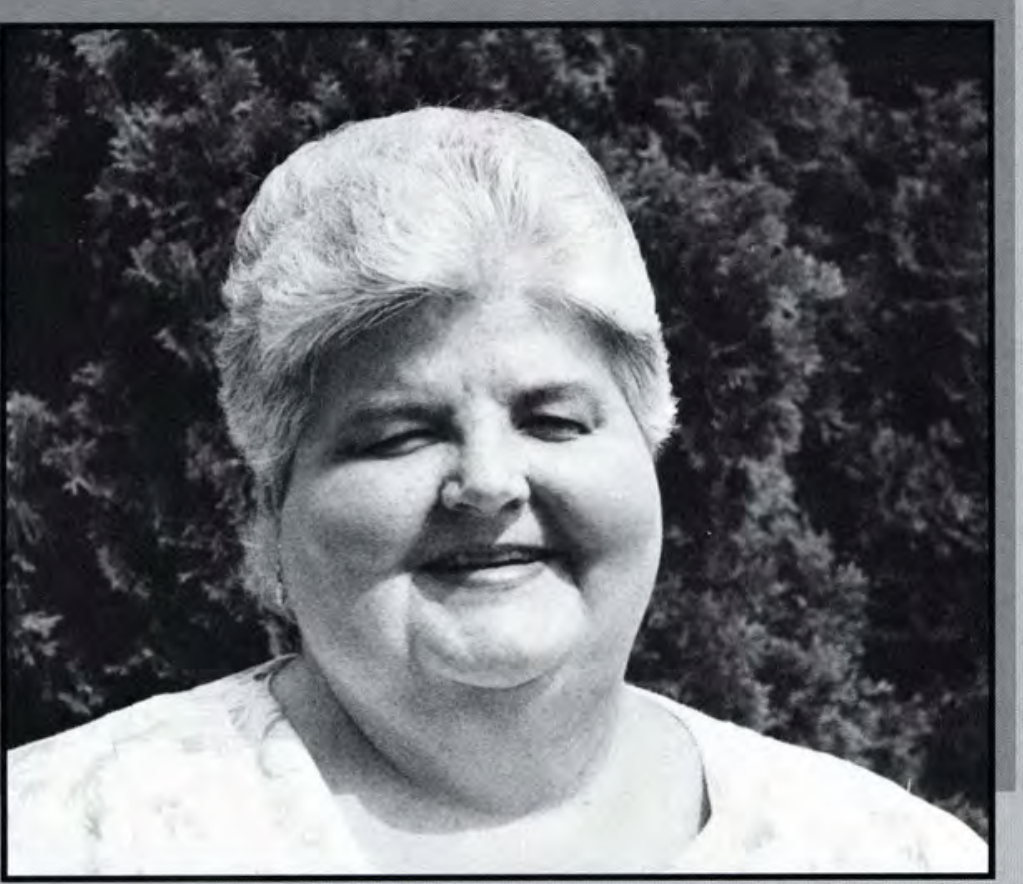

Betty has been the Director of Student Health Services since 1968. When she first came to the college in 1966, one room in the back of Faith Hall was the nurse's station. During the 70 's and 80 's, the Health Service was in the "old farmhouse." Under Betty's direction, the nursing staff has increased to 4 full time nurses, and the remodeling of Patterson Hall from a dorm to a clinic facility has occurred.

She holds the distinction of being one of the first college health nurses to be certified in the nation. State and national recognition has affirmed her contribution to health concerns and her leadership. Her peers appreciate her "example of care and concern for the college student demonstrated by her hospitality, role modeling, and her one-on-one discipling." 
Margaret Dillon Linda Divan

Pamela Elmore

Brenda Fannin

Kelly Faith

Susan Faulkner

Timothy Fisher

Nancy Fissel

Gary Fowler

Dennis Frost

David Gaffner

Jacquie Gathany

Paul Gathany

Todd Gathany

Alan Geist

Amy Gilbert

Diane Gottwals

Margaret Green

Keith Hague

Marsha Halk

Jenifer Hall

Shaun Hannay

Donna Harrison

Carolyn Hodson

Amy Holtz

Trish Huber

Scott L. Huck

Shirley Johnson

Timothy Johnson

Murtha Kaercher

JoAnne Kendall

Darla Kennedy

Toinette King

Joyce King

Glenn Knauff

Nancy Knauff

Mark Kordic

Gayle Kunz

Gregory A. Kunz

Jill Law

Patricia Lee

Faith Lynn

Kimberly Longo

Michelle Longo

Mark Mathews

Cheryl Miller

Douglas Miller

Wendy Miller

Buffie Myers

Luann Nicholas

Rose Marie Payne

Edmond Phillips

Nancy Ranger

Joyce Reese

Joyce Riggs

Beverly Robey

Kimberly Robinson Lynn Rohm

Robert Rohm

Merilee Shank

Jon Skillman

Katy Skillman

Benjamin Smith
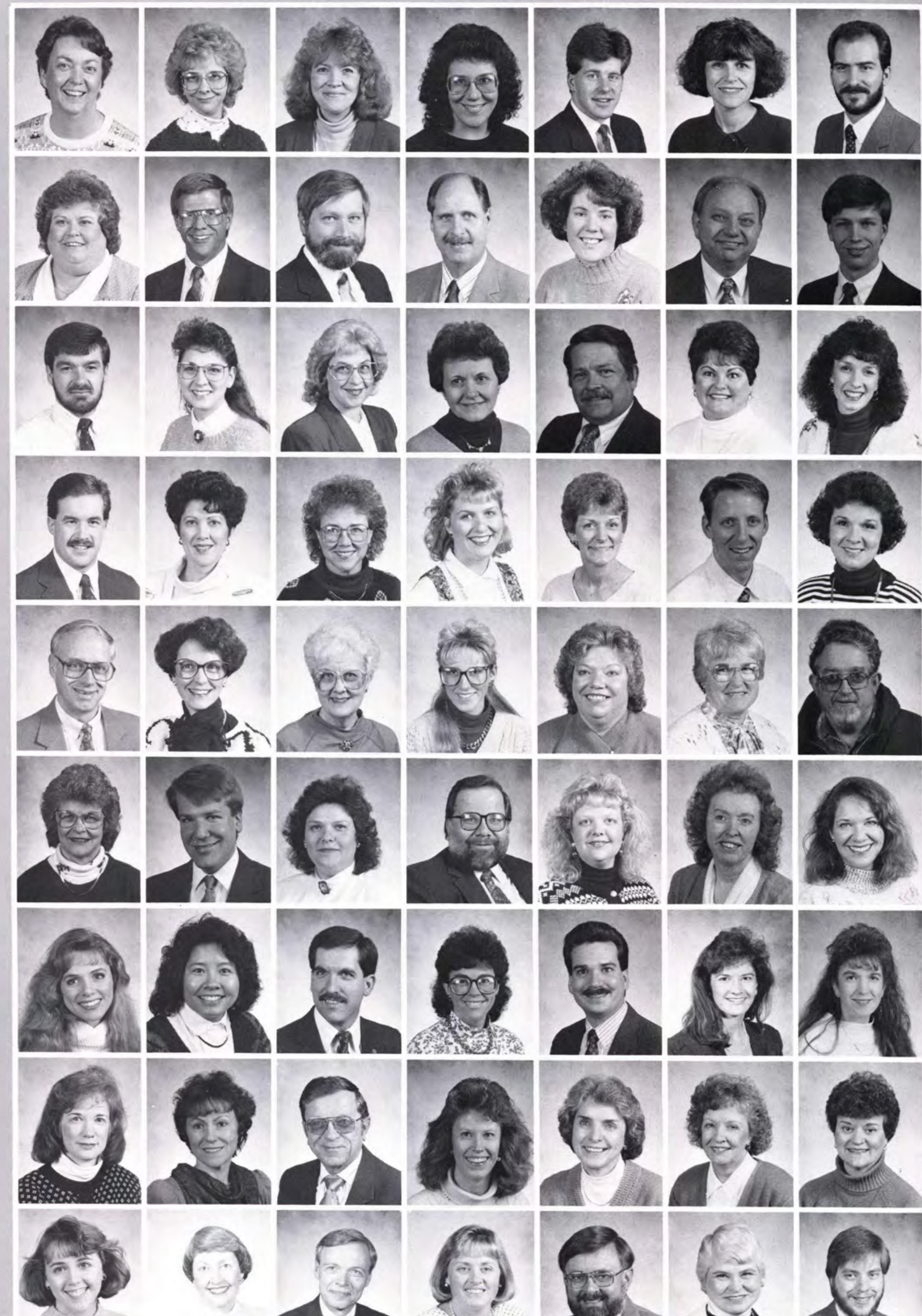

8)

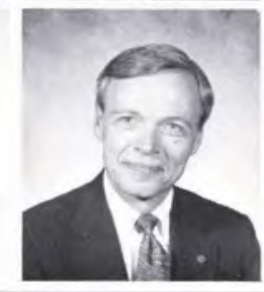

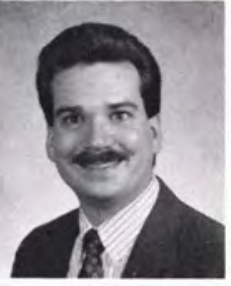
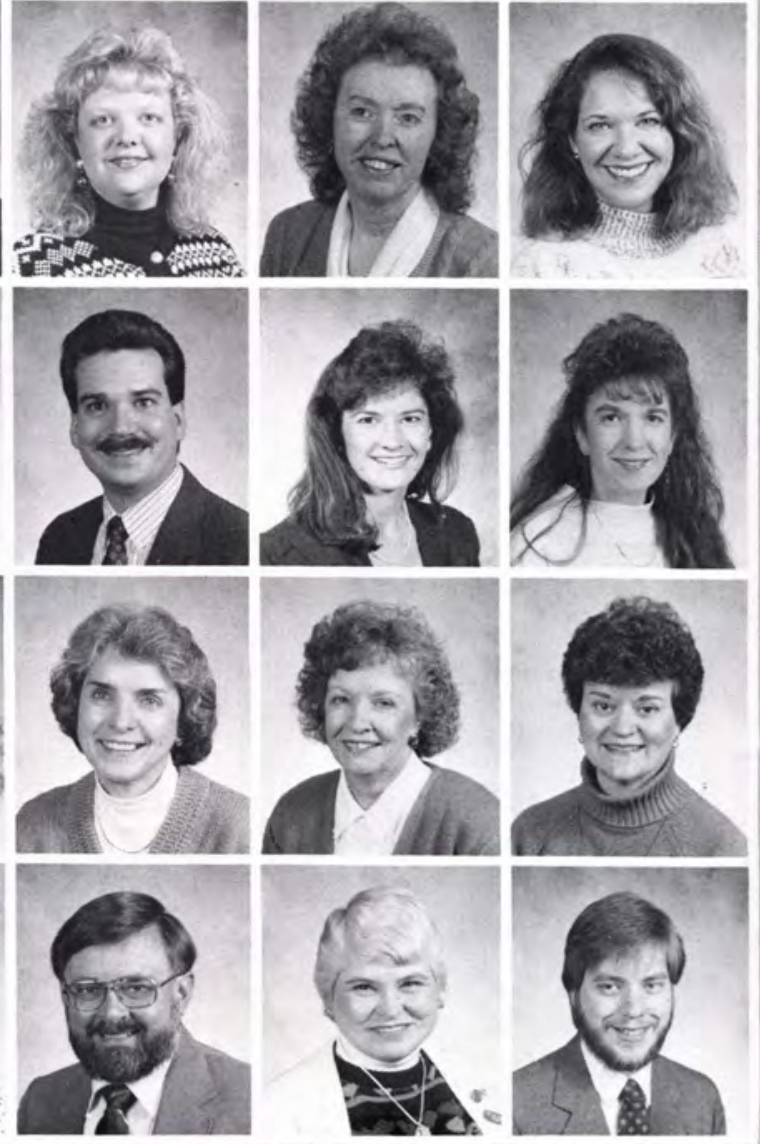

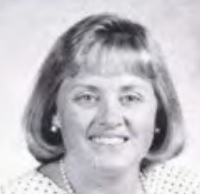




\section{Cedarville College Staff}
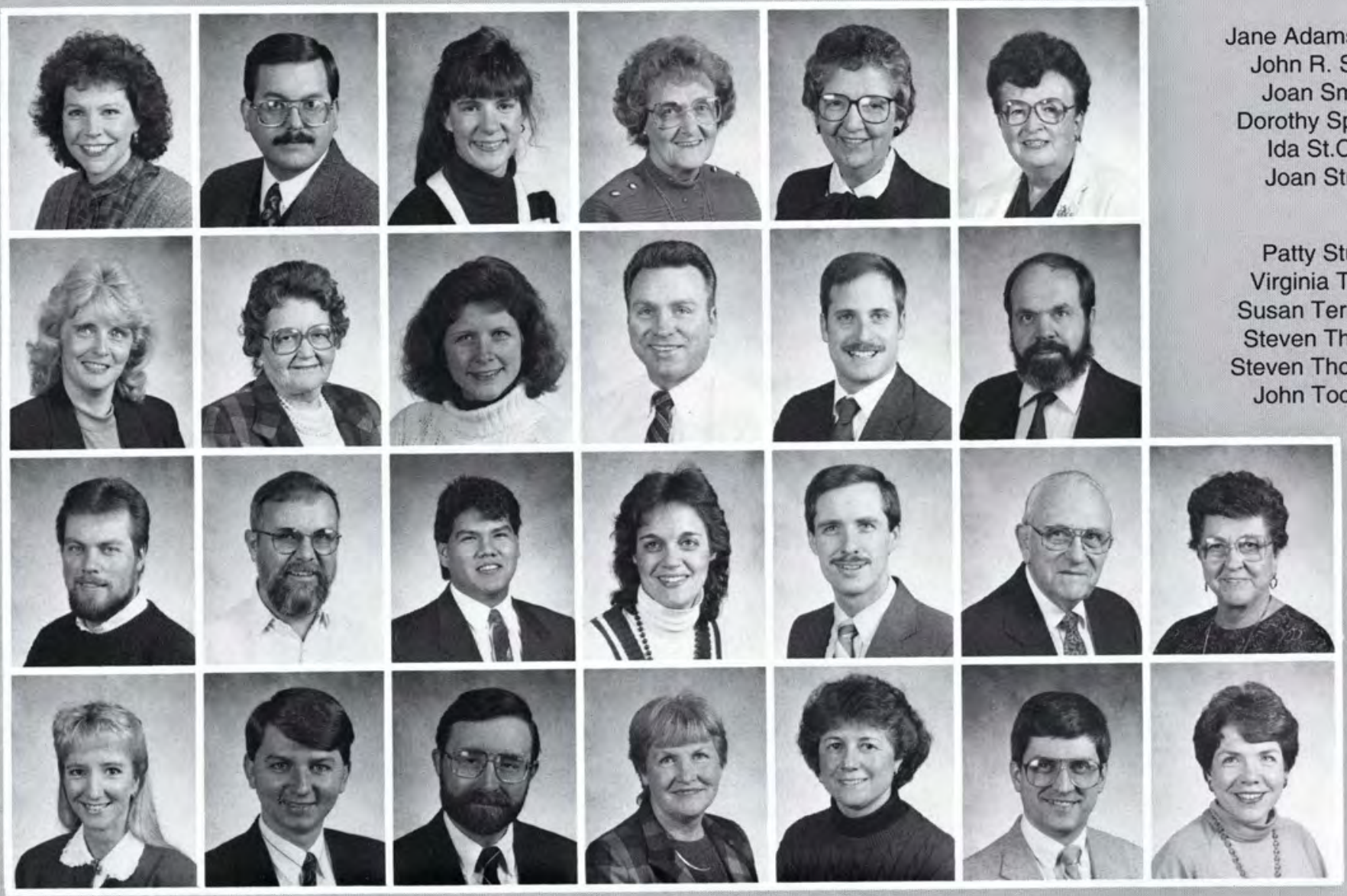

David Gidley

(1965-1992)

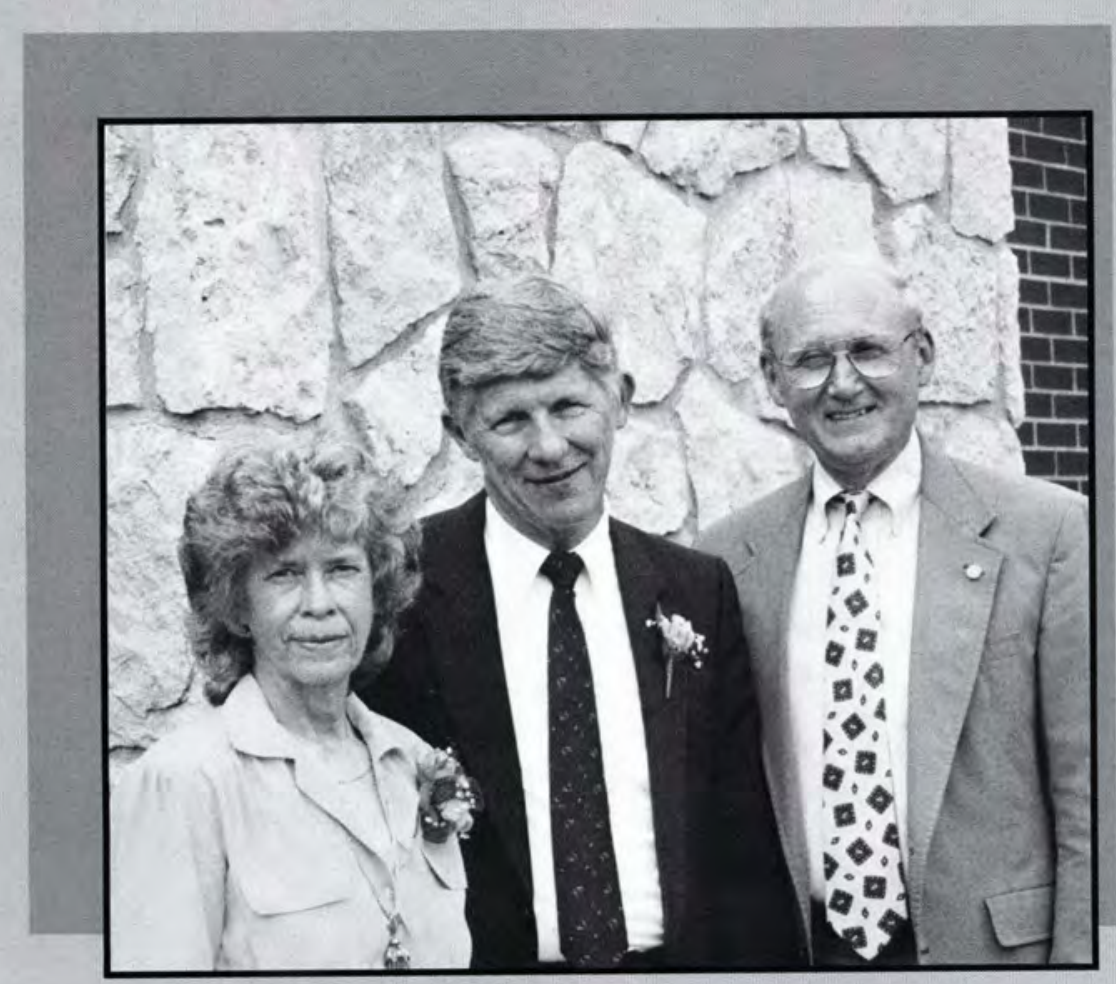
first ' 69 budget of $\$ 460,000$. ton during his tenure. Irene, and his seven grandchildren.
Jane Adams Smith John R. Smith Joan Smoot

Dorothy Spencer Ida St.Clair Joan Street

Patty Stutes Virginia Taylor Susan Terkelsen Steven Thacker Steven Thompson John Tocknell

Most students know David Gidley, Director of Financial Aid, or want to know him. He oversees $\$ 6$ million in aid for the college students. This is quite an increase from the Financial Aid Office's

Mr. Gidley's management of the monies has been a biblical example of wise and careful stewardship. Along with his sterling accomplishments in management, he completed his undergraduate degree from Cedarville College and his Master of Education from the University of Day-

Upon his retirement, he plans to manage his roses and give more aid and attention to his wife,

-Cliff Johnson 

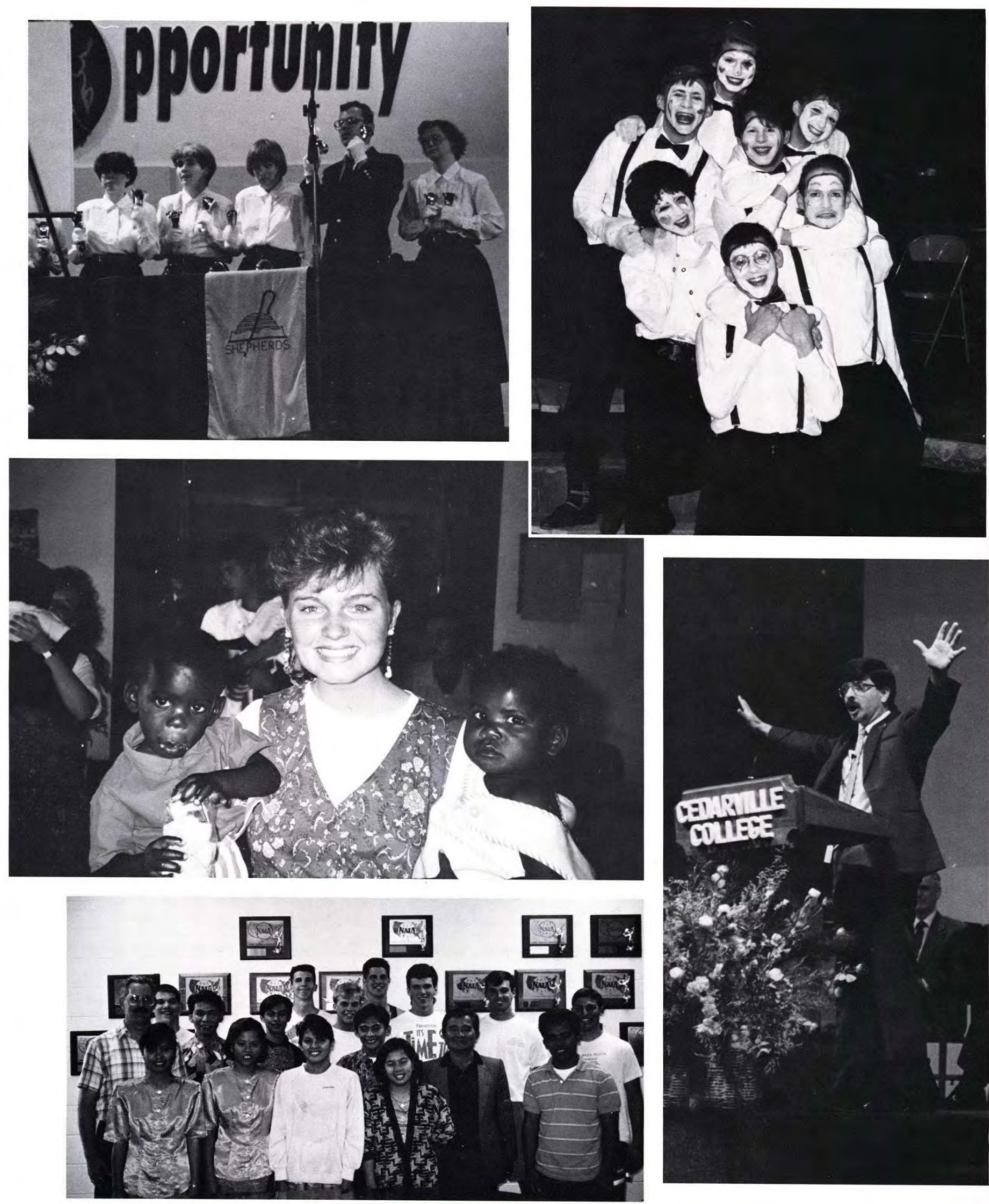

$\sqrt [ 4 ] { 2 6 } \longdiv { 2 }$ Ministries 


\section{Burdens that Build Bridges}

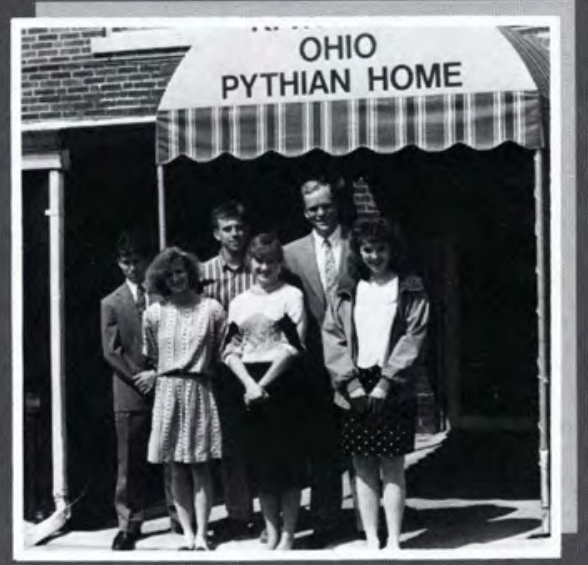

Table of Contents:

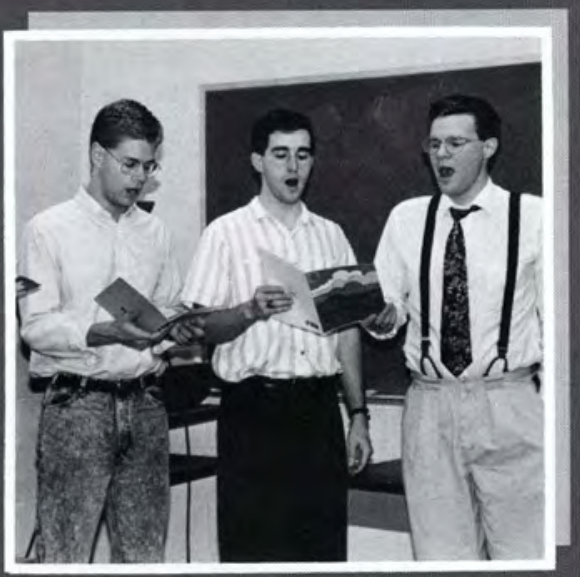

Cammunity

Ministries

Page 28

Traveling

Teams

Page 46

M951

Gary Foculer

Page 50

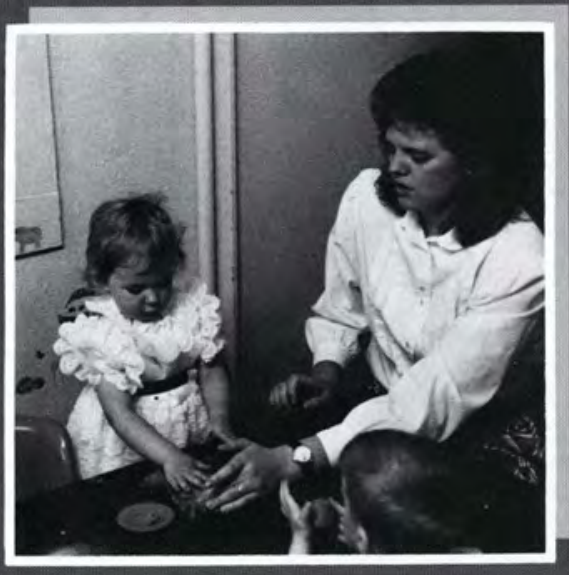

Swardbearers

Extension Teams Page 52

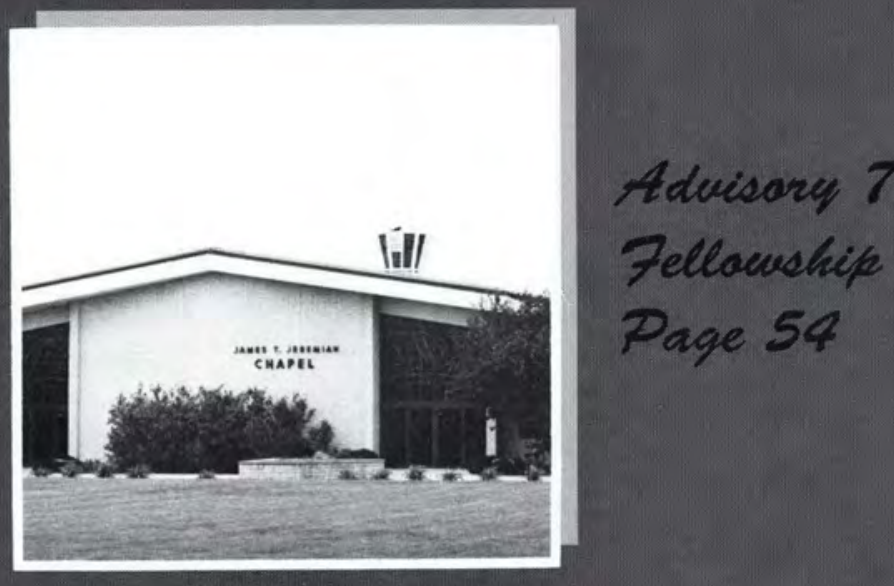

Advisory 71

Fellowenip

Page 54

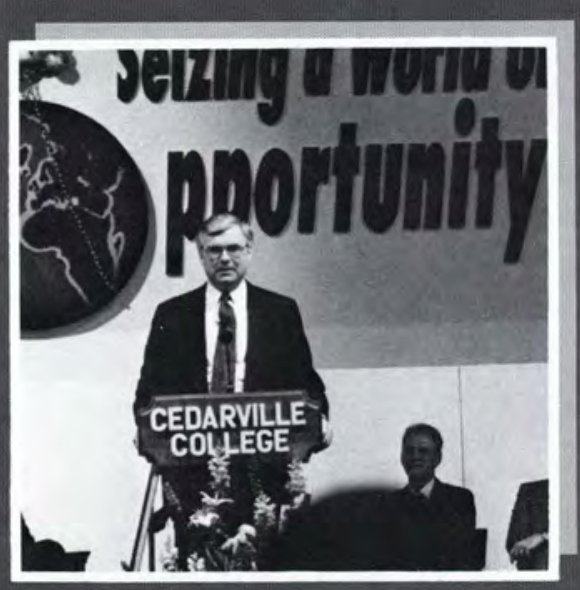

Special

Chapels

Page 56 


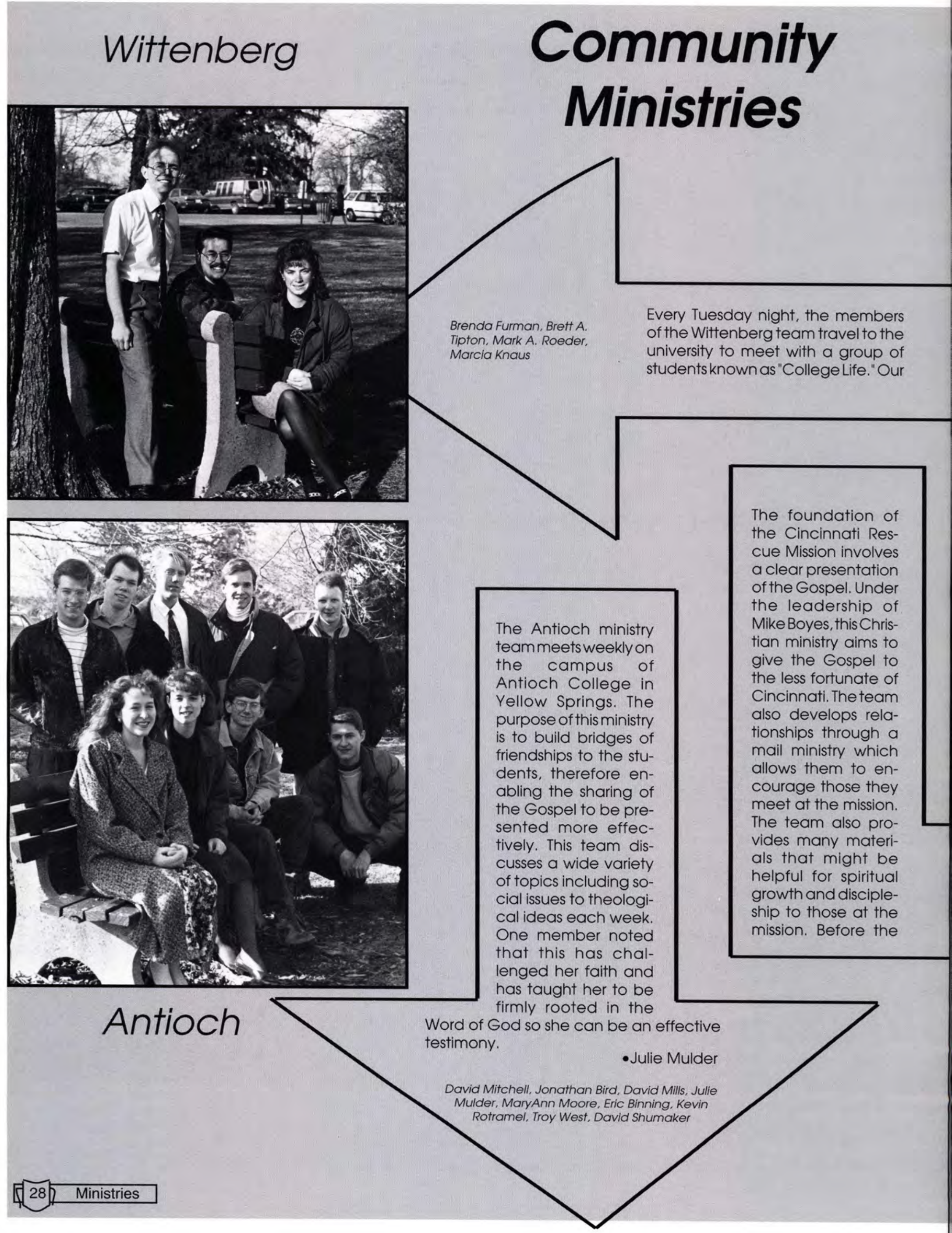




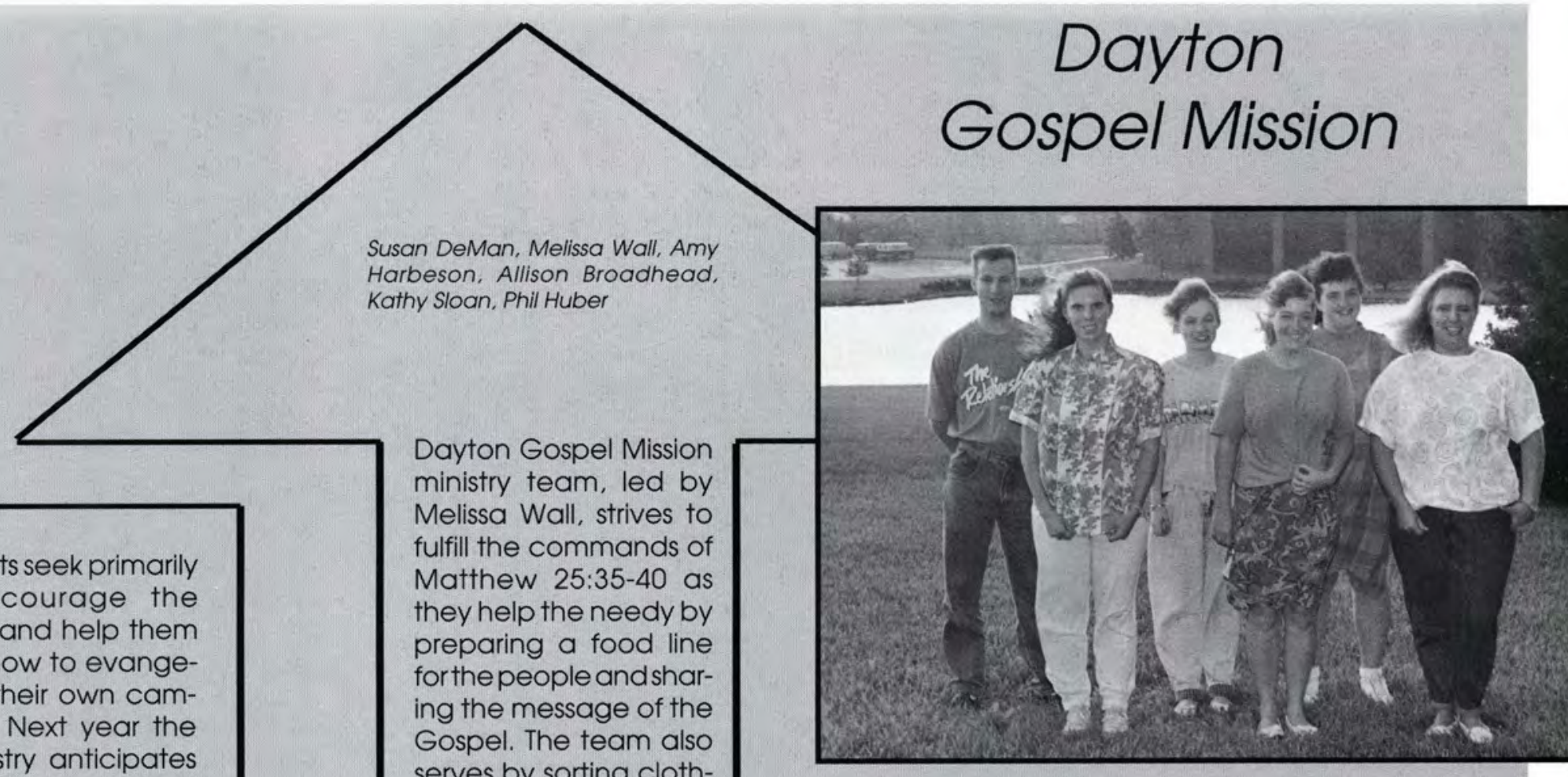

students seek primarily to encourage the group and help them learn how to evange-

lize their own campus. Next year the ministry anticipates a change in format in which members will actually be doing more of the evangelistic work as well.

mail ministry or the materials can be effective, however, the team must befriend the people and show them the deep love of God.

-Meredith Clements serves by sorting clothing, making small repairs, and cleaning. The team sings, teaches Biblestories, andspends time with the children, mindful of the verse: "Inasmuch as ye have done it unto one of the least of these My brethren, Ye have done it unto Me." 


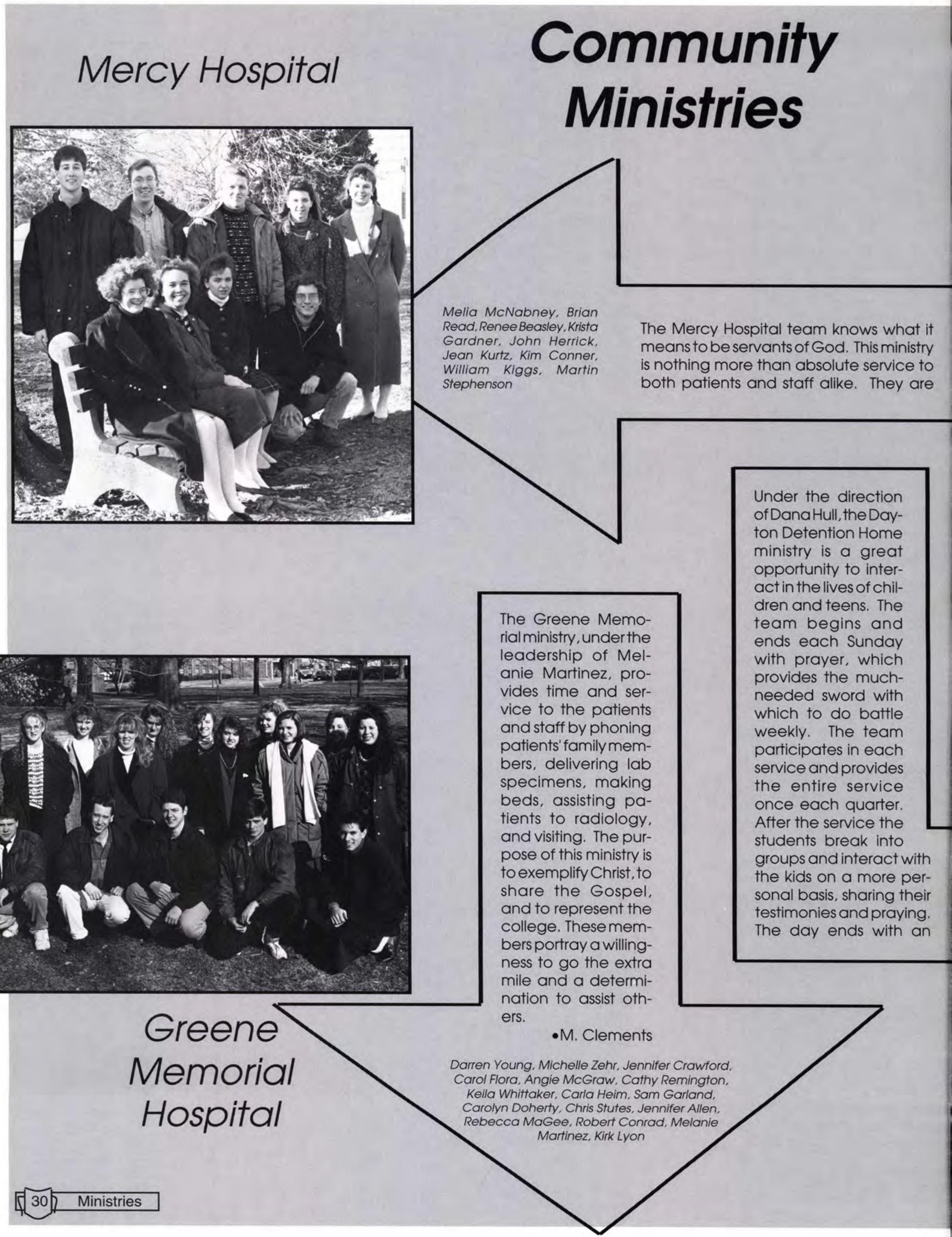




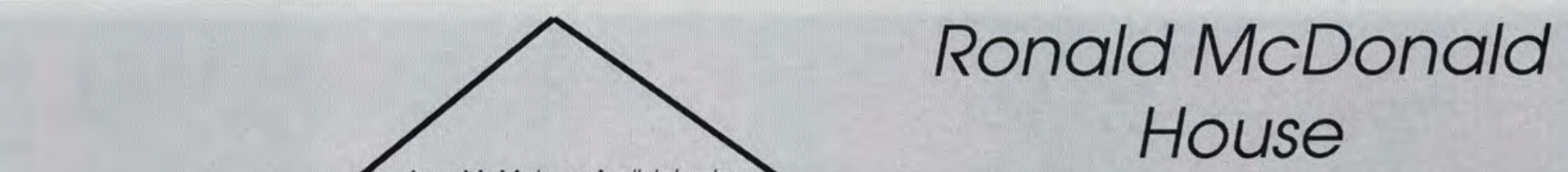

responsible for helping the nurses accomplish things that they do not have time to do such as

delivering flow-

ers, passing out food trays, and running medical records to offices. Under the direction of Jean Kurtz, the ministry team members must possess a positive attitude to serve in an atmosphere where there is stress on the part of the hospitalstaff and pain and depression on the part of the patients.

-M. Clements

Amy McMahon, April Johnston Apryl Hoover, Christine

Hahnenstein, Jena Winters, Jennifer Fortner, Carrie Grayson

Eliza Gromko, Jen Skiles, Jen

Shuler, Heather Peteres, Faith Johnston, Shelly Baesen, Cathy Hahnenstein

The Ronald McDonald House is a place for parents of a terminally ill child to stay while he or she is in the hospital. This team meets the needs of these parents both emotionally and spiritually by simple gestures of cooking meals or watching other children during visiting hours. A kind word of encouragement is sometimes a great help. Under the leadership of Sheila Dillon, this differs from most ministries, but is equally rewarding. -M. Clements

activity such as basketball, football or a variation of dodgeball.

-M. Clements

James Geise, Jon Varner Steve Hornbuckle, Allison Knowles, Tiffany Beheler. Laura Funsten, Abby Boone, Tonya Templeman, Kayrn Wyman, Janna Ferner, Jon Gudeman. Luman Strong. Todd McQueen Harold $G$. Edington, Mike Gustafson

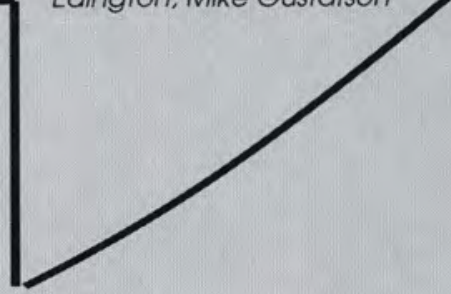

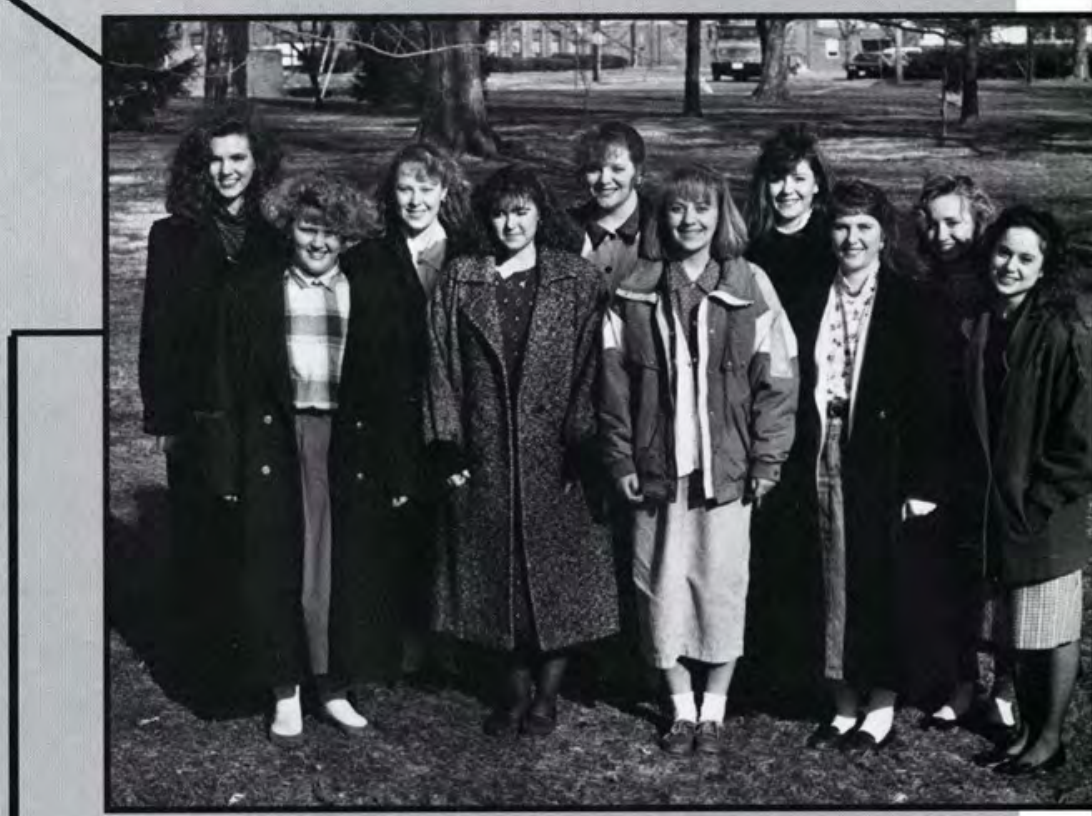

\section{Ronald McDonald} House 


\section{Greene County Jail}

\section{Community Ministries}

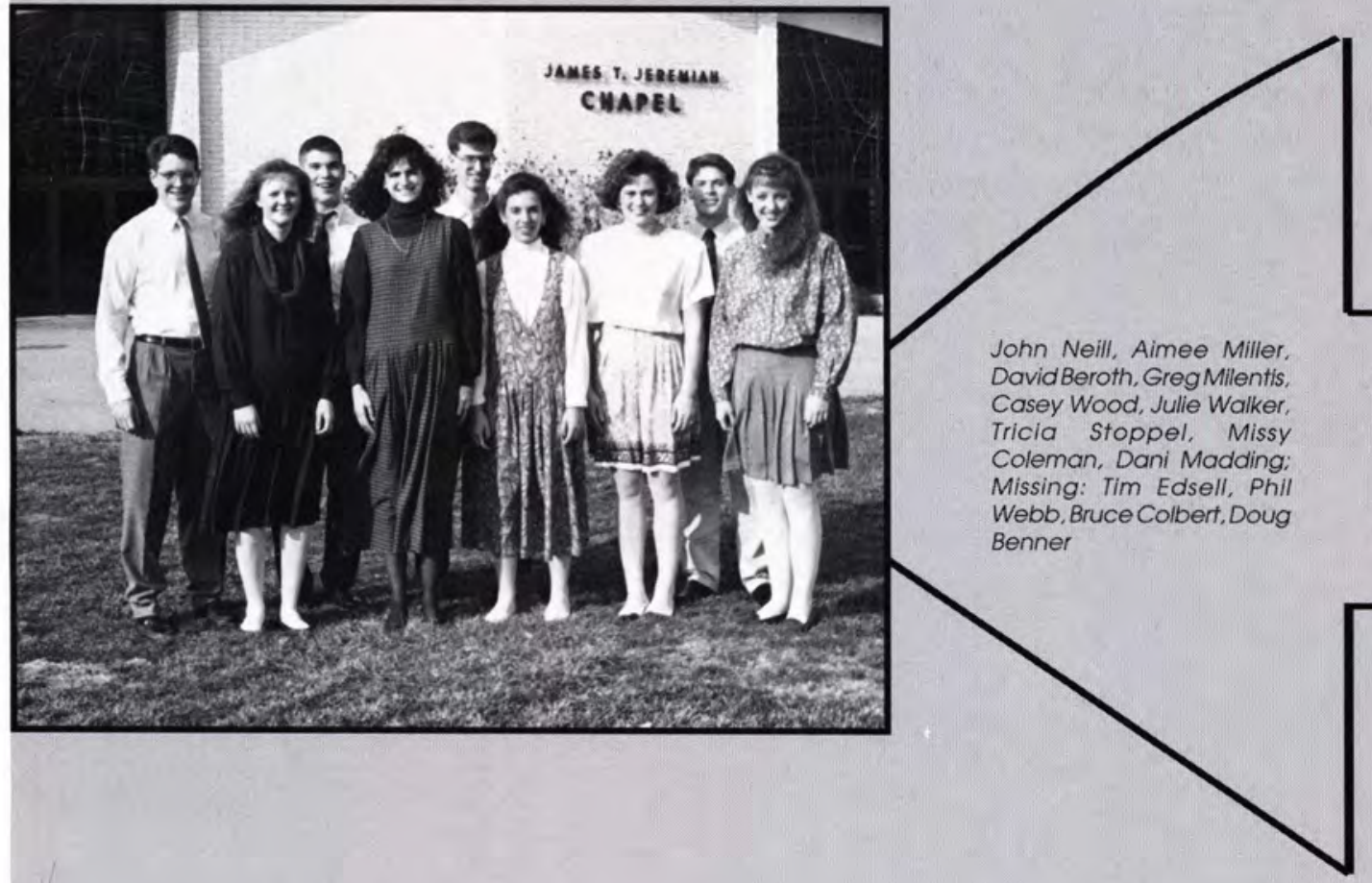

Under the leadership of Lori Shaw, the Greene County Juvenile Court ministers to the youth in Xenia and the surrounding area. This ministry team seeks to give the Gospel to the teenagers who have committed some sort of crime in Greene County. These individuals usually come from broken homes and need the attention of a Christian who will accept them as they are. The teens with which the ministry team comes in contact are very receptive to the Cedarville students and many have come to know Christ through them.

-Meredith Clements
EverySundaymorning, students travel to the Mueller Home in Springfield to work with the individuals who live there. The students sing and review memory work with the ones who are able to speak. The members of this team feel that it is a blessing to beapart of this ministry and to see the people there grow in the Lord as they minister to them. Keith Hurt, the team leader, said: "Ilearned through this ministry that everybody has gifts from God and can use them to reach people for the Lord.

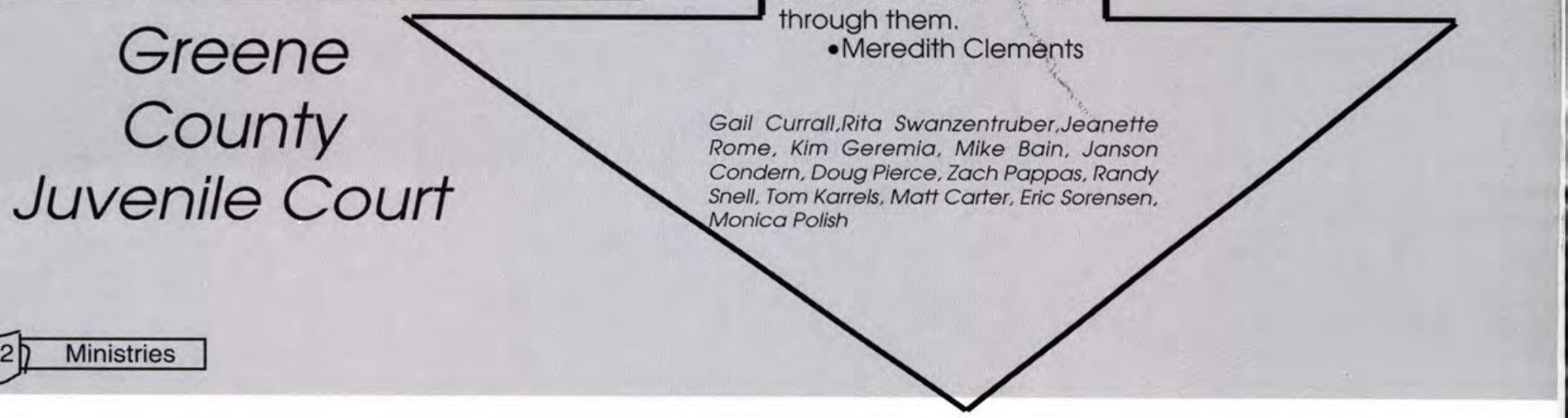




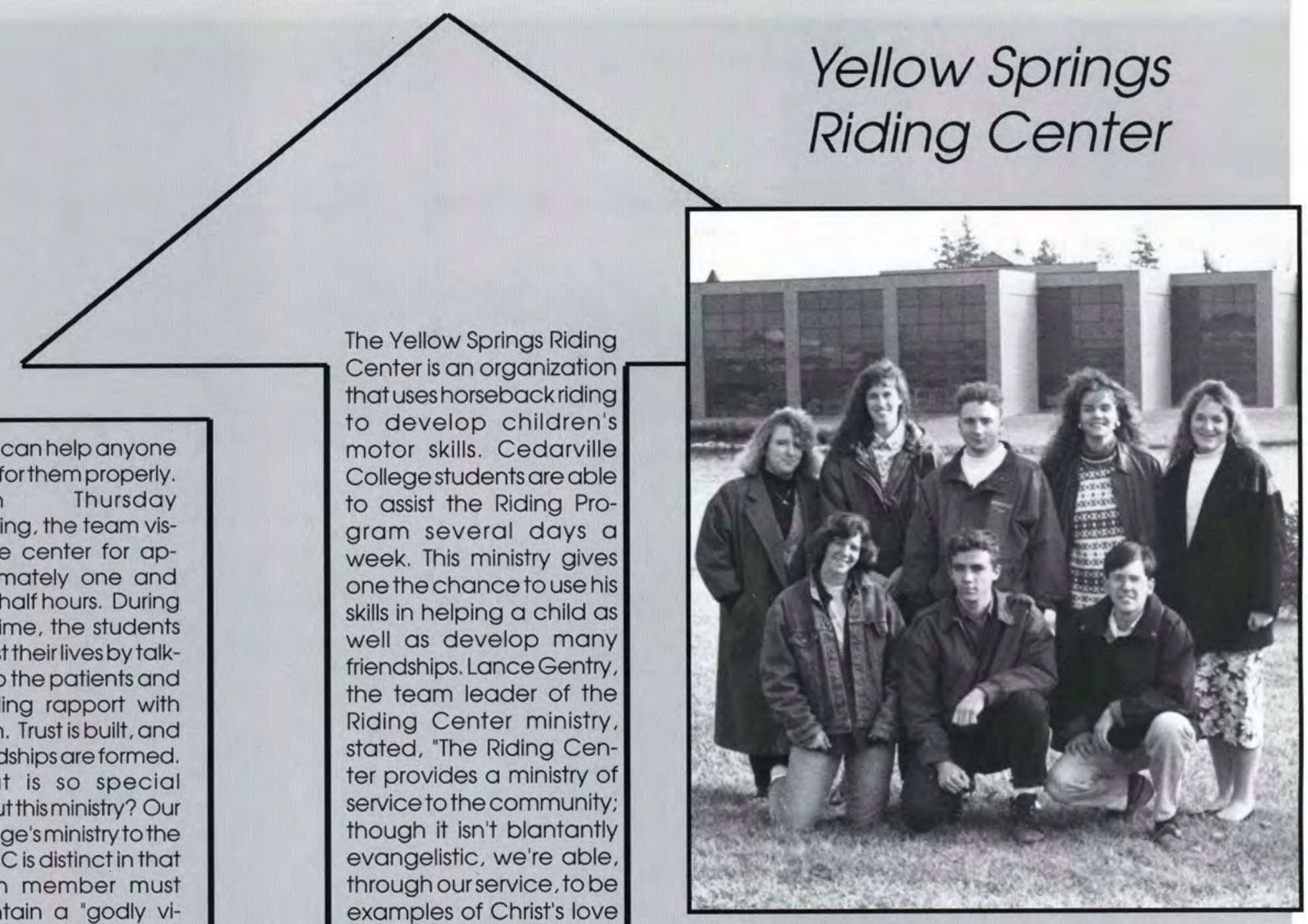

does can help anyone care for them properly. Each Thursday evening, the team visits the center for approximately one and one-half hours. During this time, the students invest their lives by talking to the patients and building rapport with them. Trust is built, and friendships are formed. What is so special aboutthisministry? Ou college'sministry to the $\mathrm{DMHC}$ is distinct in that each member must maintain a "godly vision"-- that is, an outlook which places prime importance upon the heart of each person and loves him no matter what.

- Karla Warnken grandparents. The old mix with the young in a way that is sure to put a smile on the face of Jesus.
The Yellow Springs Riding Center is an organization that useshorseback riding to develop children's motor skills. Cedarville Collegestudents are able to assist the Riding Program several days a week. This ministry gives one the chance to use his skills in helping a child as well as develop many friendships. Lance Gentry the team leader of the Riding Center ministry stated, "The Riding Center provides a ministry of service to the community; though it isn't blantantly examples of Christ's love as shown in I Peter 2:12." - Julie Mulder

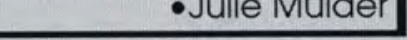

\section{Riding Center}

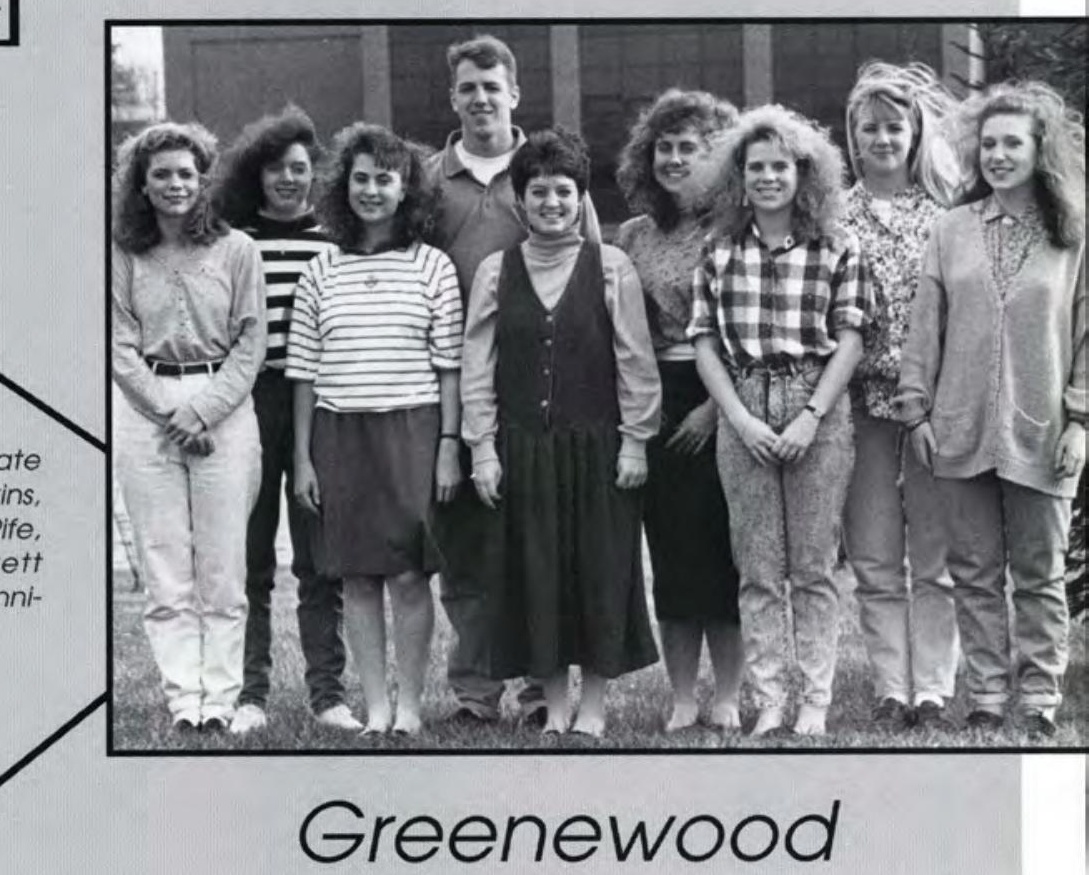

Michelle Yates, Lori Kate Lowenhar, Debbie Perkins, Laura Cambell, Mindie Rife, Jodi Woodhams, Brett Dyson, Shelly Sutton, Jennifer Gozdan.

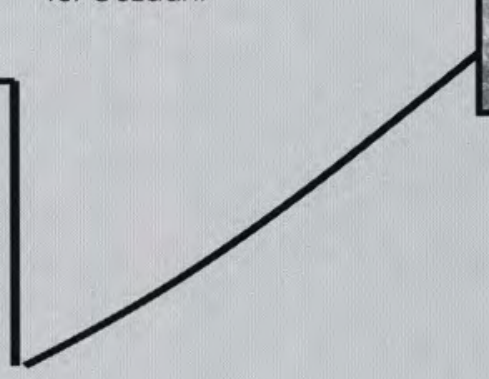
Manor 


\section{Heathergreene I}
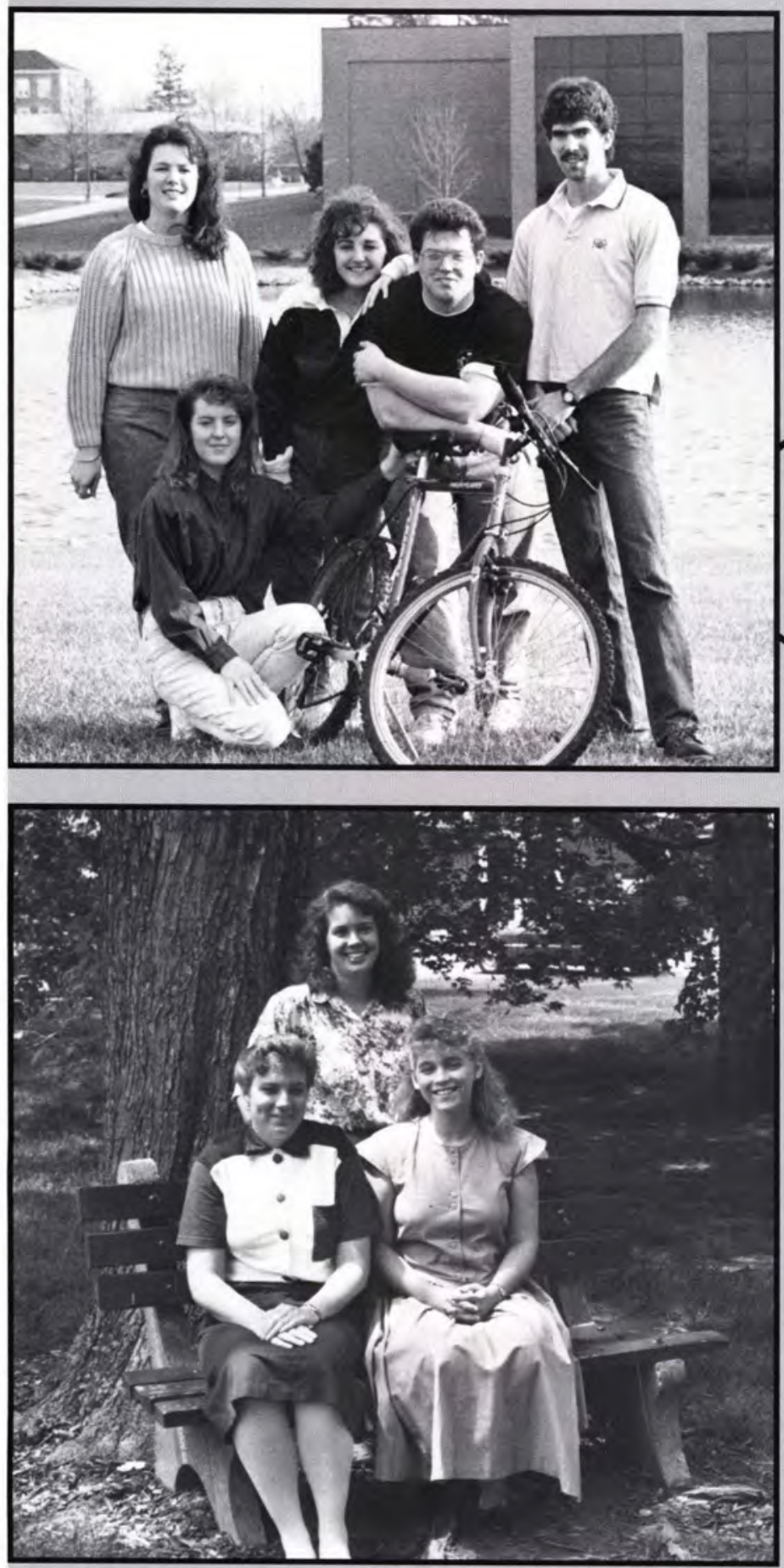

Heathergreene II

\section{Community Ministries}

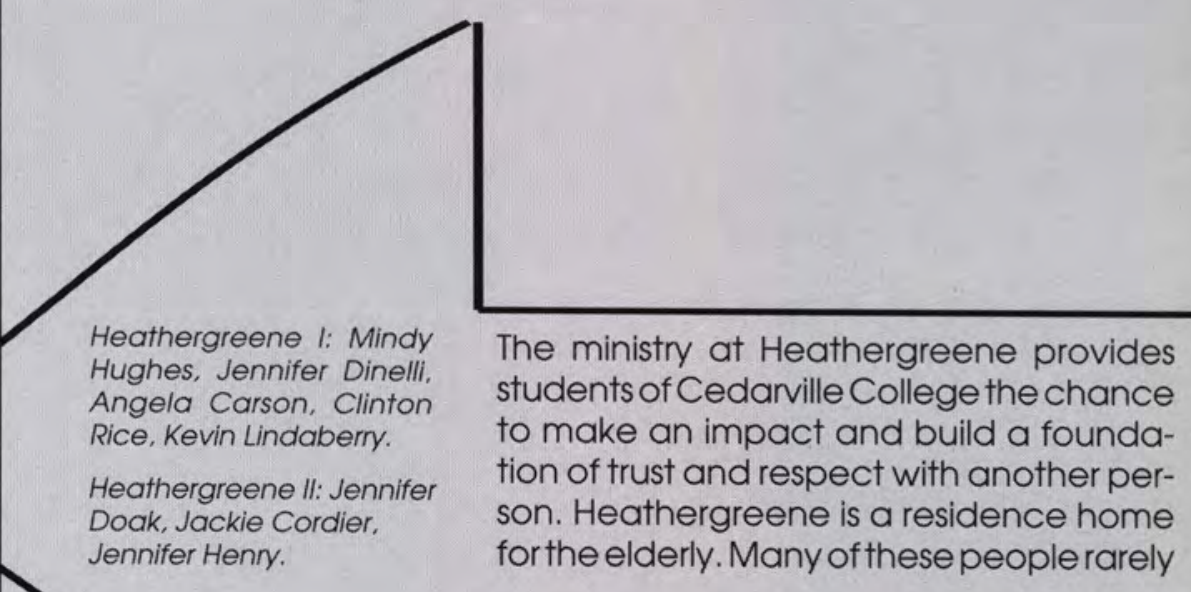

Bristol House, located in Springfield, Ohio, is another one of the ministries that is available to Cedarville students. The Bristol House is a Nursing Home for the elderly and the team visits with the residents once a week, one on one, to minister to them. They do this by talking, listening and being a friend to the residents. Mary Birley, the ministry leader, believes that the goal of this ministry team is to be a testimony for the Lord to the residents.

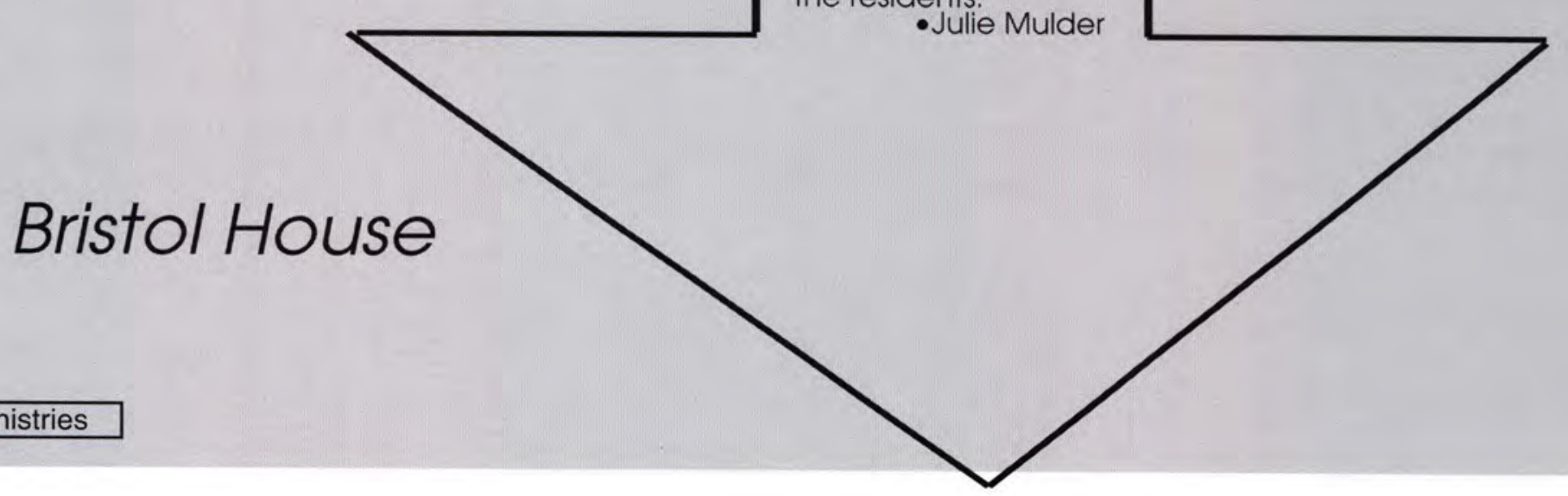

Cranky old Edna Johnson cracked a 97 year old smile as 1 informed her that we must go outside to preview spring this warm, bright February Saturday on which Cedarville students visited. Except for checkups at the hospital next door, she had barely left her fourth floor room atSt. John's in five months. Bad weather, frailty, and loneliness had kept her in previously, but not today. I hunted down a wheelchair and away we went, buzzing down the hall as nurses exclaimed. "Johnson! Where are you headed?" She would answer: "The devil doesn't want me, God's not ready for me, but today l'm going outside."

We wheeled and whirled all over St. John's pretty 


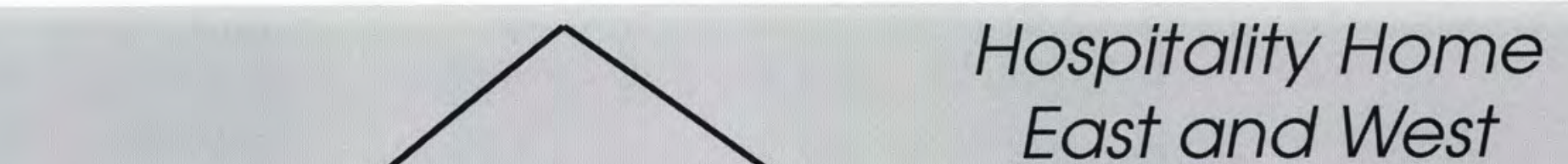

receive visits, and therefore depend heavily on Cedarville students to call on them. Each member of this Christian ministry concentrates his efforts on building friendships with two to five people. This technique allows the student to focus on getting to know every side of his friend; as a result, he can better minister and pray for the elderly person. Through these friendships, the students hope to gain the trust of their older friends and be able to present and illustrate the Gospel through their lives. They not only wish to tell of God's love but also to demonstrate and portray the love of God.

$$
\text { - Janet Payne }
$$

Here at the Hospitality Home East and West, students minister to the elderly on a weekly basis. Overtime the students find that the time spent with their new found friends changes from an obligation to a desire. They smile and eagerly await to hear the words, "I love you" from a friend. Strong friendships are built and sometimes last even when the Cedarville Collegestudent graduates.

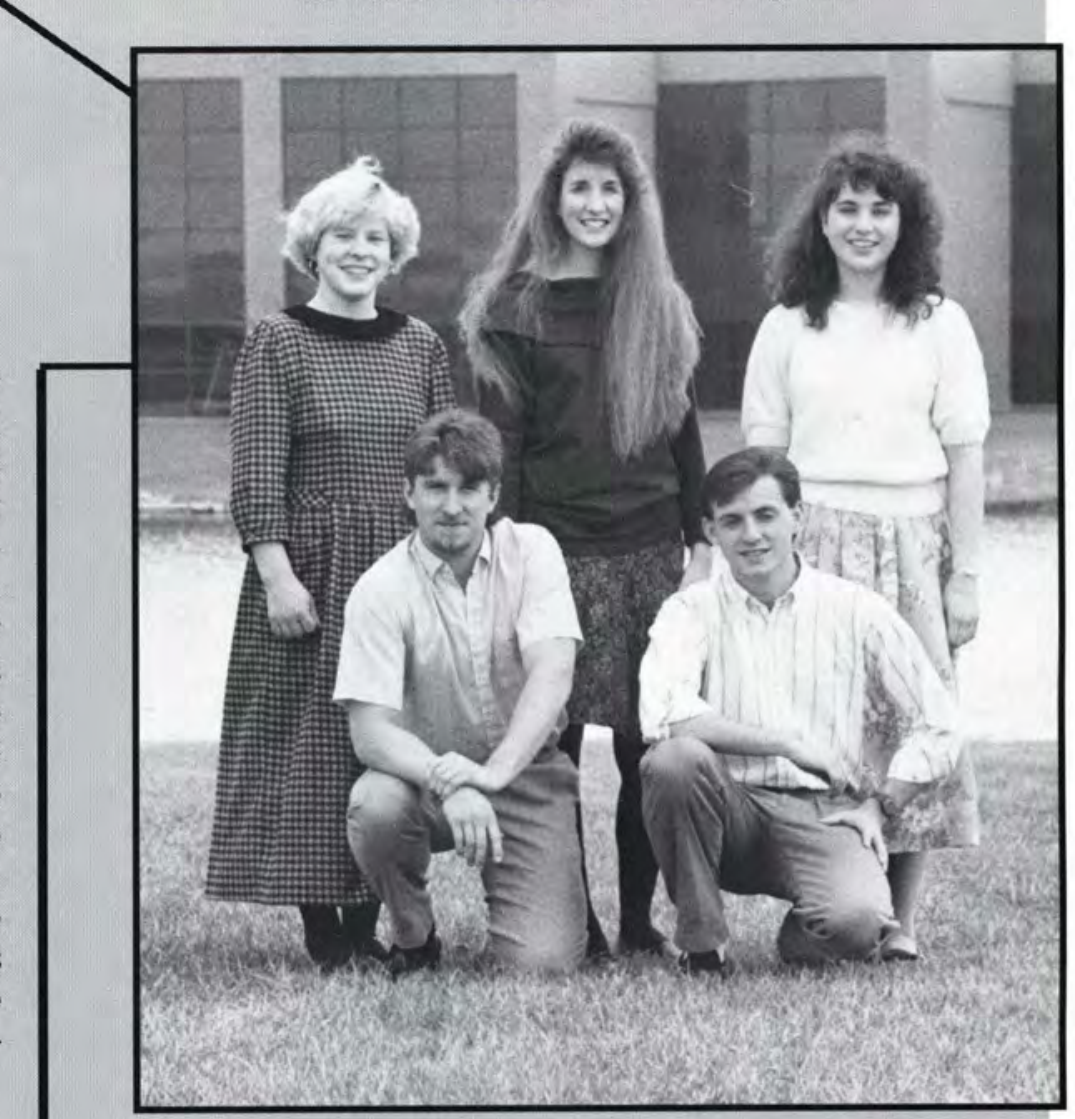

green grounds, talking about trees and her country childhood and dancing; she always said, "I would rather dance than eat!" I asked her if she would teach me a couple of steps, but she didn't think so that day. Soon she pulled her sweater closer and declared she was ready to go back in. "I understand," I answered, "We wouldn't want to get sunburned. "She grinned and asked me to come again next week.

-Rachel M. Wolford ( J. Foster)
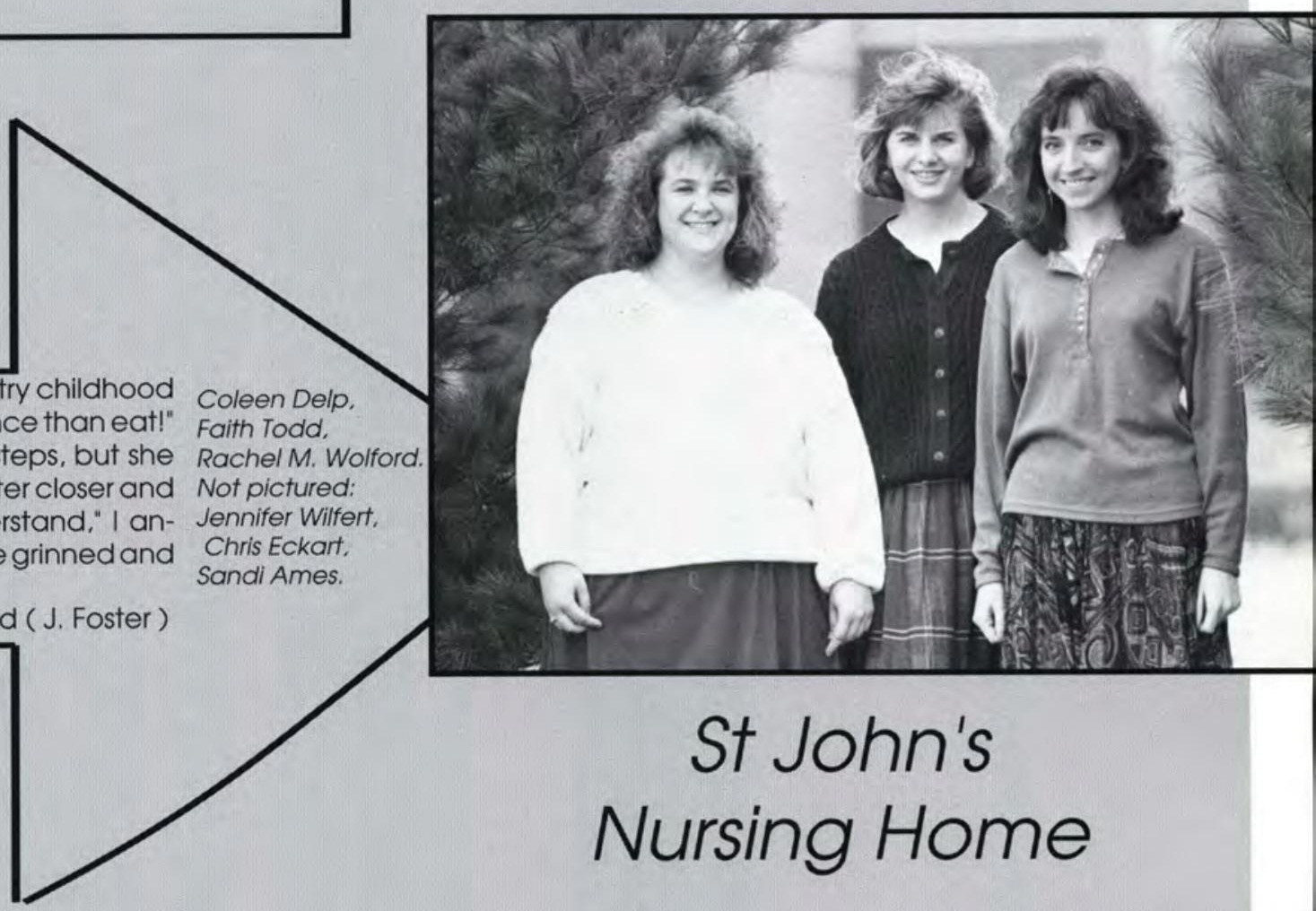


\section{Hillside \\ Independent Living}
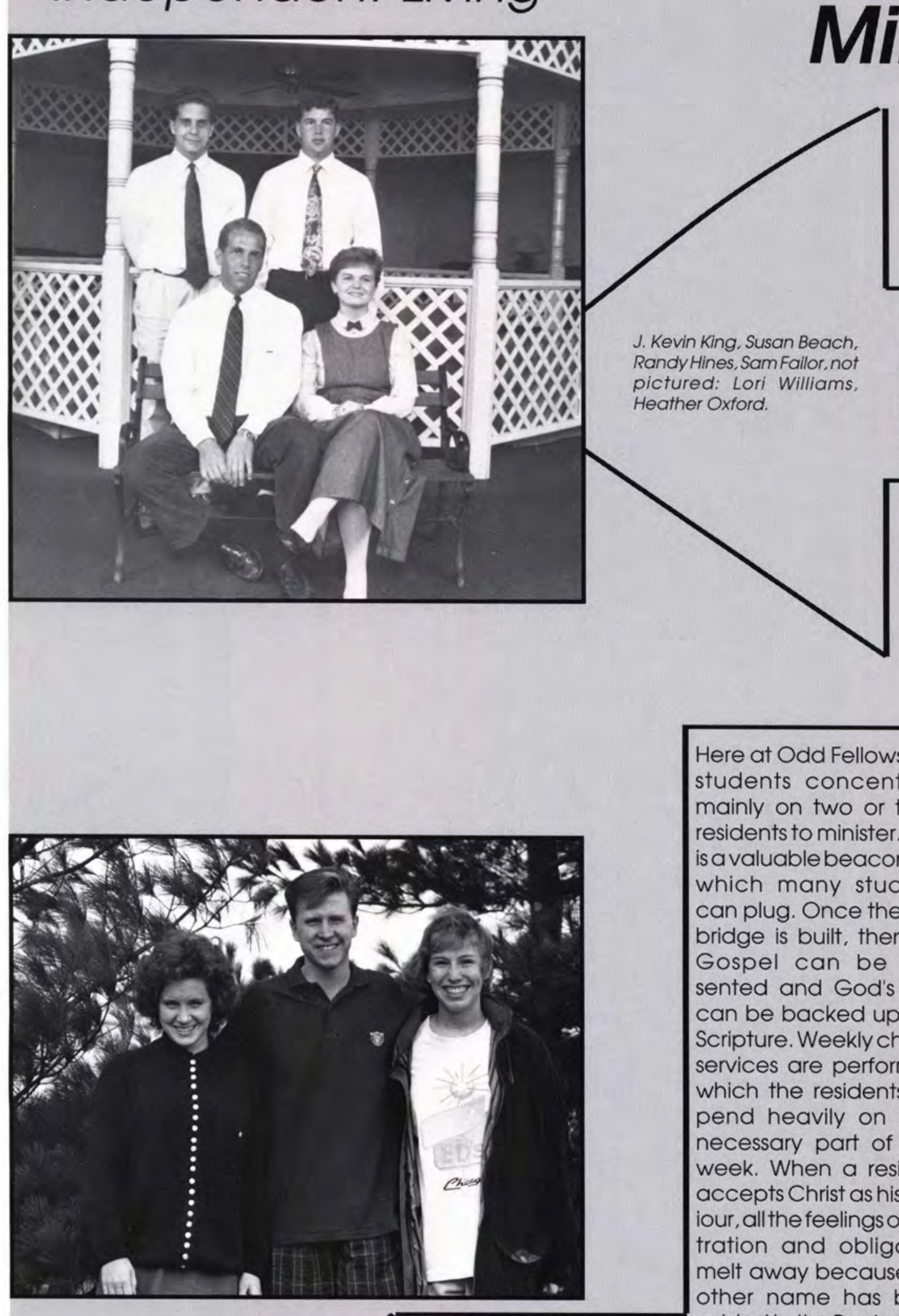

Odd Fellows

\section{Community}

\section{Ministries}

At Hillside Independent Living, students have the opportunity to build into another person's life, mainly an older person. With age comes wisdom and experience, so students gain not only a friendship with the
Here at Odd Fellows, the students concentrate mainly on two or three residents to minister. Trust is a valuable beacon into which many students can plug. Once the trust bridge is built, then the Gospel can be presented and God's love can be backed up with Scripture. Weekly church services are performed, which the residents depend heavily on as a necessary part of their week. When a resident accepts Christ as his Saviour, all the feelings of frustration and obligation melt away because another name has been added to the Book of Life.
Every Sunday morning the faithful members of this Christian ministry headfor Springfield to the Knights of Pythias nursing home. During their visit they mingle with the residents, talk with the staff, and hold a church service. They often start out singing hymns; have a prayer time; and the group leader speaks on a favorite Bible passage. Following this service, the college students have a chance to talk oneon-one with the residents of this nursing home. Often, lasting 


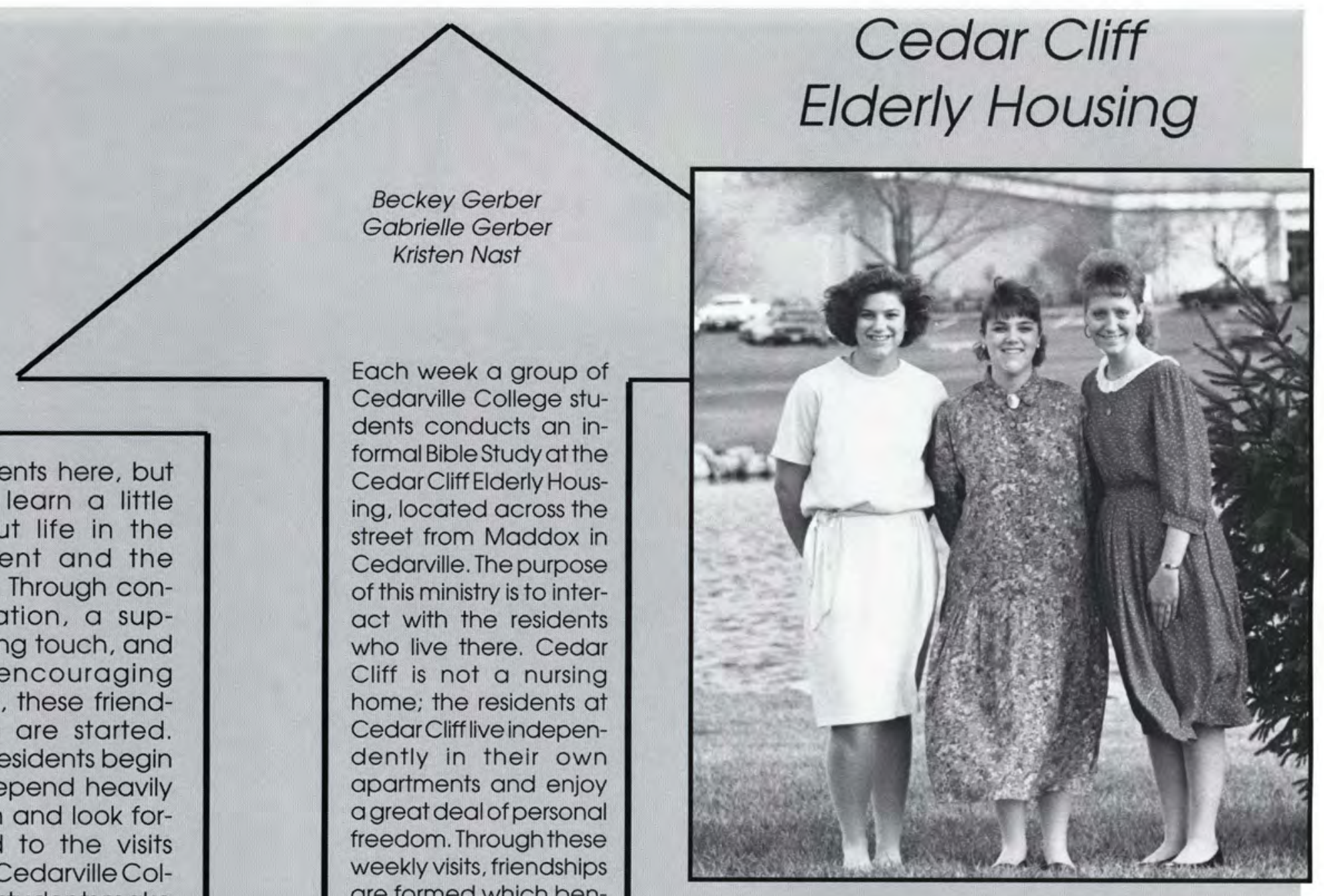

residents here, but also learn a little about life in the present and the past. Through conversation, a supporting touch, and an encouraging smile, these friendships are started. The residents begin to depend heavily upon and look forward to the visits that Cedarville Collegestudents make that brighten up their lives.

Each week a group of Cedarville College students conducts an informal Bible Study at the Cedar CliffElderly Housing, located across the street from Maddox in Cedarville. The purpose of this ministry is to interact with the residents who live there. Cedar Cliff is not a nursing home; the residents at Cedar Cliff live independently in their own apartments and enjoy a great deal of personal weekly visits, friendships are formed which benefitboth the young and the old.

\section{- Julie Mulder}

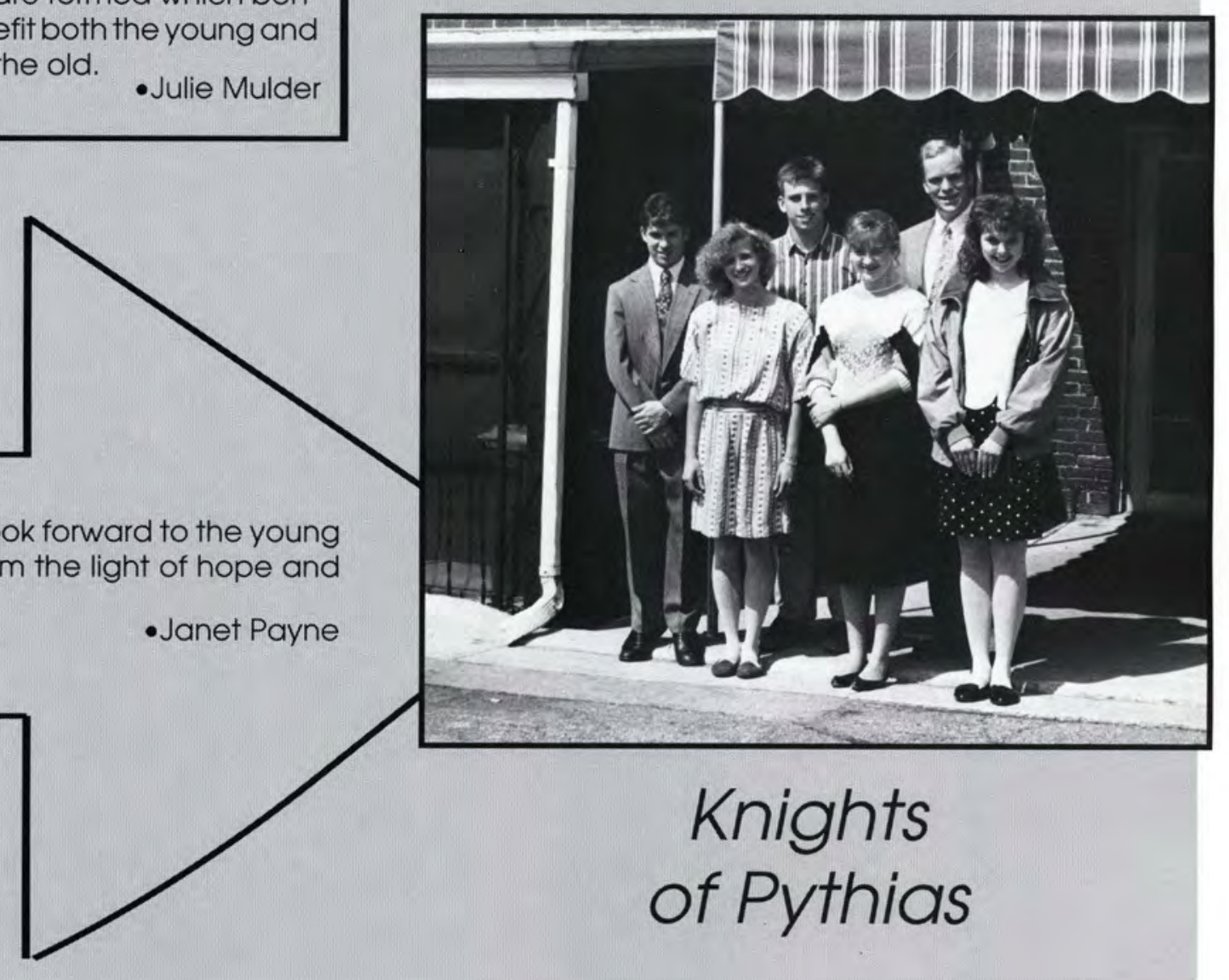

friendships are made and the people look forward to the young people returning and bringing with them the light of hope and the love of God. 


\section{Open Heirs}

\section{Community Ministries}

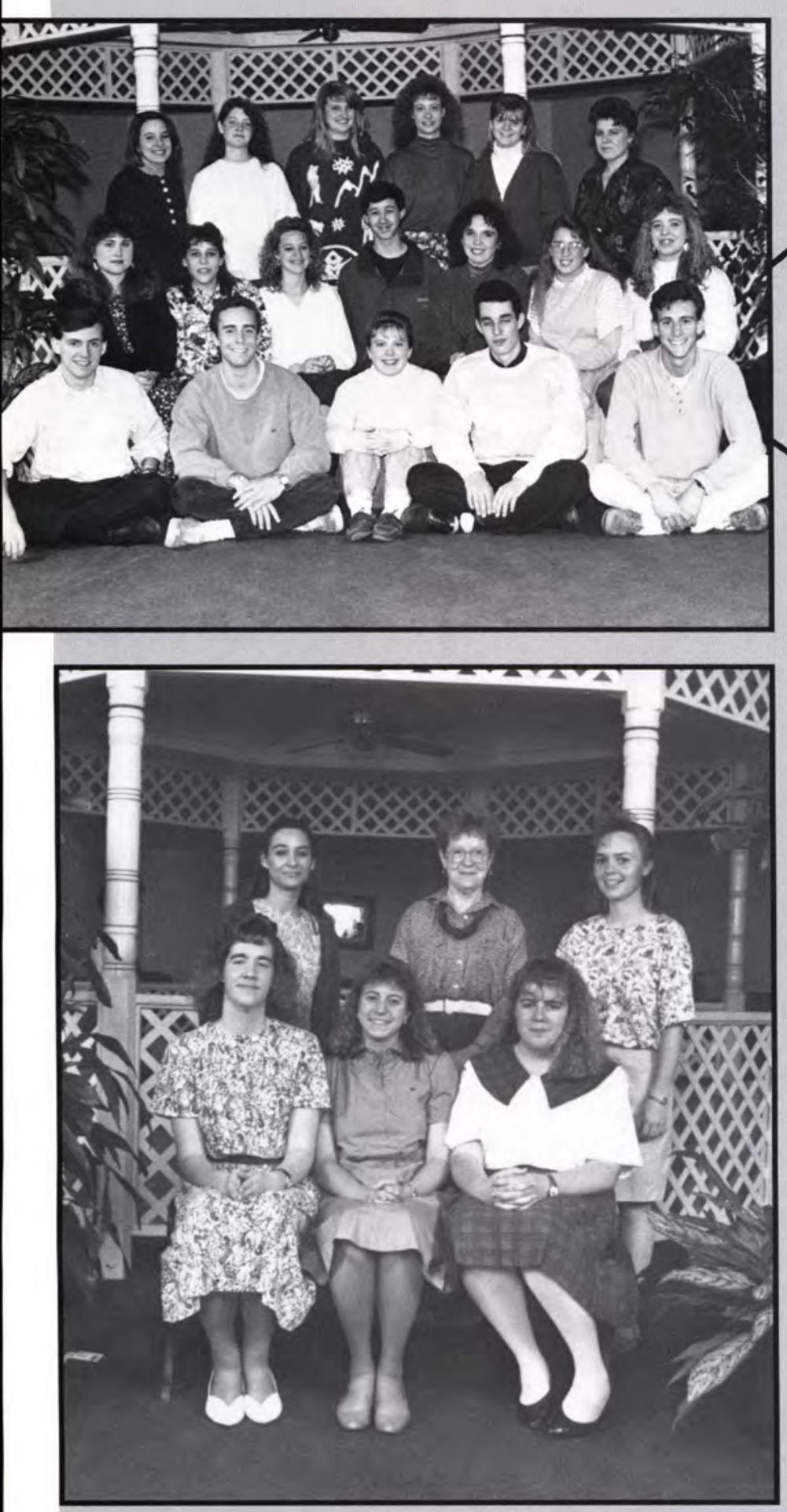

Joe Slavens, Dan Clifford Cyndi Mott, Troy Hamilton, Mark Irving. Kathryn Haygan, Tiffany Trimble, Cindi Carson, Nathan Ho, Katie Stull, Amy Geiger. Vanessa Farley. Nicole Grizenko, Becky Sturrock, Mary Jo Brooks, Lynn Walter, Sandy Hickox.

To see the pain in the eyes of a person, to hurt because of another person's rejecting the gospel, to experience the joy of a new Christian's faith with them, these are all real images seen weekly on Open Heirs.

The mission of Open Heirs can be seen Michelle Nelson. through the testimony of Johnny. One night,

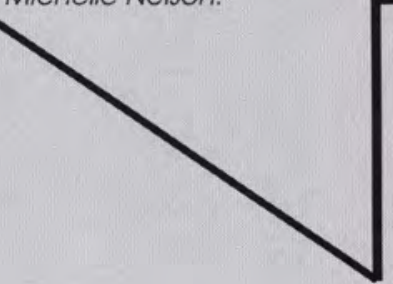

In today's society where graduate school seems almost to be a given, some adults have not even had the opportunity to completehighschool. At the county vocational school, Cedarville College students are able to help area adults obtain their GED's ( Graduate Equivalent Diploma). Meeting a practical need in people's lives allows students to also meet spiritual needs. Brandon Waltz, director of Christian Ministries at Cedarville. writes, "As relationships are built, opportunities

Bible Clubs

Seeking to reach area gospel Bible Club leaders meet with day a week. Meetings nal snacks. In admeetings, members are asked to spend kids. As their group verse, Bible club leaders have chosen Luke 18:16. 


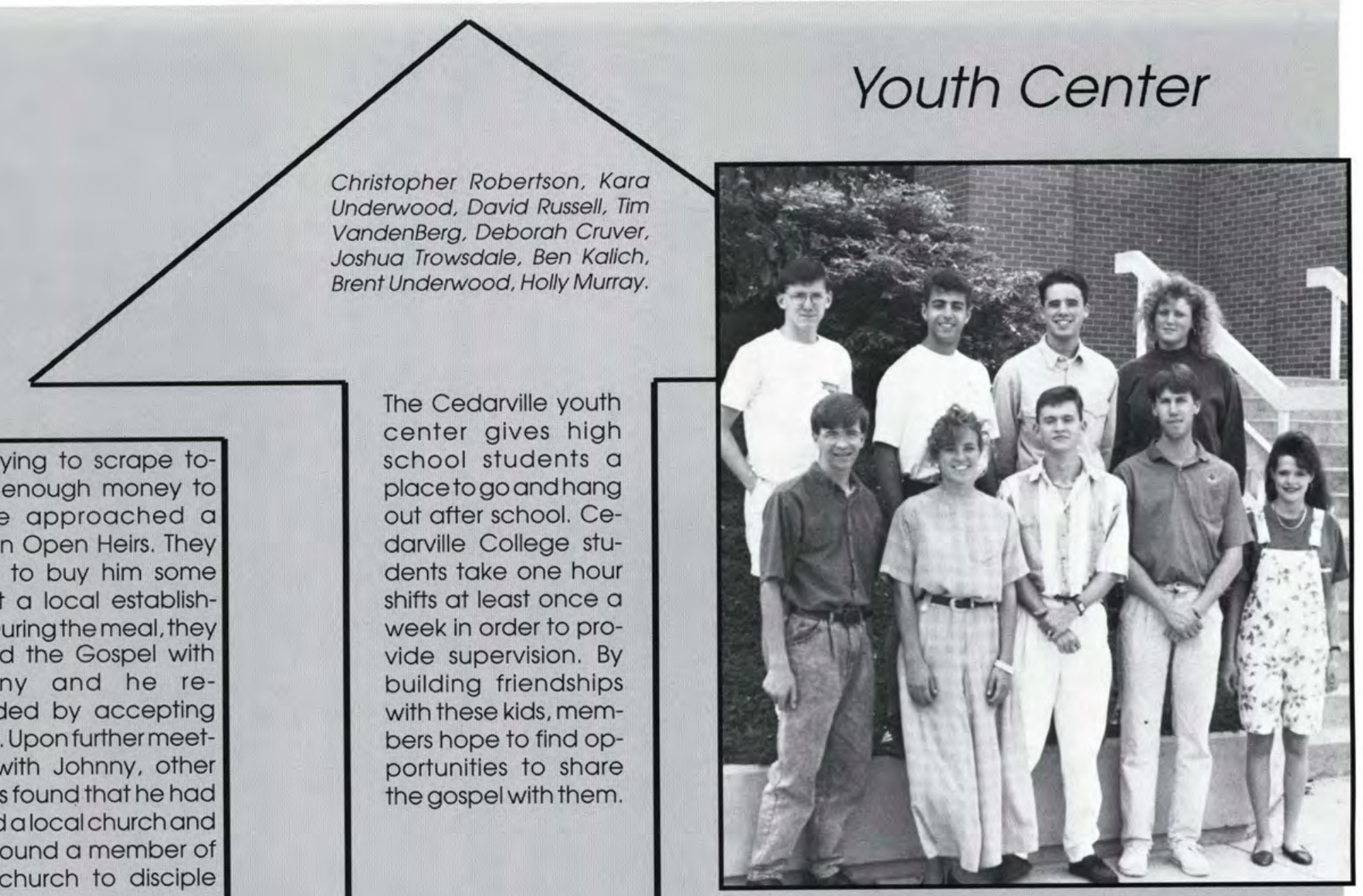

while trying to scrape together enough money to eat, he approached team on Open Heirs. They offered to buy him some food at a local establishment. During the meal, they shared the Gospel with Johnny and he responded by accepting Christ. Upon further meetings with Johnny, other teams found that he had joined a local church and had found a member of that church to disciple him.

Whether in downtown Cincinnati, Vine Street, near the University of Cincinnati, or in the heart of Columbus, Open Heirs goes on the front lines of the spiritual battlefield by taking the good news to the streets.

- Jon Heflick (Jim Foster)

for one-on-one evangelism are established through this ministry."

- Jim Foster
The Cedarville youth center gives high placetogoandhang week in order to provide supervision. By building friendships with these kids, members hope to find opportunities to share the gospel with them.

\section{Youth Center}

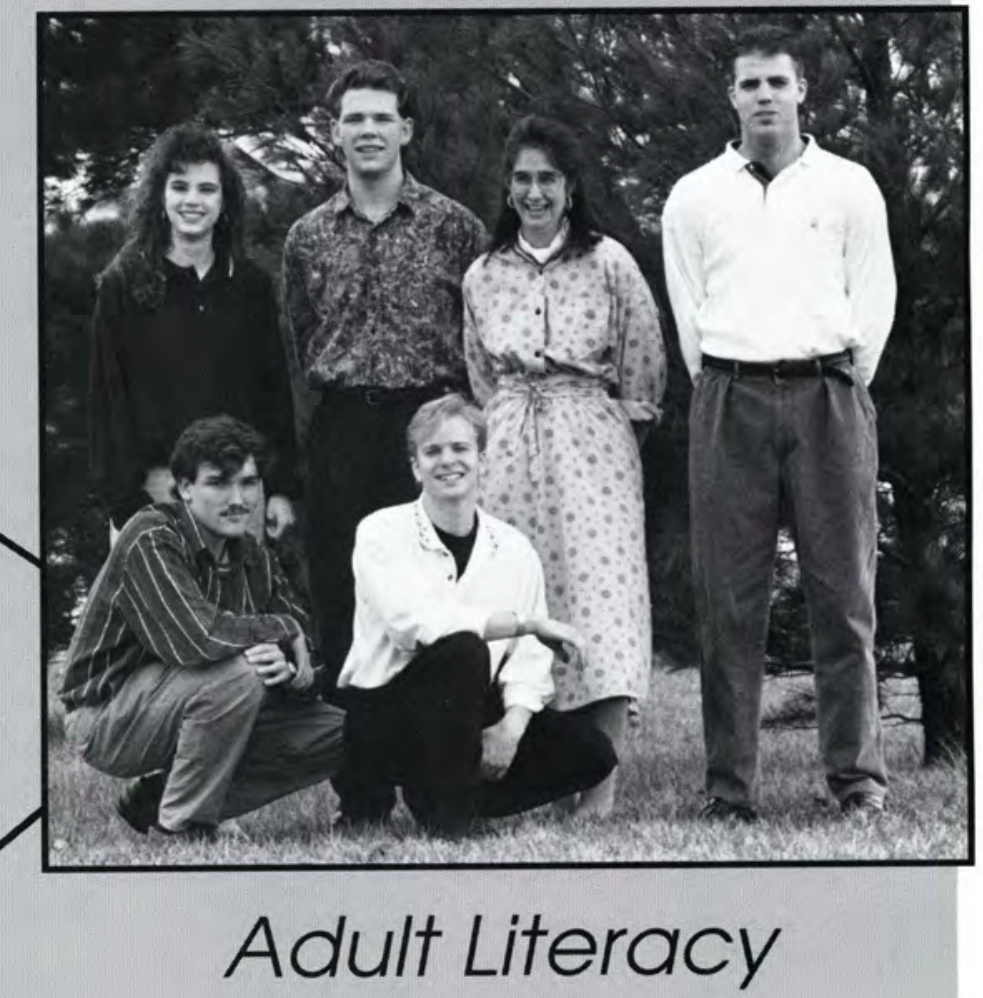

Eric Phillips, Brian Longfello, Melissa Freeman, John Gouden, Erin Ward, Matt Cutler.

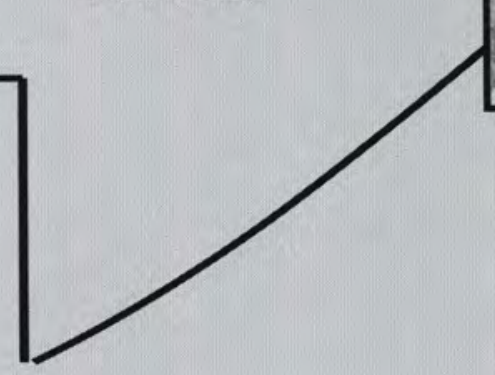




\section{Miami Valley \\ Crisis Pregnancy Center}

\section{Community
Ministries}

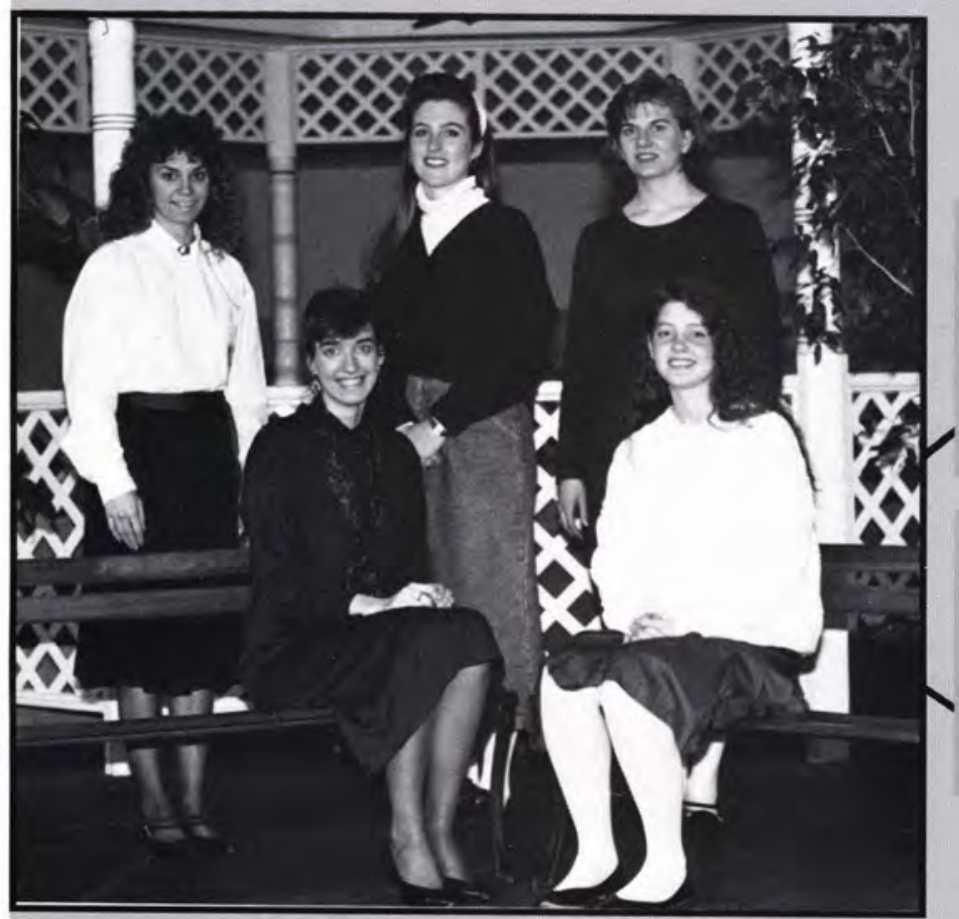

Miami Valley: Holly Moor. Faith Todd, Holly Leadbeater, Becky Stevens, Becky Strrock Kristine Post, Shelley Fox Greta Hendrics, Charlene Davis, Laura Rosebloom.

One of my favorite clients at the Miami Valley Woman's Center is one that I've been able to do the most for. She is in her late teens, yet very mature for her age. She wanted the best for her baby, and she wanted to learn as much as she could before the birth. After she took the free pregnancy test, a time was set up for her to come back for follow up (This might include Bible studies, making plans for the baby, or further counseling). We decided to go through a workbook which includes budget planning and other preparation for the baby's arrival. Because this girl's family sup-

Greene County: Laurie Bell. Christina Ash. Michelle Nelson, Karen Boggs. Not pictured: Beth Ann Pickell, Casey Waters, Nikki Musto. Shandy Buffington, Sheri Krody.

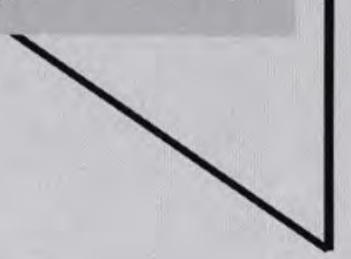

How should you tell someone not to have an abortion? Not to kill her baby? Why should a woman in a crisis pregnancy listen to a Cedarville College student?

Team leader, Kristen Sechrist, writes, "I was petrified the first time I was called to talk to a woman who was considering an abortion. As I stood face to face with a woman who couldn't look me in the eyes, who had two little kids hanging at her sides, all my past training forthe Mosesprojectvanished from my mind. A mother stood before me who needed help, and all I could do was pray. I realized that I couldn't talk her into anything, but God could talk her into everything."

-Kristen Sechrist (Jim Foster)
"Though many of the children of the Ohio Veterans Childrens Home are not orphans, our ministry there includes both teaching and tutoring as a means of looking after the young men and women placed there. Only by keeping our lives from the pollution of the world can we truly influence these who have such a great need for a Savior. Many of them have been severely hurt by those they trust, and it is a great joy for the team to see the healing power of Christ as $\mathrm{He}$ ministers to their pain and softens their hearts."

Jill Prichard, this year's leader of an A.M. team, and Tressa Park, leader of all morning teams this 


\section{Mime}

ported her, we didn't

have to set her up in a supporthome, which we offer when they are needed and available. She attends a support group for pregnant teens which meet twice a month. When the baby is born, she will be able to go to a support group for new moms. She also went through ourmaternity closetand picked out a bathing suit for the summer. After the birth of her baby, she will receive a bag full of diapers, baby clothes, blankets, towels, lotions, toys, and many other baby items. This provides an opportunity for Cedarville College students to minister to the community in a practical way. - Molly Moor (Jim Foster)
The Mime ministry team of Cedarville College communicates God's love without saying a word. This team travels to various churches giving encouragement to the Christians they meetas well as challenging them spiritually. Not only does the Mime team minister to fellow believers, but also they present the Gospel of Jesus Christ to many unsaved. Unbelievers are drawn by such a group because their message is presented in a fashion other than preaching: a simple hand gesture and a facial expression can often penetrate the soul further than any sermon.

-Meredith Clements year, aptly describe the importance of the OVCH-Cedarville College connection. $\mathrm{OVCH}$ houses and schools over 100 girls and boys ages 6-19 who have been physically, sexually, or emotionally abused, in trouble with the law, rejected by their parents, or orphaned. Cedarville College - teams seek to build into the lives of these] children through tutoring, Sunday School. and Youth Fellowship programs. The joy described by Jill and Tressa can only result from constant and committed love demonstrated by willing Cedarville students. - Karla A. Warnken

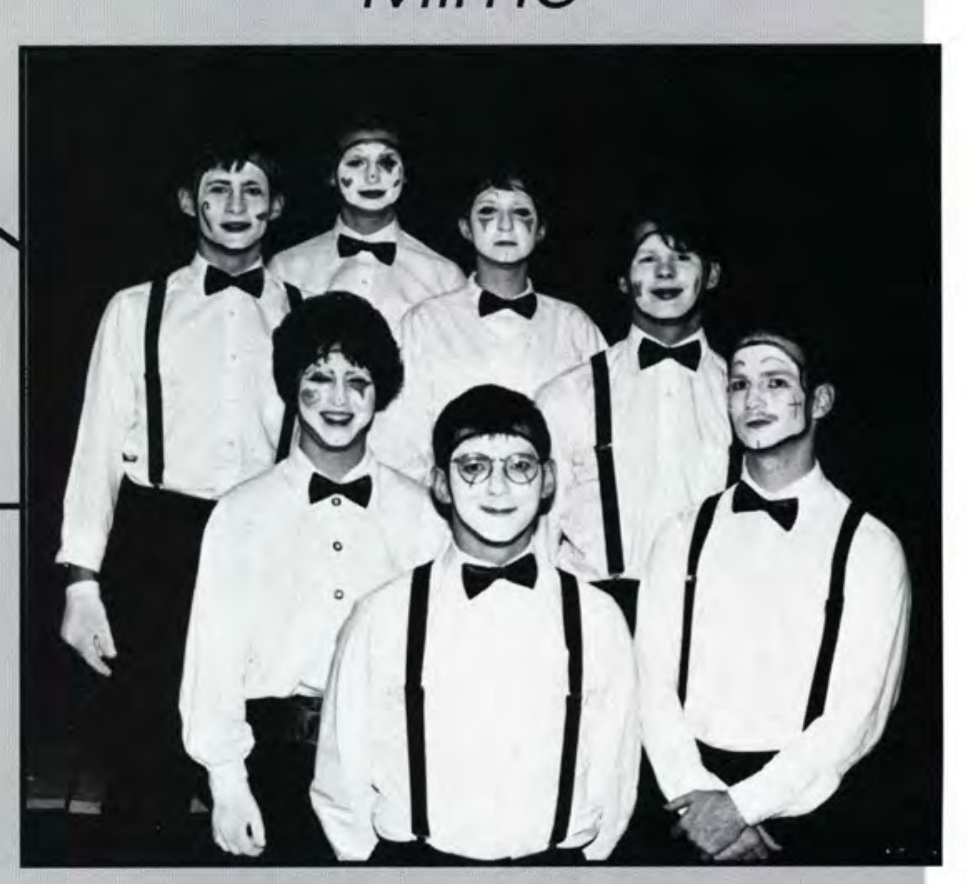

O.V.C.H.

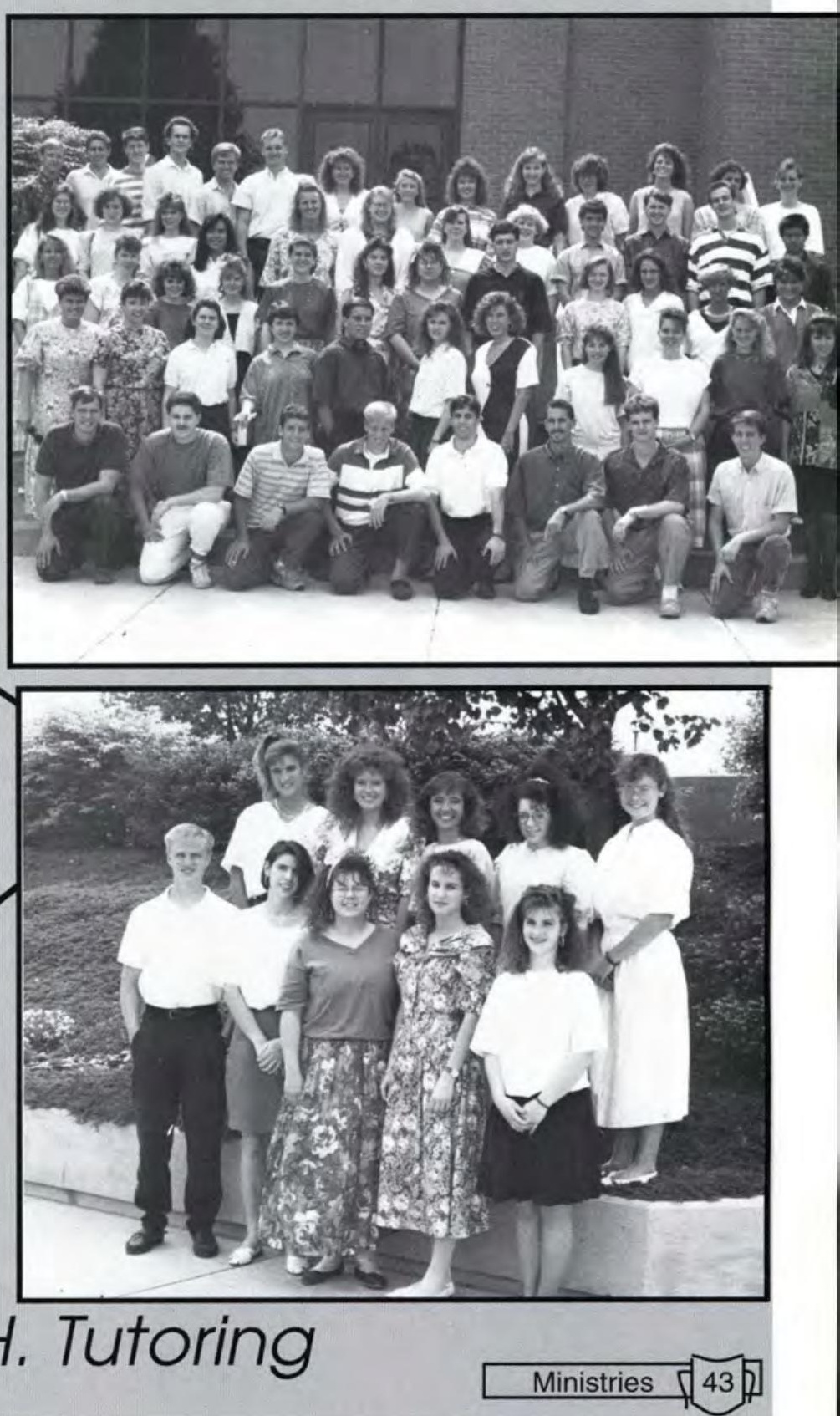




\section{Cedar Kids}

\section{Community Ministries}

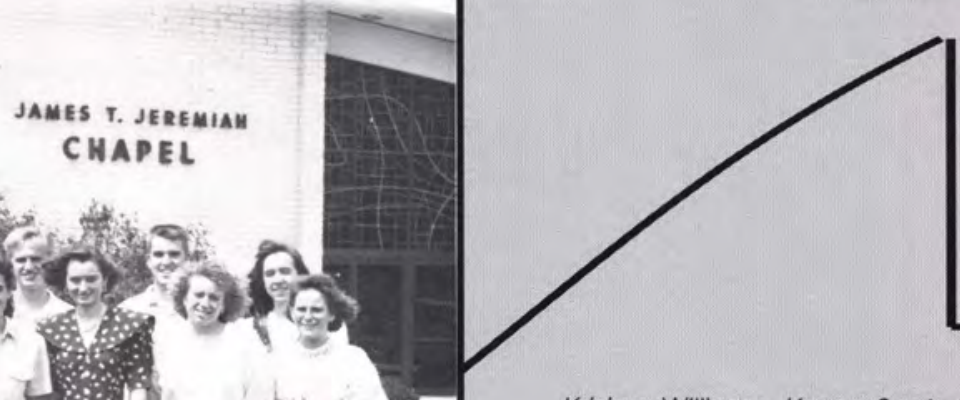

Kristen Williams, Karen Sack, Pamela Sorg, Mary Edwards, Rebecca Gillam, Michelle Profant, Jennifer McNamee, Kim Hubbard, Mike Vrbanac, Tim Gardner, Phil Calvert, Pau CedarKids

Dean, Brian Blind, Georgia Hickman is an outreach to kids in the

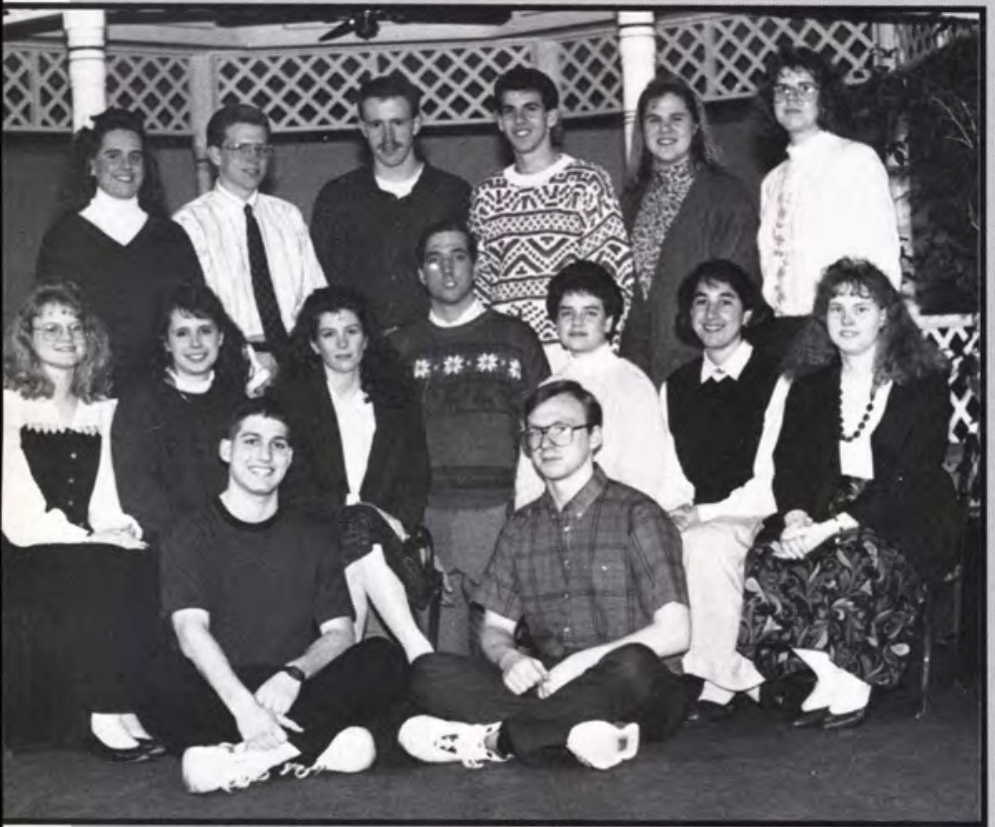

Providing snacks, making crafts, tellingstories, and giving devotions are only a few of the many things in which members of Awana teams are involved. Once a week, members of this ministry take time out of busy schedules to $\mathrm{min}$ ister to kids in area churches. $\mathrm{Be}$ cause over half of the children who come are not actually church members, the Awana program benefits them. -Mindy Boone
Members of the College Partners act as big brothers orbigsisters to students at Cedar Cliff Elementary. Seeking to give these kids positive role models and to build into their lives, members spend time each week with these children. This year they were to find something they were good at and
Awana

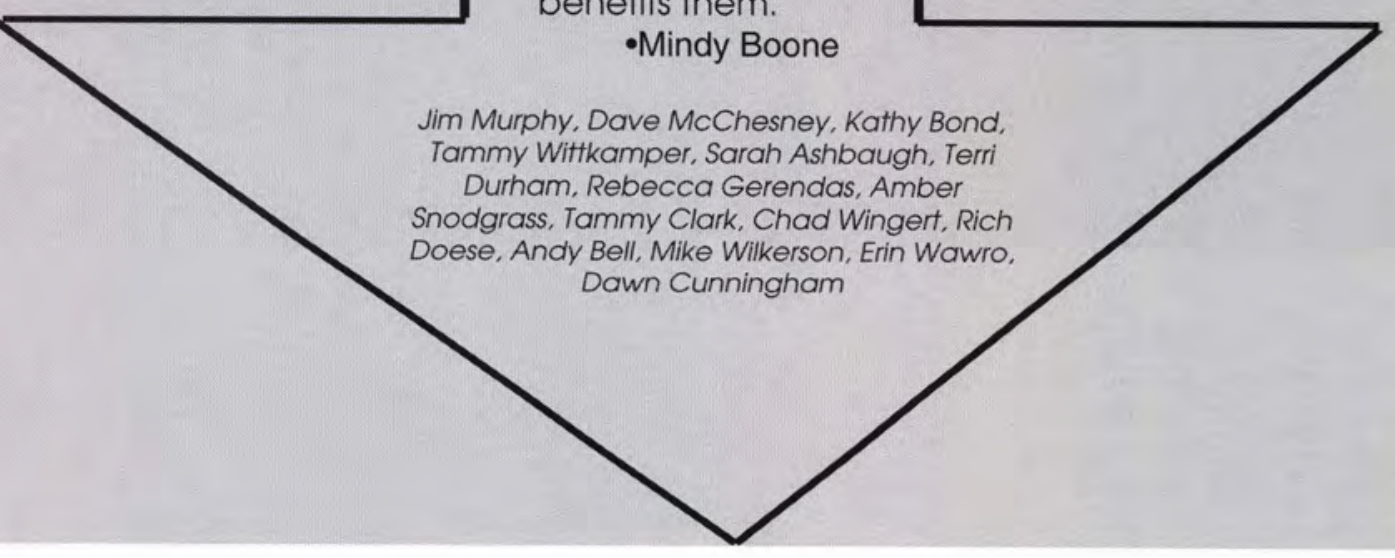




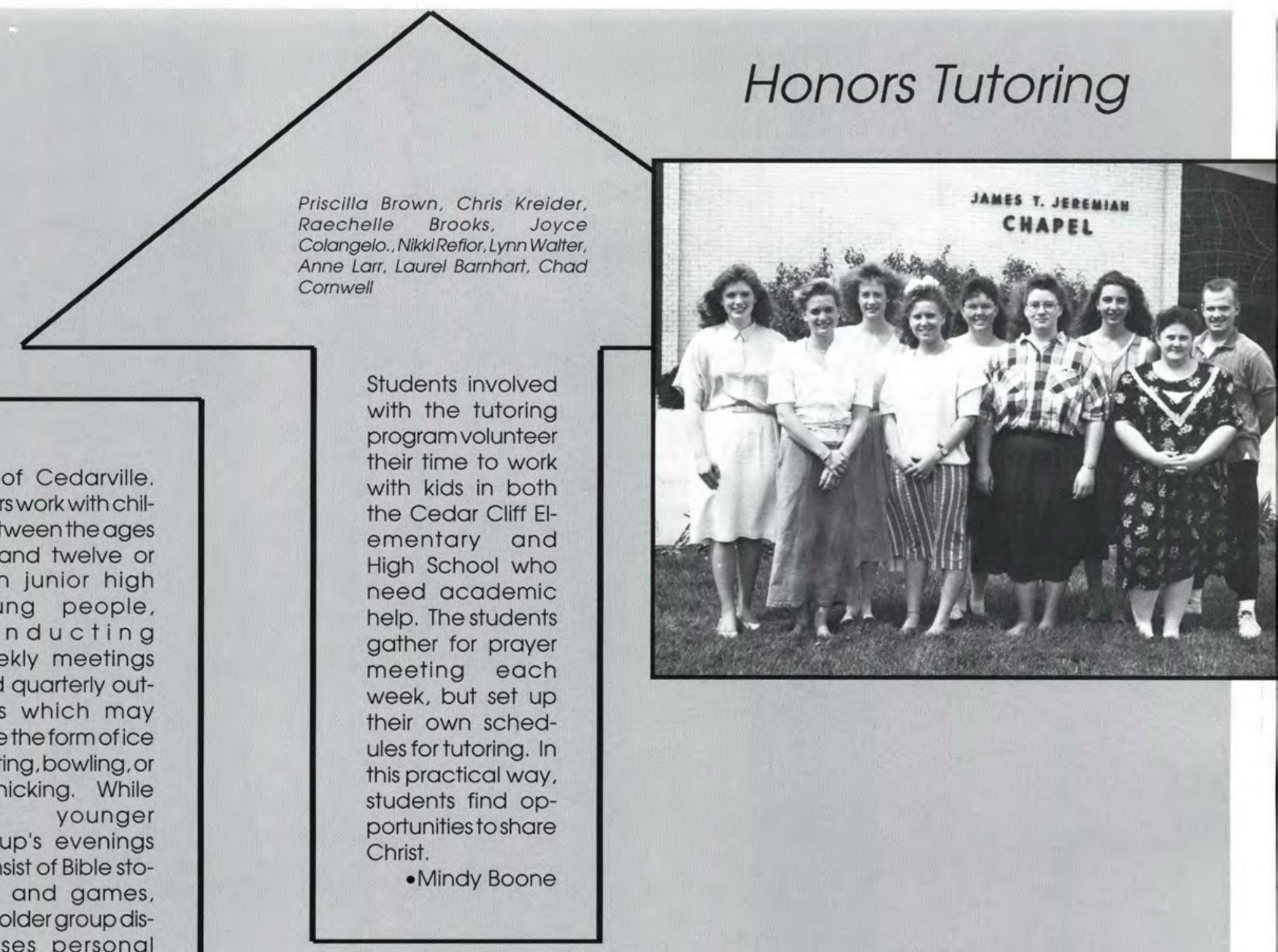

village of Cedarville. Memberswork with children between the ages of five and twelve or with junior high young people. conducting weekly meetings and quarterly outings which may take the form ofice skating, bowling, or picnicking. While the younger group's evenings consist of Bible stories and games. the older group discusses personal hygiene and participates in a Bible study.

-Mindy Boone
Students involved with the futoring programvolunteer their time to work with kids in both the Cedar Cliff Elementary and High School who need academic help. The students gather for prayer meeting each week, but set up their own schedules for tutoring. In this practical way, students find opportunitiestoshare Christ.

\section{-Mindy Boone}

\section{Honors Tutoring}

T. JEREUIAK

PALL 
Kingsmen Quartet

Brian Bales,Erin Weaver, Mark Vroegop, Jay LeBlanc, Matt Brown, Chad Coe.

\section{Abundant Life Singers}

Front row: Heather Rifenberick, Bruce McKanna, Melanie Dawson, Jennifer Dilling, Steve Caton.

Back row: Chris Handel,

Doug Schmitt, Tracie Dennison, Rob Reed, Sonja Bartlett.

\section{Lifeline Players}

Front row: Jennifer Neudeck,

Tom Mathisen, Priscilla Brown,

Edina VanMatre, Mike Heft. Back row: Tom Driscoll, Scott Mills, Tamara Wymer, Duane Baggerly, Holly Moor.
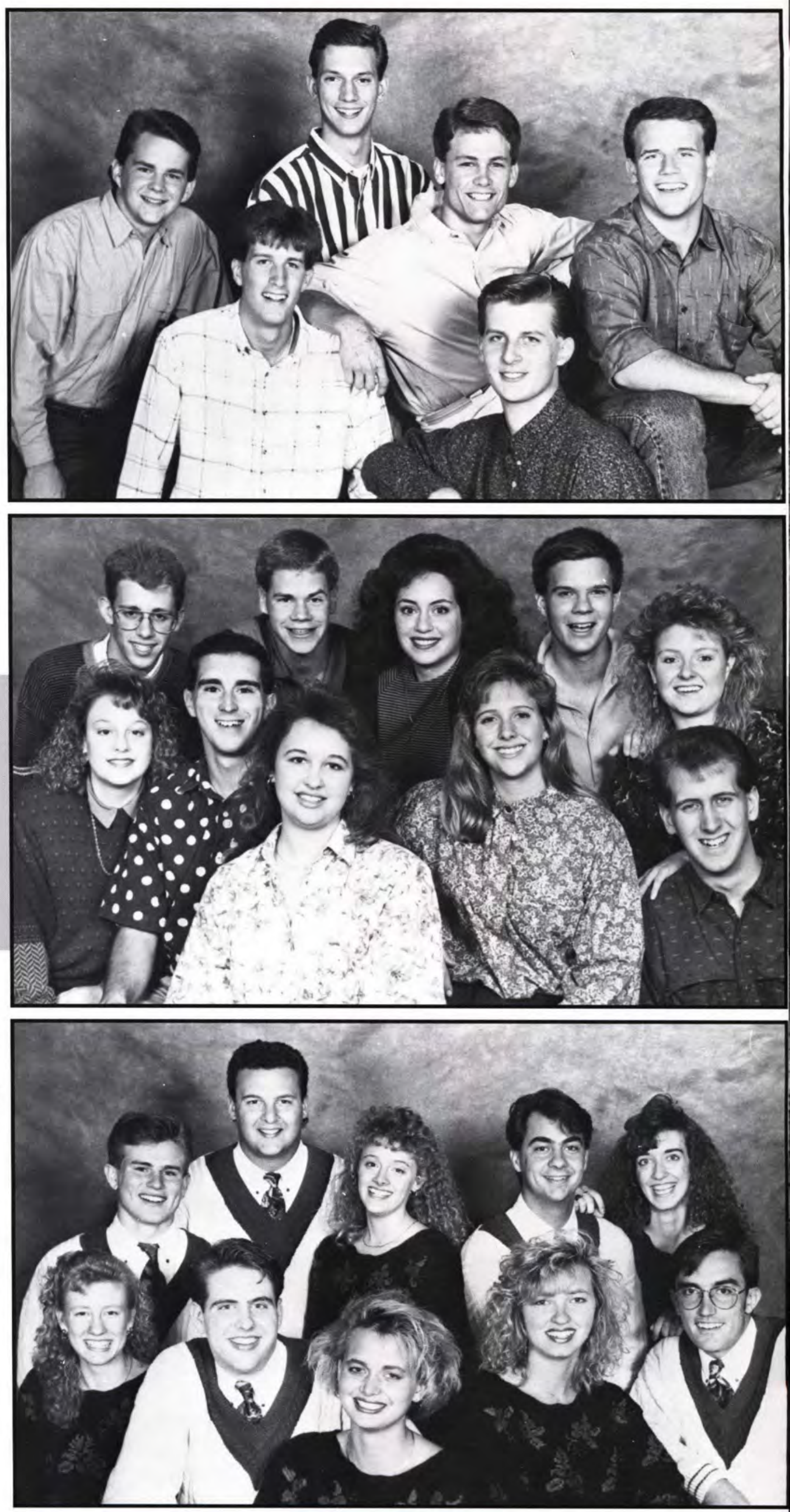


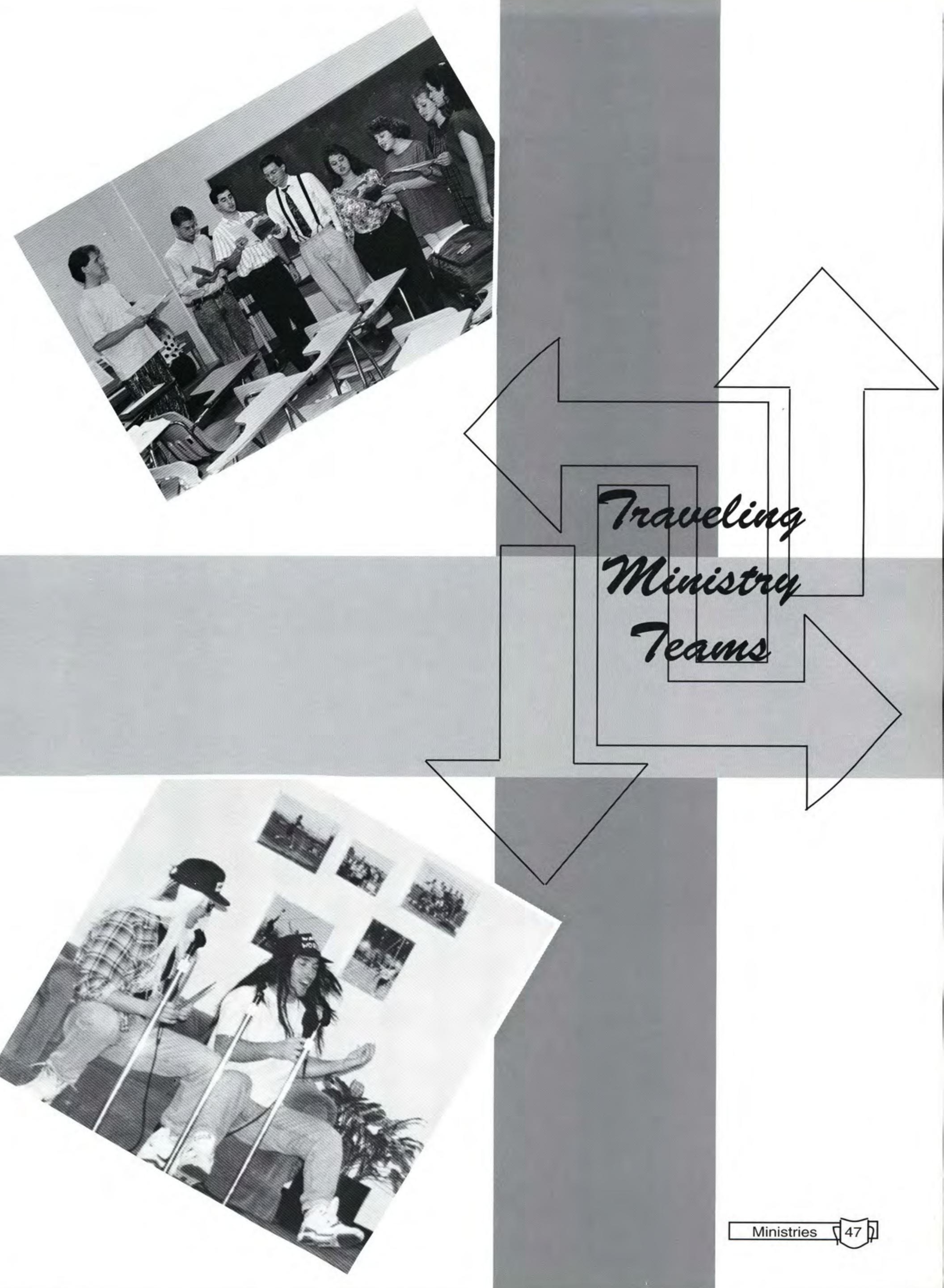




\section{Master's Puppets}

Front row: Lauren Fields, Steve Leverett, Lynn Skinner, Ali Parsell. Back row: Heidi Westbeld, Chris Good, Dan Neill.
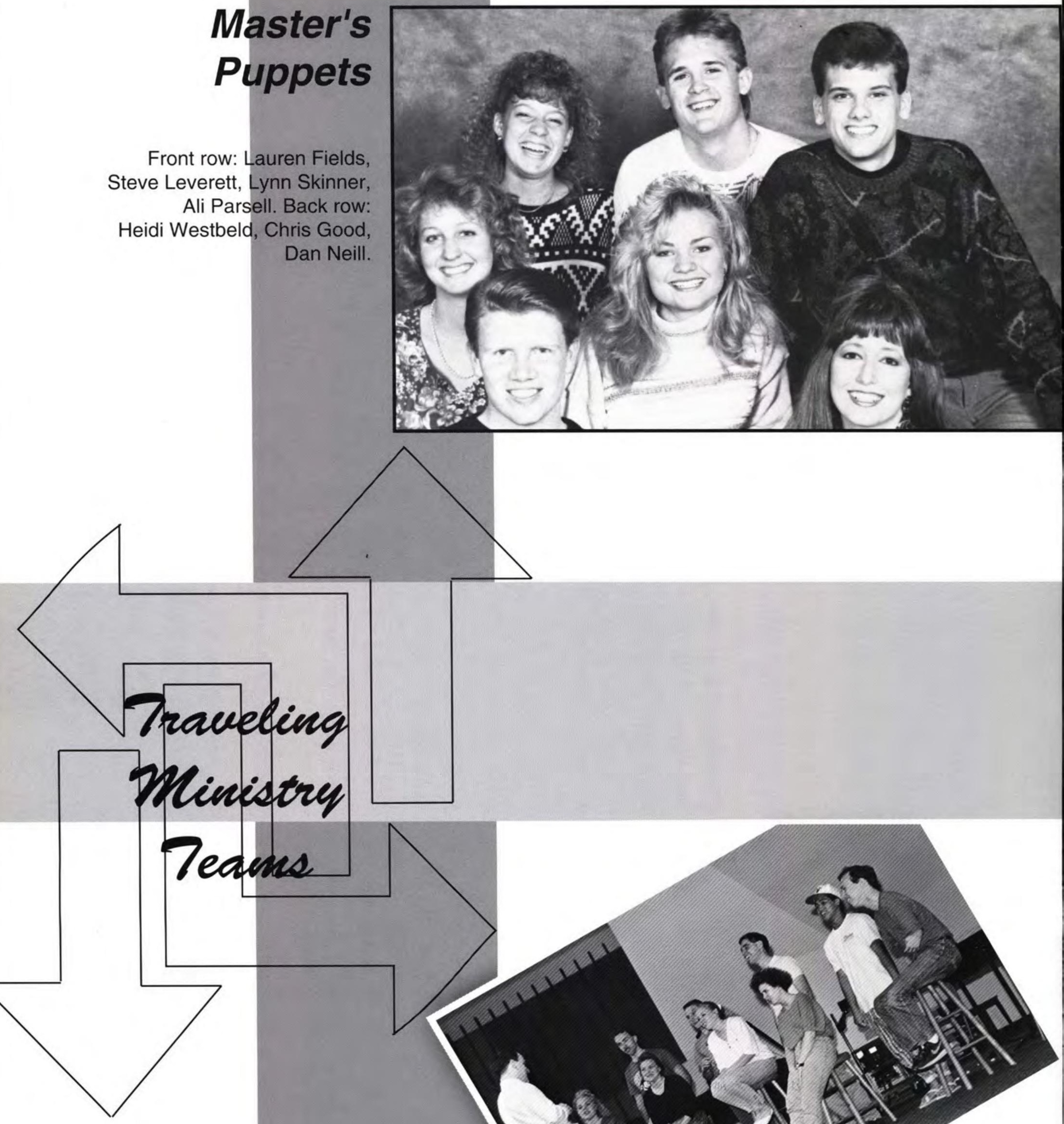

448 $\longdiv { 2 }$ Ministries

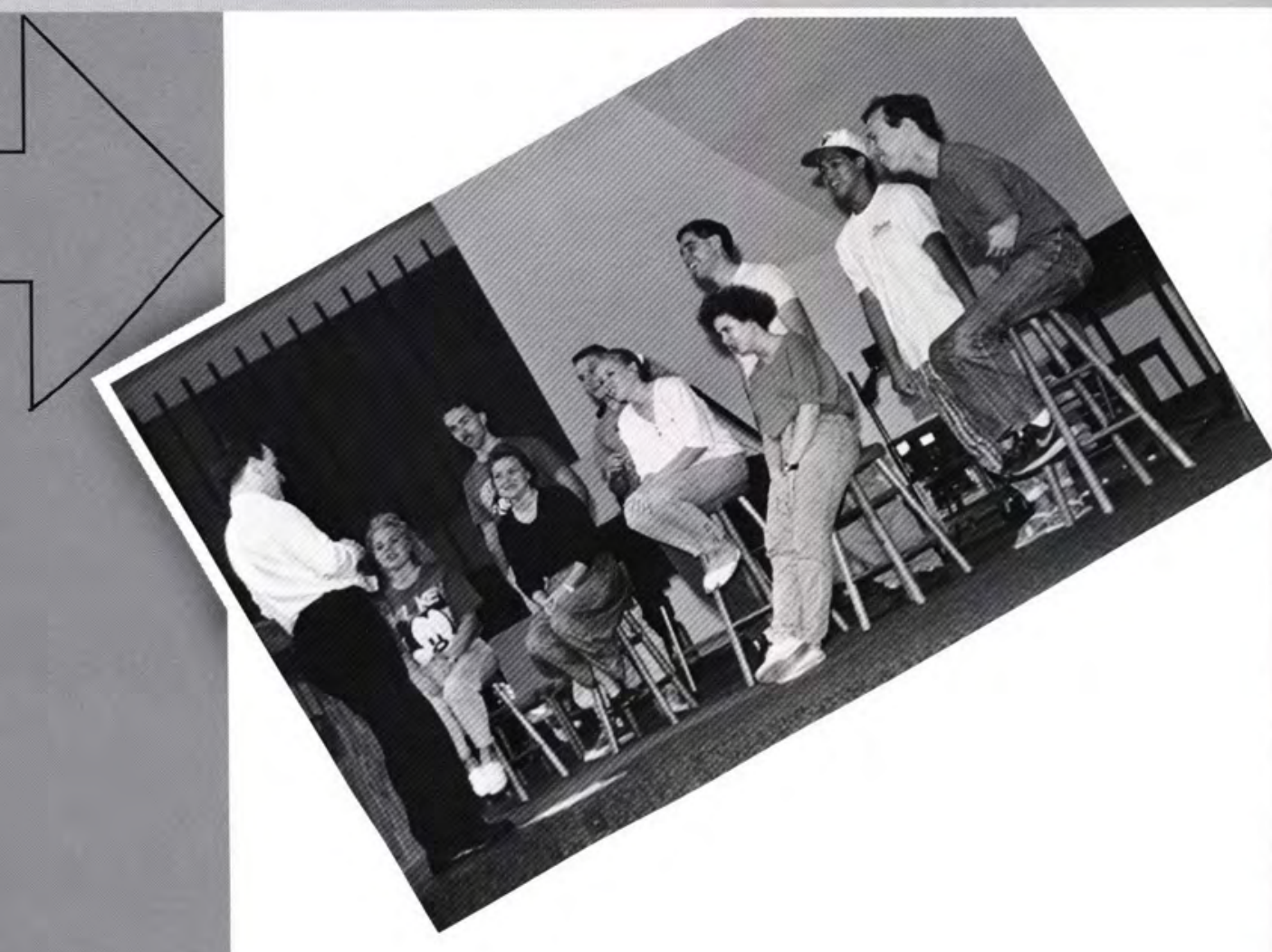




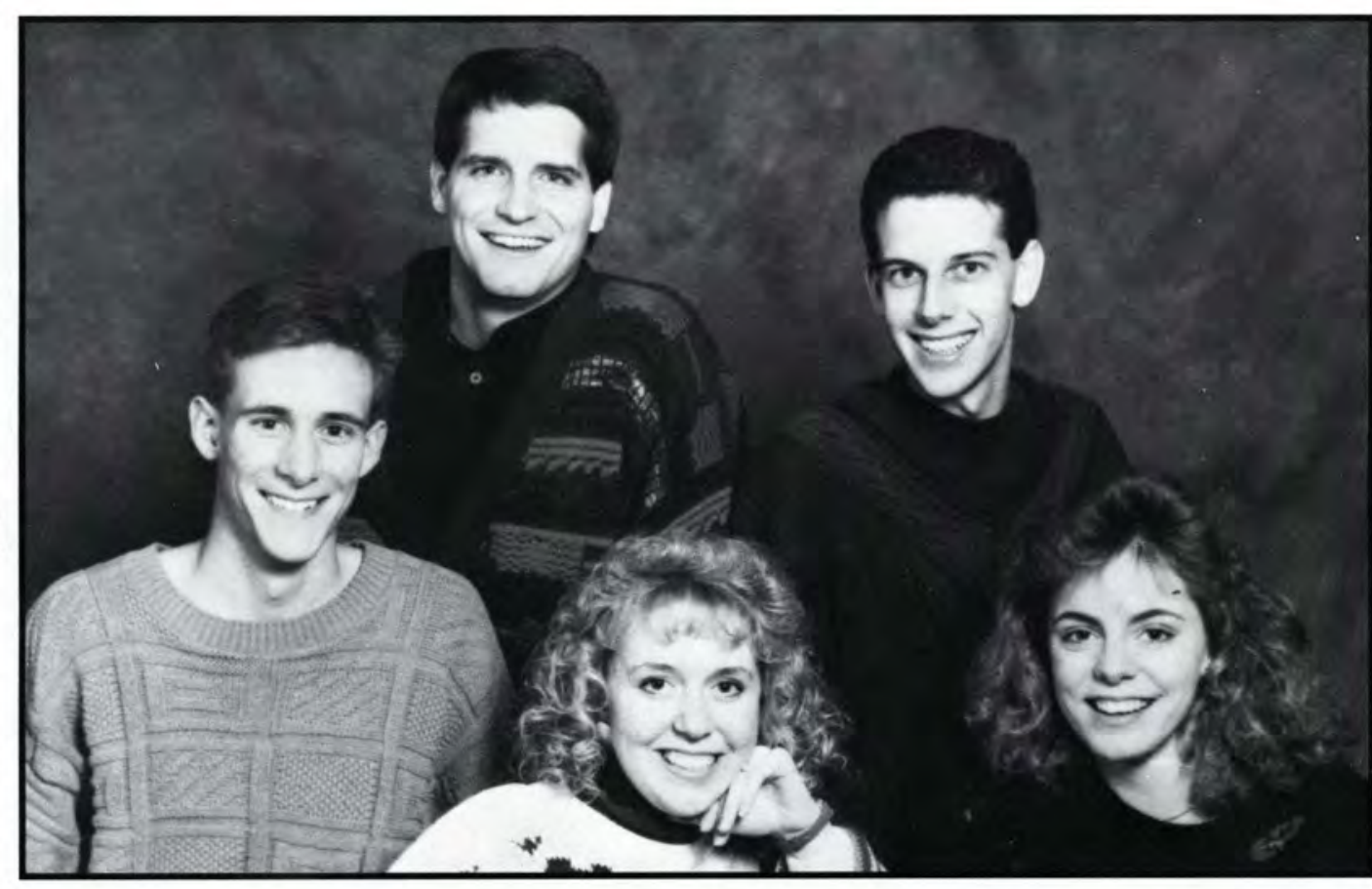

\section{Summer \\ Master's \\ Puppets}

Front row: Mark Irving,

Debbie Rotman,Amy Joe Whalen.

Back row: Wayne Leichty,

Joe Lausin.

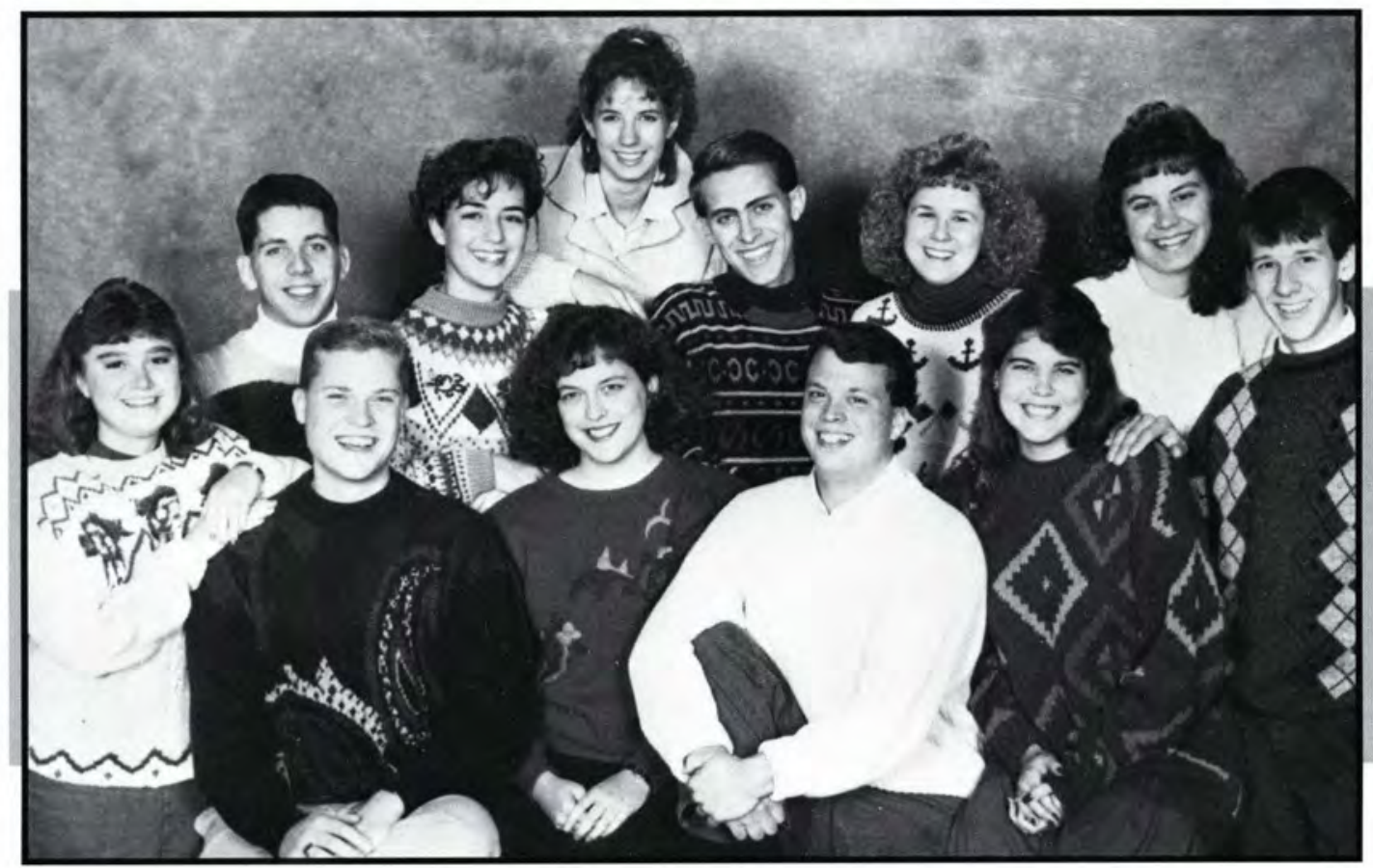

\section{Summer Swordbearers}

Front row: Shawn Abbot, Todd Fogle, Lori Jones, Cliff Roop, Andrea Gordon, Andy Shearer. Back row: Mark Jones, Molly Broman, Denise Maronn, Jeff Pence, Debby Reid, Becky Taylor.

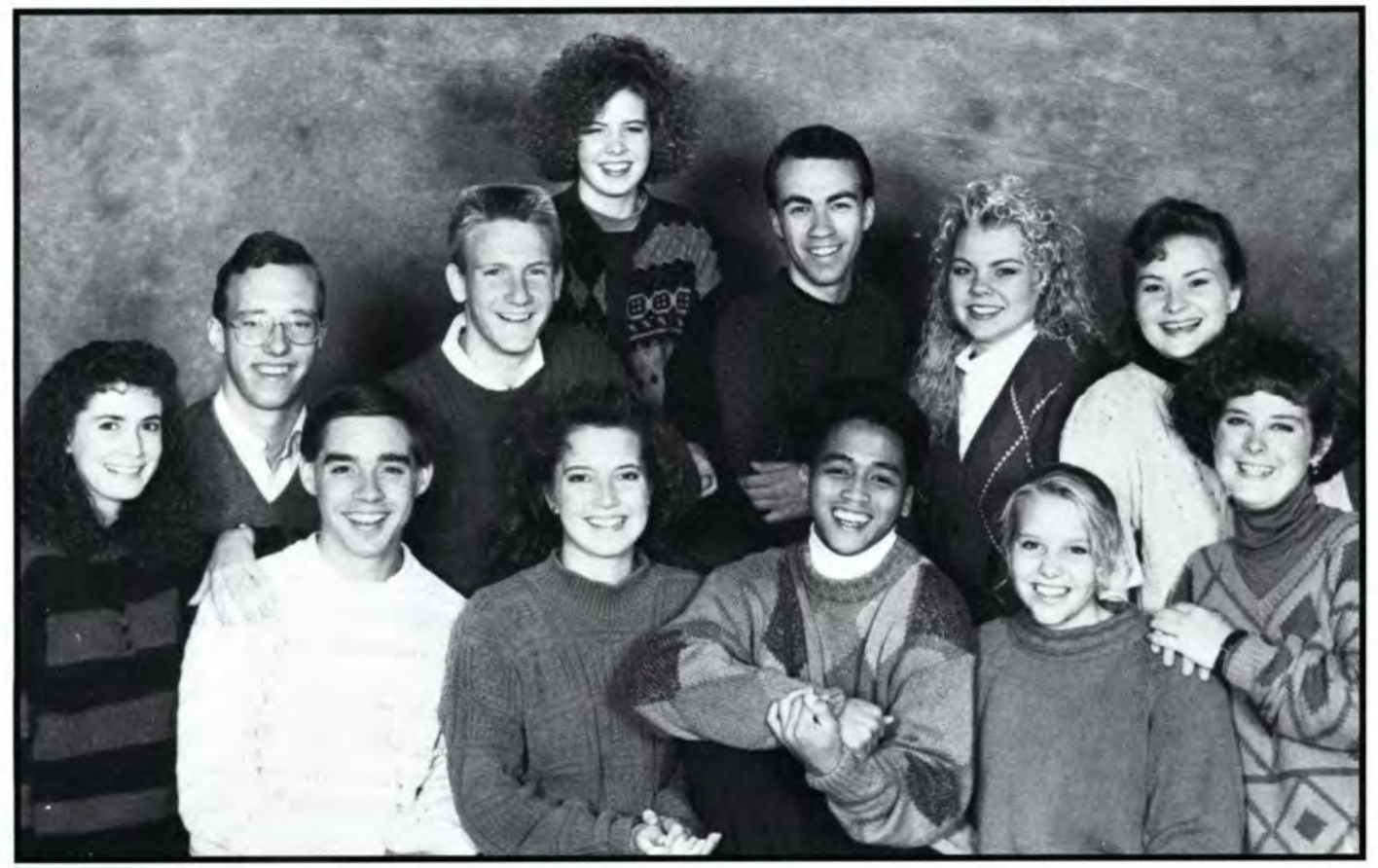

\section{Spring} Swordbearers

Front row: Karen Cushman, Jonathan Smith, Dana Hull, Lem Usita, Kathryn Simons, Ann Higley. Back row: Karl Cooper, Steve Jenks, Stephanie Sherman, Derran Reebel, Jill Hunsberger, Cindy Dolph. 


\section{Seizing Opportunities ... Beyond Cedarville \\ WHATEVER YOU ASK! The England team committed themselves to do whatever God asks of them.}

The decision by the college and MIS to hire a full-time MIS director was significant and indicates the increased importance Cedarville College is placing on missions in a day when mission organizations are feeling the effects of insufficient volunteers to meet the increased de-

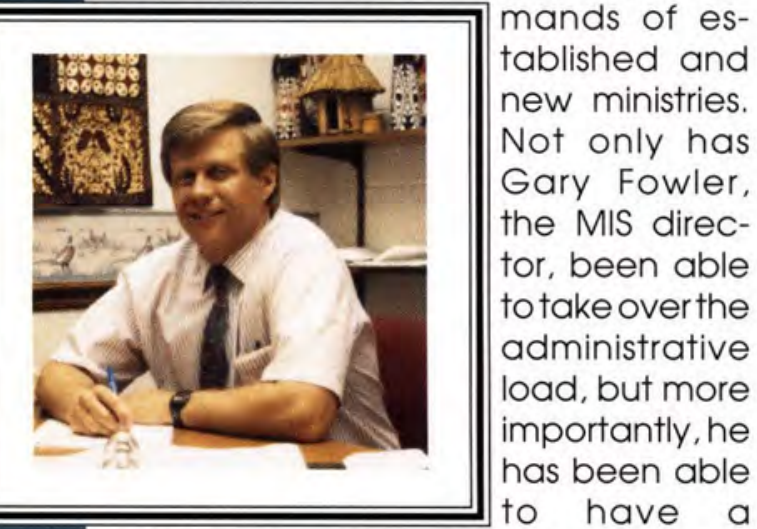

greater impact on the student body in regards to missions by spending a good deal of time in one-on-one contacts. This has been beneficial in both increasing interest in missions and in the follow-up of those who have made decisions and those returning from an MIS experience. It is this in-depth approach that we hope will encourage more students to consider committing themselves to full time mission service.

MIS is seeking to broaden its scope and promote tentmaking as an added avenue of missionary service available to our students. Numerous students have indicated their desire to invest their skills in a tentmaking type mission ministry. To encourage this, we are bringing a representative from World Wide Tentmakers to campus to speak to both our students and faculty. By doing this, we hope to be able to better integrate tentmaking into our college program.

All in all, we are rejoicing and praising the Lord for all that $\mathrm{He}$ is doing and are trusting Him to do even greater things for missions through us as we encourage and challenge our young people to take an active part in the ministry.

- Gary Fowler
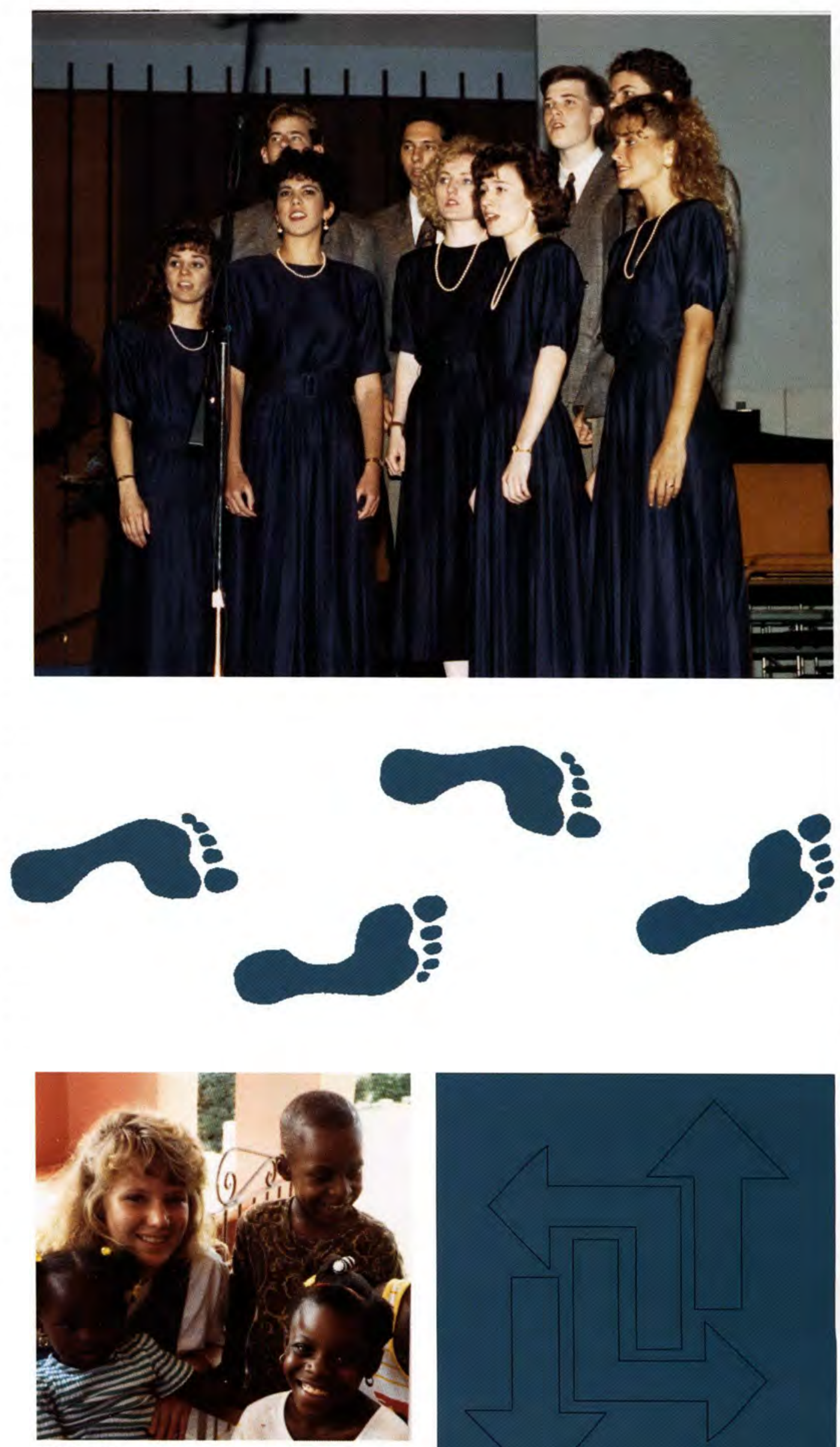

LOVE, JOY,... Stephanie Winchip shared God's love with these Jamaican children and was rewarded with joy. 


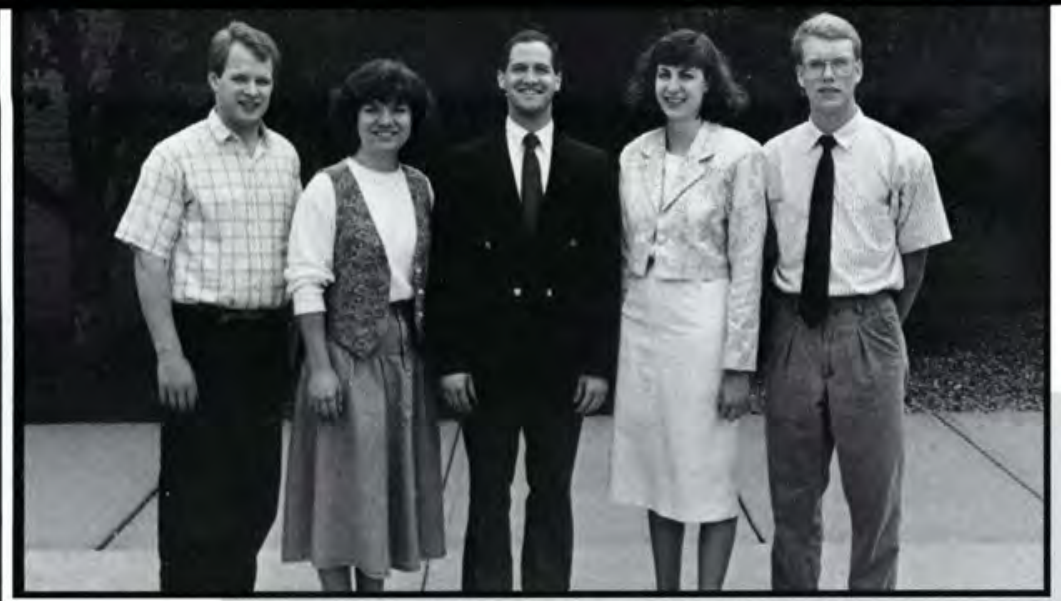

SWORDBEARERS EXECUTIVE TEAM Mike Phillips, President, Denise Uhl, Treasurer, Mark Solomon, Secretary, Lara McGovern, Public Relations, Mike Measley, Vice President.

\section{TENDER LOVING CARE}

Becky Stevens watches nursery at Grand Ave Baptist Church.

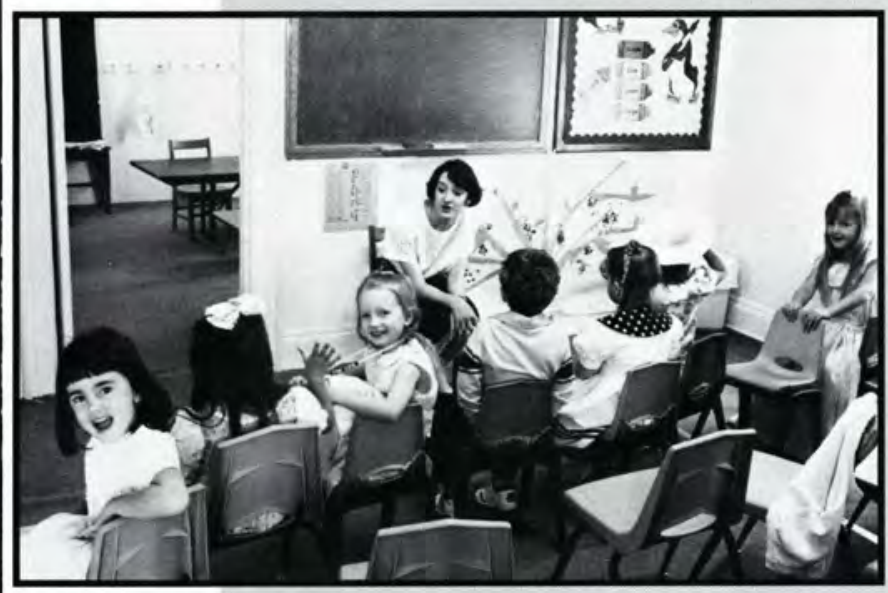

REACHING LITTLE MINDS Lindsay Hamel teaches her children's church class their daily Bible verse.

involves exposing potential college students to "real" college life and encouraging them spiritually as they deal with the pressures of teenage life.

Swordbearers also usher concerts and performances held in the James $\mathrm{T}$. Jeremiah chapel; they thrive on helping others in need, whether it is taking care of infants, playing the piano, leading congregational singing, or spending some time talking with the members of the church. Swordbearers focus ministry in the local church.

- Janet Payne

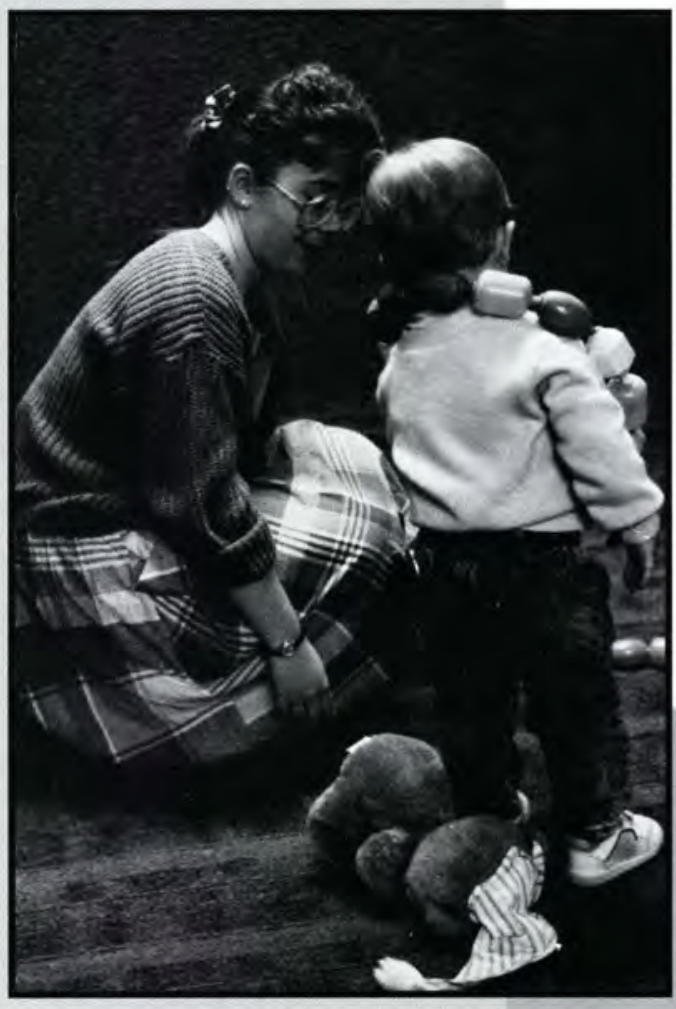

Cornerstone Baptist Church

Springfield, $\mathrm{OH}$

Kristi Van Dyke - leader

Angela Carson

Michelle Carroll

Jennifer Simmons

First Baptist Church

Tipp City, OH

Jim Pope - leader

Karl Hofheinz

Jonathan Montgomery

Jody Montgomery

Gail Henderson

Sheri McPherson

Grace Community Baptist Church

Washington Court House, $\mathrm{OH}$

Stephanie Alexander - leader

Deanna Osborne

Rachel Holley

Suzanne Harding

Todd Haseltine

Fairhaven

Dayton, $\mathrm{OH}$

Chad Grayson - leader

Matt Goding

Wright Patterson A.F.B. Chapel \#2

Allie Smith - leader

Shelly Heldreth

Nikki Starr

Catie Giles

Stephanie Kulp

Dana Gosser

Michelle Canine

Jeff Miller

Sarah Siegelin

Brian Nettlingham

Jean Kurtz

Jeff Smith

Mark Kakkuri

Devon Berry

Aaron Newcomb

Claire Grazier

Janet Chezik

\section{Rocky Ridge}

Columbus, $\mathrm{OH}$

Eric Ghere - leader

Northwest Bible Church

Lara McGovern - leader

Ruth Pfaler

Laura Tourinsky

Kathy Hagan

Connie Winch

Jeff Morgan

Trinity Alliance Church

Miamisburg, $\mathrm{OH}$

Gina Kendig - leader

Ben Biddle

Celeste Neumann

Susan O'Leary

Tim Trow

Prince of Peace United Brethren

Springfield, $\mathrm{OH}$

Tracy Justice - leader

Adrienne Seitz

Chris Gaither

Lisa Clymer

Traci Emes

Mindy Hughes

Cara Greentree

Northview Brethren Life Springboro, $\mathrm{OH}$

Kelly Darcy - leader

Nannette Schilling

Heather Barnard

John Misere

Carmen Hunt

Brian Bolger

Kim Lloyd

Shawn Bush

Calvary Baptist Church

Springfield, $\mathrm{OH}$

Victoria Johnson

Lori Lindner

Harold Beshaw

Kevin Parliament

Lori Garrigan

Matt Mitchell

Jim Foster

Beth Messiah Congregation

Columbus, $\mathrm{OH}$

Tonya Short - leader

Jennifer Lang

Lisa Zimmerman

Tracy Swackhammer

Jennifer Moore

\section{Olive Branch}

Columbus, $\mathrm{OH}$

Colynn McFadden - leader Allie Heller

Mindy Abrams 


\section{The Value of Dedication \\ In the Ad 7 of the Campus Fellowship}

The Fellowship ministry of Cedarville College provides services in the chapel on every Sunday morning, Sunday night, and Wednesday night for those of the student body who are not able to go off campus to get involved in a local church. The ministry is run by a group of elected students called the Advisory 7.

Ben Brown, the chairman of this year's Advisory 7, stated that "the main accomplishment this year of the Fellowship ministry was the meaningful worship services and the challenges to worship God." This was done by using predominantly praise choruses which tend to be more worshipful for the college-aged Christian, and even by dedicating an entire service on one occasion to praise and worship.

Brown stated that the Fellowship ministry is a very challenging one in that unlike most local churches, the attendance is highly transitory. He added, "The inconsistency in contacts and relationships is frustrating." However, in the face of the challenges of the ministry, Brown felt that he had a team of men in the Ad 7 who could only be described as "dedicated." "When a need came up, they were available." Brown cited examples of the missions project, Bibles for Russia, and the numerous prayer sessions where the Ad 7 were always present and willing to serve.

When asked what he had gained from his experience in the Fellowship ministry, Brown responded quickly, "I realized that people are at different levels in their spiritual growth and I am a fellow-struggler. I am a very driven and impatient person, and the fellowship ministry intensified my compassion for fellow-believers."

- Jesse Wesselink

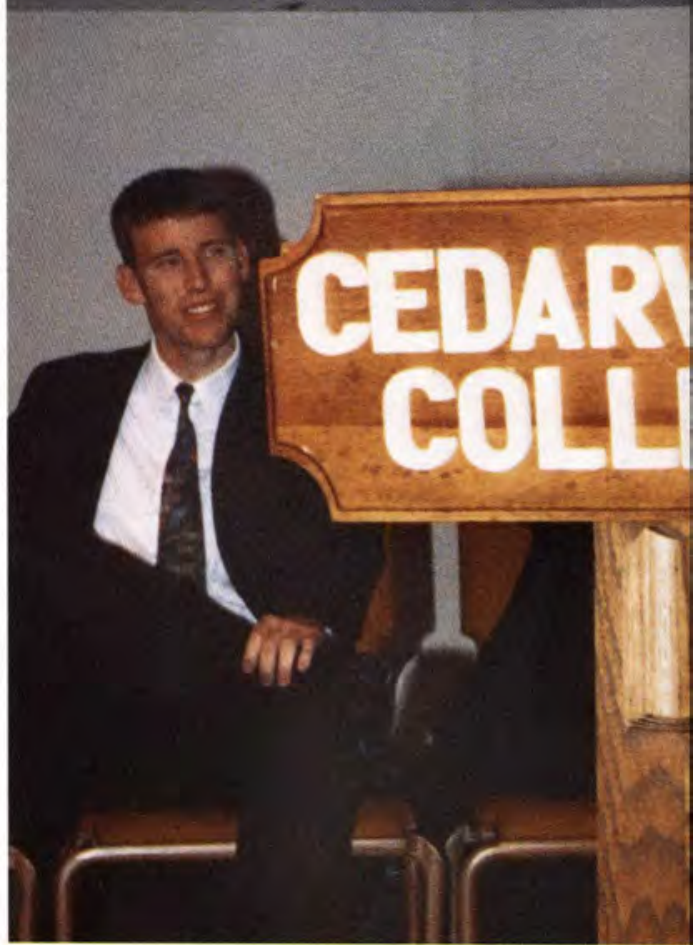

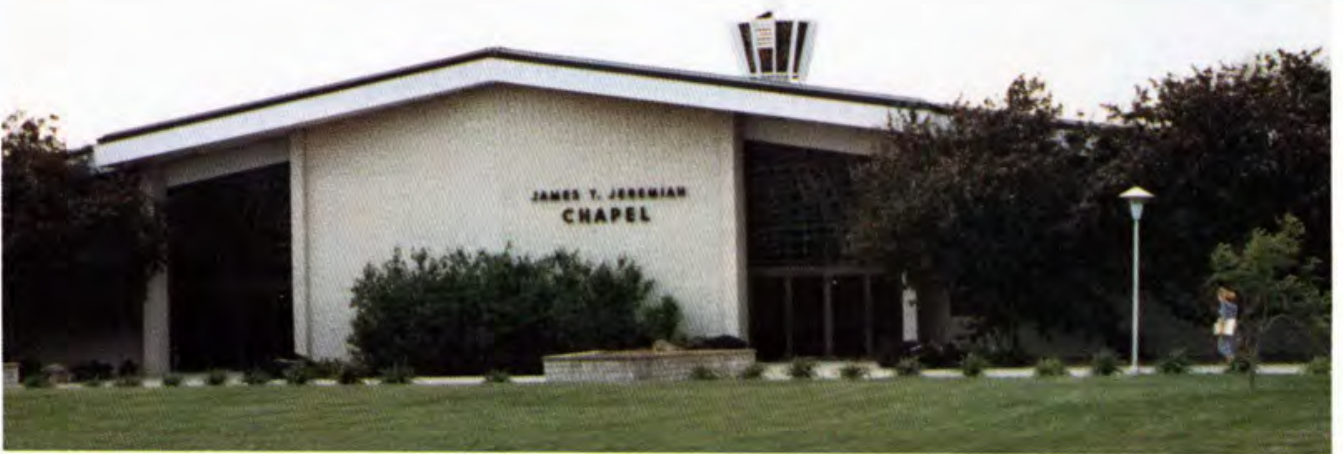

photo by Jesse Wesselink

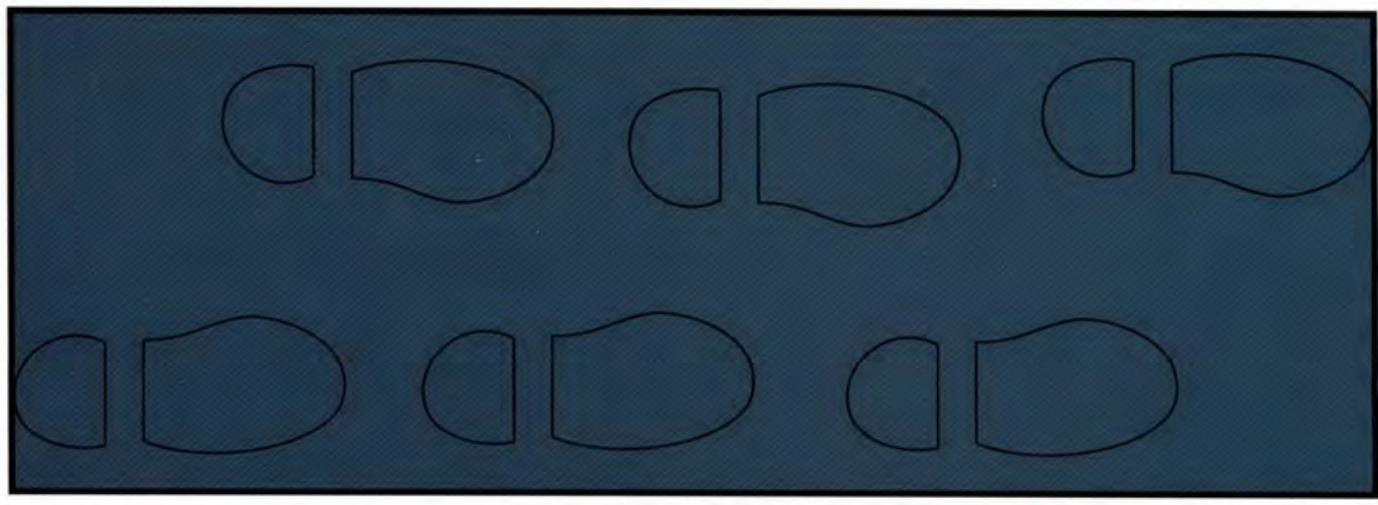

THE STORYTELLER, Brent Apperson used practical illustrations to make the Word come alive. 
MODEL? Dr. Rogers proudly displays his academic garb at the fall convocation service.

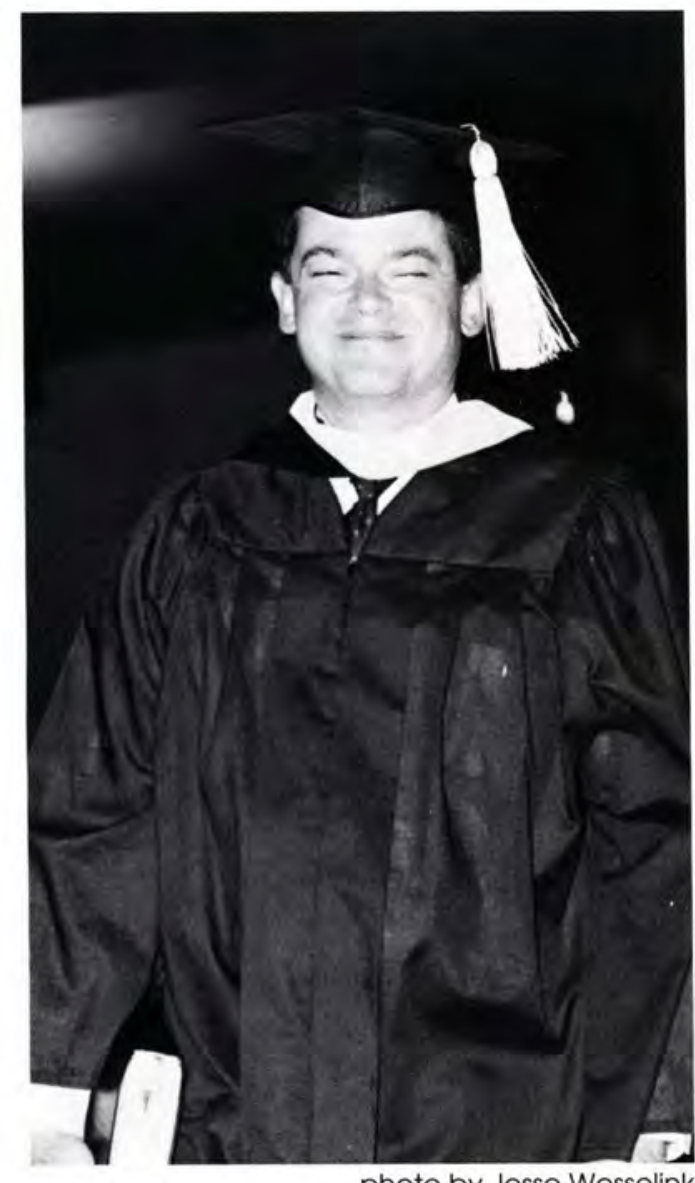
photo by Jesse Wesselink . Chapels Beyond Compare A Call to Action

It's 9:00 a.m. and the Cedarville College campus is stirring. Some have - been awake for quite some time and - have even attended an eighto'clock - class. Others are just rousing from : their deep sleep which followed ei- ther a night of studies or a night of : play. Regardless of where they are at : nine o'clock, at nine fifty all of the - students are marching their way into : the chapel for the daily ten o'clock service.

All of this year's chapel services have been outstanding in their impact on the hearts and minds of students and faculty, but certainly none more than the Winter Bible Confer- ence with guest speaker Dr. Bruce - Wilkinson. Dr. Wilkinson in his weeklong series of messages challenged the student body to prayer, aggres-

sive witness, and more than anything else maturity in the Christian walk. Employing a variety of teaching styles and methods, Dr. Wilkinson left images and challenges that will remain : for years to come in the minds of all those listening.

At the concluding service of the : conference, Dr. Wilkinson kept his: promise to reveal the identity of the : "Cedarville 100." After he delivered: a stirring report of what he had experienced on his recent trip to Russia, he called for at least 100 people to come forward to commit themselves to pursue ministry in Russia. Well over 100 people came forward and filled the front of the chapel, setting the spiritual flavor of the rest of the year.

- Jesse Wesselink
DON'T PASS OVER THE JEWS. Rev. William Aiken helped the audience understand the Jewish Passover in light of its customs and its fulfillment by Christ.
ANTHONYMUNOZ, of the CincinnatiBengals, shared his signature, as well as his testimony.

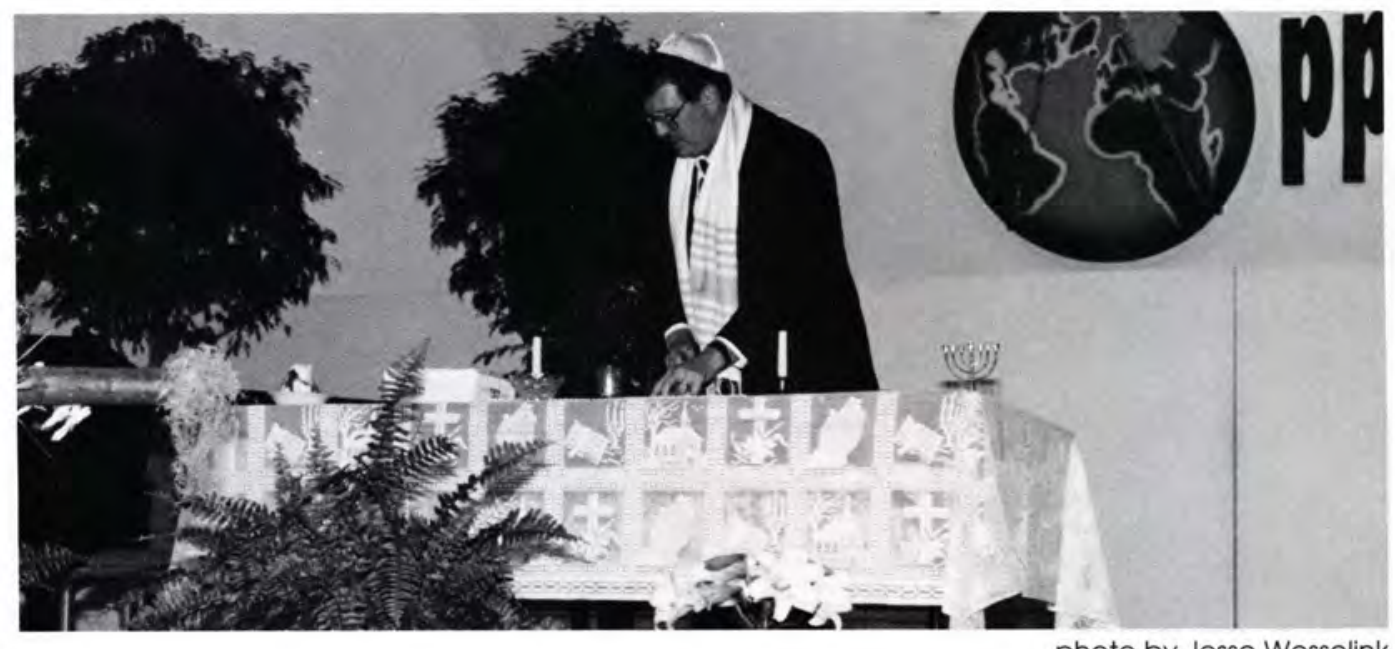

photo by Jesse Wesselink

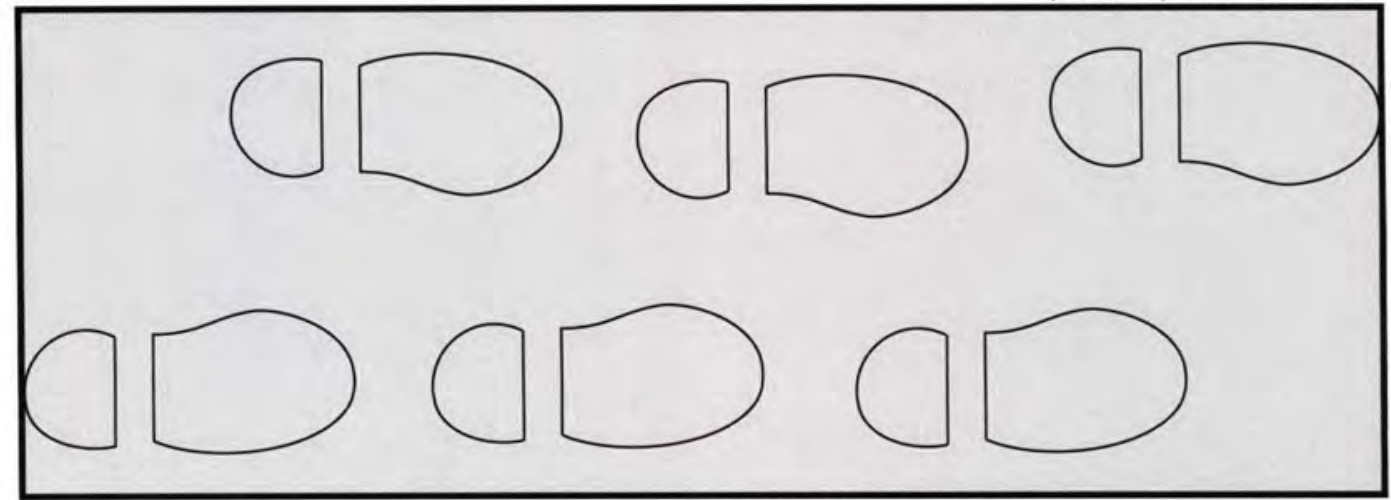

photo by Marsha Olsen

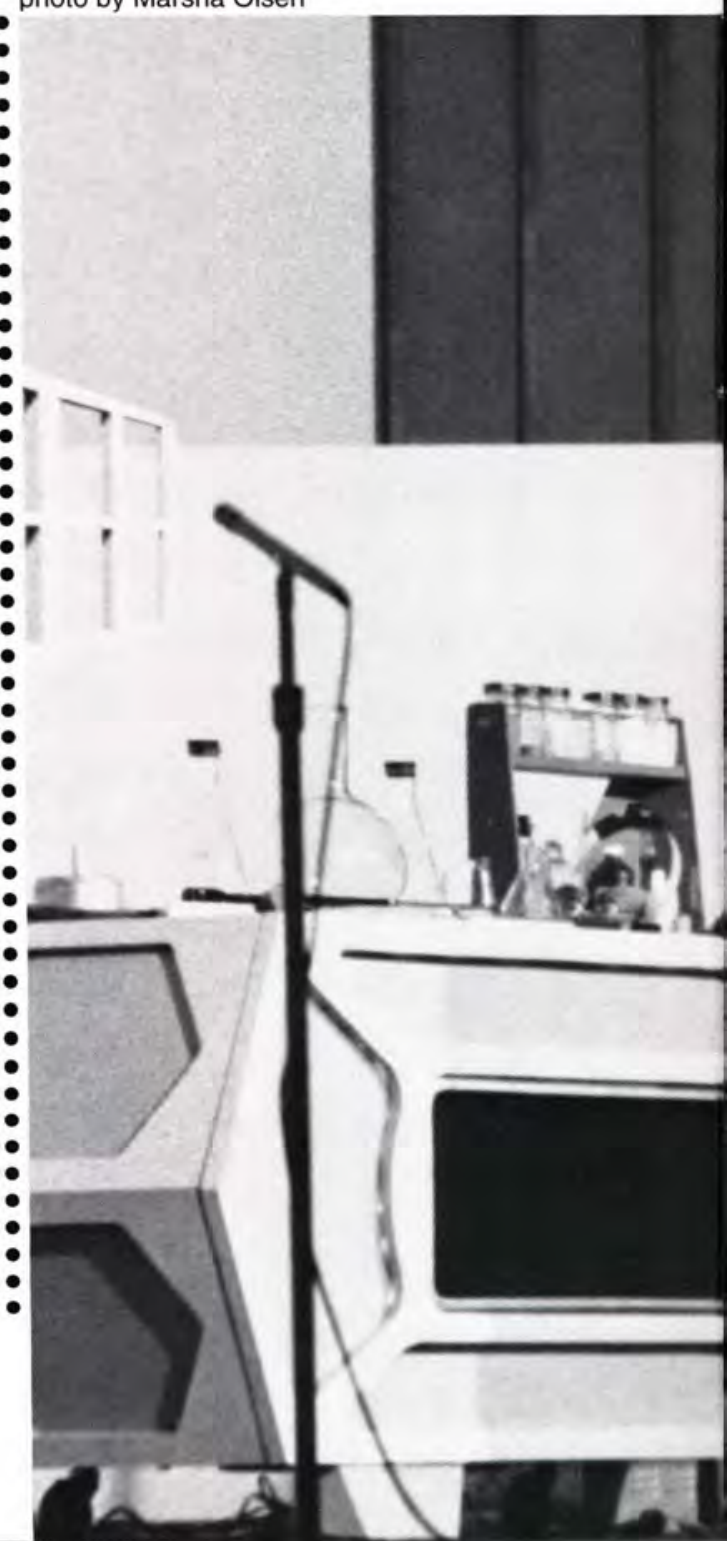




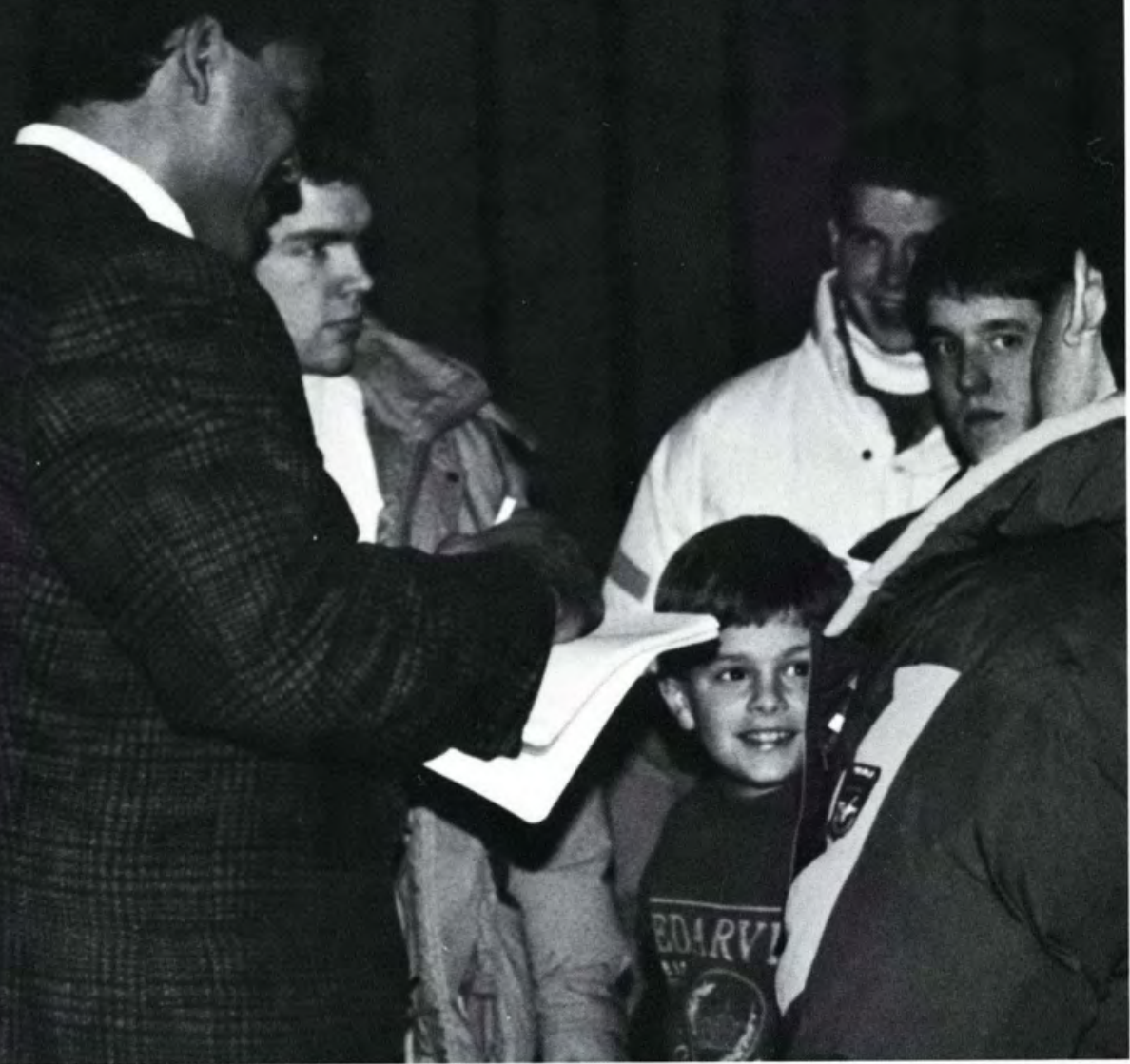

66

Chapel is the heartbeat of this college!

-President Dixon

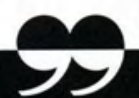

photo by Marsha Olsen

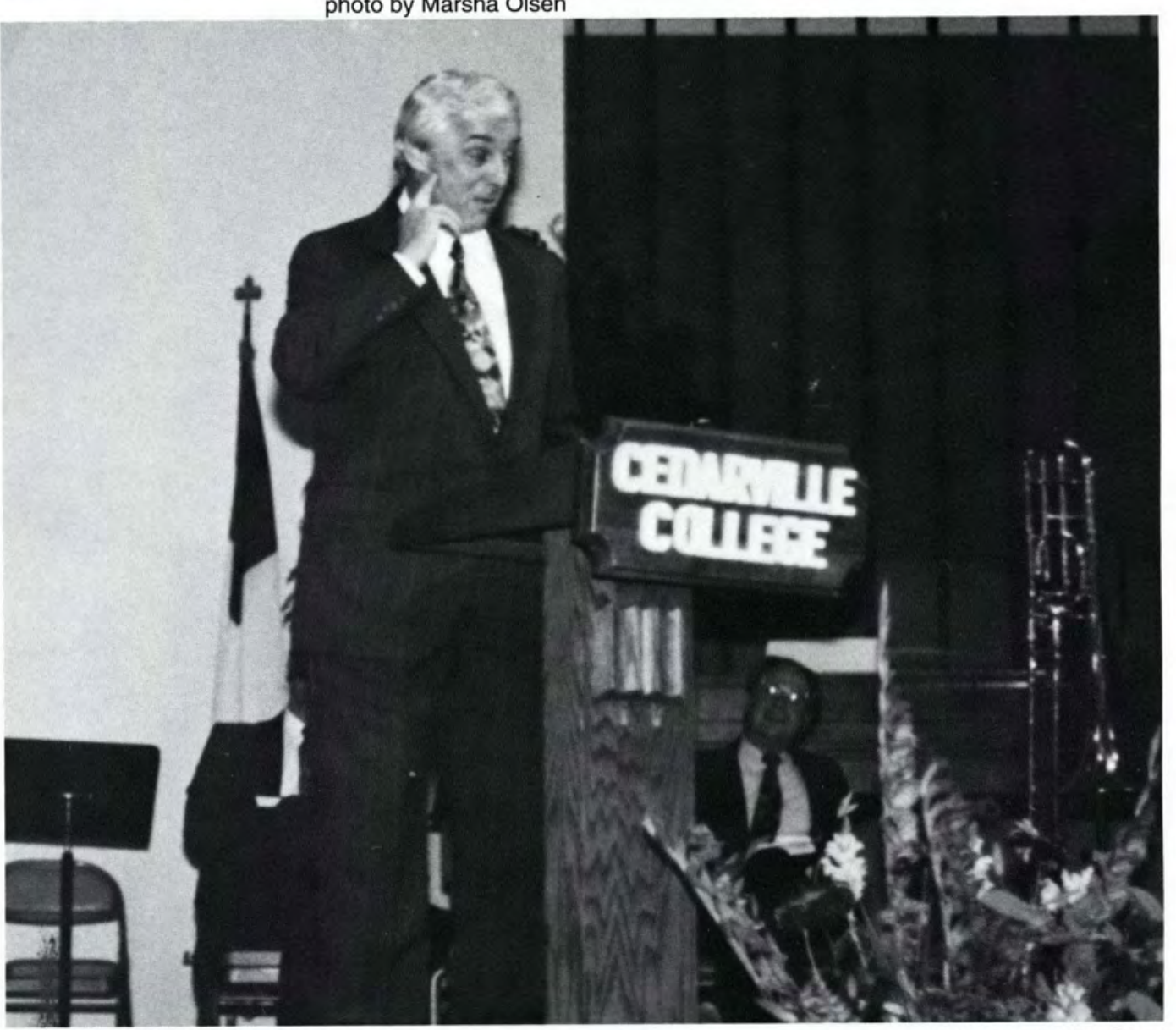

EYE HATH NOT SEEN. Dr. David Jeremiah, featured photo by Marsha Olsen speaker of the fall Bible conference, reminded listeners that although no one has seen God, worship is man's response to God's revelation of Himself. 

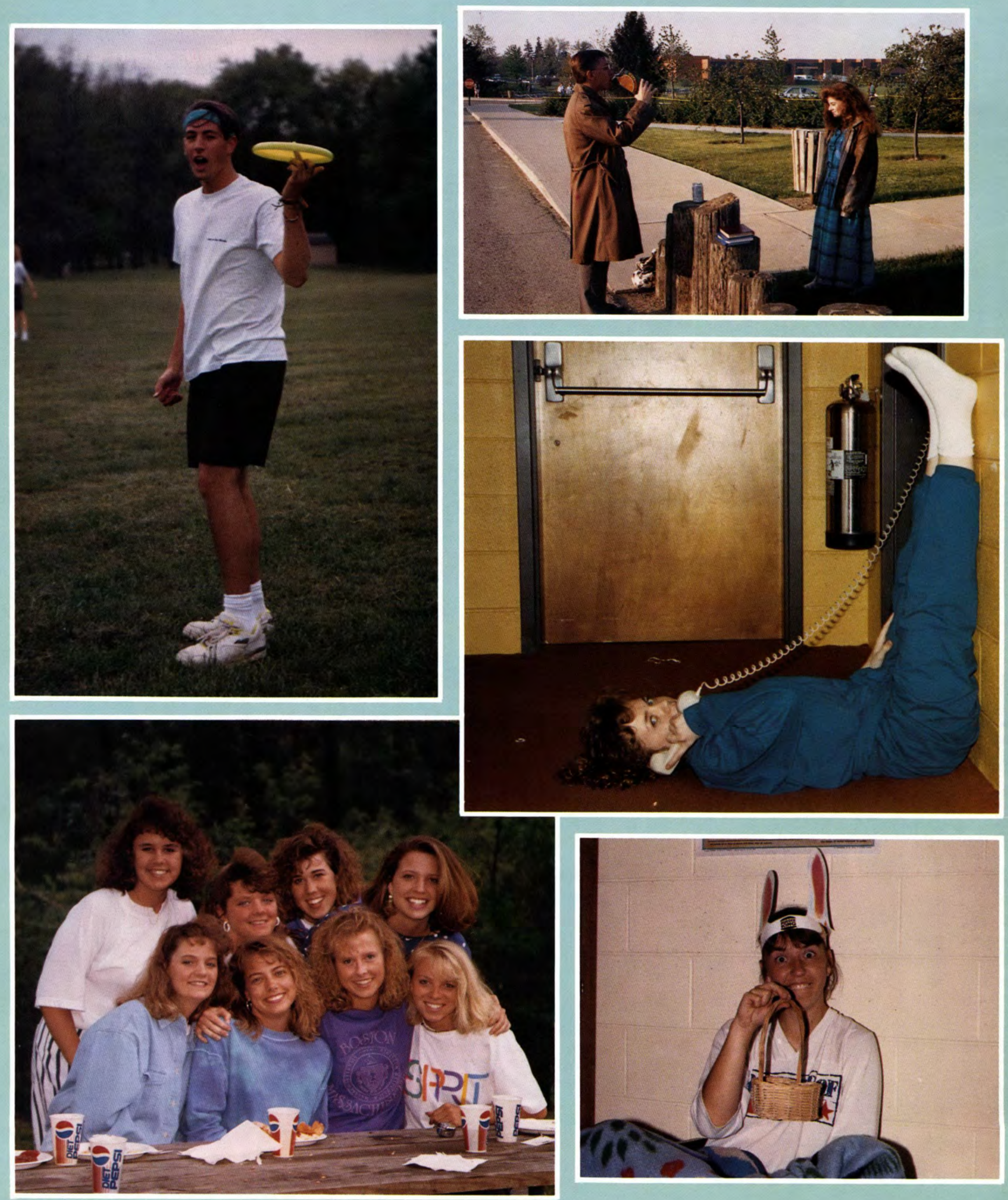

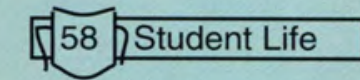

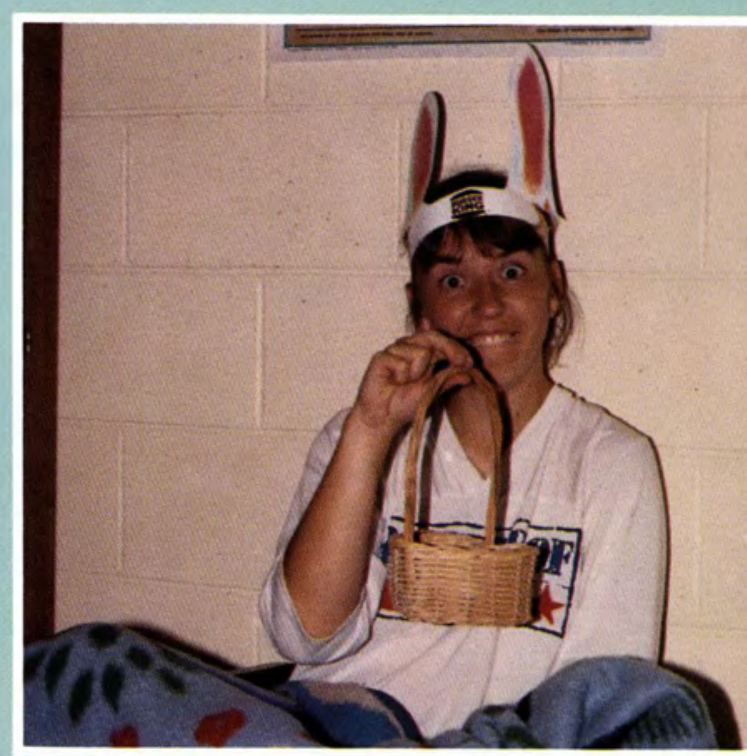


Friendships Through the Frenzy

Table of Contents:

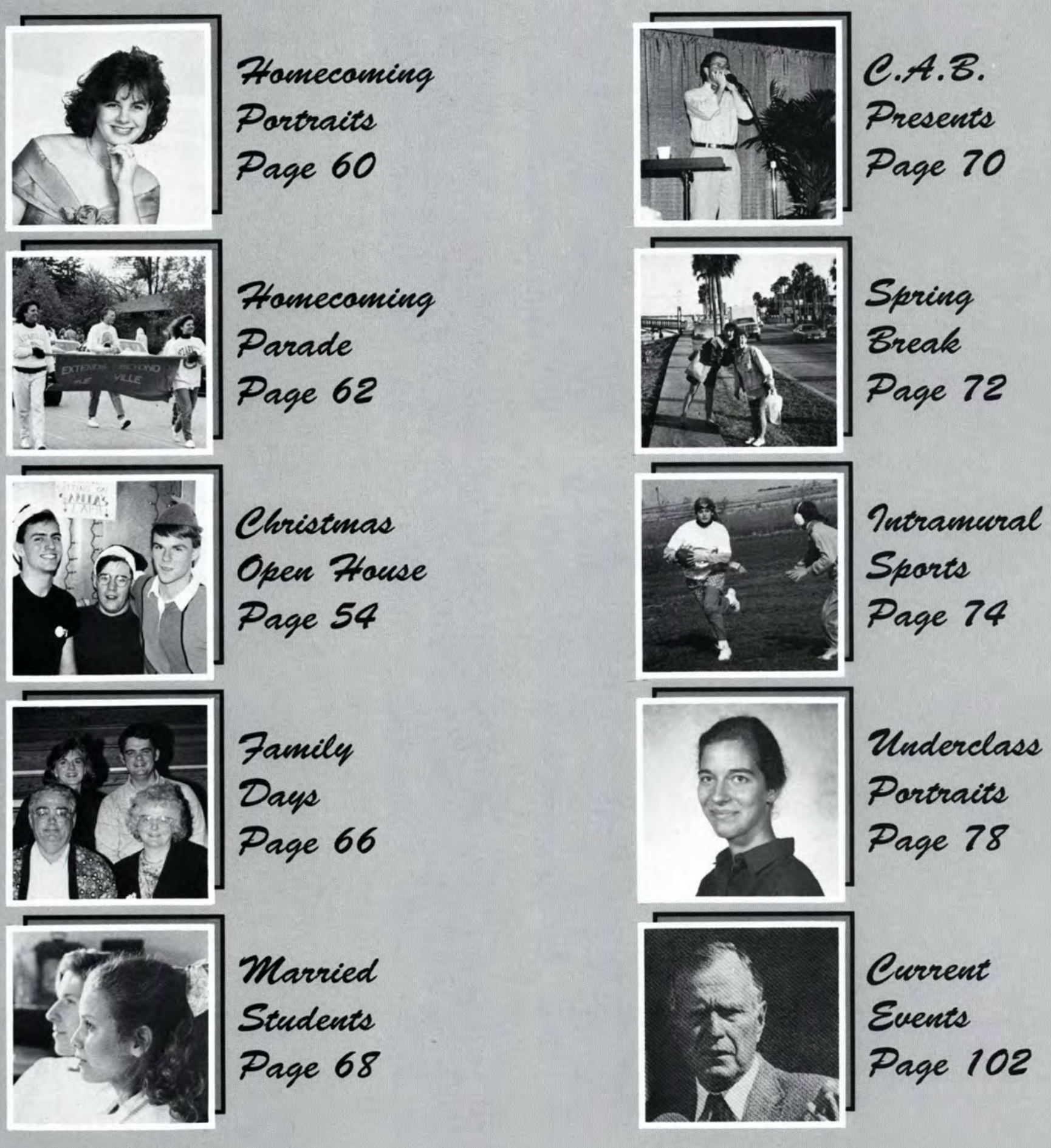




\section{Under the Sea:}

\section{Glittering waves surround "Isle of Altantis"}

On Saturday evening, October 12, Cedarville students from a plethora of states and foreign countries met "under the sea." No, they did not assemble to scuba dive nor to explore; they assembled to enjoy seafood, comedy, and each other as they celebrated Homecoming 1991. The "sea" was Chuck's cafeteria, transformed into an underwater fantasyland, "Isle Atlantis." This theme penetrated the decorating to the extent that goldfish swam around in glass bowls underneath beautiful flower arrangements. As an added bonus, one person sitting at each table received this centerpiece to keep as a living memoir of the evening.

Guyne Davies and Matt Moore set the stage for the evening by unfolding the intriging myth behind the "Isle Atlantis" theme. Student bodychaplain PaulAnderson then led in prayer before the meal, which included seafood, mixed vegetables, rice, boneless chicken breast, hush puppies and dessert.

One of the highlights of the evening was the procession and introduction of the Homecom- ing court, culminating with the crowning of the 1991 Homecoming queen, Kelly Scott. The Grand Marshall for this year's Homecoming festivities, Dr. David Matson, was also introduced and asked to say a few words. Finally, Christian comedian Steve Geyer took the stage. His dialogue ranged from the humor to be found in malelfemale differences to the serious subject of how he came to comprehend more clearly our Heavenly Father's unconditional love.

- Angie Mouser

\section{WHILE COMEDIAN STEVE GEYER PERFORMS,}

Cedarville students relax during the banquet.

WITH A PEARL DROP SMILE, Susan Beach shows her enthusiasm while Shelly Sutton looks on.

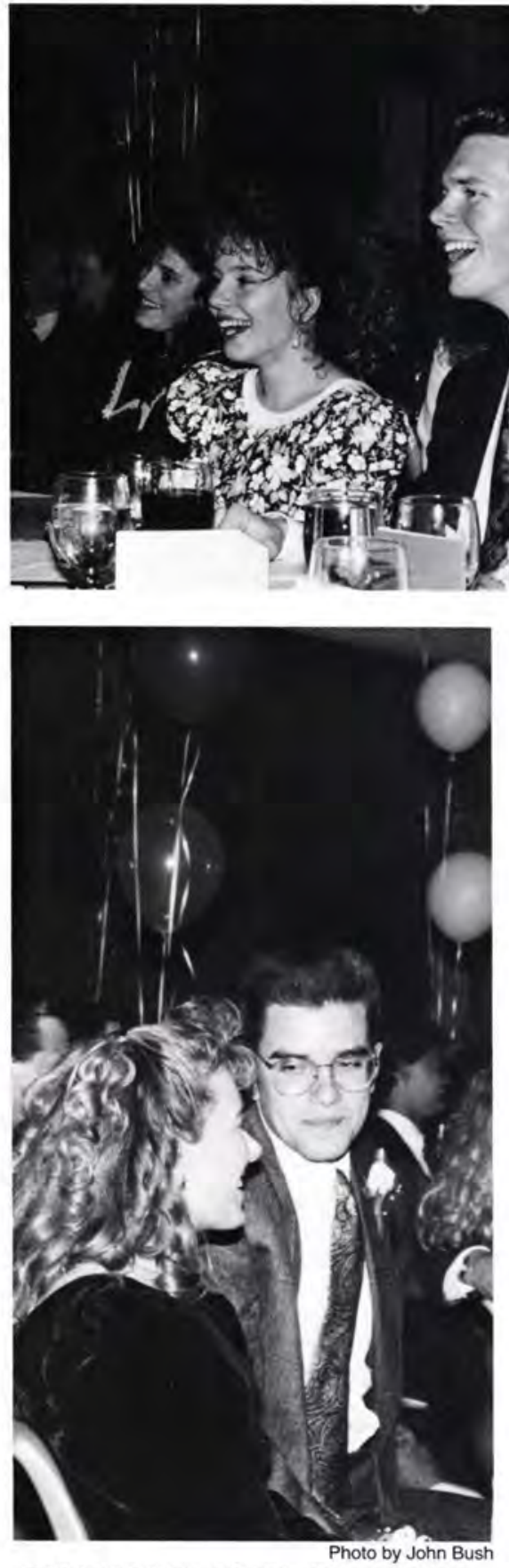

ENJOYING ISLE ATLANTIS, Maribeth Tramel and John Jacobson share their undersea adventure.
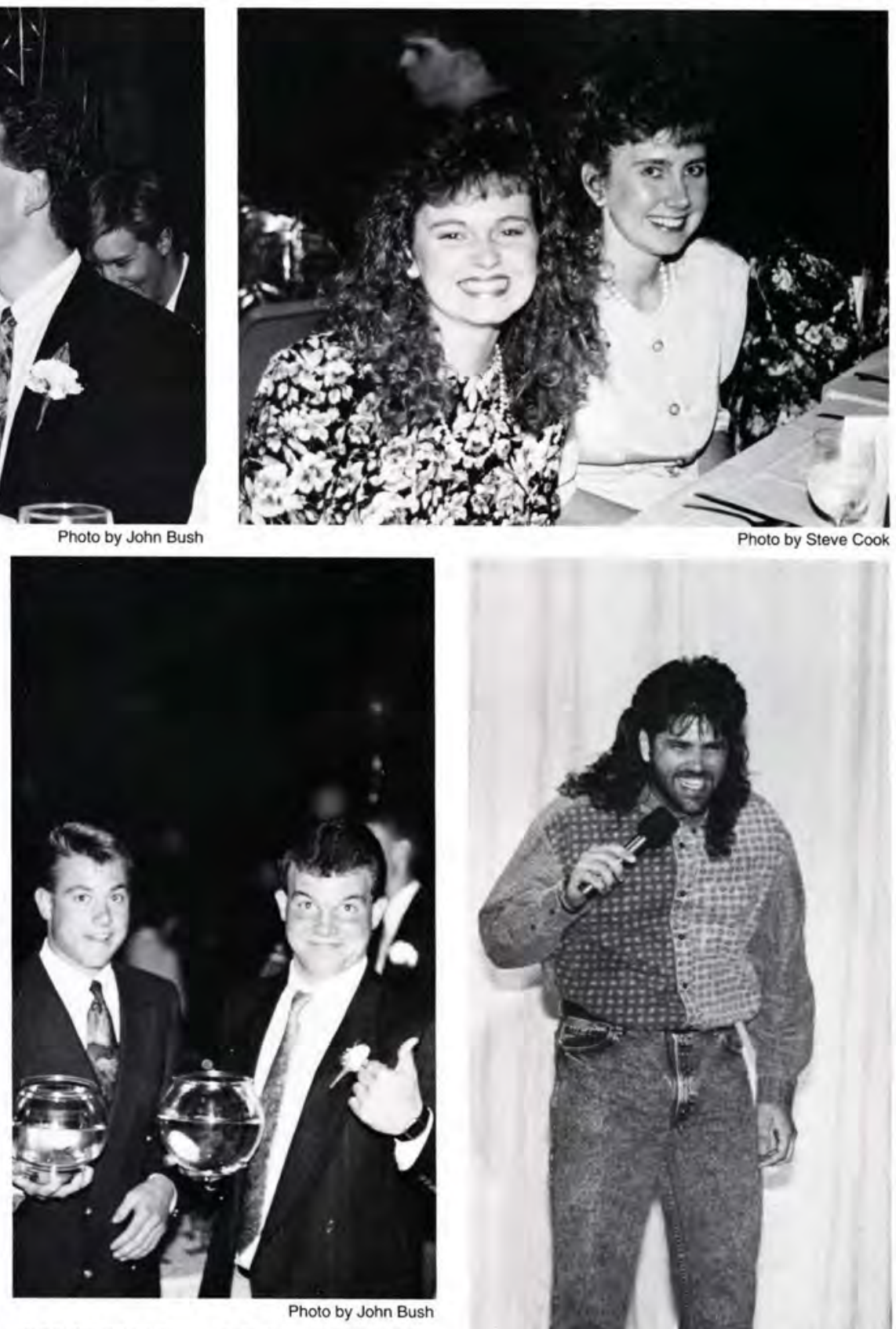

SHOWING OFF THEIR CATCH of the evening are Greg Lawrence and Joe Lausin.

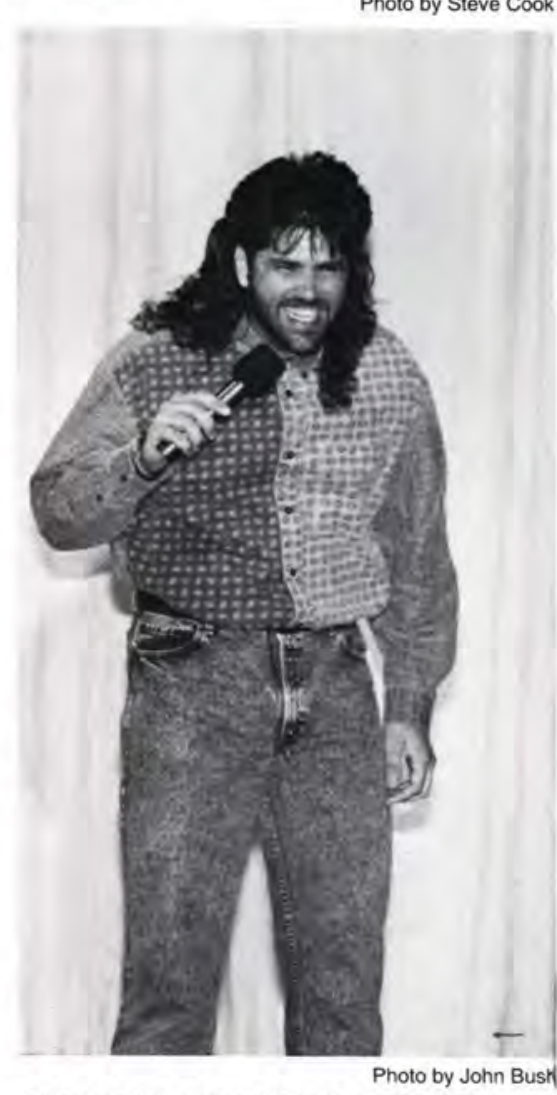

COMEDIAN STEVE GEYER just can't get the right words out. 


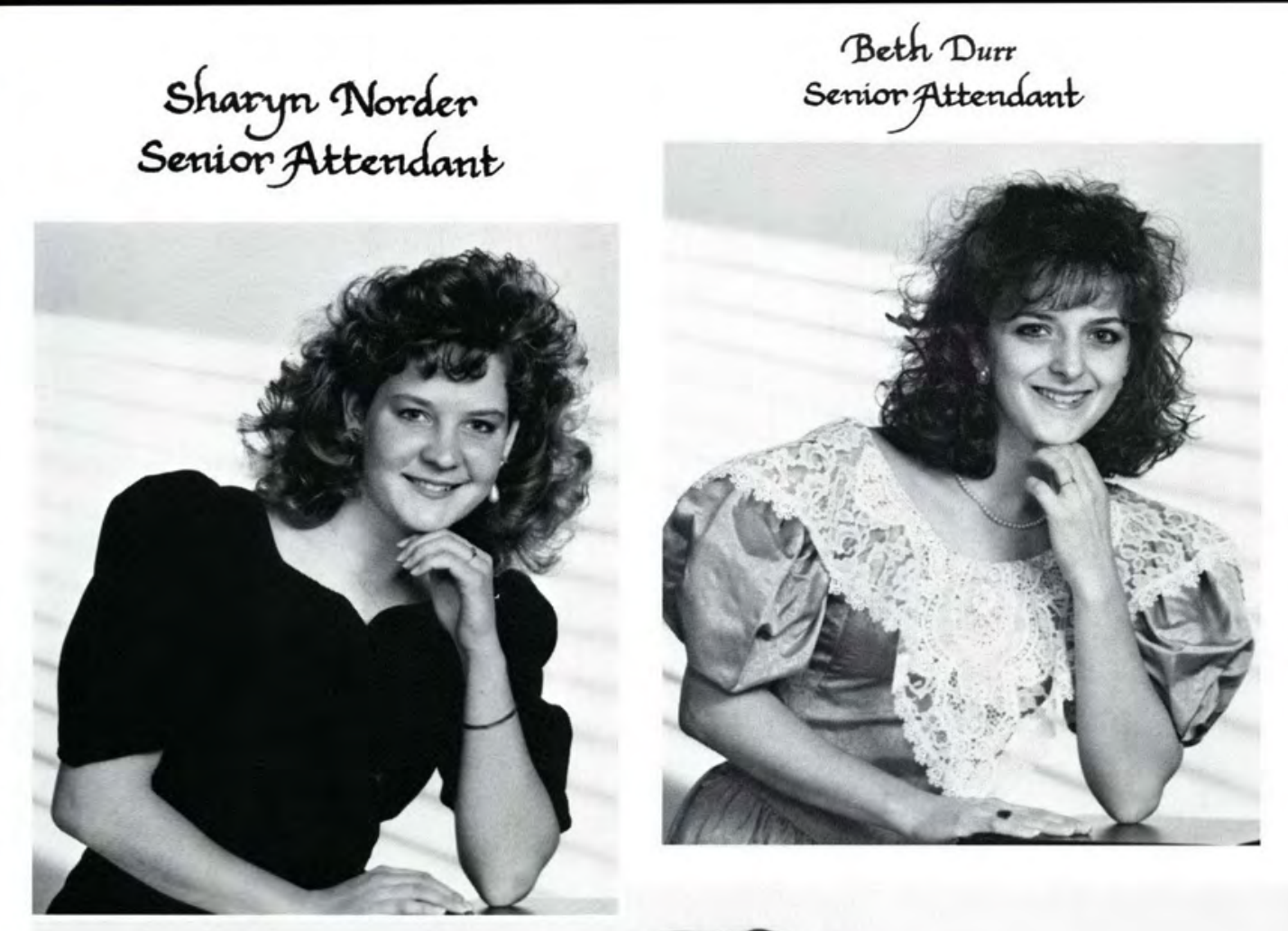

Beth Durr
Senior Attendant
Sarah Flile

Senior Attendant

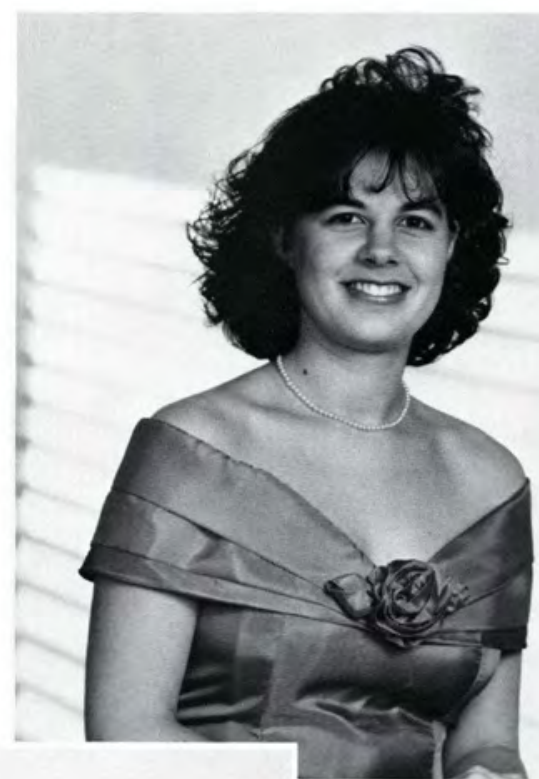

Kelly Scott Homeconaing Queen

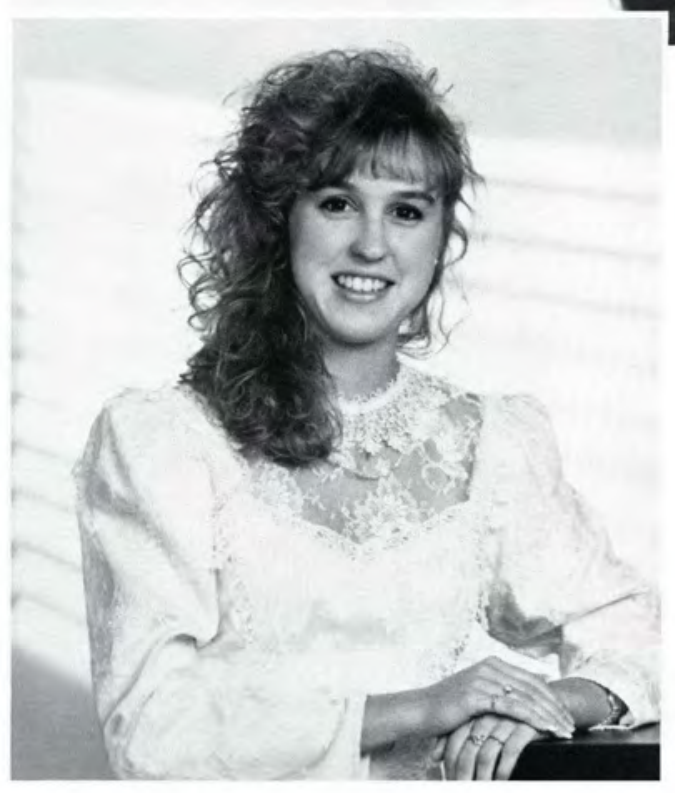

Allison Knowles Junior Attendant

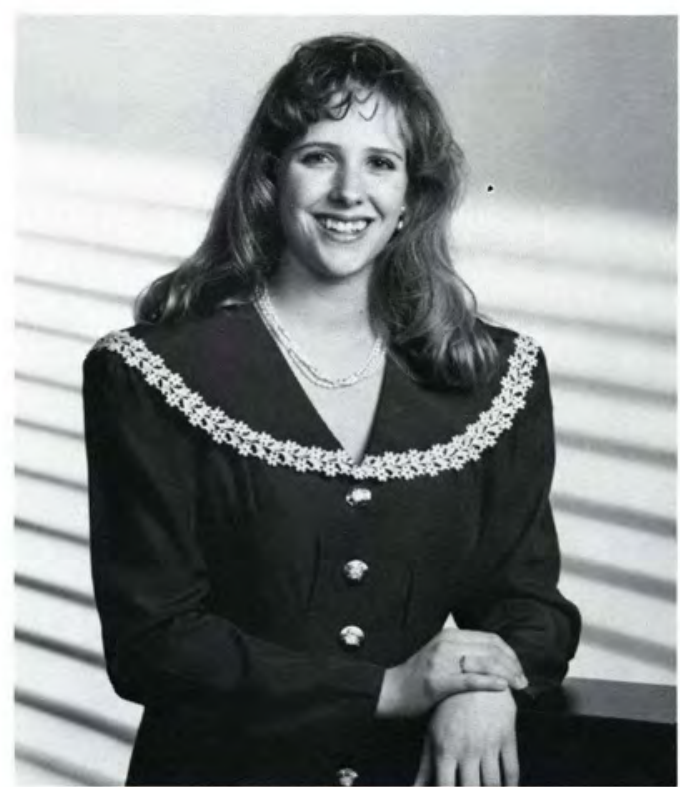

Jennifer Dilling Sophomore Attendant

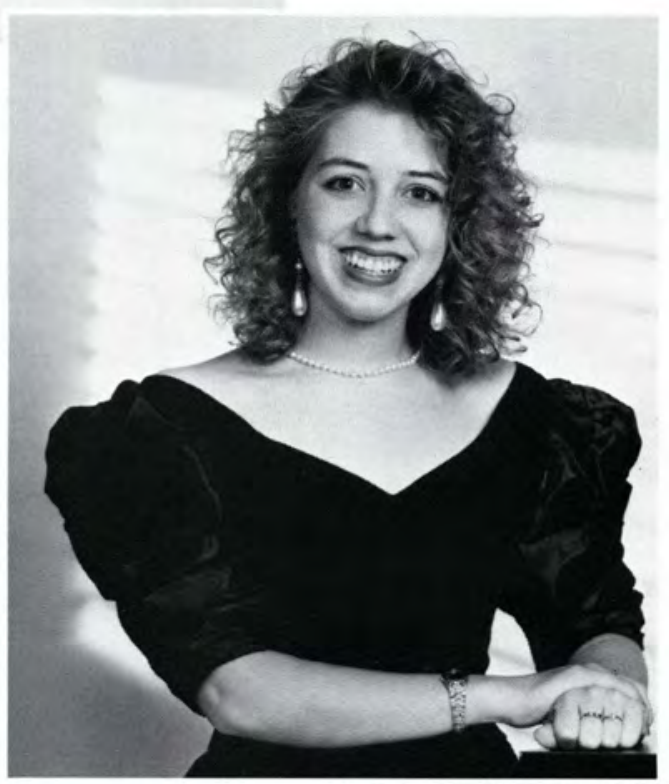

Jennifer Butler

Freshman Attendant 


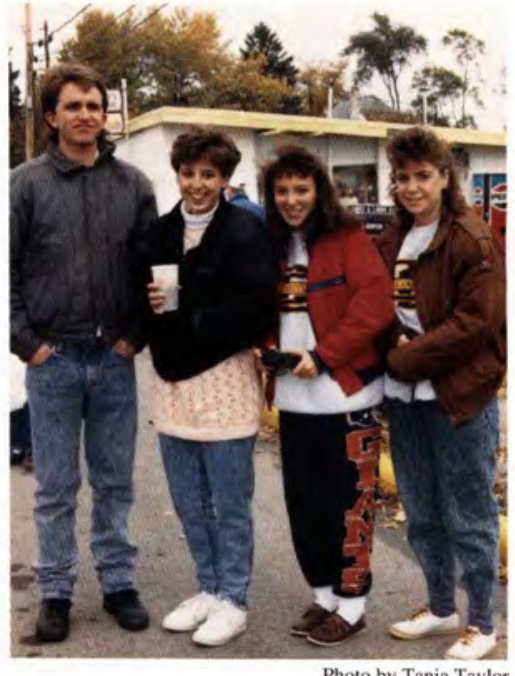

"Ialways look forward to fall. I'mback in use after a long, hot, lonely summer. The high school students are roaming my hallways, my bells are ringing to signal the start of classes, and teachers are writing on my chalkboards. But, best of all, fall is the timefor the homecoming parade of the college across thelstreet: the day when our own little Main street is transformedinto ourown version of Madison Avenue."

7 "I've seen every one of the Cedarville College parades, and each has been better E than the one before. This year's was no exception!"

- "Despite the cold and wind, students, alumni, and Cedarville residents-lined the street in anticipation of the coming events. Promptly at 10:00 a.m., the chapel bell chimed, and the parade began with the traditional opening banner. The banner was followed by bands, class and organizational floats (each trying to outdo the other for trophies), and, as usual, plenty of candy tossing. I think I even saw what resembled large, blue smurfs, but that couldn't be right, or could it?"

"The highlight of the whole day came when the queen and her court graced Main Street with their presence. The crowd shrieked-and huddled closer, trying to get a betterview. Anxious photographers darted into the street attempting to find just the right angle." "But all too soon, the onlookers vanished one by one, and soon Main Street became just another quiet avenue once again."

-Mindy Boone

DESPITE THE FRIGID

WEATHER, Deanna Wilcox,

Brenda Furman, and their friends manage to smile.

THEIR FIRST FLOAT.

Freshmen begin their college journey atop the freshman class

float.
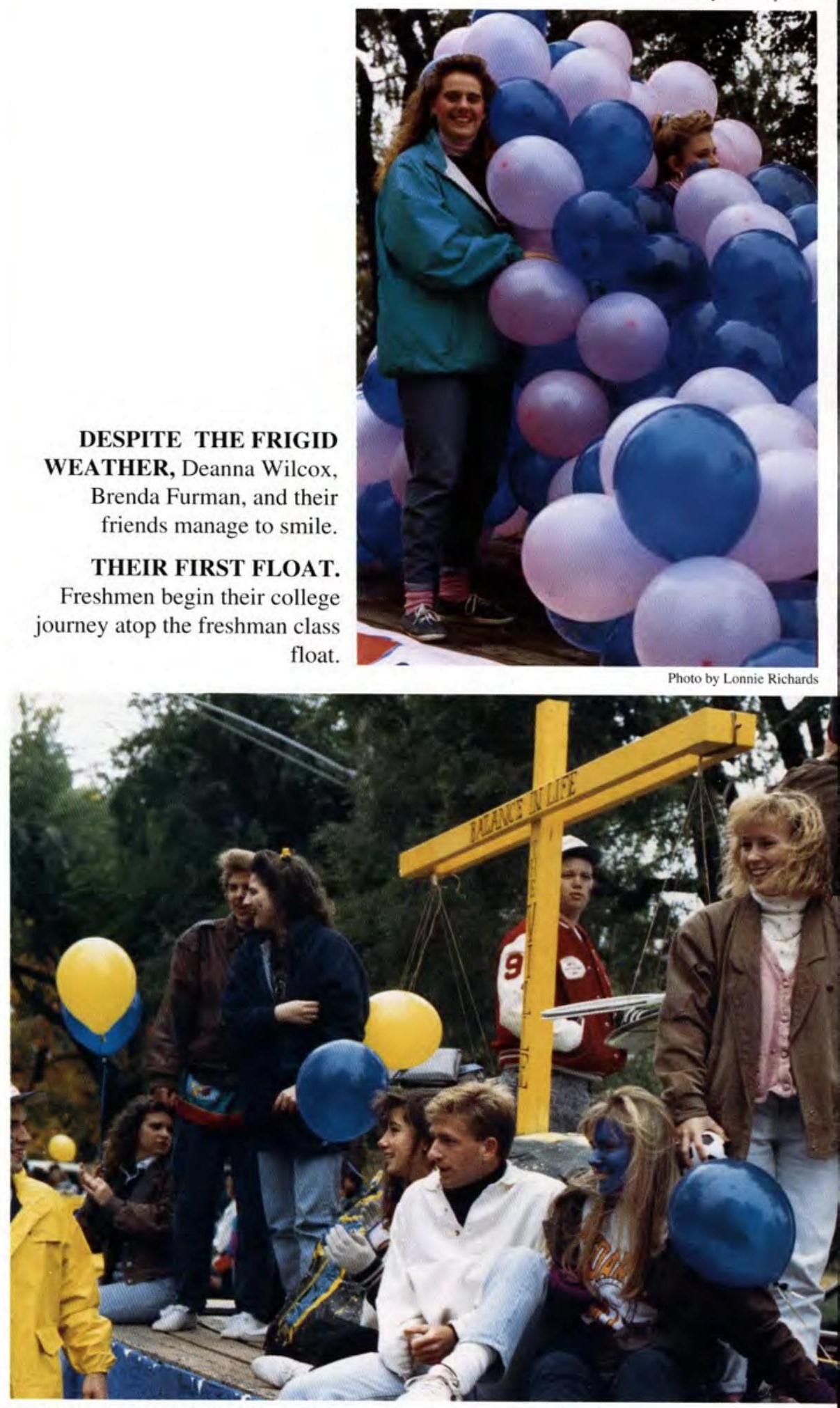

WITH A PROUD SMILE, Tammy Clark enjoys her ride in the Homecoming parade. 


\section{Need a Little}

\section{Christmas?}

\section{Decking the Halls at Open House}

Returning from Thanksgiving, students began anxiously to anticipate the approach of Christmas. Unfortunately, their spirits were dampened by the reminder that finals would soon arrive. To help students avoid burnout and to meet their need for a little Christmas, Student Services scheduled the annual residence hall open houses. Returning with wrapping paper, ornaments, lights, and Santa hats, students began to decorate their halls and units furiously. A campus-wide competition encouraged students to be creative in developing themes. The winning men and women used the themes "Under the Christmas Tree" and "Christmas Around the World" respectively. After the judges had passed, their candy was gone, and Dr. Dixon had breezed through, the students collapsed--ready to endure the final two weeks before break. -Marsha Olsen

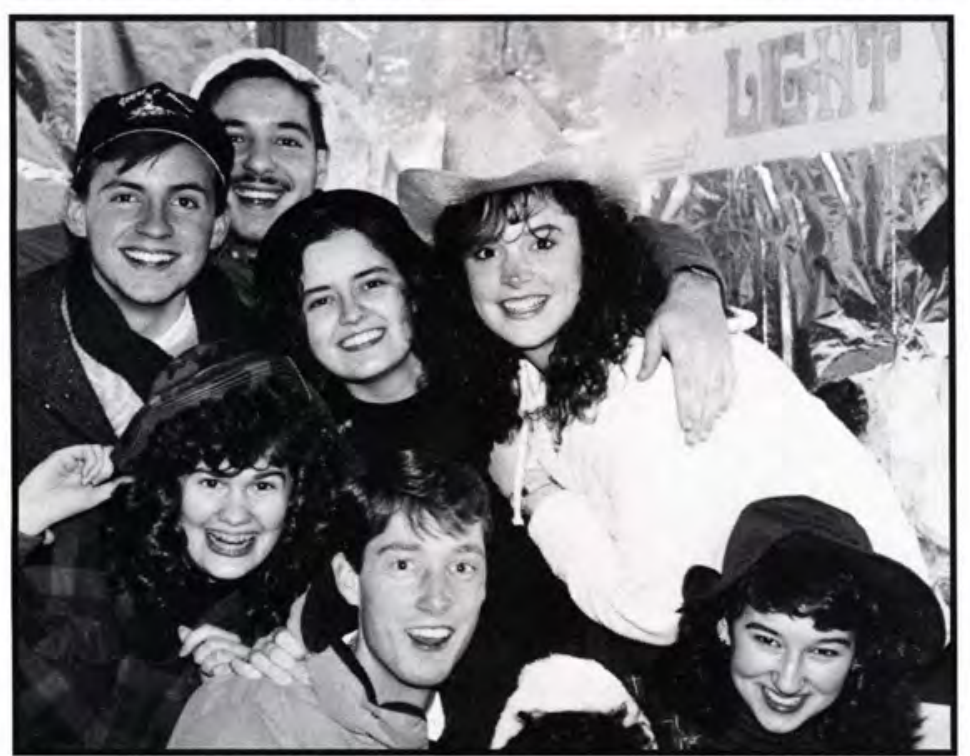

OPEN HOUSE brings out the best in everyone.

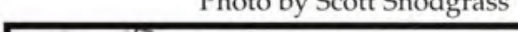

Photo by Scott Snodgrass

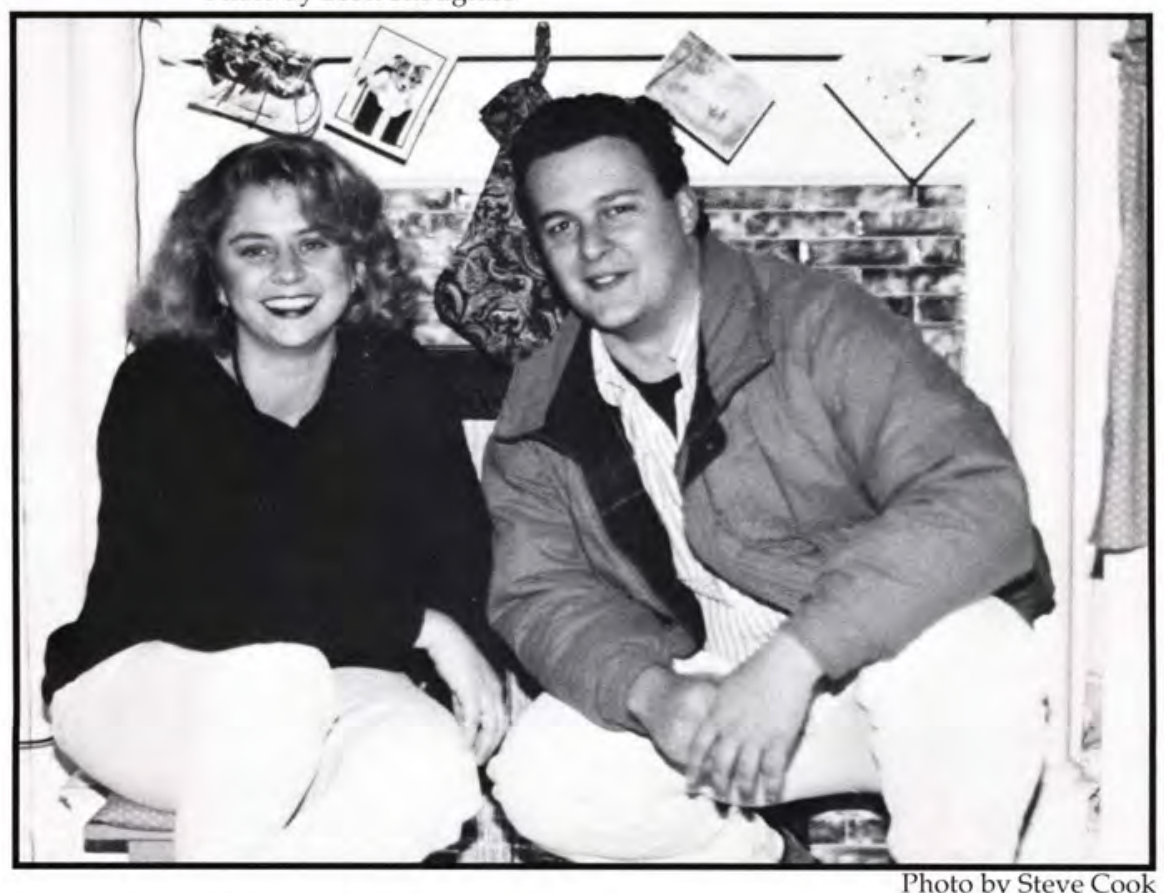

A HARRIMAN FIREPLACE sets the mood for Jerri Cook's visitor, Scott Mills
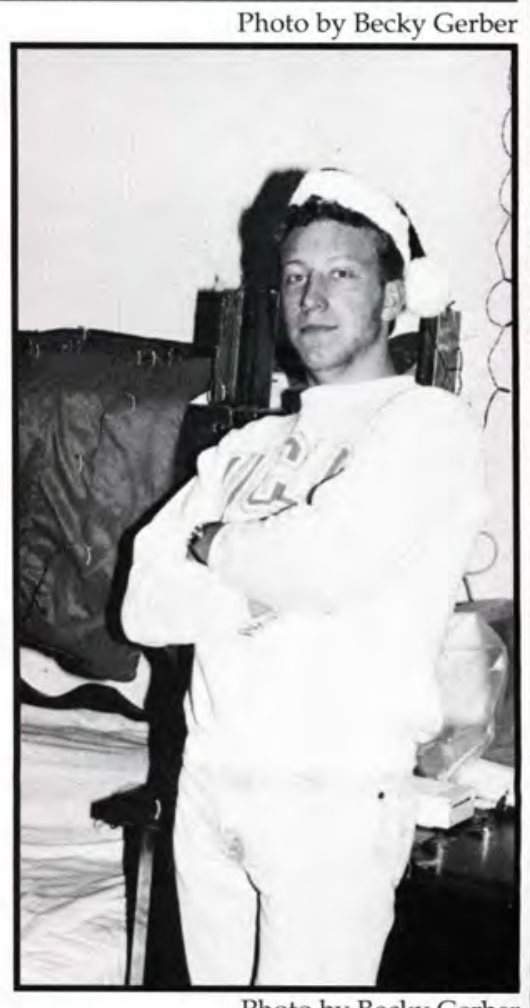

Photo by Becky Gerber BECAUSE OF FIRE CODE 776 which forbids live trees in the room, Jim Geise decorates his bunk with festive lights. 


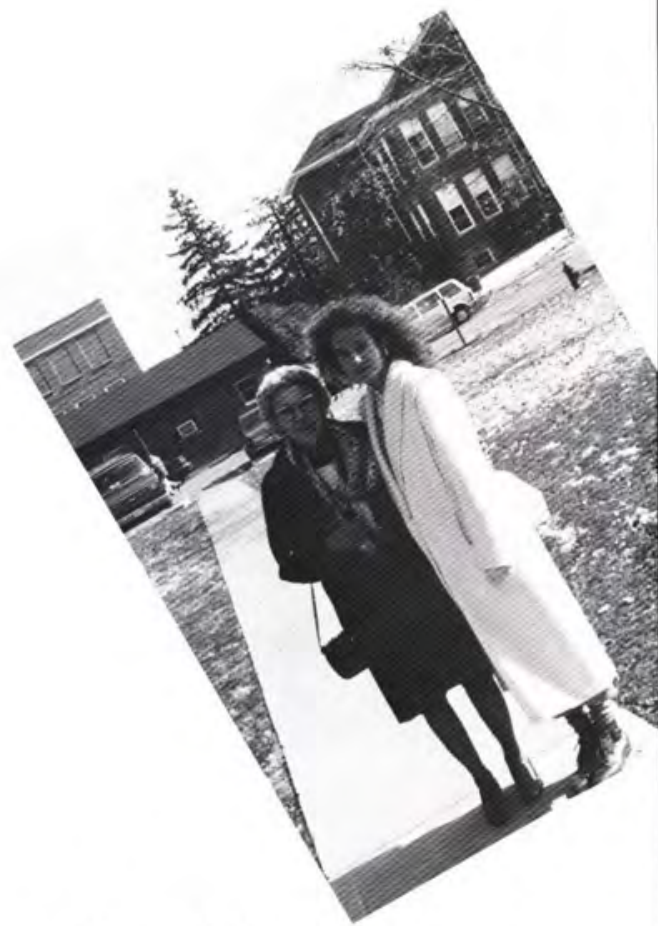

Family Days at Cedarville

The Cedarville College family expands three times a year to include both alumni, parents, and siblings. Homecoming is a time for former students to return to their alma mater and reflect on days past. This special weekend is surrounded by such events as the Homecoming soccer game, the annual parade, and many opportunities to interact with the friends made many years ago. It also allows the alumni to meet once again with the family they called Cedarville for four years of their lives, a memory that never fades.

Lil Sibs' Weekend creates a special weekend for younger brothers and sisters to spend time with an older family member on the Cedarville College campus. Many exciting activities take place during that weekend in February; the ADO-DOE Cupid's Bash has become an annual event that encourages the siblings to interact with the college students. A weekend favorite is the basketball game where lil sibs get a real taste of college life.

Parents' Weekend, held the first weekend in May, is a wonderful time for parents to experience a slice of life on campus as well as take in various entertainment including the spring drama production and the annual Pops Concert. This fun-filled weekend also provides parents with the chance to attend classes and meet their son's or daughter's professors. Thoroughly enjoyed by parents and students alike, this weekend provides the much needed motivation to make it through those last five weeks of school.

-Meredith Clements

\section{Honoring Our}

\section{Heritage}

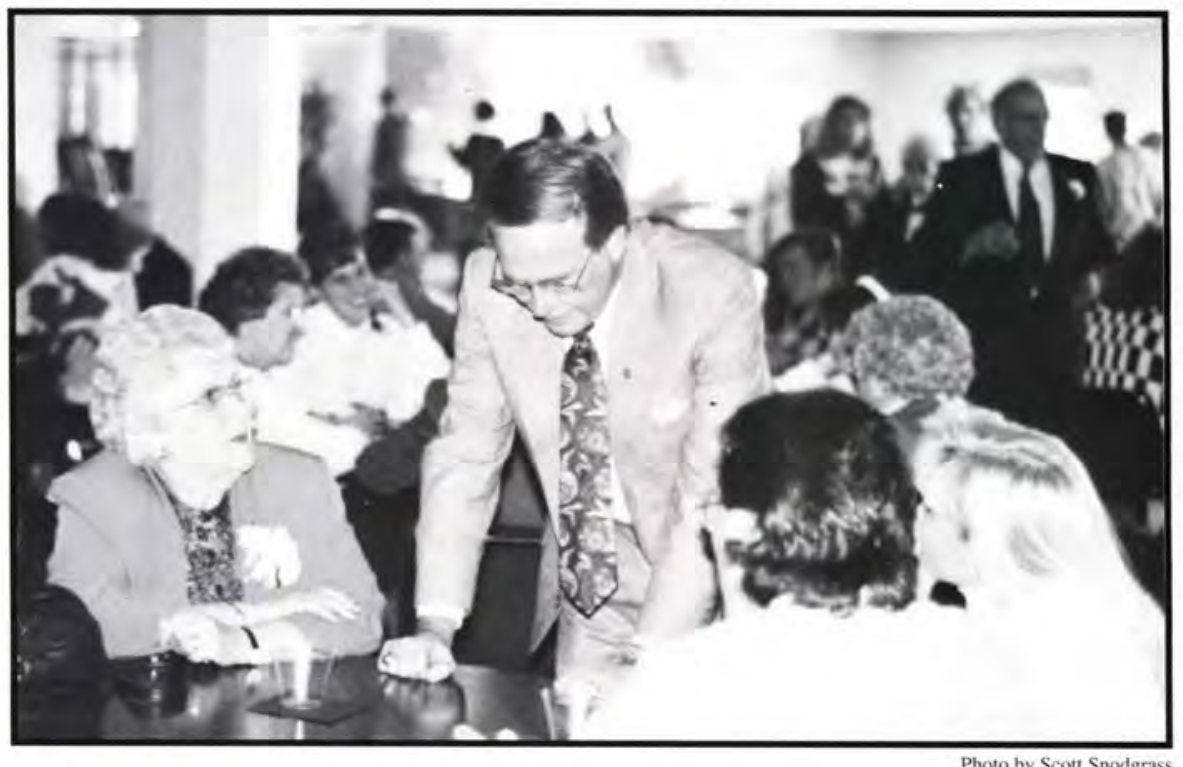

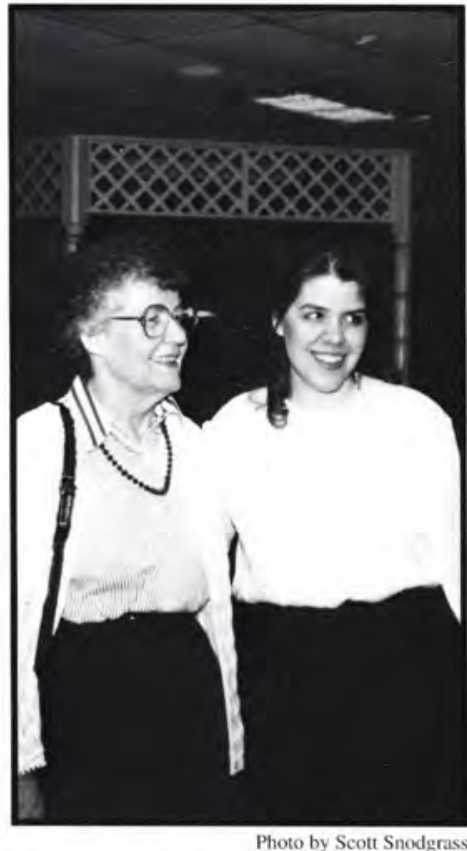

TOP: A RARE MOMENT.

Dr. Dixon struggles to get the words out.

ENJOYING HER PARENTS COMPANY, Connie Winch smiles for Parents' Weekend.

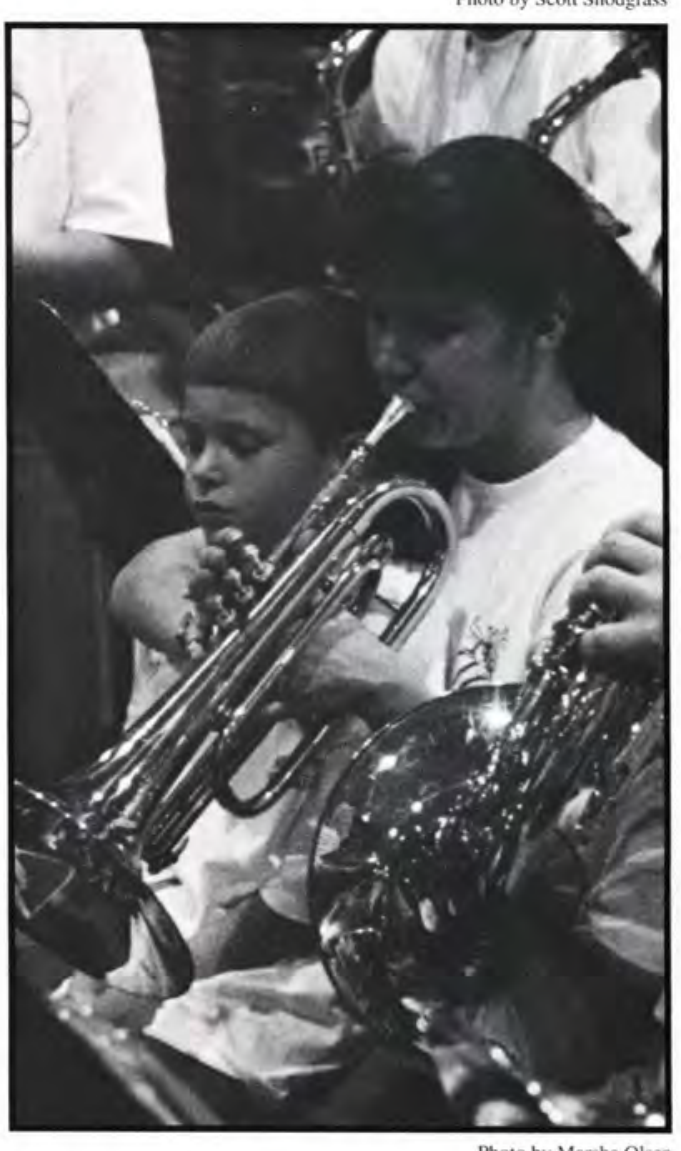

TOGETHERNESS. Some people just can't get enough of their little brothers. 

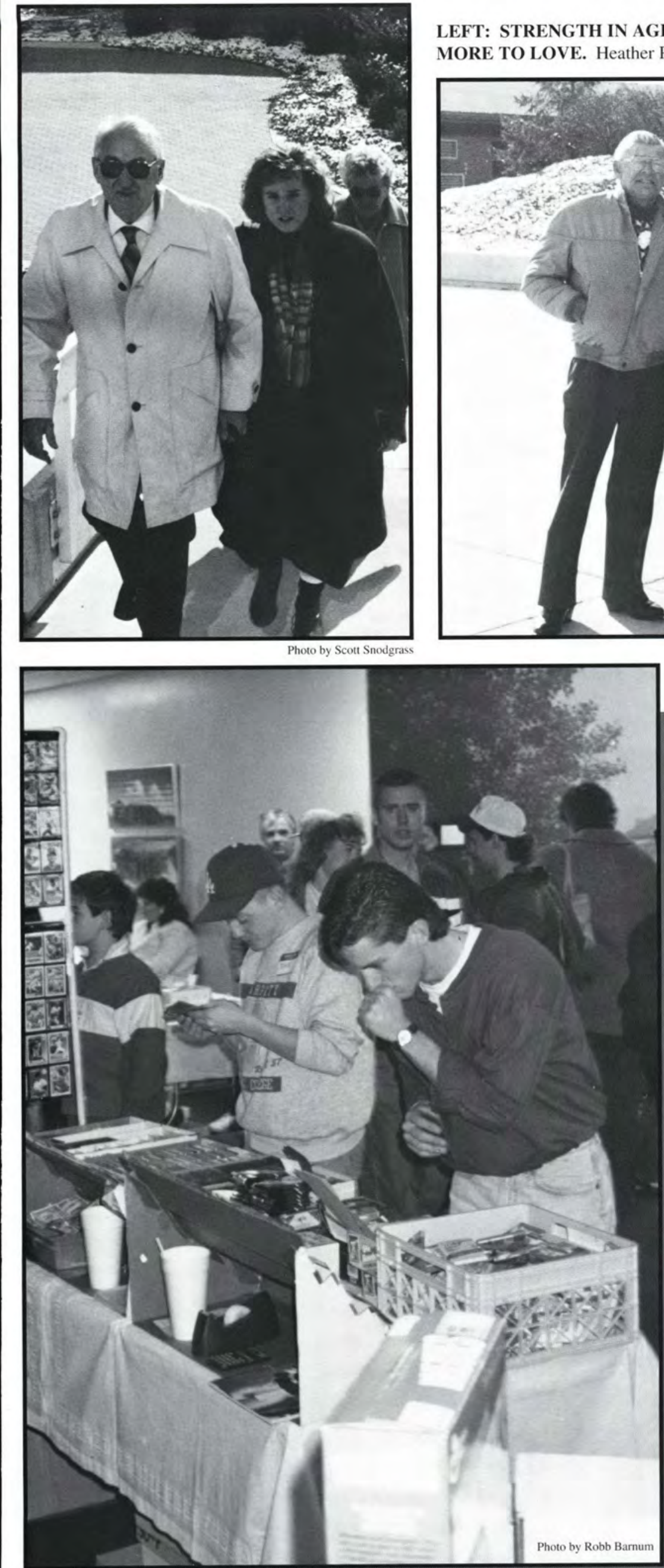

LITTLE SIBS' WEEKEND holds the ever popular Baseball Card Show for all Cedarville students and their sibs.
LEFT: STRENGTH IN AGE. Nothing like a strong arm to hold on a snowy Cedarville day.

MORE TO LOVE. Heather Perry agrees that two sets of grandparents are definitely better than one.
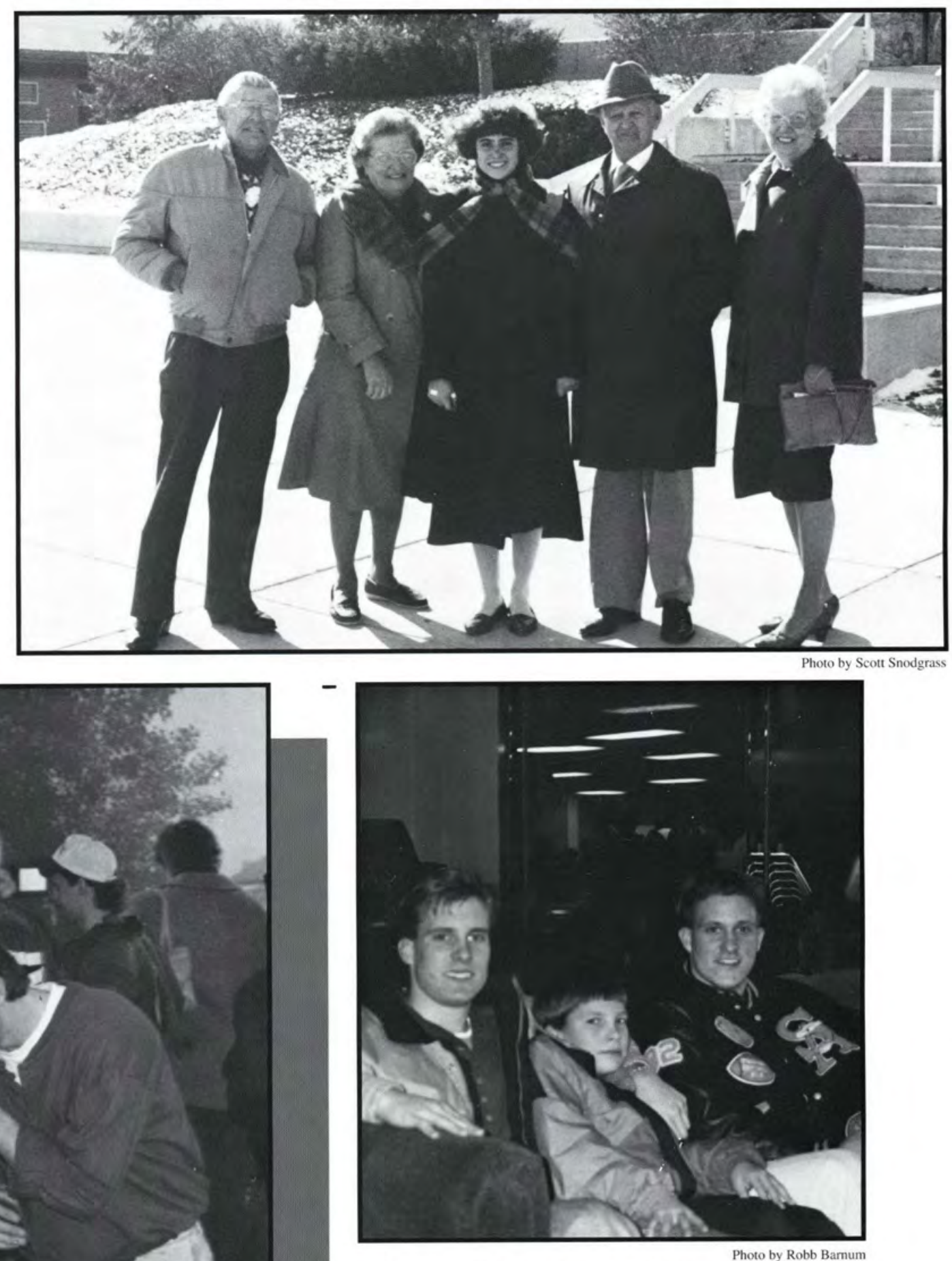

BROTHERS? Craig Yoder and company take a

break from the action during Lil Sibs' Weekend. 


\section{Straight From the Heart}

Once again I found myself sitting in the James T. Jeremiah chapel, attending another concert and listening to perfect people sing about their picture perfect lives. I wonder if any of them have ever doubted their faith or experienced guilt.

I was so engrossed in my thoughts that I didn't even hear Michael Card announced. When I looked up, all I saw was a man dressed in Dockers and moccasins leading everyone in "El-Shaddai." Then I realized that I was encountering Michael Card. Instantly I could sense that he was different than other performers. Instead of opening with a song, he led the entire audience in worship to God. While I was singing, I could truly feel the Spirit of the
Lord.

Michael Card's songs were quite thought-provoking. Many of his lyrics prompted me to search and evaluate my walk with God. My favorite song dealt with faith and how unattainable it seems. "To be guided by a hand I cannot hold. To hear with my heart; to see with my soul; to trust in a way I cannot see. That's what faith must be." Instantly, a warm feeling of unconditional love from God washed over me.

Michael Card and his band are not any ordinary band. Faithfully they travel all over the United States renewing Christians everywhere and motivating us to look beyond face value and see God for who He really is.

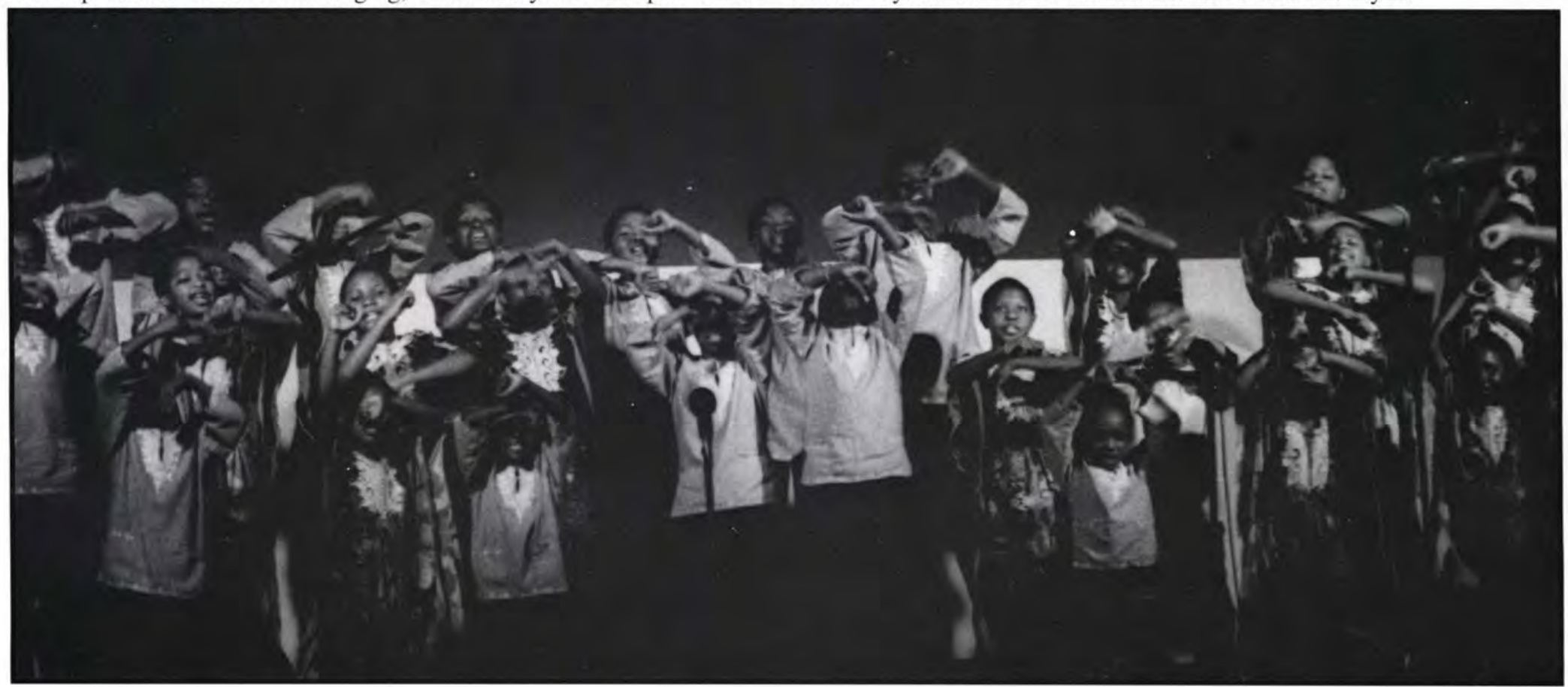

The African Children's Choir enchants the student body with their lively music to

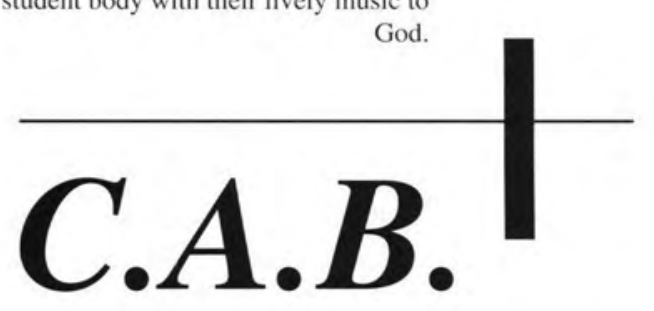

Presents

Buddy Green leads praising to God through his harmonica and singing

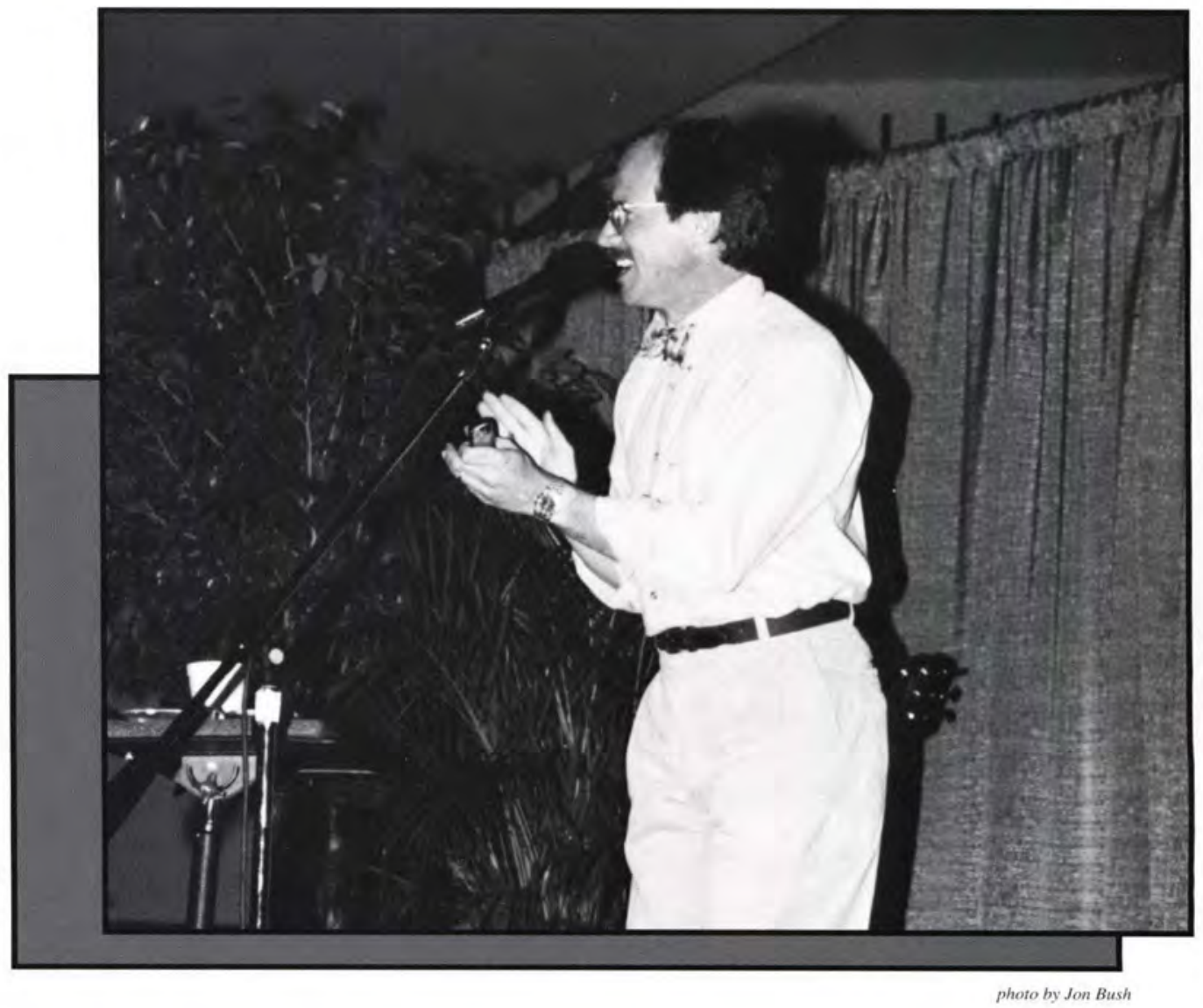


Steve Green touches the hearts of Cedarville College in sincere worship to God.

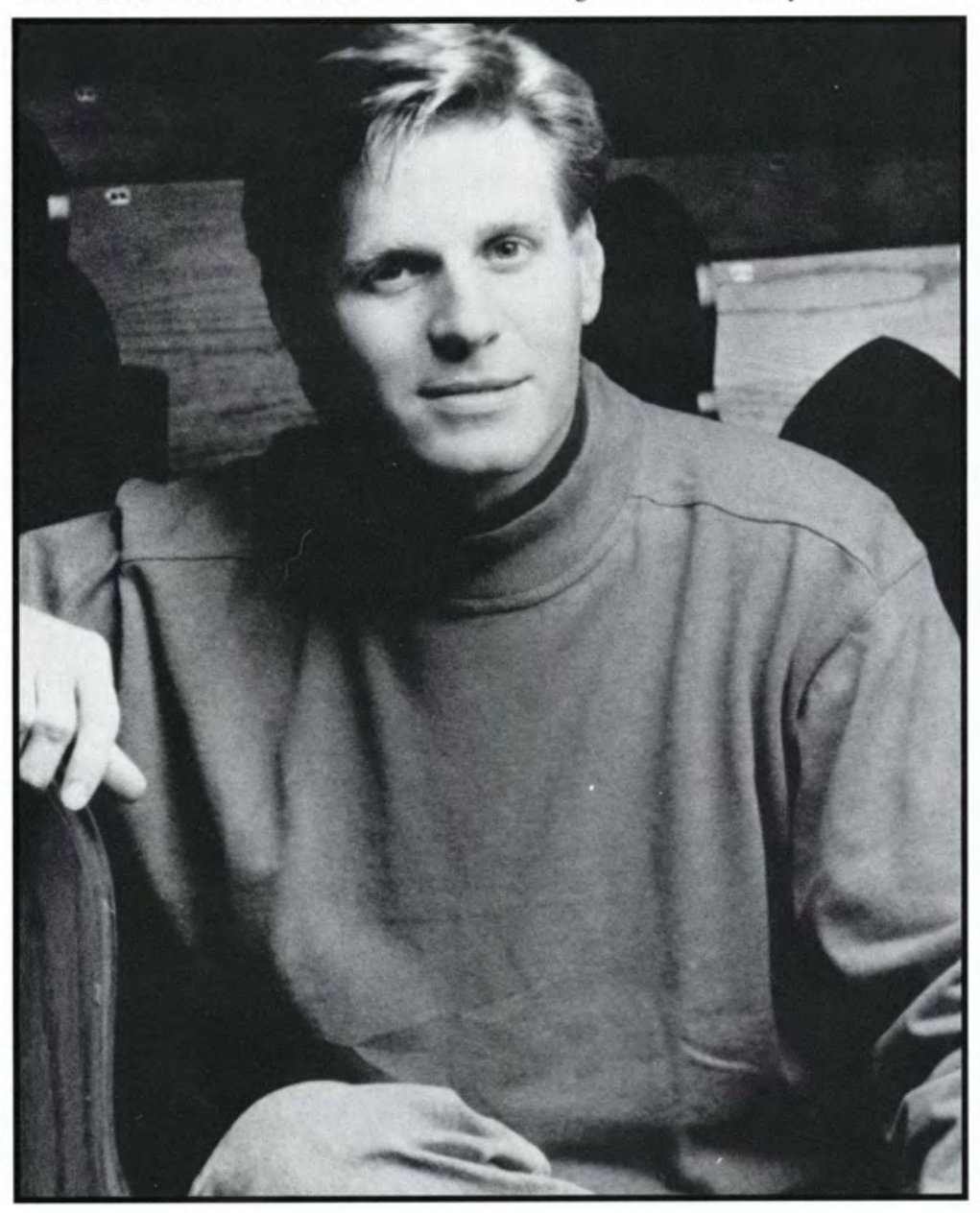

Dan Korem educates the audience on the trickery employed by faith healers and psychics.

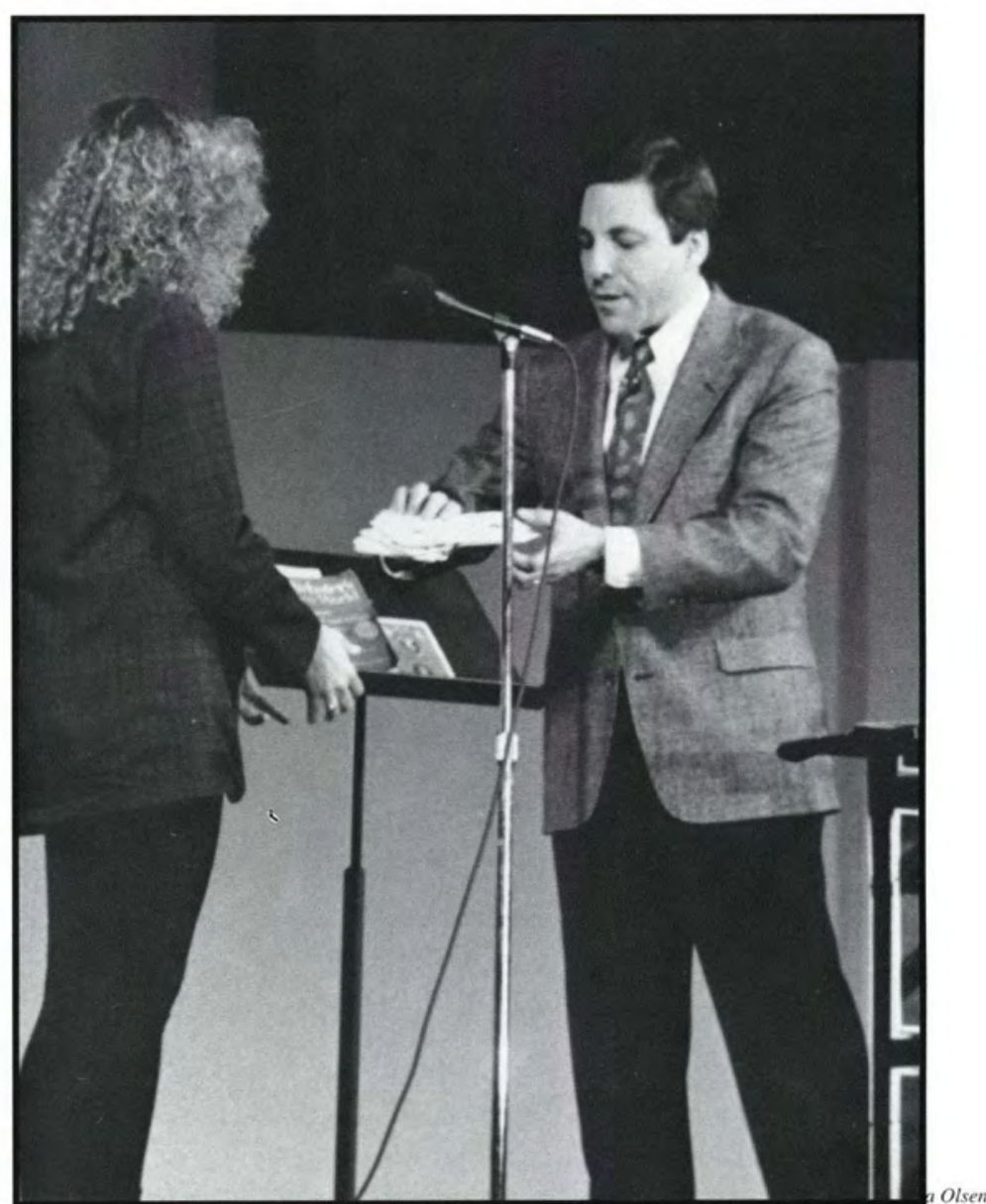

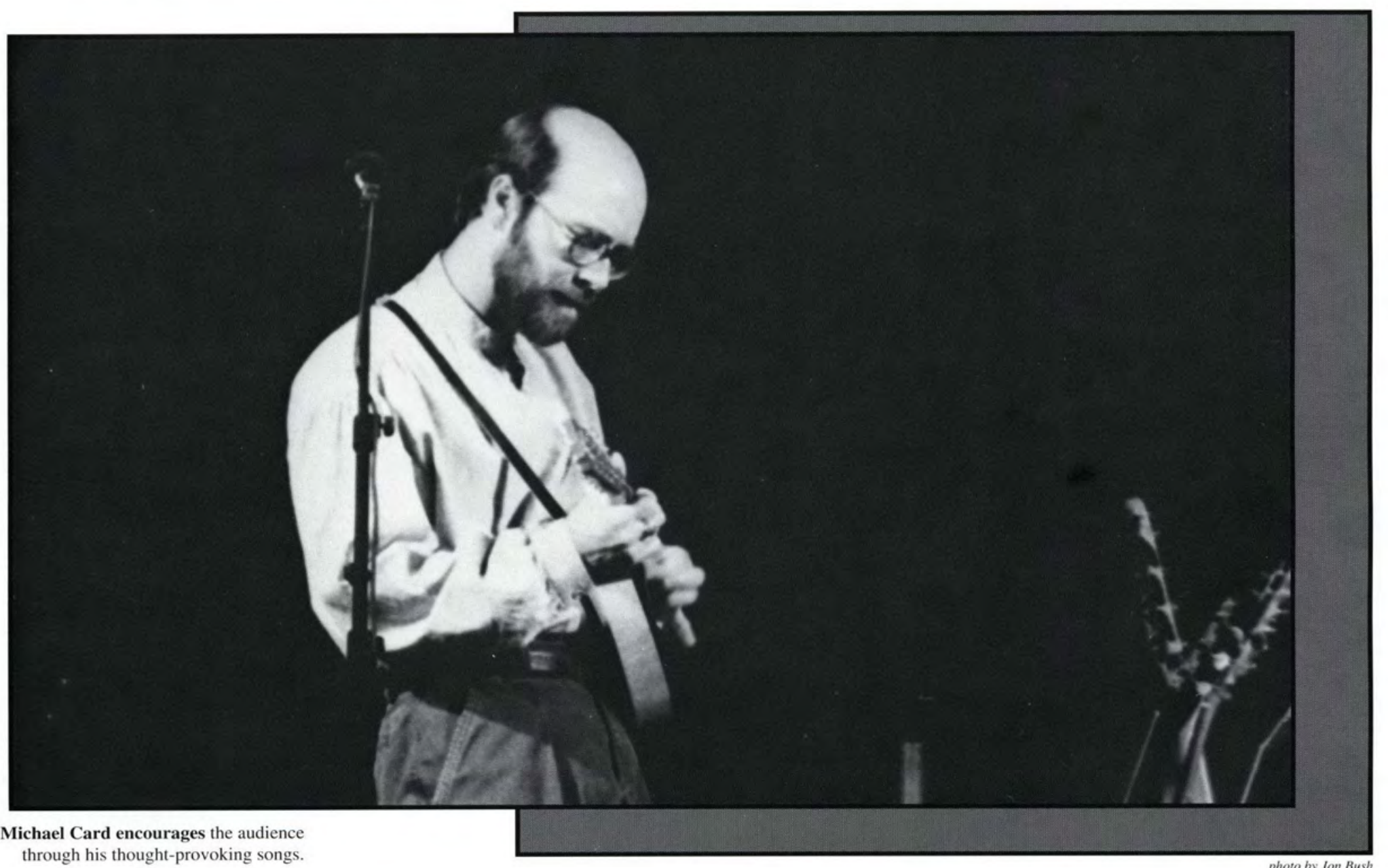




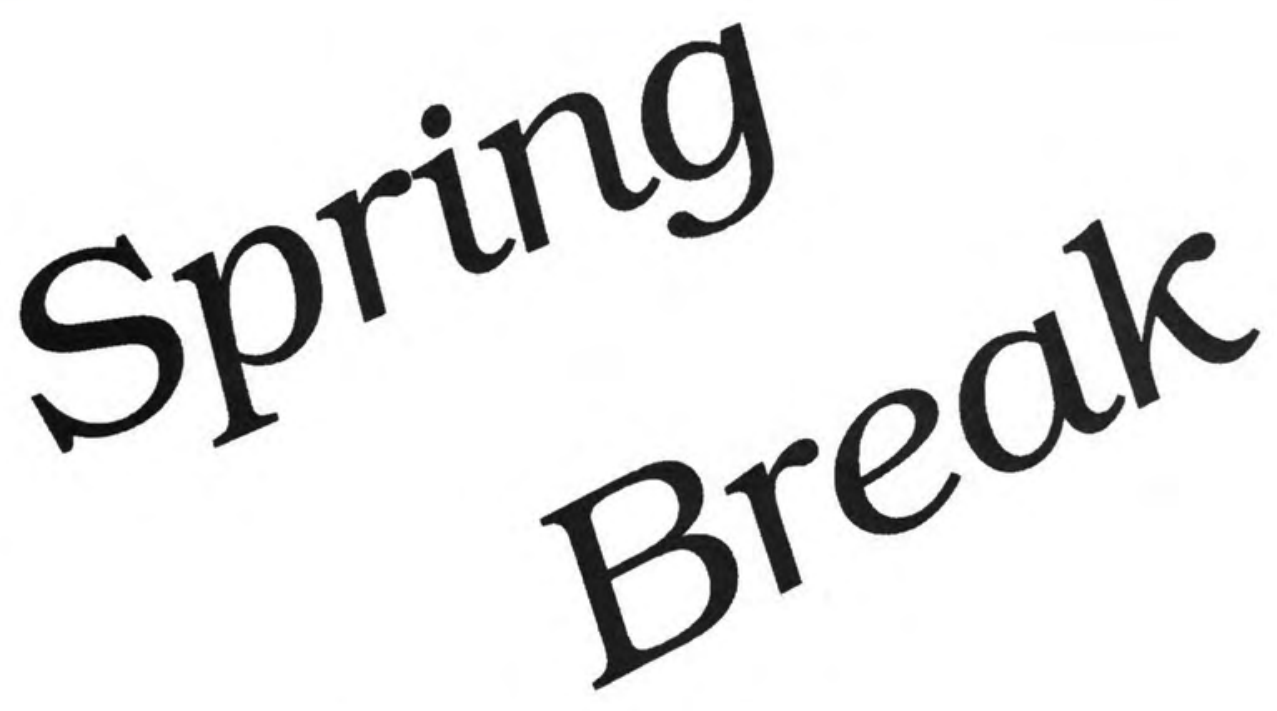

HOME IS WHERE THE HEART IS.

Susan and Sarah Denlinger demonstrate that welcome feeling home can give you.

FEELING A LITTLE LEFT OUT? Chris

Handel just hates being left out!

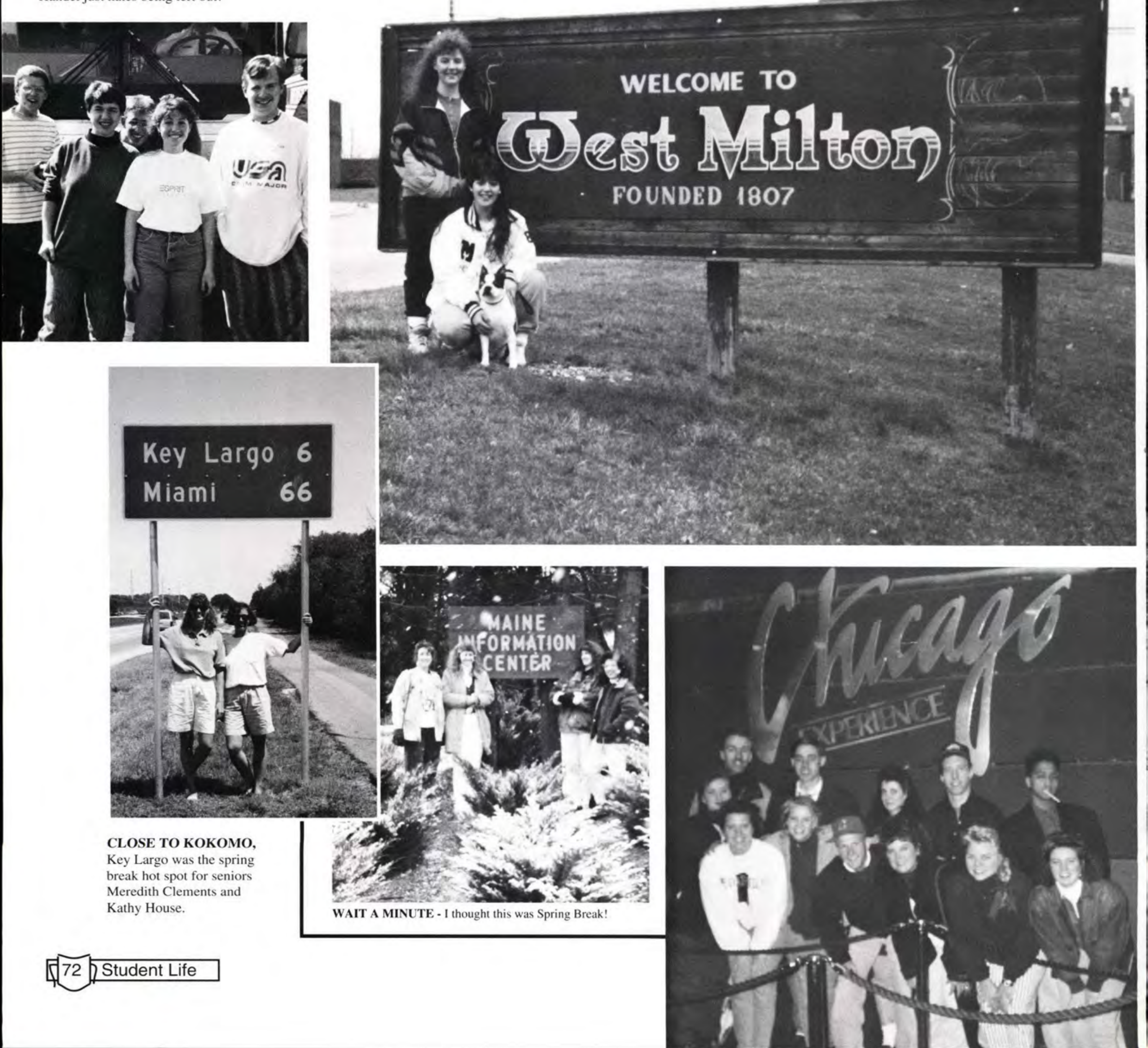



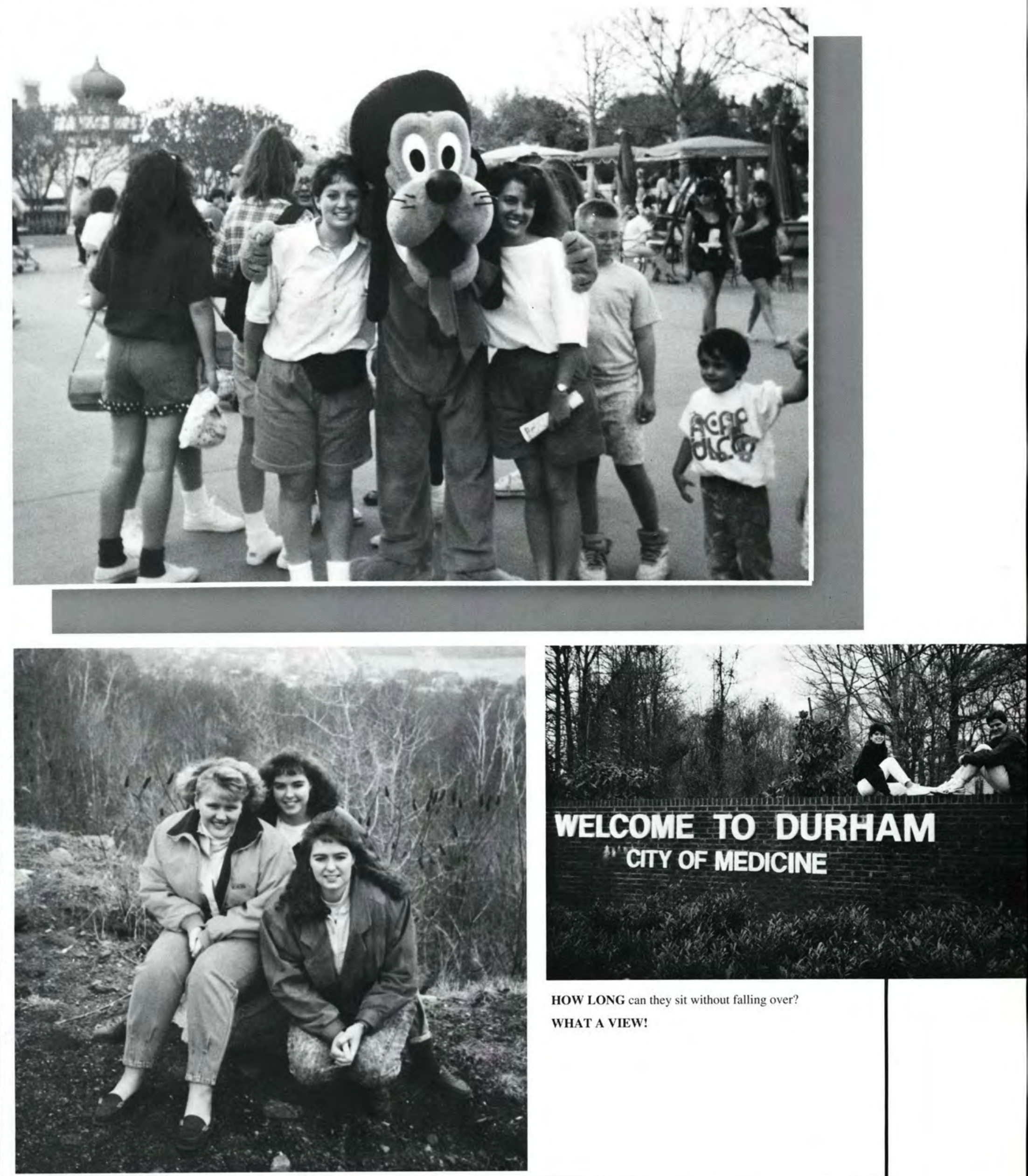

\section{WELCOME TO DURHAM "CITY OF MEDICINE}

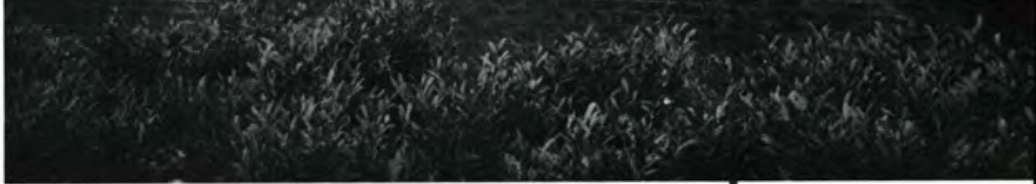

HOW LONG can they sit without falling over?

WHAT A VIEW! 
HEAD FOR THE BEACH or as close as they can with the sand volleyball tournament.

\section{Intramurals}

More than just a game

STRUTTING THEIR STUFF, these Cedarville women battle it out for the soccer championship. POWDERPUFF FOOTBALL shows who are the real athletes at Cedarville.
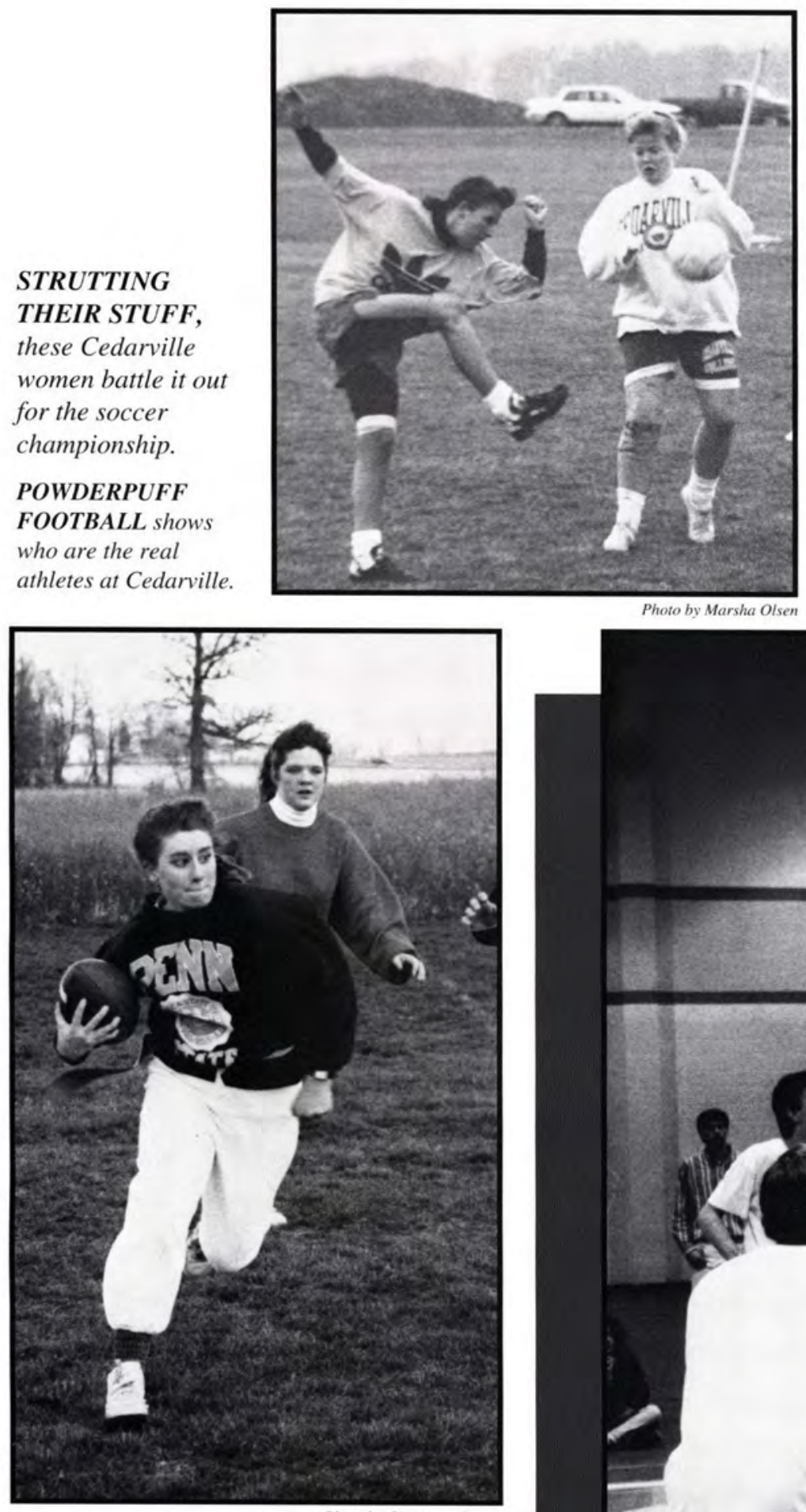

Photo by Cinnamon Brown

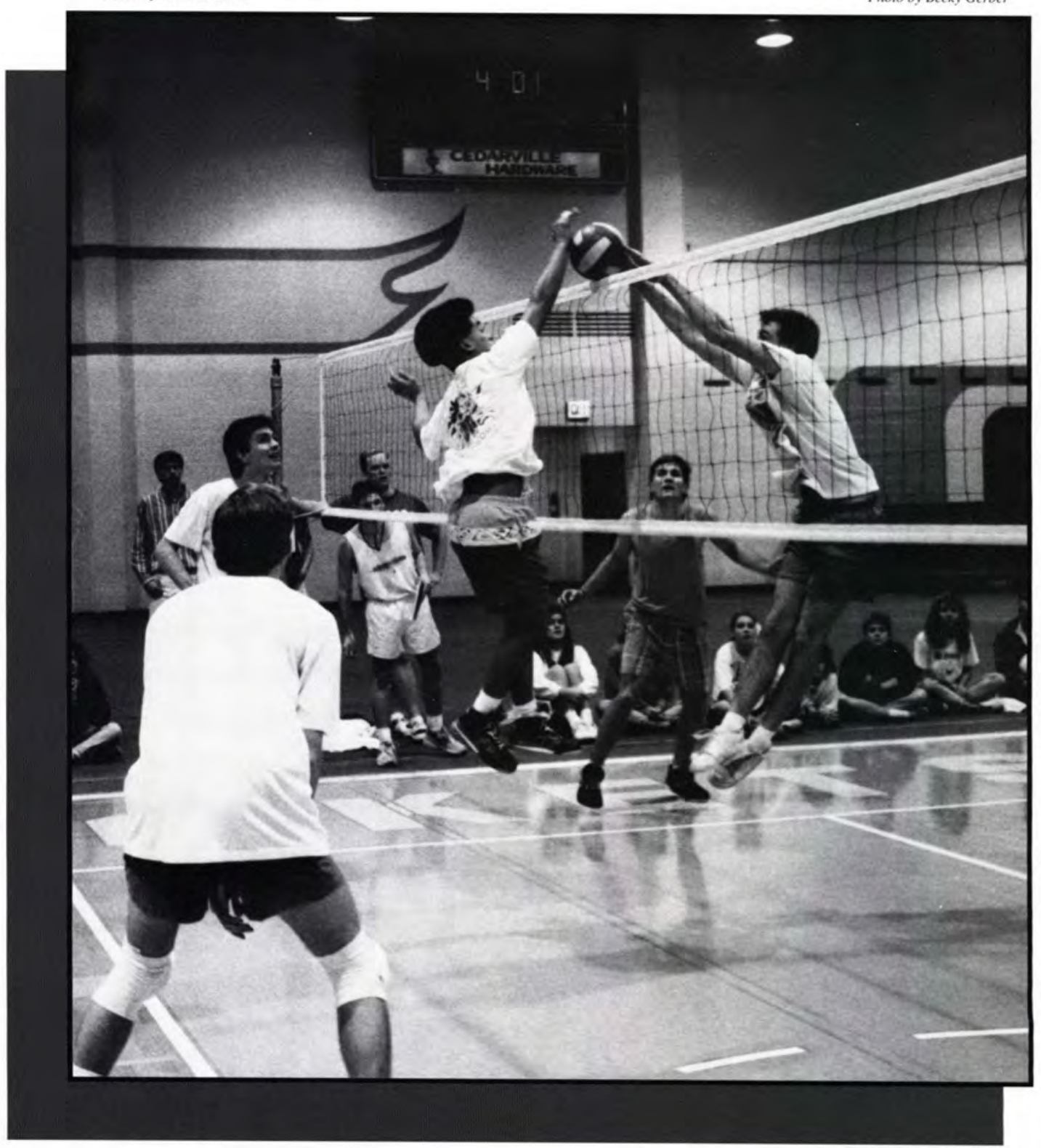




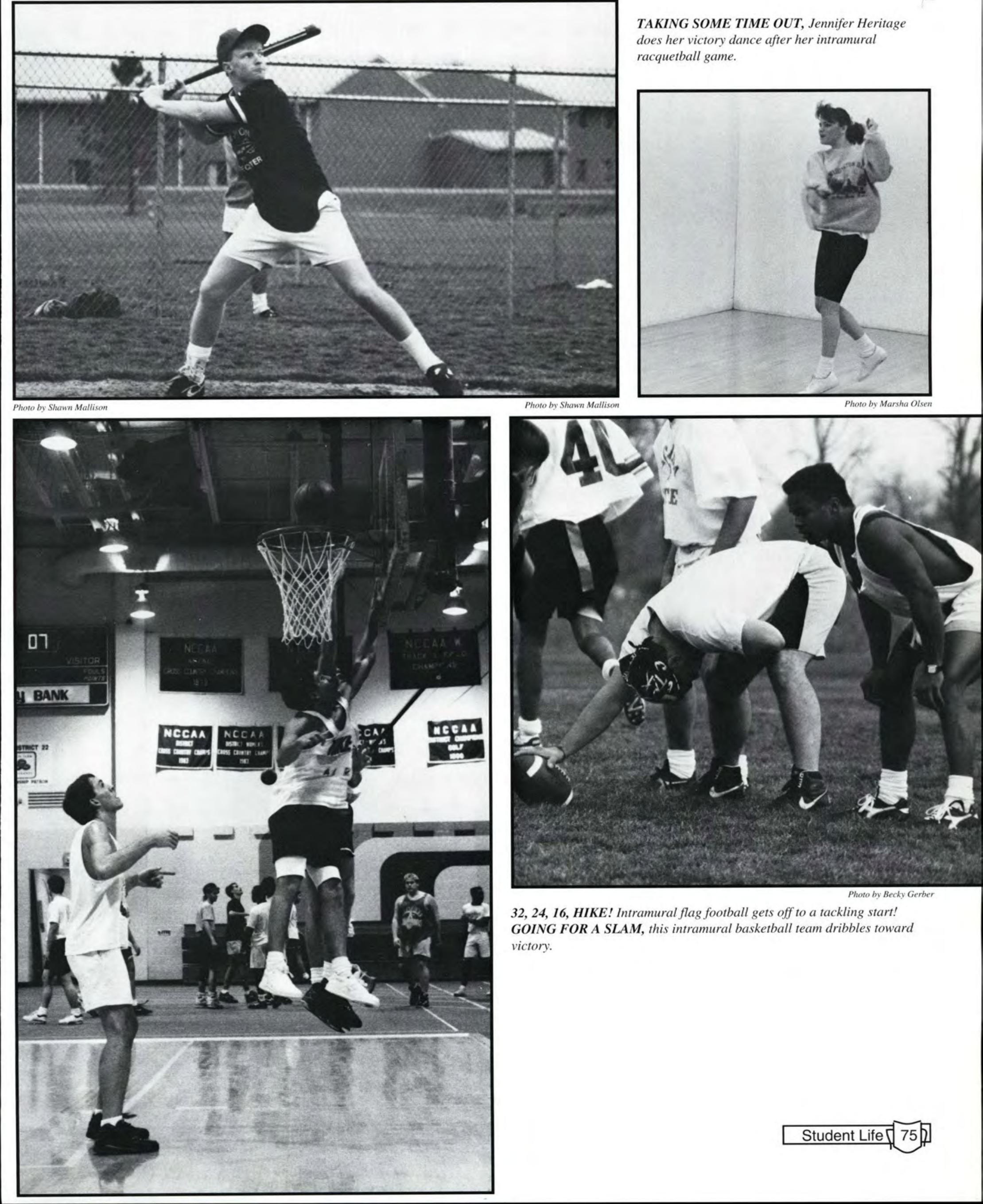




\section{Offering Valuable Advice:}

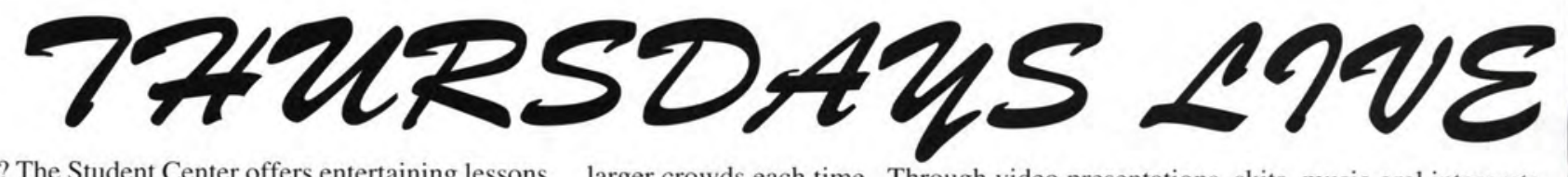

Nothing to do on a Thursday night? The Student Center offers entertaining lessons in life!

"Thursdays Live" was this year's addition to the social fanfare offered at Cedarville College. This idea, borne by professor Carl Ruby, allowed students to be related to, not preached at; and entertained, not insulted. At the same time, it bluntly, honestly dealt with relevant issues facing college-aged individuals.

Presented in the Student Center one evening each quarter, "Thursdays Live" drew

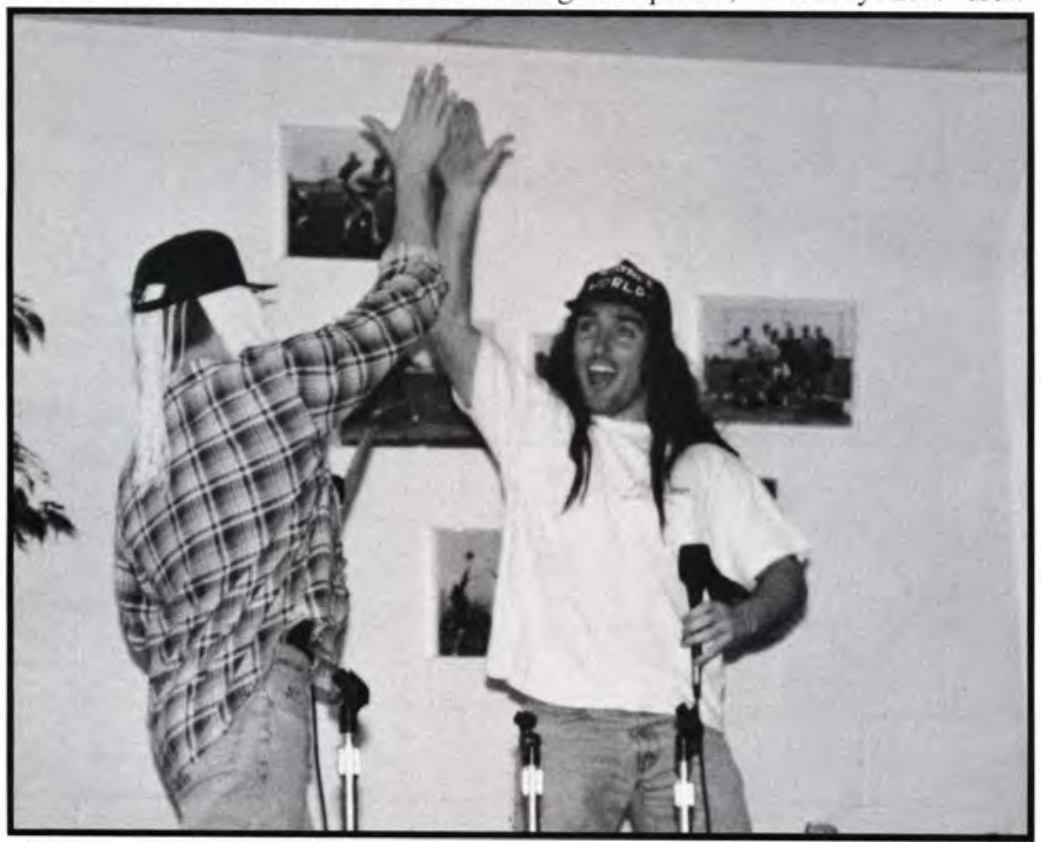

Mike Hieft entertains the audience with his great acting abilities.
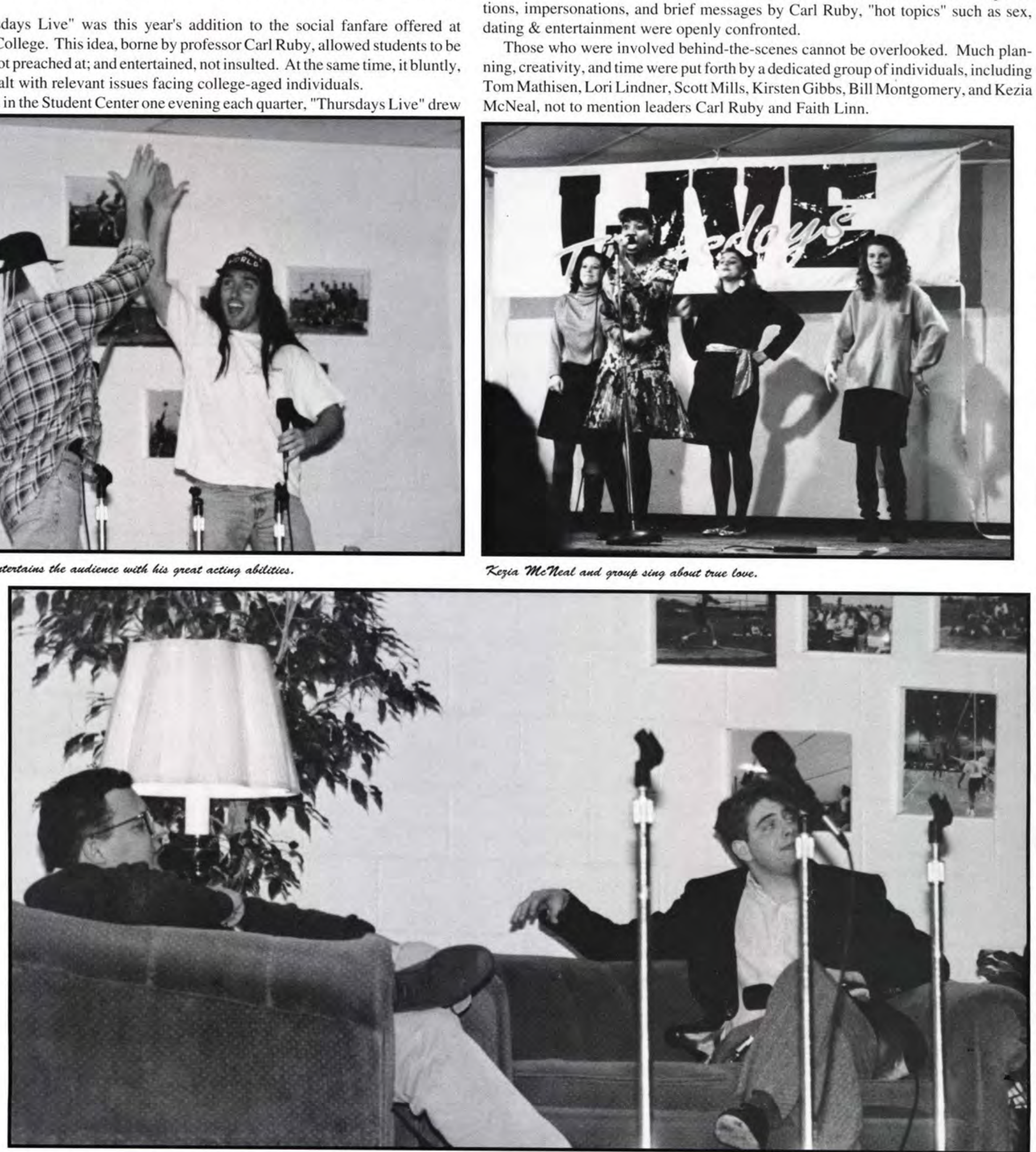
dating \& entertainment were openly confronted

Those who were involved behind-the-scenes cannot be overlooked. Much planning, creativity, and time were put forth by a dedicated group of individuals, including Tom Mathisen, Lori Lindner, Scott Mills, Kirsten Gibbs, Bill Montgomery, and Kezia McNeal, not to mention leaders Carl Ruby and Faith Linn.

Keria Mineal and group sing about true loue.

? 

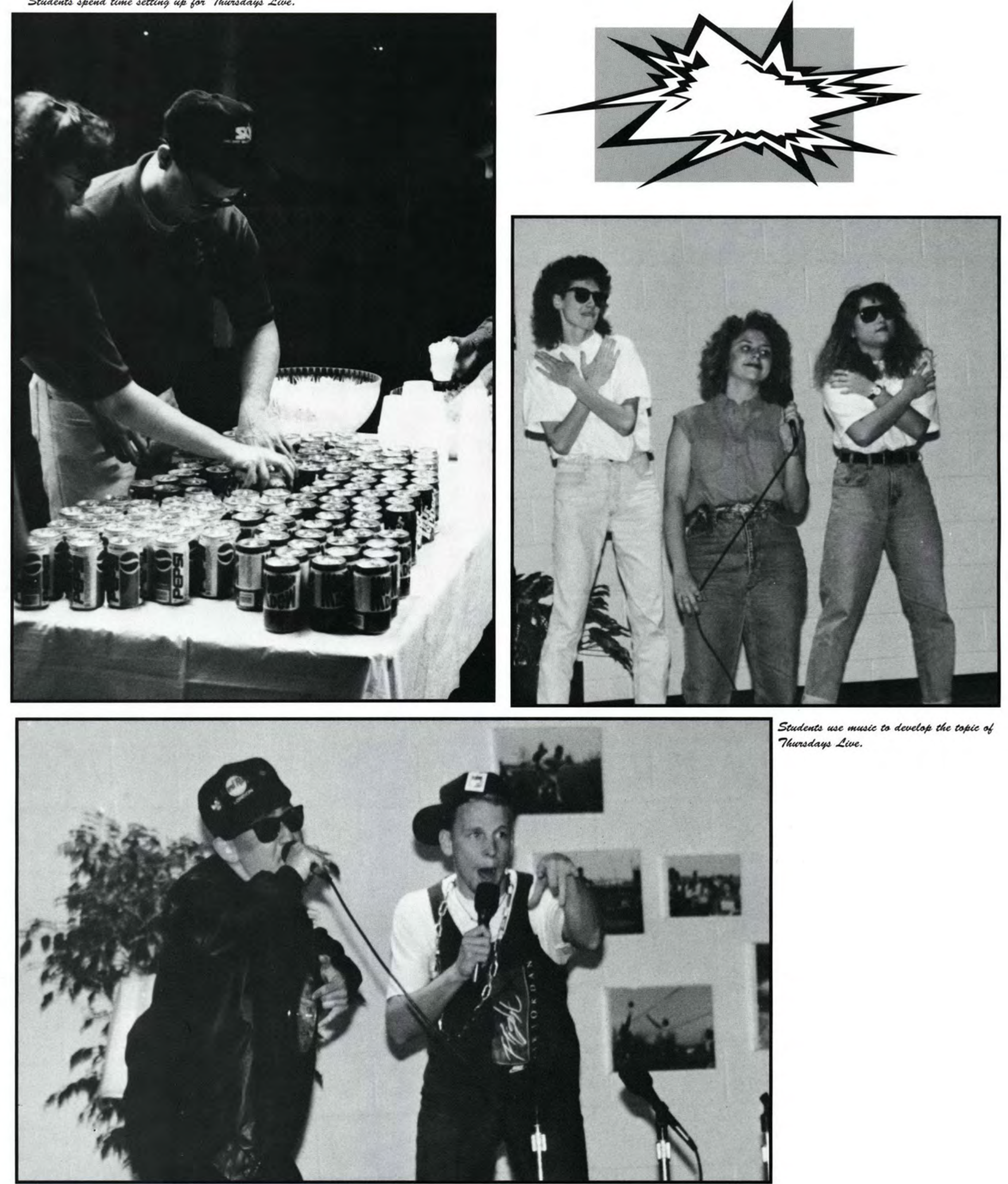

Students use music to develop the tapic of

Thuorsdays Live uses rap to get the point acrose. 


\section{Facing the Challenge Freshman Class}

Abrams, Melinda Allen, Jennifer Ames, Sandra Anderson, Kerry Ashcraft, Milinda Bader, Kimberly Bain, Michael

Baker, Kathy Bandy, Larry Barnes, Amy Barnhart, Laurel Barrett, Janie

Bartley, Mary Barton, Alesia

Bartosiewicz, Jennifer Bauer, Erik

Beabout, Victoria Beaty, Carrie Beck, Karen Beebe, Wesley Beecher, Robert

Beheler, Tiffany Beitler, Nathan Bell, Laurie

Bellew, Michelle Bennett, Alicia Berkheiser, Rebecca

Berry, Devon Bierly, Cinnamon Biggs, Maria

Blew, Amanda Boggs, Karen Bond, Kathryn

Bondorff, Jacqueline Bonga, Janet Borton, Jason
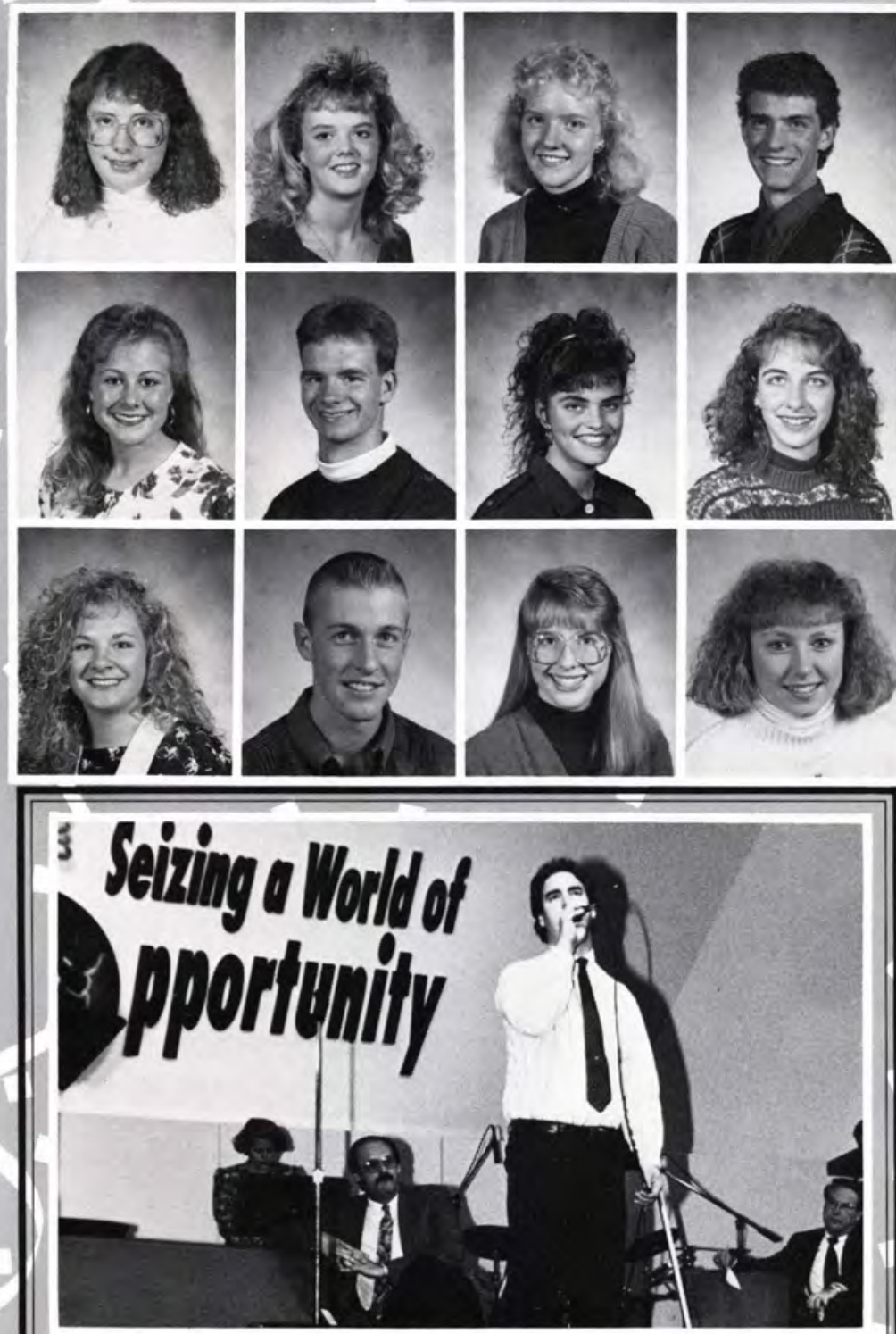

Many alumni shared with the college family in song.

\section{Alumni Week in Chapel}

Homecoming is the one chance each year that past graduates are able to return to their alma mater and reflect on times past. Present students had the opportunity this week to listen to alumni speak in chapel and see for themselves how Cedarville College has influenced other people's lives. Every speaker glowed when he spoke of Cedarville and pondered the past with sincere gratitude for all that this school did for him - not only academically, but spiritually and socially as well.

Jim Carrington, a 1982 graduate and a pastor in Milwaukee, Wisconsin, challenged everyone to realize his or her responsibility to the world, the church, and each other. He expressed his heartfelt concern for the unsaved.

Dr. Rex Rogers, the president of Grand Rapids Bible College and a 1974 graduate, spoke of his recent travels to the Soviet Union. He also encouraged students to find God's direction in their lives and allow God to lead.

Prof. Robert Forrum and Jennifer Stevens Bean, a 1988 graduate, also prompted everyone to appreciate the present and to seize every opportunity possible while attending Cedarville College.

- Janet Payne
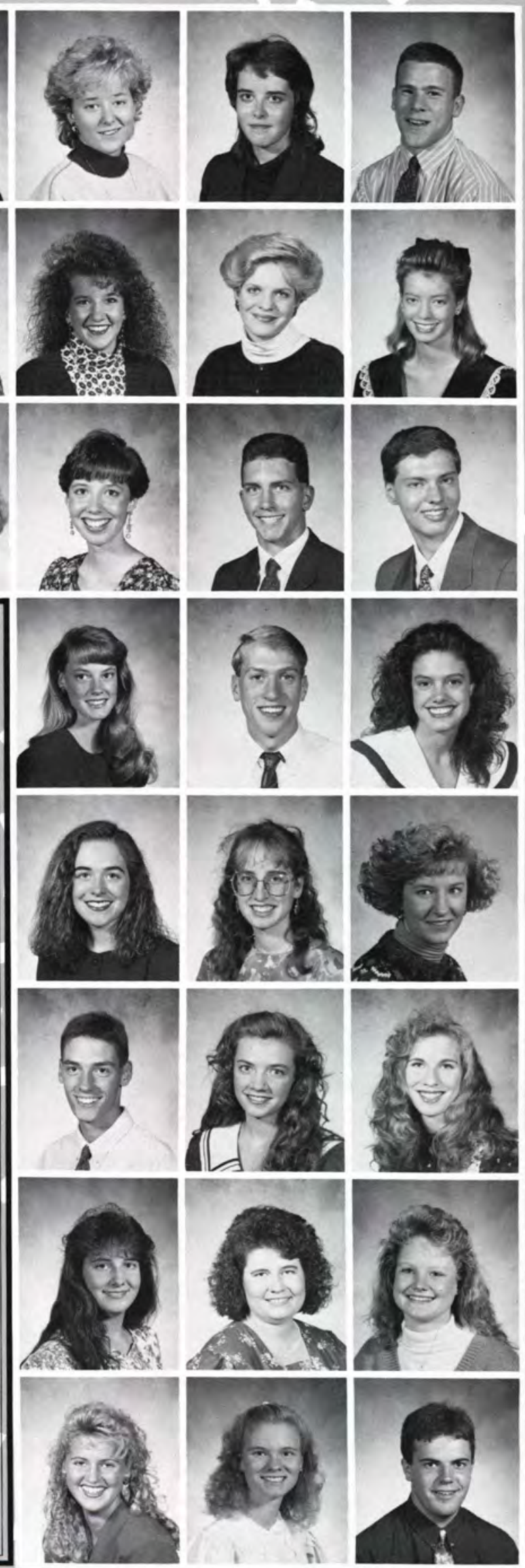

Damon, Gail

Dawson, Jonathon

Dawson, Melanie

Dean, Paul

Dear, Jennifer

Desai, Rajan

Devaney, Todd

Dewalk, April

Dick, Jodi

Dick, Michael

Dieter, Gail

Diller, Rachel

Dinelli, Jennifer

Dodson, William

Drew, Shelli

Droke, William

Eash, Dawanna

Eastlund, Kimberly

Eaton, Bryan

Emes, Traci

Etchison, Lon

Farley, Vanessa

Fath, Kevin

Ferner, Janna

Fields, Lauren

Finley, Lorena

Fisher, Ronna

Flora, Carol

Fox, Ruth

Fox, Shelley

Fuller, Jill

Funsten, Laura

Furby, Gina

Gadell, Nicole

Gaither, Christine

Gardner, Timothy

Garland, Samuel

Garmany, Stacey

Geelhood, Philip

Geiger, David

Geise, Michele

Gentry, Douglas

George, Andrea

Gephart, Julie

Gerber, Rebeccah

Gess, Kathleen

Gess, Shawn
Goetsch, Jeremy

a

Goodwin, Daniel

Goulden, John

Goulden, John
Gozdan, Jennifer
Grace, Joseph

Graham, Aaron

Grayson, Chad

Green, Christopher

Greentree, Carla

Griffith, Corey

Grissom, Joanna

Gritsavage, Heidi

Grizenko, Nicole

Grygiel, Charline

Hagan, Kathryn
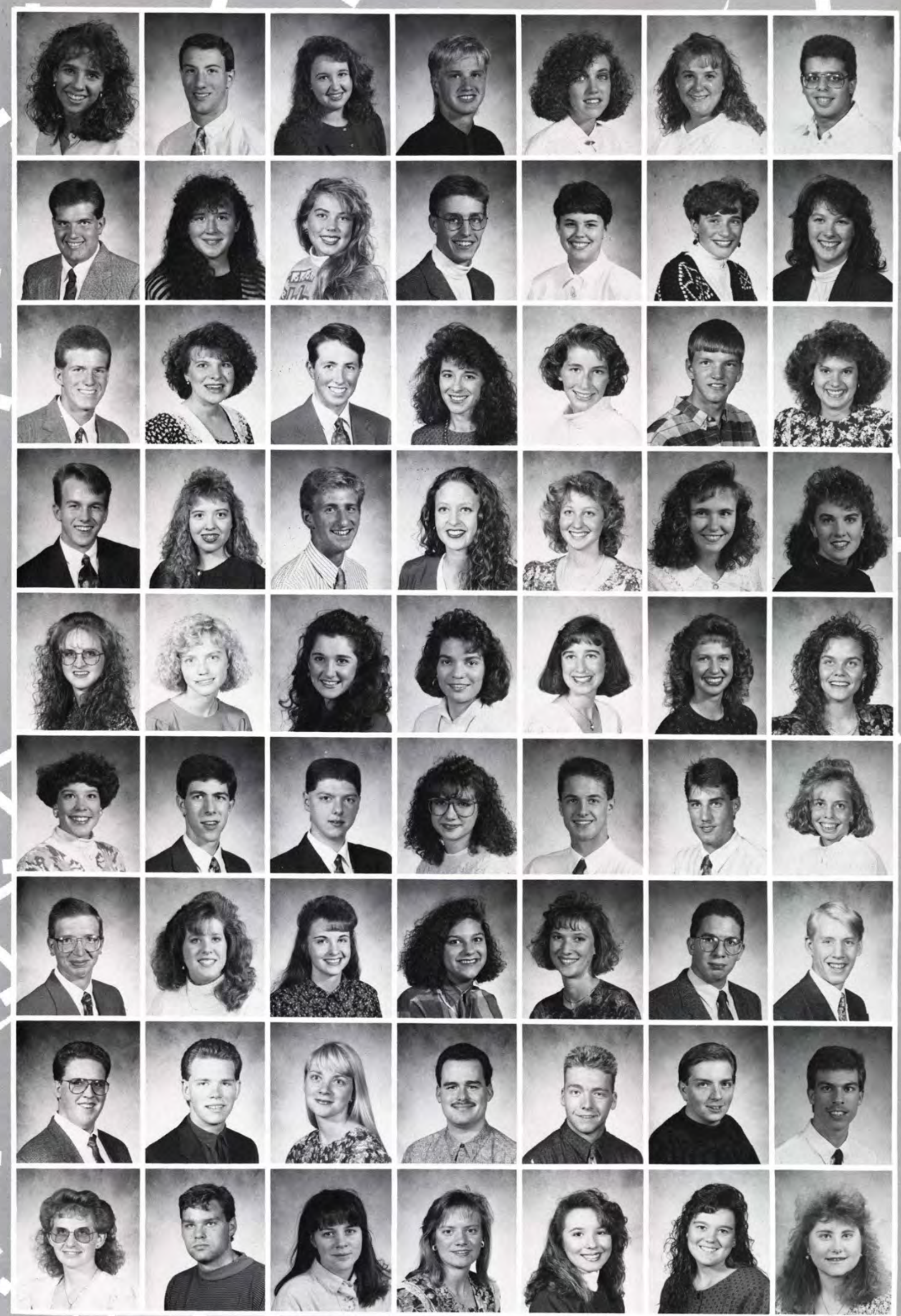

$\sqrt[480]{\text { Underclass }}$ 


Pierce, Chanda Piper, Sharon Plough, Amy Pool, Charlene Pope, Melissa Popp, Pamela Porter, Jennifer

Potter, Jaimee

Powers, Laura

Prentis, Tara

Profant, Michelle

Quinn, Matthew

Raby, Jonathan

Radtlce, Trip

Rayder, Aaron Read, Brian

Reed, Kristy

Reich, Rachel

Reini Eric
Reser, Terrie

Rexrode, David

Reynolds, Matthew

Rhode, Larry

Riblet, Jared

Richardson, Laura

Richner, Rebecca

Rikje, Carolyn

Rinehart, Ann

\section{Robbins, Michelle}

Rohm, Jeffrey

Roseboom, Laura

Rosenvold, Leah

Ross, Michelle

Rotman, Debra

Rotroff, Jenny

Royal, Lori

Royer, Brenda

Rudd, David

Ruetz, Benjamin

Ruhl, Dustin

Rutkowshi, Melissa

Salzman, Greg

Sanders, Stephanie Sarber, Candace

Scharfe, Jocelyn

Schneckenberger, Charles

Schwind, Beth

Schwinn, Scott

Seachrist, Heather

D

Sechrist, Kristen

Secord, Mandi

Seely, April
Shaffer, Kimberly

Shand, Timothy

Shaneyfelt, Amy

Shank, Staci

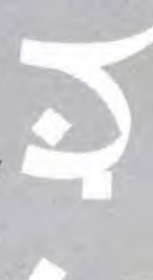

Sharp, Julieanne

Sherman, Stephanie A.

Sherman, Stephanie L.

Shook, Lori

Short, Jay

Shuler, Jennifer

Siegelin, Sarah
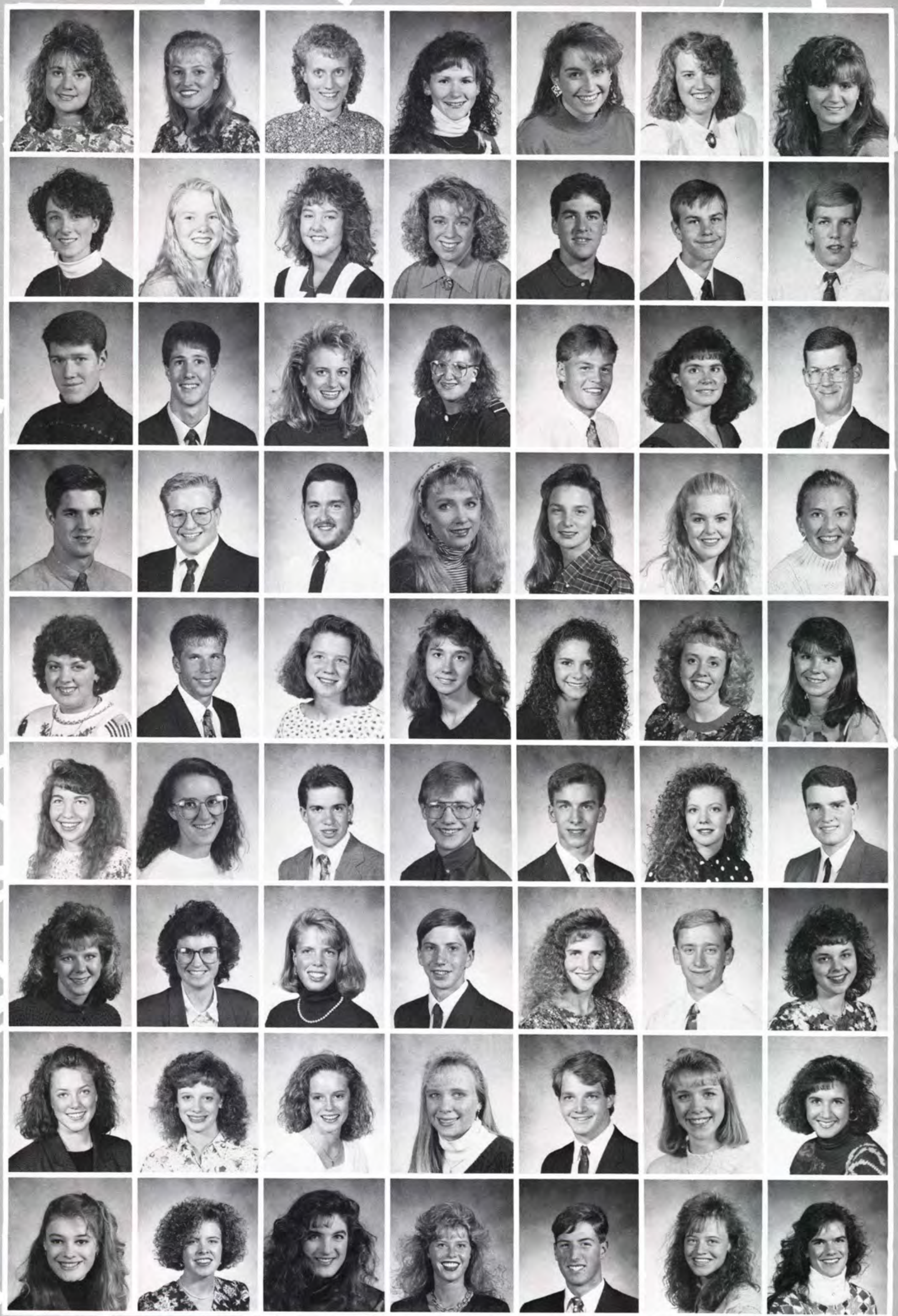
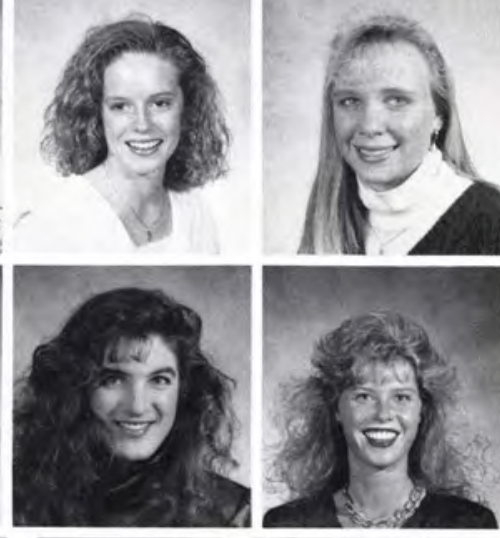
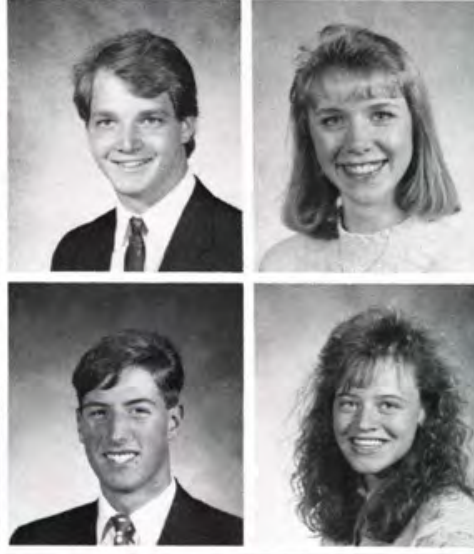
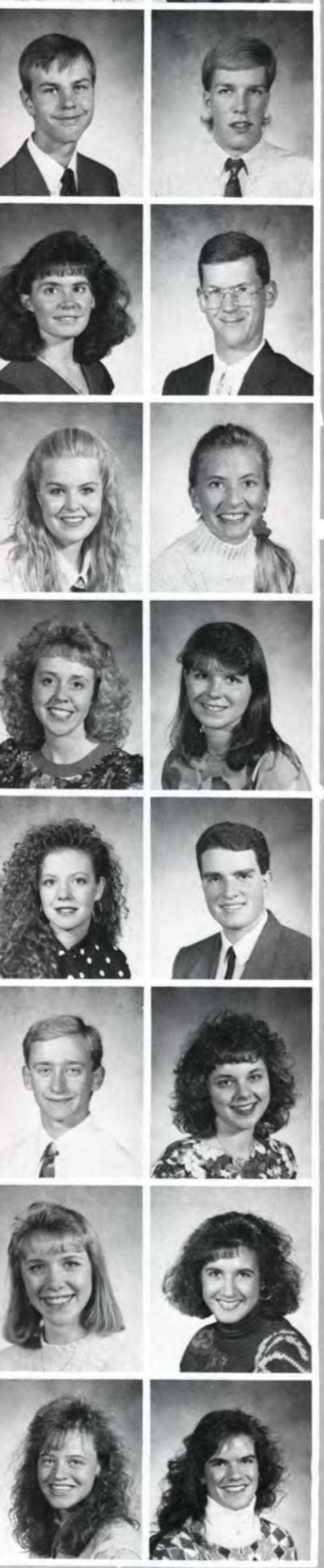

484 Underclass 


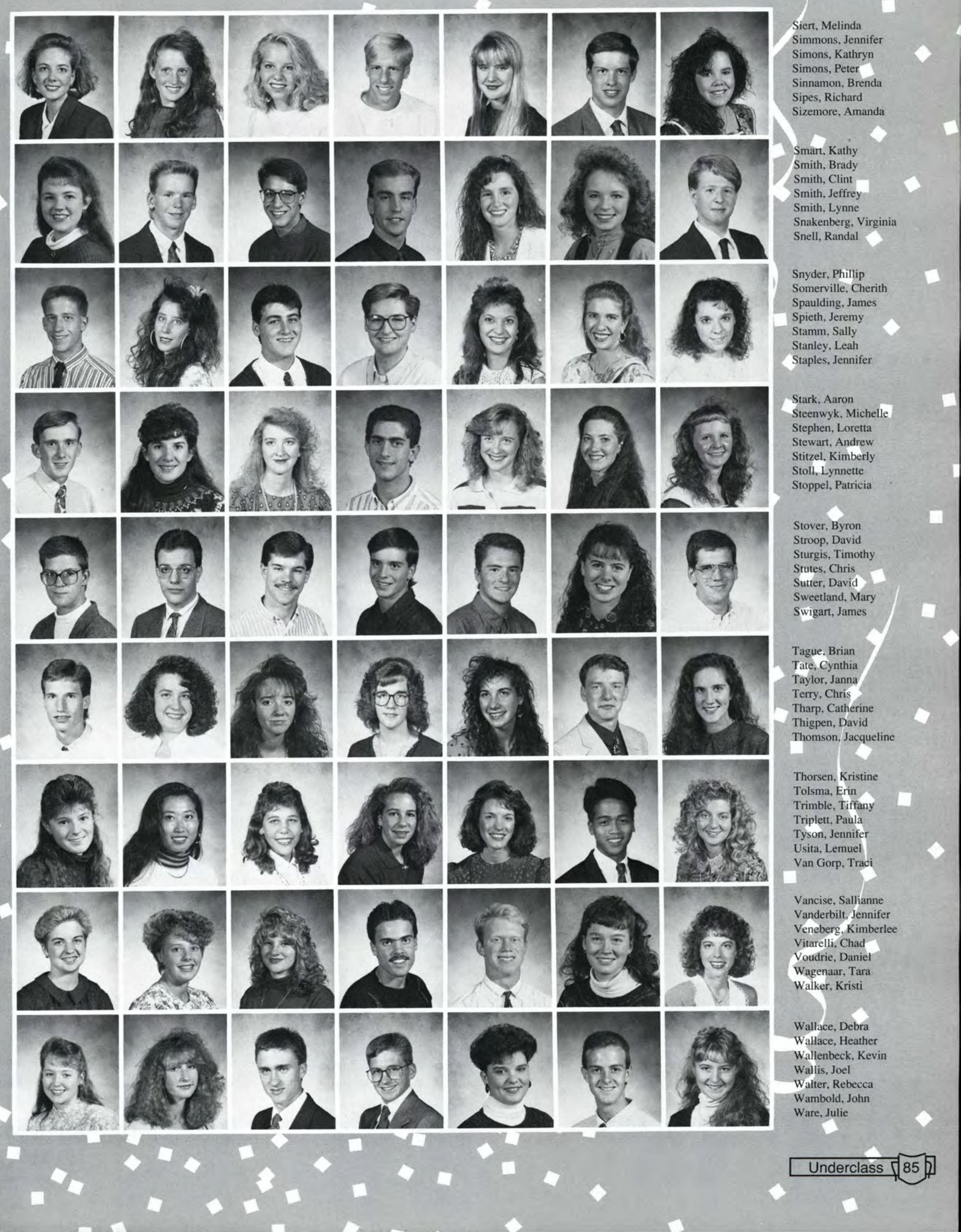


Warnshuis, James

Wawro, Erin

Weaver, Erin

Webb, Philip

Weise, Ann

Wenger, Ruth

Whalen, Steve Whisman, David White, Amy

White, Sharon

Whittaker, Keila Wiedemann, Jody

Wilkinson, Stacey

Willett, Charles

Williams, Kristen

Williamson, Jennifer Wilson, Adam

Wilson, Christopher

\section{'Matinee of Masterpieces'}

Stepping into the chapel on November 12 just after 4:30 (I was slightly late as usual), I was greeted by a symphony of voices singing praises to God. I quickly took a seat, put my head back, closed my eyes, and just listened to the performance. What I was to hear during the rest of that half-hour concert was appropriately titled a "Matinee of Masterpieces."

After the opening number, one of the chorale members gave a short narration about the next piece, a Mozart

\section{ESO U O T A B L E O U O T E S9 I rose from my seat and left the chapel feeling relaxed and refreshed.}

selection accompanied by a string ensemble. This became the pattern for the rest of the concert: a short narration followed by the musical selection, each of which was centered around a spiritual theme. After the Mozart piece came "He Is Watching Over Israel," part of Mendelssohn's Elijah and a selection from Beethoven's only oratorio, $\underline{\text { Christ on the Mount of Olives. }}$

The concert concluded with the African American spiritual "Sing When the Spirit Says Sing," featuring the soloist Tracie Dennison. Before long the last notes of the song were sung, and the audience was applauding the performance. I rose from my seat and left the chapel feeling relaxed and refreshed.

- Mindy Boone
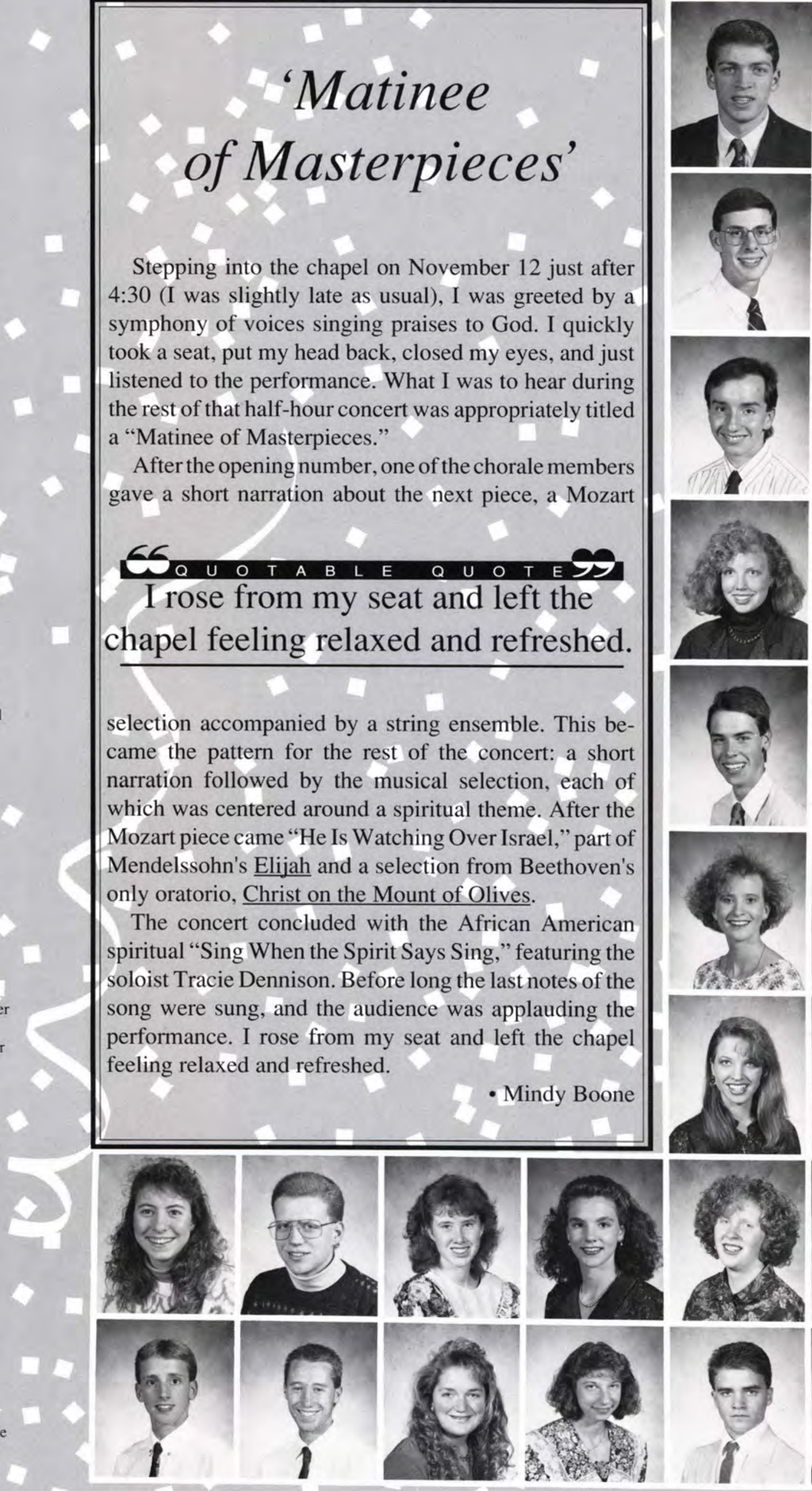

Wymer, Brian

Young, Darren

Zehr, Michelle

Zenner, Jennifer

Zimmerman, Eric

Zimmerman, Justine

Zuiderveen, Mark

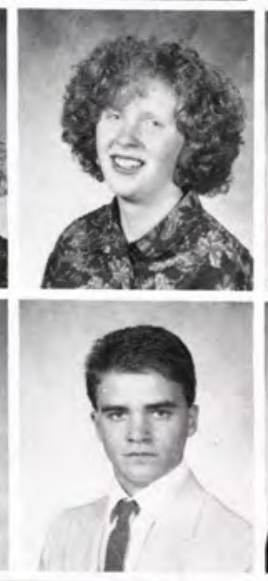

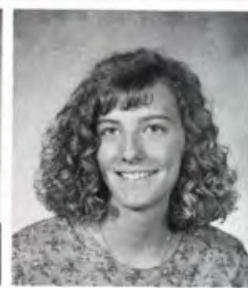
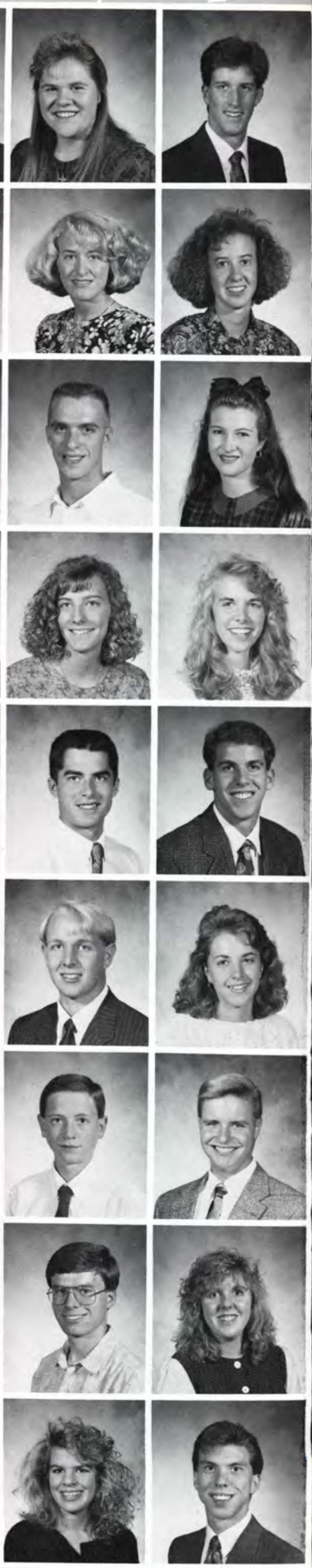


\section{Sophomore Class}
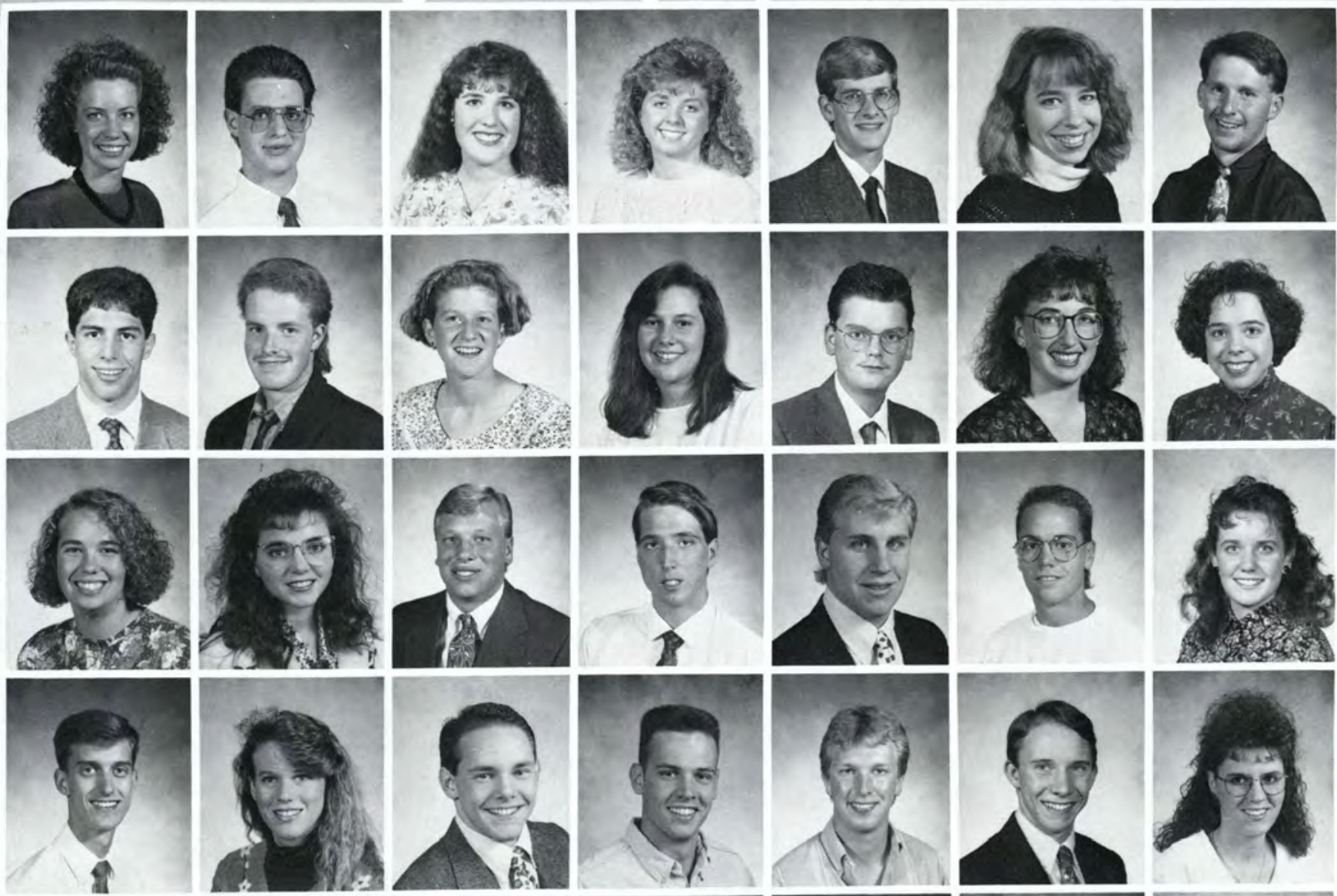

Abbas, Kimberly

Abbott, Stephen

Alexander, Stephanie

Allen, Denise

Armour, Paul

Armstrong, Rebecca

Ashcraft, Eric
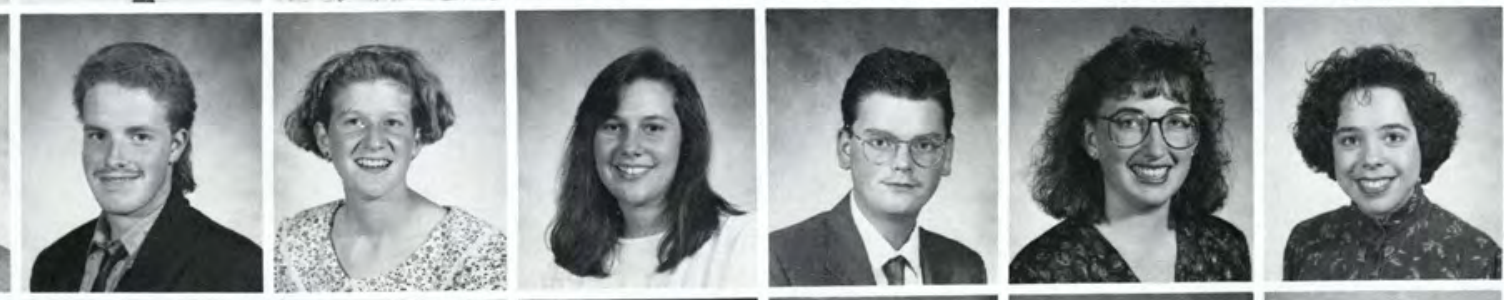

Awabdy, Nicholas

Bader, Scott

Baesen, Shelly

Barnard, Shannon

Barnes, Brian

Barnitz, Lisa

Baughey, Kristen
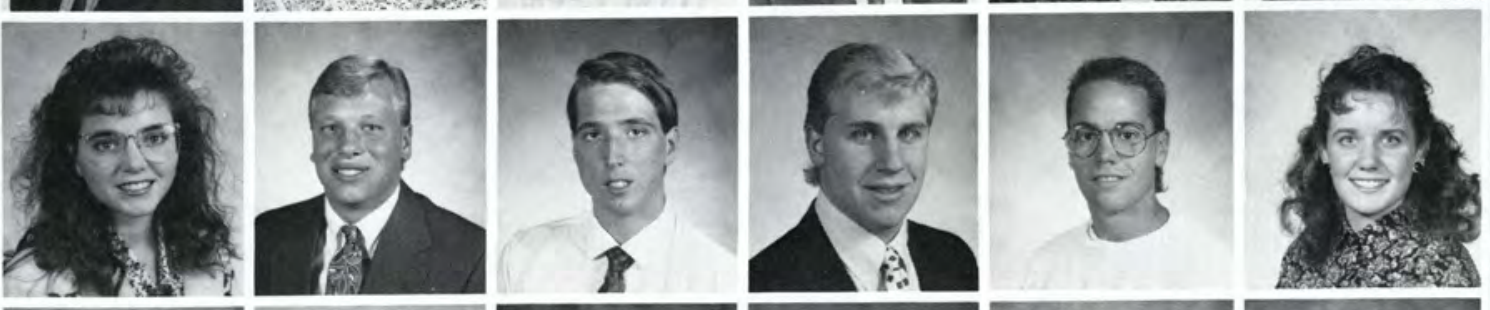

Beasley, Renee

\section{Beck, Kristine}

Beiler, Jeffrey

Bell, Andrew

Belmont, Kevin

Benim, James

Benim, Shari
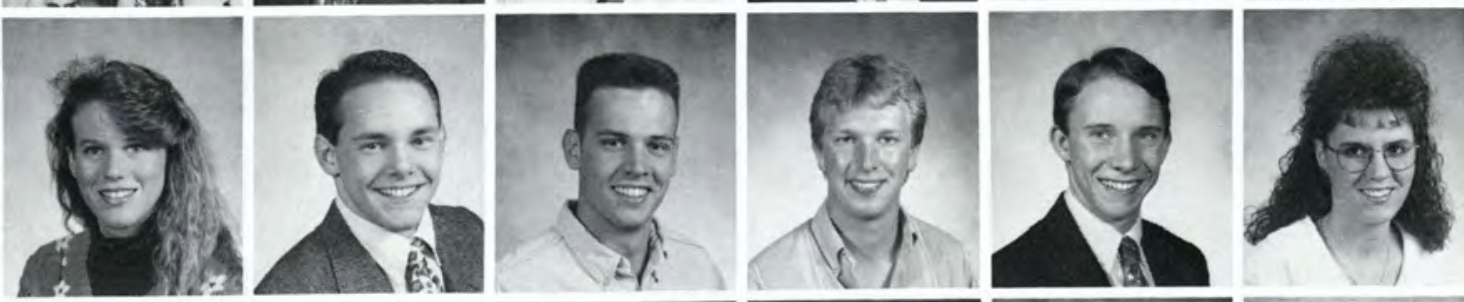

Beroth, Edward

Berry, Christina

Beshaw, Harold

Besosa, Robert

Bickel, Nathan

Biddle, Benjamin

Biggers, Kristie
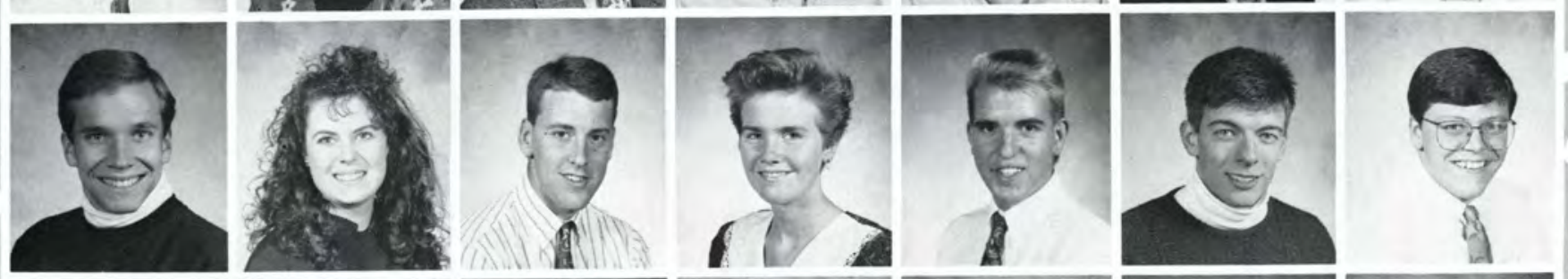

Binning, Eric

Bird, Melissa

Bishop, Aaron

Blenis, Darcey

Blind, Brian

Bockmann, Thomas

Bolger, Brian
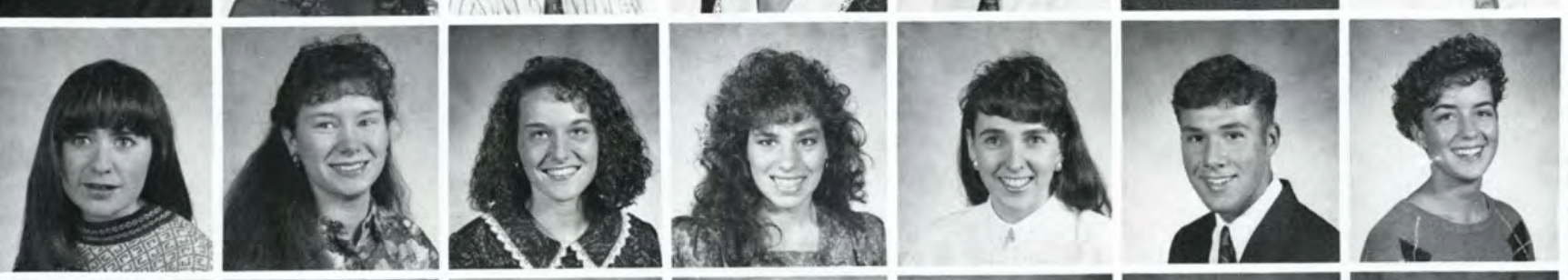

Boone, Abigail

Bork, Jenifer

Borkholder, Misty

Bouchard, Jenae

Bower, Carmen

Breneman, Todd

Broman, Molly
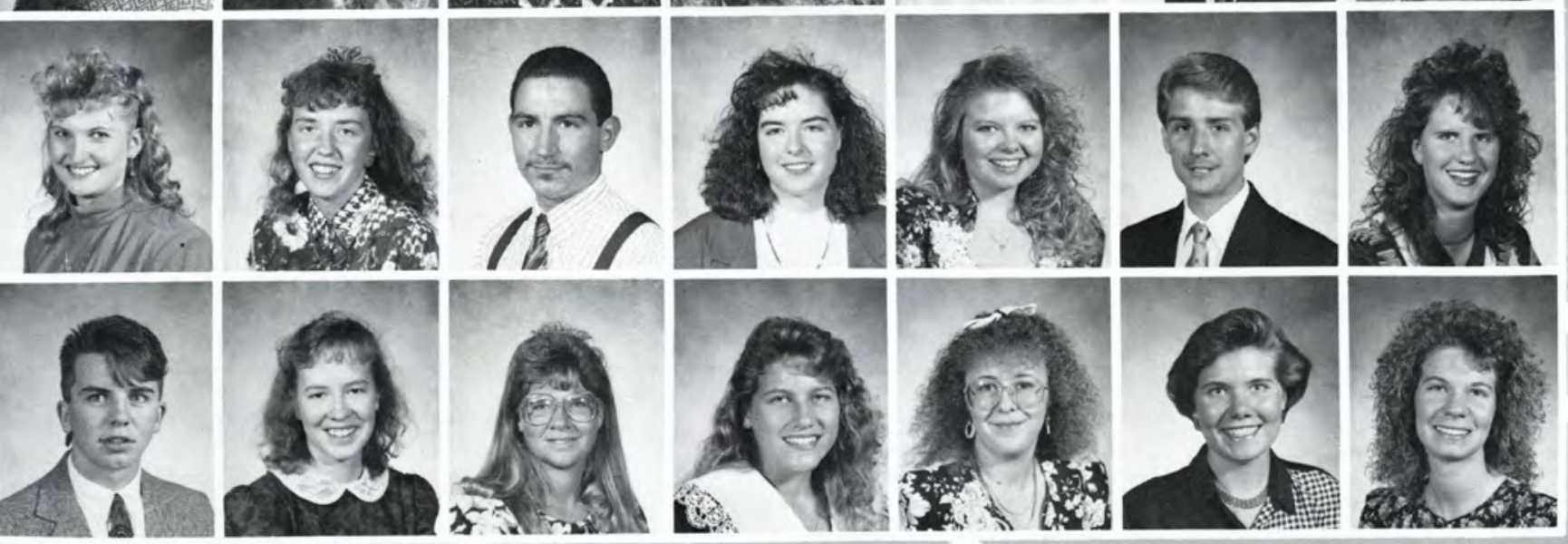

Brooks, Mary Jo

Brown, Cinnamon

Brown, Daniel

Brown, Melanie

Brown, Stephanie

Buckingham, Jeffrey

Burke, Rebekah

Burns, Robert

Bush, Sharon

Bush, Shawn

Byler, Kendra

Call, Rebecca

Calvert, Rebecca
Campbell, Julie

Underclass $\sqrt{877}$ 
Campbell, Laura

Carlson, Betsy

Carnahan, Brian

Case, April

Check, Beverly

Chezik, Janet

Christman, Robert

Clark, Susan

Clark, Tammy

Clidence, Lisa

Clifford, Daniel

Coffelt, Joy

Colangelo, Joyce

Colbert, Bruce

Collins, Michael

Combs, Susan

Comegys, Miriam

Condren, Jodie

Conkel, Kevin

Cooper, Karl

Cornett, Jennifer

Cramer, Brian

Cripe, Laura

Crouthamel, Scott

Crow, Jennifer

Cunningham, Amy D.

Cunningham, Amy L.

Currall, Gail

Curtis, Melody

Cushman, Karen

Cutler, Matthew

Dalton, Jennifer

Davis, Charlene

Davis, Cheryl

Davis, Greg

Davis, Kelly

Davis, Melissa

Dayton, Krista

De Man, Susan

Deinum, Cheryl

Dennison, Tracie

Deshetsky, Kristine

Detterman, Monte

Dettwiler, Paul

Dilling, Jennifer

Dillon, Jennifer

Doak, Jennifer

Dobert, Nathan

Doherty, Carolyn

Duvall, Robert

Eckart, Christopher

Edgerton, Jonathan

Edington, Harold

Edwards, Mary

Elmore, Nathan

Entner, Todd

Erickson, Donald

Ernst, Daniel

Estenor, Elsa

Everson, Yolanda

Ewing, Christin

Fales, Elizabeth

Farkus, Andrew
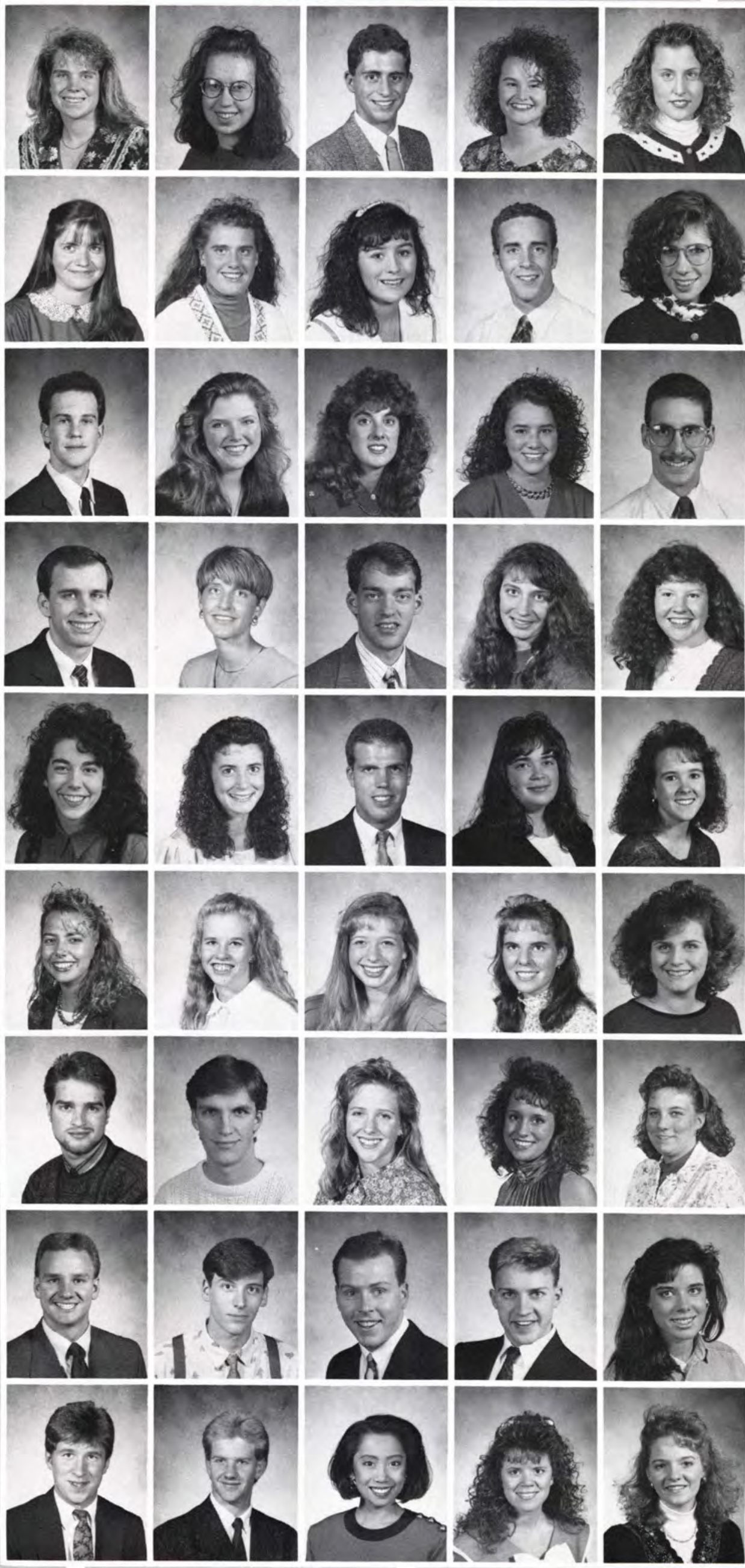
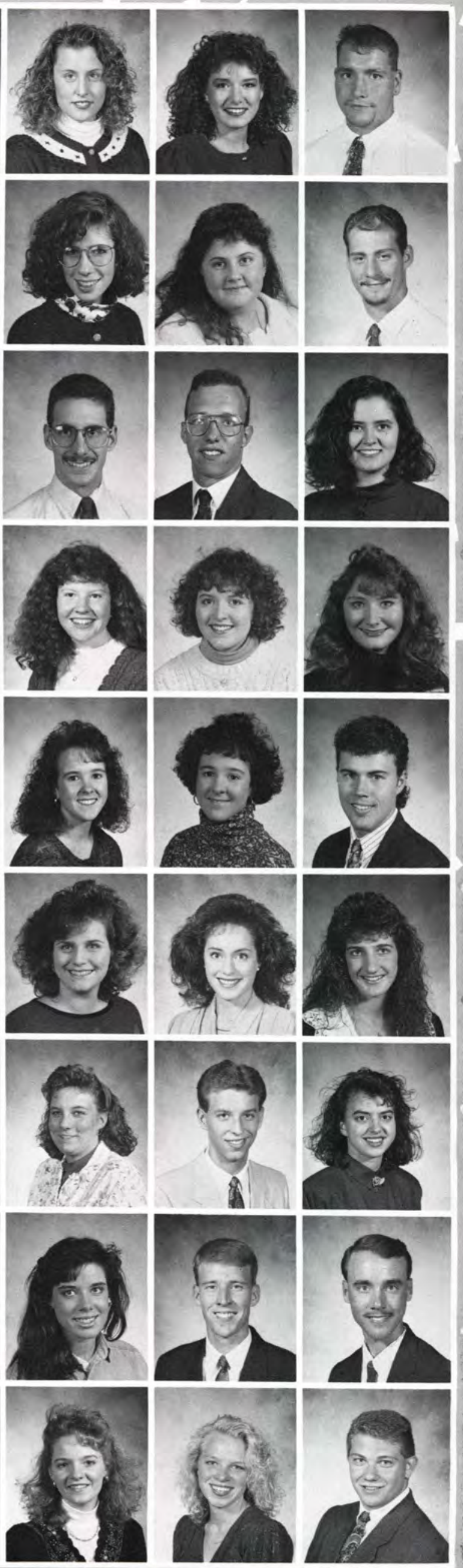


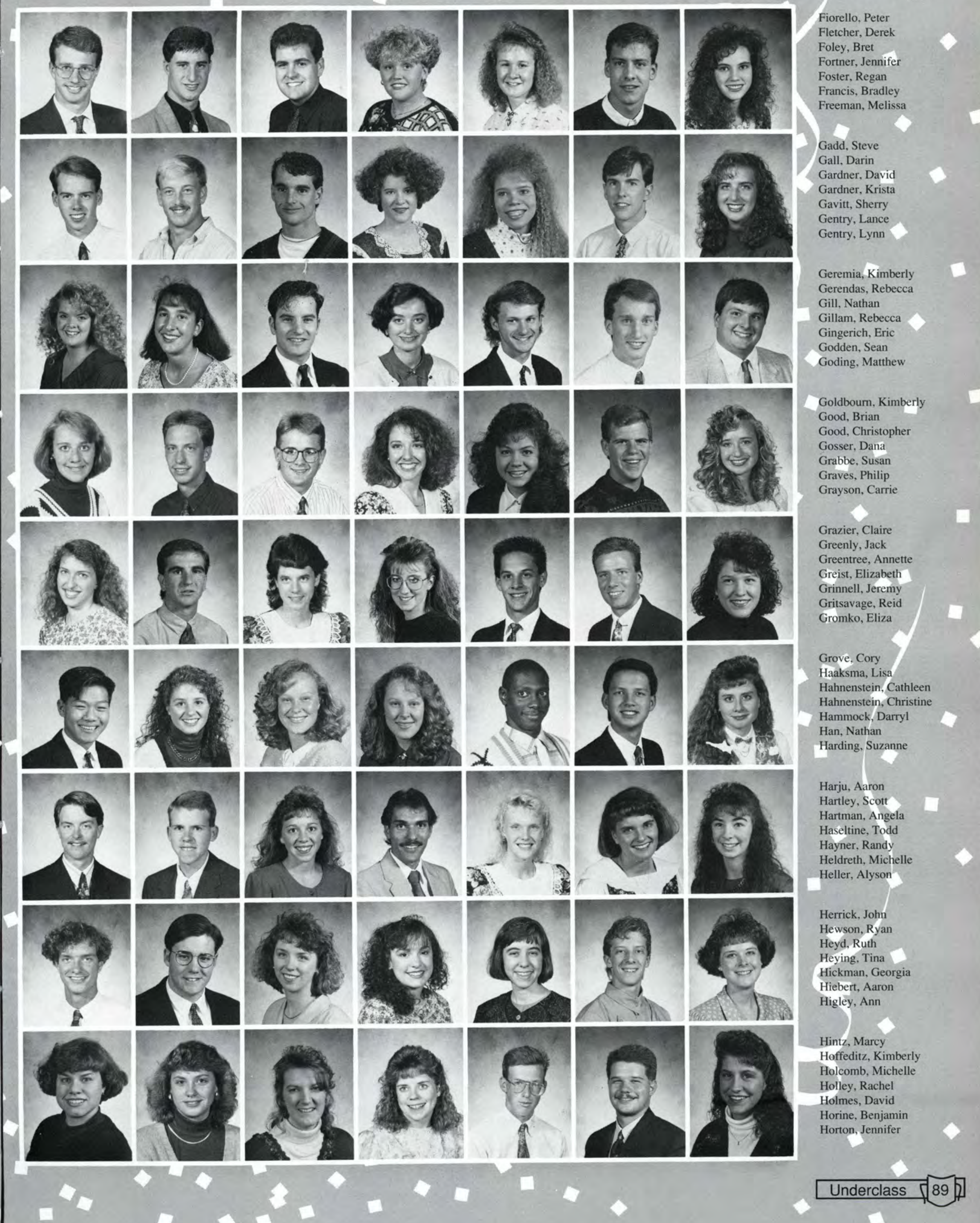


Houston, Rhonda Howard, Rachel Howell, Tiffany Hoy, Timothy Huber, Pearl Huber, Philip Hudson, Julie

Hull, Dana

Hunsaker, Stephanie Hunt, Carmen Iten, Bradford Jackson, Juli Jariga, William Johnson, Janelle

Johnson, Jennifer Johnson, Marcy Johnston, April Johnston Faith Joiner, Randall Jones, Christian Justice, Tracy

Kadlecik, Bradd Kalich, Benjamin Karrels, Tom Katrinak, Carrie Kaufman, Devin Keib, Timothy Keller, Julie
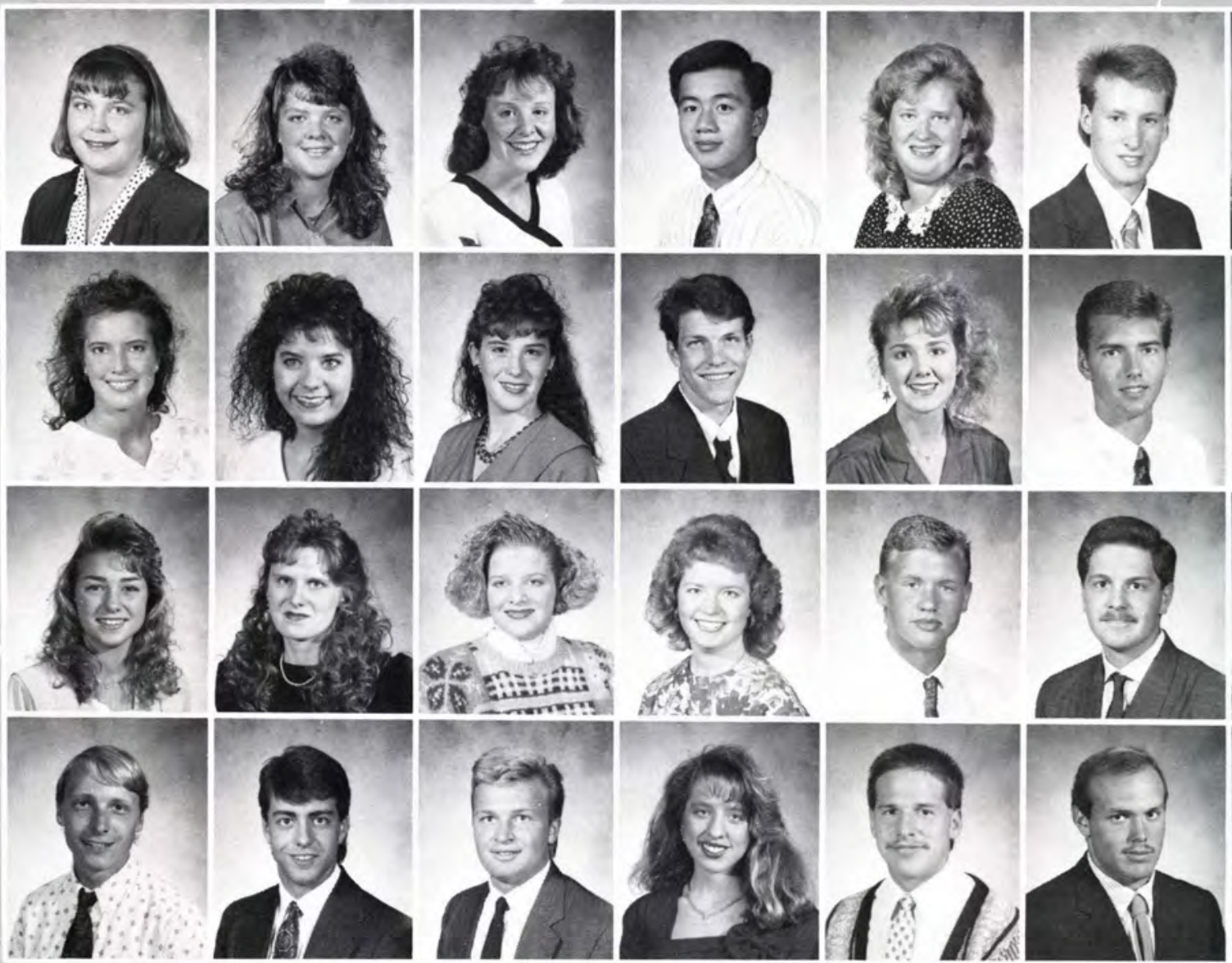

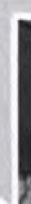

Who could be coming when Dr. Dixon's smile is just a little bit brighter and he enthusiastically reminds us to attend what he considers to be one of the year's finest attractions? You guessed it -- Buddy Greene. If you know anything about Buddy Greene, you'll know that he is one of Dr. Dixon's favorites, and that his upbeat style with country flair allows no one in the audience the option of sitting still. Eyen if you aren't partial to country or southern gospel, you will enjoy Greene's concert and strong testimony. His enthusiastic performance on both the guitar and harmonica has just what it takes to really get Cedarville moving.

In addition to all the action, Greene returned to Cedarville this fall to close the 1991 Homecoming festivities with another outstanding performance. If you plan to spend a passive evening attending one of his concerts, you will be surprised. Greene involves his audience in his songs whether they be rousing celebrations of God's work or meditative worship. Everyone at Cedarville, especially Dr. Dixon, anticipates the return of Buddy Greene to campus because it means an evening of fun and excitement for all.

- Nicki Beecher

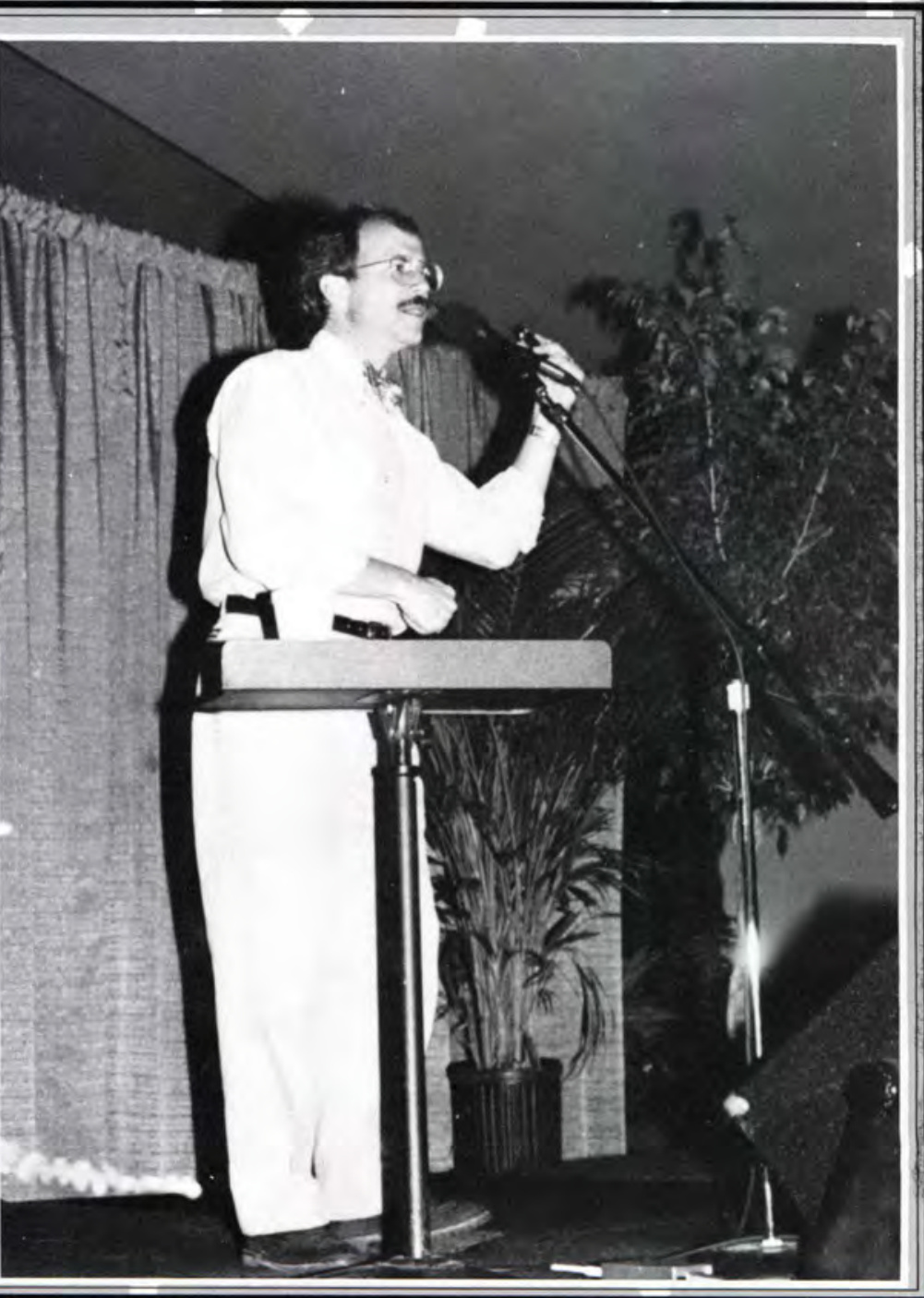



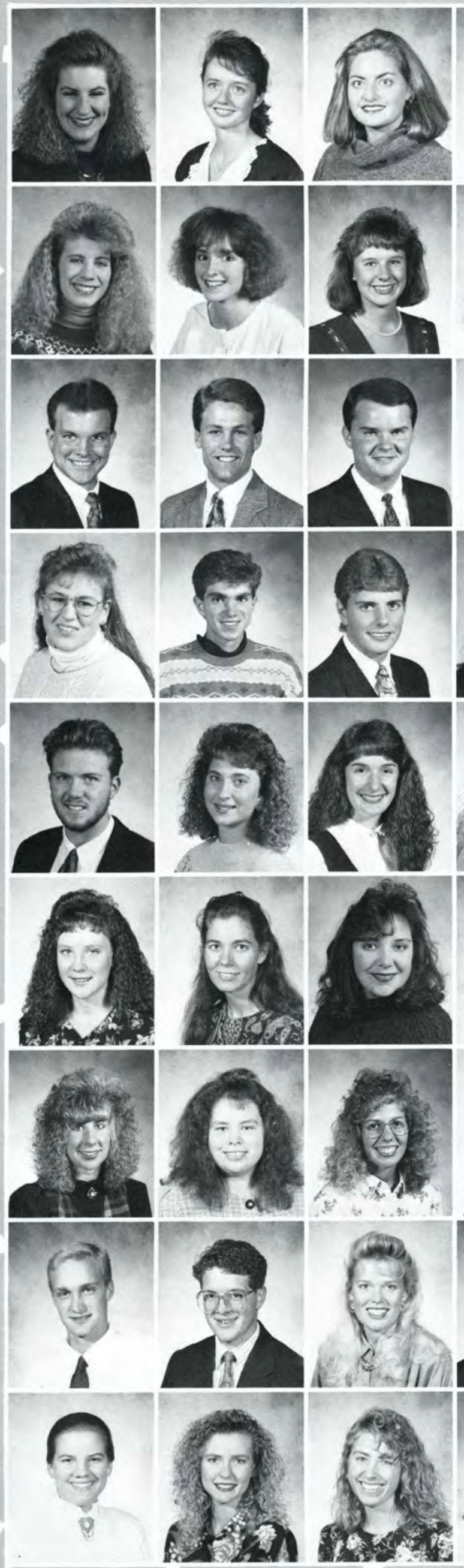
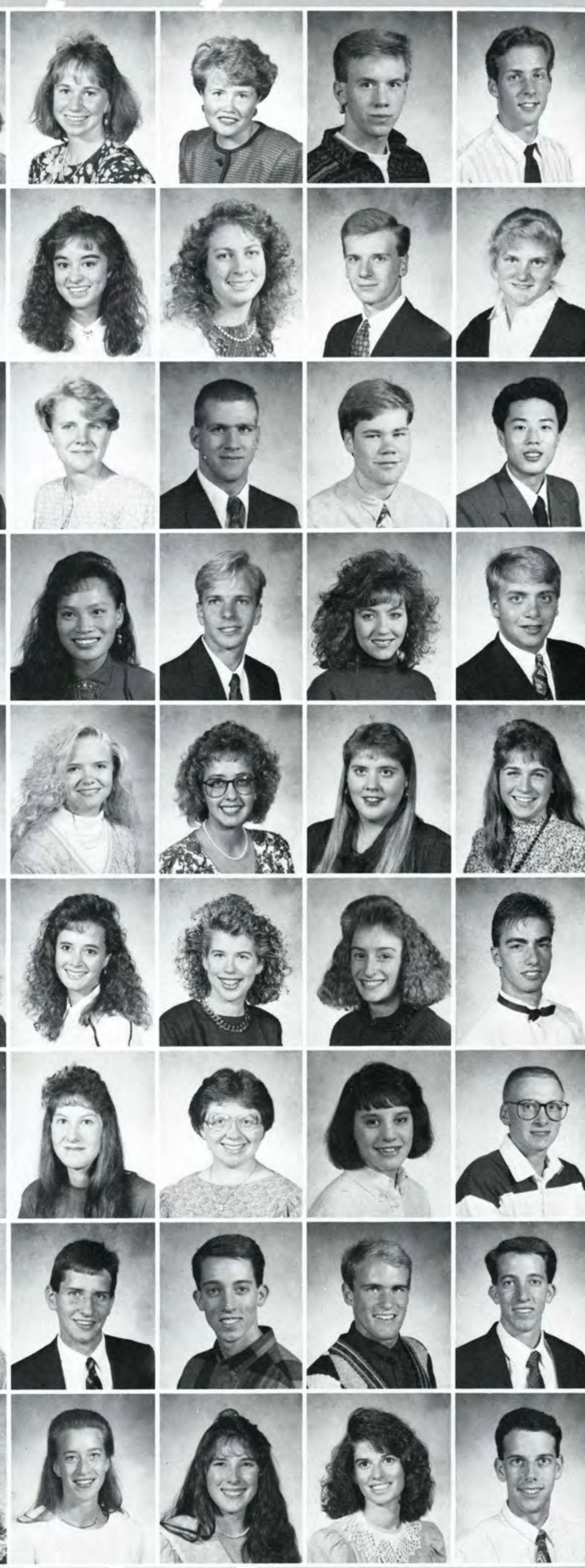
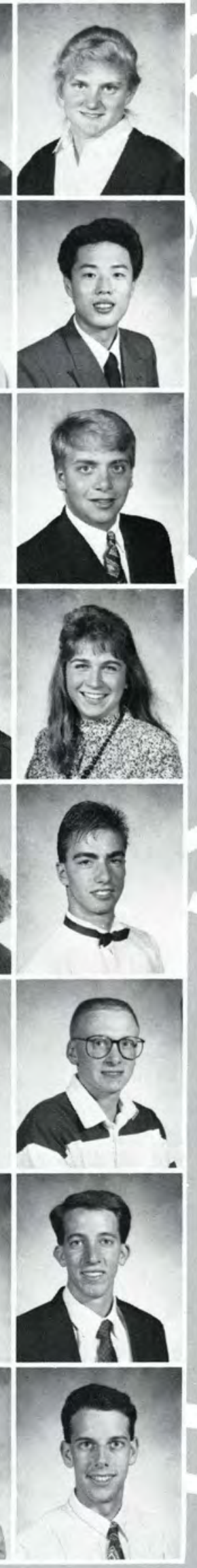

Kenyon, Kerri

Killian, Brenda

Kirkley, Jacqueline

Knaus, Marcia

Koch, Deborah

Krueger, Heidi

Kulp, Stephanie

Kurtz, Jean

Landrum, Kristi

Lang, Craig

Lang, Jennifer

Lausin, Joseph

Le Blanc, Jay

Lenhart, Adam

Lensch, Robin

Leonard, Jonathan

Leshan, Michael

Lightly, Lisa

Lindaberry, Jeffrey

Linnehan, Ryan

Lloyd, Jennifer

Longfellow, Brian

Longo, Lisa

Lough, Jonathon

Lover, Rodney

Lowenhar, Lori

Lucas, Brenda

Lucas, Kelly

Ludwig, Ramona

Lund, Sena

Lunn, Rebecca

Lush, Laura

Lyndaker, Anita

Ma Gee, Rebecca

Mach, Julie

Mann, Carrie

Manning, Patricia

Mascari, Jason

Mc Clish, Michelle

Mc Conkey, Tracy

Mc Cullough, Shelly

Mc Fadden, Colynn

Mc Fadden, Julie

Mc Gillvary, Suzanne

Meeder, Jon

Meek, Gregory

Milentis, Gregory

Miller, Annette

Miller, Brian

Miller, Eric

Miller, Jeff

Miller, Jeffrey

Miller, Regina

Miller, Rhona

Mills, Robin

Milner, Kristin

Miner, Kelly

Mitchell, Amy

Moore, David 
Morgan, Kristine

Morse, Hope

Mosley, Donald

Mulanax, Tina

Mullins, Scott

Murphy, James

Murphy, Kara

Murray, Holly

Neubert, Tanya

Neudeck, Jennifer

Newcomb, Aaron

Newell, Kimberly

Newton, Lorraine

Nickelson, Dawn

Norman, Christopher

Noss, David

O'Leary, Susan

Ooms, Bradley

Orser, William

Osborn, Deanna

Pakson, Gary

Palmer, Bradley

Pangburn, Dawn

Pappas, Zachary

Parrow, Chad

Passineau, Michael

Pawluk, Laurie

Perkins, Deborah

Perkins, Matthew

Perler, Stacey

Peters, Heather

Phillips, Cheryl

Pierce, Alex

Pierce, Douglas

Plush, Jonathan

Poiesz, Mildred

Post, Kristine

Potts, Brannon

Prusinowski, Maureen

Radcliff, June

Rajna, Gabriella

Randall, Lee

Rathbun, April

Ratliff, David

Reebel, Derran

Reich, Betsy

Reich, Betty

Reiner, Daniel

Reiter, Stephen

Remington, Cathy

Rennie, Christopher

Rhyne, Benjamin

Richardson, Rebecca

Riddle, Gregory

Rife, Melinda

Rinehart, Sandra

Riner, Patrick

Robertson, Christopher

Rodgers, Lori

Rowland, Janet

Russell, David

Russell, Rusty
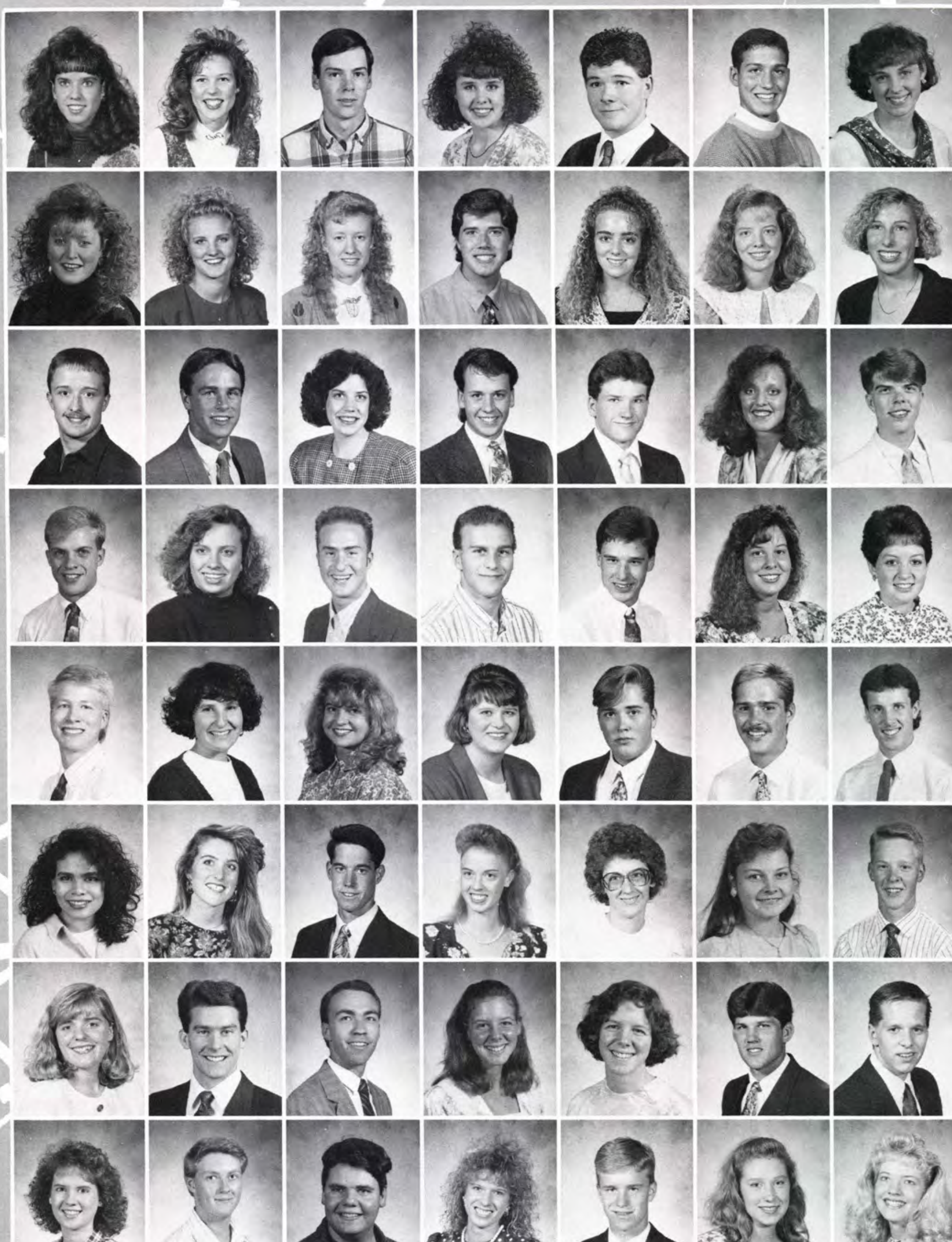

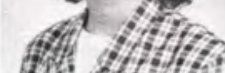
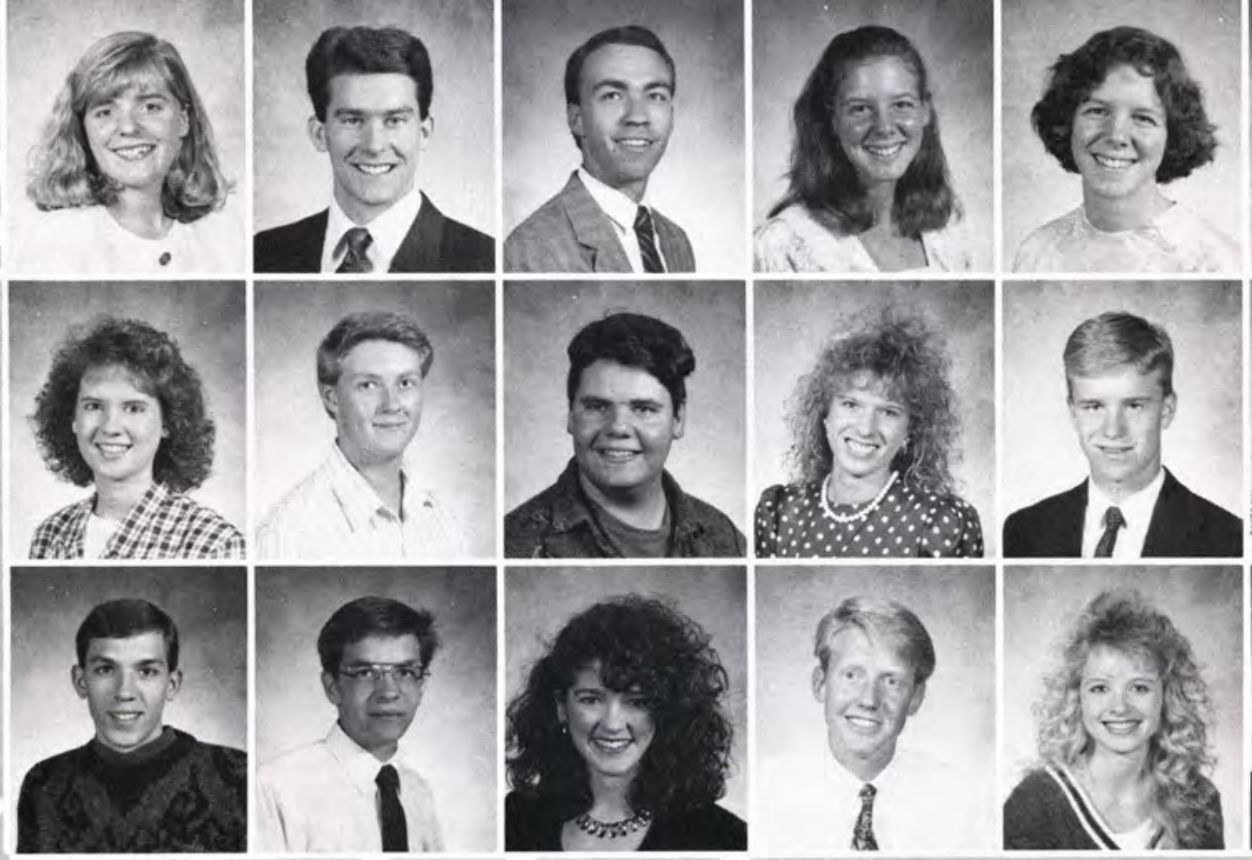
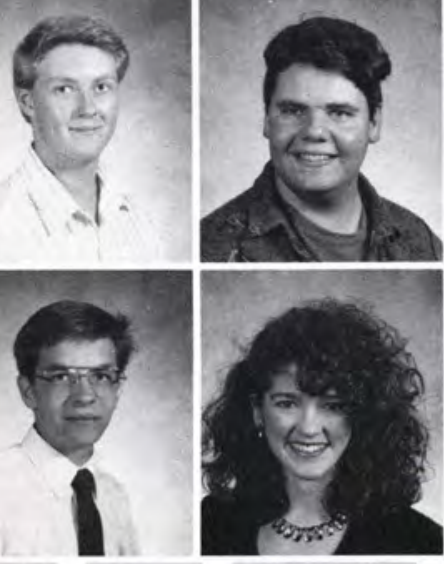
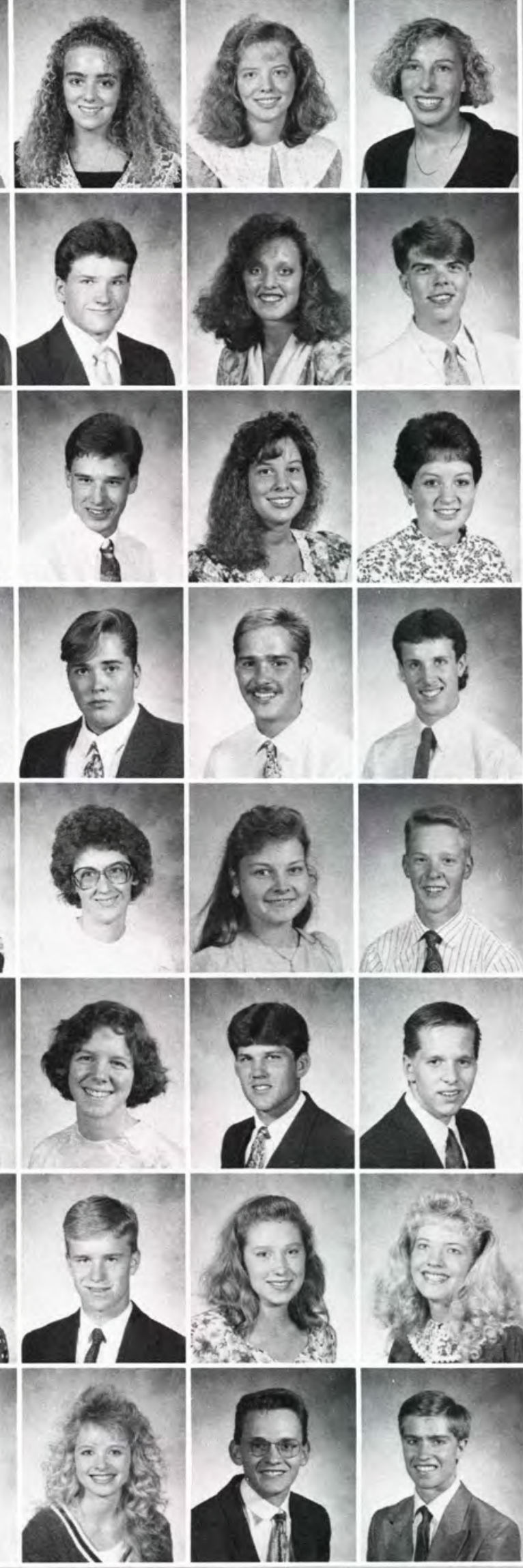

402 Underclass 

Walter, Lynn Walter, Melanie Walters, Wendy

Wandell, Brenda Ward, Erin

Webster, Jim

Wenger, Shannon Westbeld, Heidi Westlake, Leanne

Weyand, Wendy Weyhe, Jill White, Laurel

Whitten, Scott Wilfert, Jennifer Williams, Julie Wilt, Kenneth Wingate, Tina

1

Wittkamper, Tammy Wong, Mark

Wood, Jeffrey

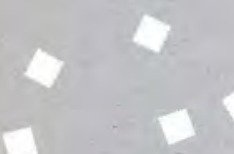

Woodhams, Jodi Woodward, Timothy Wylie, Kristen

Yates, Michelle Zalut, Lynn Zerby, Daniel
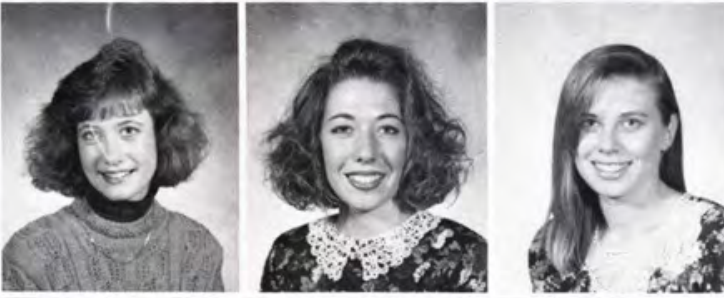

\section{An Evening In the Limelight}

What do Brian Blackburn's song "Tear Down My Guard"; The Corkscrew Brothers played by Chris Eckart, Eric Phillips and Karl Cooper; and a stand-up routine by Chris Pincket all have in common? NOTHING, except that these were three of the acts in the Annual Talent Show "An Evening In the Limelight" sponsored by the men of Alpha Chi in the Student Center on February 1, 1992.

The host for the evening was Mr. Jon Purple who kept things rolling with various trivia questions about Dr. Dixon, as well as introducing each act.

The first half of the show was specifically designed to be the more serious; after a brief intermission, the tone of the whole production was increasingly lighter. Each act was in competition with the others for a series of cash prizes given to the best serious act and comedy act, based upon the audience's popular votes.

Refreshments were available before, during and after the show. The audience enjoyed themselves immensely.

Alpha Chi should be pleased with the efforts and success of the Talent Show.

- Julie Mulder

Angie Mouser sings in the Alpha Chi Talent Show.
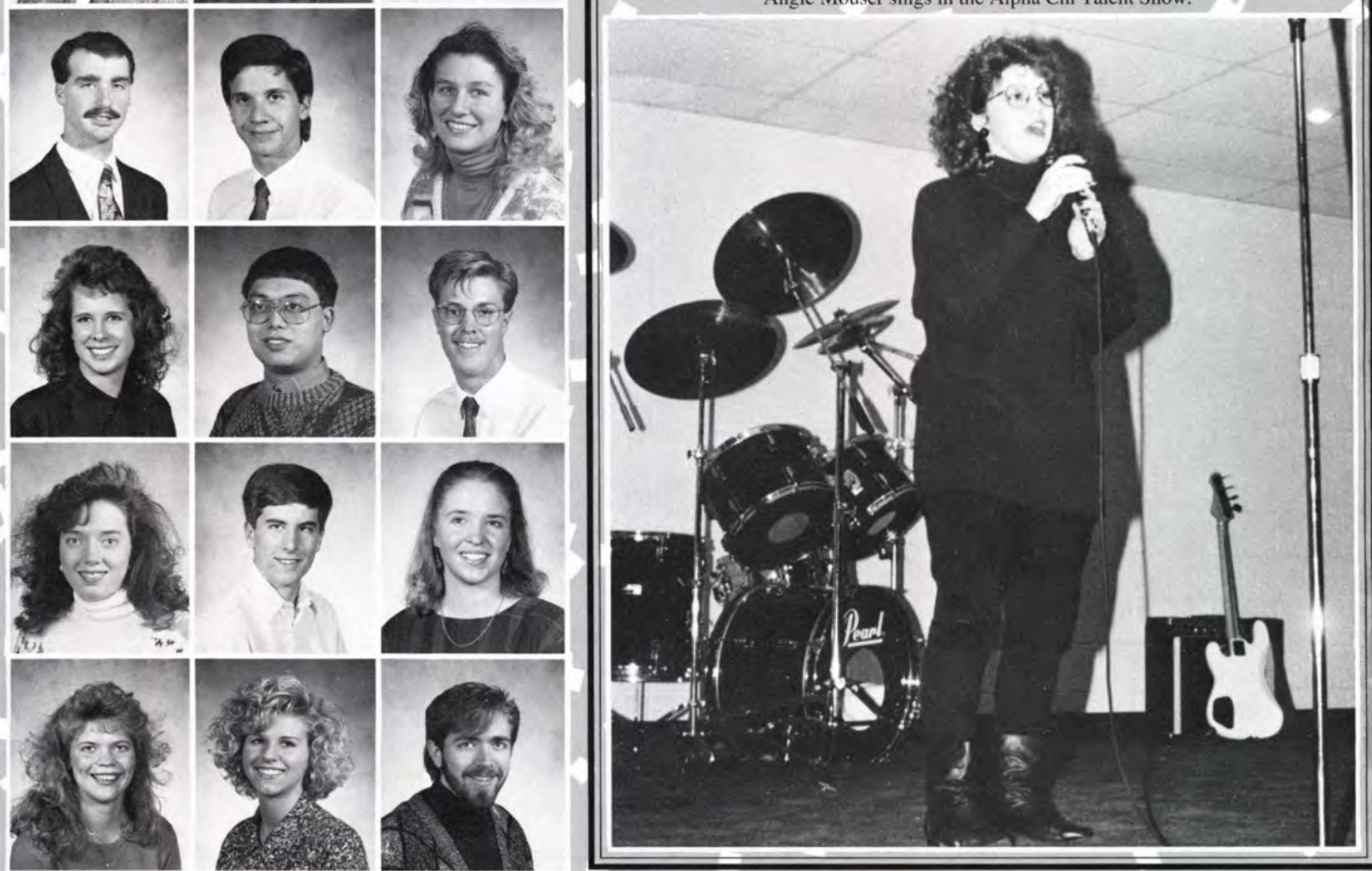



King, Kevin

King, Melissa

Kinsey, Steven

Knowles, Allison

Krody, Sheri

Kropp, Wayne

Lahman, Jennifer

Lancaster, Susan

Lane, Elizabeth

Lawrence, Gregory

Lawson, Renee

Lee, James

Leeds, Sheri

Lindaberry, Kevin

Lloyd, Kimberly

Locke, Kimberly

Lomelino, Kimberly

Lutz, Beth

Marshall, Laura

Marshall, Robert

Martens, Matthew

Martin, Lee

Mathisen, Thomas

Mathwin, Steven

Mc Chesney, David

Mc Comb-Davies, Beverly

Mc Coy, Kimberly

Mc Coy, Molly

Mc Cutcheon, John

Mc Donald, Rachel

Mc Grady, Paul

Mc Guire, Christina

Mc Intosh, Paul

Mc Kanna, Bruce

Mc Laughlin, Amy

Mc Millen, Mark

Mc Millen, Matthew

Mc Nabney, Melia

Mc Pherson, Sherilyn

Mc Queen, Todd

Megilligan, Brian

Meigs, Stephen

Misirian, Nathan

Mitchell, Matthew

Mitchell, Micah

Montgomery, William

Moor, Holly

Moore, Bruce

Moore, Maryann

Morales, Jennifer

Morgan, Jeffrey

Mulder, Julie

Mummey, Julie

Munk, James

Myers, David

Myles, Melinda

Neil, Daniel

Nelson, Michelle

Nettleingham, Brian

O'Keefe, Kayley

O'Neal, Christine

Oligee, Stacy

Olsen, Marsha
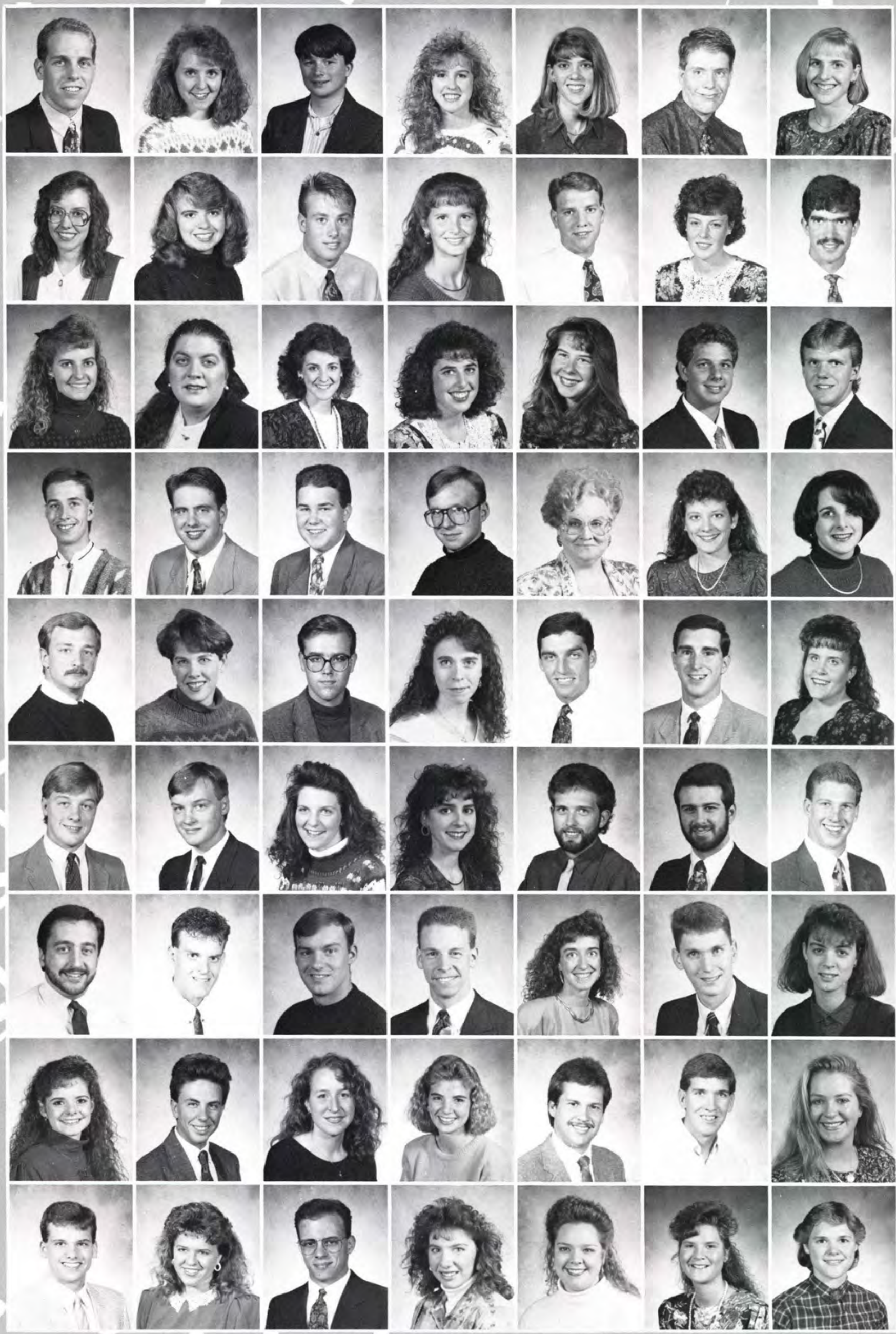




\section{Coup in the \\ Soviet}

Soviet President Mikhail S. Gorbachev and his family were placed under house arrest in the Crimea on August 19, 1991, as an eight-man emergency committee led by Vice President Gennady Yanayev took power in a coup attempt in the Soviet Union.

Convoys of Soviet tanks moved into Moscow, less than two miles from the Kremlin. Yeltsin called on Russians to resist the takeover, and resist they did. Constructing a protective human wall around Yeltsin's headquarters, his supporters demanded Gorbachev's return.

As a former Gorbachev adviser spoke to the crowds, denouncing the coup, hands were raised in applause.

On Wednesday, as the Commu-

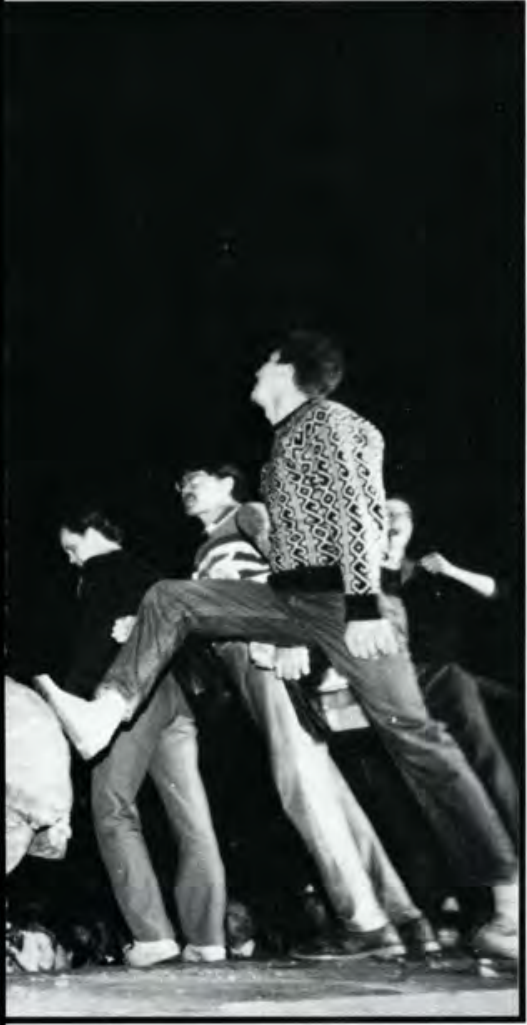

Photos by Associated Press
New York, NY
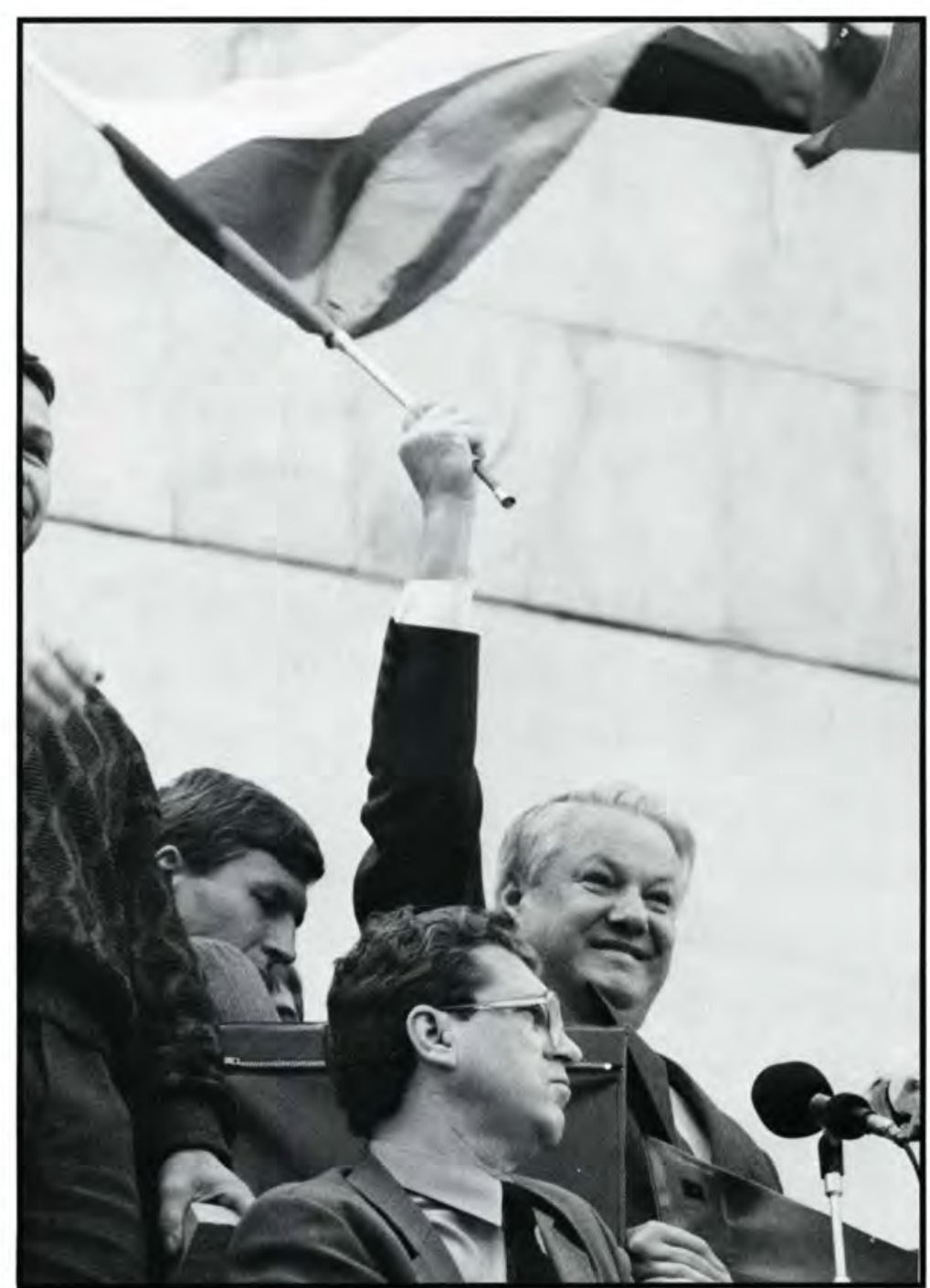

RUSSIAN PRESIDENT BORIS YELTSIN waved the white-blue-and-red Russian tricolor flag from the Russian Federation building before a crowd of about 100,000 jubilant supporters celebrating the end of the three-day coup attempt.

\section{Kuwait Oil Well Fires}

Firefighters were unprepared for the sight they were met with in Kuwait -- scores of oil wells sending plumes of red and orange flames thirty yards into the air. Oil lakes and soot blackened the sand.

During the seven-month Iraqi occupation of Kuwait, more than 730 oil wells were damaged or set ablaze. Firefighting crews have been able to extinguish 584 wells since the effort began in March 1991.

When the effort to combat the blazes began in March, it took an average of four days to put out one well fire. Now the teams are averaging 8.5 wells each day.

Teams from the United States, Canada, China, Iran, Kuwait, Hungary and France are all working together to clean up this environmental disaster.

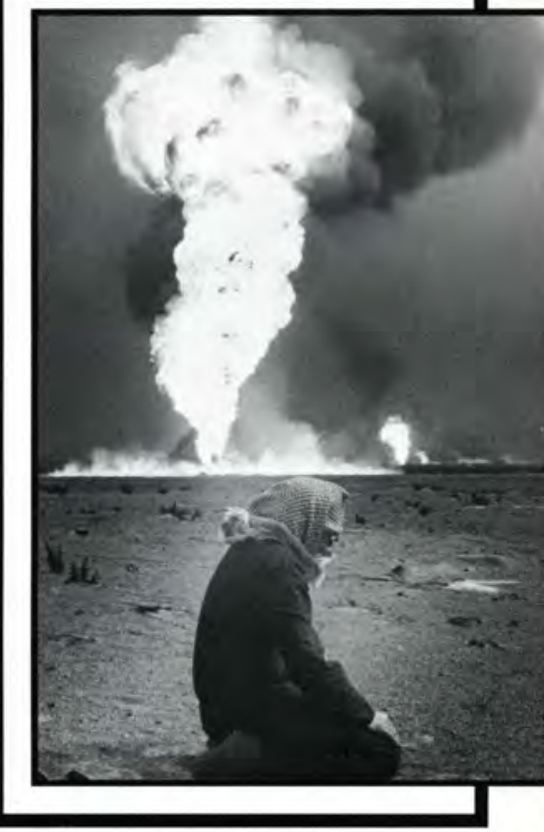




\section{Solar Eclipse}

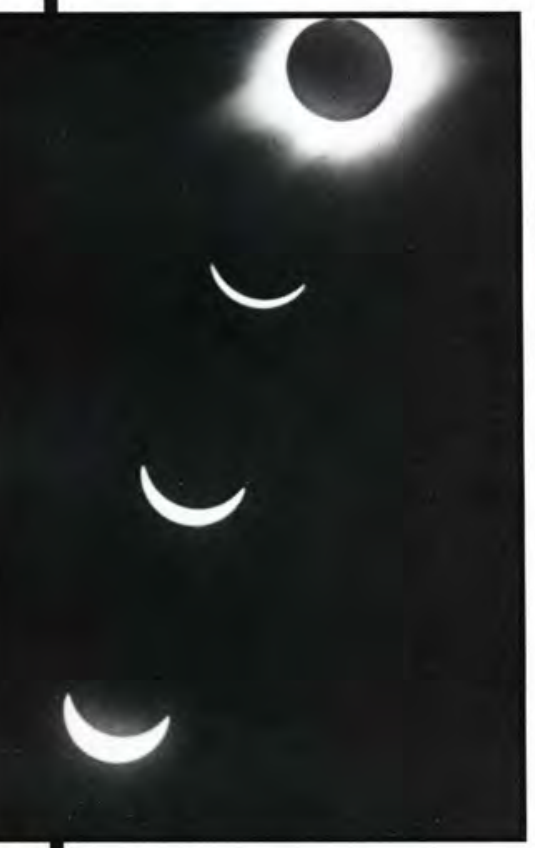

On July 11, 1991, the moon slipped over the sun in the celestial ceremony of the eclipse, turning day into night for thousands of viewers and scientists.

About 500 astronomers and tens of thousands of tourists came to see the moon line up between the sun and Earth and plunge into darkness a 160-milewide swath stretching from Hawaii to Mexico's Baja Peninsula, central and southern Mexico, Central America, Colombia and Brazil.

\section{Operation Welcome Home}

Desert Storm Commander General H. Norman Schwarzkopf gave a thumbs up to the crowd as he made his way up Broadway during New York's Operation Welcome Home ticker tape parade in June 1991.

Schwarzkopf, General Colin Powell and Defense Secretary Dick Cheney were the grand marshals of the New York parade, with over 600,000 people turning out to welcome the soldiers home. More than 1 million people attended a welcome home parade May 19 in Hollywood, and an estimated 800,000 turned out for the parade in Washington.

"U.S.A.! U.S.A.!" the flagwaving crowd chanted during a half-hour of nighttime fireworks over the East River in New York City. The \$1 million display was accompanied by the New York Pops Orchestra. A teary-eyed Korean War veteran said, "These young boys put their lives on the line and now they're getting their rewards."

by Associated Press

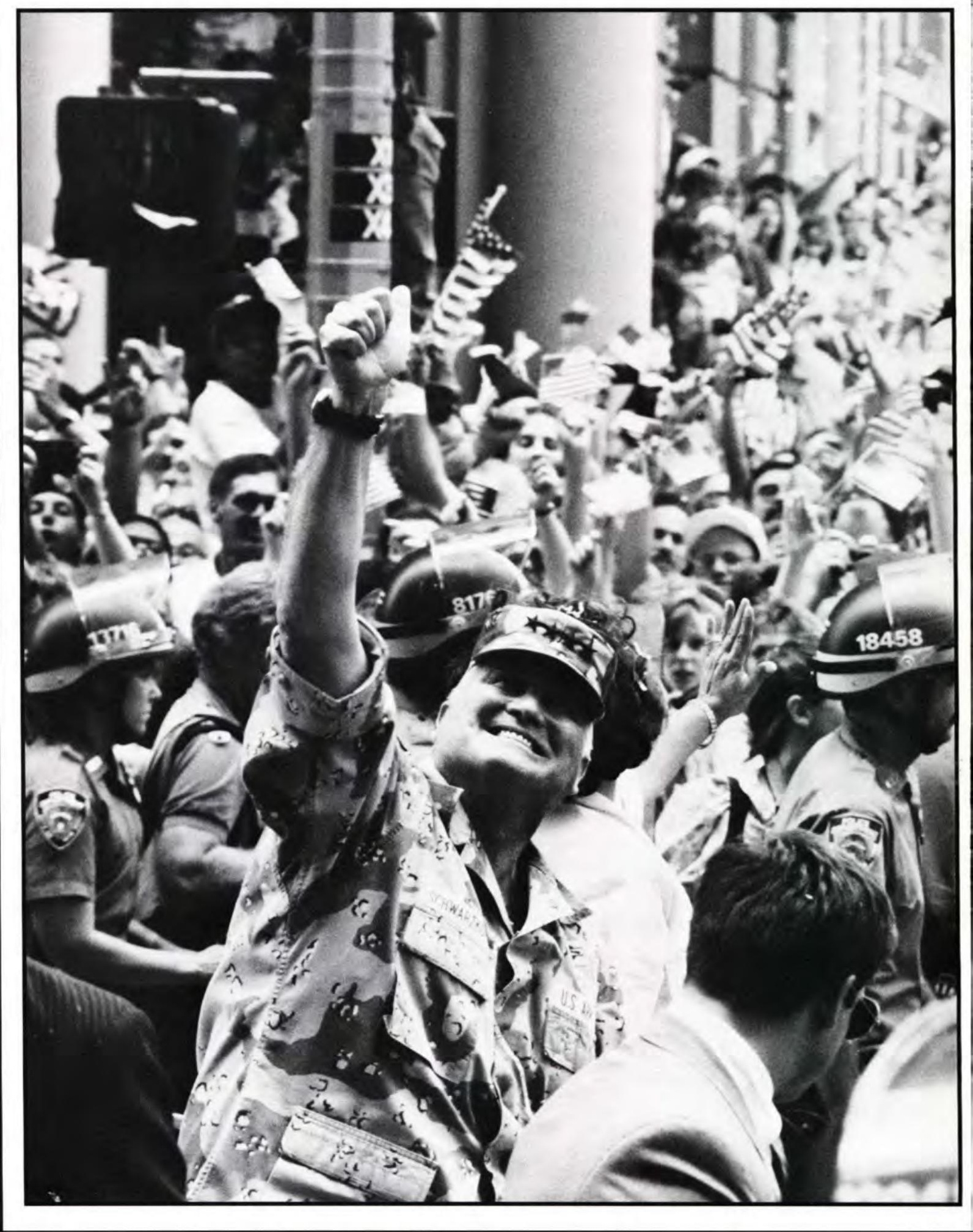




\section{Five U.S. Presidents Open Reagan Library}

Ronald Reagan threw open the doors of his presidential library on November 5, 1991, and invited the public to judge his turn in the White House.

A military band played "Hail to the Chief" and the crowd of 4,200 invited guests cheered as President Bush and former Presidents Carter, Nixon and Ford joined Reagan in the first gather-

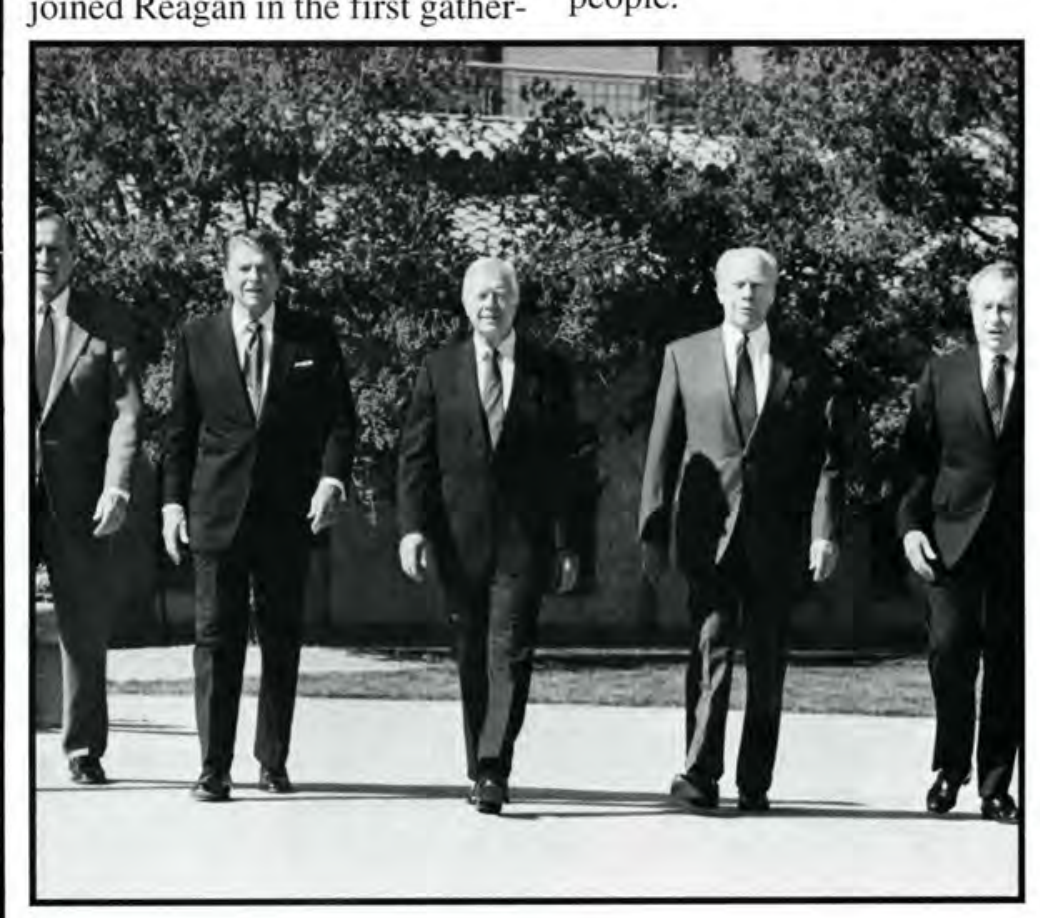

ing ever of five past or current presidents.

Each president took a turn at the microphone, praising Reagan and reflecting on their own presidential challenges.

"The doors of this library are open now and all are welcome," Reagan said. "The judgment of history is left to you, the of history

\section{Biosphere 2}

A sealed structure of steel and glass will be "home" for two years to four men and four women. The structure, called Biosphere 2, is about the size of $21 / 2$ football fields and contains all necessities of life. For two years, nothing will be introduced from the outside.

This $\$ 100$ million project has taken seven years to put together and hopes to be the model for other self-sufficient environments. Planets other than Earth may one day be the base for similar structures.

Both participants and backers of the Biosphere 2 maintain that the project will provide significant data.

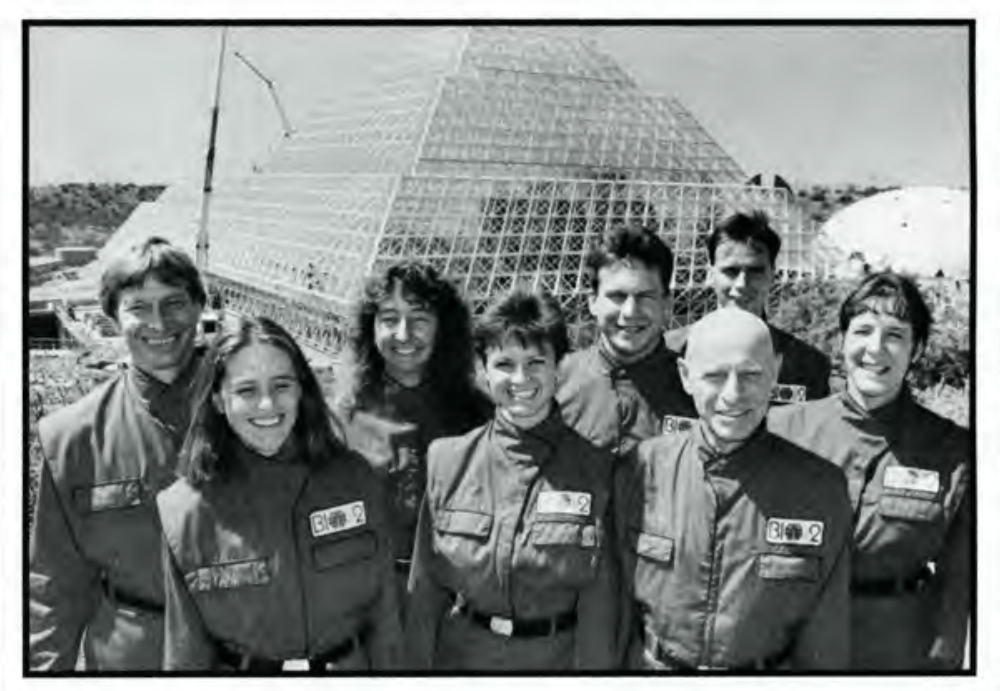

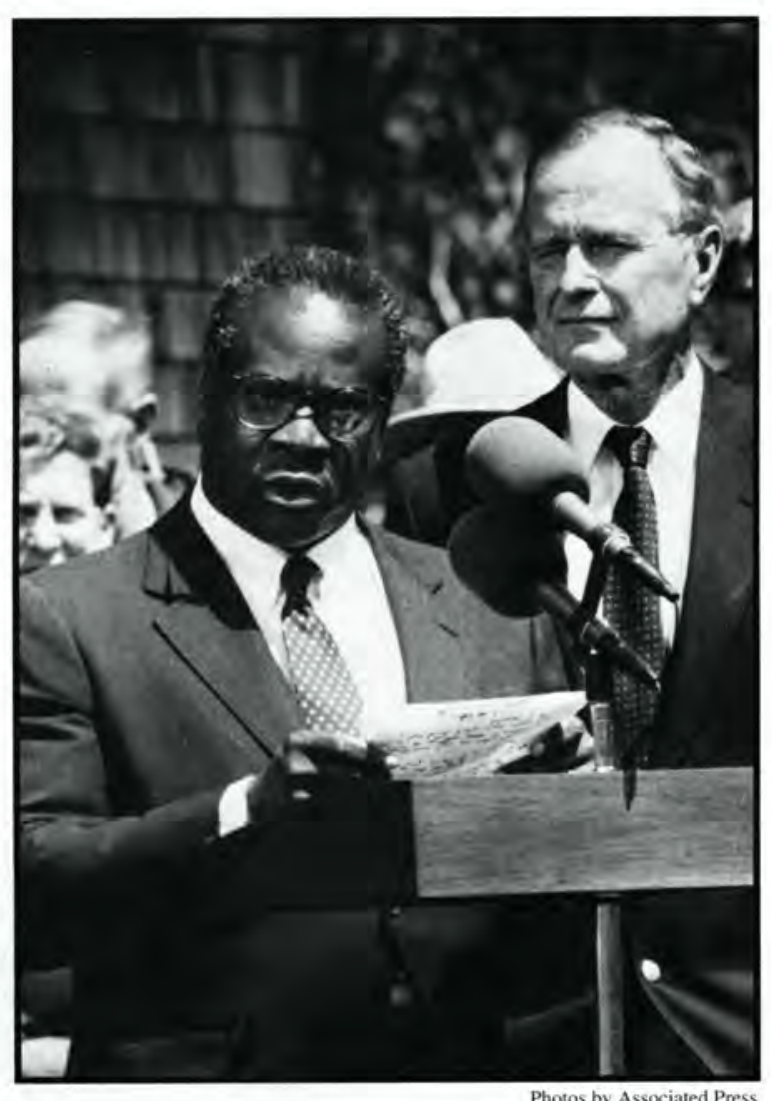

Photos by Associated Press

\section{Clarence Thomas}

\section{6th Supreme Court Judge}

Forty-three-year-old Clarence Thomas grew up poor, Black and Democratic in Pinpoint, Georgia, but later switched parties and became a controversial symbol of Black conservatism.

"Only in America," Thomas said after President Bush announced his nomination as the second Black justice on the Supreme Court. Thomas will succeed Thurgood Marshall who has retired.

Prior to Thomas' nomination to the Supreme Court, he served as an assistant attorney general in Missouri, a legislative assistant to Sen. John Danforth, seven years as chairman of the Equal Employment Opportunity commission and a judge of the U.S. Circuit Court of Appeals for the District of Columbia.

On October 18, 1991, Clarence Thomas became the 106th United States Supreme Court Justice. -Articles by Associated Press 


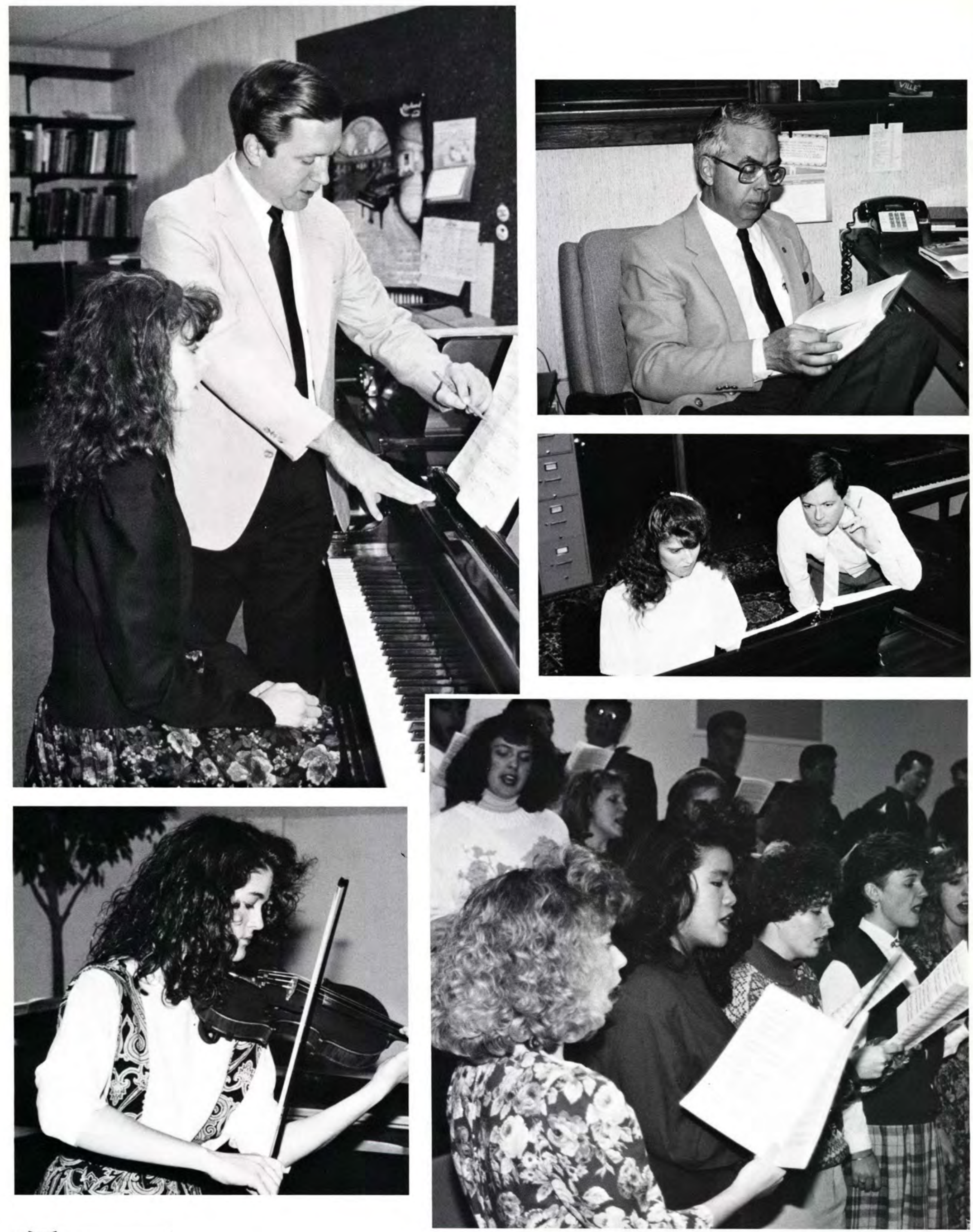

4106 Fine Arts 


\section{The Effart Behind the Excellence}

\section{ABLE OF CONTENTS:}

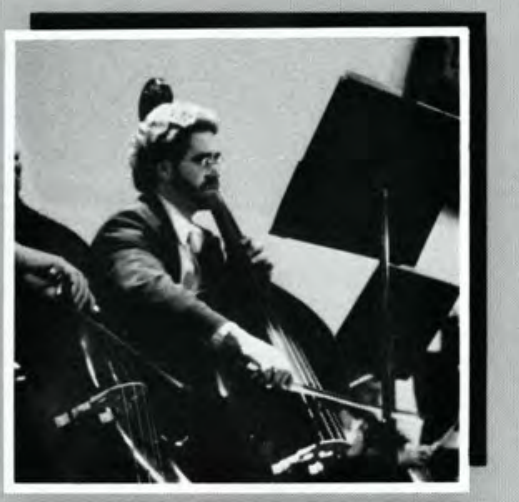

Antist

Series

Page 108

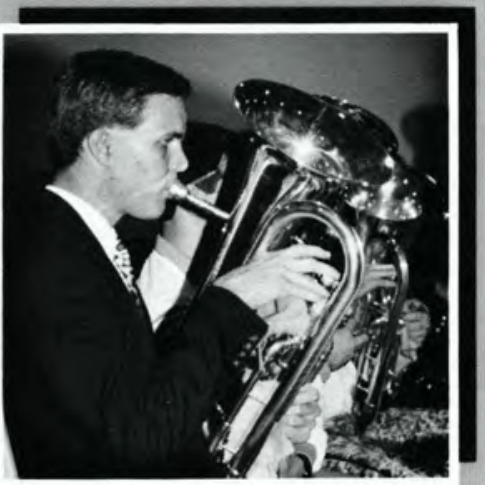

Music Group

Rehearsals

Page 110
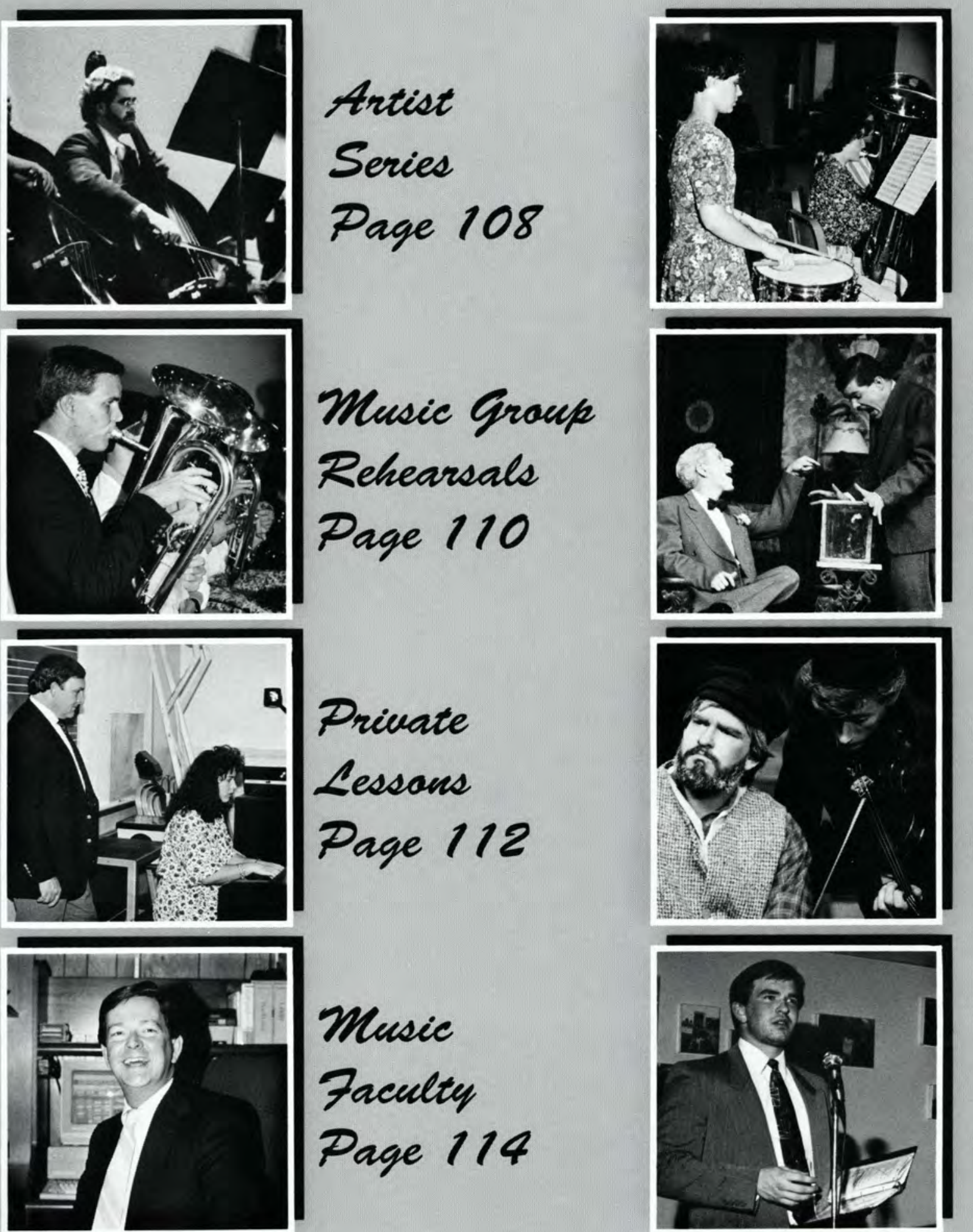

Music

Groups

Page 116

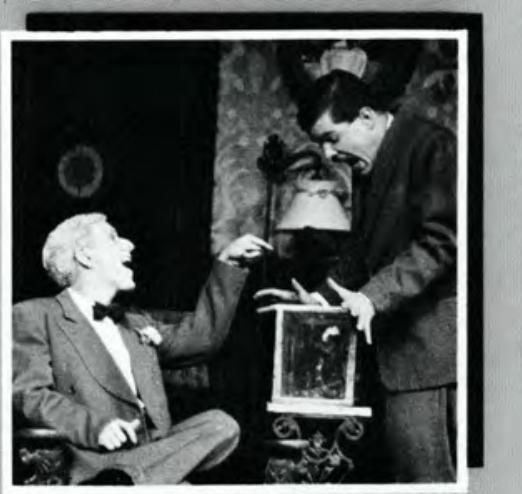

Fall

Praduction

Page 120

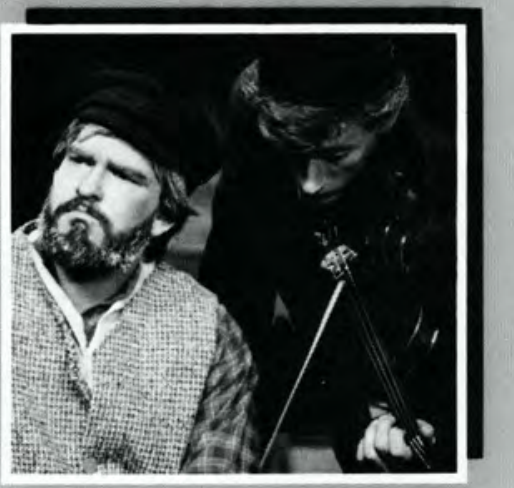

Spring

Lessans

Page 112

Music

Faculty

Page 114

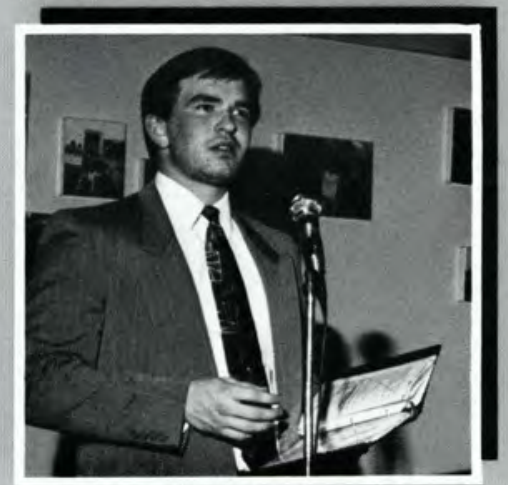

Production

Page 122

Farensice

Team

Page 124 


\section{The Vienna Choir Boys...In Cedarville?}

The bus finally pulled in at our destination -- a small college in Ohio on the edge of a cornfield. After stepping off the bus and stretching our legs, we went into the chapel and began to loosen up our voices for this evening's concert.

Being a member of the Vienna Choir Boys has taken us all over the world. It is quite an honor. Our history goes back almost 500 years to the time of Emperor Maximilian I and his decree "to have chorasters in the Imperial Chapel." To become a part of the choir, we had to attend a special preparatory school where we not only studied voice but also specialized on an instrument.
Tonight's concert boasted a wide variety of music. We began with some classical favorites from Mozart, Purcell, and Heiller. Then, after a short intermission, we performed Mozart's operetta, "The Caliph's Goose," complete with props and elaborate costumes. But, our favorite part of the concert was the Christmas section, in which we sang some familiar carols, such as "Deck the Halls," as well as some more unfamiliar tunes.

At the conclusion of our concert, we received an applause comparable to those we receive in Europe. We hope to return to Cedarville soon.

-Mindy Boone
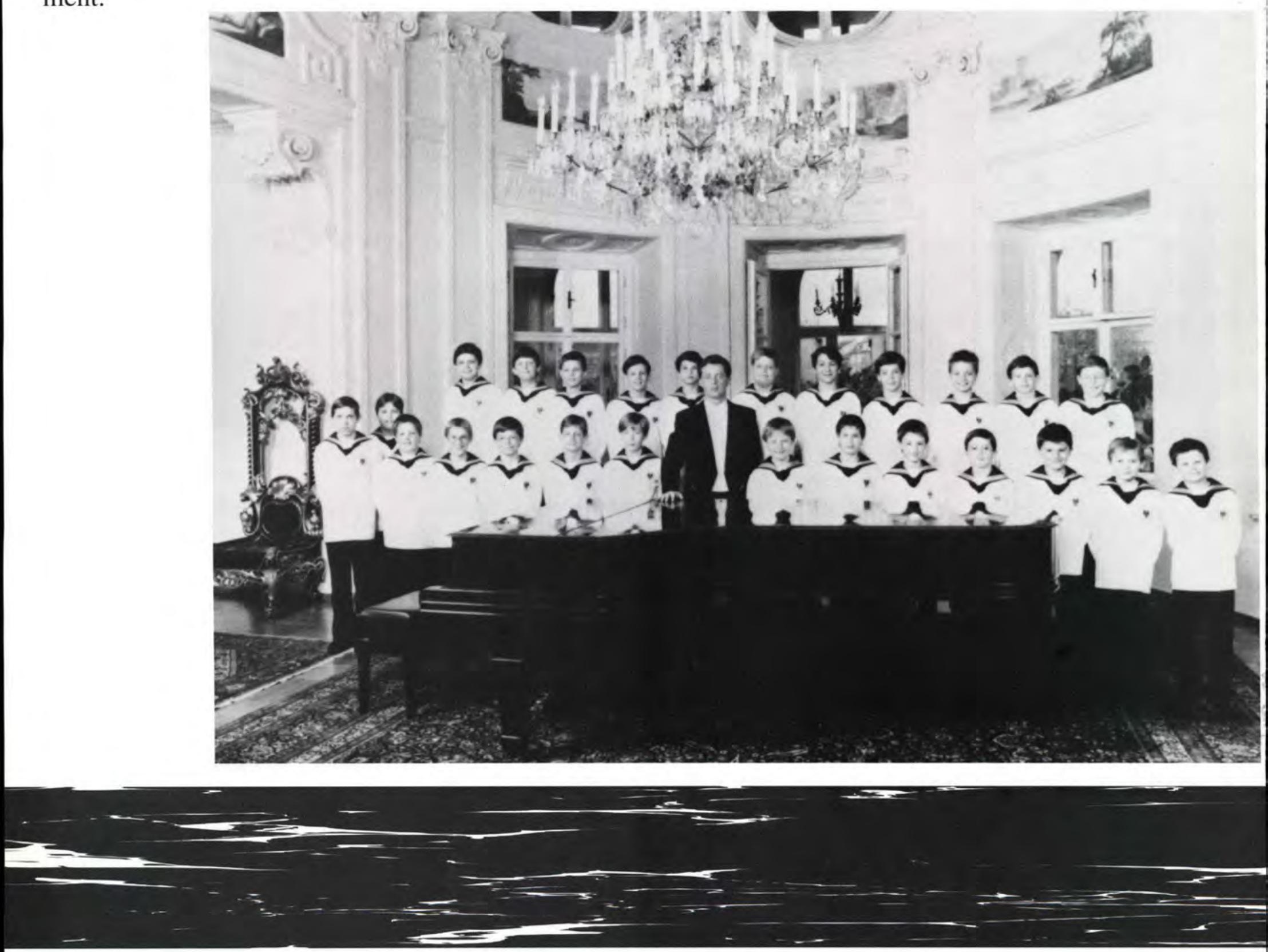

Vienna Choir Boys 
STRIKE UP THE BAND...Mr. Pagnard does an excellent job of leading the Brass Choir

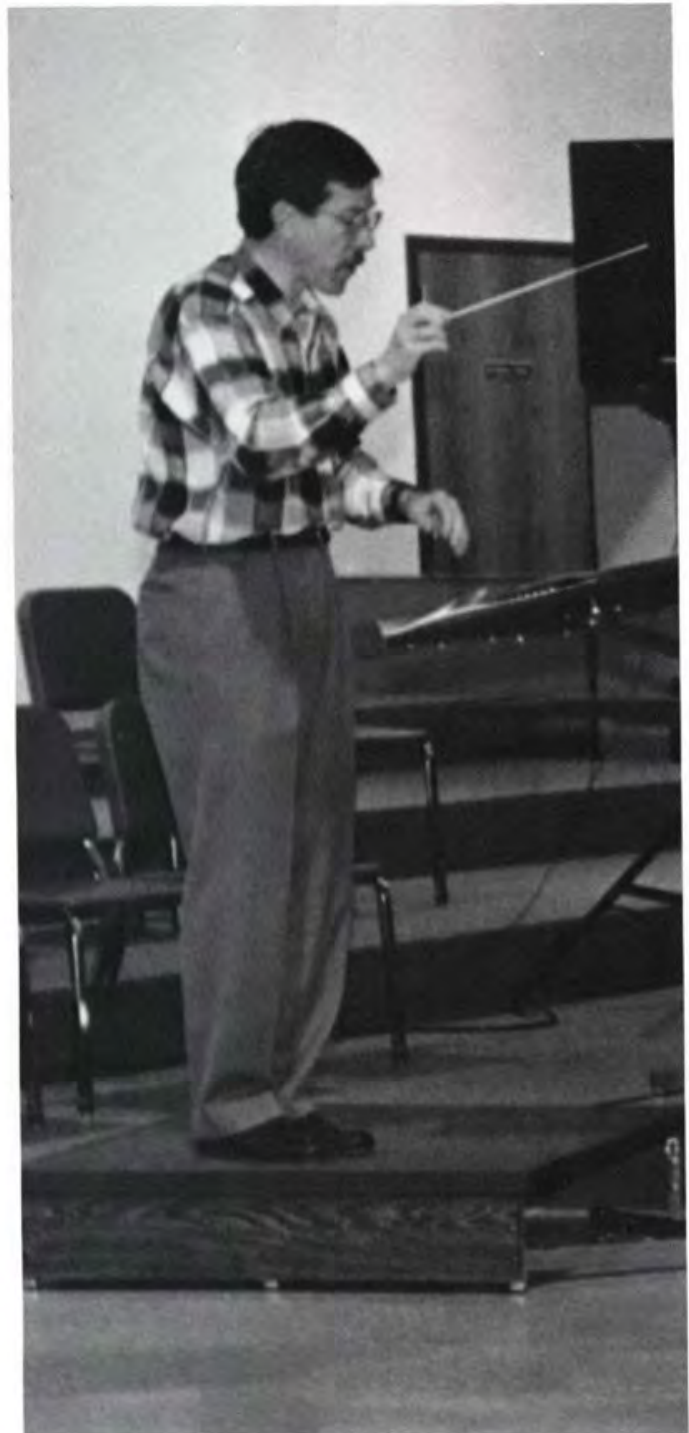

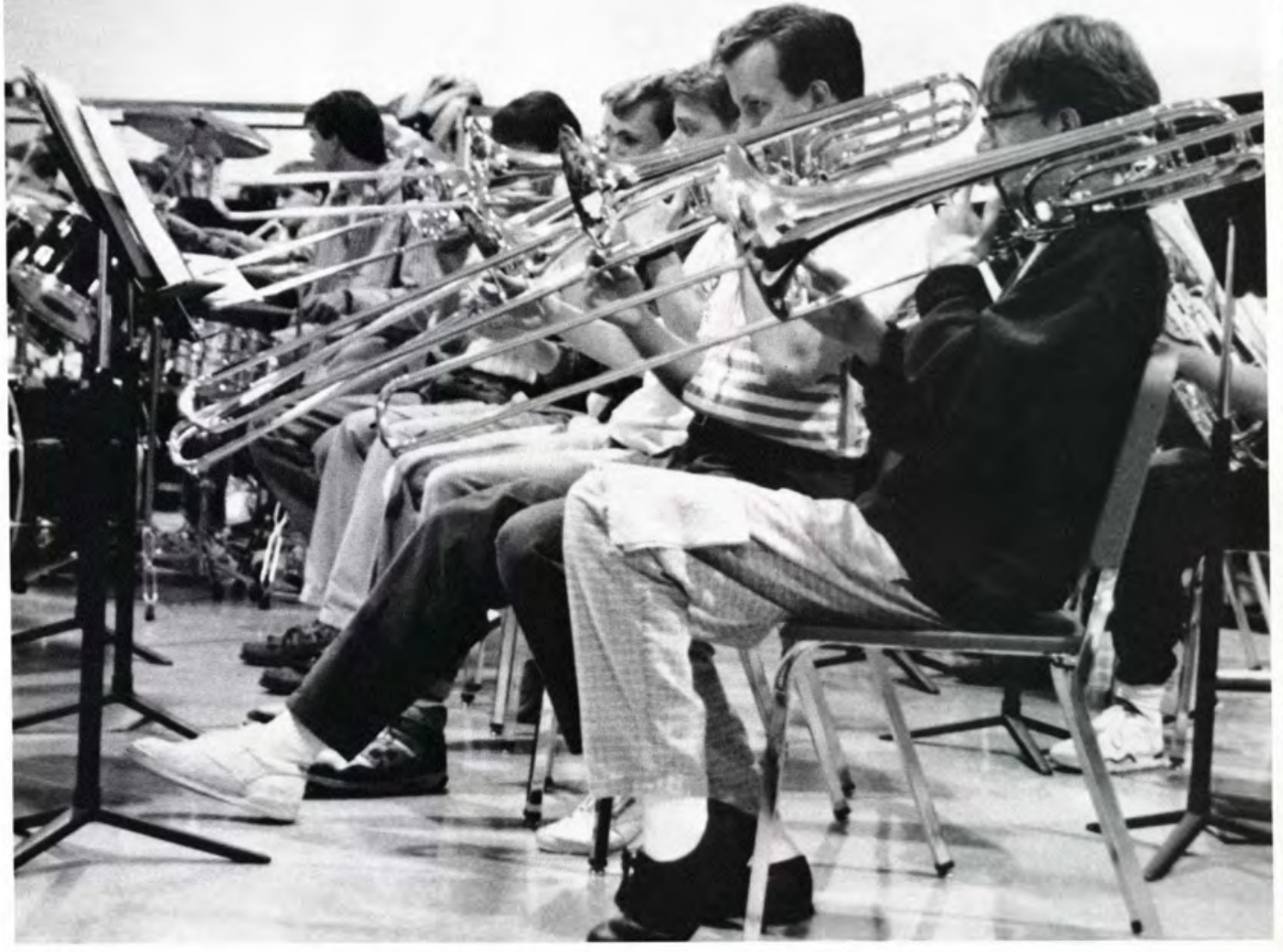
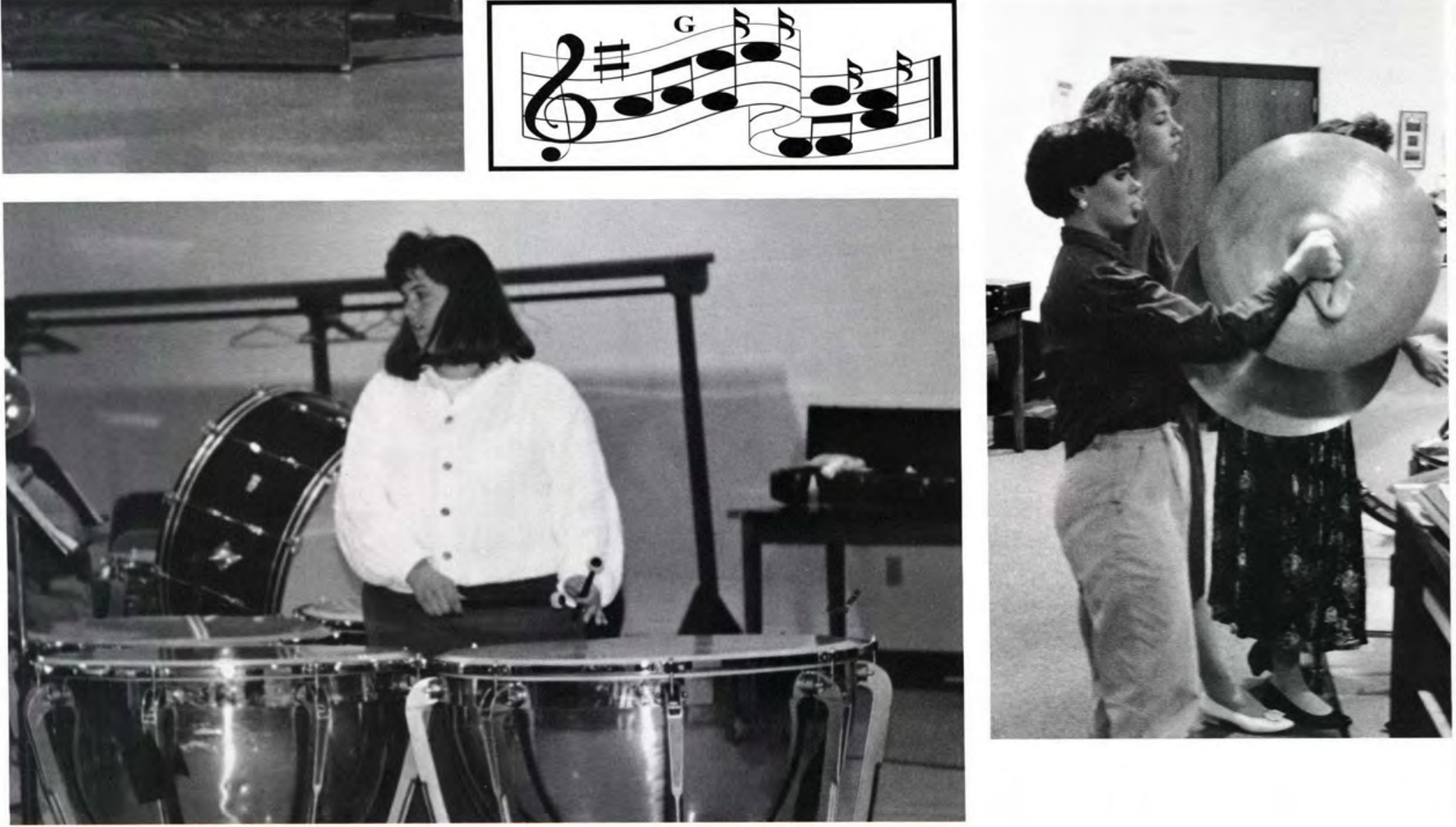
CREATING BEAUTIFUL MUSIC...The women of the Concert Chorale practice for an upcoming performance.

\section{Sacrificing Off-Stage}

\section{Music Group Rehearsals}

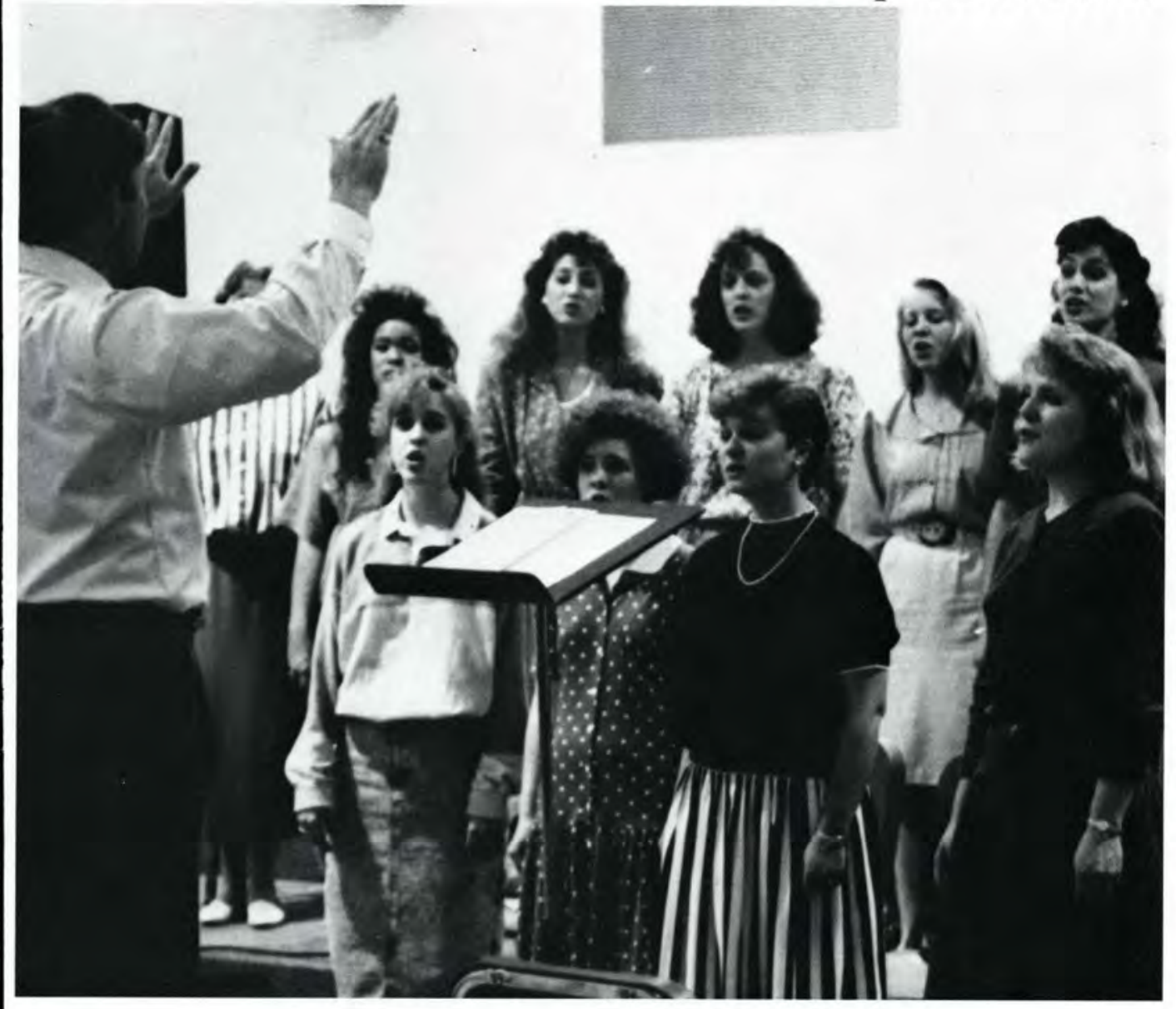

"Pops Concert." "Matinee of Masterpieces." "Music Showcase." "Oratorio." These are just a few of the performances in which various music groups on campus must perform. This list doesn't even begin to scratch the surface as one thinks about chapel services, performances on the road, and stage productions. These performances provide opportunities for Cedarville to display its commitment to excellence and beautiful music.

However, not seen are the hours spent in Alford Auditorium or the fine arts building practicing as a group or individually. Each music group spends an average of at least two hours each week rehearsing. Music is analyzed, played and replayed. Timing is perfected. Add to rehearsals the hours spent in private lessons and personal practice time and the sum of students' time devoted to musical excellence is staggering.

The performances we see from the Woodwind Choir, the Chamber Orchestra, the Symphonic Band, the Chorale, the Brass Ensemble and the Women's Choir on a regular basis are sometimes fun, sometimes beautiful, sometimes inspiring, but always well done. The level of quality we experience at such performances is due to a lot of talent and even more hard work.

- Jesse Wesselink

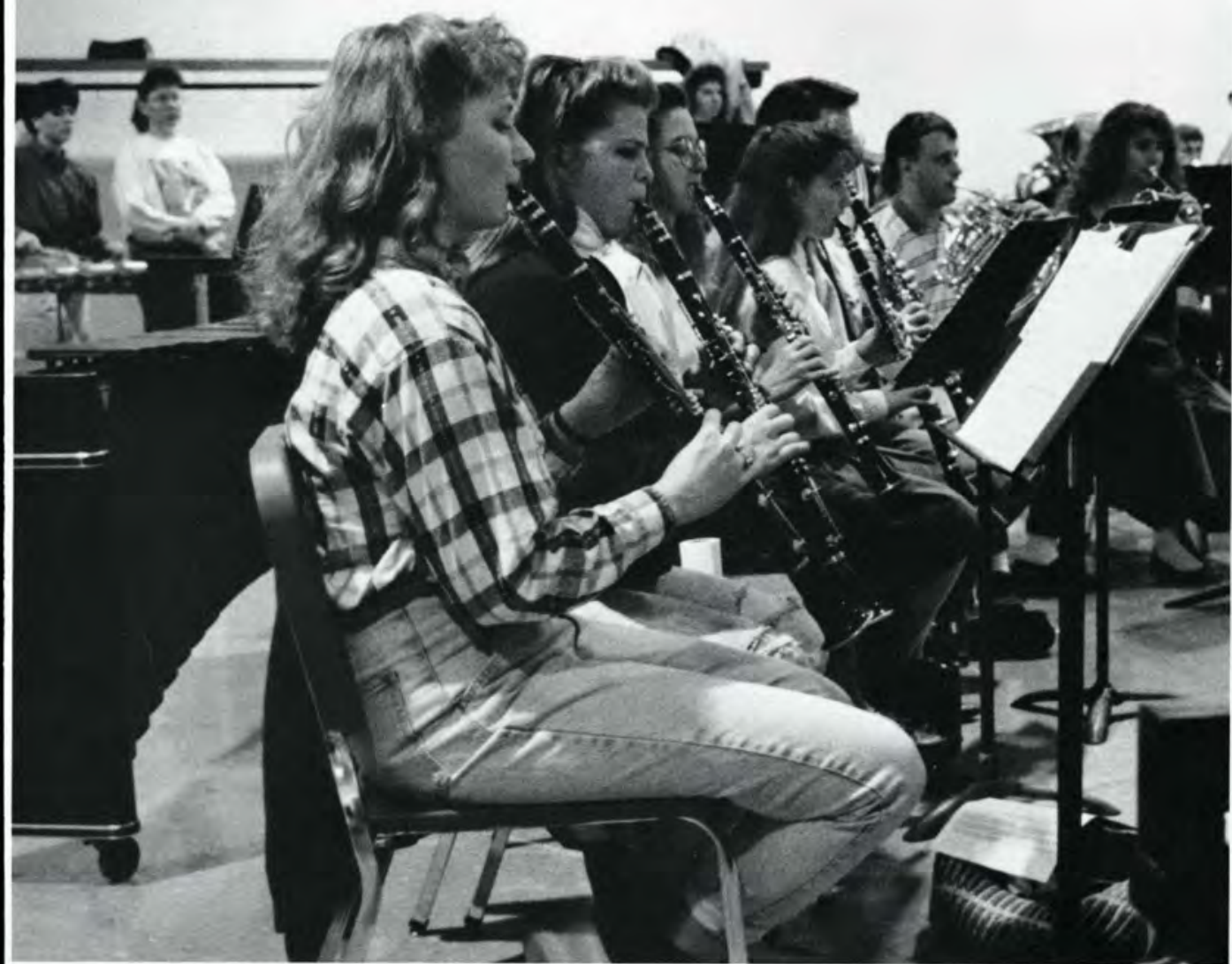

TOTAL DEDICATION...Showing up to band rehearsal: takes willpower and dedication.
PRACTICE, PRACTICE and more practice is what keeps Shelly Fox intent on her music.

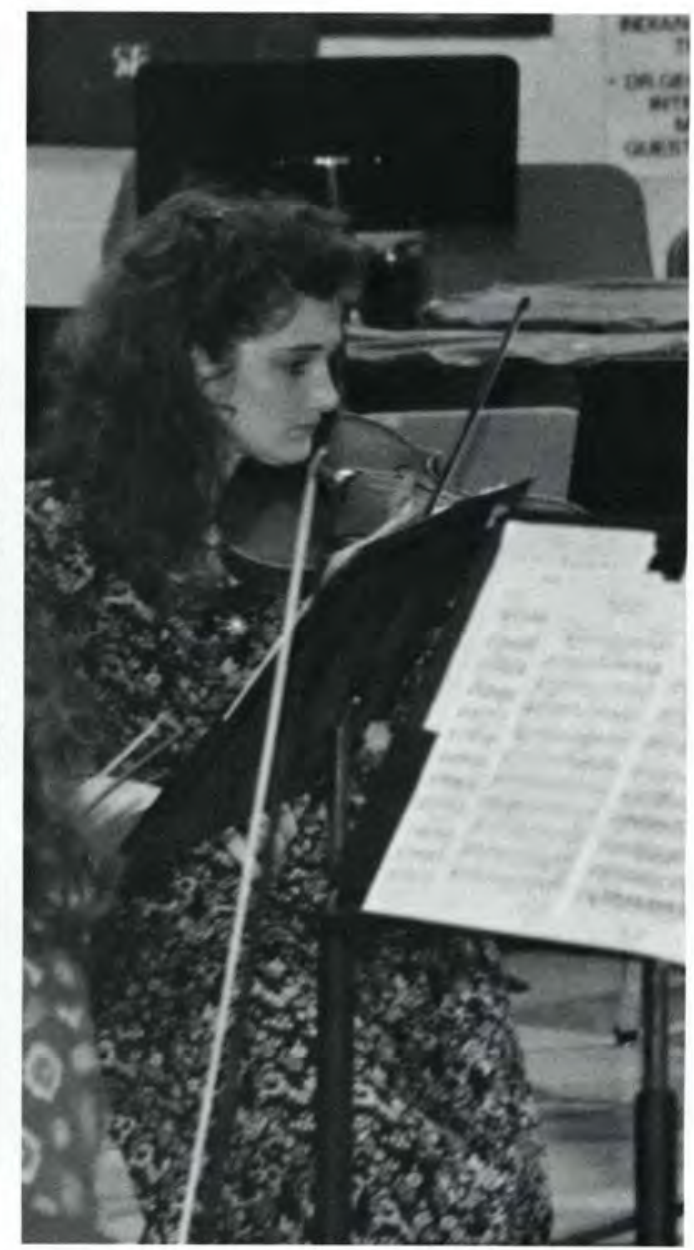

Fine Arts 111 


\section{Beyond Practice}

Private lessons provide enjoyment despite hectic college schedules.

"With classes and every-

thing else you do, how do

you find time to take music

lessons?"

Abby answers quickly, almost instinctively, "You

find time to do the things you want to do, the things that are important."

Abby Boone, a sophomore majoring in English education, takes voice lessons from Mrs. Corey. She, along with several other students, spends much of her time practicing and developing her talent for the Lord.

"Singing has made me more confident, and not just in the area of music." She praises the quality teachers here at the college, especially mentioning all the time and practice each puts in to achieve his best.

Practicing has become a priority to Abby as well. "If you have a talent, you should develop it. If you don't, you are wasting something God has given you to use for Him." This holds true not only for musicians but also for those in other disciplines.

- Mindy Boone

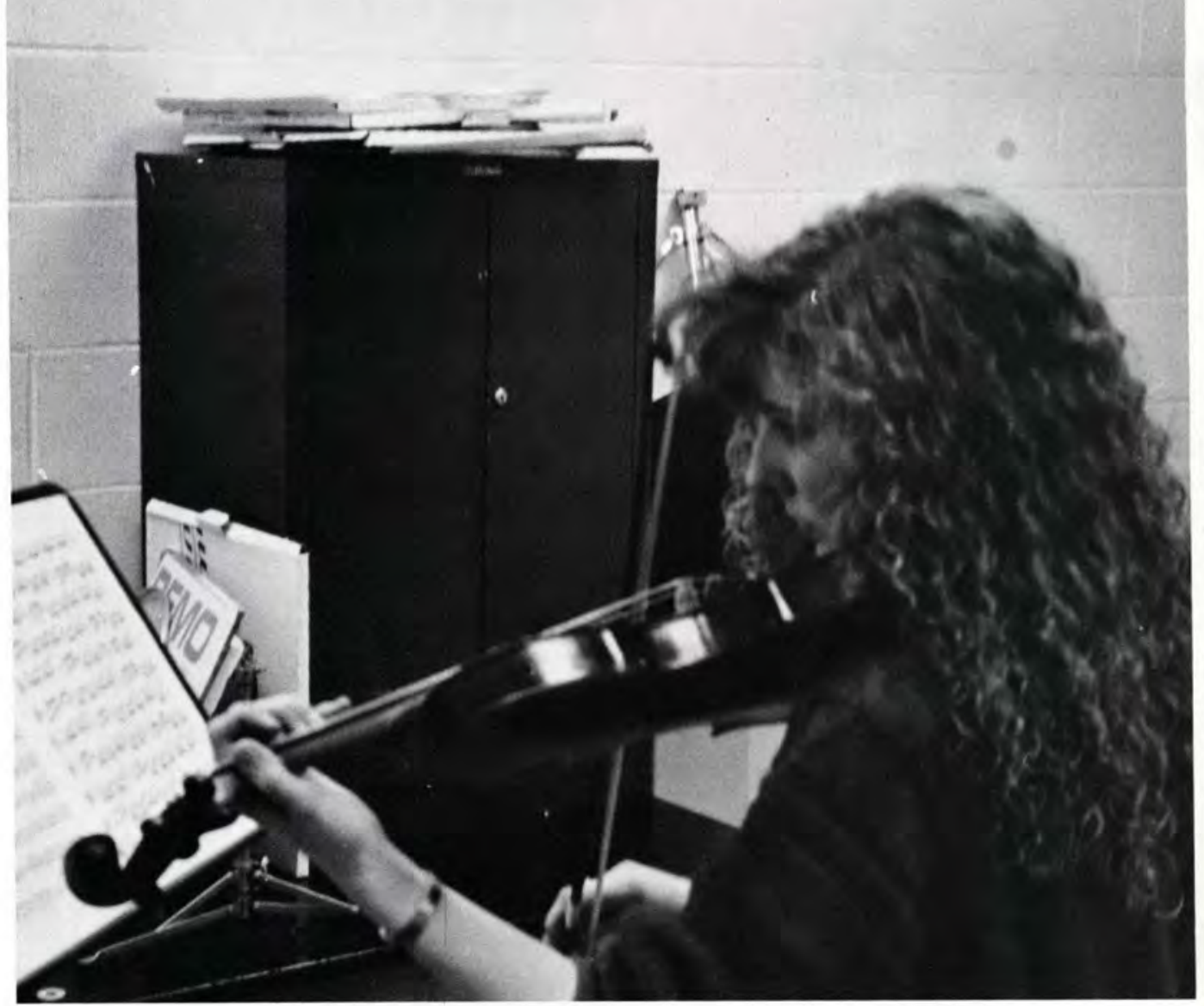

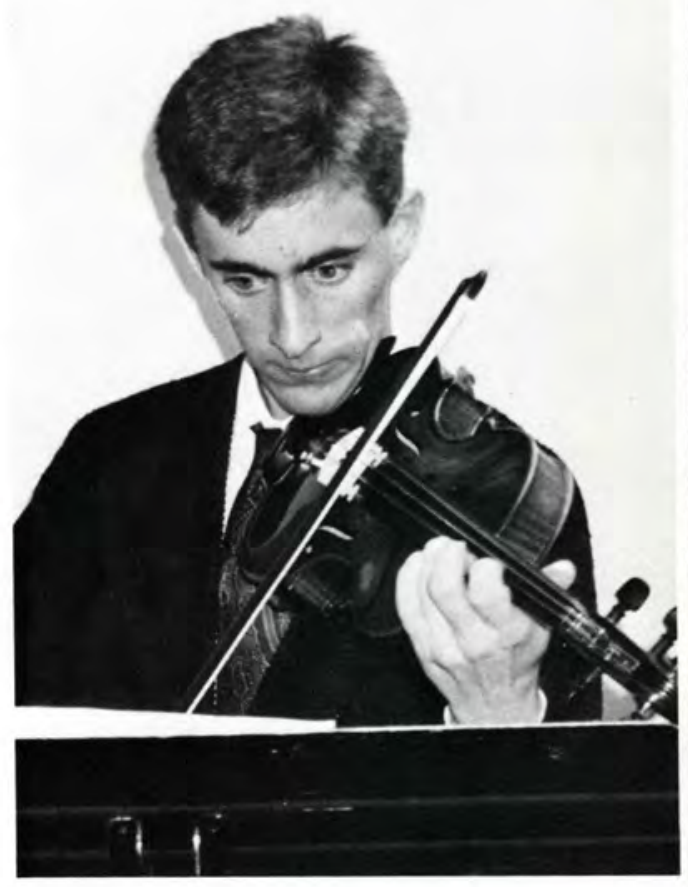

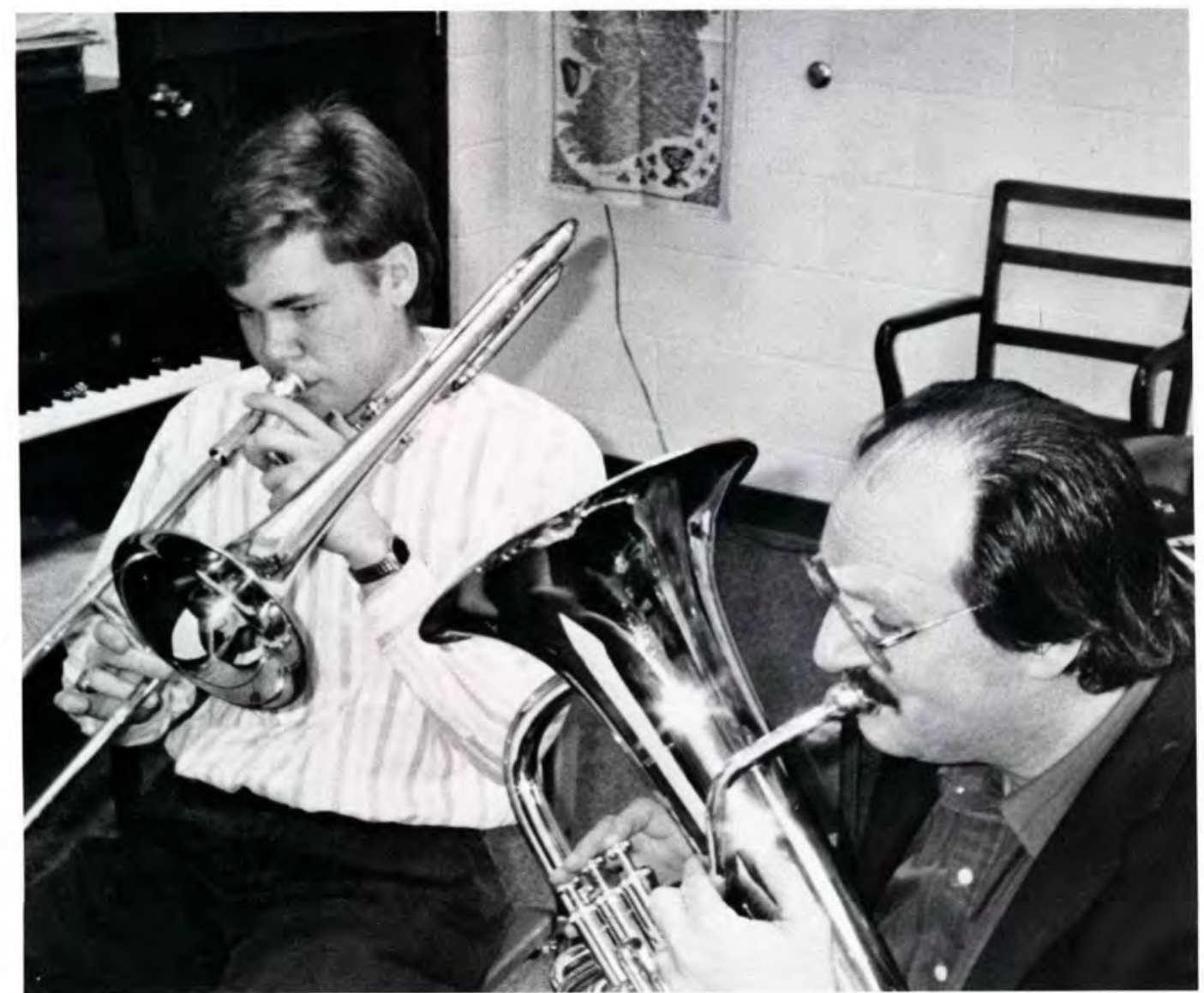

DYNAMIC DUO. Mr. Michael DiCuirci on baritone assists Fine Arts Michael Lichen on trombone.

PRACTICE MAKES PERFECT. Intent on perfecting his piece, Steve Cook practices his violin. 
TOTAL PREPARATION...Intent on her music, Mindy Mc Phearson prepares for her lesson.
THE MELLOW SOUNDS of a saxophone duet emanate lain.

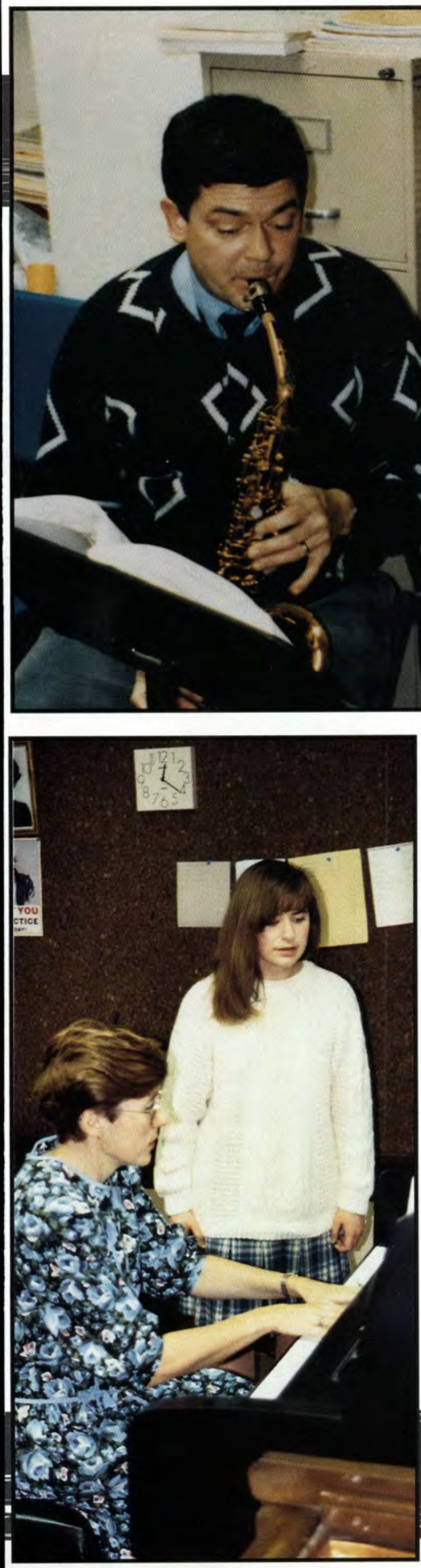

THE SOUND OF MUSIC...Abby Boone goes over the song she is learning with voice teacher Mrs. Corey. from Professor Jerry Rodgers and student Curtis Chamber-

TRY AGAIN....Gretchen Pike cringes as she strikes a rather unpleasant note.
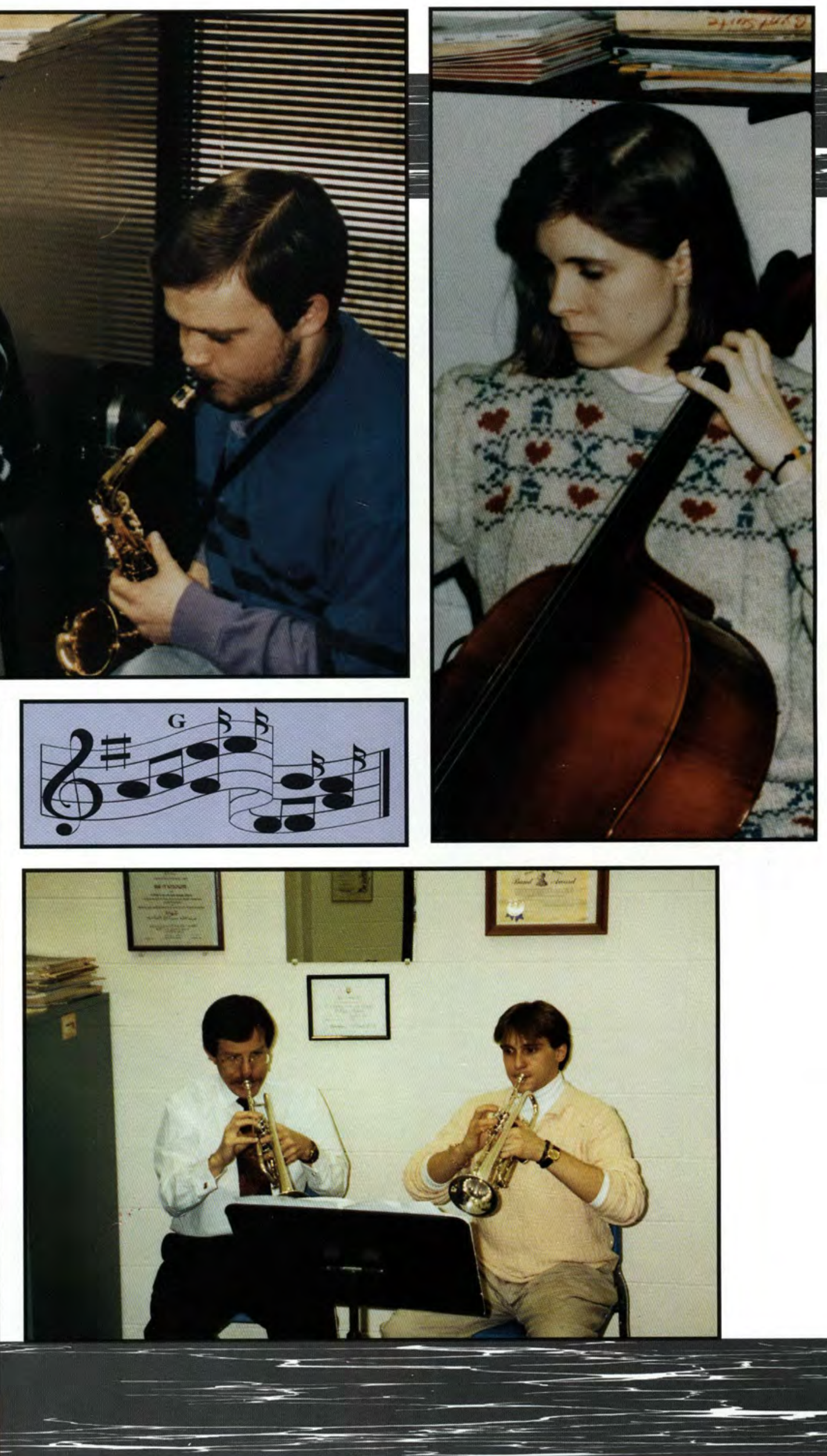

MASTERFUL MUSIC A trumper duer emanates from

Professor Pagnard and student trumpeter Jonathan Misere.

Fine Arts 


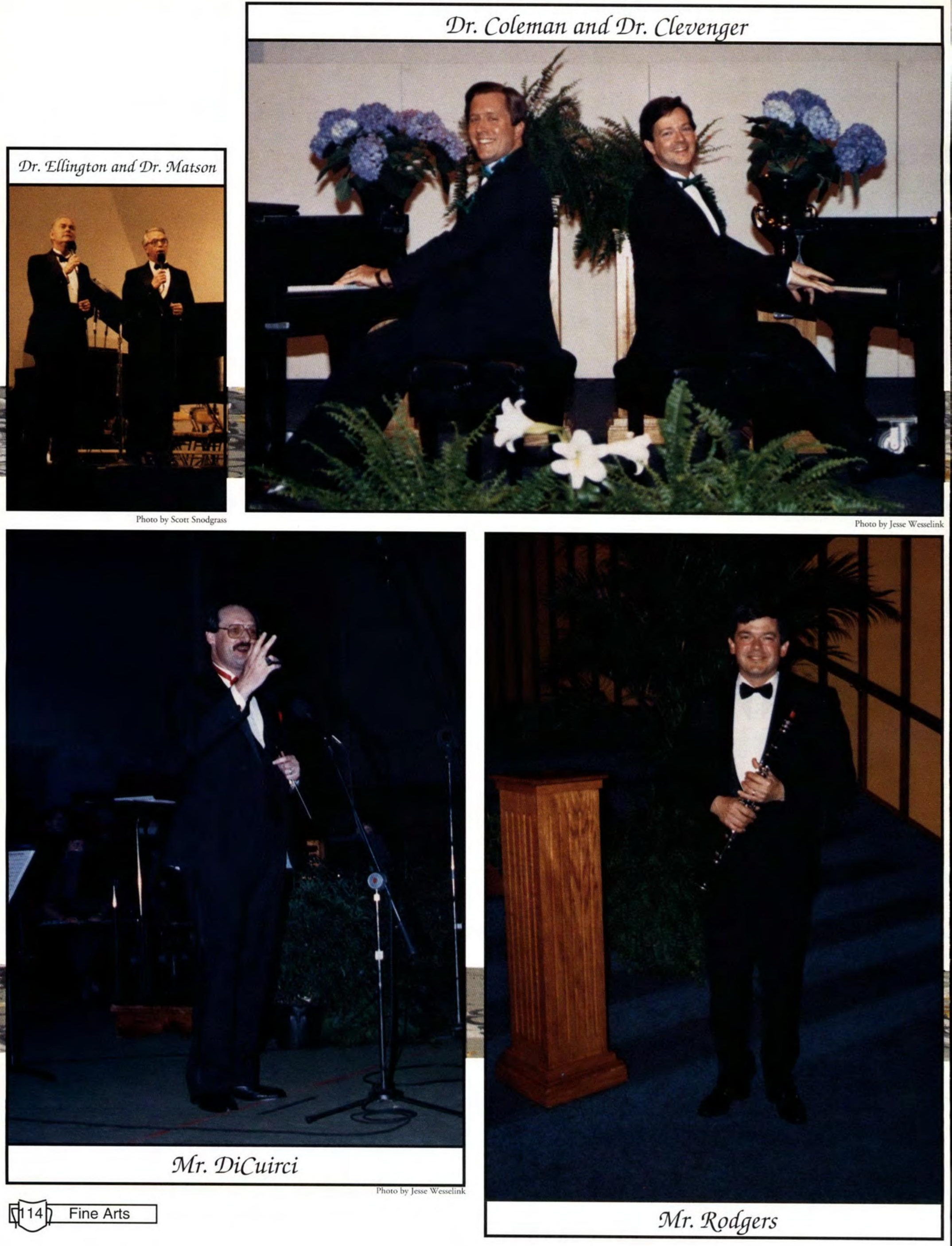




\section{Music Faculty \\ Giving of Themselves to Better Others}

Music faculty should have one foot firmly planted inside the institution and one foot outside in the performance arena; most of us are, in fact, performing artists at some level. Because we live in two worlds, so to speak, we feel pulled in two different directions. Frankly, there's more money to be made in performance, but the thing that keeps us teaching is the ministry of discipleship we have with you -- multiplying our effectiveness

\section{Mrs. Rodgers}

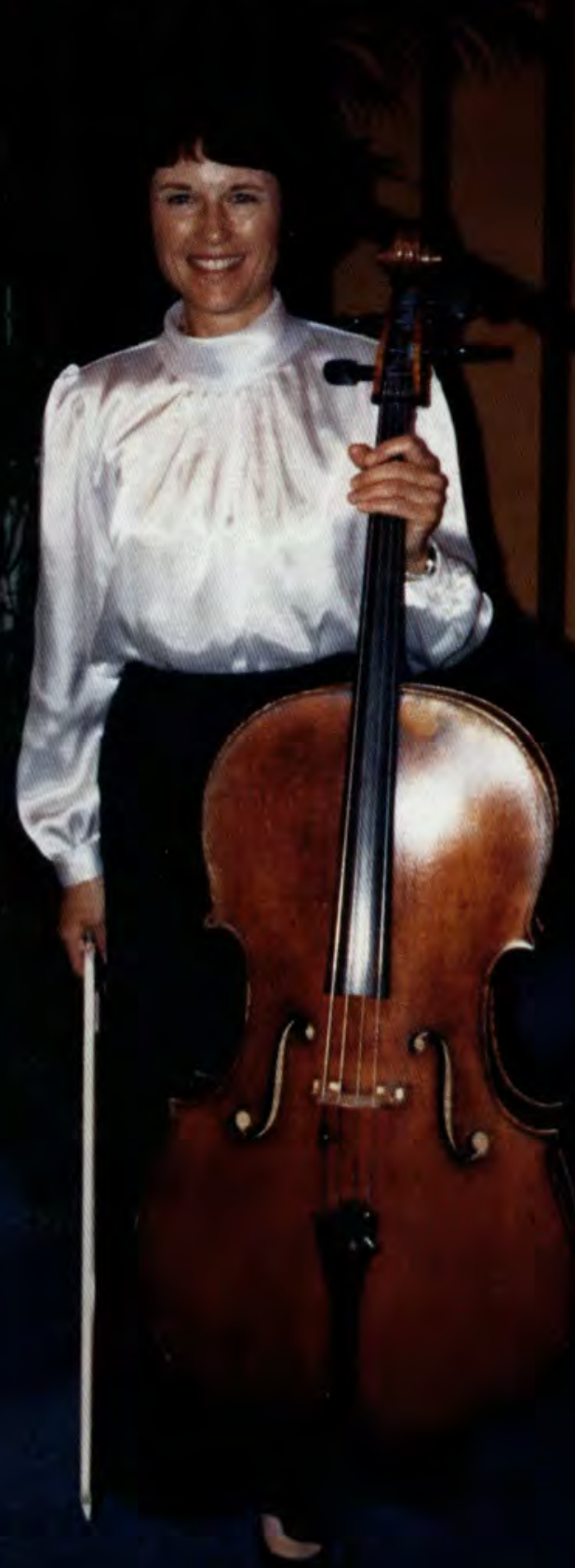

by reproducing ourselves in the lives of our students.

The way we teach music is a direct continuation of the original university concept: the Magister (Master teacher) imparts the art and craft of music to the Discipulus (student-disciple) in a relationship more akin to an apprenticeship than it is to the classroom method. It's a very special application of the Great Commission, to make individual disciples and model the Christian life before them.

-Charles R. Clevenger, DMA Music Department Chair

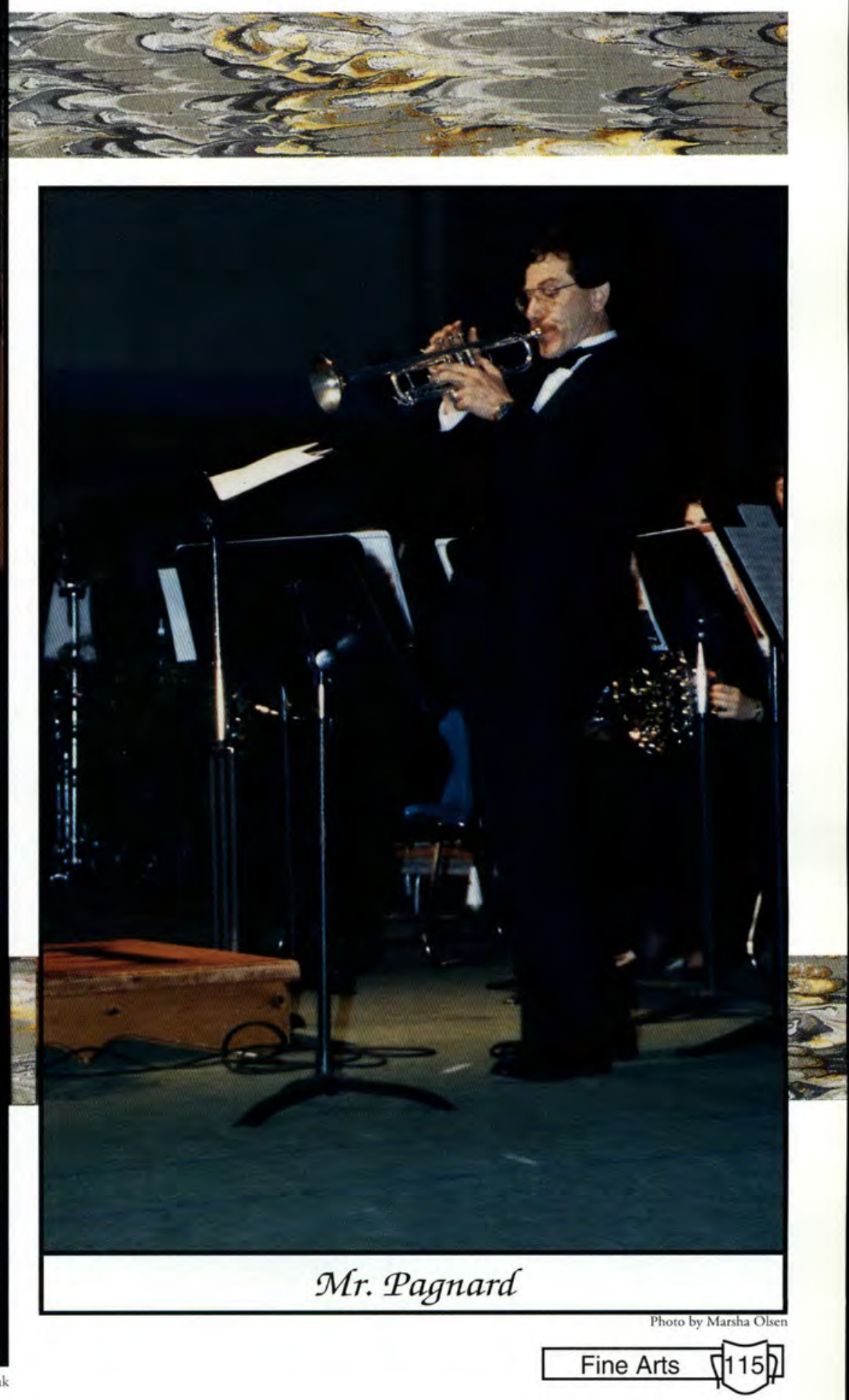




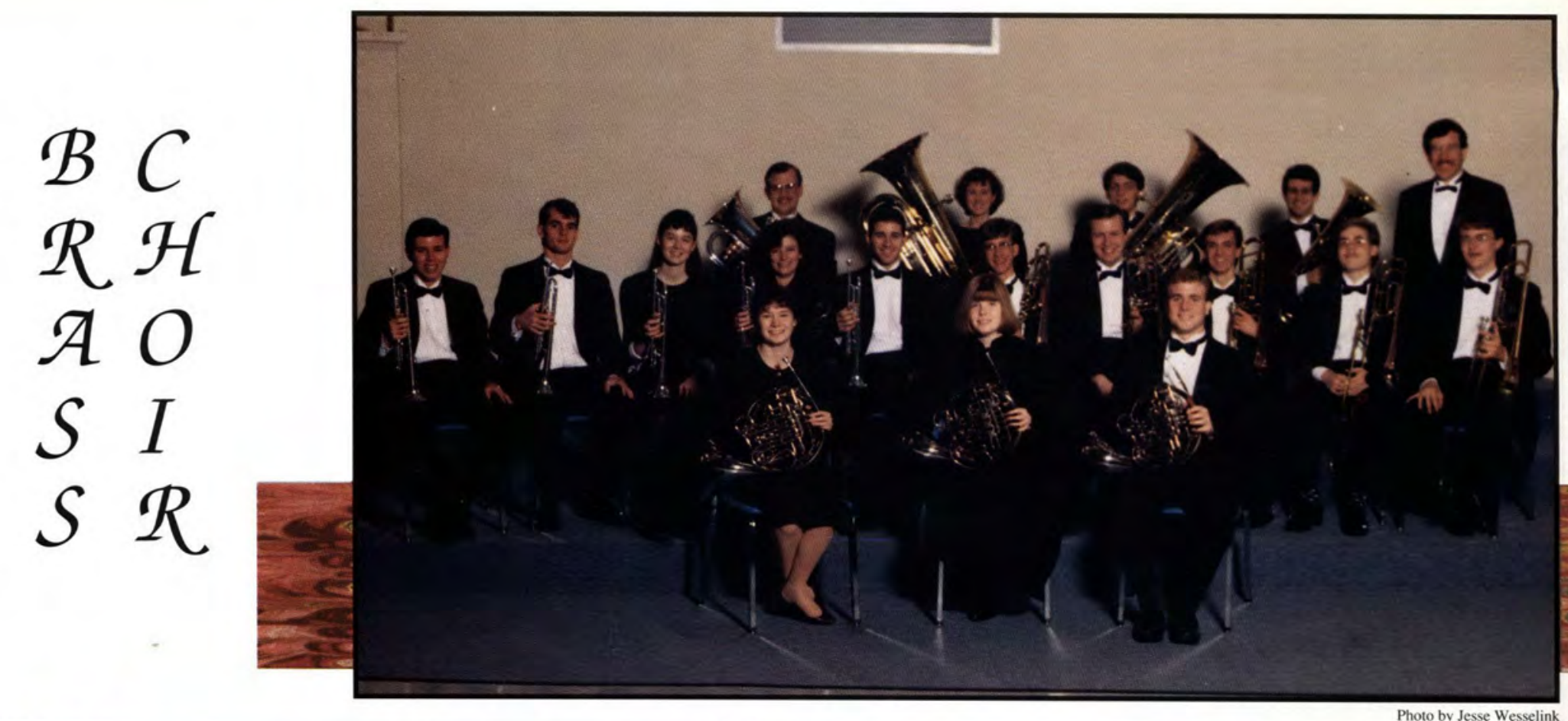
mouriod

to by Scott S

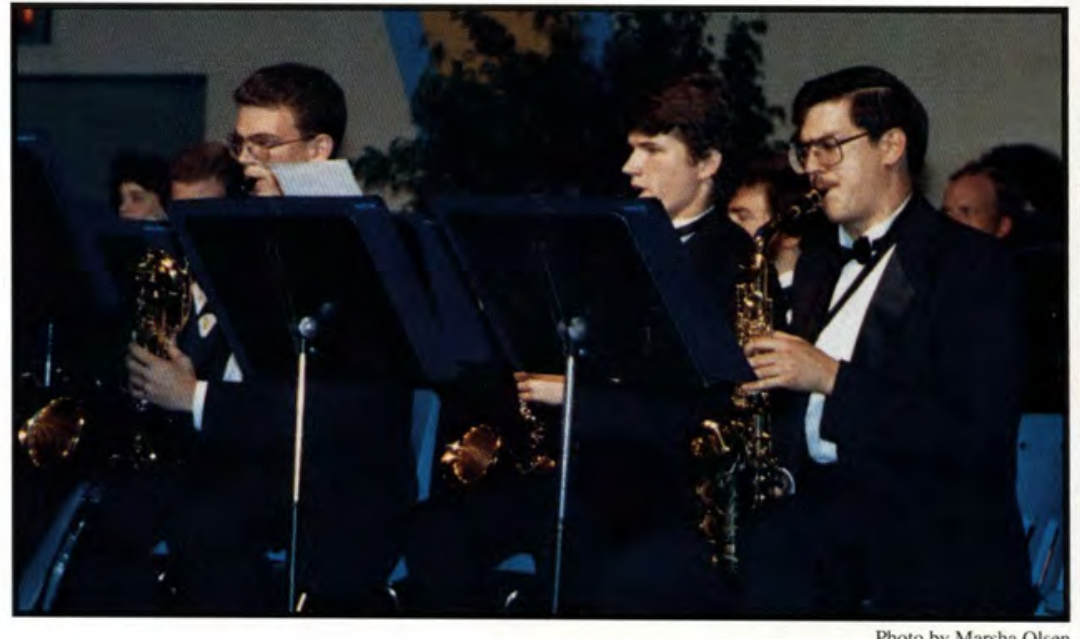

$C O$
$\mathcal{H} \mathcal{R}$
$\mathcal{A} \mathcal{C}$
$\mathcal{M} \mathcal{H}$
$\mathcal{B} \mathcal{E}$
$\mathcal{E} \mathcal{S}$
$\mathcal{R} \mathcal{T}$
$\mathcal{R}$
$\mathcal{A}$

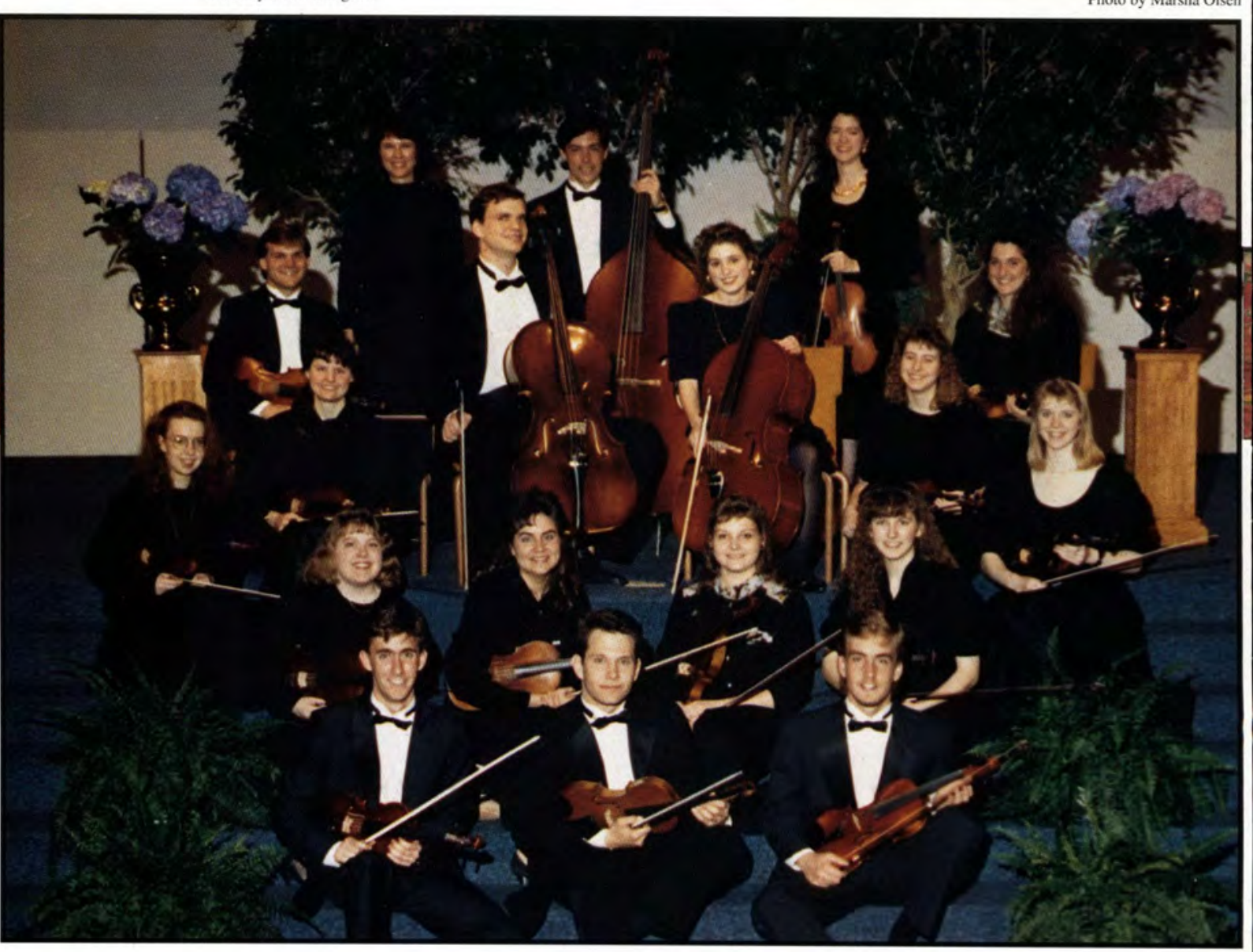




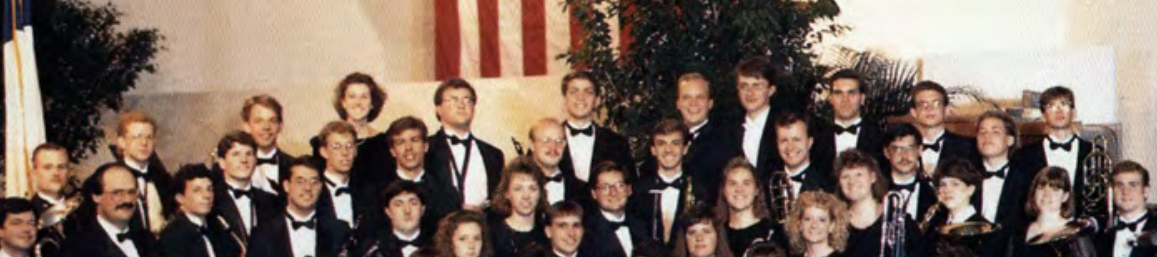

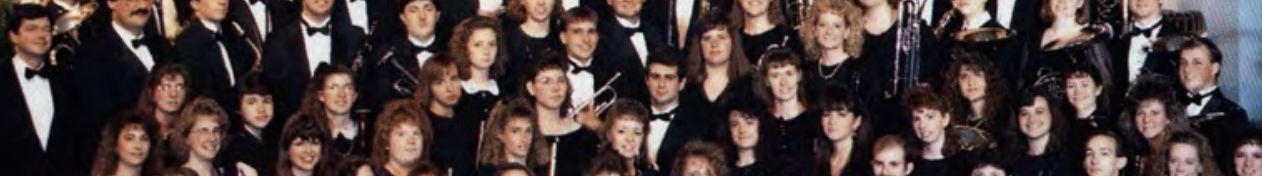

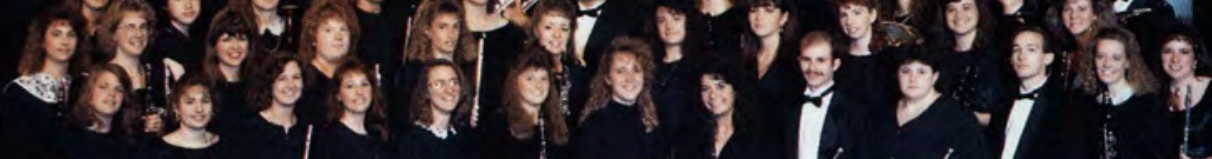

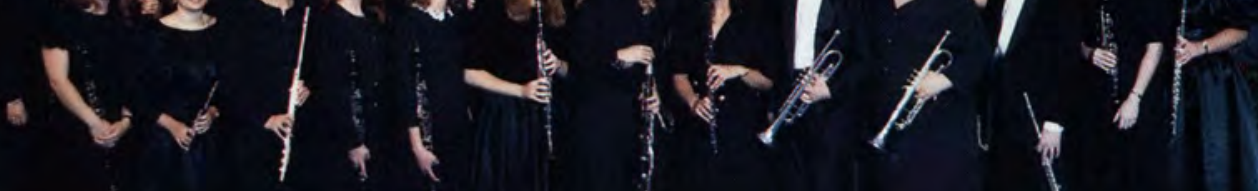
$\mathcal{S} \mathcal{B}$
$\mathcal{Y} \mathcal{A}$
$\mathcal{M N}$
$\mathcal{P} \mathcal{D}$
$\mathcal{H}$

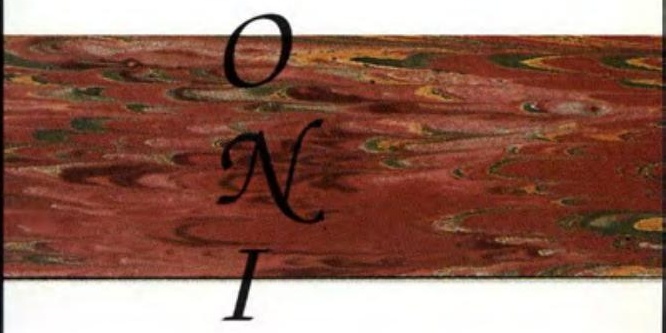

$\checkmark$

ע
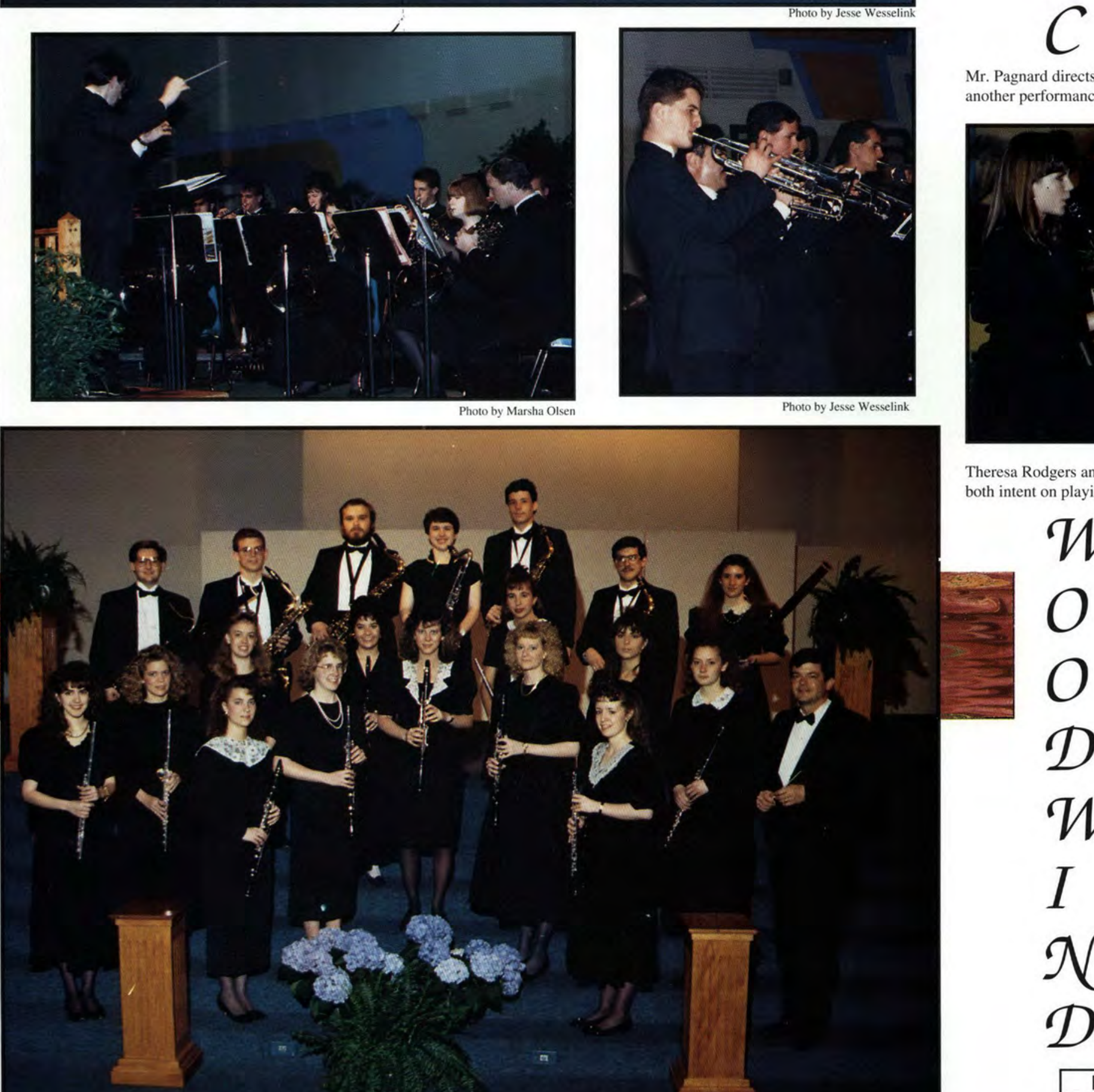

Theresa Rodgers and Tammy Haberstich both intent on playing their instruments.

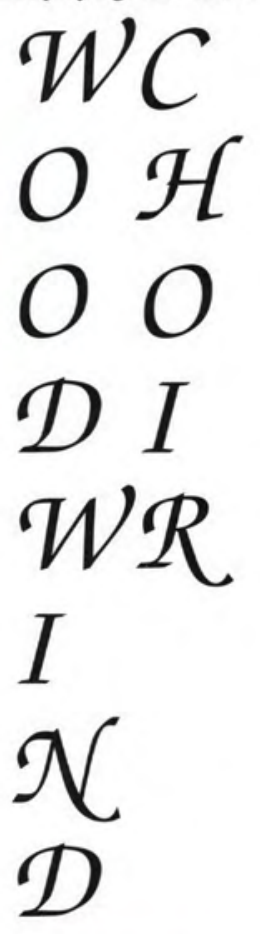

Fine Arts 117 


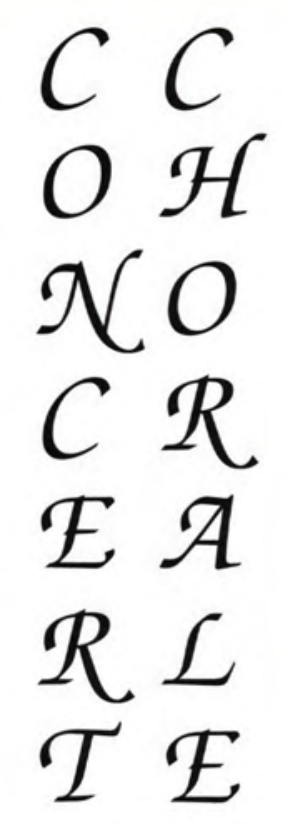
की को

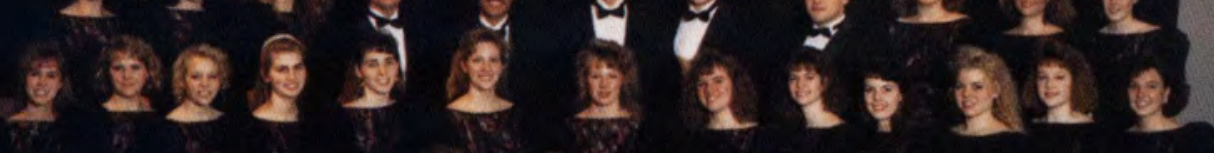
2 221 is 2

1111111711

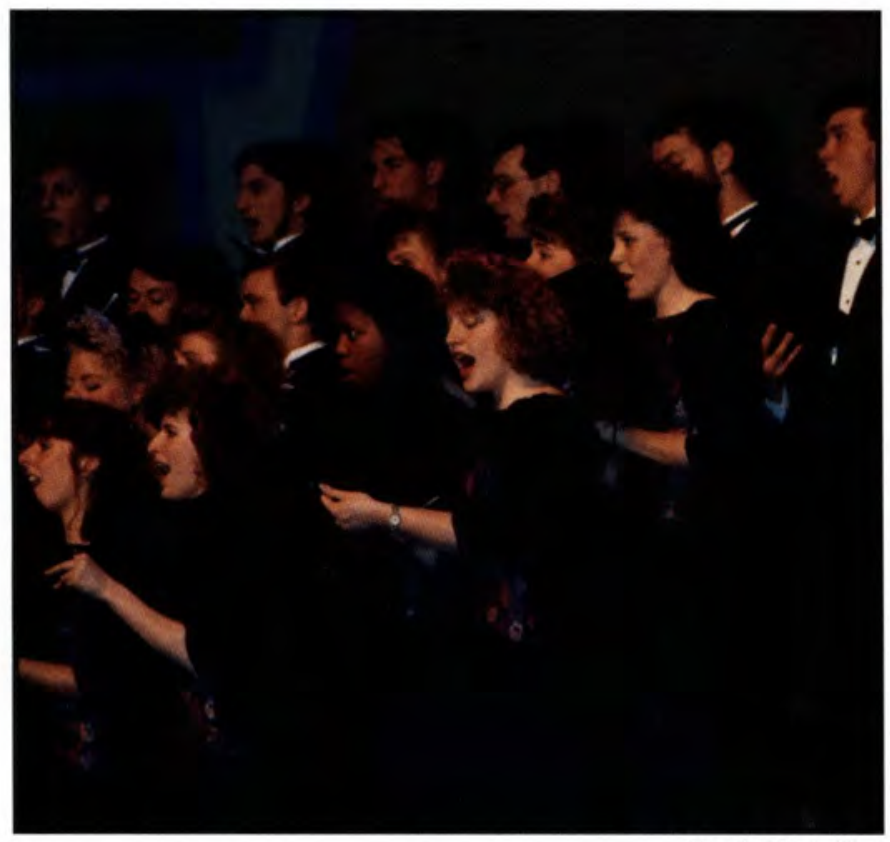

M $C$

$\theta \hat{\jmath}$.

MO

E I

$\mathcal{N} R$

$S$

.
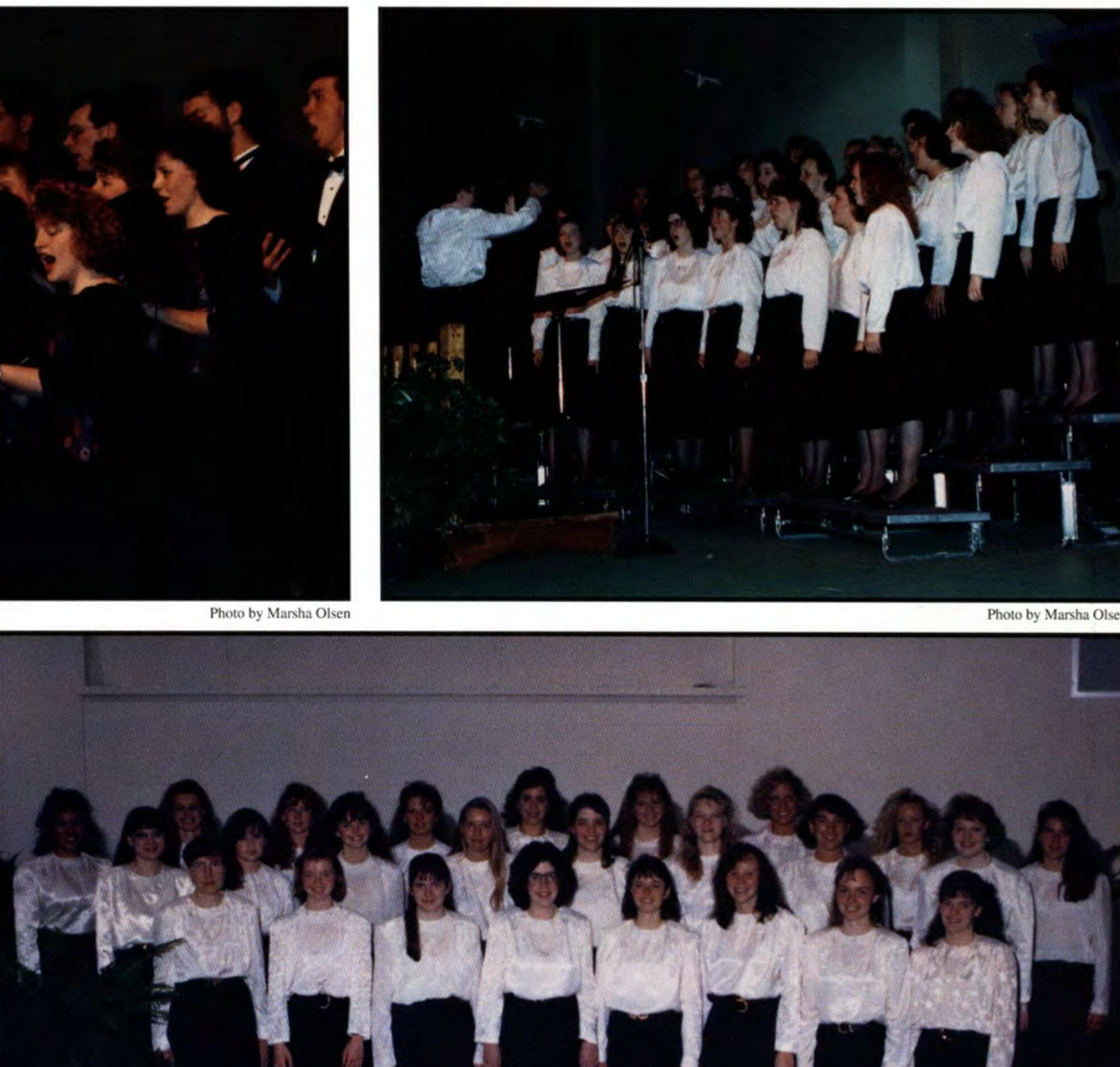

. 


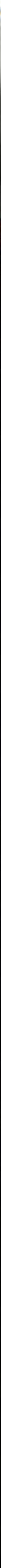




\section{CAST}

Penelope Sycamore ........... Sheryl Lombardo Essie Carmichael .................... Lori Lindner Rfreba ….............................. Tracy Quinn Paul Sycamore .......... Andrew M. Eastman Mr. De Pinna ........ Kenneth M. MacLeod Ed Carmichael ...... Nathan Charles Dobert Donald ............................... Greg Riddle Martin Vanderfiof ............ Bruce D. Quick Alice Sycamore ............... Chantelle Y. Sain Mr. Henderson ....................... Tim Sturgis Tony Kirby ...................... Aaron Newcomb Boris Kolenkov ............ D. Scott Ludington Miss Welfington ........... Susanne $\mathcal{N}$. Mustice Mr. Kirby ....................... Gary L. Childers Mrs. Kirby ……................. Shelly D. Sutton FBI Agents ............ Timothiy Jofin Cowley Rory Patterson Grand Duchess Olga Katrina ...tin. Read Rayetta Dunfiam Student Director ............... Sonja Van Wert

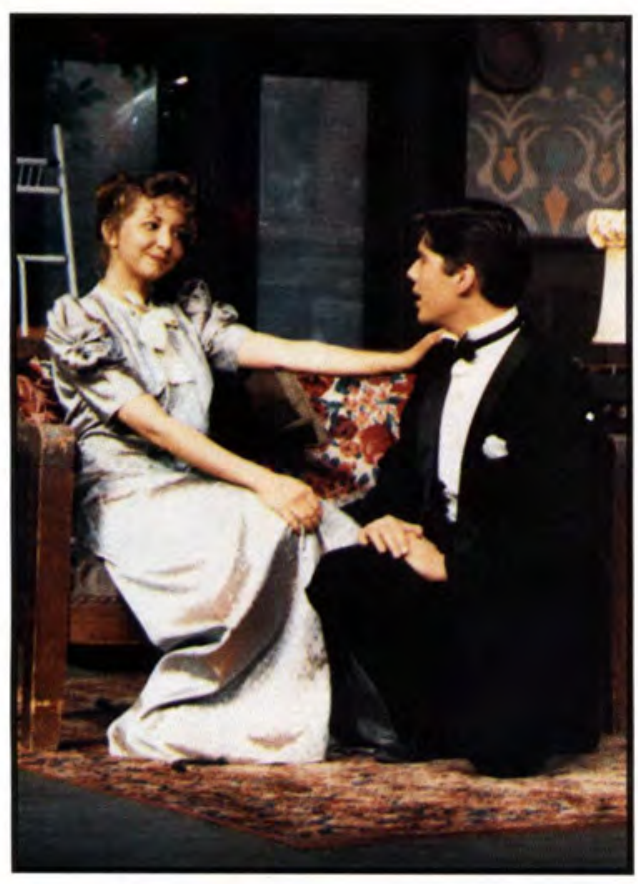

"First you thank the young man for getting engaged to you." (Chantelle Sain, Aaron Newcomb)

(Middle Left) '... and I've been a happy man ever since. " (Bruce Quick)

(Middle Right) 'I invited fim to dinner and he just

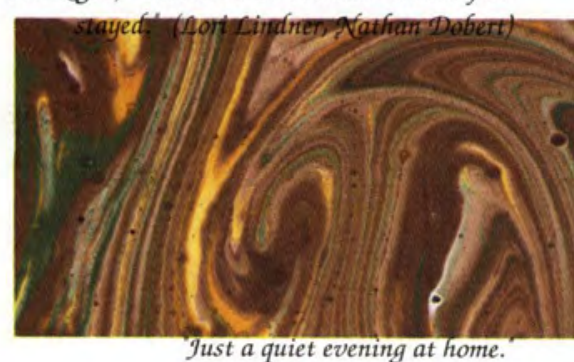
Tust a quiet evening at home.

120 Fine Arts

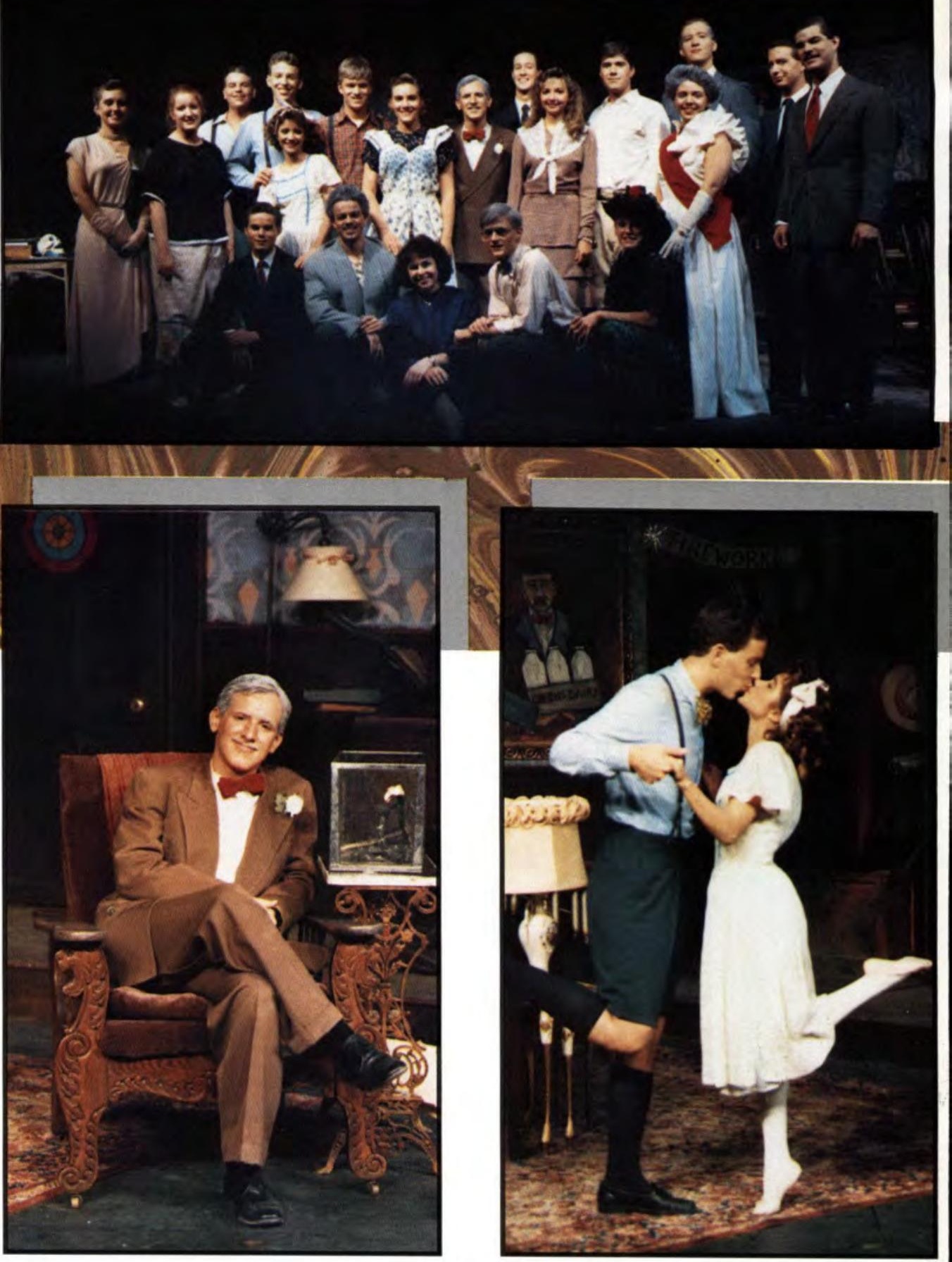




\section{WORTH ${ }^{\text {What st }} \mathcal{T}$

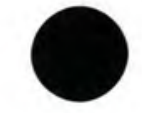

If "You Can't Take It With You"

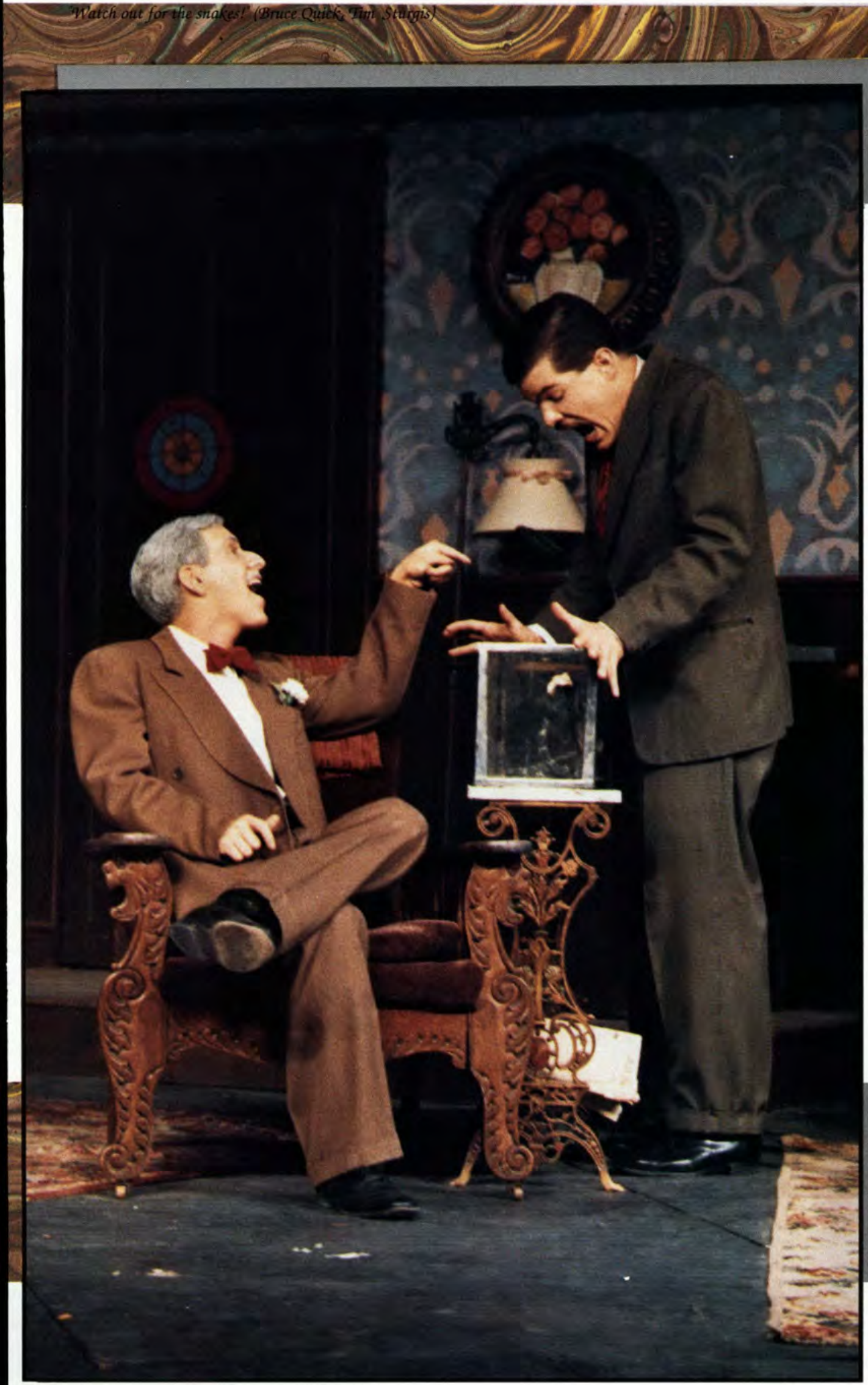

wer. Wealth. Prestige. To the world these are important priorities in life. But are these the only important things? In a humorous and drastic manner, the Village Players showed that, yes, there is more to life than work. The play "You Can't Take It With You" was set in the nineteen thirties during the Great Depression when humor was a lacking necessity. Through the flaky lives and happenings of the Sycamore family, the Village Players demonstrated that to live life to the fullest is the only way to be truly happy and content. The theme of the play which was seen throughout was "enjoy life and what is pleasurable to you now because you can't take it with you when you die." The props were very authentic and effective; fireworks were used by Mr. Sycamore (Andrew Eastman) as a hobby (Yes, they did set off the smoke alarms one night). A live snake had a horrifying effect on Mrs. Kirby, played by Shelly Sutton, during the scene in which Mrs. Kirby and her husband (Gary Childers) came to meet the Sycamore family for the first time.

The cast was talented and superior, playing their parts to the utmost. Martin Vanderhof, at whose house the play takes place, kept the audience laughing with his quick wit and keen perspective on life. An example of his quick wit was his refusal to pay the IRS because he felt that he had better things to do with his money! Essie Carmichael (Lori Lindner), in her childlike way, presented an interesting thought with the line, "Life is beautiful if you just let it come to you." Even Penelope Sycamore (played by Sheryl Lombardo) by her airy manuerisms and tove for people made one stop and laugh and think about what reatly is $\mathrm{m}$ 
"This will be the biggest production Cedarville has ever seen," Dr. Robey's prediction rang ominously in the ears of the cast. Some doubted. Some rejoiced. But all were convinced as three months of rigorous rehearsal, unprecedented ticket sales, and raving reviews proved those words to be true, and wonderful, old Alford became a "second home" to the largest cast and crew in Cedarville history.

"Fiddler on the Roof" was a truly unforgettable experience for the cast and all involved. It is a special privilege to "get inside" such a wonderful piece of musical literature and bring the theme, characters, and songs to life. Many in the cast and orchestra had grown up with the "Fiddler" and found special fulfillment in performing the familiar melodies of "If I Were a Rich Man," "Sunrise, Sunset," and "Matchmaker."

Fulfillment, however, is the result of hard work, and "Fiddler" presented many unique challenges. Director Dr. David Robey spent innumerable hours organizing and planning every major step and every minute detail, while Mrs. Rogers and the orchestra worked diligently to prepare the musical groundwork. Memorization of lines, lyrics, and dance steps consumed the cast's energy and time from the first rehearsal until "Fiddler Week," where the seven consecutive performances became a true "tour de force."

While the stage is bare and the music is silenced, the memories linger. Memories of a man and his people that endured the test of time. Memories of a cast and crew that shed sweat and tears together. Memories of a production that honored God and made its mark in this little "corner of the world."

-Matt Moore
Grandma Tzritel (Jerri Cook) sings, "a blessing on your head, to see your daughter wed. Mazeltove!"

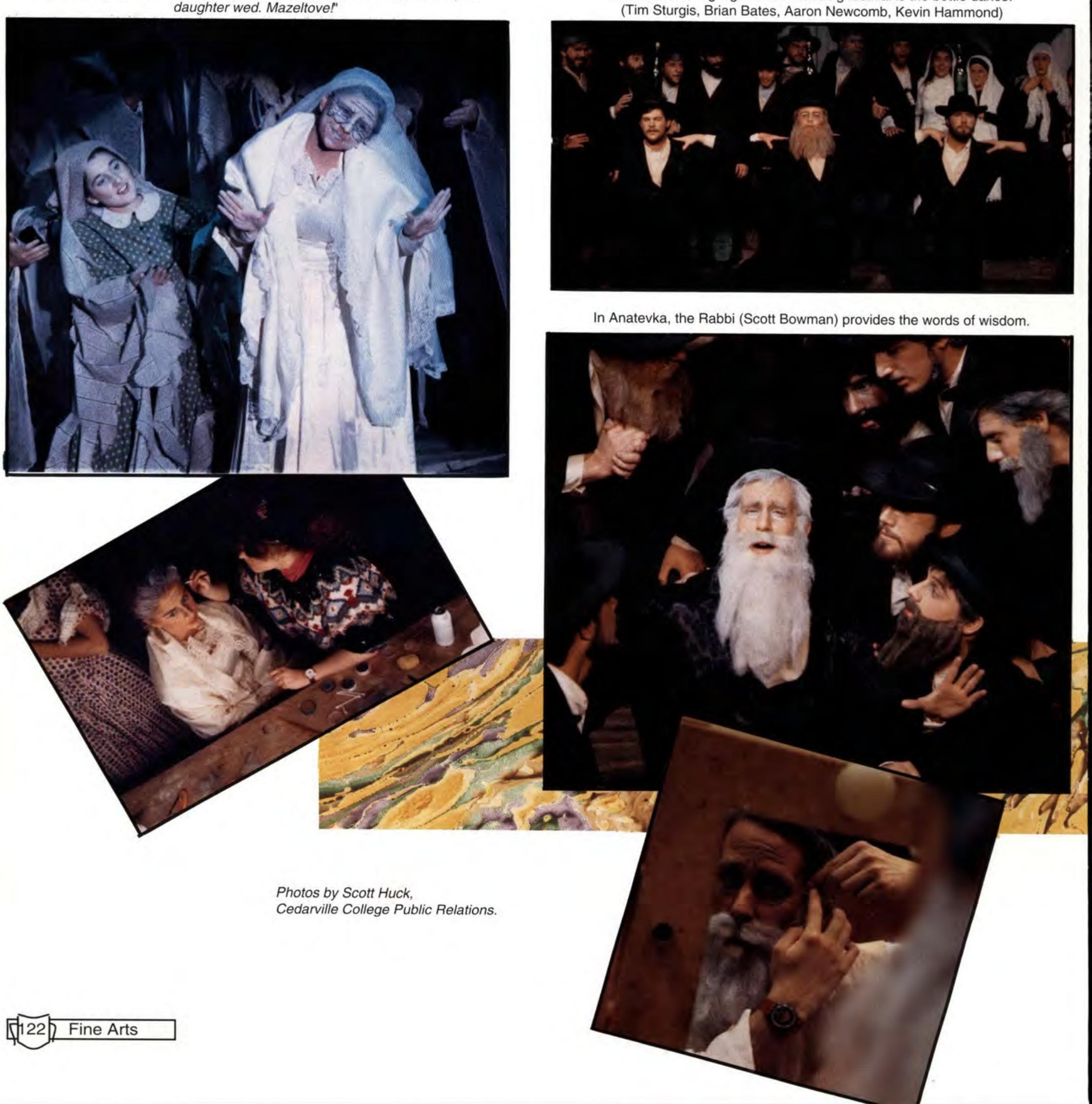

The dramatic highlight of the wedding festival is the bottle dance. (Tim Sturgis, Brian Bates, Aaron Newcomb, Kevin Hammond)

In Anatevka, the Rabbi (Scott Bowman) provides the words of wisdom. 
"... And the state champions for the third consecutive year, Cedarville College!" These words signalled the close of a highly successful year for the 1991-92 Cedarville College Forensics Team. Once again we were able to defend our title as state champion defeating prestigious institutions including Wittenburg University, Ohio University, Miami University and the Ohio State University

Forensics is intercollegiate speech competition. This competition consists of three main categories: limited preparation speaking, original oratory and oral interpretation. Each competitor is judged comparatively according to professionalism, creativity, mastery of the event and overall performance. Of the total nine events Cedarville's novice team took five state novice championships and Cedarville's varsity team took four overall state championships to emerge the clear victors.

For many colleges and universities success is measured merely in the numbers of trophies which are received. However, for a Cedarville competitor success cannot be assessed tangibly; rather it is evaluated in the intangible rewards which are gained through our competition. A few of these rewards are self-fulfillment, personal and professional development, the opportunity to encourage fellow team members and the ability to share our beliefs with competitors from other schools. Of course, I believe that it is meaningfully significant that we have been able to be successful tangibly as well. This success has given us even more openings to share with others about our reasons for competition and life.

- Jodi L. Culp
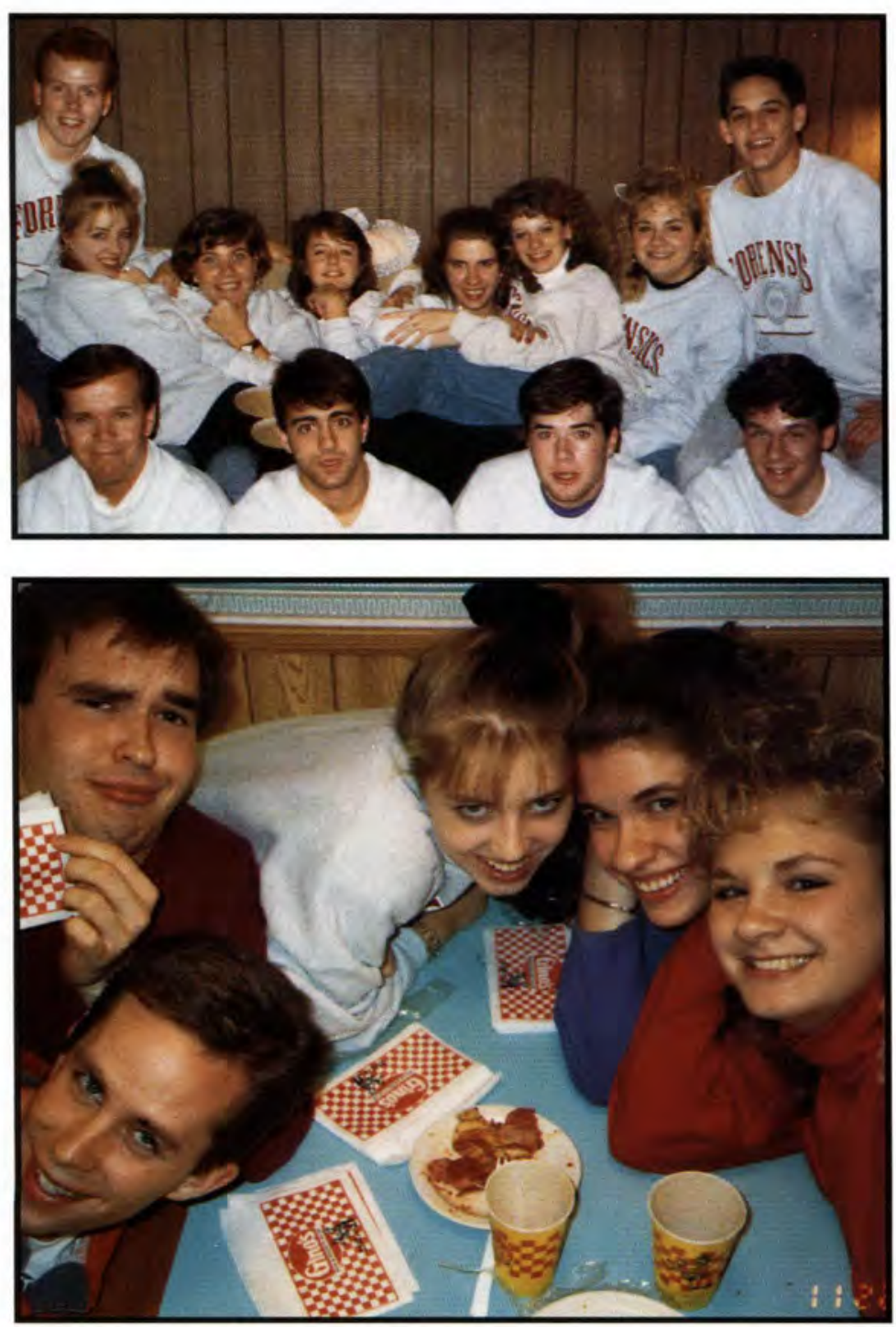

MAYBE THE BEST, most relaxing time of the whole competition weekend.

THE NOVICE FORENSICS TEAM relaxes after a weekend tournament in Michigan. (Top Photo)
FORENSICS AND FELLOWSHIP.... The Forensics team celebrates friendship at the annual Forensic's Christmas party at the Robey home.
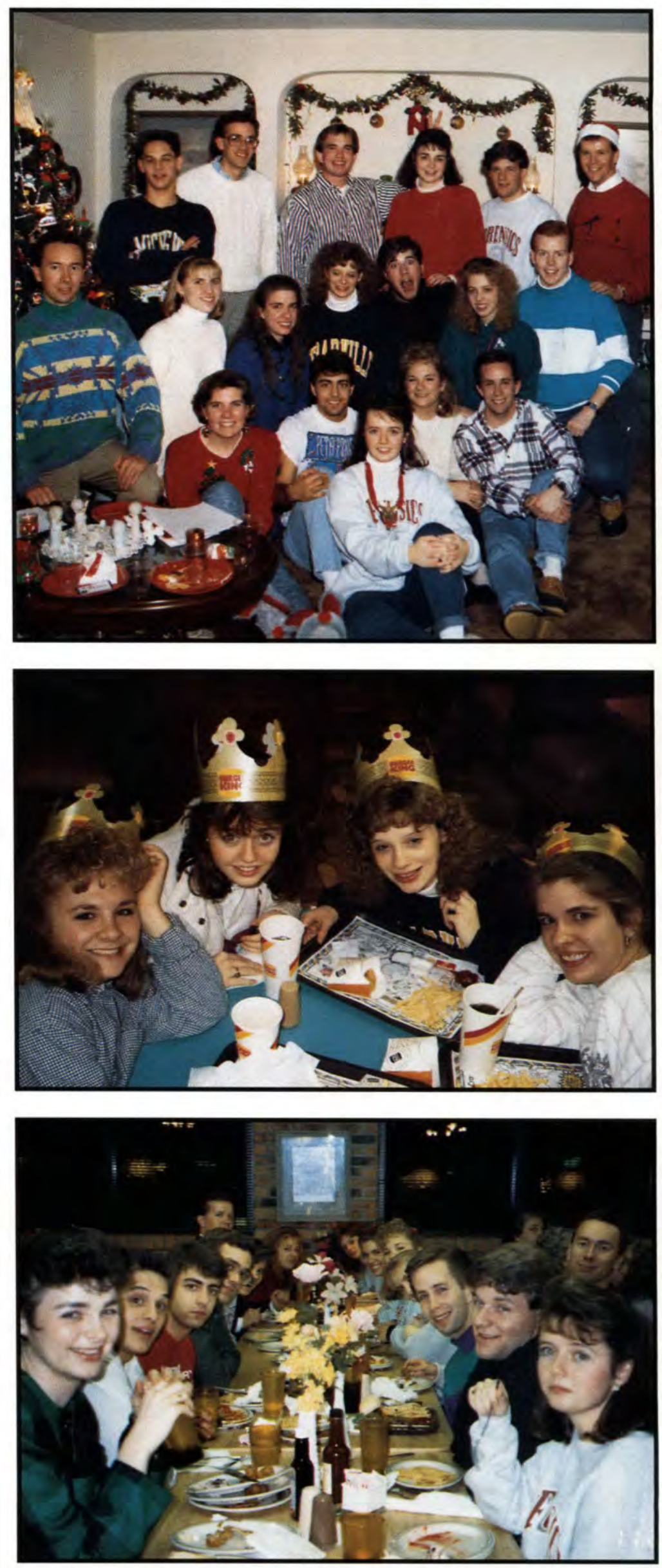

FULL STOMACHS, SHARP MINDS...The Forensics team eats out during a competition trip.

DINING OUT...Competing in a speech tournament can work up a royal appetite. (Center Photo) 


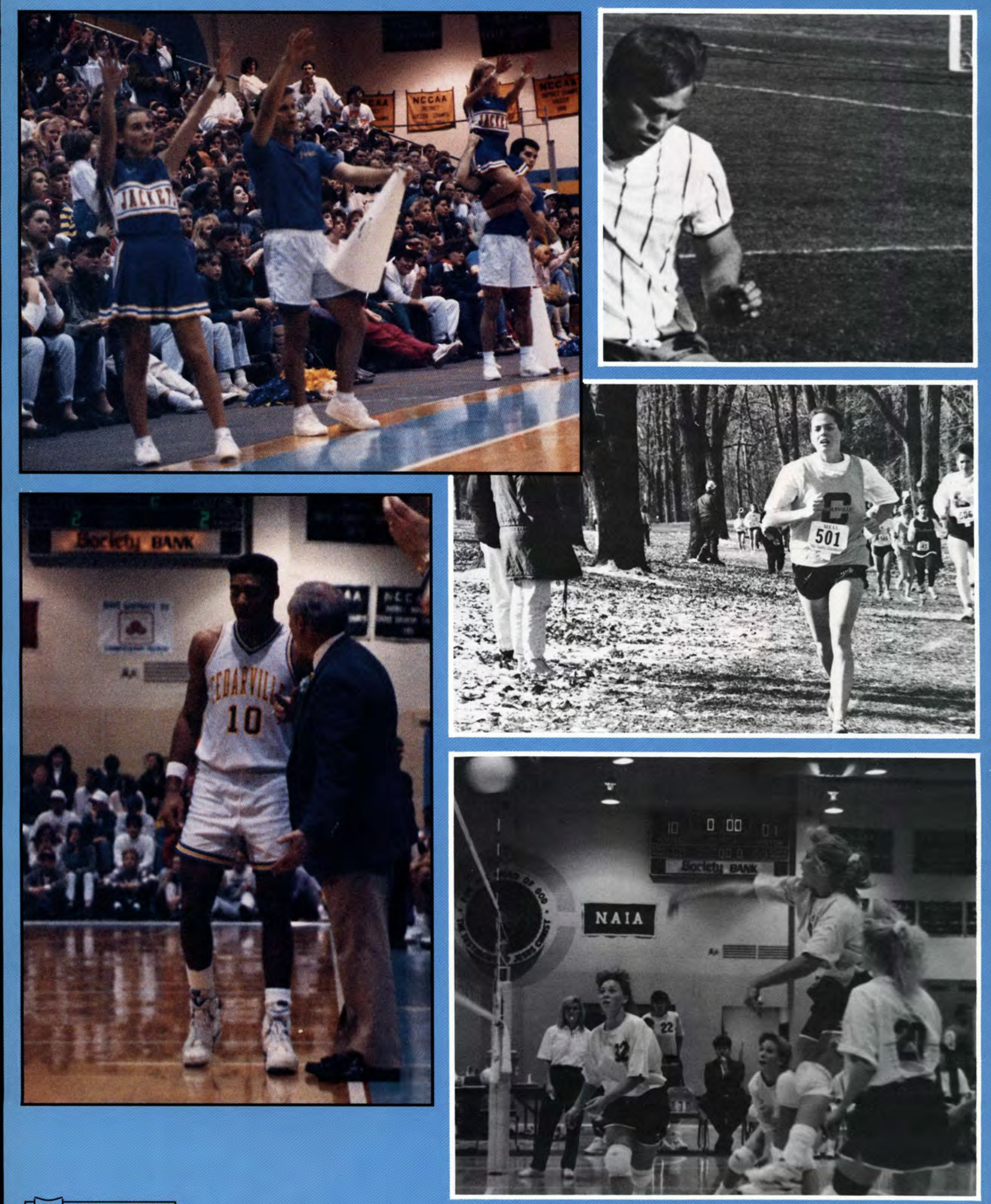

$\sqrt [ 4 ] { 1 2 6 } \longdiv { \text { Sports } }$ 


\section{A Testimany Admidst Triumph}

\section{ABLE OZ CONTENTS:}

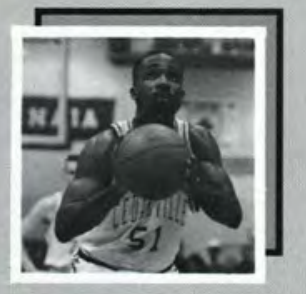

MENS

BASKE7B,ALL

Page 128

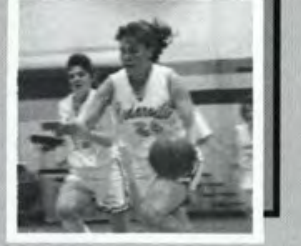

wOMEN'S

BASKE7BALL

Page 130

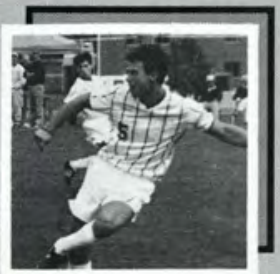

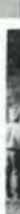
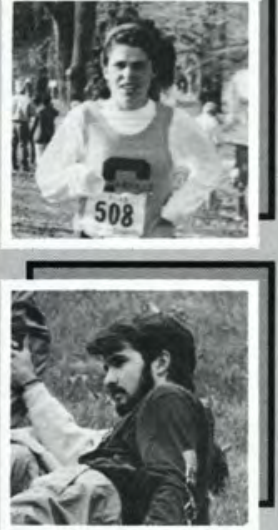

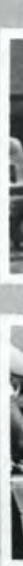

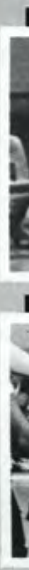

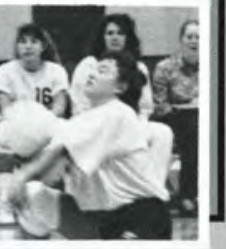

SOCCER

Page 132

CROSS-COUNTRY $784 M 57075$

Page 134

CROSS-COUNTRY

eAnOTOS

Page 136

VOLLEYBALL

Page 138

SPIRT7

Page 140

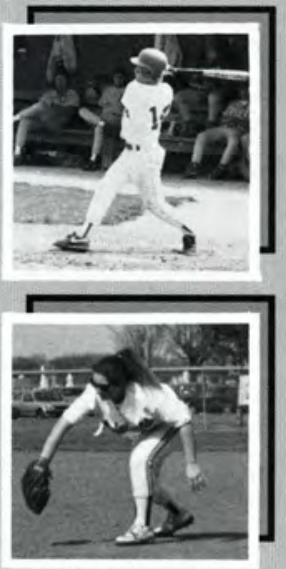

B,4SEBALL

Page 142

S0778,4LL

Page 144

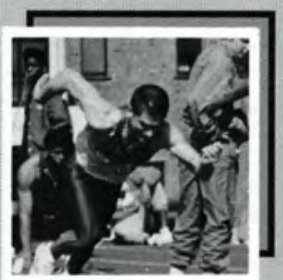

mens

7 RACK

Page 146

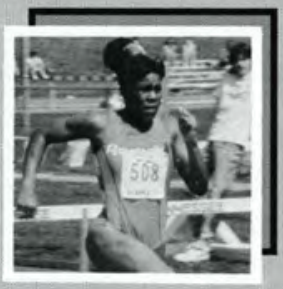

woMEN'S

TRACK

Page 148

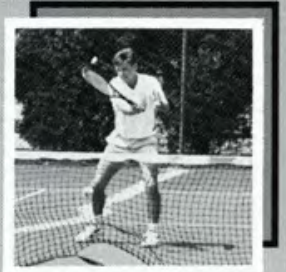

mens

7 Enท

Page 150

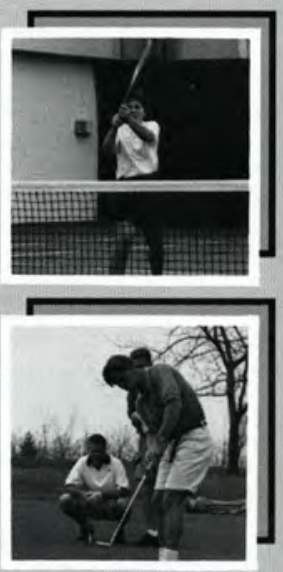

women's

7EnทีS

Page 152

9017

Page 154 


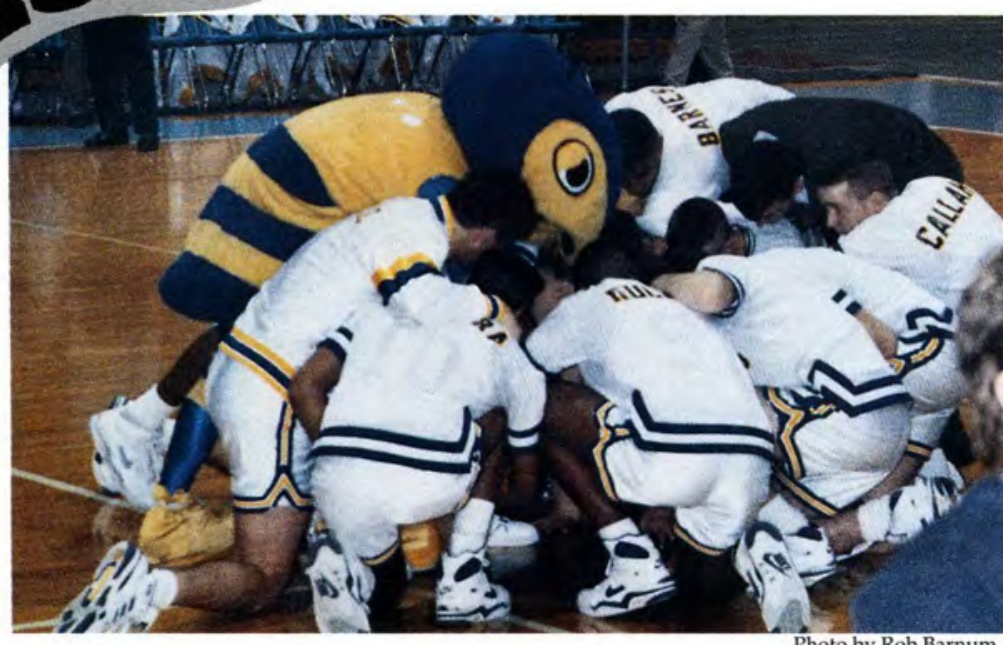

PAUSING FOR PRAYER... The team and "bee" begin the game the right way - on their knees.

KEEPING COOL... Head coach Don Callan focuses on

the play at hand.
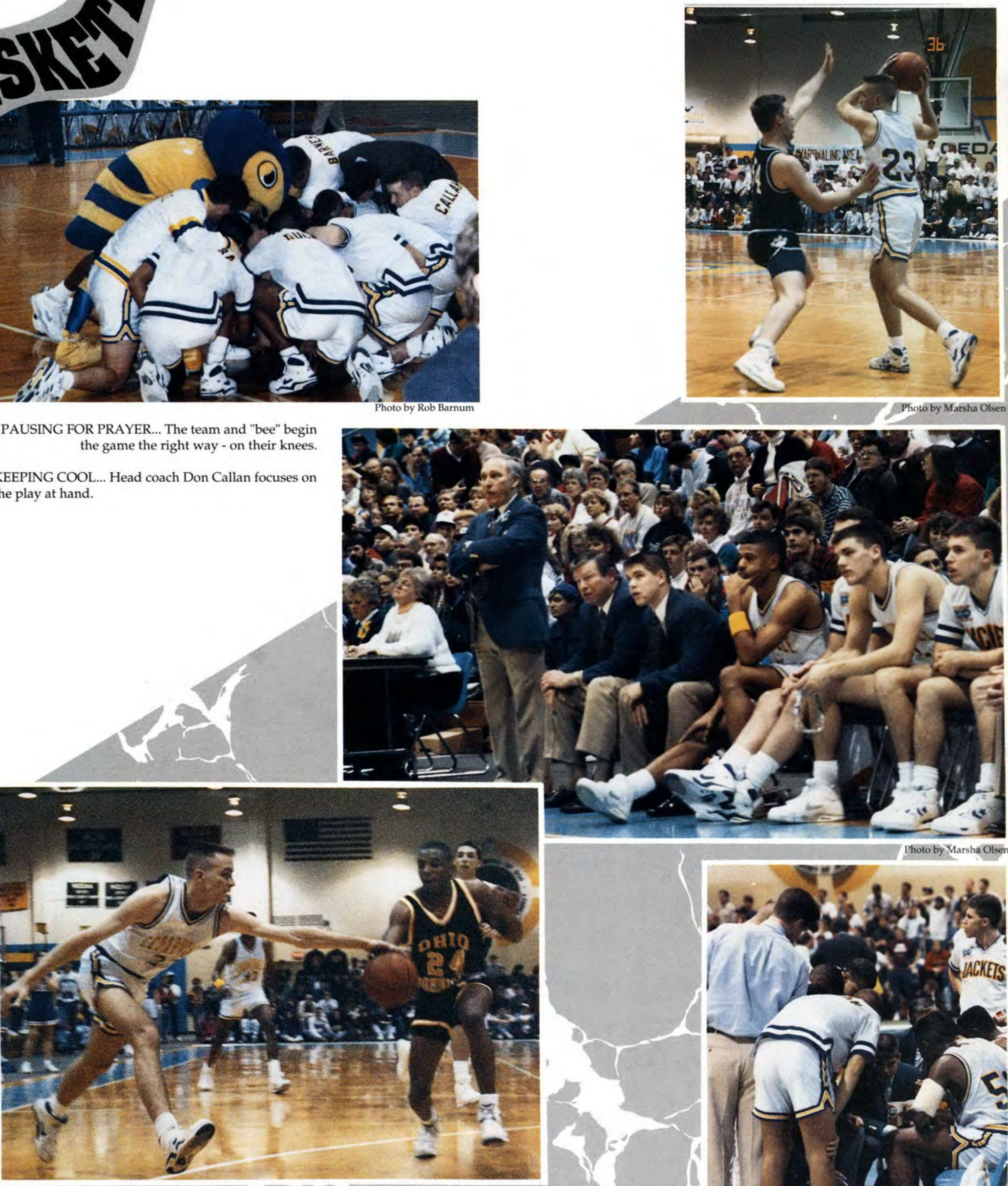
$b_{0}=2 y=9 x$
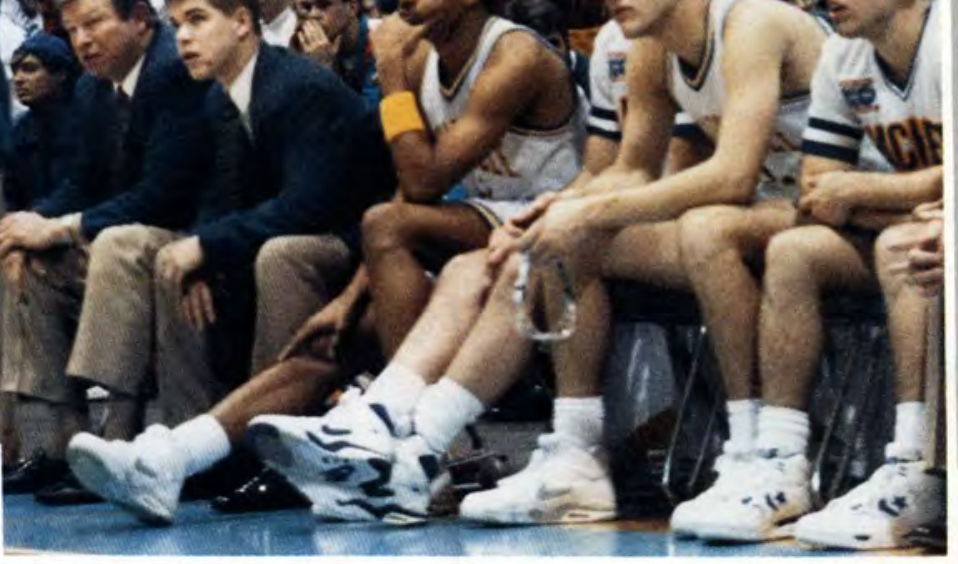

\section{STRETCHING WITH SKHLL... Jaden Callahan makes a perfect steal from an Ohio Domini-} The Jackets regroup for some timeout instruction. 


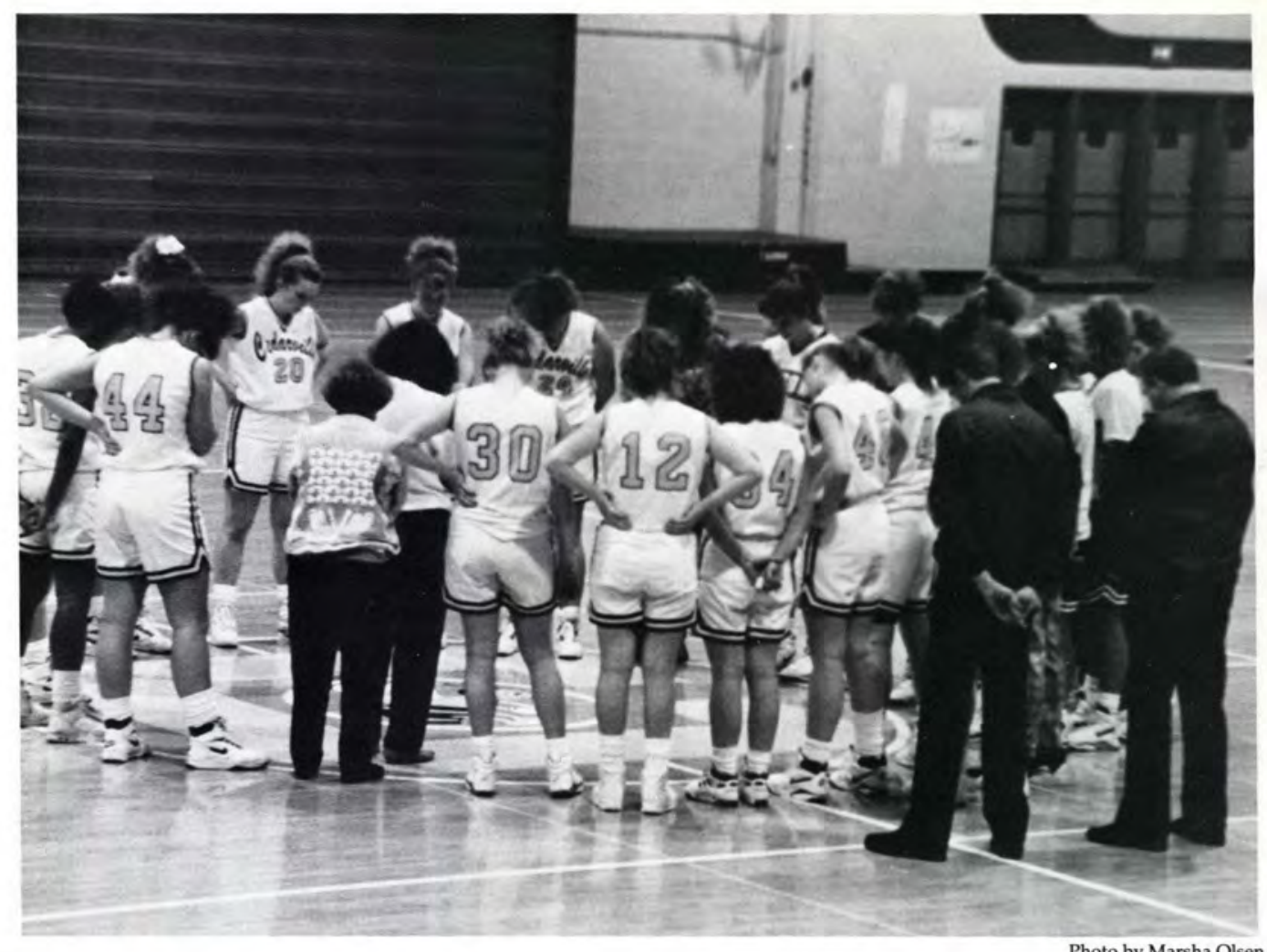

BEGINNING WITH POWER...The Lady Jackets know how to have a great game.

A GRIPPING GAME... The Lady Jackets concentrate on the game as they patiently wait to play.

Photo by Marsha Olsen

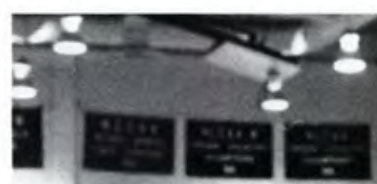

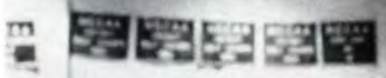
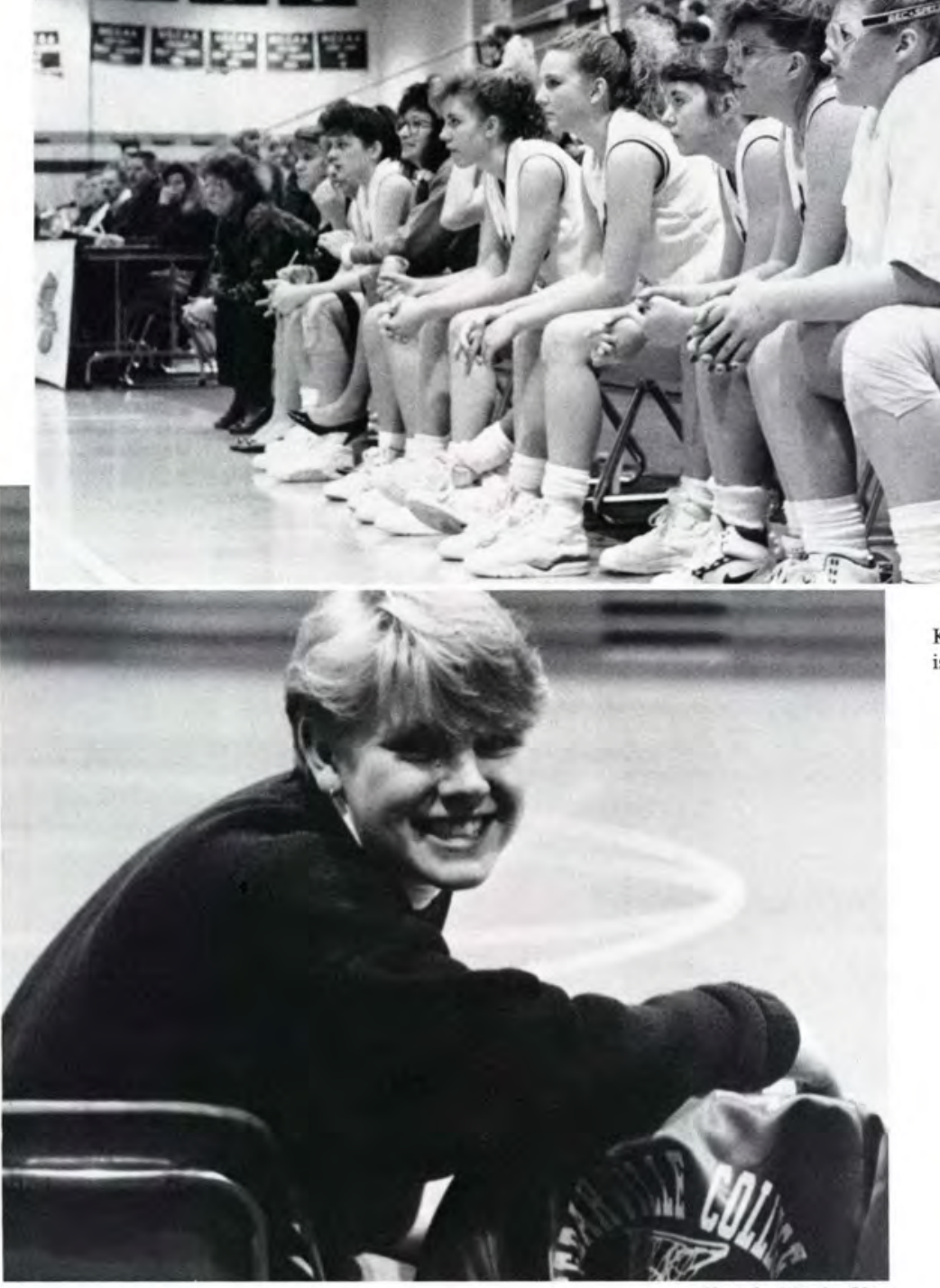

$\sqrt{1 3 0 \longdiv { \text { Sports } }}$

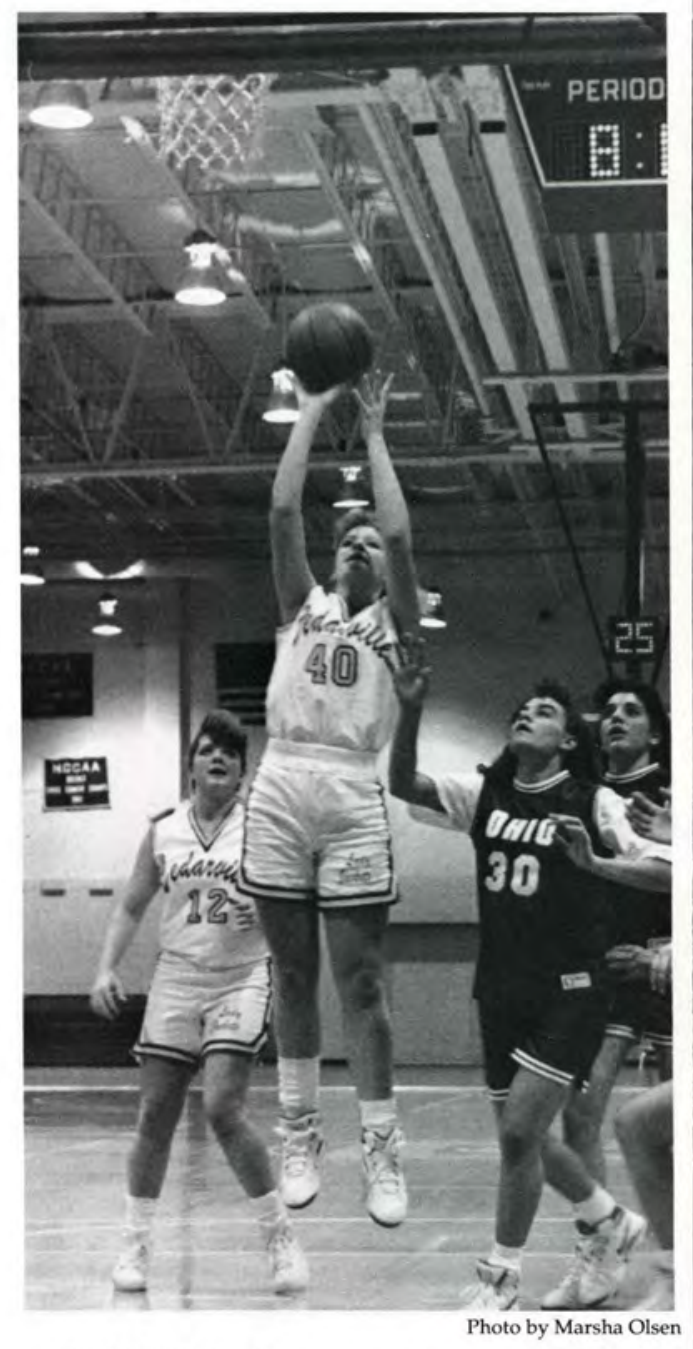

TEAMWORK... The name of the game as Rachel Howard plays back up for Amy Zehr's basket. 


\section{UNDER NEW LEADERSHIP... Lady Jackets Gain Experience}

IT'S A BIRD, IT'S A JORDAN... No, it's Shaundra Randolph scoring for the Lady Jackets.
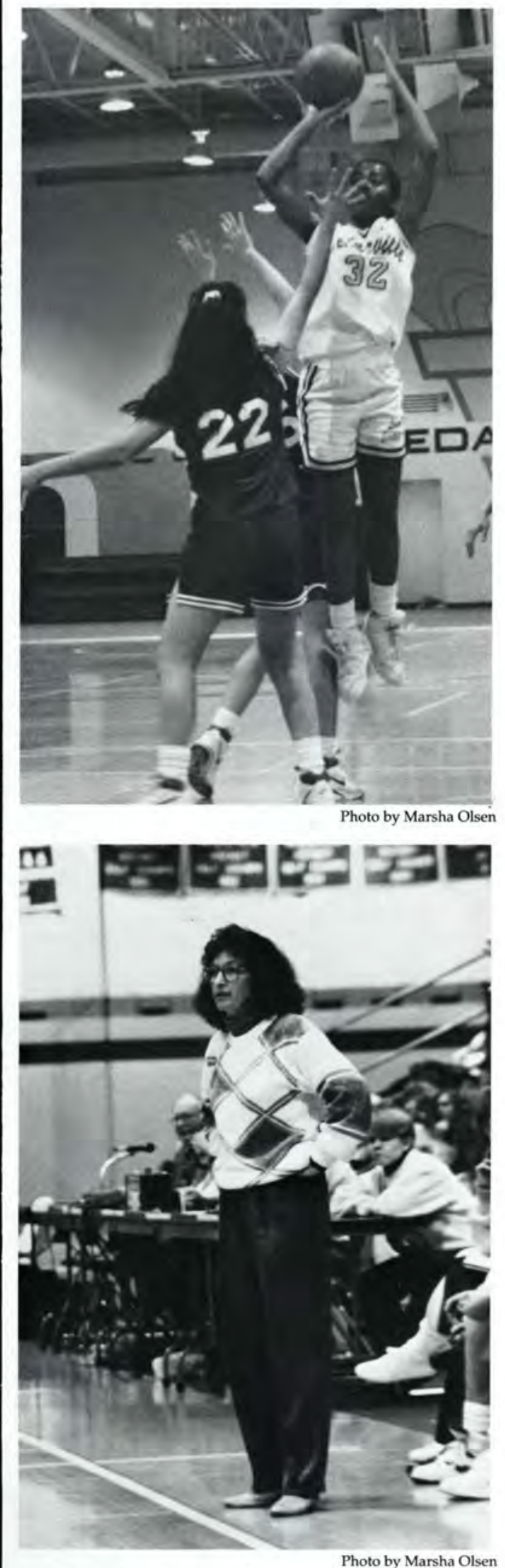

BEHIND THE LINE... Head coach, Kathy Freese keeps a close eye on the performance of her Lady Jackets.
Cedarville finished the women's basketball season at 15-15 for only their second .500 record in the past nine years. The accomplishment came under the leadership of firstyear head coach Kathy Freese.

The Lady Jackets qualified for both the NCCAA District III and NAIA District 22 Division II playoffs. In the NCCAA event, Cedarville opened with a 72-65 win at Oakland City, Indiana before losing to eventual national champion Huntington, Indiana.

In the NAIA playoffs, the Jackets began with a 71-68 win in overtime at Tiffin. They ended their season at Georgetown, Kentucky with an 83-52 loss.

Senior center Diane Rank led the team

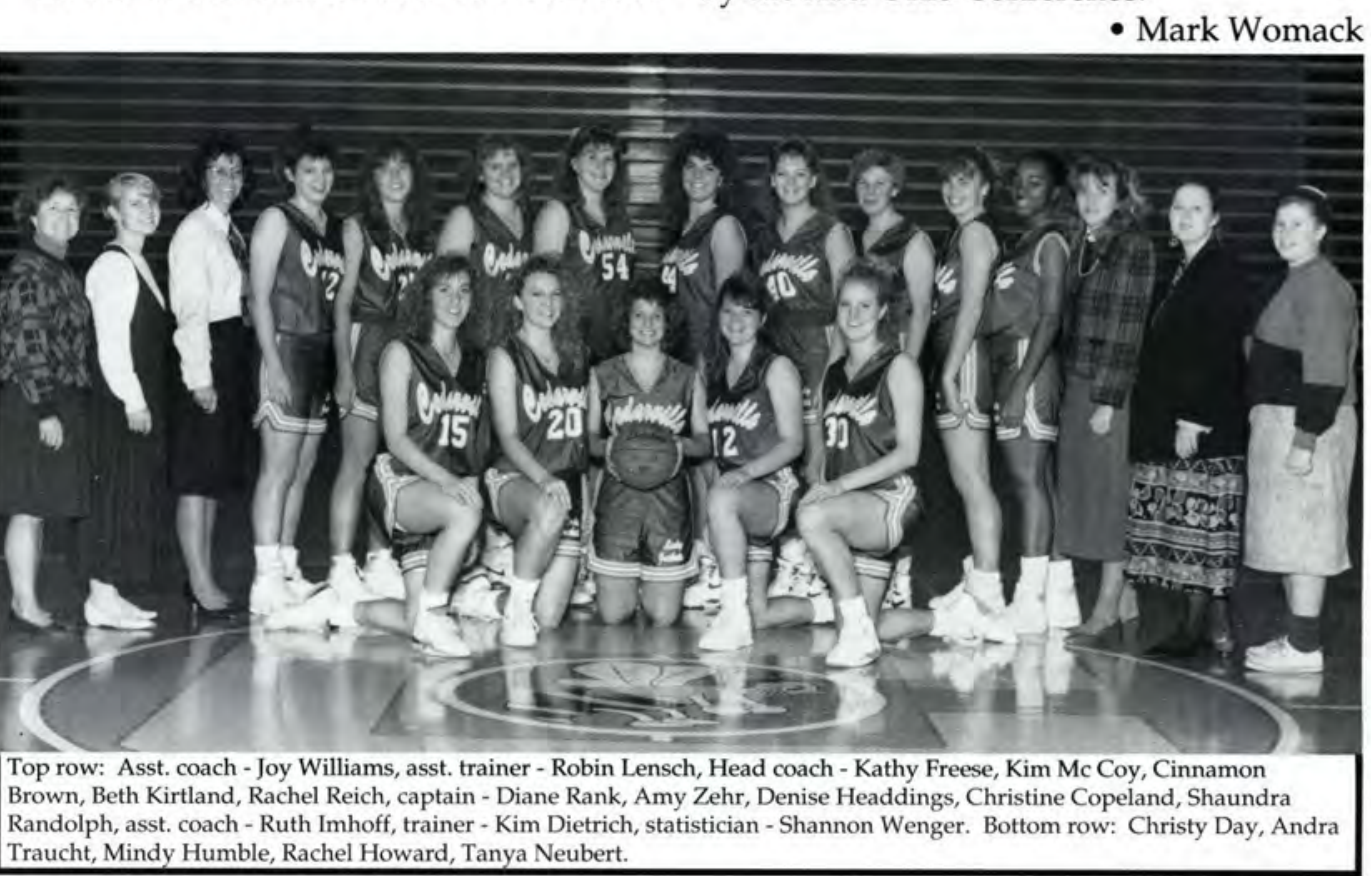
Traucht, Mindy Humble, Rachel Howard, Tanya Neubert. while wrapping up a memorable career. She averaged 18.7 points and 9.4 rebounds per game and was named to the NCCAA AllAmerica first team for the second straight time.

Rank was also selected to the post-season teams by NAIA District 22 Division II, NCCAA District III, and the Mid-Ohio Conference. She was a Scholar-Athlete in both the NAIA and NCCAA.

Junior forward Amy Zehr was named to the NCCAA All-America second team after averaging 15.8 points and 11.2 rebounds per game. She was also selected to the AllNCCAA District III team and was honored by the Mid-Ohio Conference.

- Mark Womack

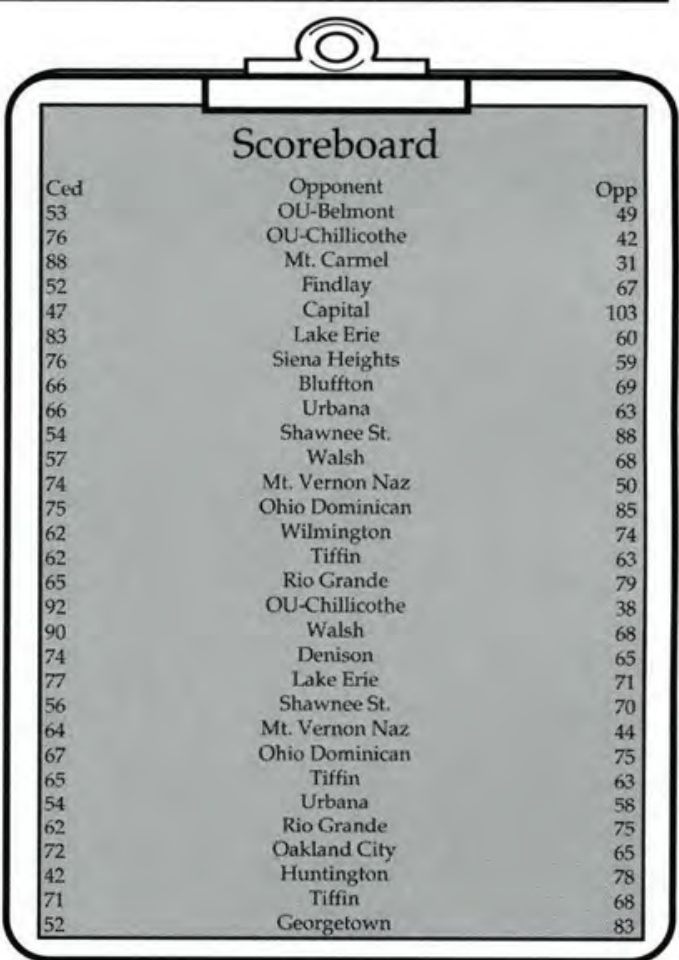



Continued from

9/28 Cedarville/entip Friendship

Invitational, Joh Park. The women won

the team cham and Krista Pritchard was the indir mpion. The men were second, E Tran under 28:00. "Kevin, $1 \quad 1 \rightarrow 2 .$, as the most fun race of my ii Detured and laughed while we ran." 10/11 All-Ohio Championship. The women finished 6 th out of 34 . The men were 14 th out of 36. "I also talked with John from CSU. He was hard to communicate with because of his thick Ugandan accent."

10/18 Cincinnati Invitational. The women won Then men were 3 rd out of 12 . "Chad and I cooled down with two Miami guys... we gave them tracts."

11/2 NAIA District 22 Championship. Findlay, $\mathrm{OH}$. The women were ranked between 12th and 14th in the nation all season; the men between 20th and 25th. Both wanted to earn a trip to nationals. On a bitter cold, windy, and snowy day we had our chance. The women ran hard and finished second. Unfortunately, they had to win to go. Krista Pritchard and Mindy Schwaderer qualified in individuals. The men only had to finish 3rd, and we did!

11/9 National Christian College Championship. John Bryan Park. The women's goal was to win this final race of their season. They did, and in dominating fashion. Four women, Krista, Mindy, Sharie Bolender and Brenda Paulhamus all earned NCCAA All-American status. The men finished 4th, with Peter and Kevin both being named NCCAA All-Americans. "It was fun! I ran faster than I set my goal for this year. I was thrilled to receive All-American. Just to be there with all those 'Big guys' ...I don't feel like I belong with them."

11/16 The final race of the season. The men finished a respectable 22nd. Most importantly, however, was that both teams had opportunities throughout the season to use their tremendous athletic talent to share Christ's love.
PARTNERS IN CRIME... Kevin Conkel and Peter Casaletto continue working together through the race as they have through out the tough season.

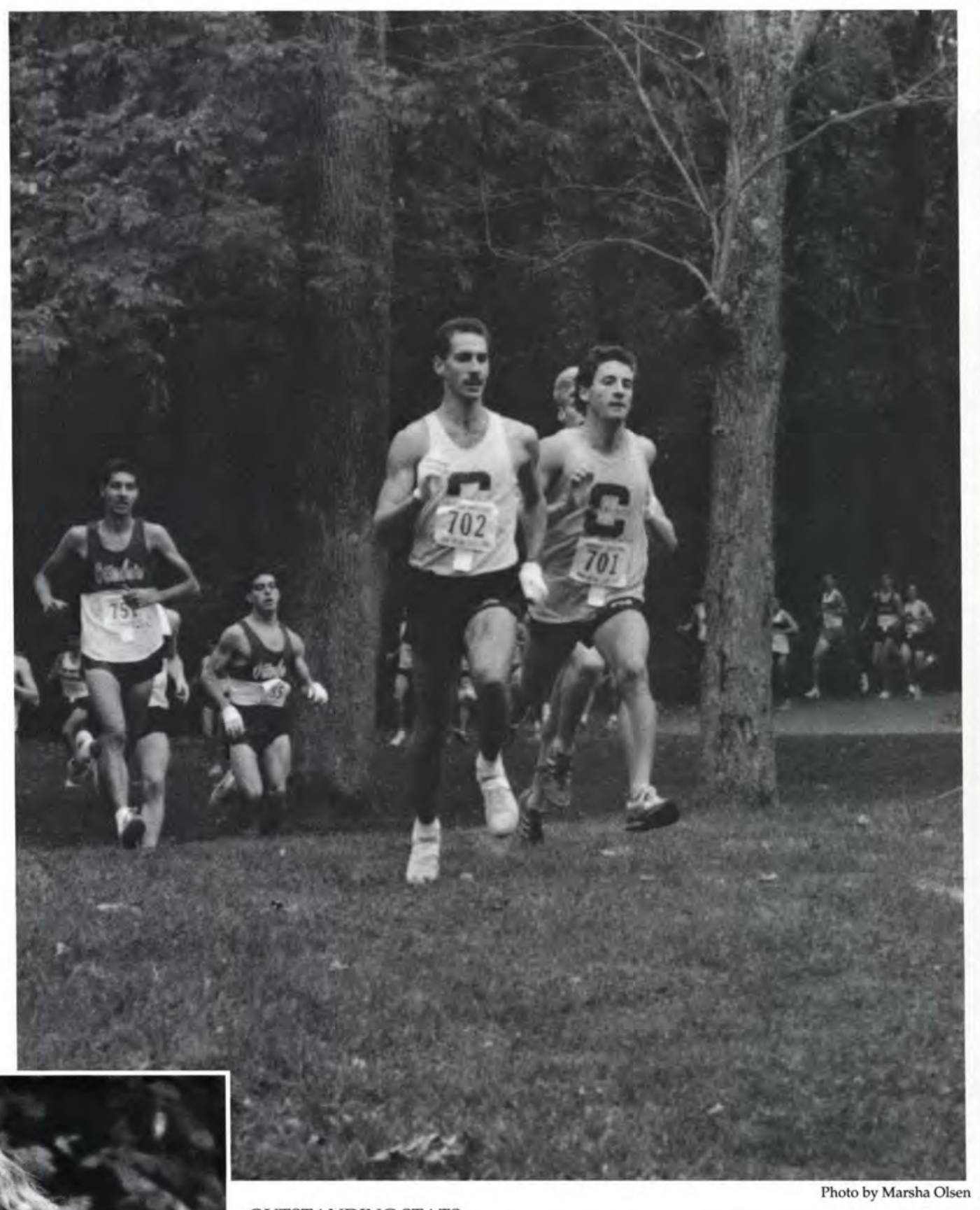

OUTSTANDING STATS.

Alan Mc Elroy and Brenda Woods smile at the list of the teams' successes.

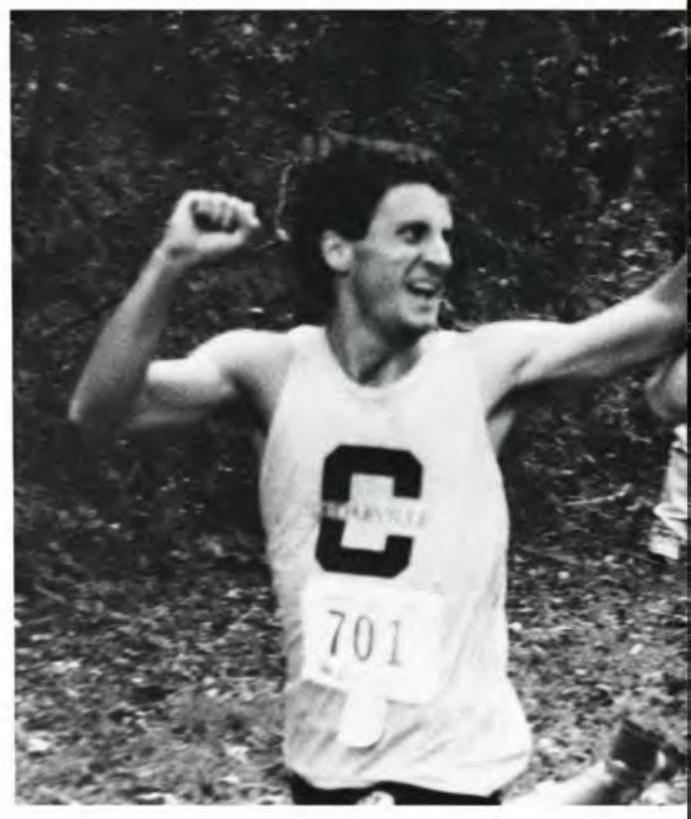


Working to hold her spot, Brenda Paulhamus strides into this rigorous leg of the race.

LEADING WITH PRIDE... Krista Pritchard pushes ahead to lead the pack.

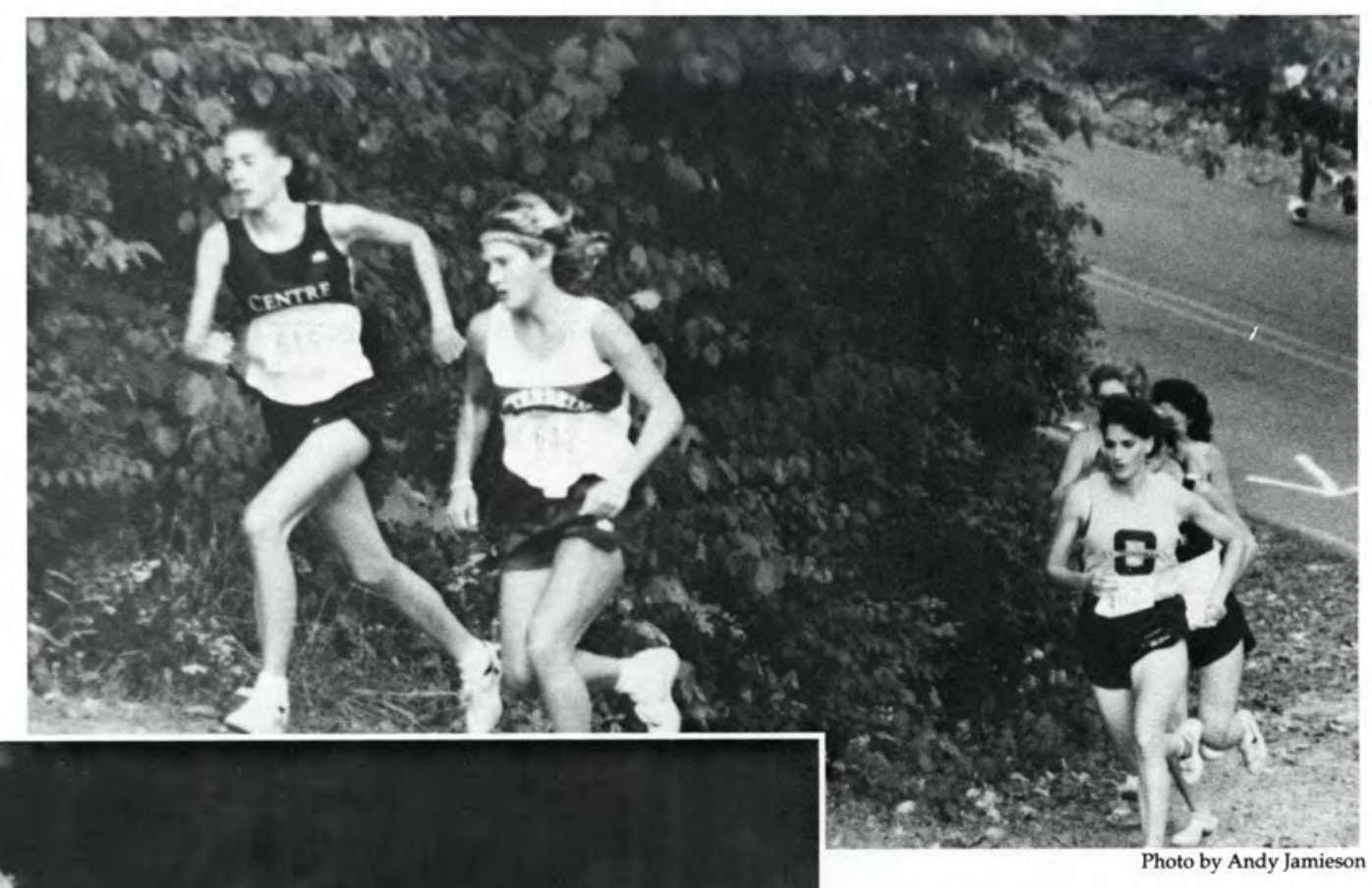

Photo by Andy Jamieson

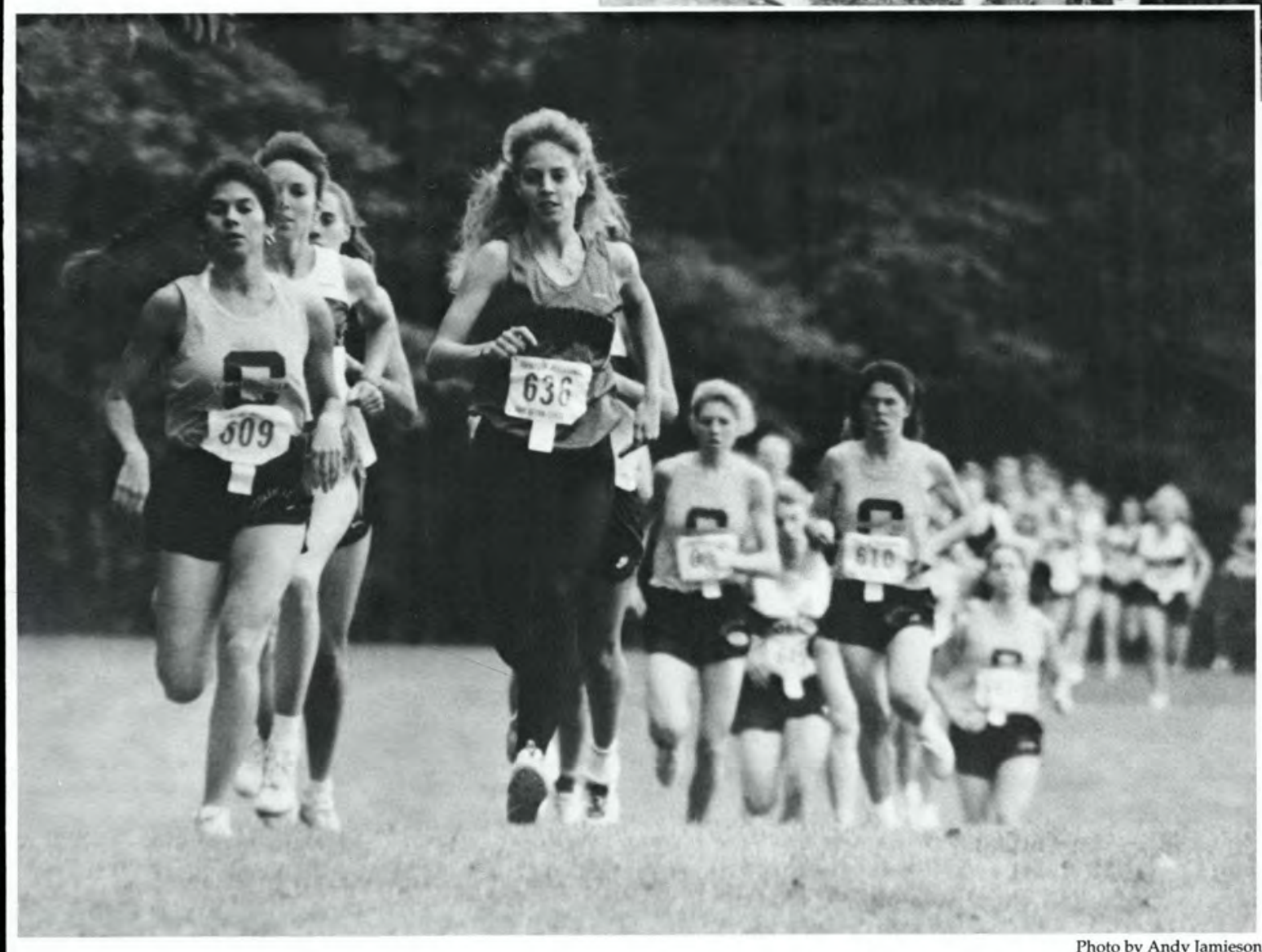

Photo by Andy Jamieson

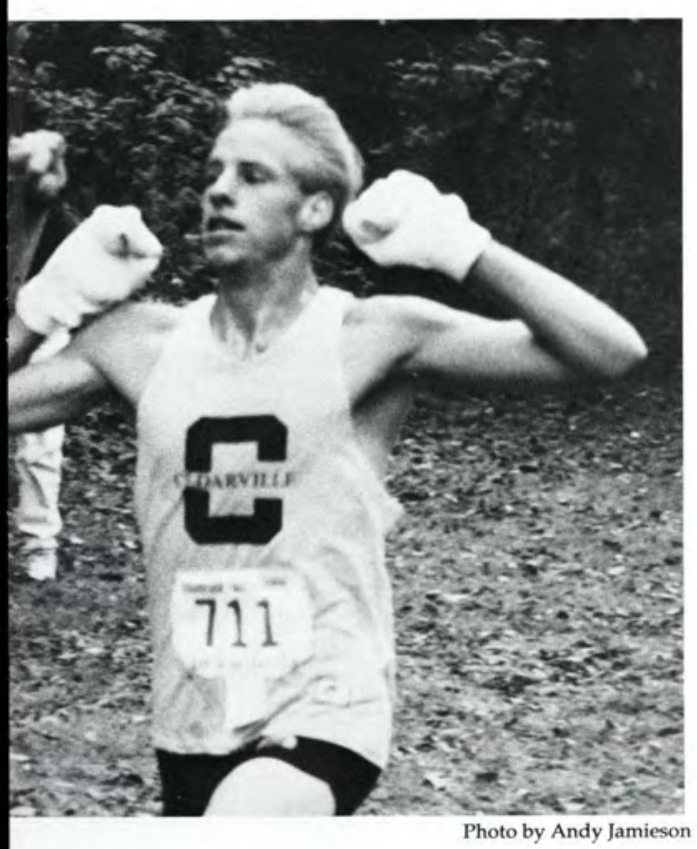

THE THRILL OF VICTORY... Peter Casaletto and

Pete Simons rejoice together as winning teammates. 


\section{A FINISH \\ WITH ZLAIR \\ Lady Yellow Jackets \\ Ignite A Winning \\ Season}

ning volleyball by finishing the 1991 season with a $26-22$ record. The lady Jackets also qualified for the NAIA District 22 playoffs.

Junior hitter Amy Zehr led the team as expected. She topped the club in kills (3.46 per game), digs (4.80), and blocks (0.87). Zehr, who holds numerous school records in just two years of play, was named to the All-NAIA District 22 and All-NCCAA District III teams, as well as the Cedarville Invitational All-Tournament team.

Zehr and teammate Lori Hamilton were voted to share Most Valuable Player honors on the team. Hamilton ranked second in the club in digs (4.16) and third in kills (2.38). She was selected to the All-NCCAA District III team and the Lake Erie Invitational All-Tournament team, and was tabbed honorable mention by NAIA District 22 .

Dee Hauser and Deb Henry joined Hamilton as the veterans on the squad and the team's only third-year players. Hauser was named the Jackets' best defensive player, and Henry was presented the Coach's Award from head coach Elaine Brown.

Other awards went to Elizabeth Miller (most valuable blocker), Julie Sharpe (most improved), Lynette Cruz (Scholar-Athlete and serve receive percentage). The Comeback Award went to both Cruz and Hamilton.

Sophomore setter Angie Hartman set school records for most assists (819) in one season, most attempts $(2,527)$, and highest per game assist average (7.00).

Cedarville played as an independent in 1991. The Lady Jackets will begin play in the Mid-Ohio Conference next season

2 - Mark Womack

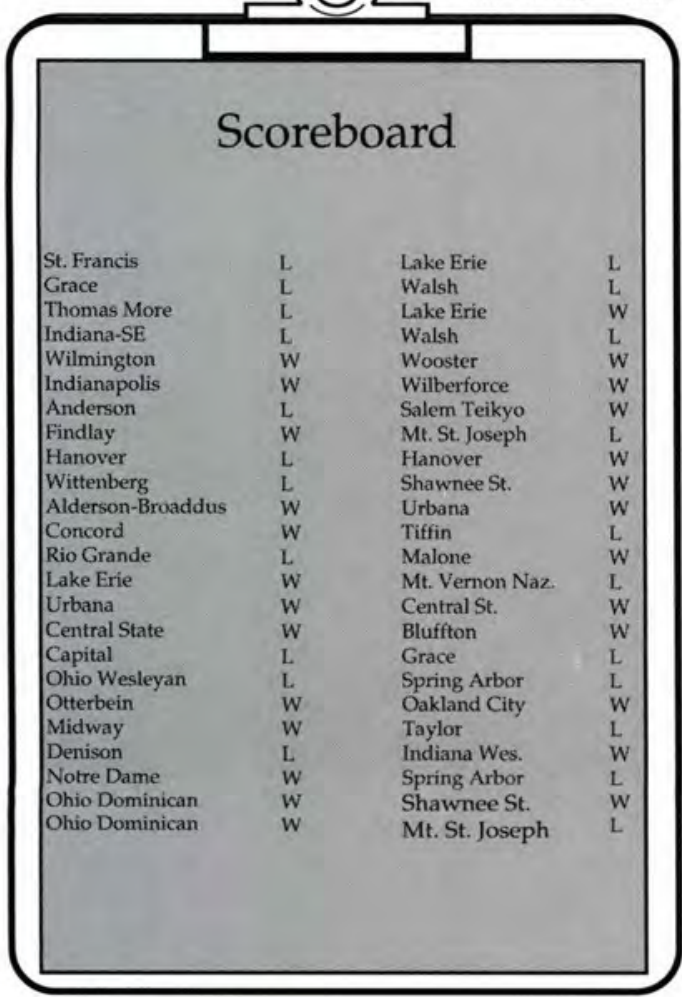

$1 3 8 \longdiv { \text { Sports } }$
GETTING IT GOING...Dee Hauser begins the game with a skilled serve.

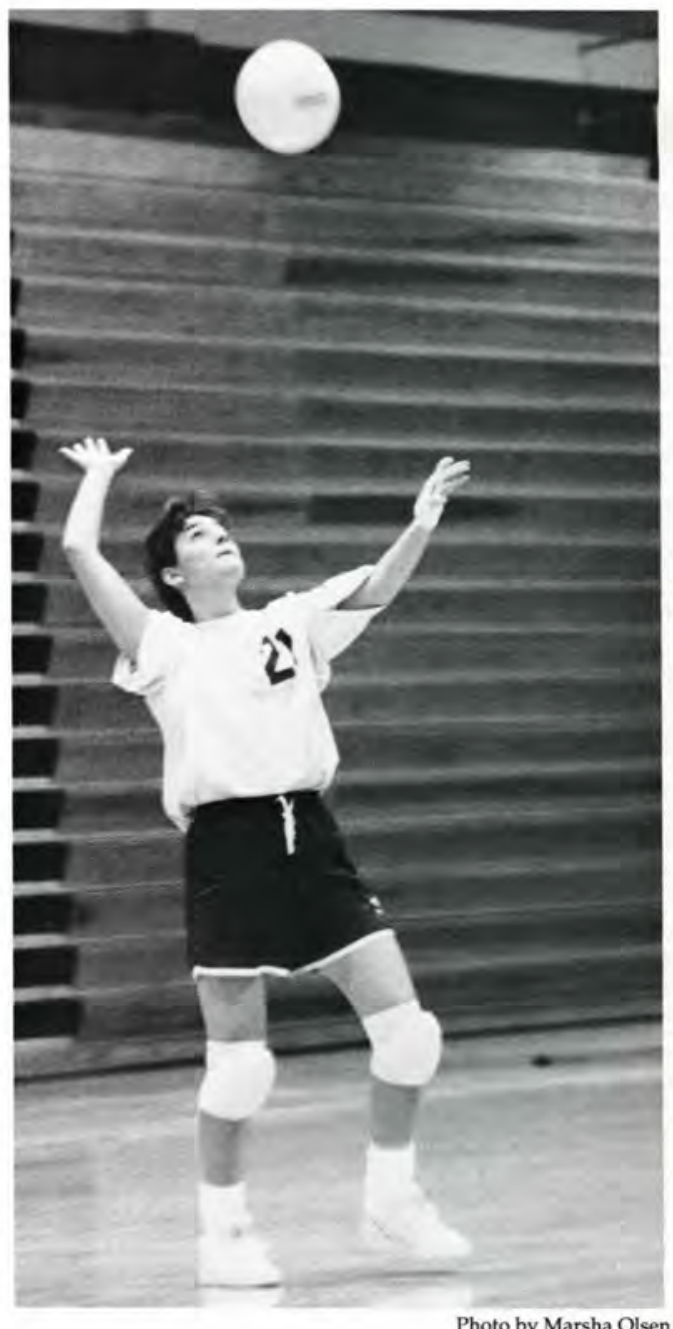

Photo by Marsha Olsen
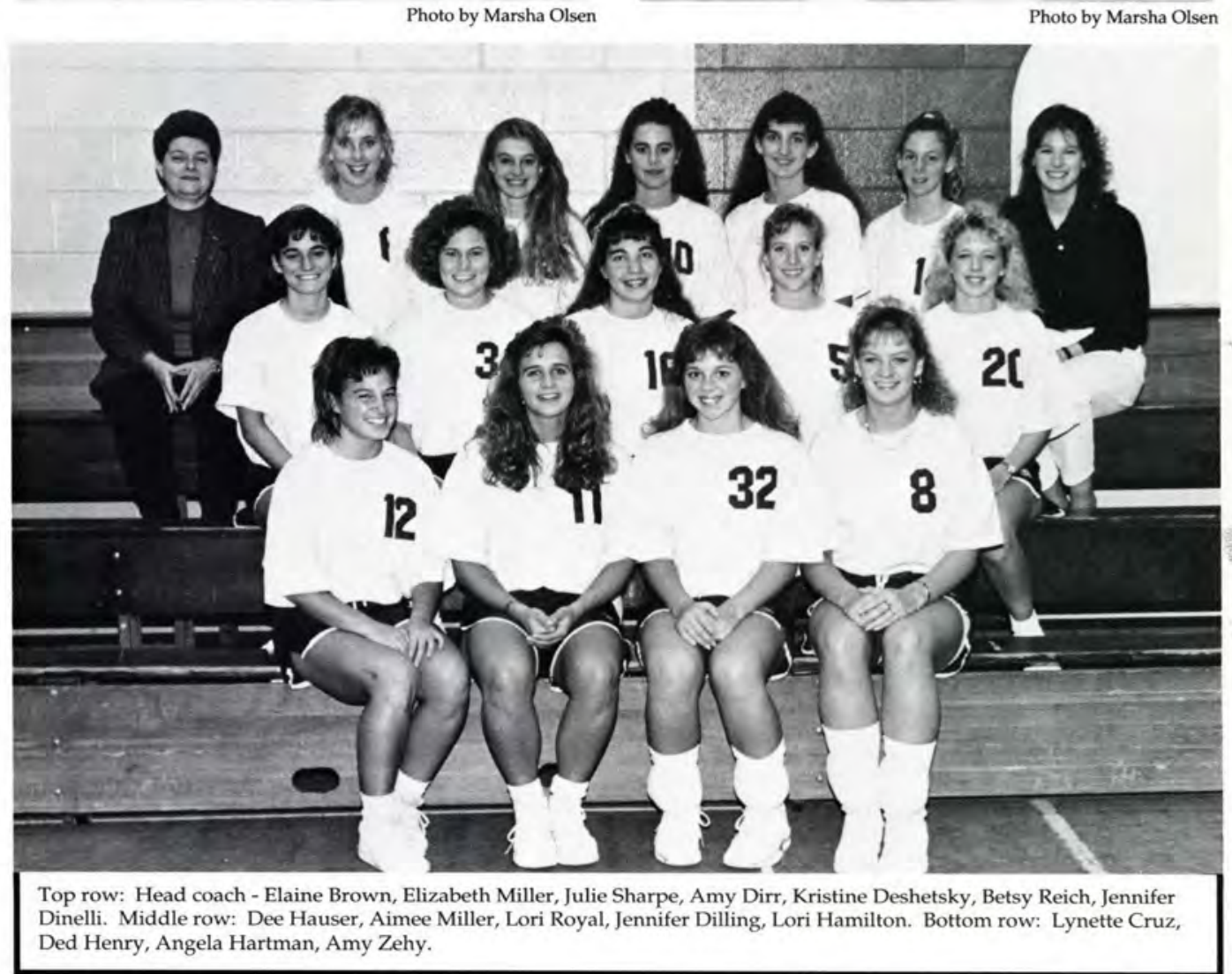


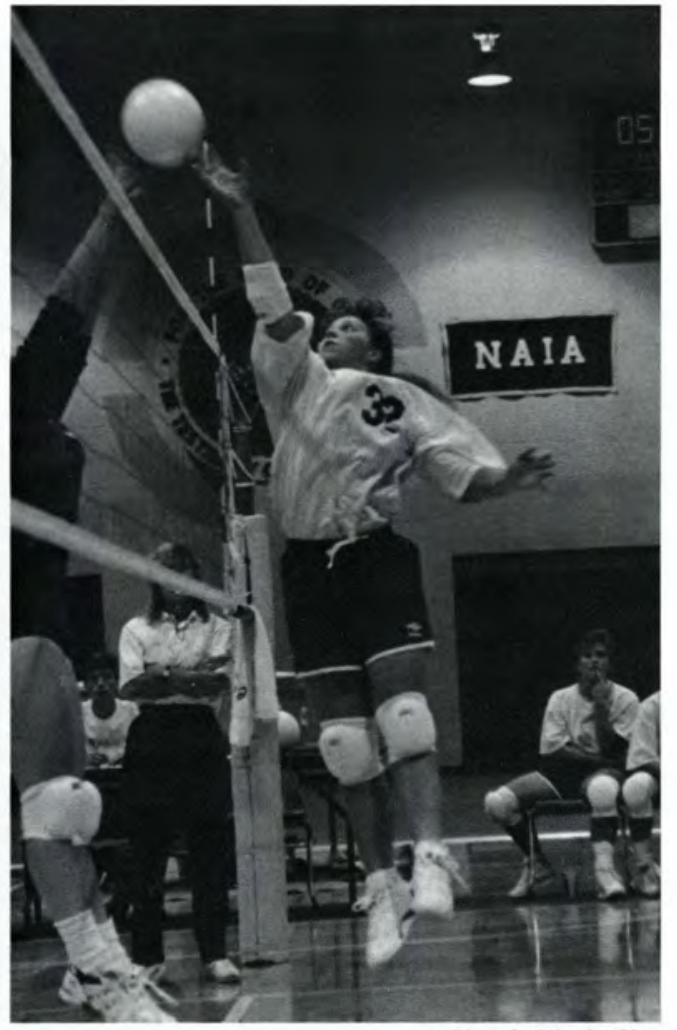

Angie Hartman jumps for the ball with a look of determination.

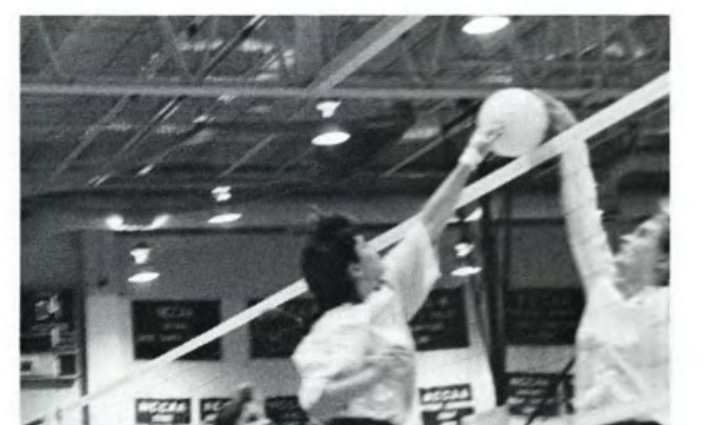

Photo by Marsha Olsen
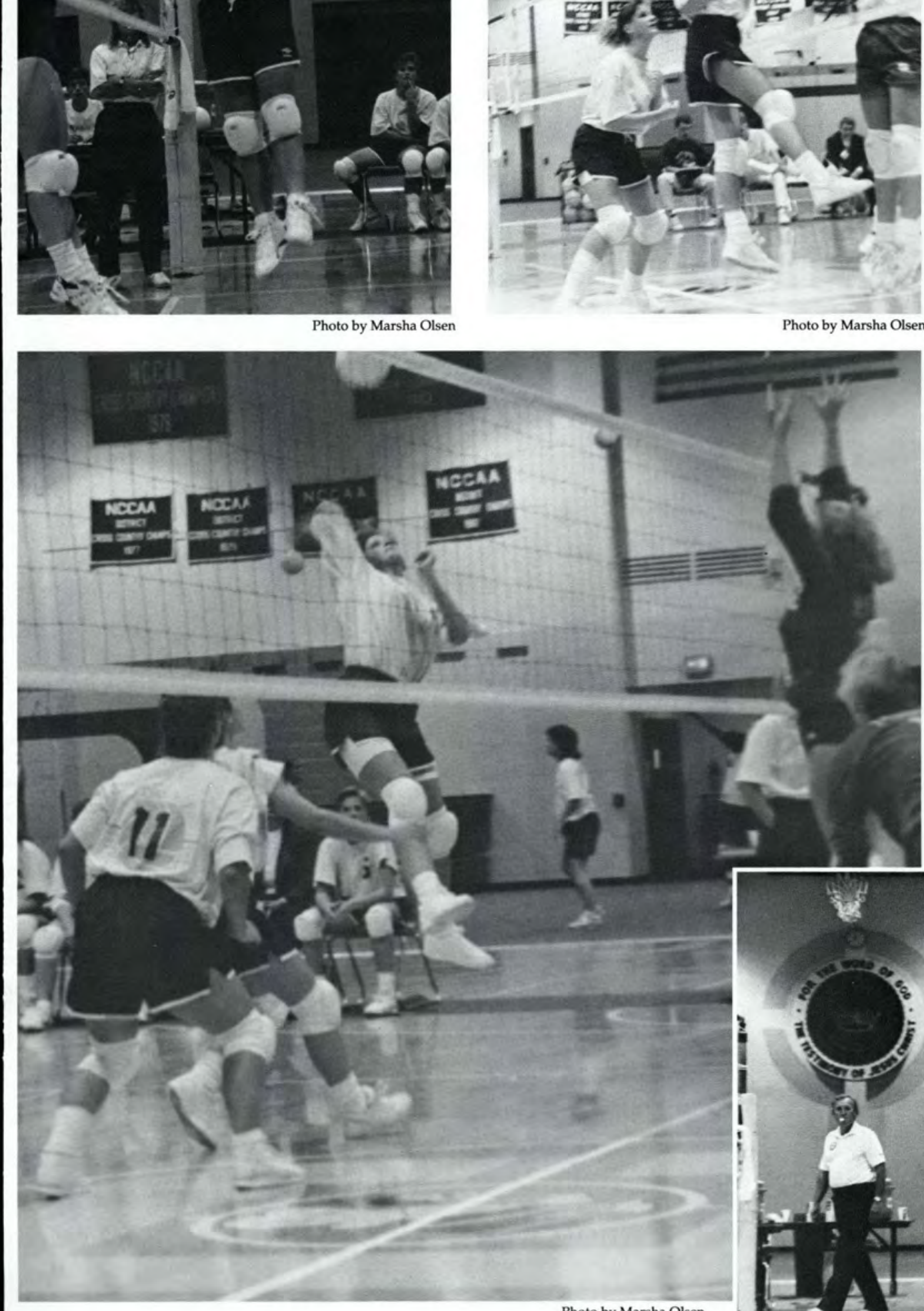

WITH FLAIR AND FINESSE... this Lady Jacket goes for a spike.

With focused concentration, Angie Hartman sets up for a score.
Photo by Marsha Olsen

WITH SKILL AND ACCURACY... Lynette Cruz smoothily works the ball over the net.

YOU CAN DO IT!... Lori Hamilton stretches to reach the ball as teammates provide support.

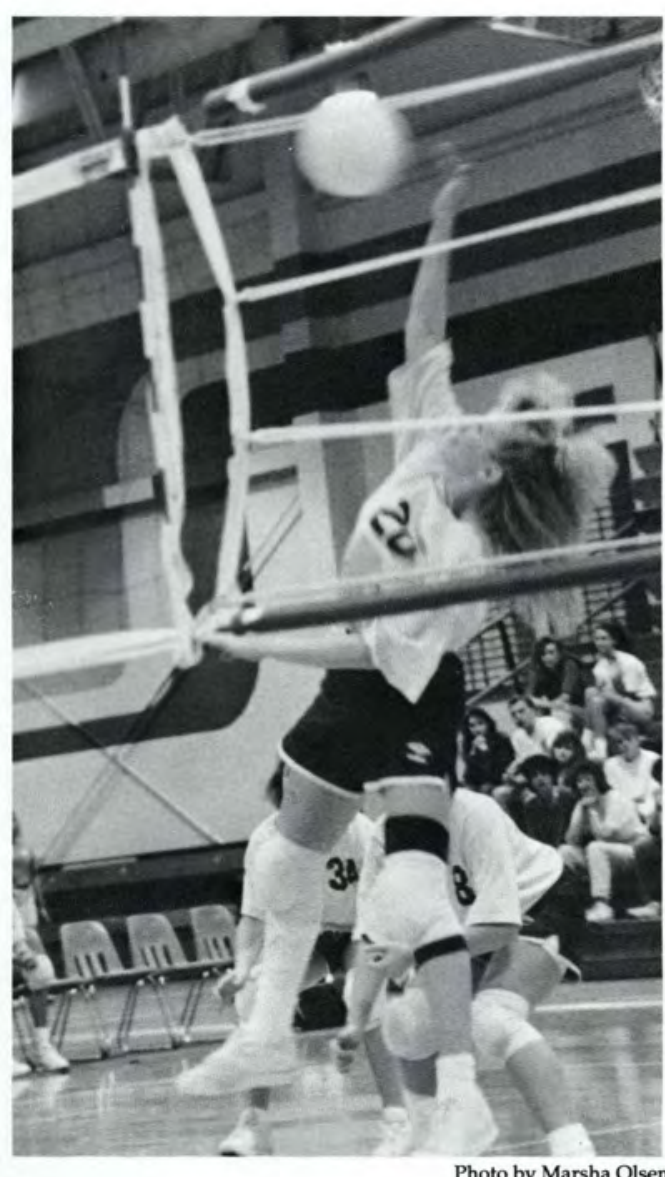

Photo by Marsha Olsen

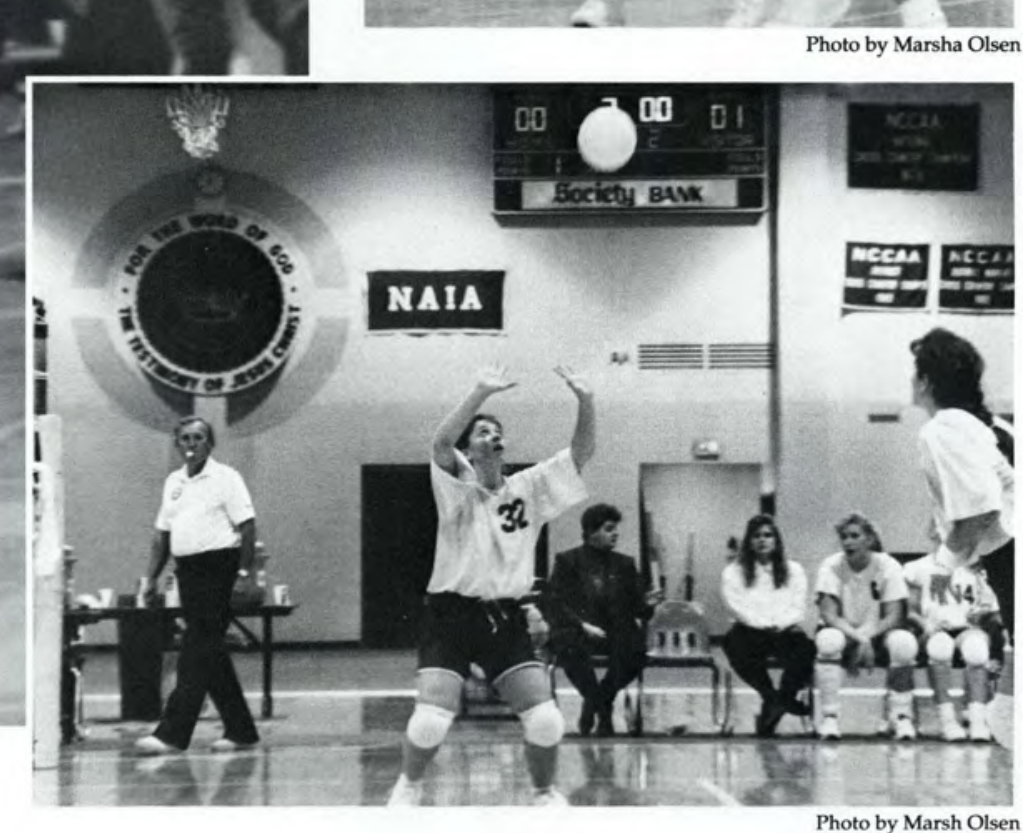

Photo by Marsh Olsen 


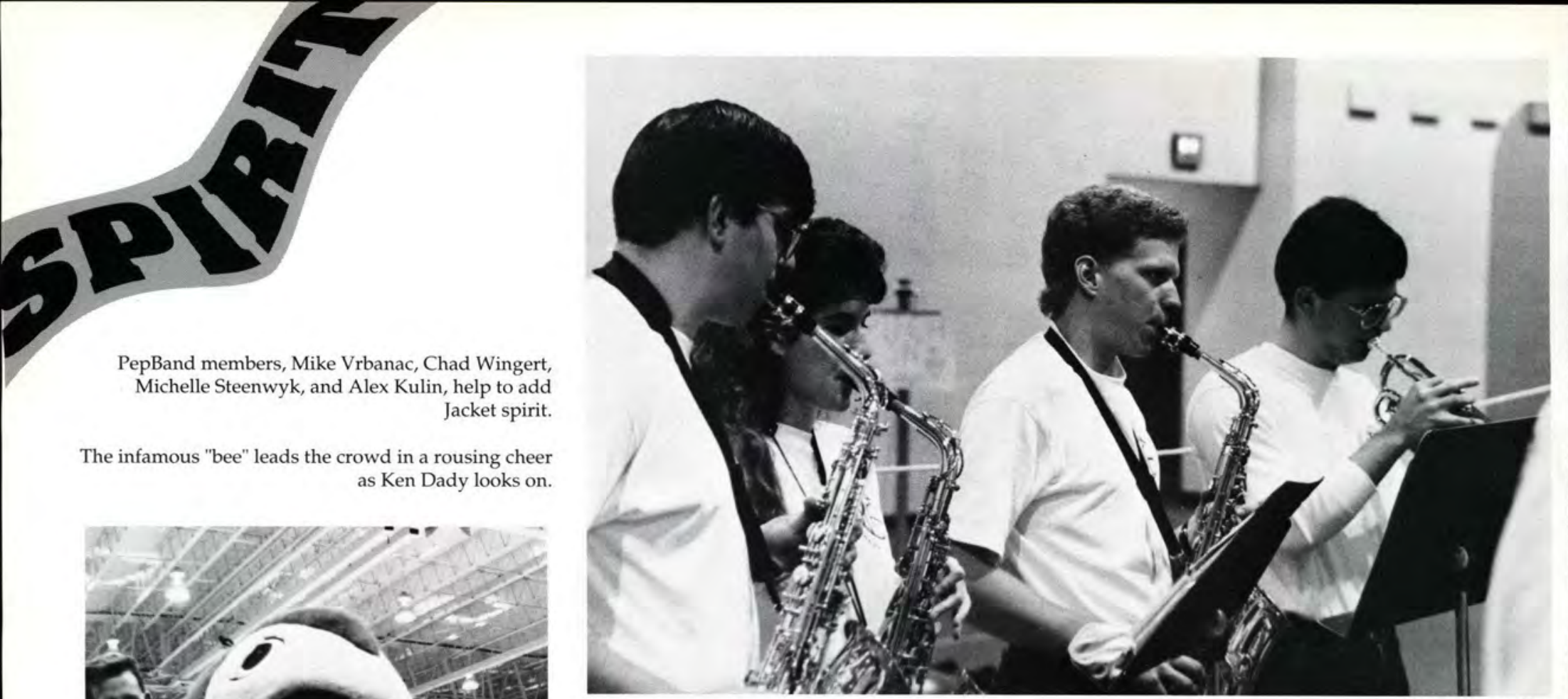

PepBand members, Mike Vrbanac, Chad Wingert, Jacket spirit.

The infamous "bee" leads the crowd in a rousing cheer
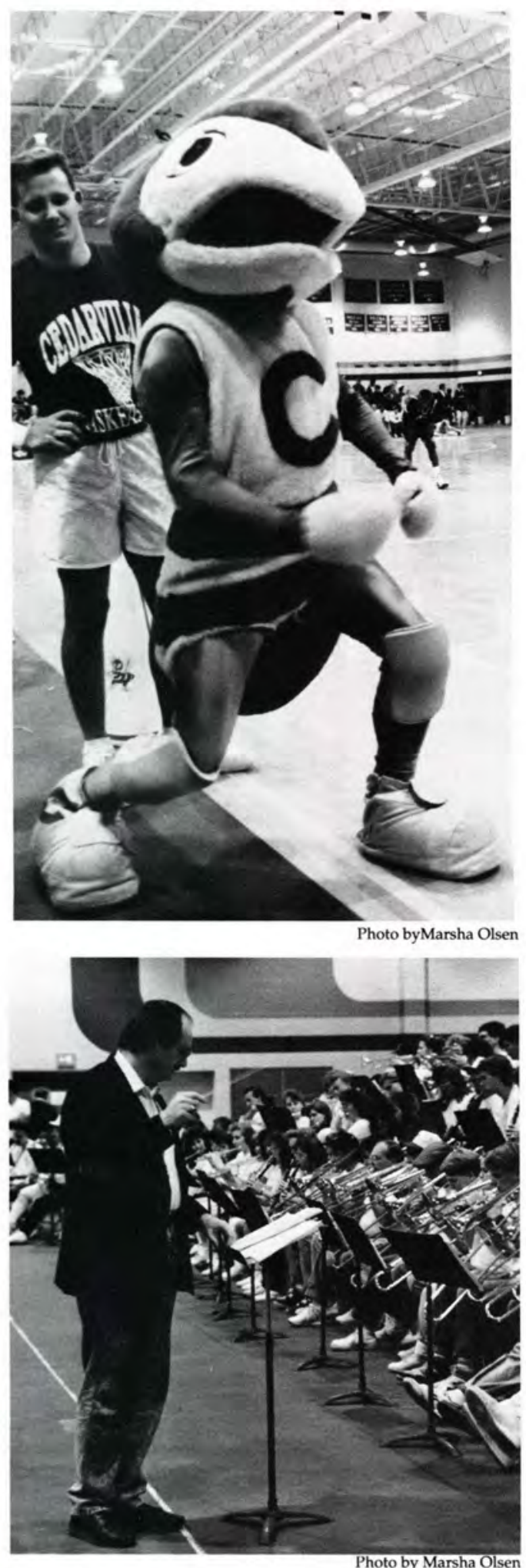

Photo by Marsha Olsen

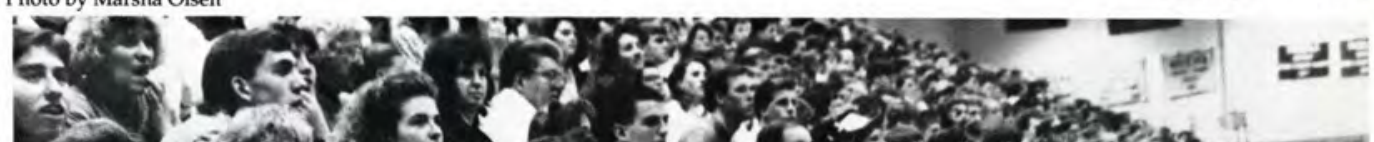
35 os ${ }^{3}$. imed

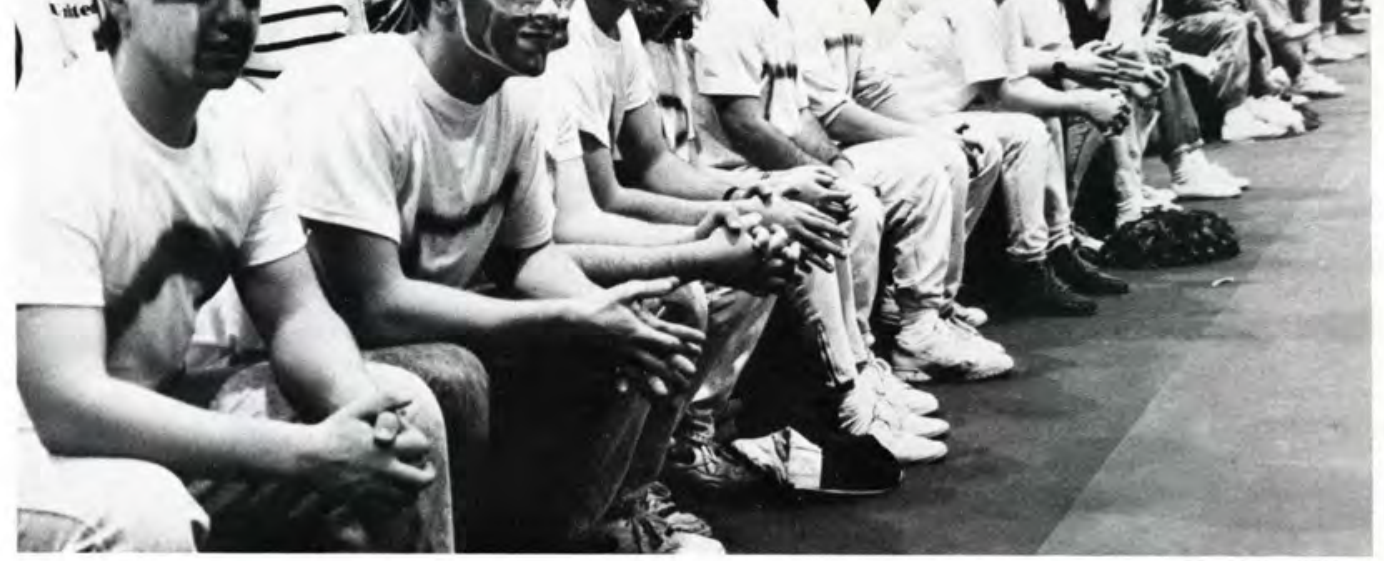

PACKING IN THE PRIDE... Loyal fans don their war paint to back the Jackets.

LEADER OF THE BAND... Mike DiCuirci directs the PepBand in an exciting version of "Hang on Sloopy."
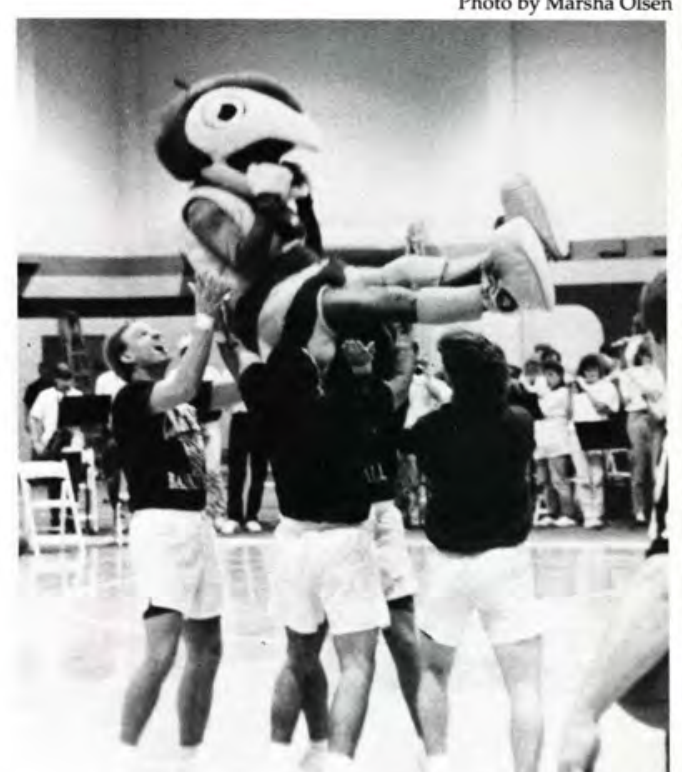

The Jacket Cheerleaders perform yet another amazing stunt with our fearless "bee."

$4 1 4 0 \longdiv { 2 \text { Sports } }$ 
It was a tough season all over for the Cedarville College baseball team. The Yellow Jackets struggled to a 3-25 campaign in 1992 which included a school record 20-game losing streak. But head coach Tom Sizer's team won two of the last three games to finish the schedule on a positive note.

Seniors Eric Ghere and David (center) KEEPING THEM ON BASE First baseman Willie Dodson keeps the runner in check with a toss from the

pitcher.

HEADING FOR HOME Dan Ambrose rounds third and is signaled home.
Carrick were named Co-MVP's of the squad. Ghere, who saw action both on the mound and at shortstop, batted .304 and led the team with 14 runs scored and 14 rbi's.
He was an honorable mention selection in NAIA District 22. Carrick completed his fourth year in the program by hitting .300 as both a pitcher and infielder.

Dan Brown and Tim Edsell also earned spots on the NAIA District 22 honorable mention list. Brown hit .309 as a designated hitter, while Edsell played third base and carried a .284 batting average.

Cedarville posted victories over Earlham, Urbana, and Central State. The Jackets dropped six games by two runs or less.

- Mark Womack

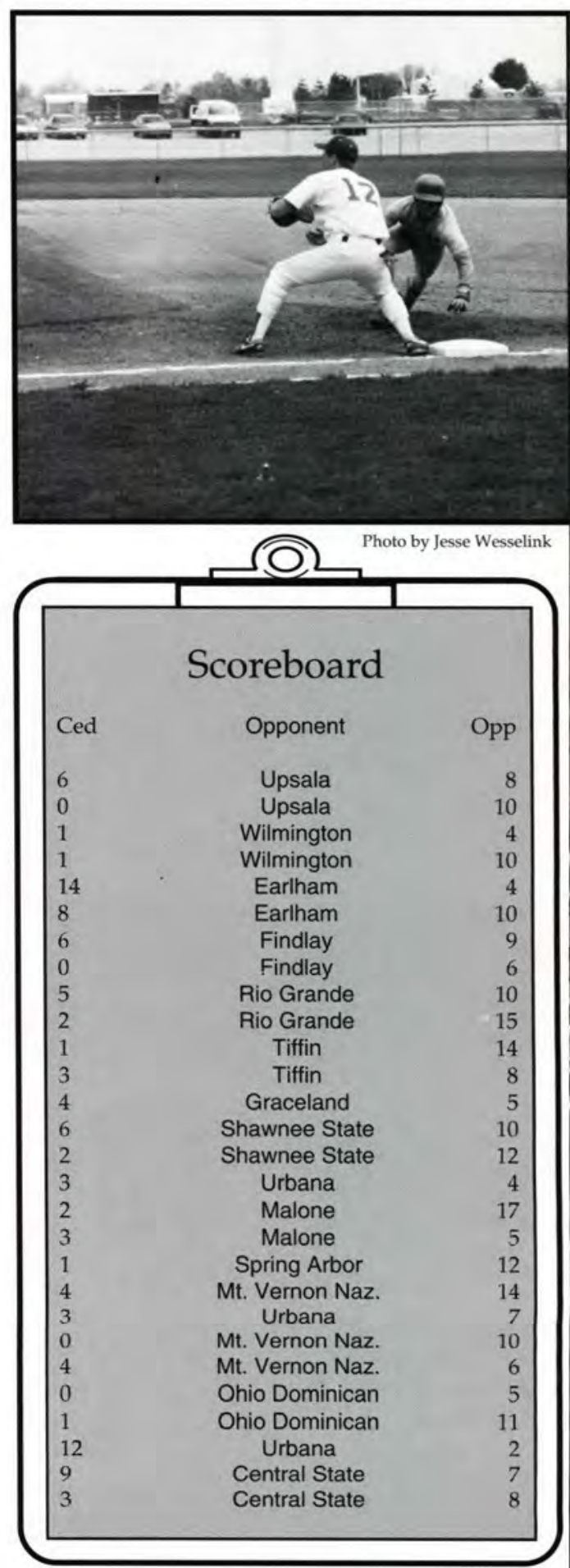

FIRING 'EM UP Coach Tom Sizer rallies the team before Photo by Jesse Wesselink 

TAKING FLIGHT Pete Ruby takes to the air in the long jump.
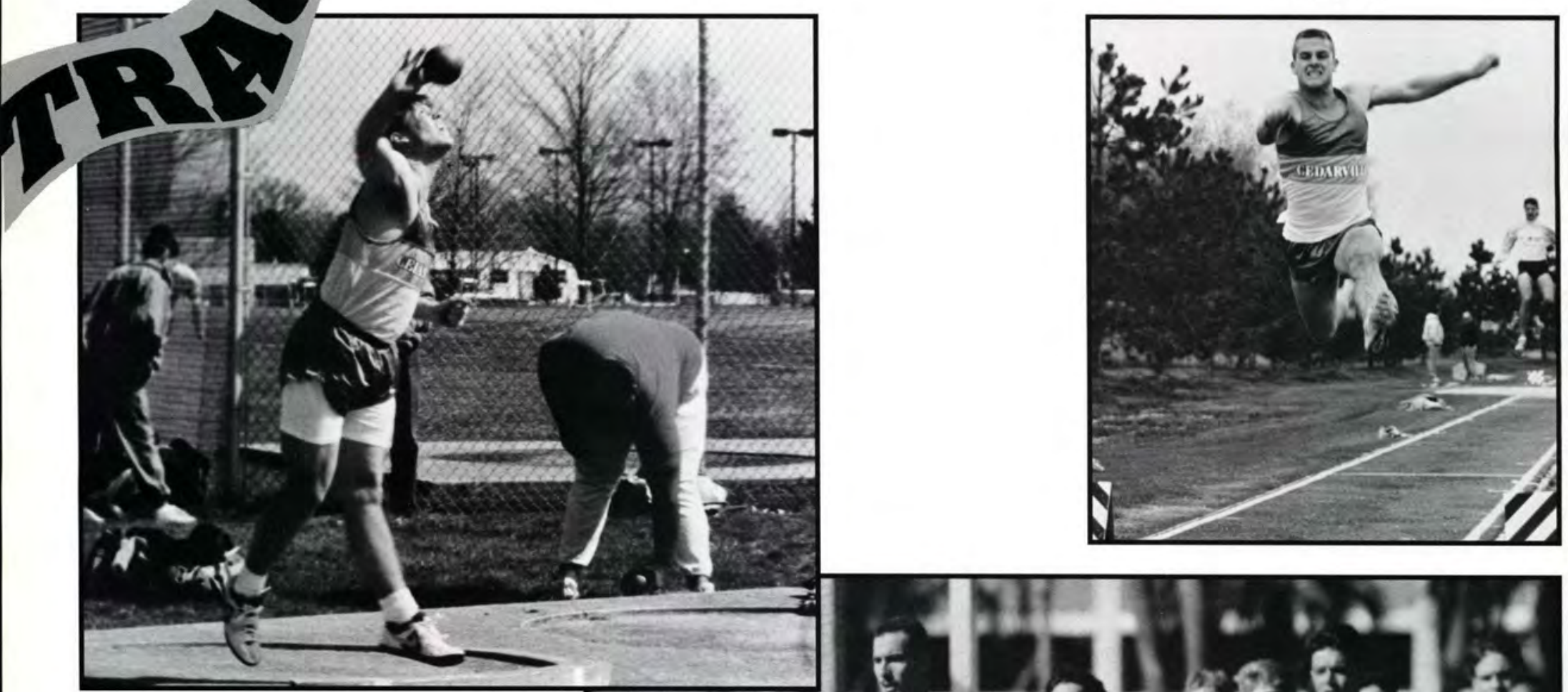

TOUGH SHOT Rich Sipes gives his all in shotput.

OUT IN FRONT Kevin Conkel races to the finish in the 1500 meter.

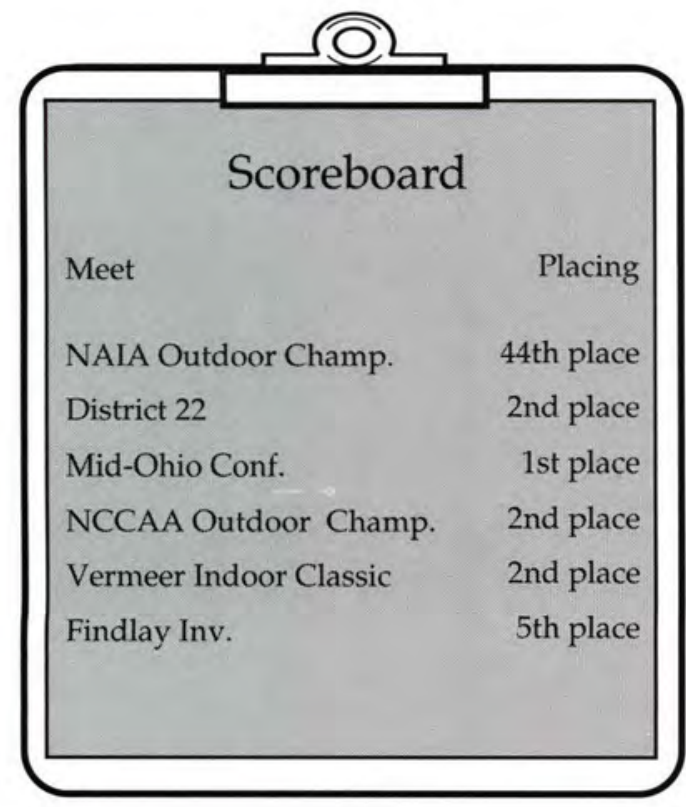

$\sqrt[4 1 4 6 \longdiv { 2 p o r t s }]{ }$
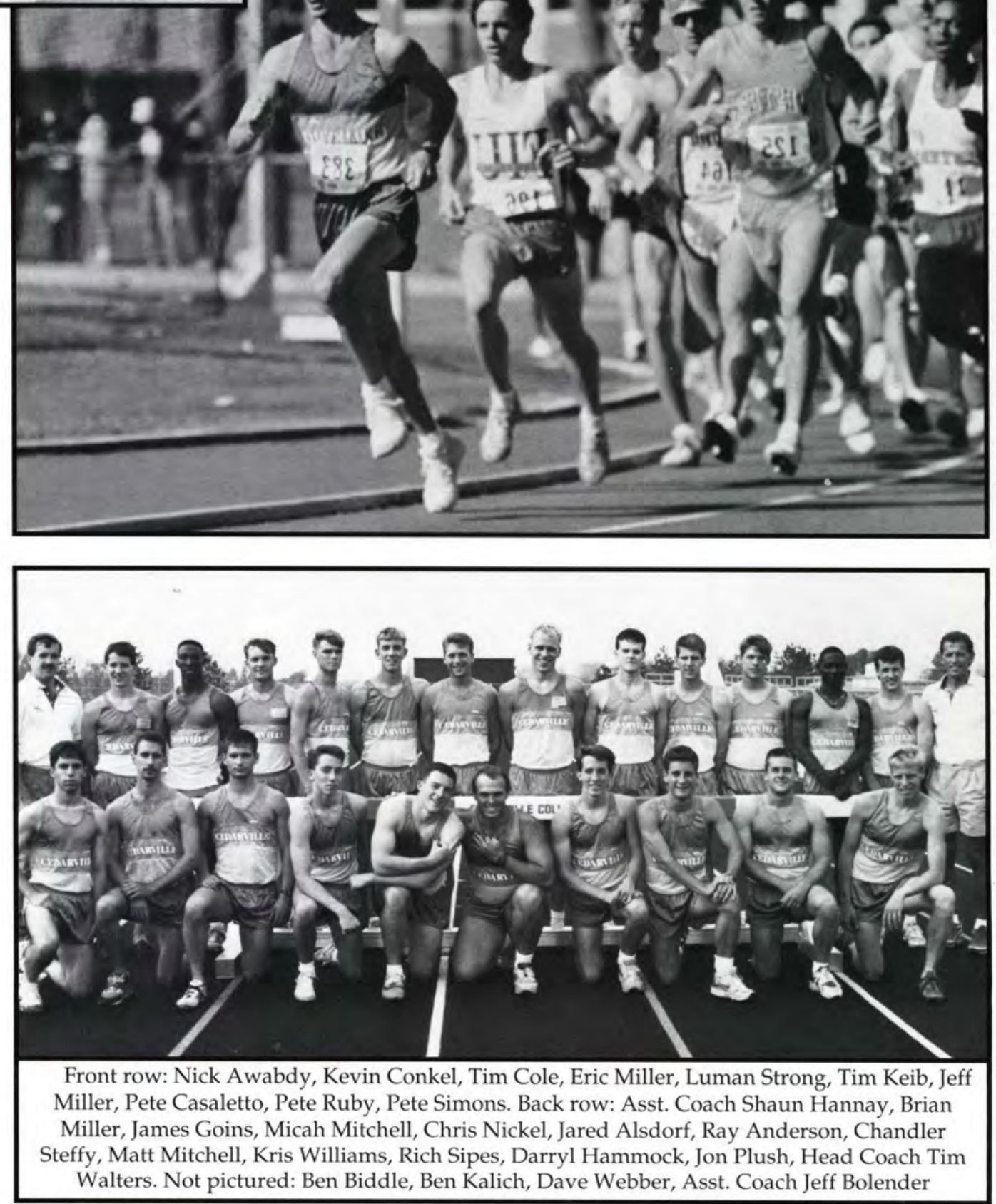
The Lady Jackets' track \& field season was highlighted by the efforts of freshman Stephanie Sherman. She became Cedarville's first-ever NAIA Outdoor National Champion when she won the triple jump at $40^{\prime} 1 / 2$ " at the national meet at Simon Fraser University in British Columbia, Canada.

Sherman was the favorite entering the meet since she had the longest jump during the season in the NAIA Nationals at 40'3" which occurred in a meet at the University of Tennessee. She was also an NAIA Indoor All-American in the triple jump where she placed second at 39'2". Her
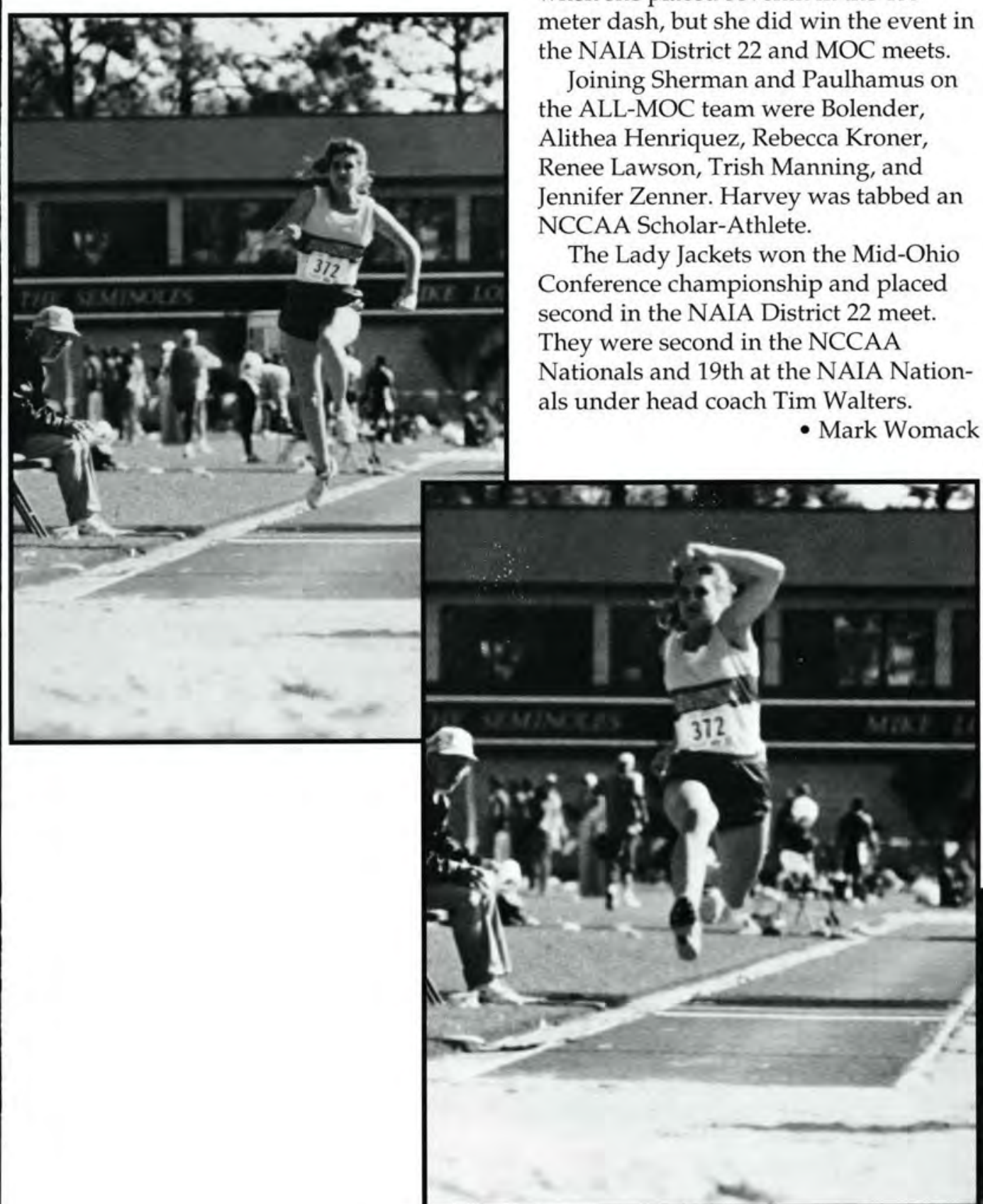

PUSHING THE LIMITS Stephanie Sherman stretches for every inch in the triple jump.

longest leap of the indoor season was 40 '8 1/2" at the Mason Dixon Games in Louisville, Ky.

Sherman was an NCCAA All-

American by winning both the long and triple jumps. She won both events in the NAIA District 22 meet where her 36'11" effort in the triple jump was new meet record, and she won four events in the Mid-Ohio Conference meet.

Brenda Paulhamus, Sharie Bolender, Krista Pritchard, and Tammy Harvey all gained spots on the NCCAA All-

America squad. Paulhamus missed NAIA All-America status by one spot when she placed seventh in the 400 meter dash, but she did win the event in the NAIA District 22 and MOC meets.

Joining Sherman and Paulhamus on the ALL-MOC team were Bolender, Alithea Henriquez, Rebecca Kroner, Renee Lawson, Trish Manning, and Jennifer Zenner. Harvey was tabbed an NCCAA Scholar-Athlete.

The Lady Jackets won the Mid-Ohio Conference championship and placed second in the NAIA District 22 meet. They were second in the NCCAA Nationals and 19th at the NAIA Nation- Mark Womack

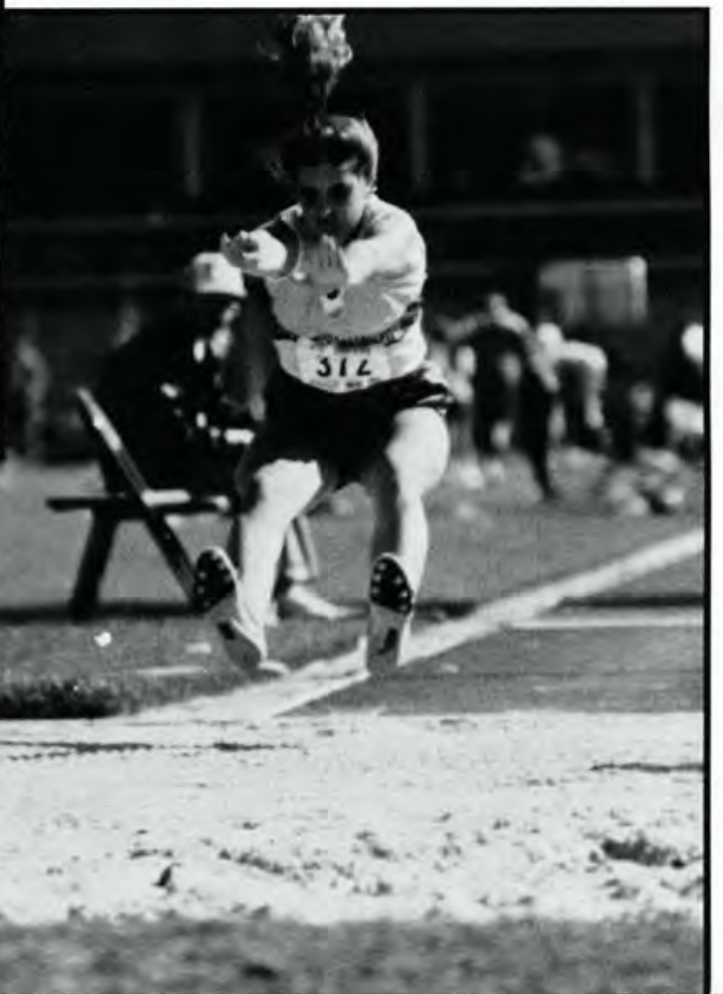




\section{Net \\ Jackets \\ Continue \\ to Dominate \\ Improvement}

The Yellow Jacket men's tennis team continued its dominance in NAIA District 22 and Mid-Ohio Conference by winning both championships. Coach Murray

Murdoch's team had a 17-3 record and was ranked in the NAIA Top 20.

Cedarville made its 25th appearance at the NAIA National Tournament in Kansas City. Murdoch, who was inducted into the NAIA Hall of Fame and serves as national tournament director, saw his 27 year career record improve to 53066.

Matt Kibble earned MOC Player of the Year and All-NAIA District 22 honors for the second straight year. He had a 19-5 singles record and was the District 22 runner-up. Kibble, who still has one year left, has a 64-10 career record at Cedarville.

Mike Anthony, Mike Baker, Brannon Potts, Brian Clark, and Sanjiv Sant Singh all were named to the NAIA District 22 and Mid-Ohio Conference teams. Todd Enter was also tabbed to the All-MOC unit.

The Jackets had one of their toughest draws ever in Kansas City. Kibble won the match before being eliminated by a seeded player.

Kibble and Anthony, who were the District 22 doubles runners-up, got to the second round at the national tournament prior to losing to a seeded team. Baker and Potts also teamed up for another doubles win.

-Mark Womack
SELF-DEFENSE TENNIS Mike Anthony quickly reacts to a ball hit right at him.
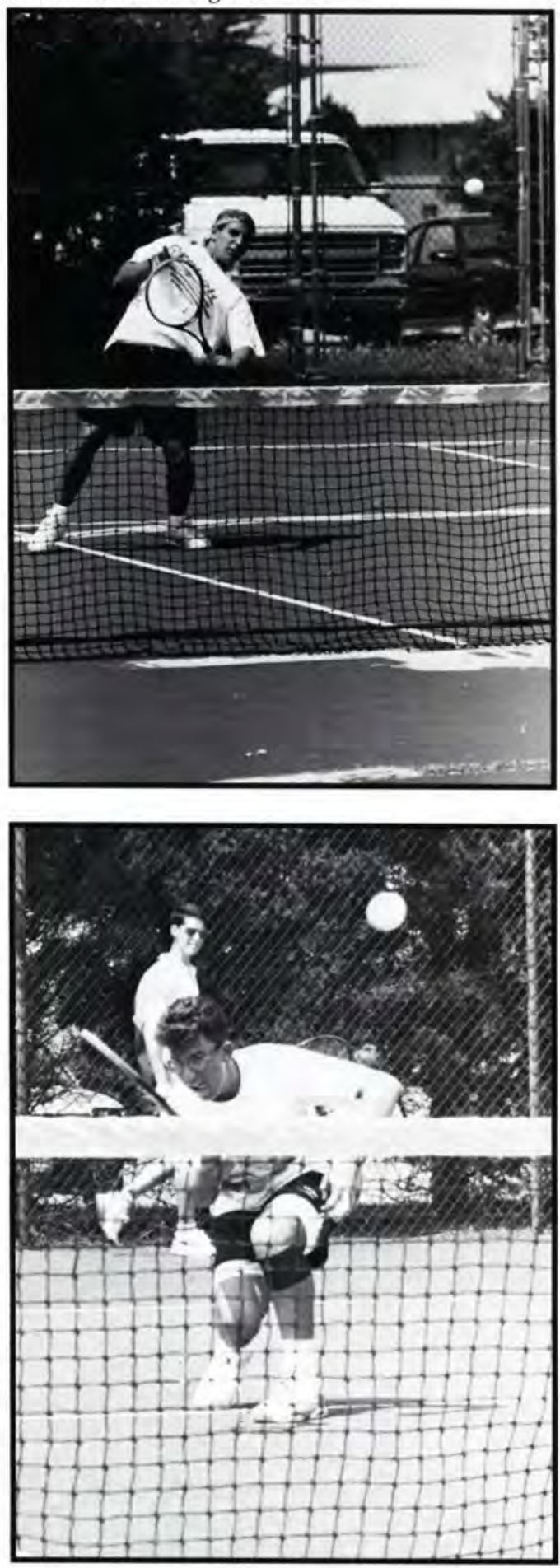

A SHOT WITH THOUGHT Matt Kibble intently stoops to get the good angle.
A REACHING RECOVERY Matt Kibble stretches to save and overhead lob.

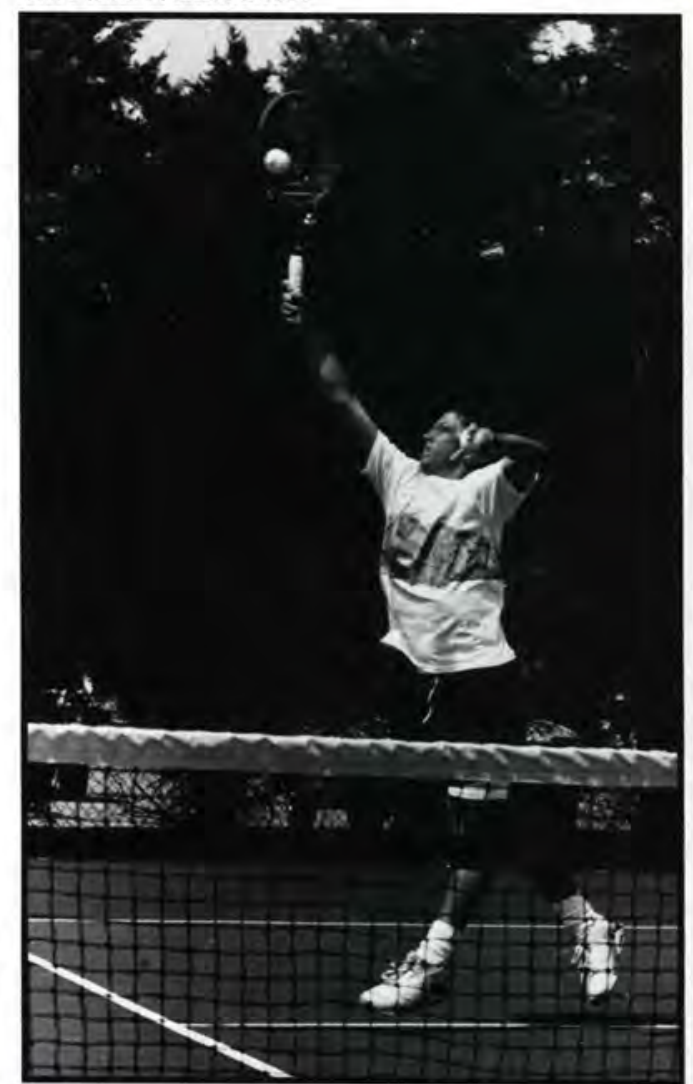



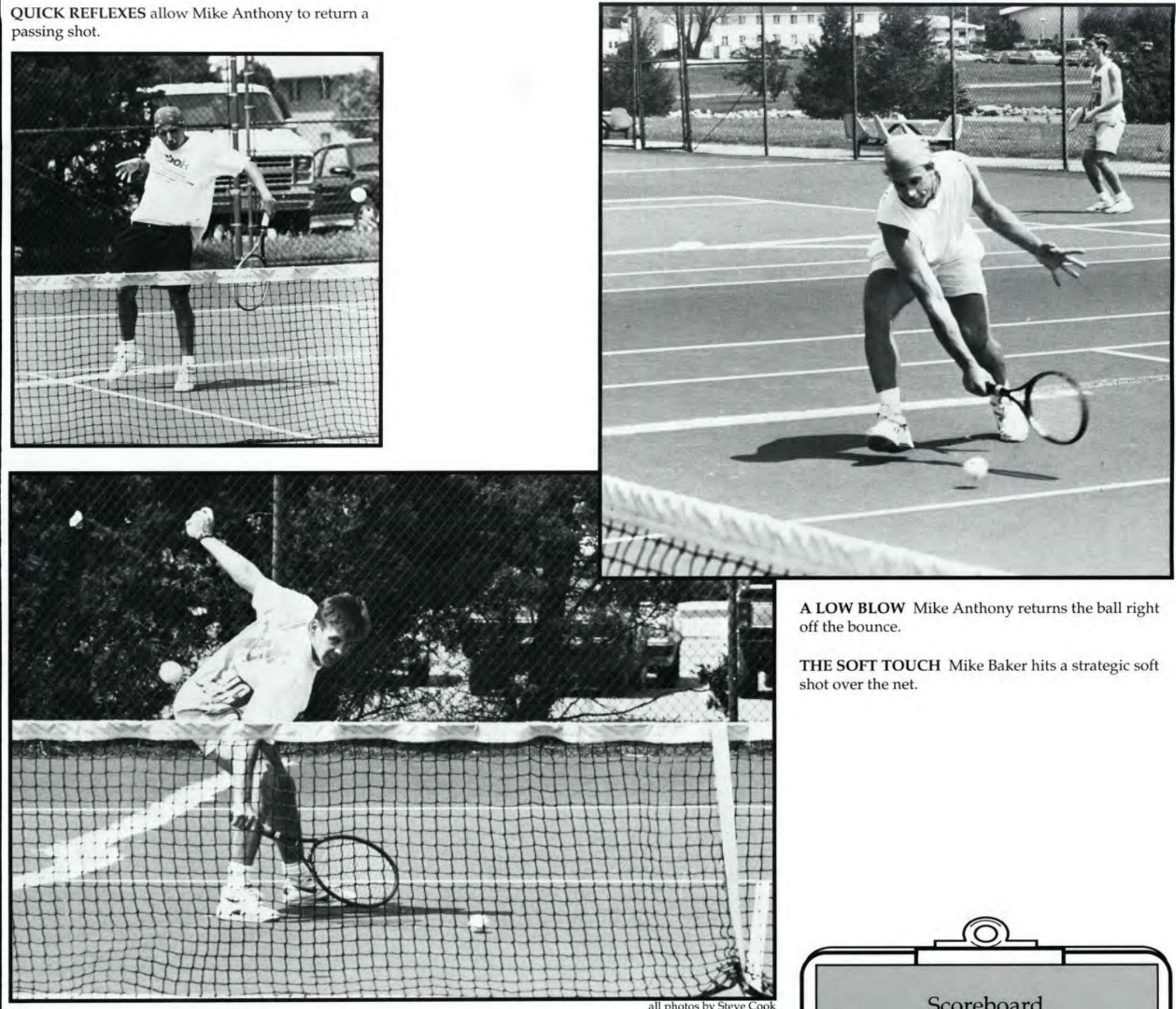

A LOW BLOW Mike Anthony returns the ball right off the bounce.

THE SOFT TOUCH Mike Baker hits a strategic soft shot over the net.
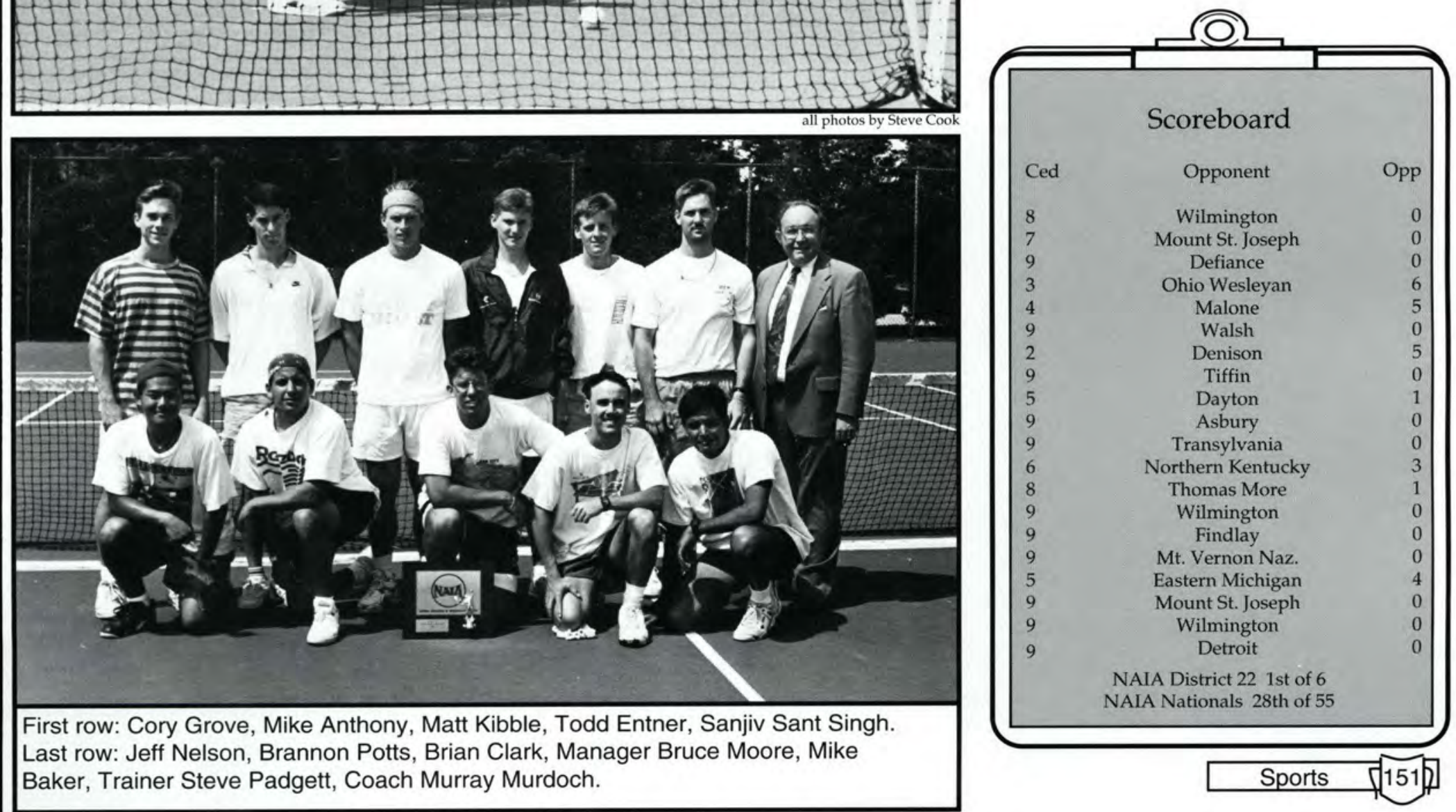

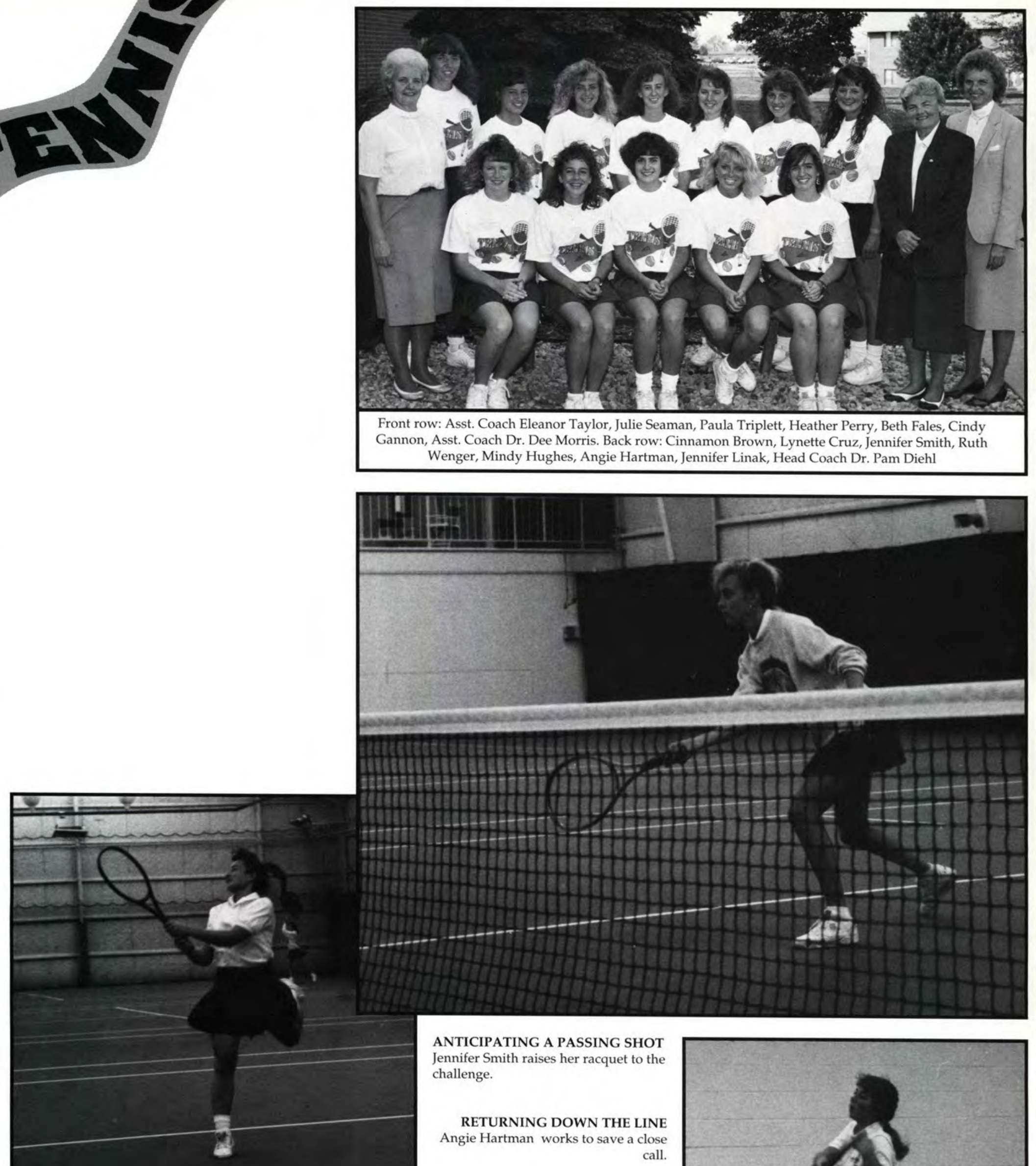

ANTICIPATING A PASSING SHOT Jennifer Smith raises her racquet to the challenge.

RETURNING DOWN THE LINE Angie Hartman works to save a close call. cross-court.

4152

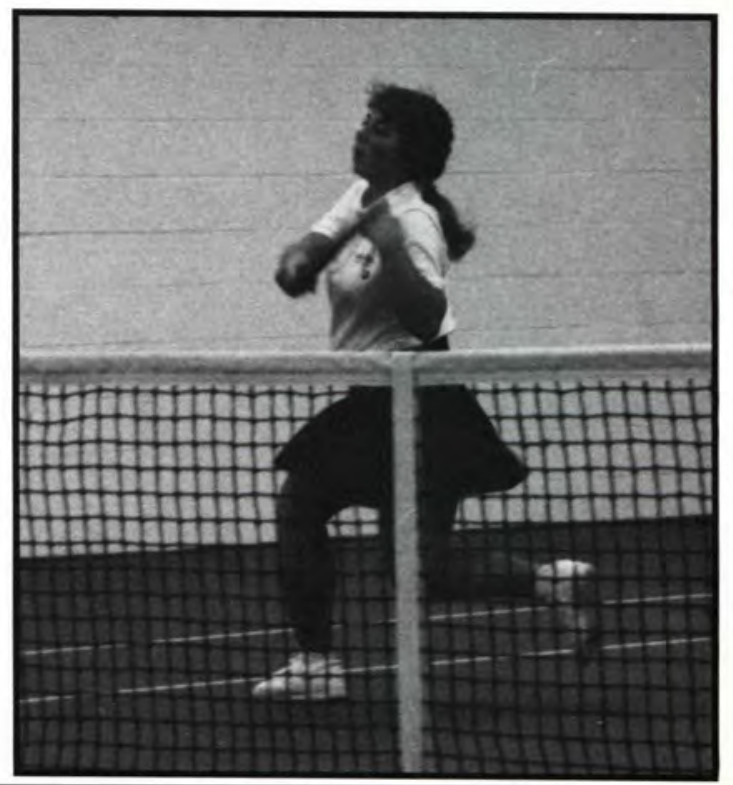




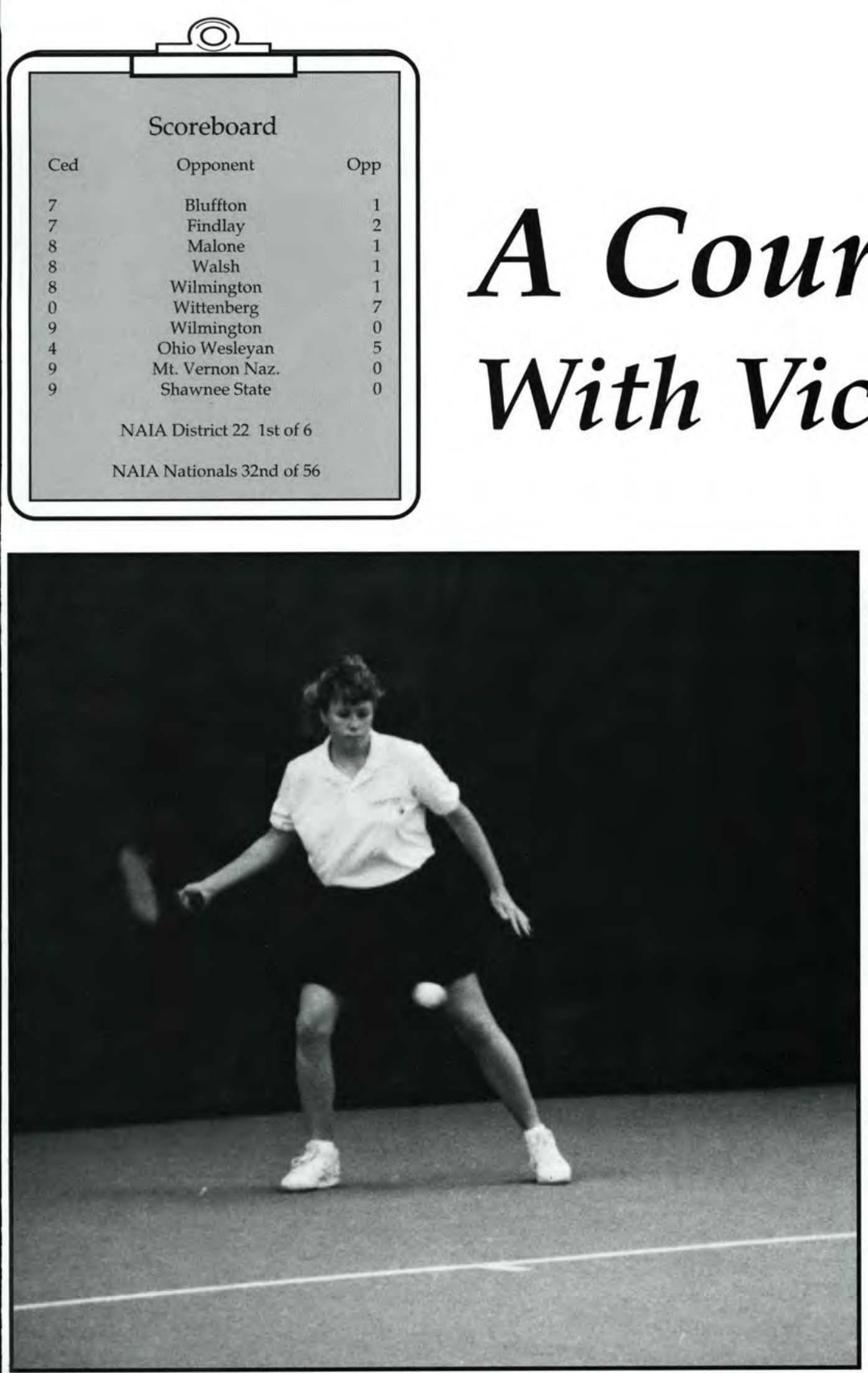

FOREHAND IN GOOD FORM Julie Seaman prepares for her next shot.
Cedarville College won its third straight NAIA District 22 title in women's tennis. The lady netters, 8-2 overall, also copped the firstever Mid-Ohio Conference championship to be awarded in women's tennis.

Pam Diehl was tabbed NAIA District 22 Coach of the Year. She also continued her role as the NAIA national tournament director.

Angie Hartman led the Lady Jackets selections to the all-district team by winning the first flight singles crown, and by teaming up with Paula Triplett to capture the top doubles flight. Triplett was voted to the all-district team as was Lynette Cruz, who won the third singles flight.

Jennifer Smith and Julie Seaman combined for the third flight doubles title. Smith was also a winner at number six singles.

Cinnamon Brown and Mindy Hughes were named to the NAIA Scholar-Athlete Team. Brown was the lone Cedarville player to win a singles match at the national tournament, while Smith and Seaman notched one victory in doubles.

- Mark Womack 


\section{Solid as Iron} a new era under first-year coach Elvin King. He follows the footsteps of former coaches Bob Gromacki and Allen Monroe, who each spent 16-year careers leading the linksters.

Sophomore Ted Kruse had the lowest scoring average on the team with 82.8 strokes per 18 holes. His highlight of the season came when he won the Columbus State Invitational with a 79 in blustery conditions.

Greg Lawrence averaged 83.3 and carded the squad's low round of the year with a 76 at Walsh Invitational. Todd Roberts averaged 85.5.

The Jackets placed third out of six schools in the Mid-Ohio Conference and fifth of seven at the NAIA

District 22 Tournament. They finished seventh out of 12 schools in their own 11th Annual Cedarville Invitational.

-Mark Womack another hole.
The Yellow Jacket golf team began
A DRIVING FORCE Brian Blackburn tees off

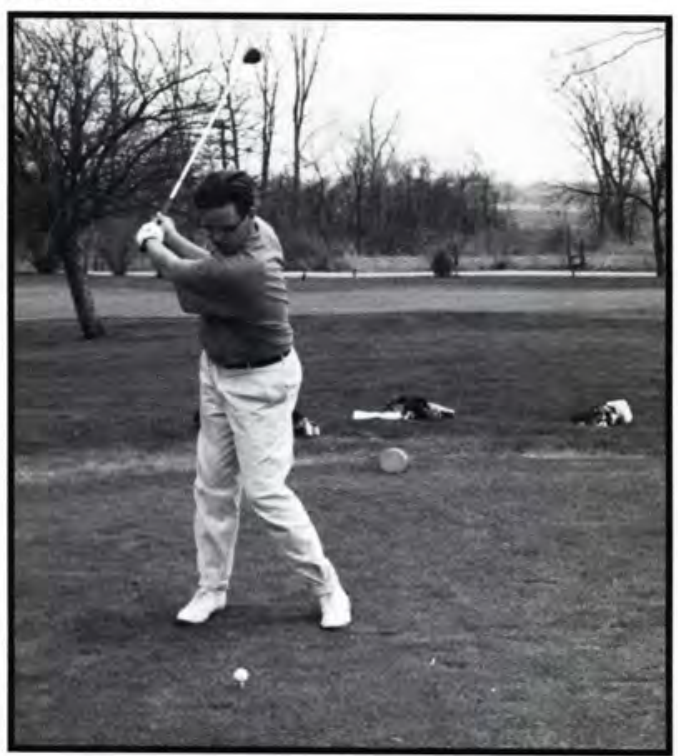

PRECISION PUTTING (left to right) Coach King, Ted Cruse, Henry Roy and Bob Cunningham do their best to sink a putt.
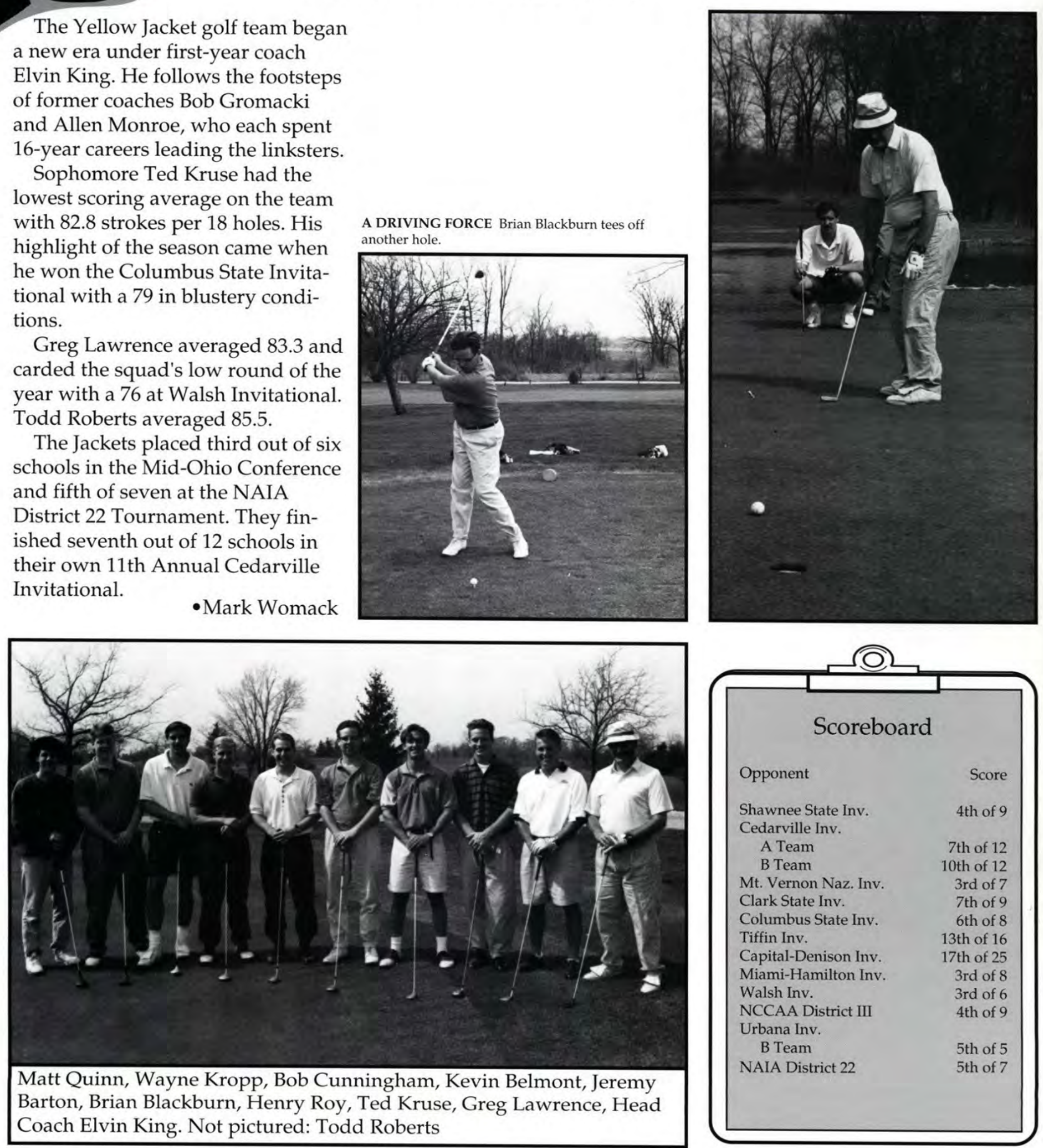

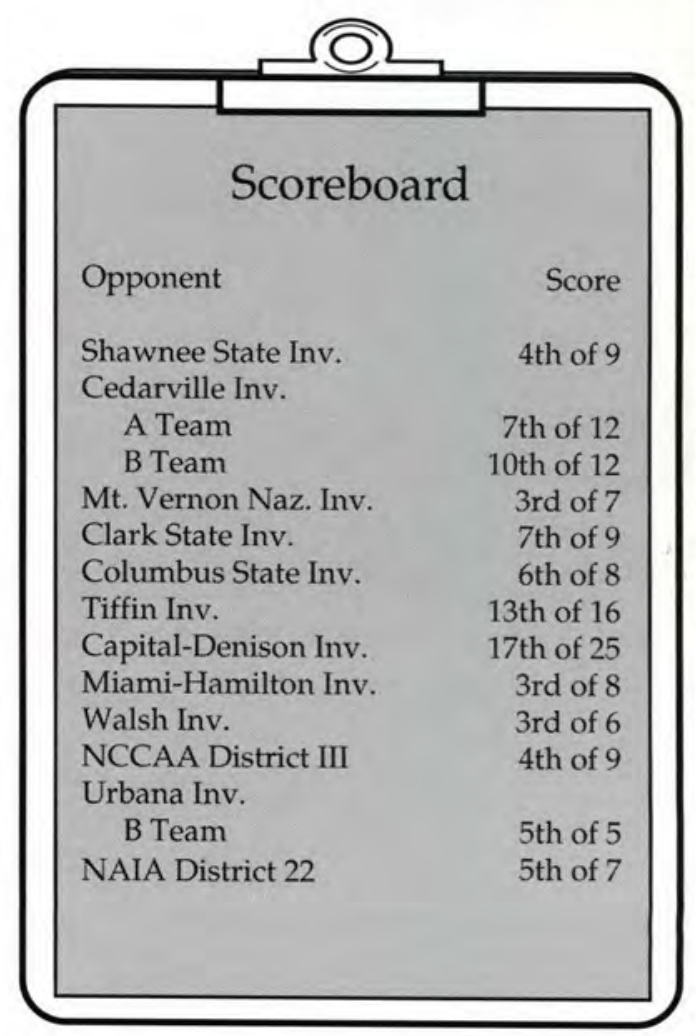



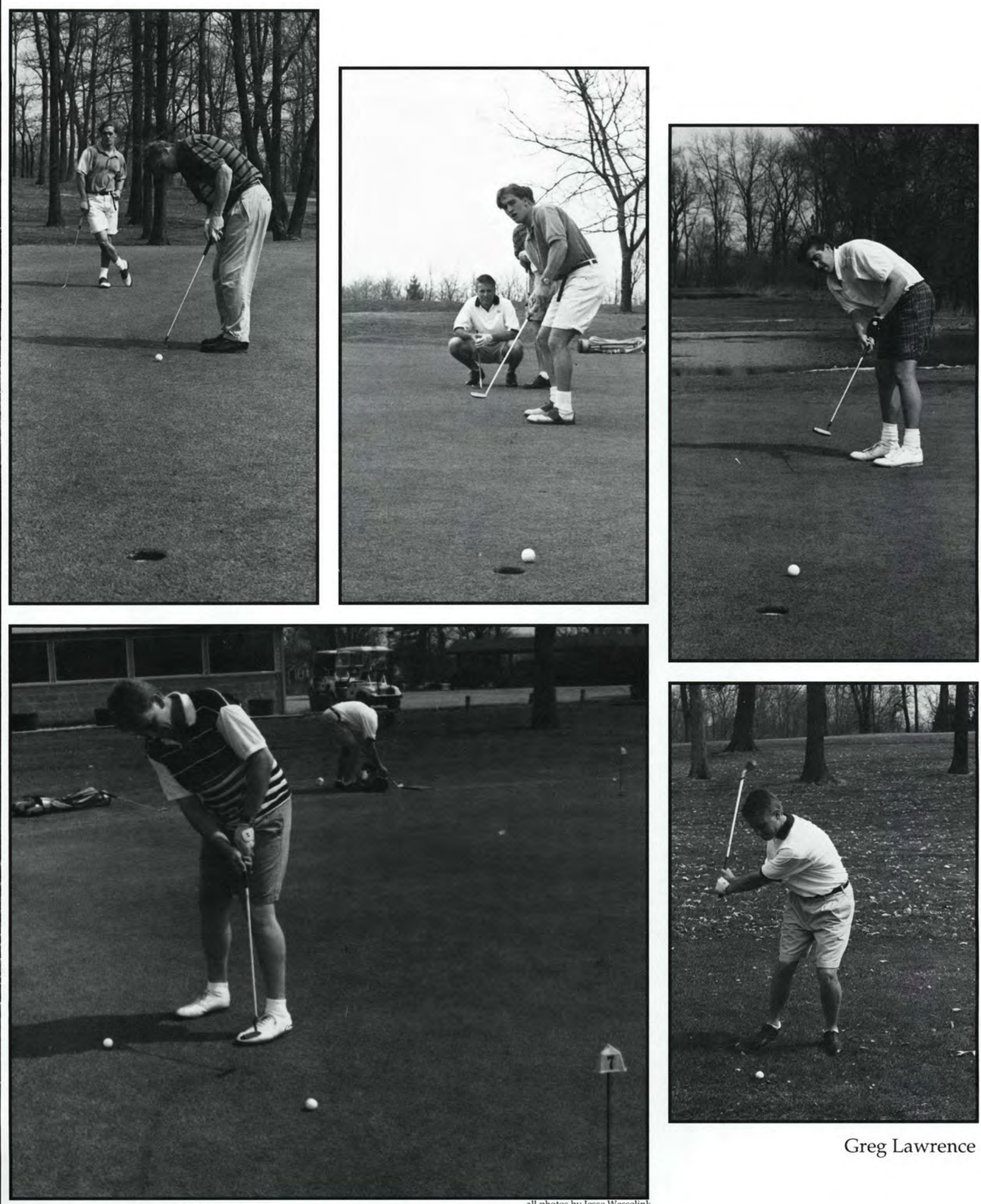

Greg Lawrence 

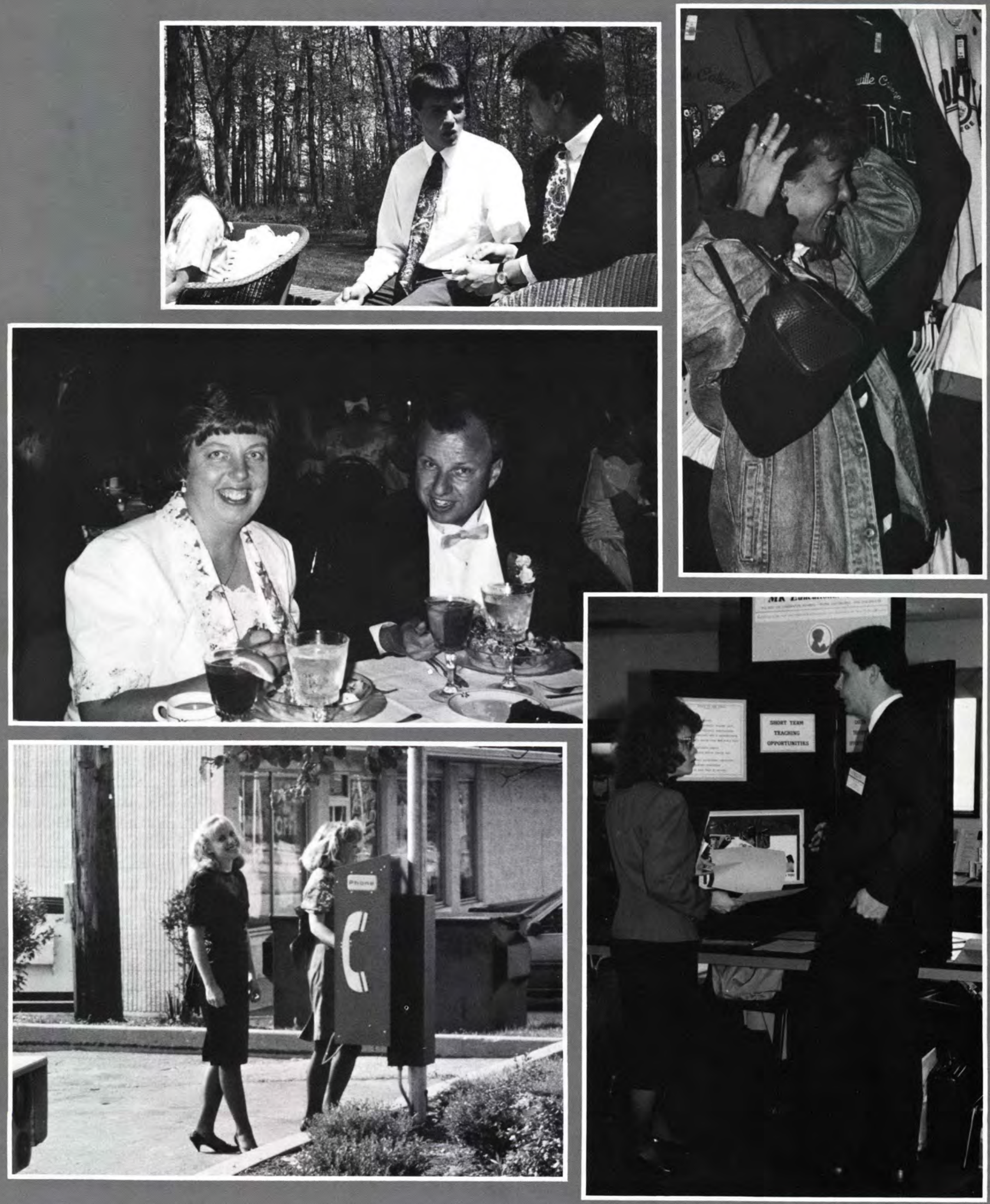

406 


\section{Products of Fis Plan}

\section{Table of Contents:}

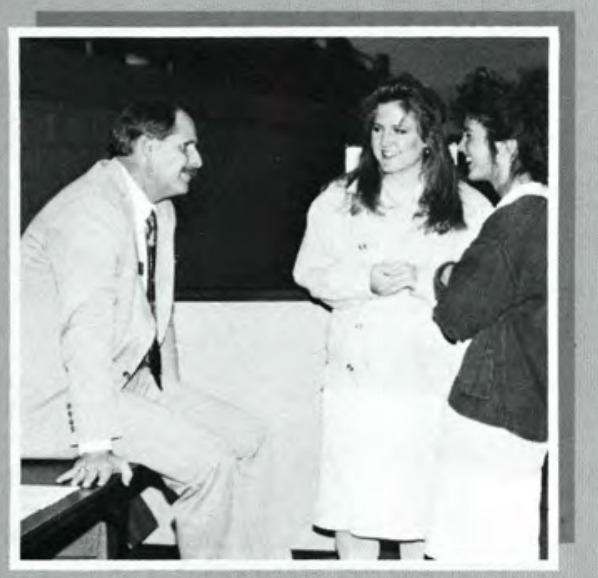

Seniar

Jole Search Page 158

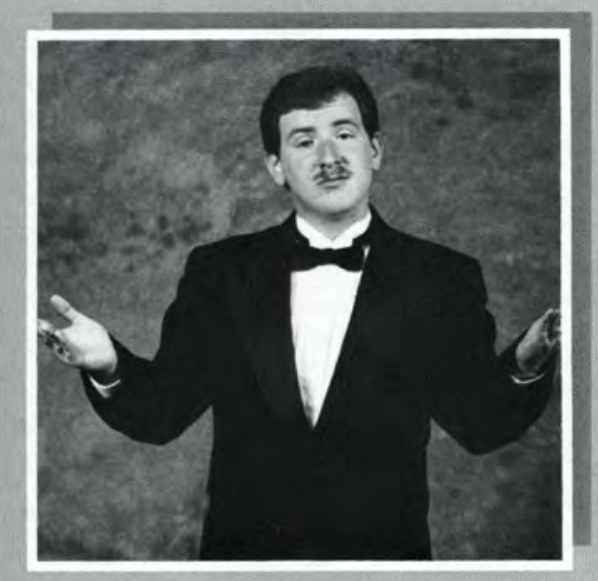

Seniar

Recitalists Page 162

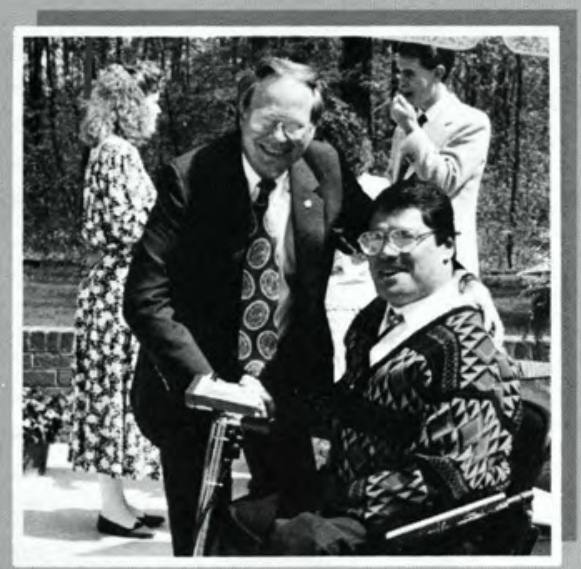

Seniar

Night

Page 164

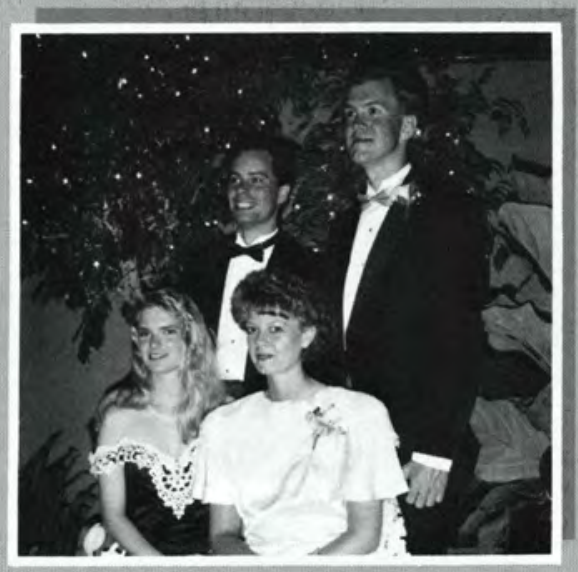

Guniar/

Seniar

Banquet

Page 166

Commencement

Page 168
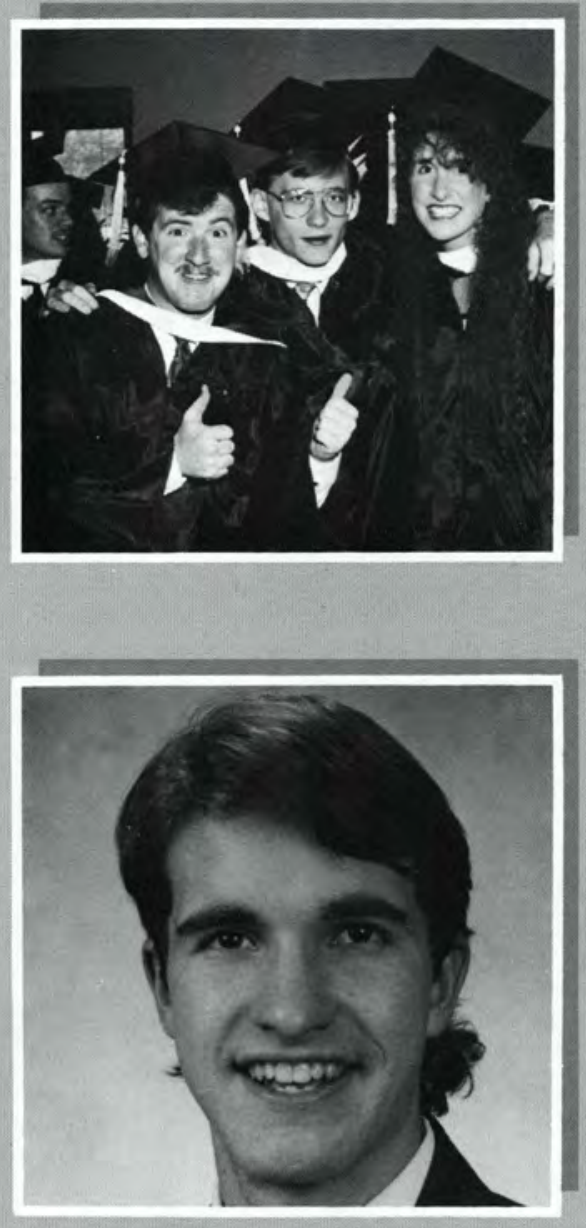

Seniar

Partraits

Page 172 
HOPING FOR A JOB POSSIBILITY, Bouchra Sefiane stops to talk with a representative at the Job Fair.

DESIRING A PROSPECT, Norm Byers talks with a representative on Career Day.
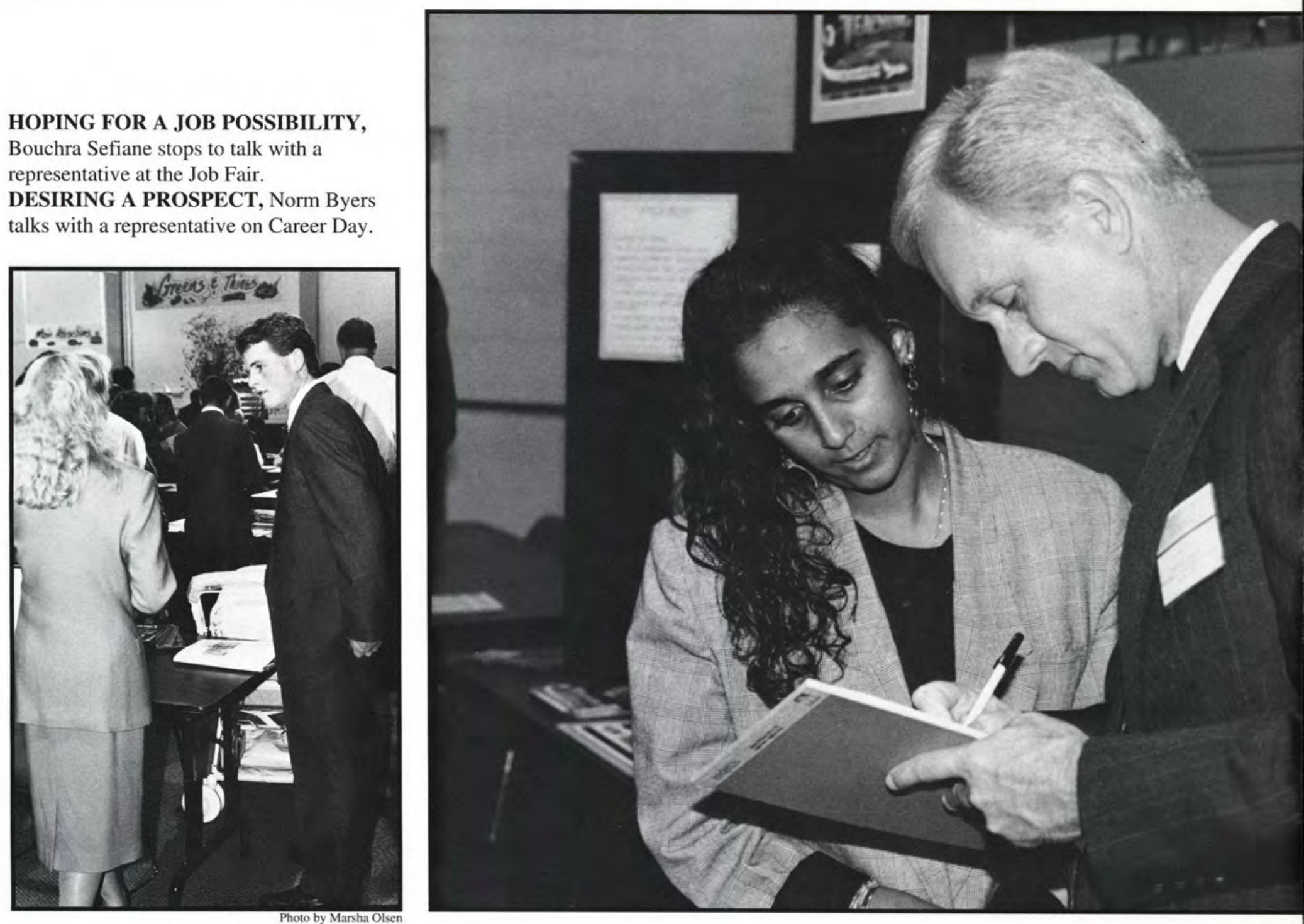

\section{NURSING CAREER DAY. Josette}

Walborn talks with a representative from St. Luke's Hospital.
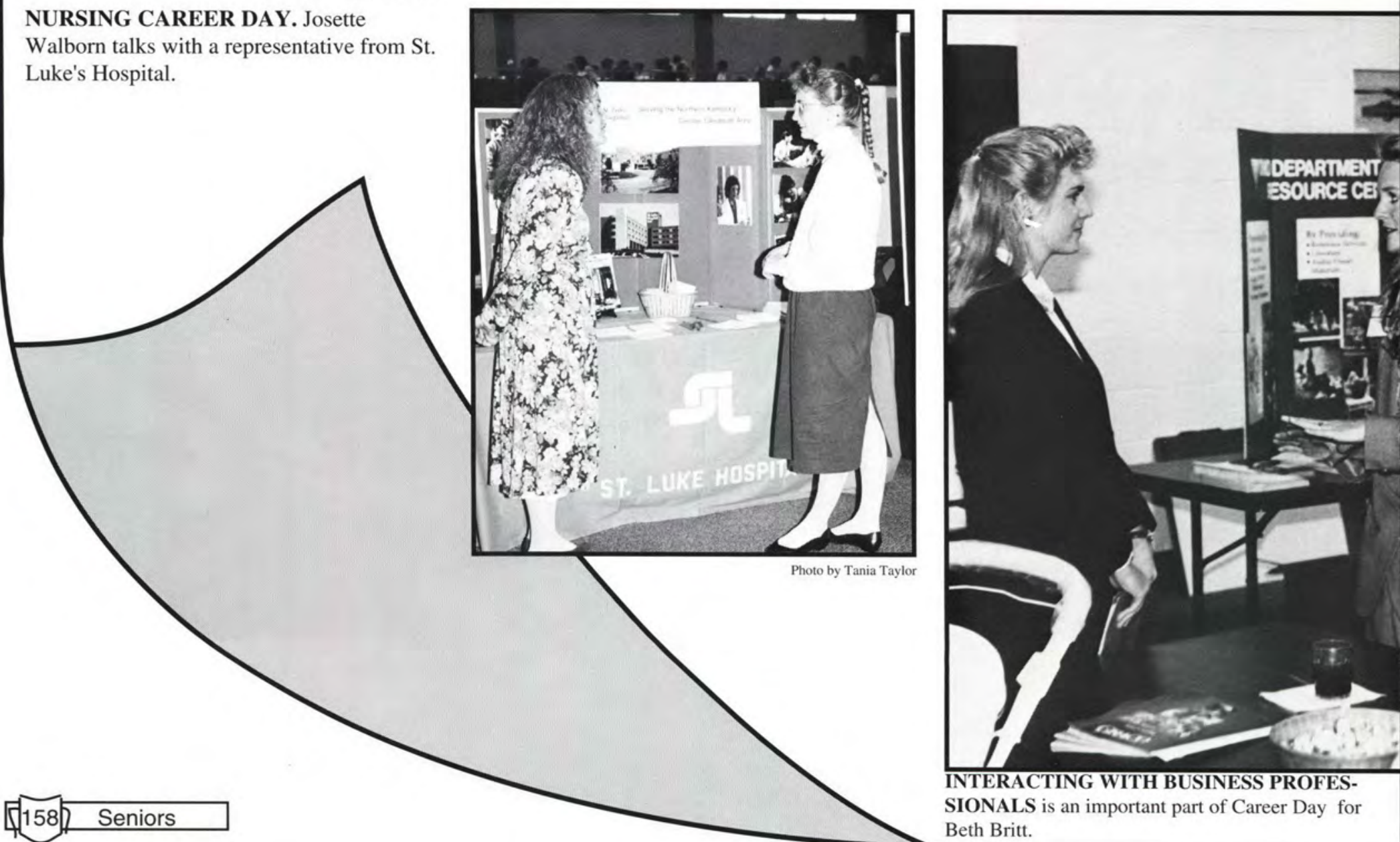
THE CLASS OF 1992 sings "Will You Be the One?" in a moving Senior Class Chapel
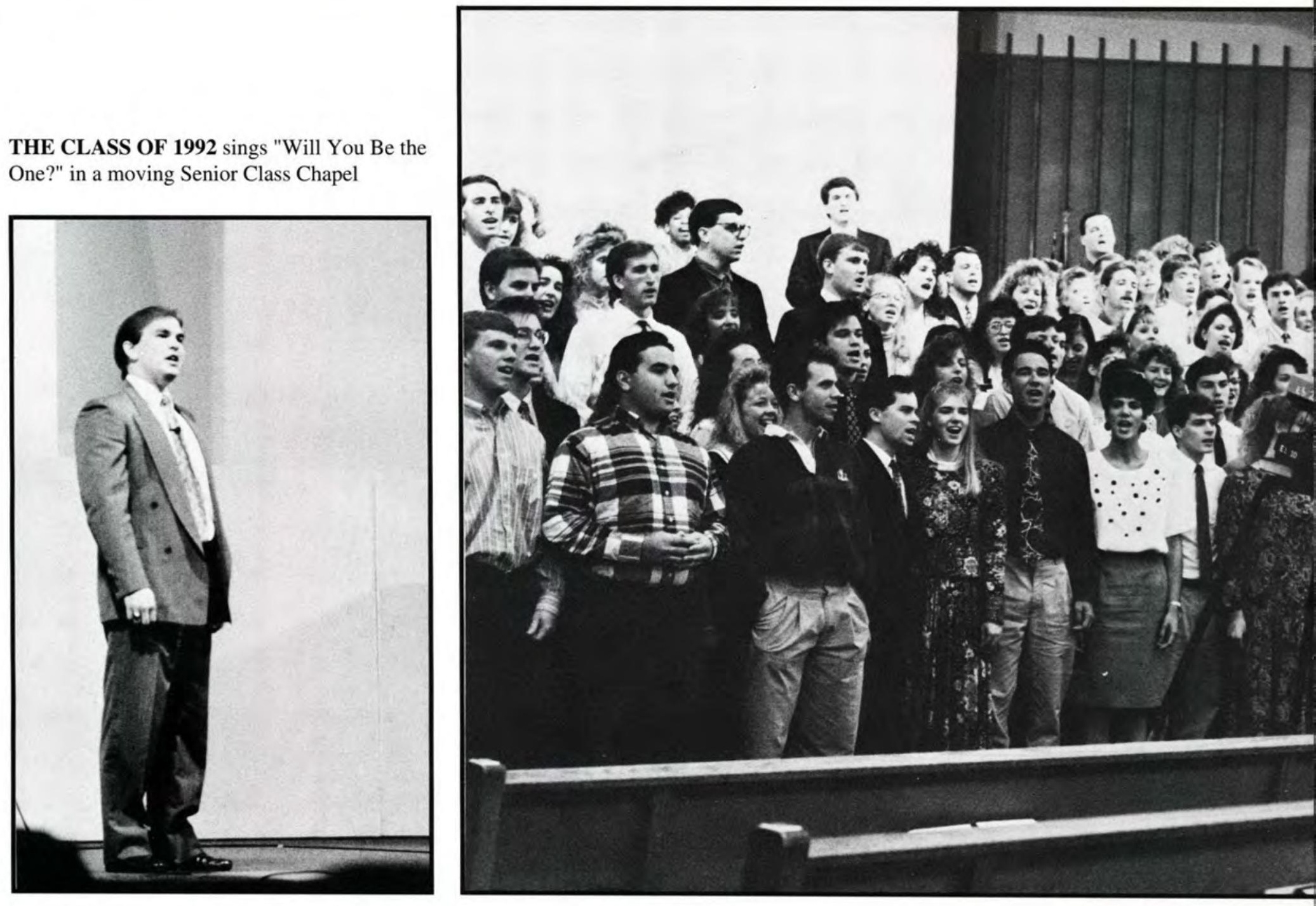

SENIOR CLASS CHAPLAIN, Matt Moore, challenges the student body to leave a lasting legacy.

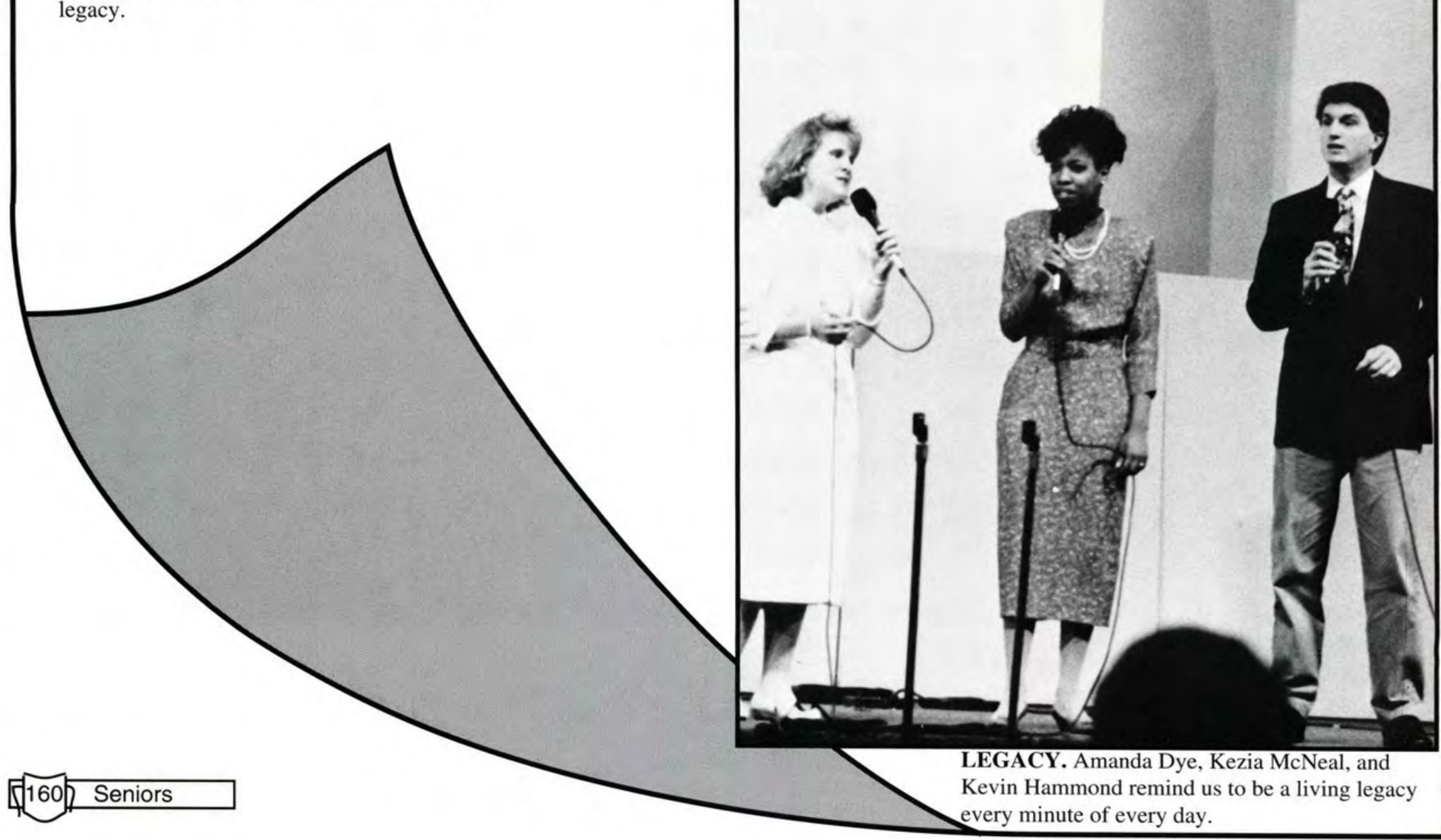



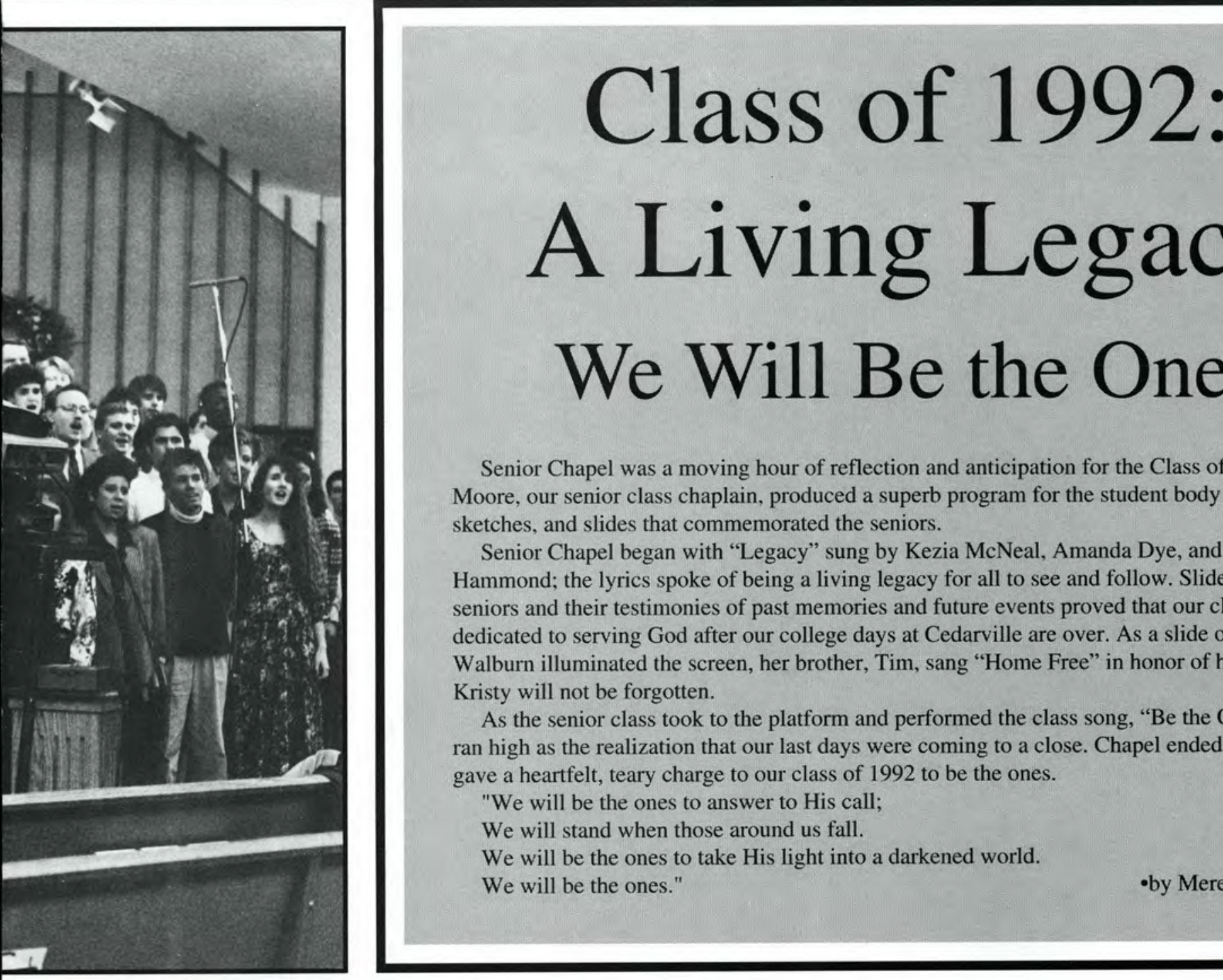

\section{A Living Legacy \\ We Will Be the Ones}

Senior Chapel was a moving hour of reflection and anticipation for the Class of 1992. Matt Moore, our senior class chaplain, produced a superb program for the student body with songs, sketches, and slides that commemorated the seniors.

Senior Chapel began with "Legacy" sung by Kezia McNeal, Amanda Dye, and Kevin Hammond; the lyrics spoke of being a living legacy for all to see and follow. Slides of various seniors and their testimonies of past memories and future events proved that our class of 1992 is dedicated to serving God after our college days at Cedarville are over. As a slide of Kristy Walburn illuminated the screen, her brother, Tim, sang "Home Free" in honor of her memory. Kristy will not be forgotten.

As the senior class took to the platform and performed the class song, "Be the One," emotions ran high as the realization that our last days were coming to a close. Chapel ended as Dr. Dixon gave a heartfelt, teary charge to our class of 1992 to be the ones.

"We will be the ones to answer to His call;

We will stand when those around us fall.

We will be the ones to take His light into a darkened world.

We will be the ones."

-by Meredith Clements
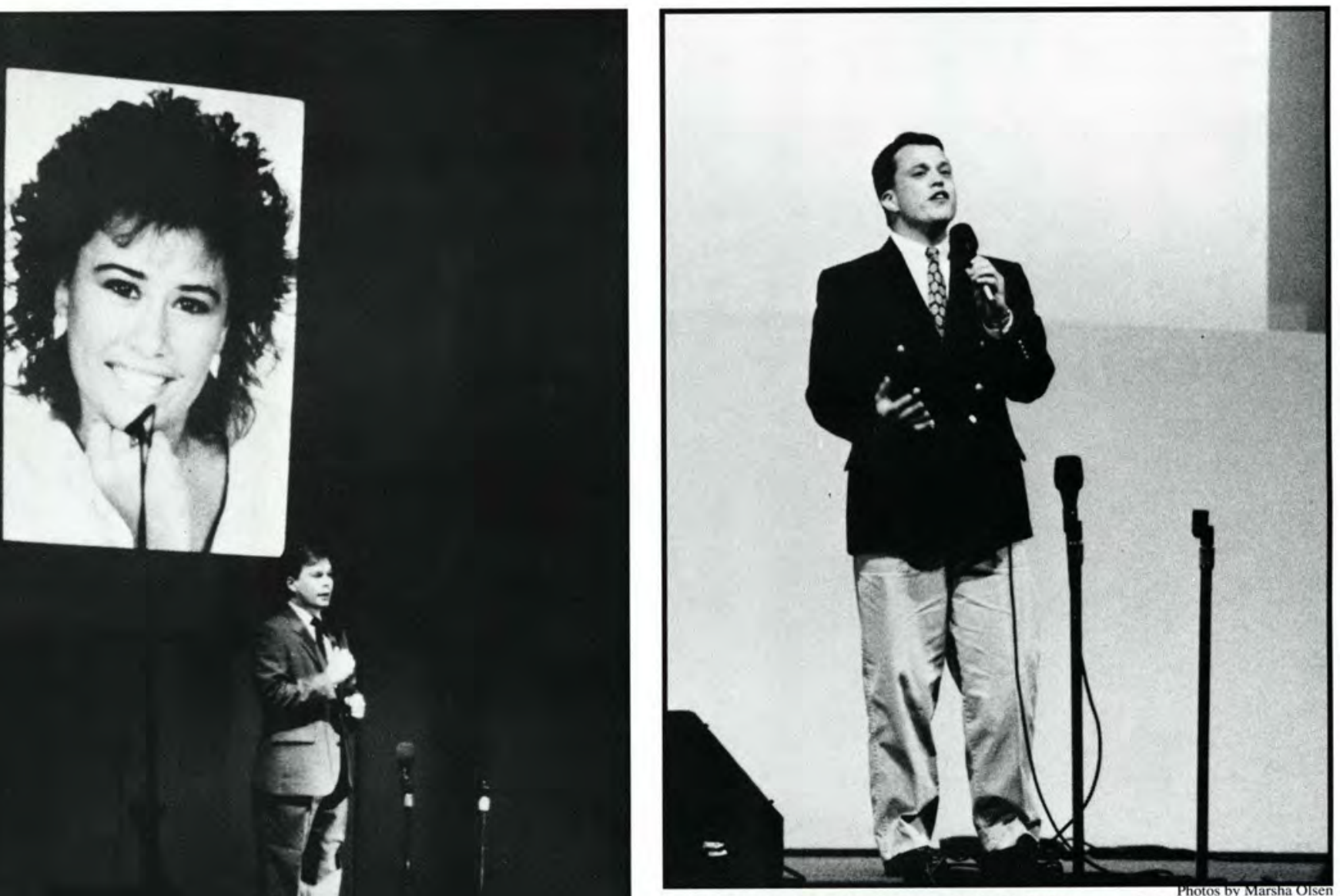

A CHALLENGING MESSAGE. Cliff Roop reinforces the message of chapel through song.

A LEGACY LIVES ON. Tim Walborn sings "Home Free" in honor of his sister Kristy who lives on in the hearts of the class of 1992. 


\section{Senior}

Recitalists

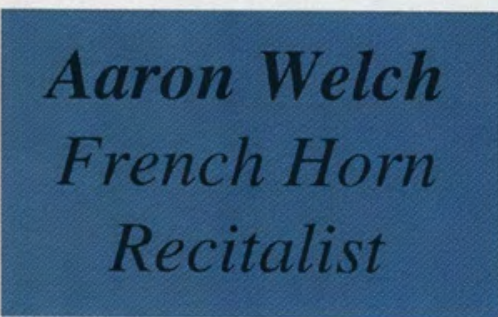

\section{Rebecca Scott Piano Recitalist}

Tracy Starr Voice Recitalist
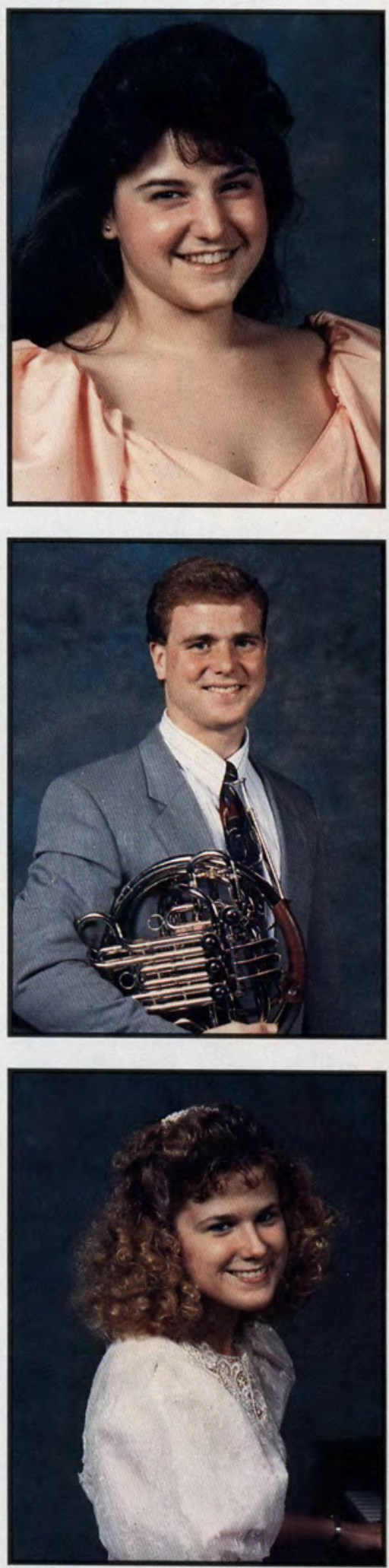

Debbie Reid Music

Composition Recitalist

\section{Paul Carlson}

Trombone Recitalist
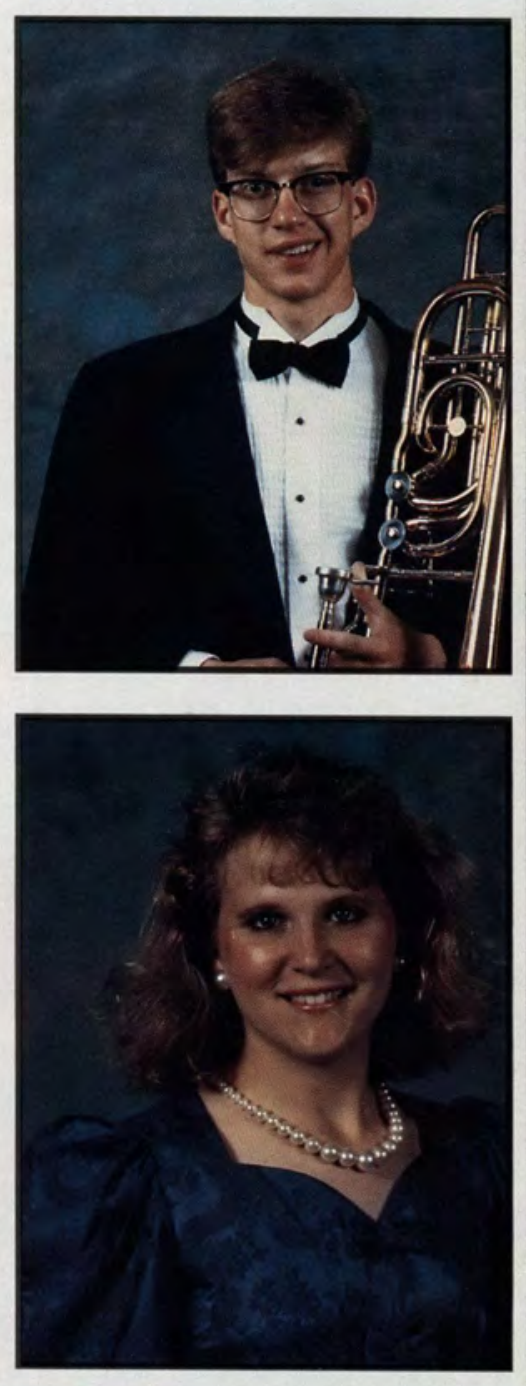

Amanda Dye

Voice Recitalist 

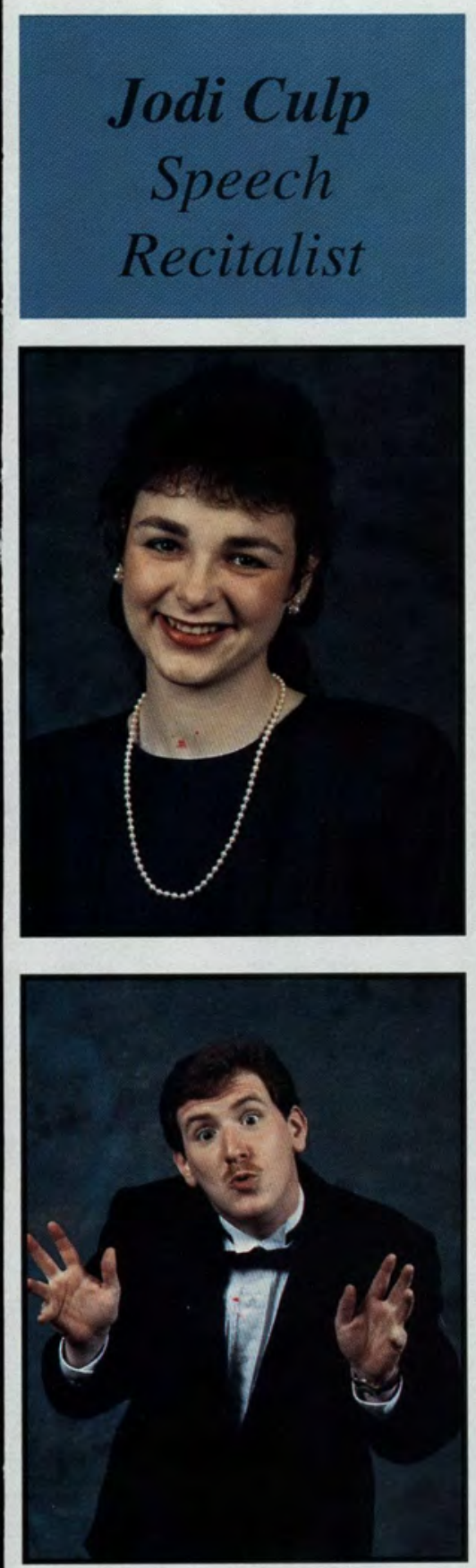

Bruce Quick Speech Recitalist
Matt Moore

Speech Recitalist
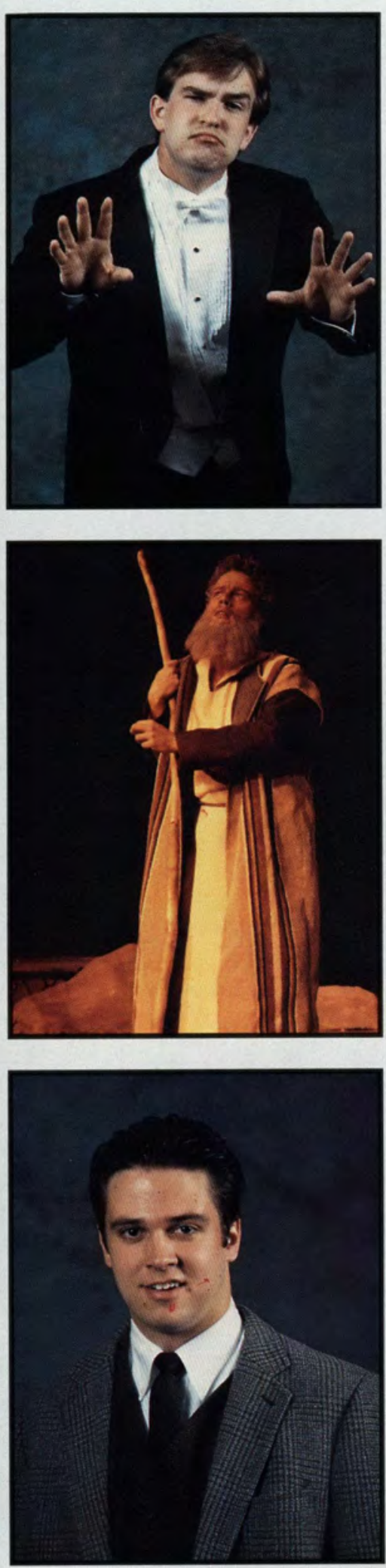

Andrew Rudd

Speech

Recitalist

\section{Partraits}

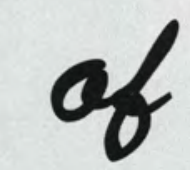

Excellence
Scott Ludington

Speech Recitalist

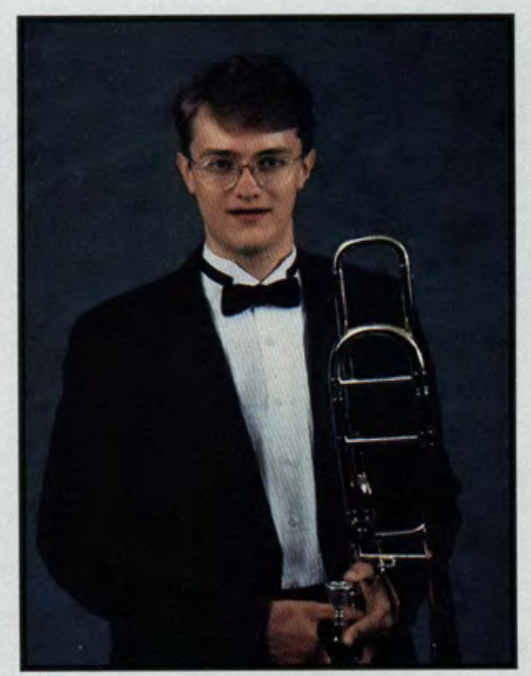

Keith Watson

Trombone

Recitalist 


\section{More Than Just Familiar Faces}

\section{Reflections of a Senior}

It's time to pick up caps and gowns? Already? Are you sure? If seniors didn't say it out loud, we were all thinking it. It seems like just yesterday we were hiking to the Indian Mound for our freshman class picture, and here we stand waiting to pick up our regalia for our final meeting as an entire group.

As I look around, I see mostly familiar faces. Some I have grown to know and love. We grew together, made mistakes together, cried together and laughed together. We built friendships that will now slip into a new phase as God leads us in different directions.

Other faces are familiar in the same way my home furnishings are familiar. I've seen them every day but never really talked with them. They weren't deeply involved in my life, nor I in theirs. But still I'll miss them. In a way those friendly faces have helped shape my definition of home for the past four years. Even more than just familiar faces, they are people who have undergone similar experiences as I. I might never have talked with them, yet I feel they understand me.

Now we must face the future, redefining "home" again. New faces will come, but for now the old familiar ones will be missed. -Jesse Wesselink
SENIORS endure one of their last lines at Cedarville.
Photo by Jesse Wesselink

GIVING HONOR TO WHOM HONOR IS DUE, Scott Luddington gives honor to Dr. Dixon as his fellow

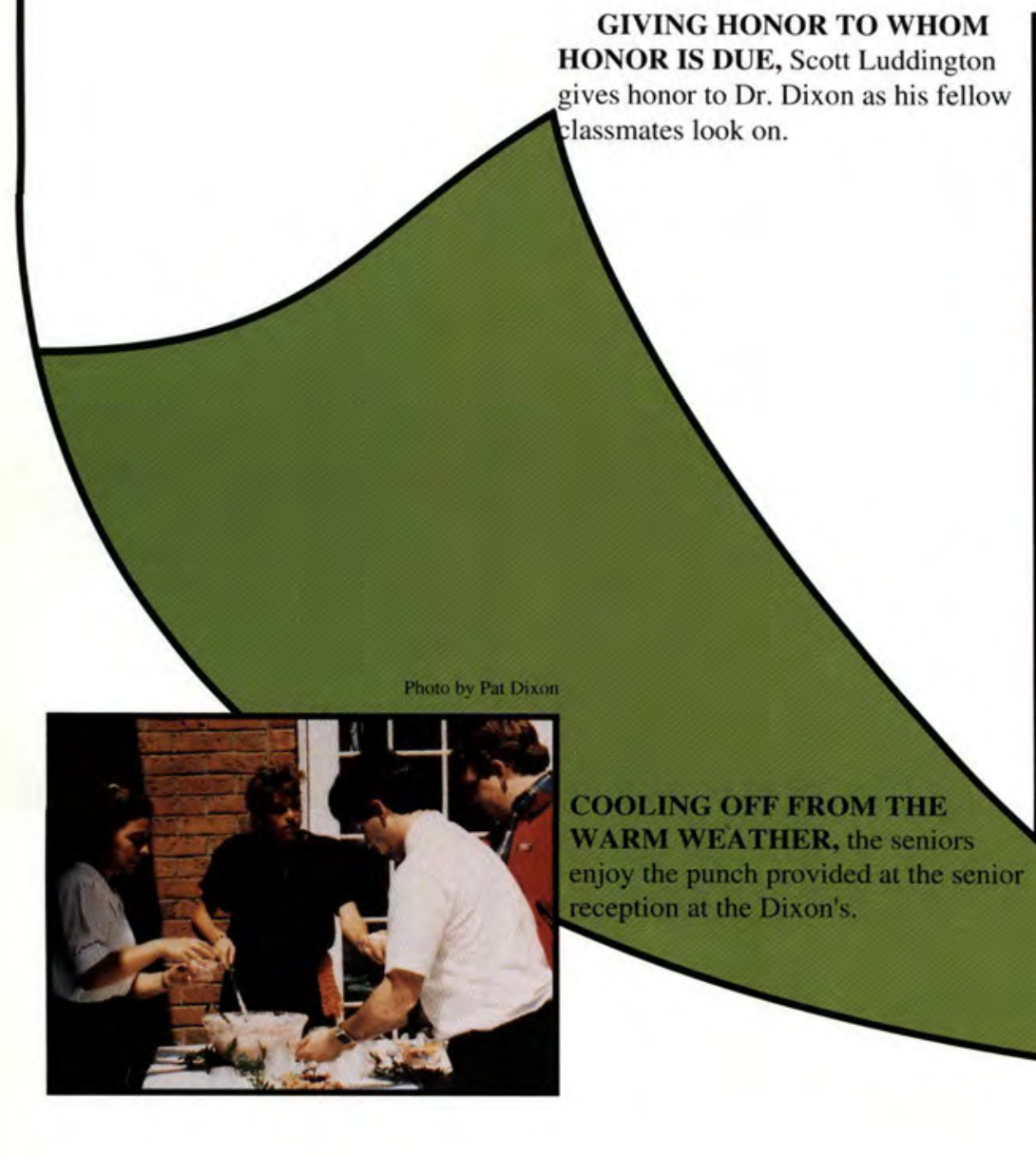
COOLING OFF FROM THE WARM WEATHER, the senior enjoy the punch provided at the senior reception at the Dixon's.

classmates look on.
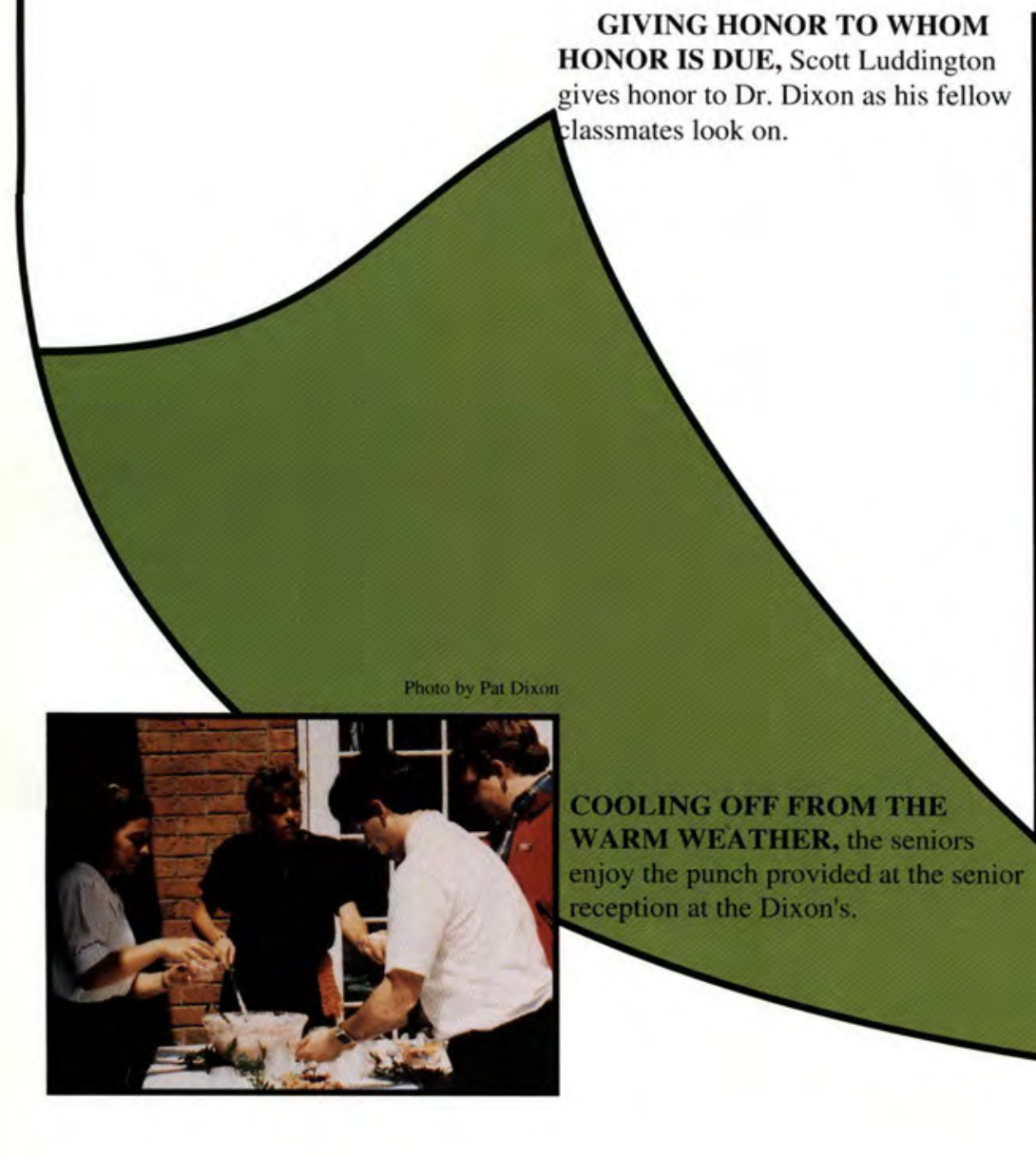

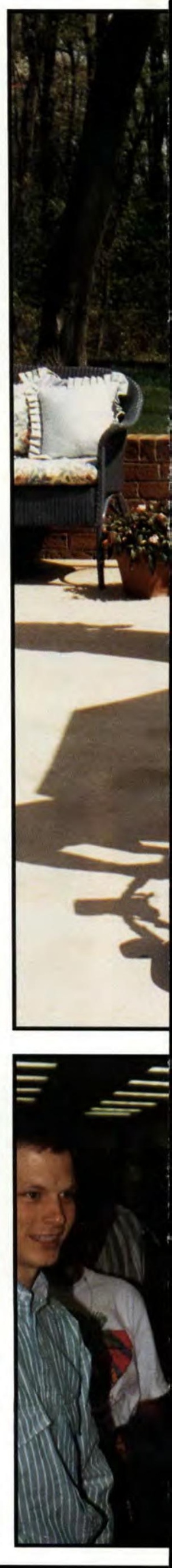



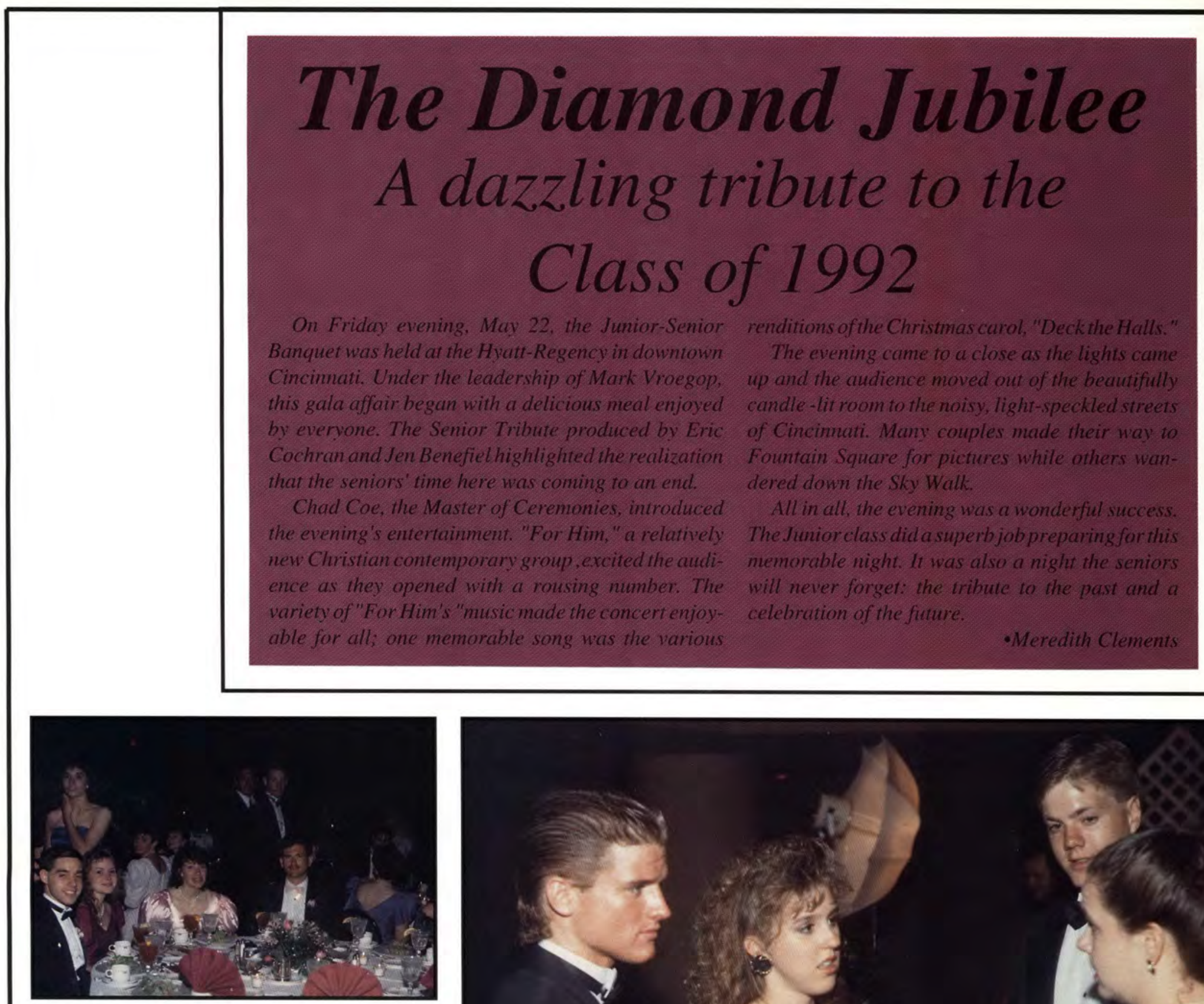

\section{A BEAUTIFULLY ADORNED}

TABLE created the setting for truly memorable evening.

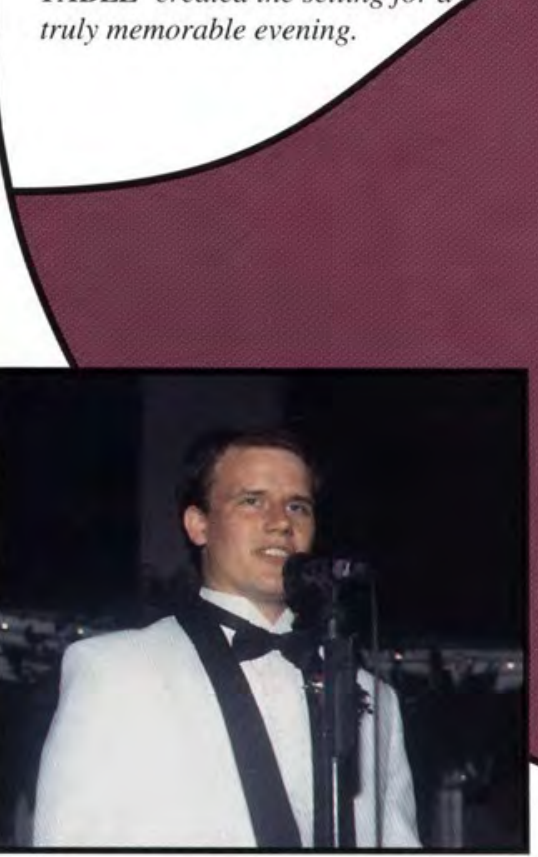

THE MASTER OF CEREMONIES,

Chad Coe, introduces the entertainment for the evening.

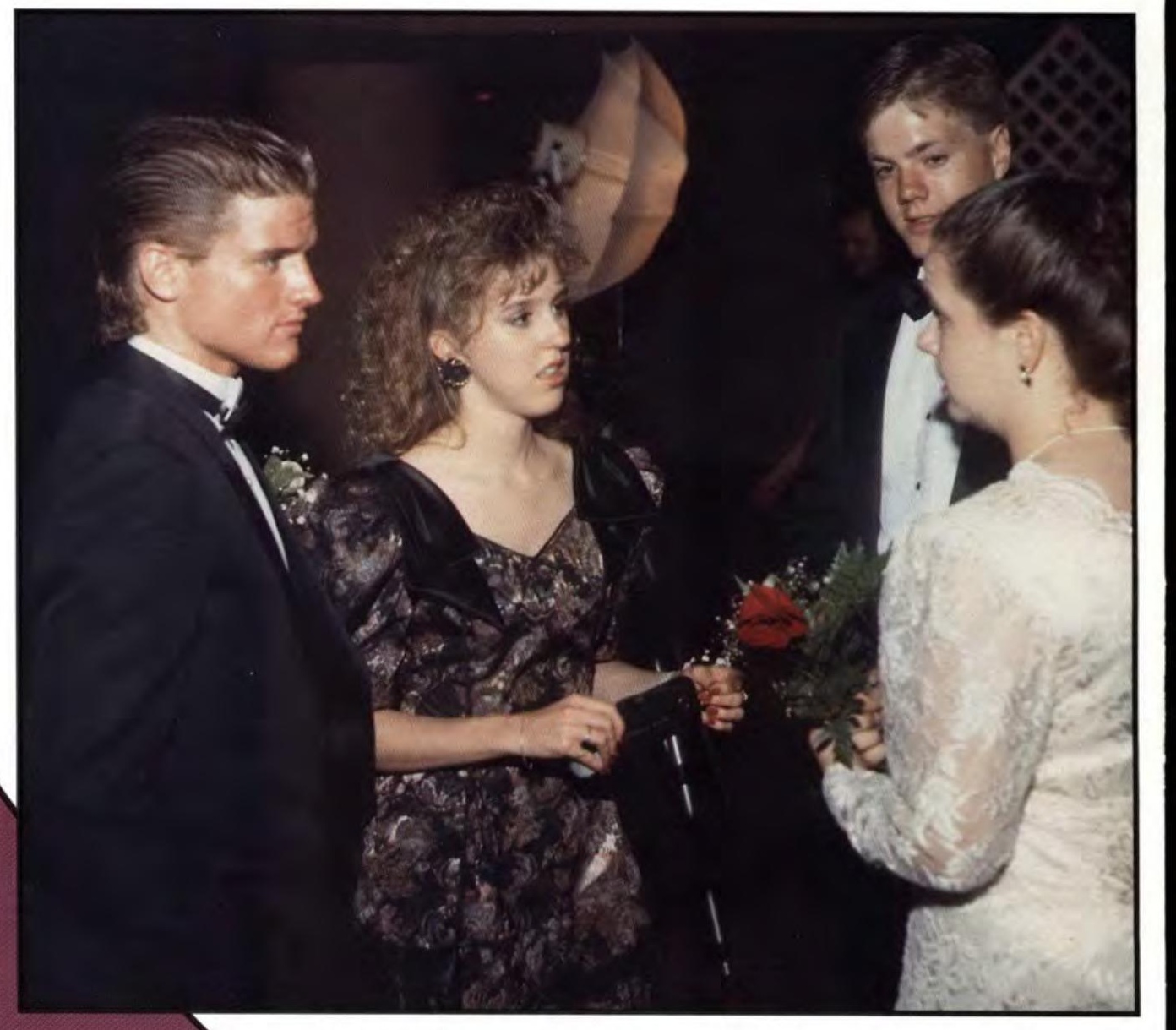

SOCIALIZING BEFORE THE BANQUET, Kevin Parliament and Allison Knowles prepare for a relaxing evening of elegance. 


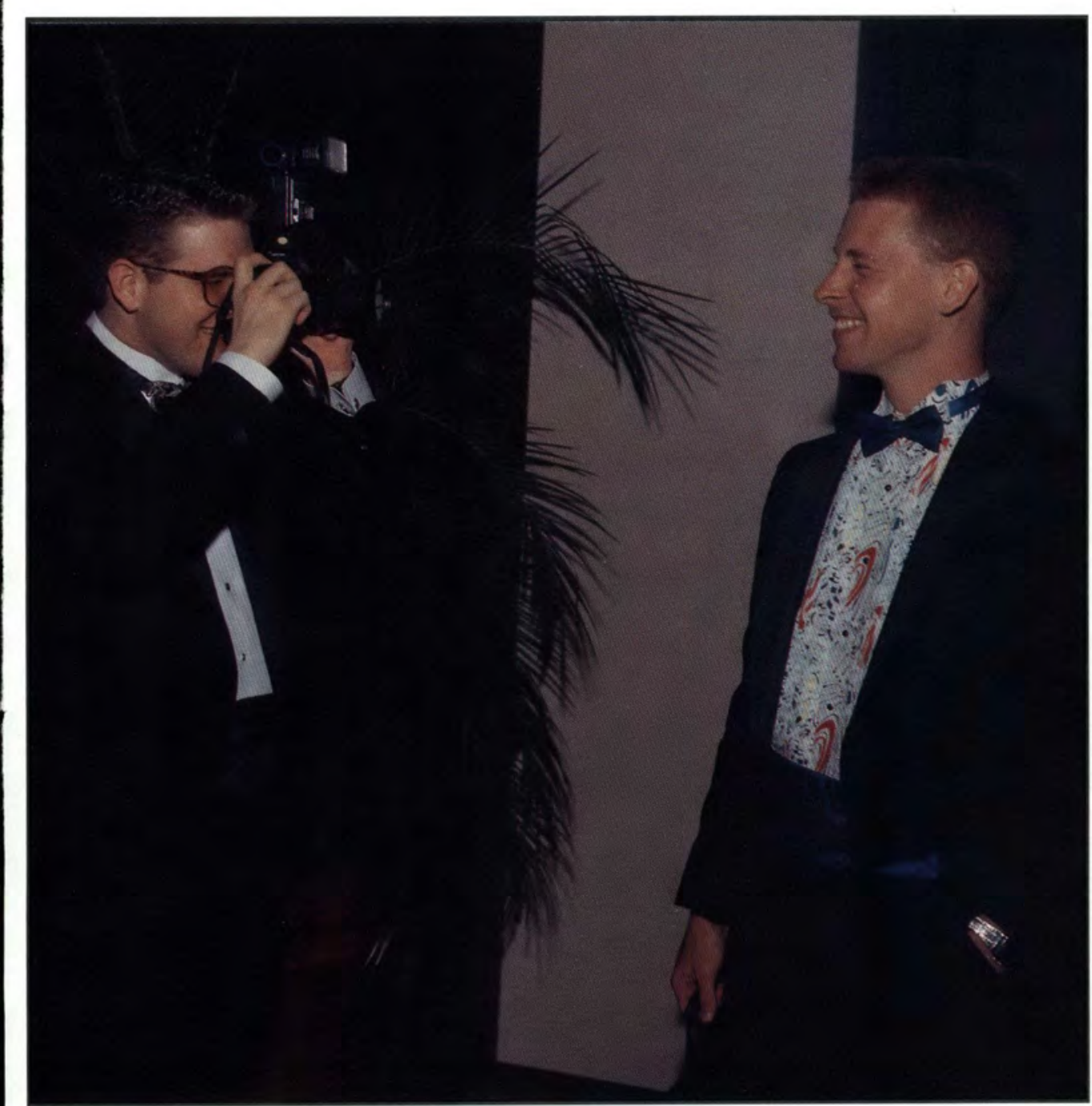

WITH A WILD SHIRT, Bill Montgomery says cheese as he is photographed to create a lasting memory.

WITH A MENU IN HIS HAND, Bruce Quick

compares tonight's menu with Chuck's.
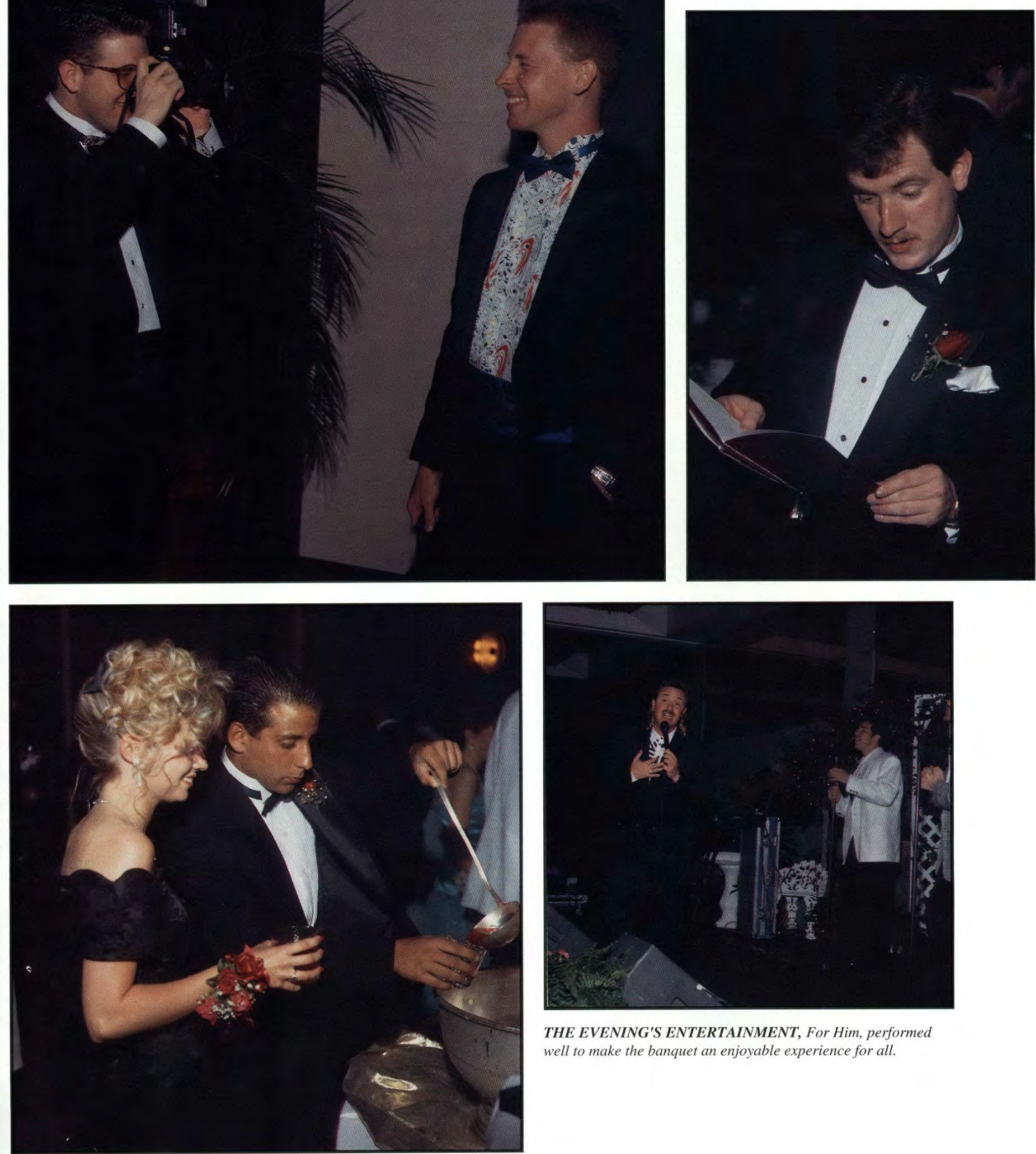

THE EVENING'S ENTERTAINMENT, For Him, performed well to make the banquet an enjoyable experience for all. 


\section{'We Will Be The Ones To Answer To His Call.'}

Rene Maxwell, Senior Class President, presents the class gift to Dr. Dixon.

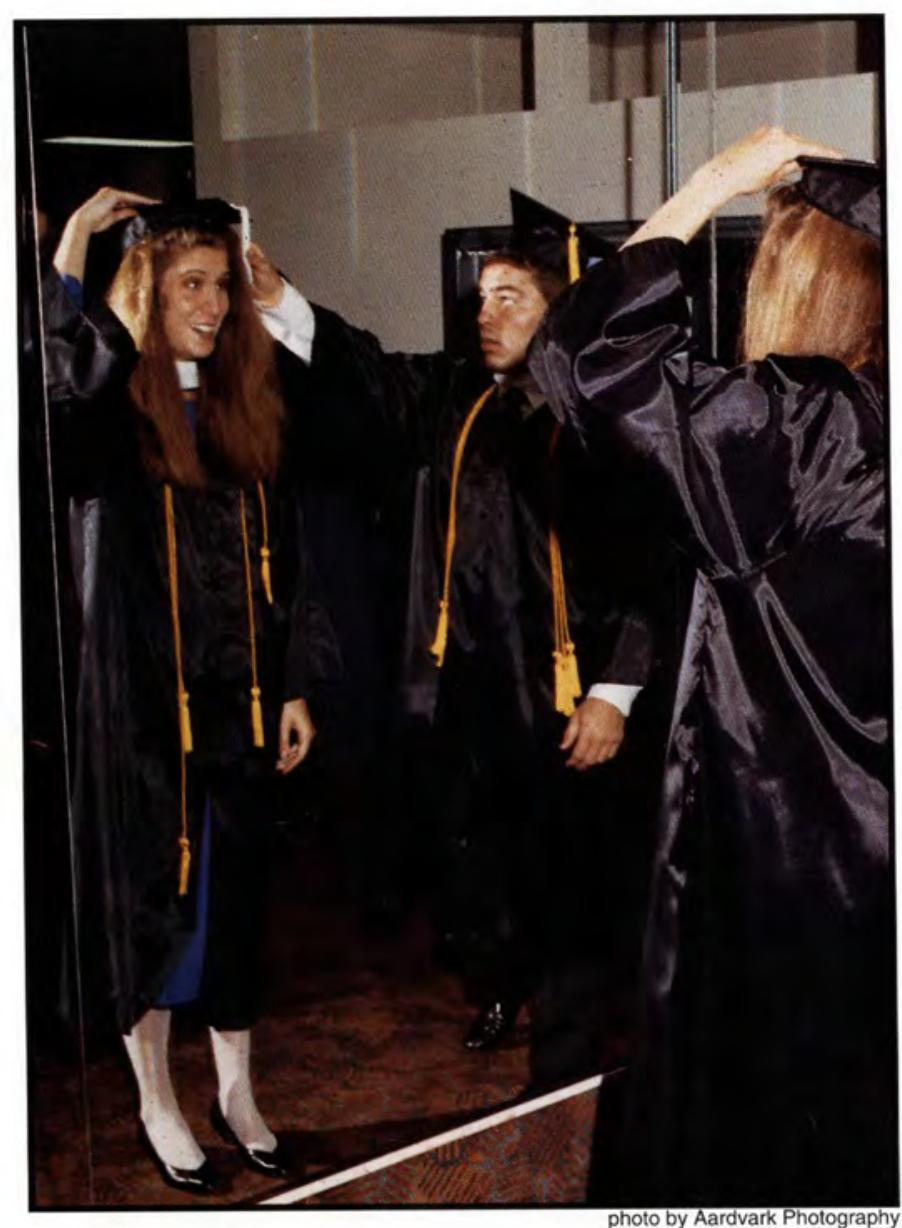

A HELPING HAND Graduates find the regalia a bit tricky to wear.

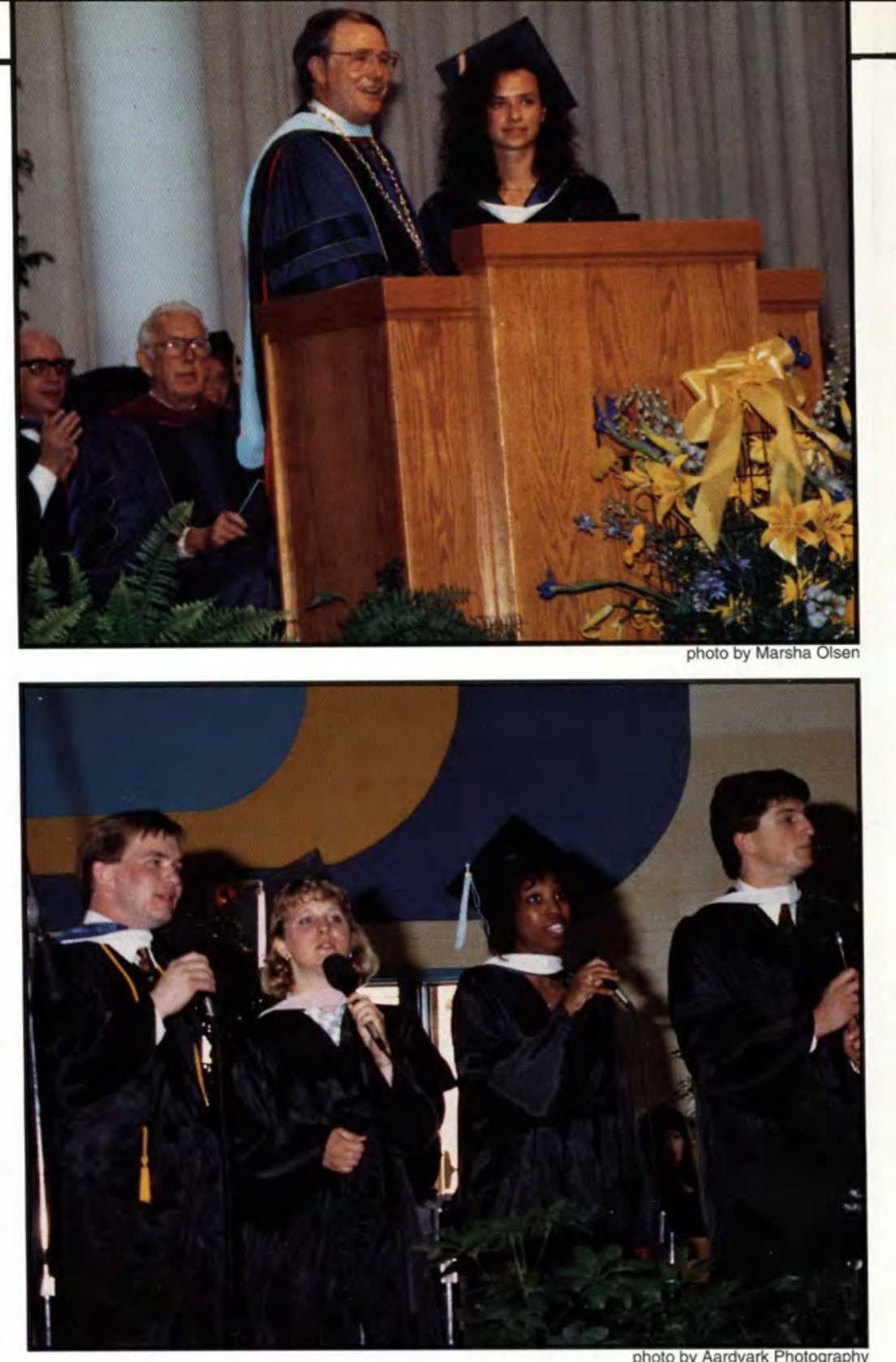

"WE WILL BE THE ONES" Seniors lead their class in the class song.

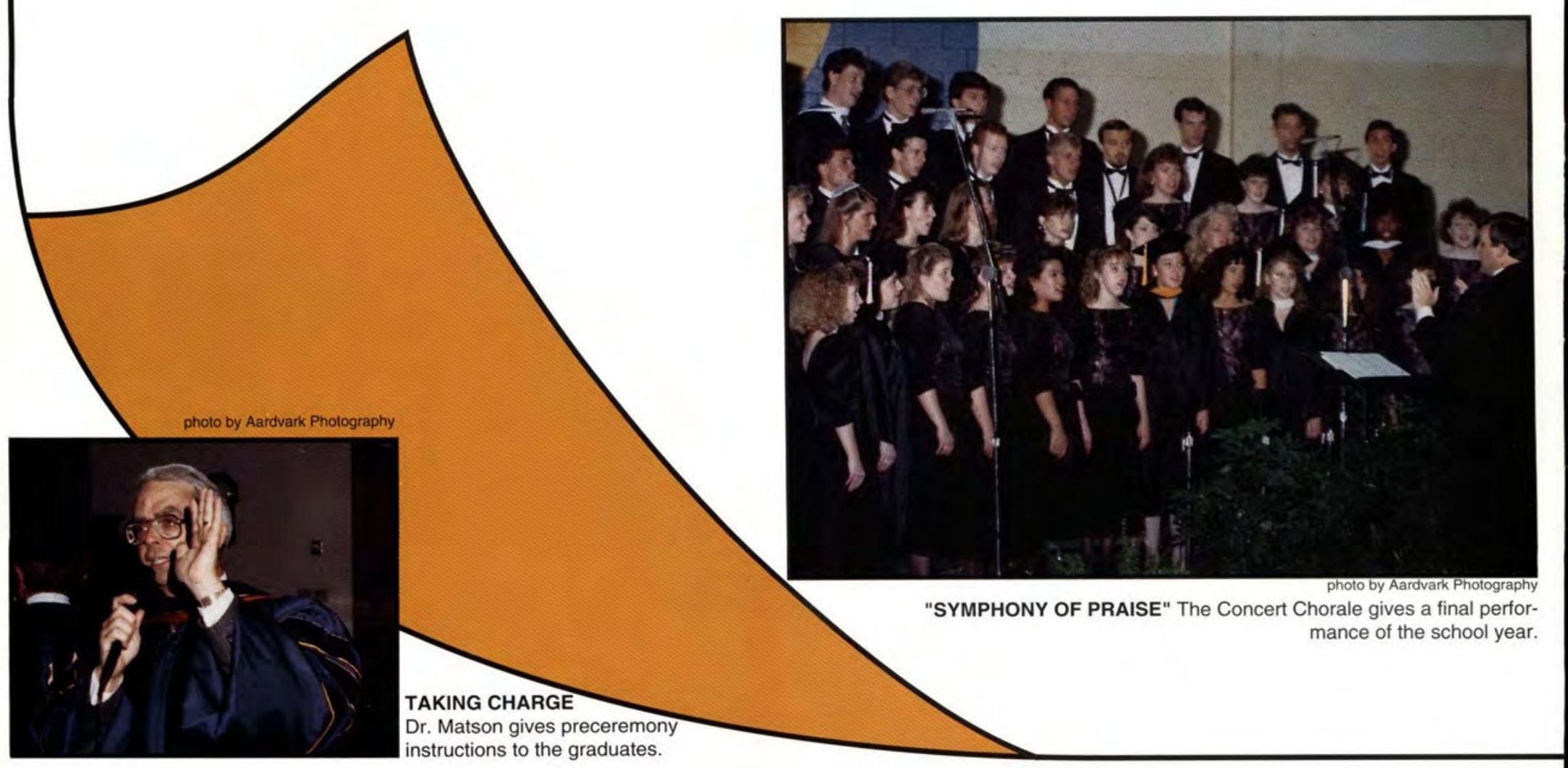




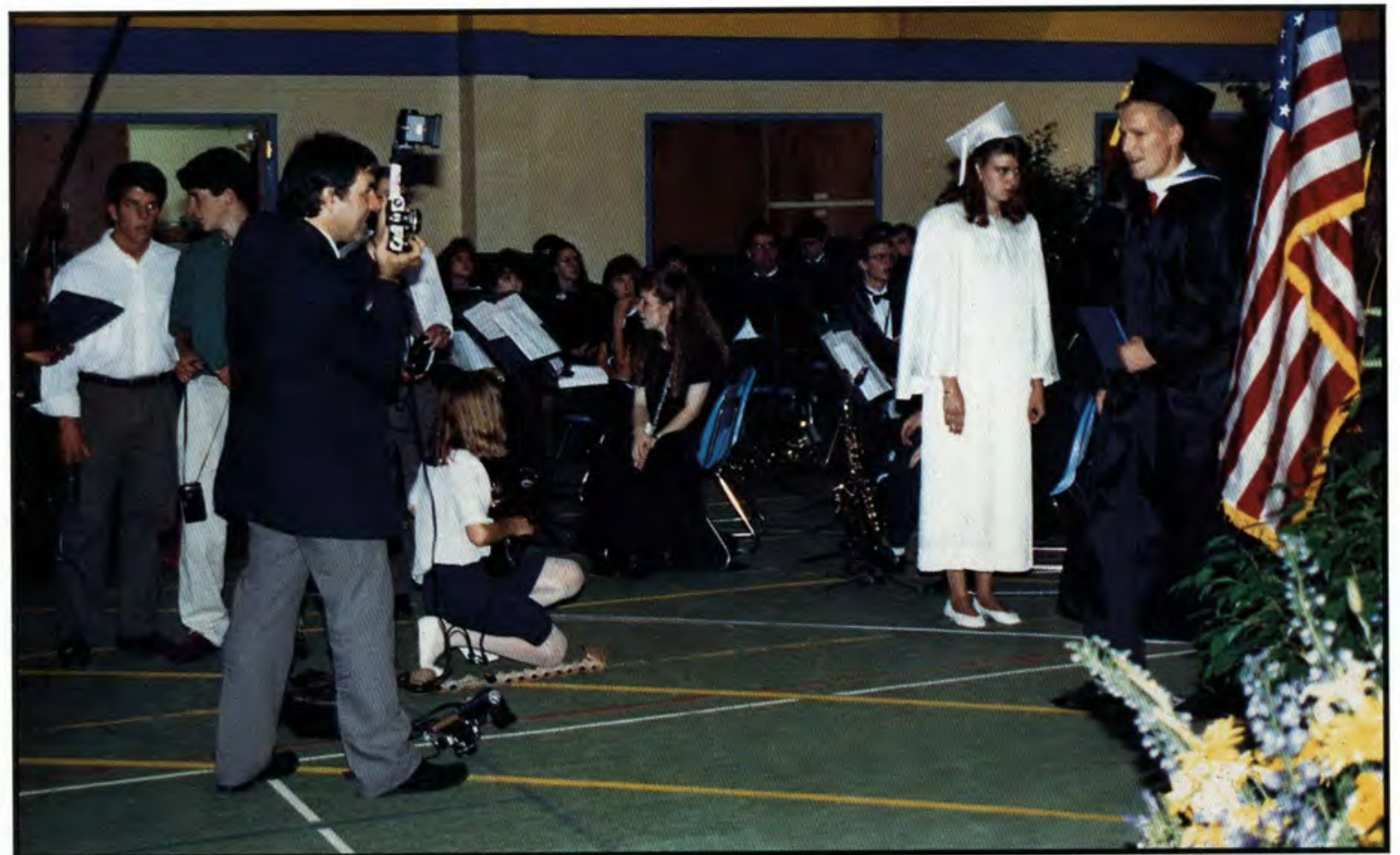

photo by Aardvark Photography
PAUSING FOR A SMILE

Graduates give a passing smile to yet another pointed camera.

MAKING IT OFFICIAL Melanie Wolf leads the class in the turning of the tassels.

\section{Commencem
1992}

Cedarville College's largest senior class of 420 was graduated on June 6,1992 . Commencement is a most exciting convocation on campus. Relatives and friends of the graduates are a vital part of this God honoring event. Mindy Boone, an English education major, exclaims, "So many people behind one diploma. Multiply that by 420 graduates and imagine the number of people involved!" This ceremony is the seniors' opportunity to express praise and thankfulness to God, family, friends, faculty and staff for their input into their four years of education.

It is also a time to be challenged by President Dixon's annual commencement address: "Pagan America and the world around us are in desperate need of some biblical family modeling from you graduates. The vast majority of our citizens knows America's problems go back to the breakdown of the traditional biblical family."

After his challenge came the awarding of diplomas and special senior honors: President's Trophy Awardees, Kezia McNeal and Matthew Moore; Faculty Scholarship Awardee, Robert Rodebaugh. Mindy's feelings express what most graduates felt at the closing: "Diploma in hand, I regained my seat and began to think about all that lay behind President Dixon's words, '...I bestow upon you the appropriate degrees with all the rights and privileges pertaining thereto.'" photo by Aardvark Photography

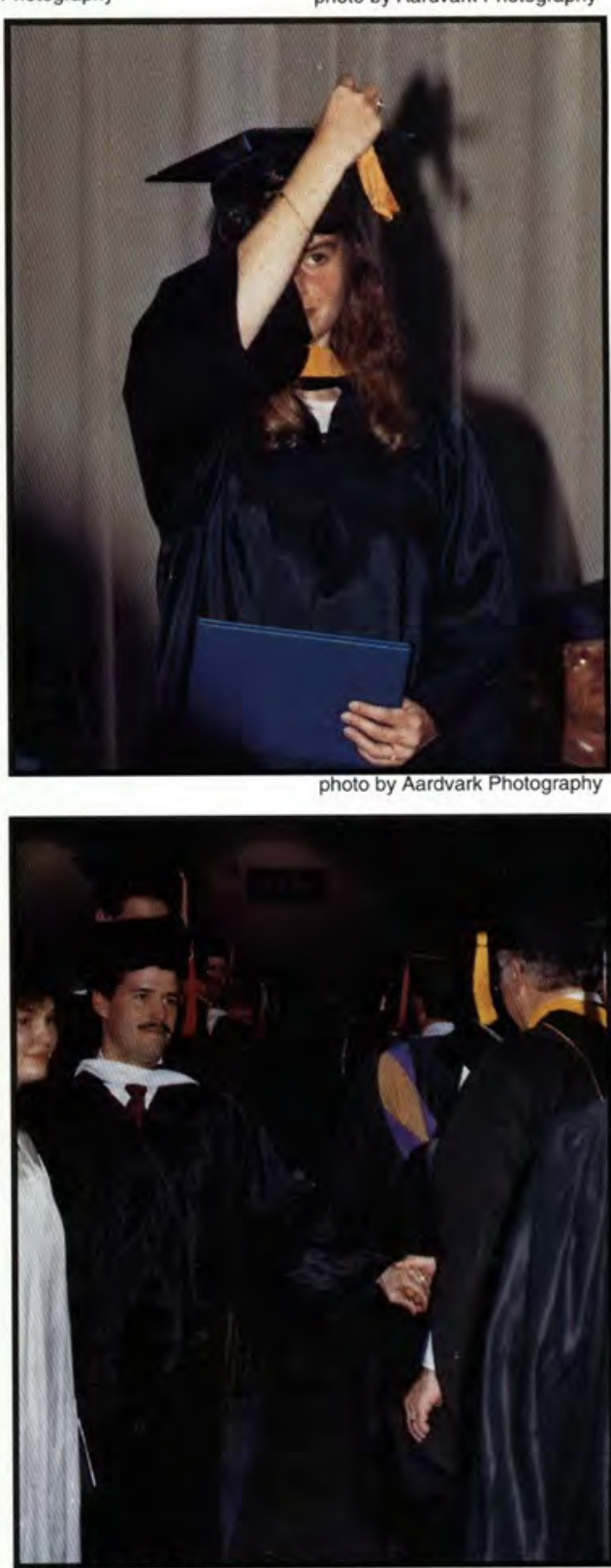

LAST GOODBYES Tim Heinrich bids faculty members farewell on their way out of the ceremony.

Seniors 


\section{'We Will Stand \\ When Those Around Us Fall.'}

WITH A LOOK OF GRATITUDE Joy Sissom sings to the parents and faculty present at the Nurses' Convocation.

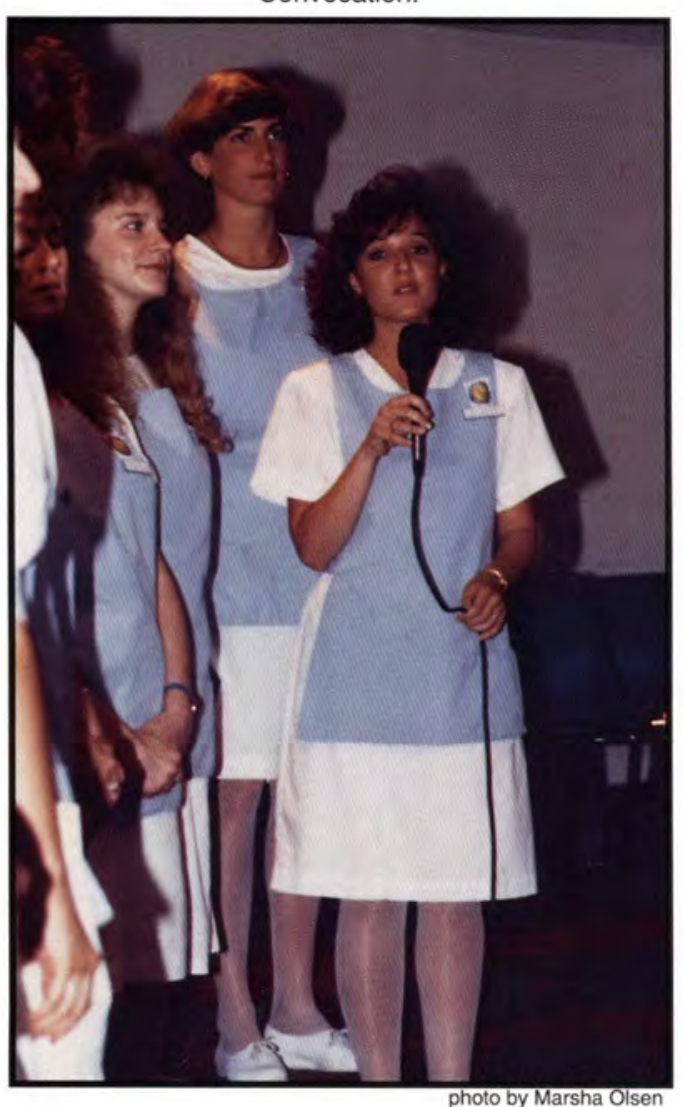

photo by Marsha Olsen

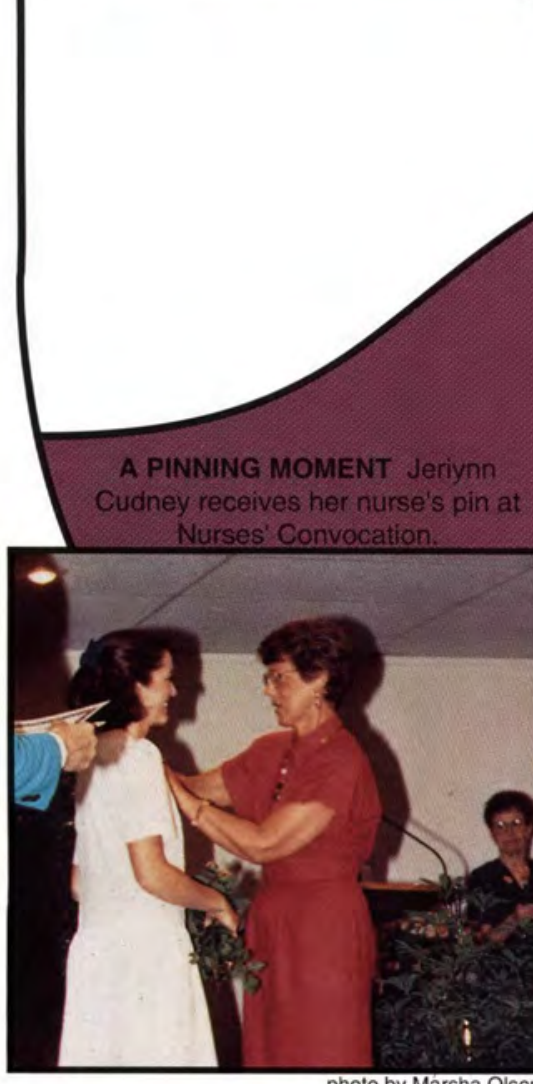

4170 Seniors
ONLY FOUR HUNDRED TO GO Dr. Dixon presents

Raul Mosely with his diploma.

ONE LAST CHALLENGE Dr. Dixon addresses the '92 graduates with a message from Jeremiah 29:11.
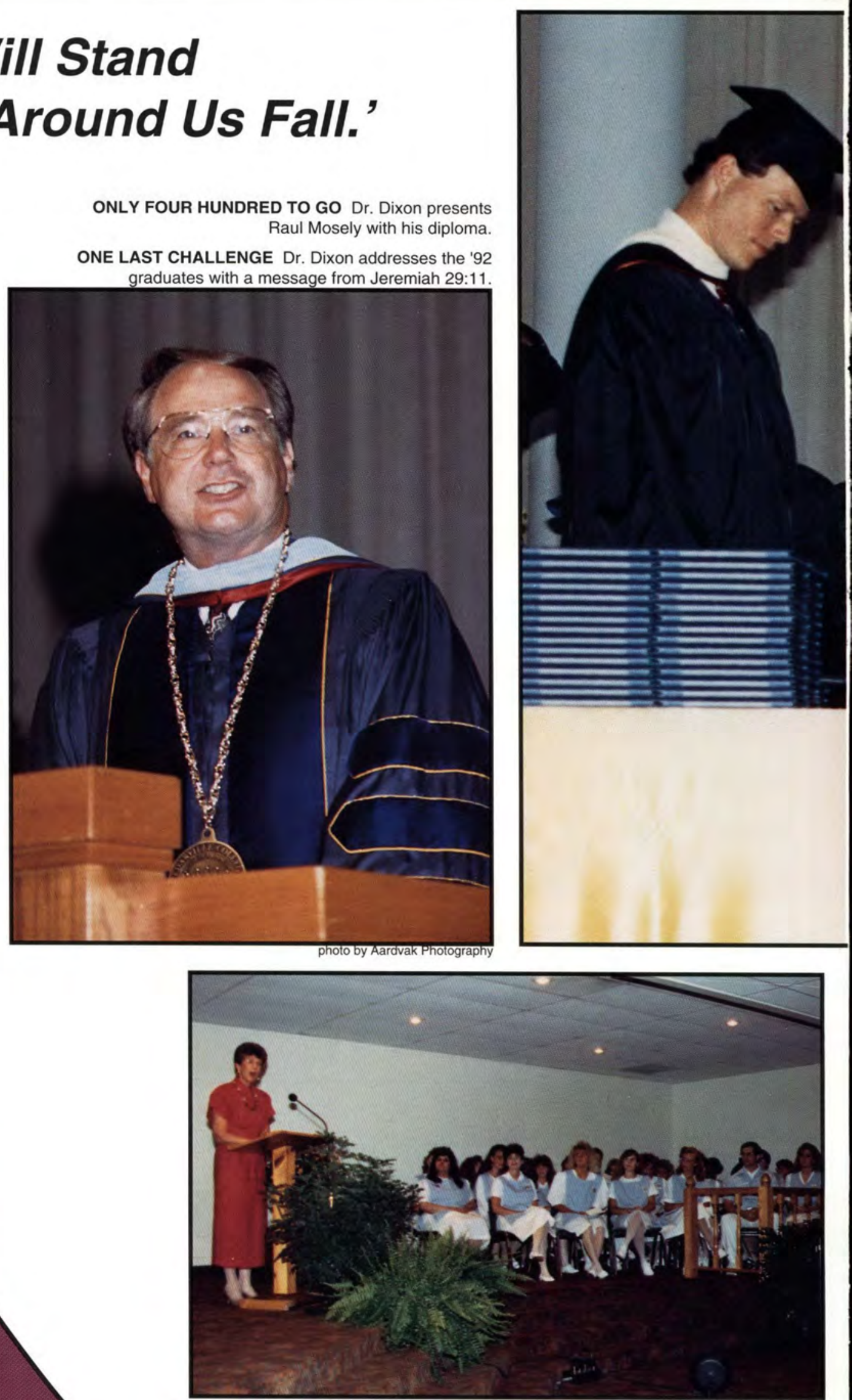

photo by Marsha Olsen

FINAL WORDS. Dr. Irene Alyn addresses Nursing graduates and parents at the Nurses' Convocation. 


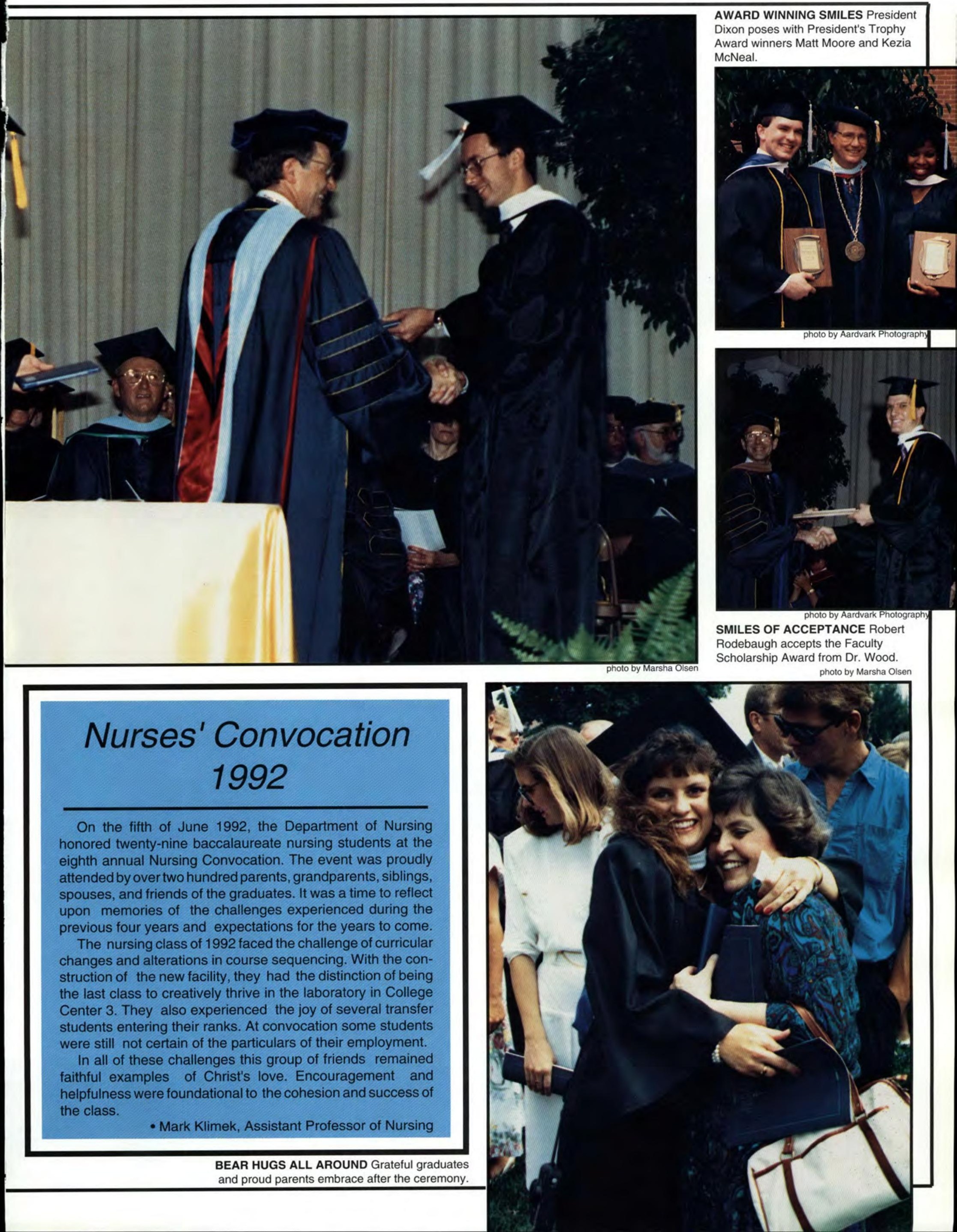




\section{Class of 1992 \\ Facing the Future}

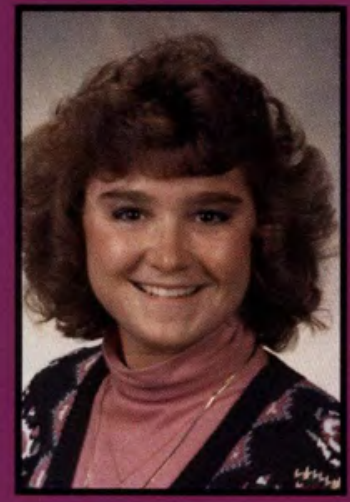

Shawn Abbot

Keedysville, $M D$

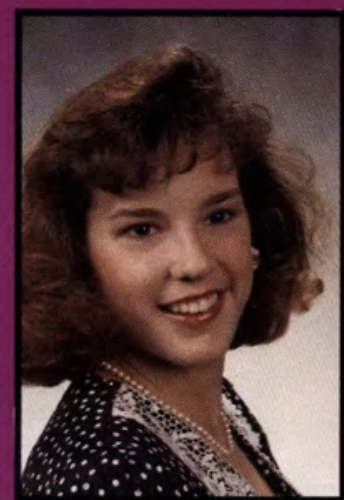

leather Anderson

Education
pring Lake. Mi

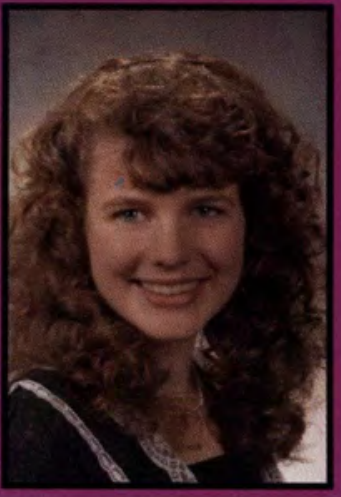

Rebecca Aud

Communication Arts

Halifax, PA
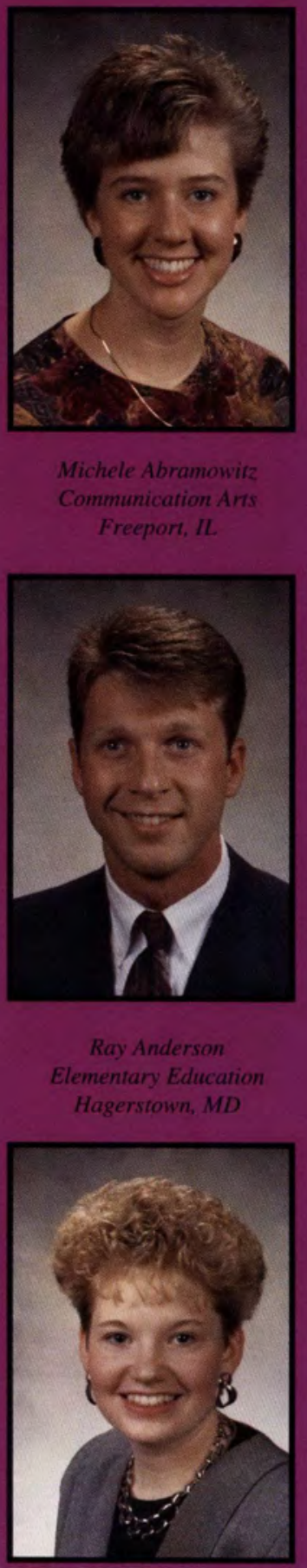

Barbara Aughinbaugh

Elementary Education

Pataskala, $\mathrm{OH}$

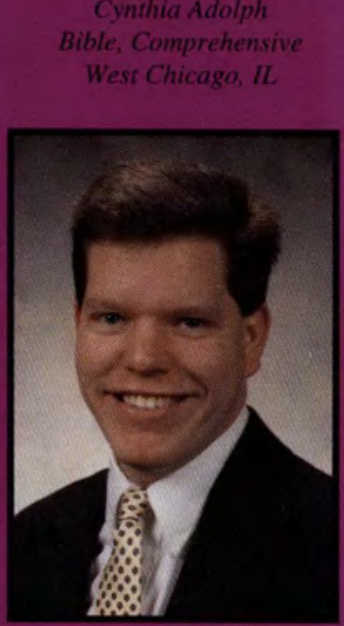

Flementary Educat

Fenton. M
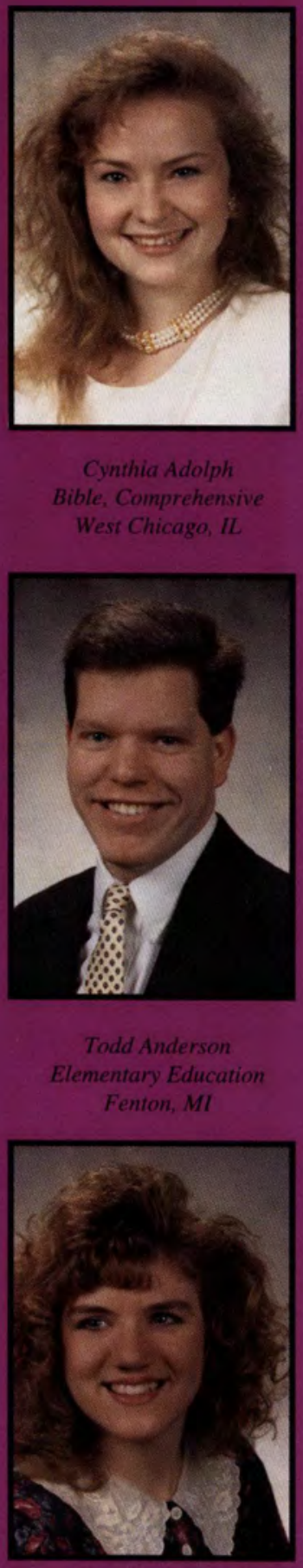

Kimberly Averitt

English
Centenville $\mathrm{OH}$

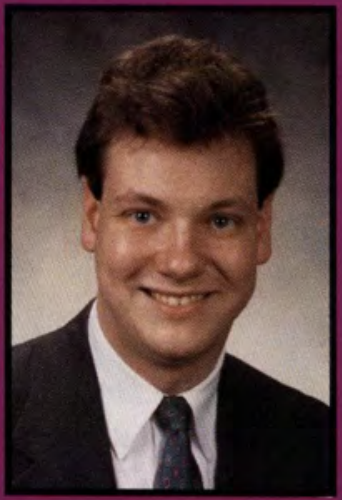

Stephen Alexande

Pittsburgh, PA

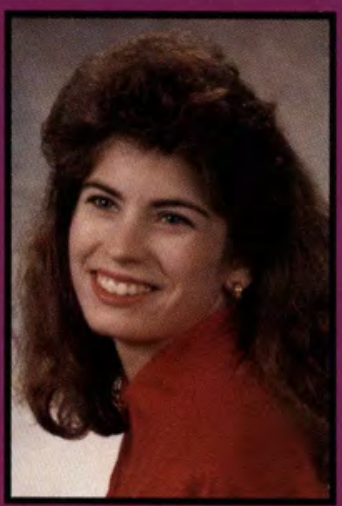

Christina Ash Nursing

Hanover, IN

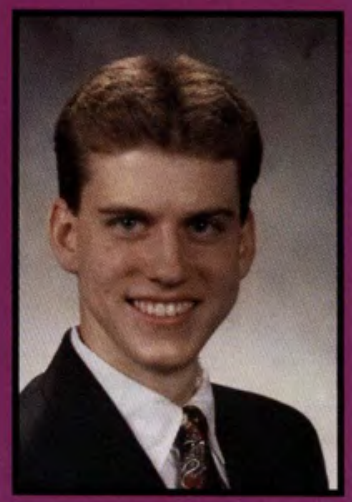

Philip Baab

Mathematics

Grand Rapids, $M$

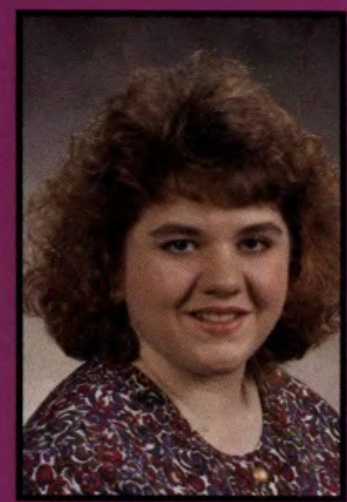

Patricia Allen

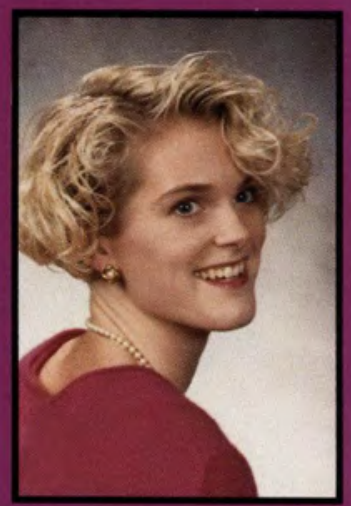

Amv Ashbaugh Educatio

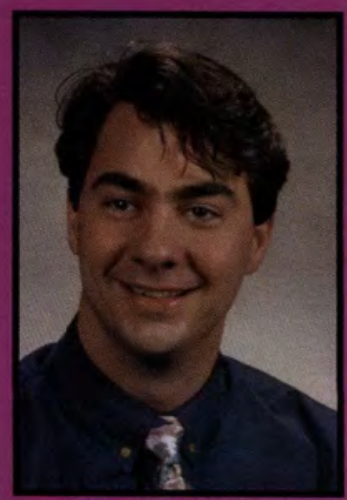

Duane Baggerly Psychology 

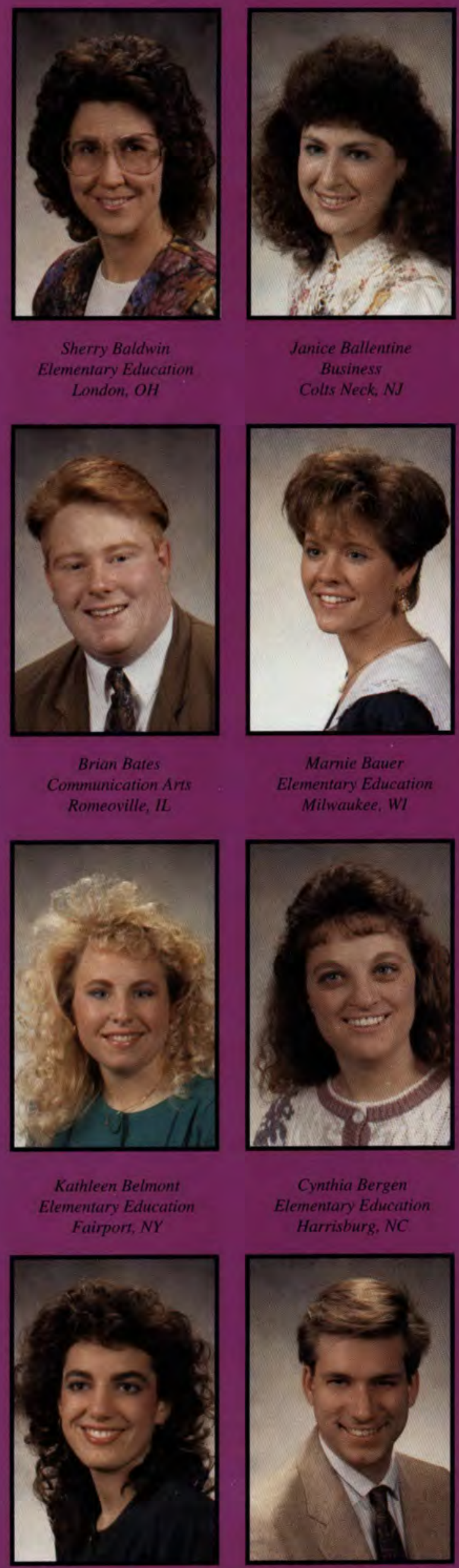
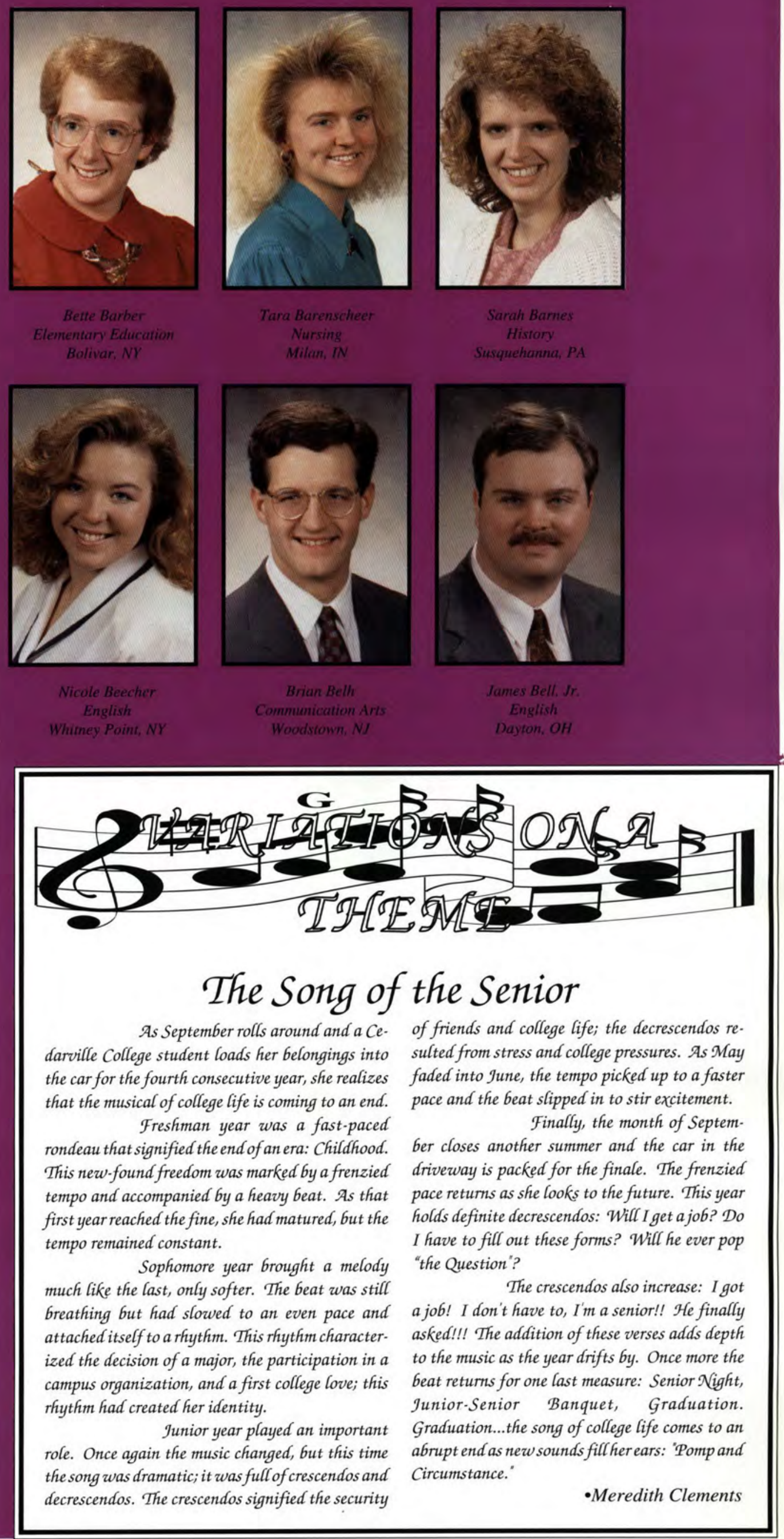

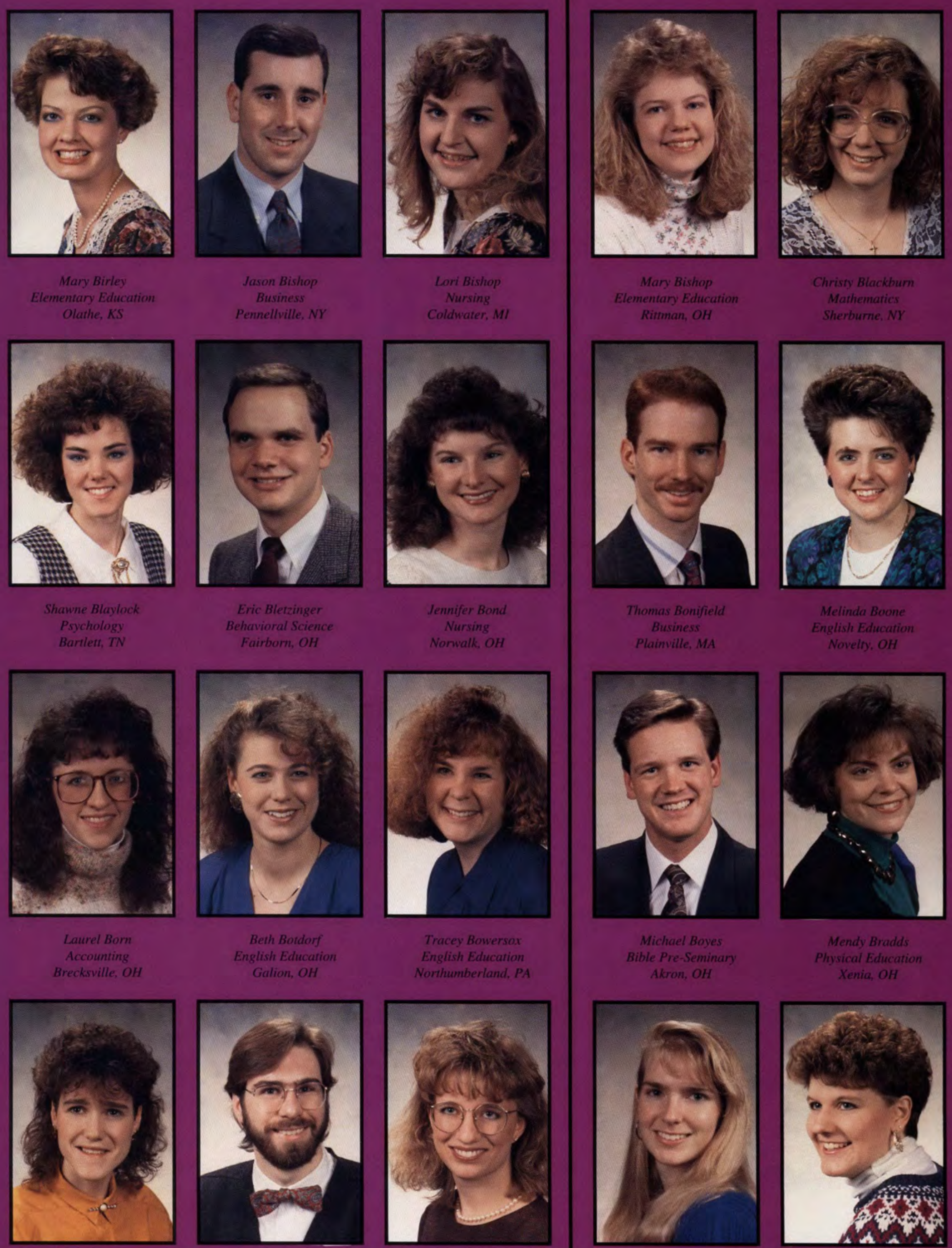

[174t Seniors 

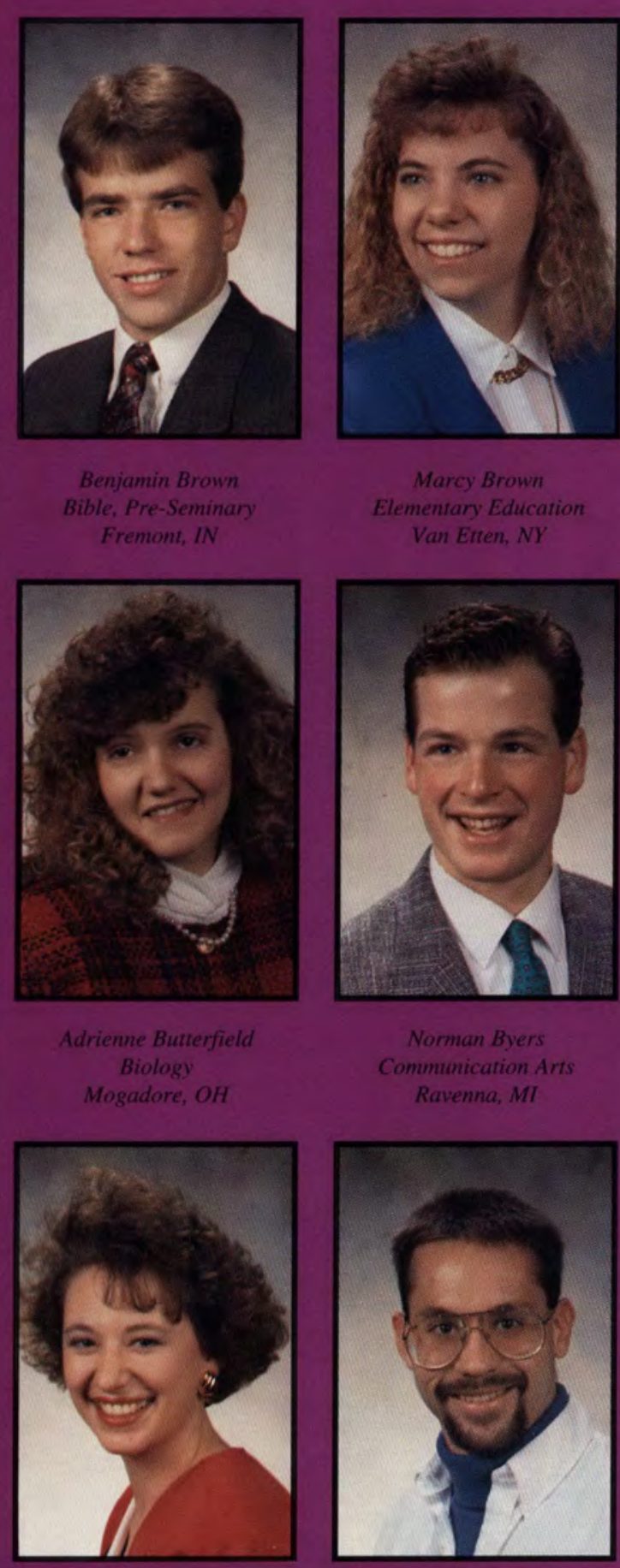
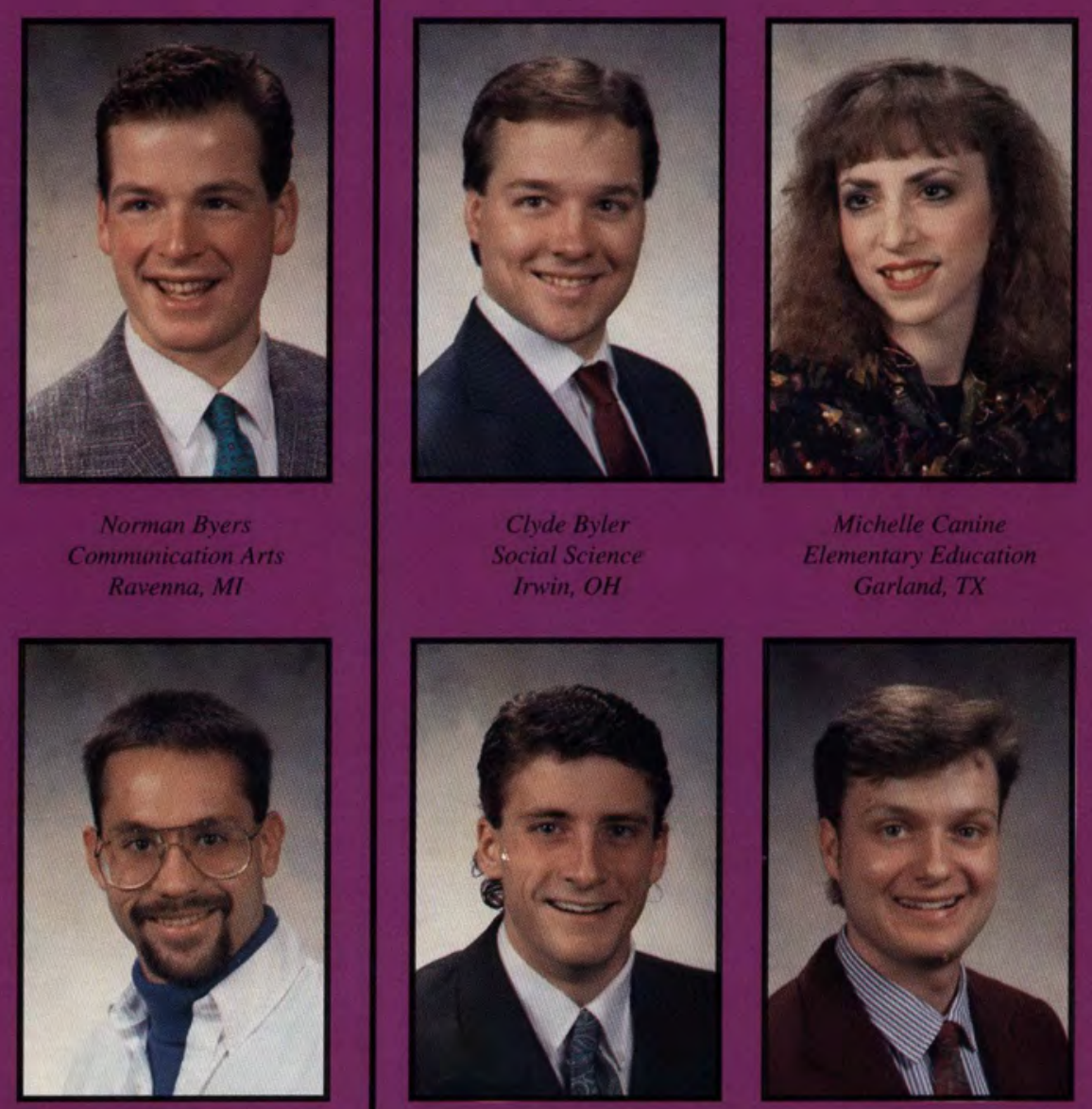

Perer Cos

Andover. MA
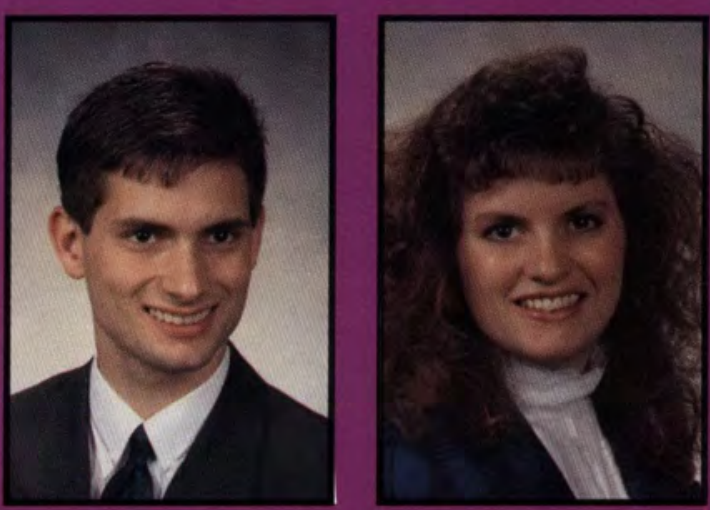

Michelle Canine

Brendon Cearle
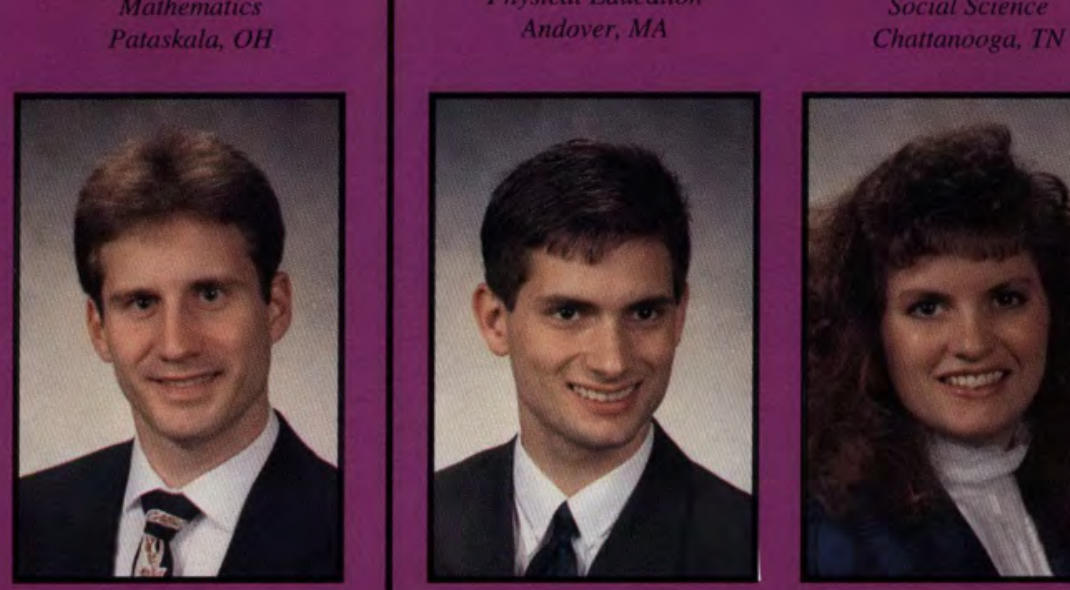

raticititics

Bible Comprehens

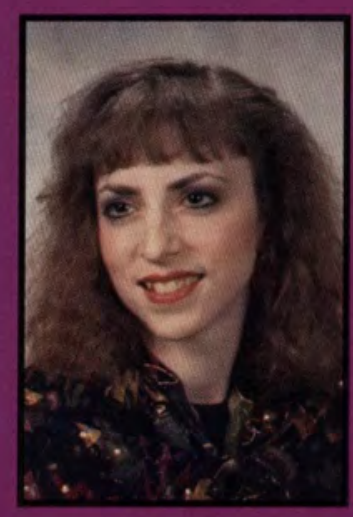

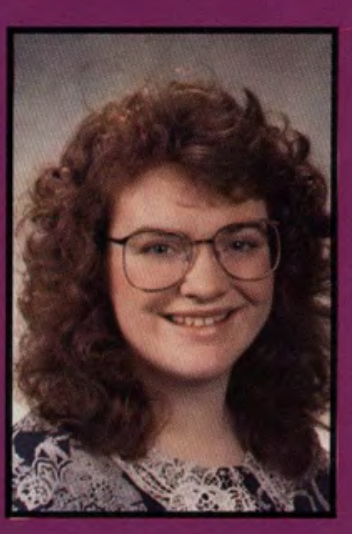
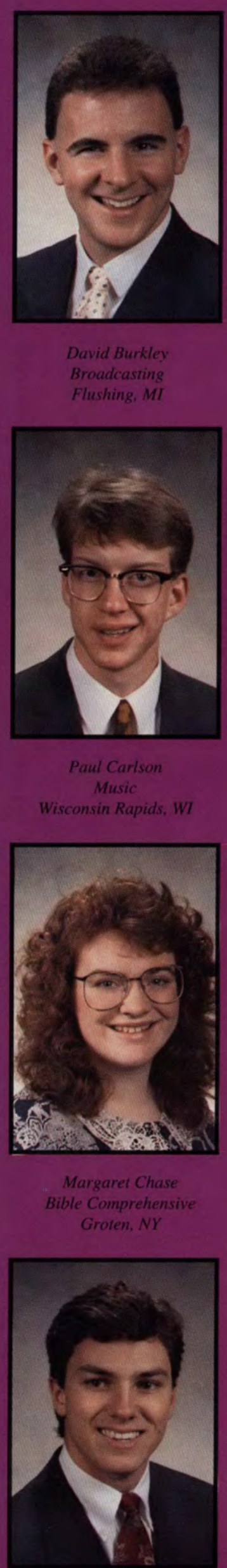

David Burkle

Broadcasting
Flushing. MI

Paul can

Groten, NY

Janson Condren
Mathematics 

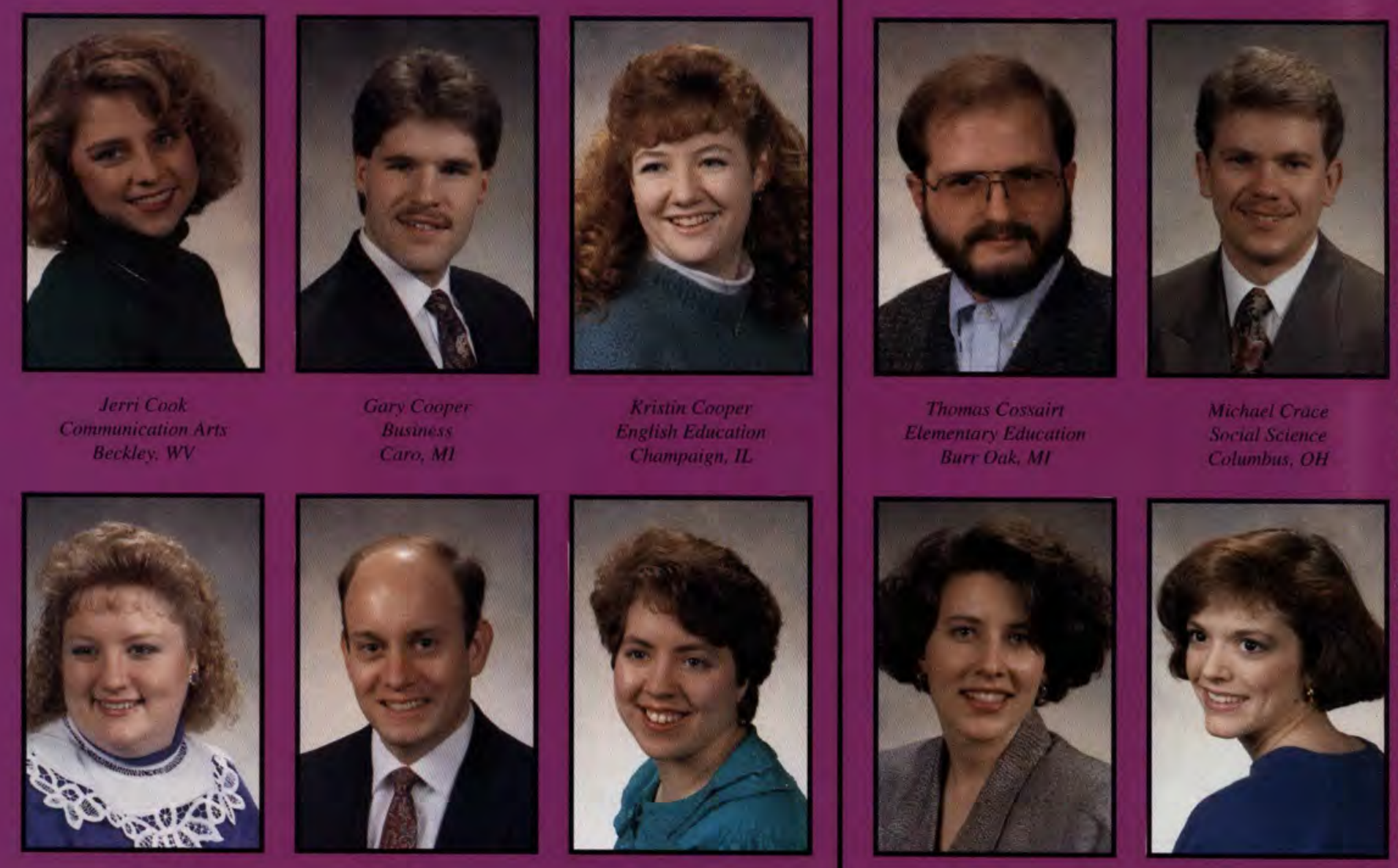

\section{R IPOrtrait of Victorry}

Tammy Harvey represents what sports and life should be about. As a figh school freshman, Tammy ran with the best in the state. Nearly everyone in Cedarville would have difficulty duplicating the times she had posted by the end of tent h grade. At this point, Tammy suffered some injuries, Gut two years later she enrolled at Cedarville with high fopes for her runing career.

$\mathcal{A}$ trip to $\mathcal{N}$ AIA nationals in cross-country and $\mathcal{N C C A}$ A All-American status in track indicated that Tammy's running was again on the upward climb. Unfortunately, instead of going on to become one of the best runners in Cedarville fistory, Tammy spent the large part of the next two years in and out of training rooms, swimming pools, and ice cold whirlpools. She raced occasionally, usually not as well as in the past; but once in a while, agood workout or race would give Coach King, Tammy, and her teammates a glimmer of hope for the future.

Meanwhile, Tammy was enjoying school. She liked her major, fell in love with a fellow runner; and, despite not racing frequently, was named co-captain of the cross-country team her junior year. Tammy's upbeat spirit and desire to serve God helped unify the team.

Going into Tammy's senior season, the captains of the team, Tammy, Brenda Paulfiamous, Kris Williams, and Peter Casaletto, all of whom had been running together since they were freshmen, wanted the team to emphasize evangelism. They prayed for team unity, opportunities to witness, and strength during competition. Success began to come. Both teams were running well; they were sharing the Gospel; and God blessed Tammy with some excellent performances.

As the season drew to a close, the girls needed to win their district meet in order to advance to $\mathcal{N}$ (AIA nationals. Although Cedarville's women fiad been ranked as high as twelfth in the nation, on a freezing, snowy day at Findlay, they came up nine points short. Tammy was sick and did not run as well as she fiad fioped; fier last chance to compete at nationals was gone.

The final meet of the season and Tammy's career occurred a week later at John Bryan Park. Family and friends came out on a cold, yet sunny, day to see

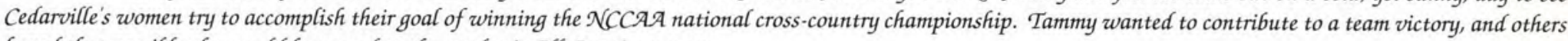
hoped that possibly she would be named to the academic All-American team.

At the post-meet banquet a few hours later, points had been tallied, stomachs filled, and awards were handed out. Cedarville's women were national champions, and Tammy was an academic All-American.

The final and most prestigious award given each year is the Wheeler Award. This goes to one male and one female runner each year who best exemplify the finest aspects of sport -. an atflete who performs exceptionally well throughout the year both on the course and in the classroom, someone active in ministry, and, most importantly, a person that always represents the best quality of a Christian atflete. This year's winner was Tammy Harvey. 

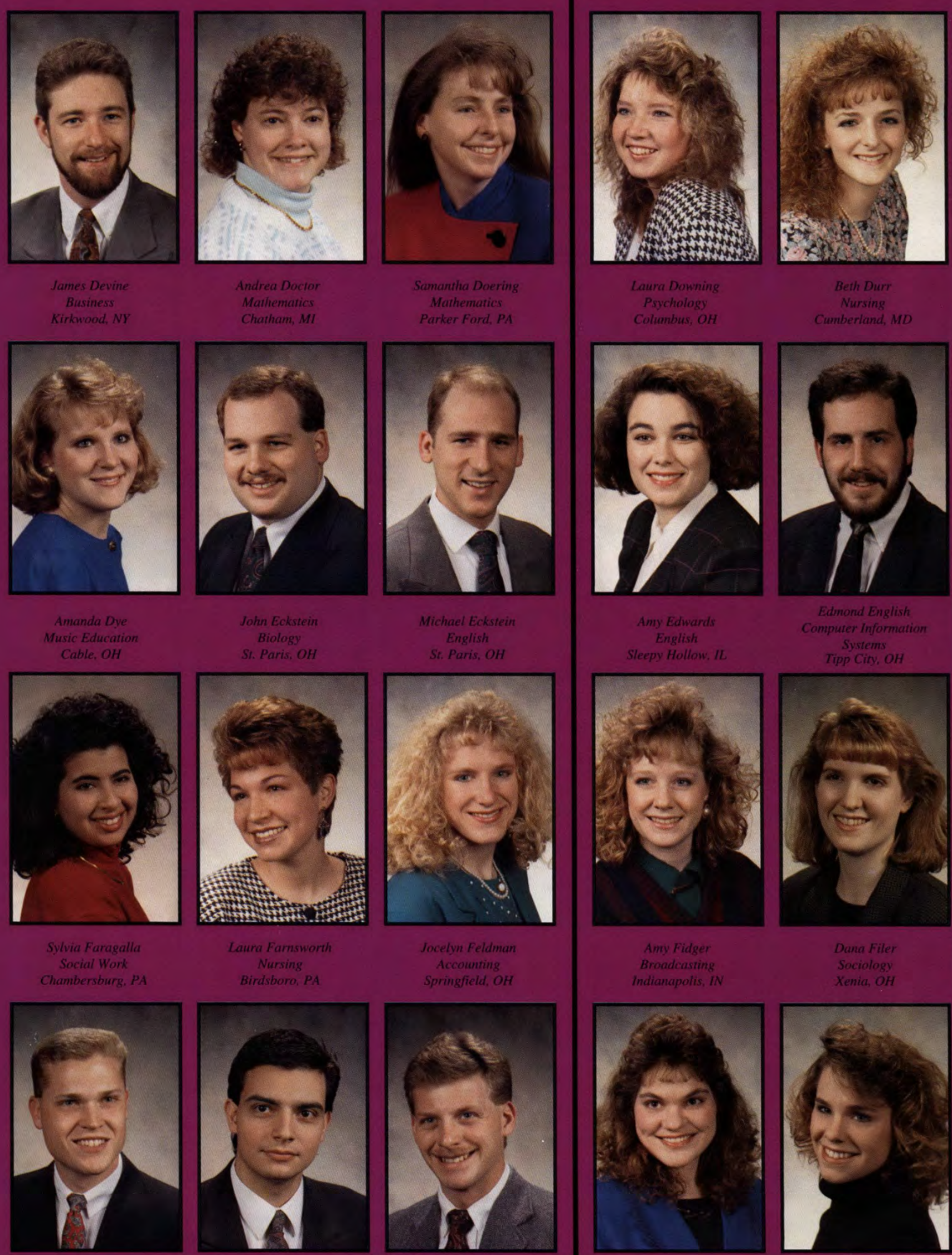
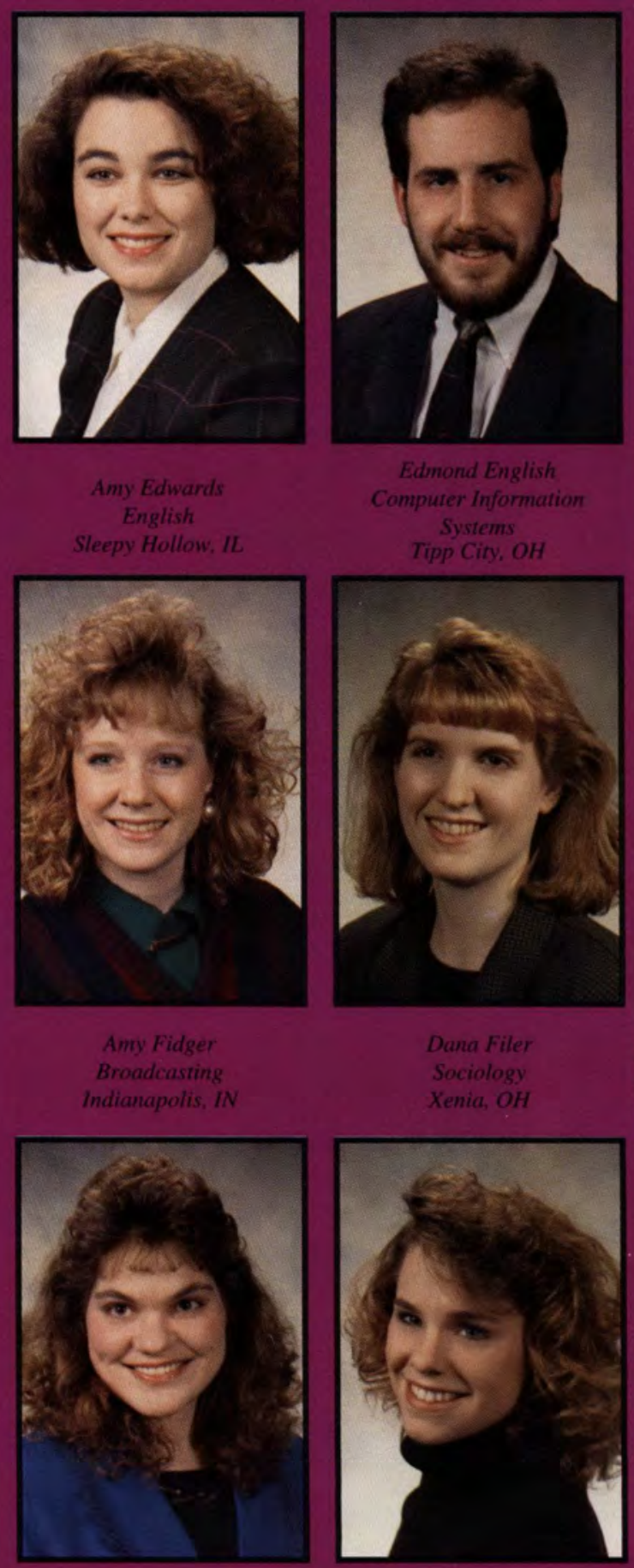

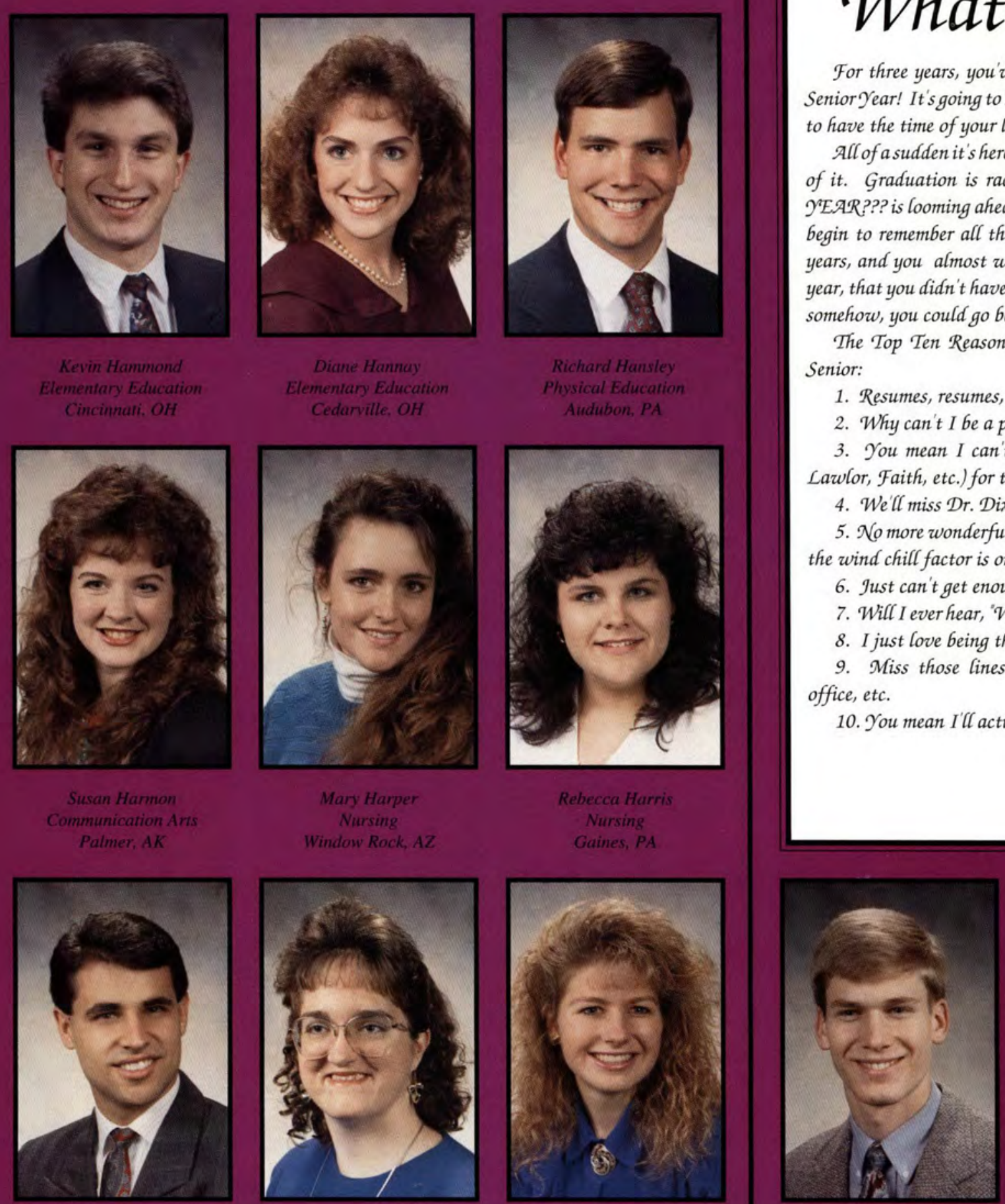

For three years, you've been waiting for $1 \mathcal{I} \cdot$ your Senioryear! It's going to be wonderful, and you're going to have the time of your life.

All of a sudden it's here, and you re right in the middle of it. Graduation is racing toward you, and $\mathcal{N}$ (EXT $Y^{\prime} E \mathcal{A R}$ ??? is looming ahead. As the pressure builds, you begin to remember all the fun of those underclassman years, and you almost wish that this isn't your Senior year, that you didn't have to graduate in June, and that, somehow, you could go back and do it all over again.

The Top Ten Reasons for $\mathcal{N} O \mathcal{T}$ Wanting to be a Senior:

1. Resumes, resumes, resumes!!!

2. Why can't I be a professional student?

3. You mean I can't live in (Choose one: Printy, Lawlor, Faith, etc.) for the rest of my life?

4. Well miss Dr. Dixon's Dandelion speech

5. 스 more wonderful announcements such as, "And the wind chill factor is one degree above zero.

6. Iust can't get enough of Chuck's.

7. Will I ever hear, "Where are your values?" again??

8. I just love being the last one in the shower.

9. Miss those lines -cafeteria, registration, post office, etc.

10. You mean I'll actually five to date????

- Mindy Boone
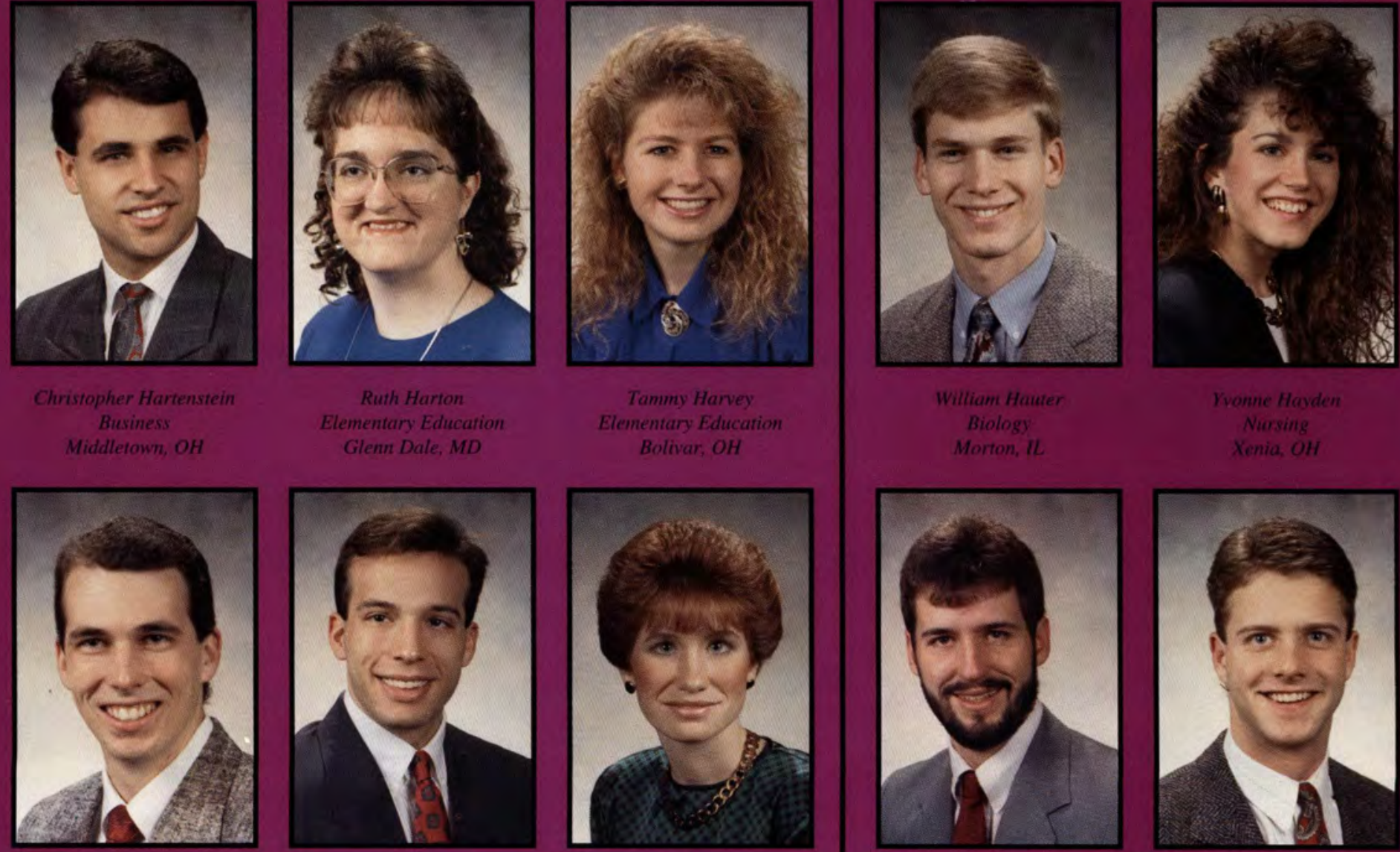


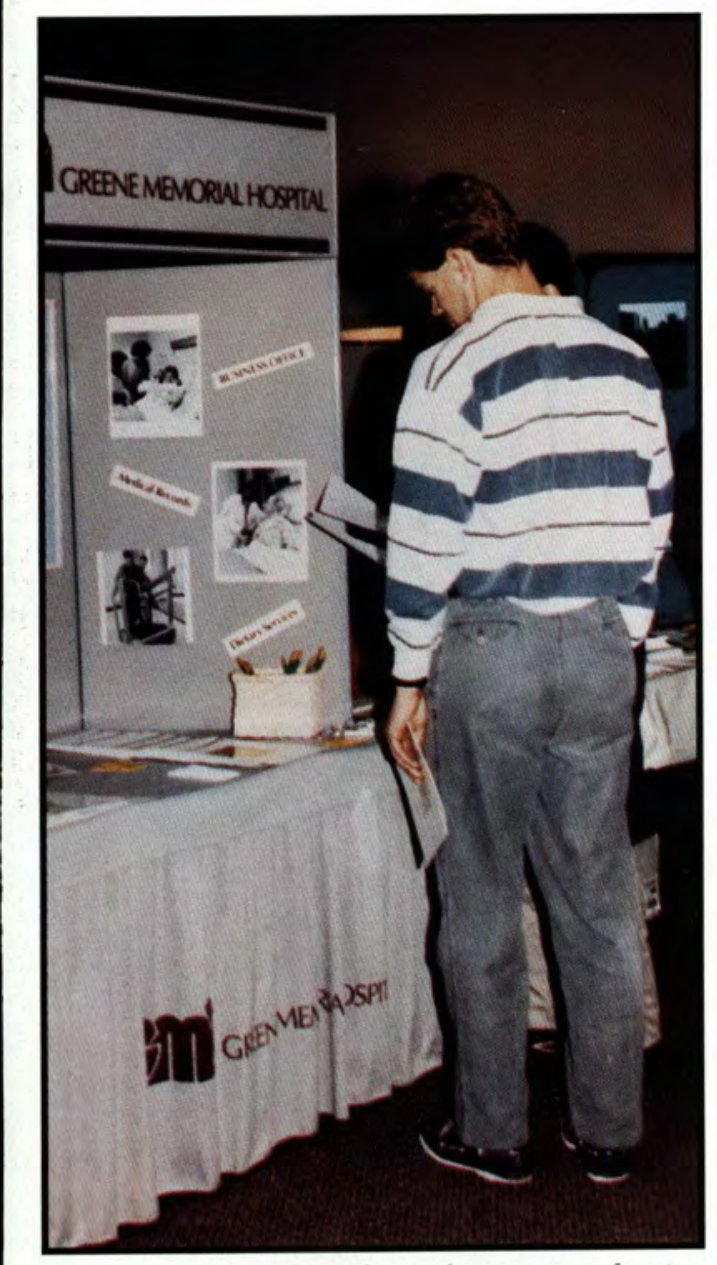

Career Day, 1992 - Io6 search provides one source of anxiety for seniors.

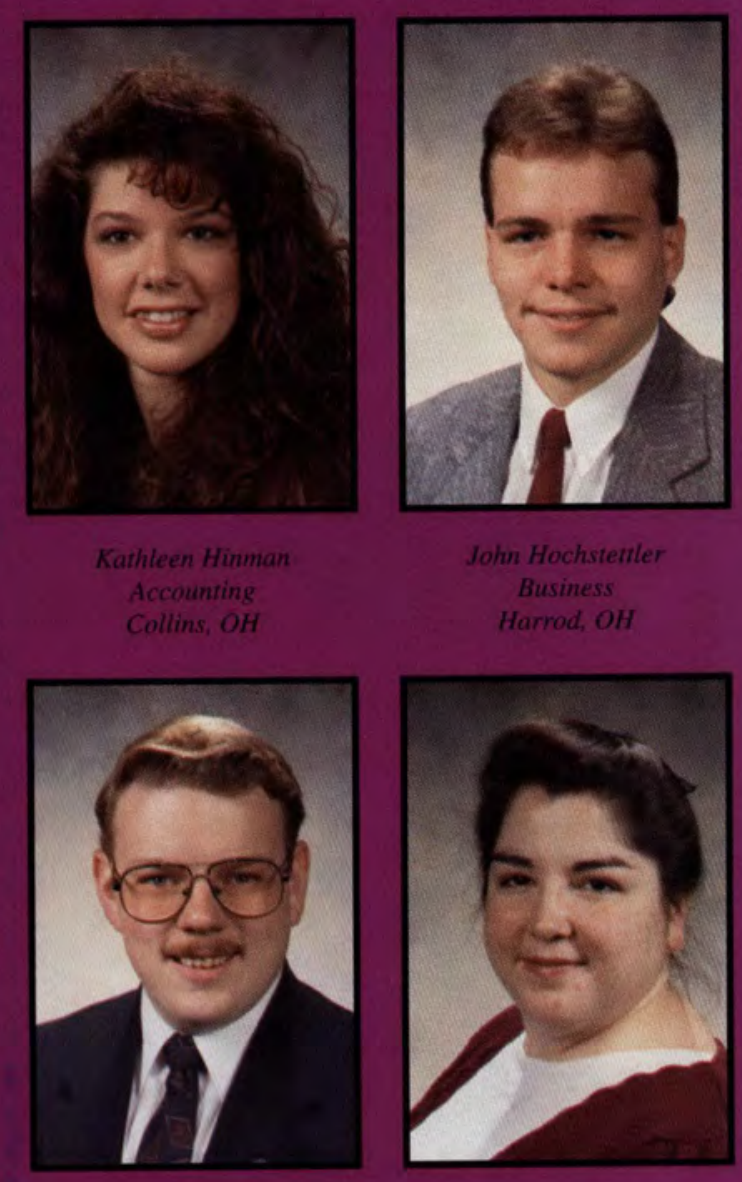

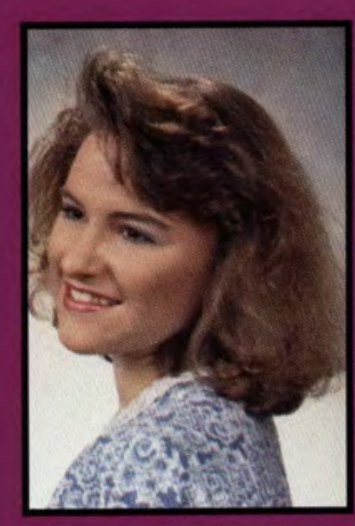
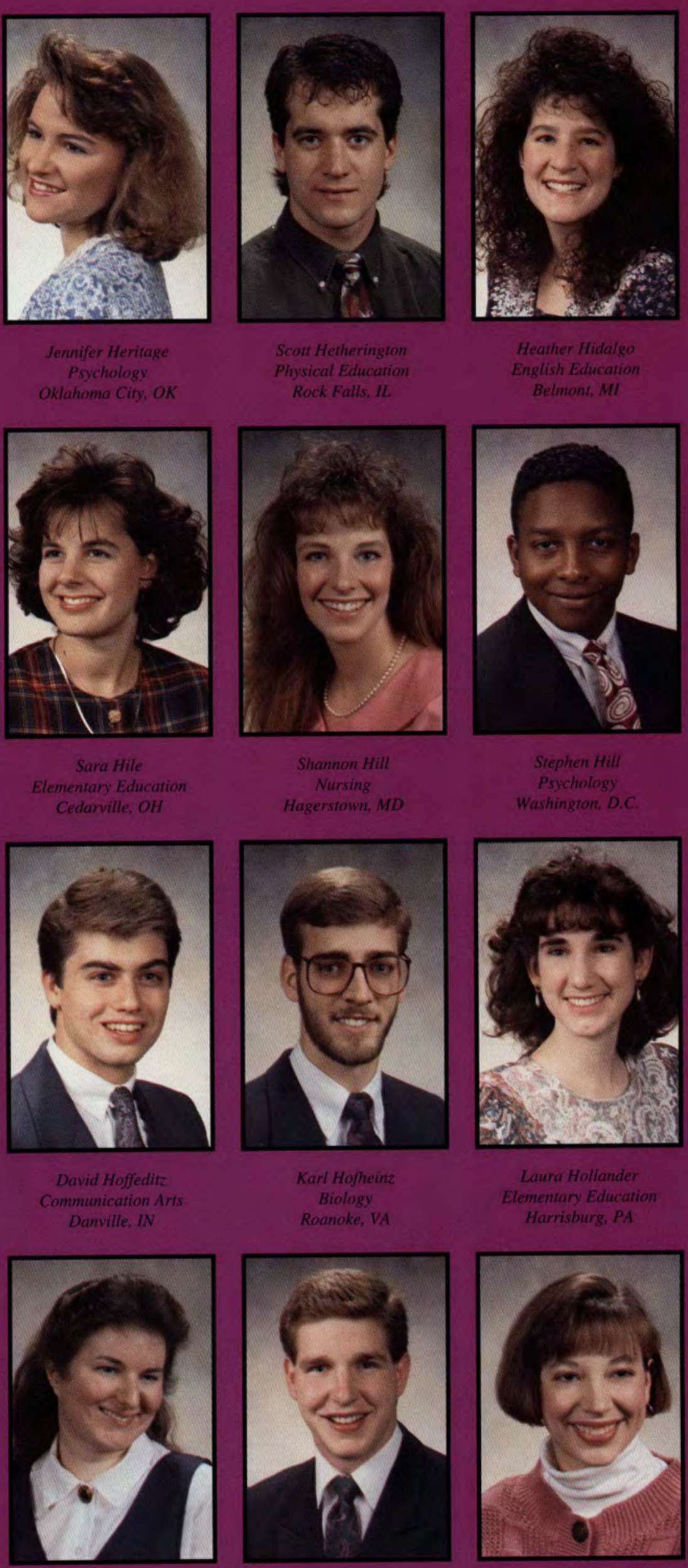

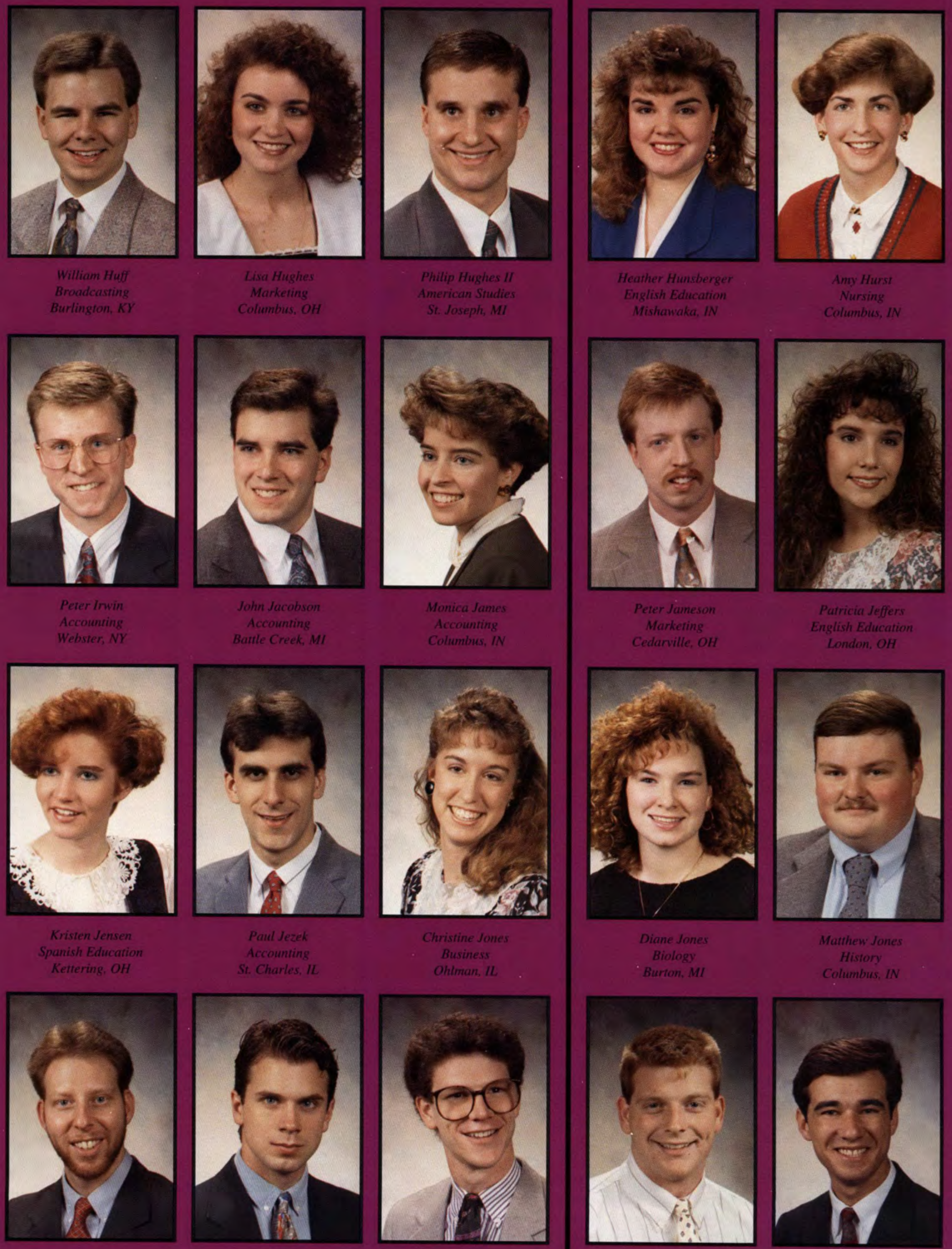

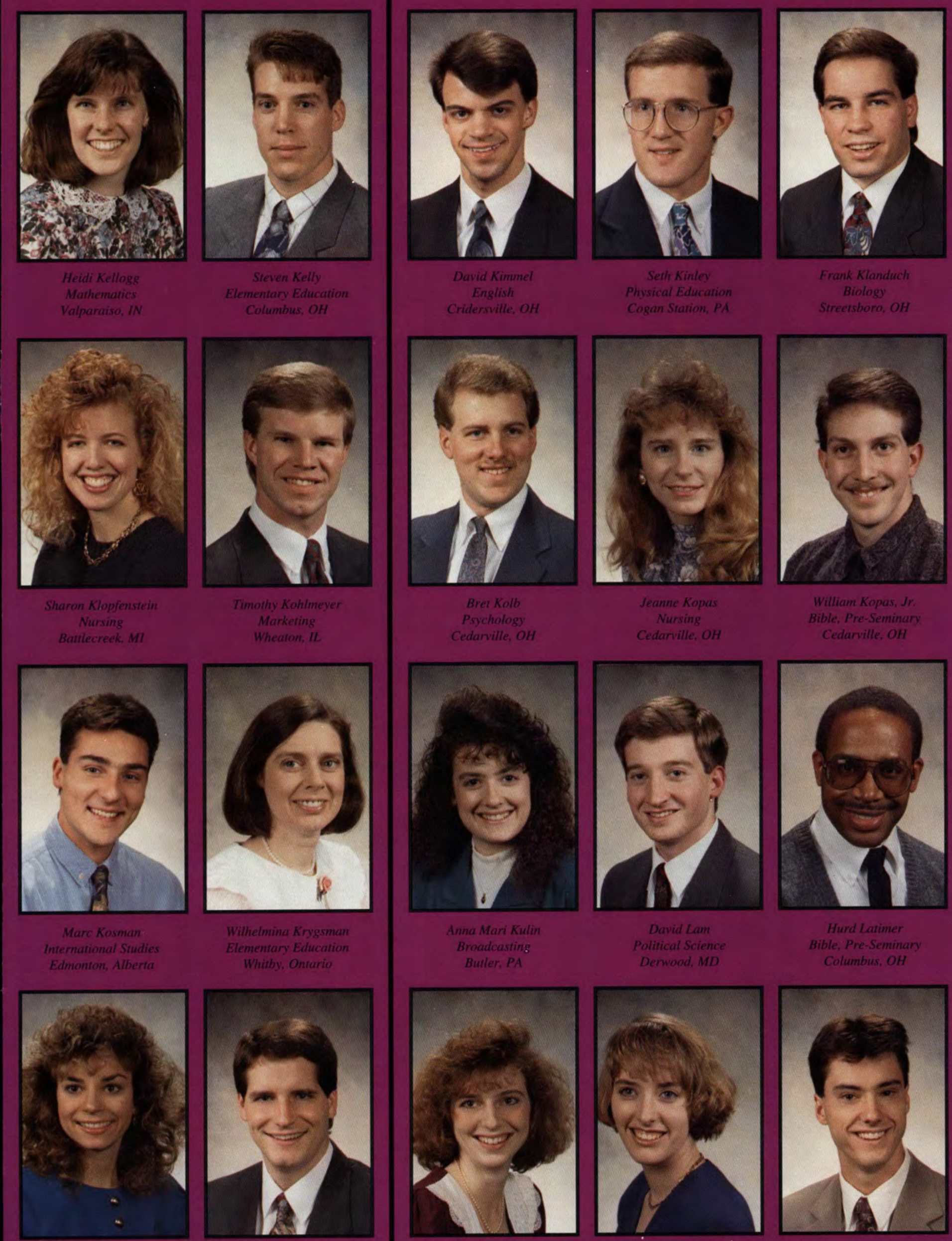

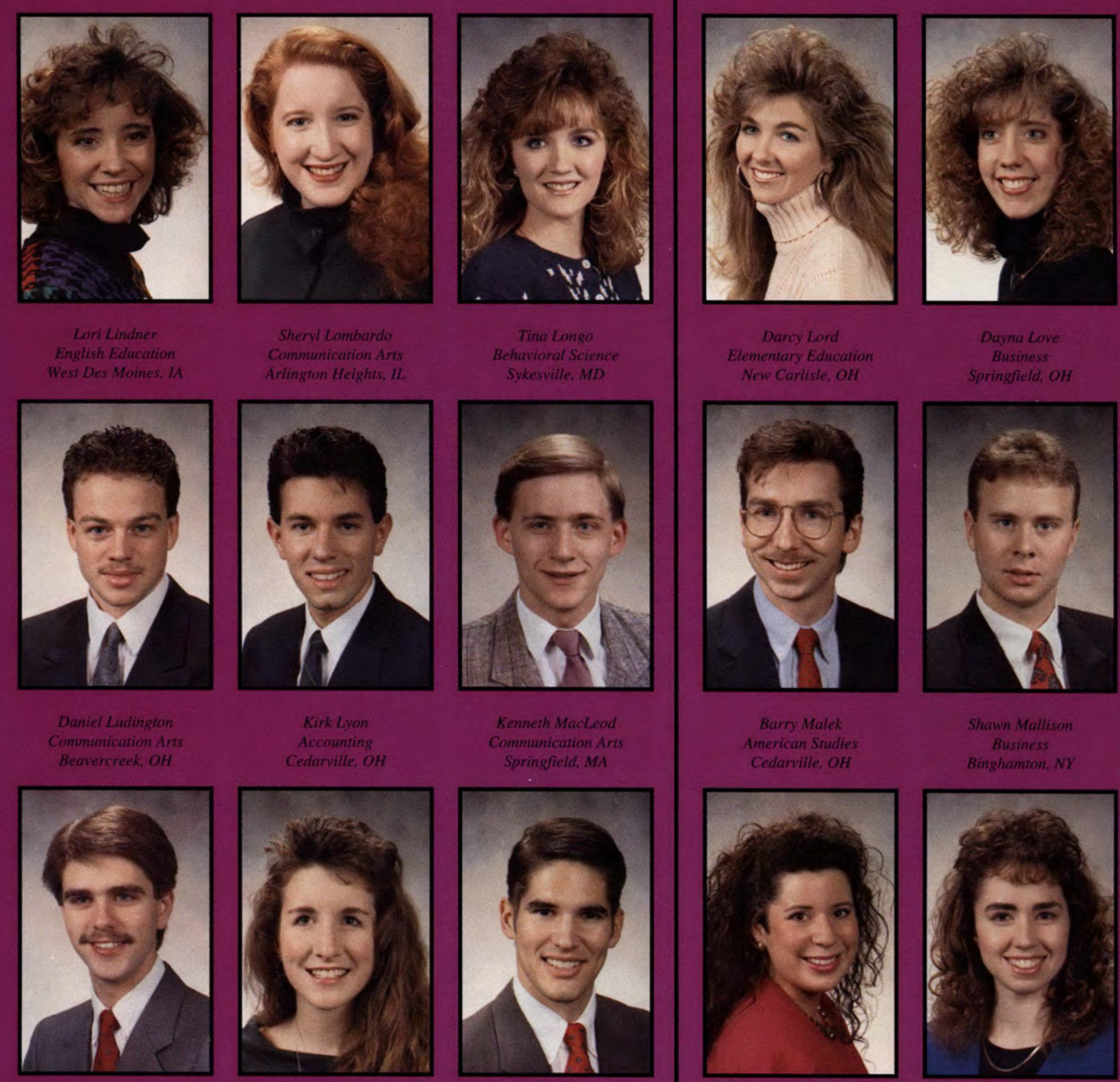

Buffalo Grove, I
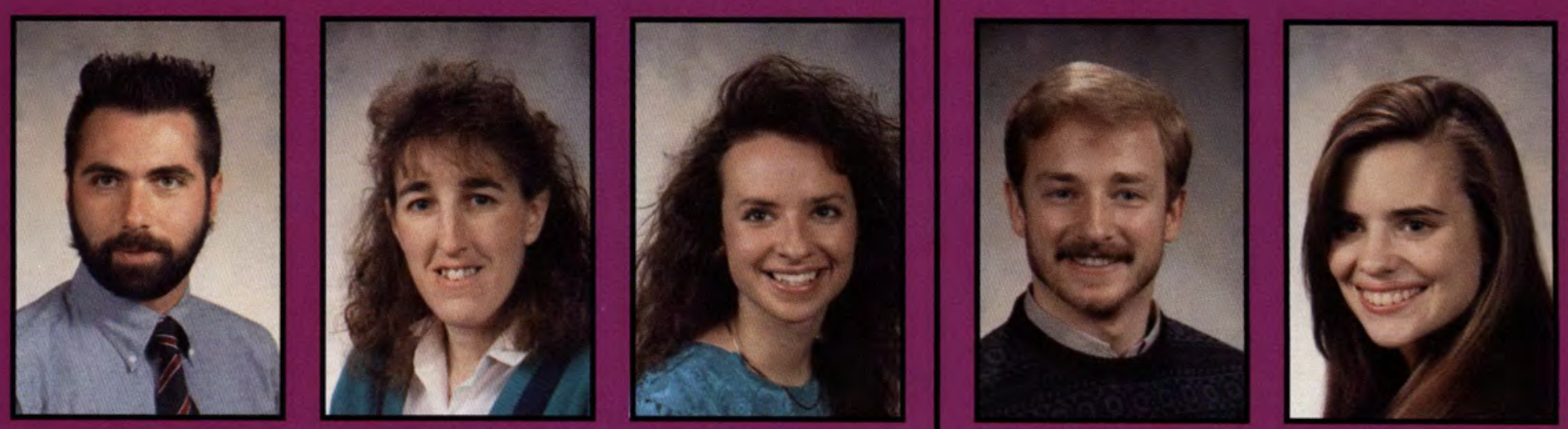

Cedanville, $\mathrm{OH}$ 

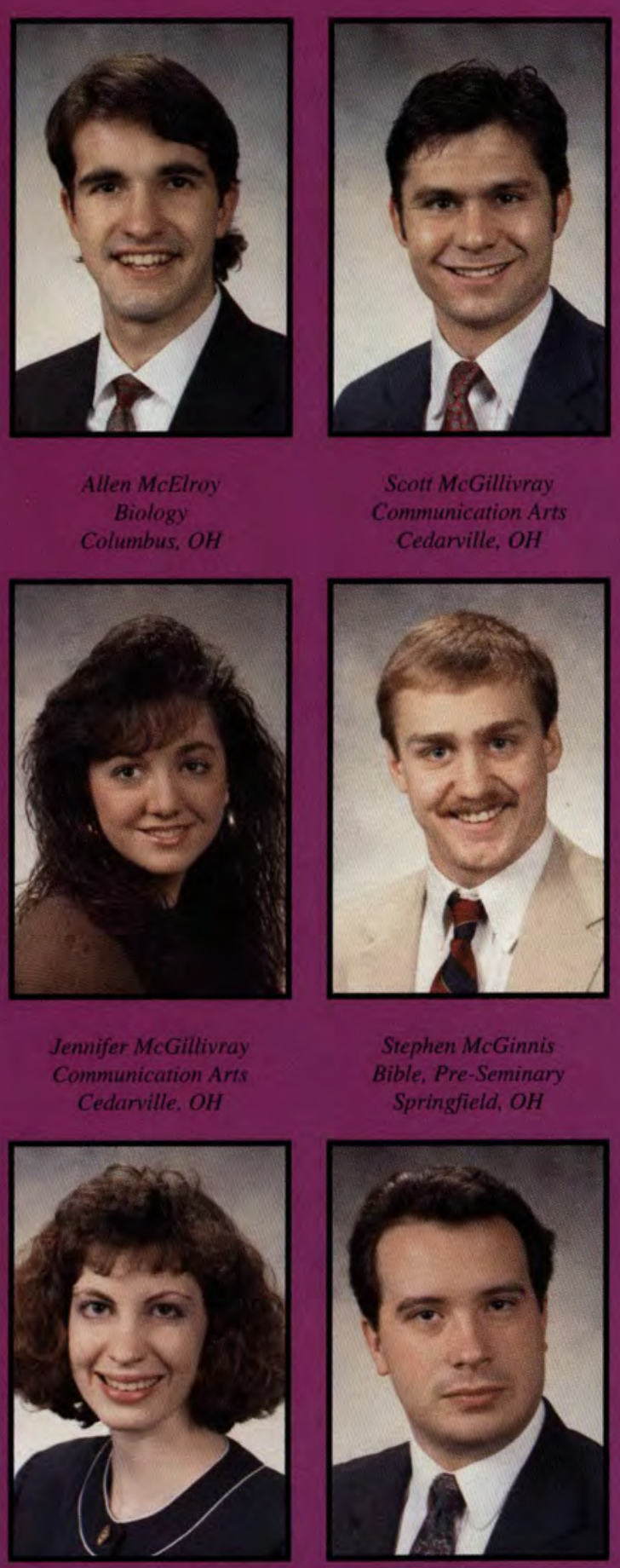

Lara McGover
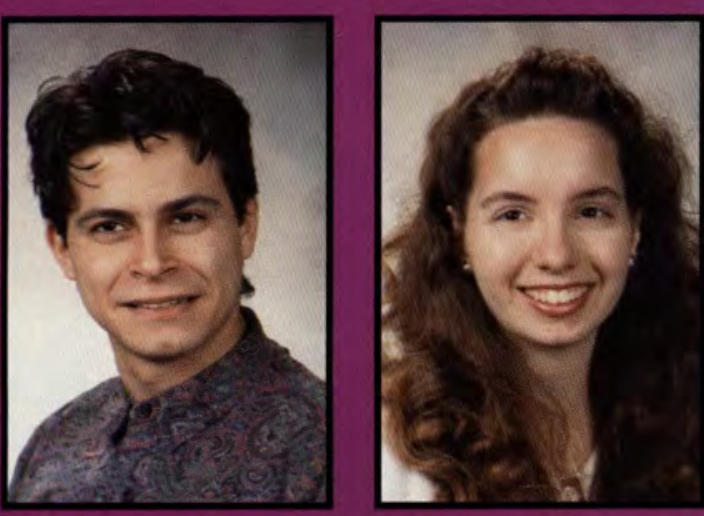

Learring to

\section{Trust the Lord}

Last year, Ianette Rehfeld was attending The Master's College, in California, majoring in $\mathcal{N}$ (ursing, enjoying her friends, and being active on the cross-country and drama teams. When those plans were shaken, she realized that God had something else in store for her life.

She says, 'It was in November and I was told that Master's was dropping the Nursing Department. I was left wondering what to do and where to go, but I prayed knowing God is faithful and $\mathcal{H}$ e would direct. A6out that time, a friend shared with me the possibility of coming to Cedarville College. Dr. Conway also came out to Master's to visit and shared about the Nursing Program here at Cedarville, and I decided that although I enjoyed Master's, the Lord was leading me to come to Cedarville College. I firmly believe that when we truly seek God with our prayers, $\mathcal{H}$ e is faithful and gives us the strength ... His strength... to do His will. I've enjoyed the Galance here at Cedarville from various ministries and chapels to the excellent education I've received.

'A verse that means a lot to me is I Chronicles 28:9. It speaks about being wholehearted and fiaving a willing mind, not folding back. These are the things that I've learned are the most important in the Christian life. I'm truly thankful for the opportunity to be at Cedarville and for the changes it has brought in my life."

- Iulie Mulder
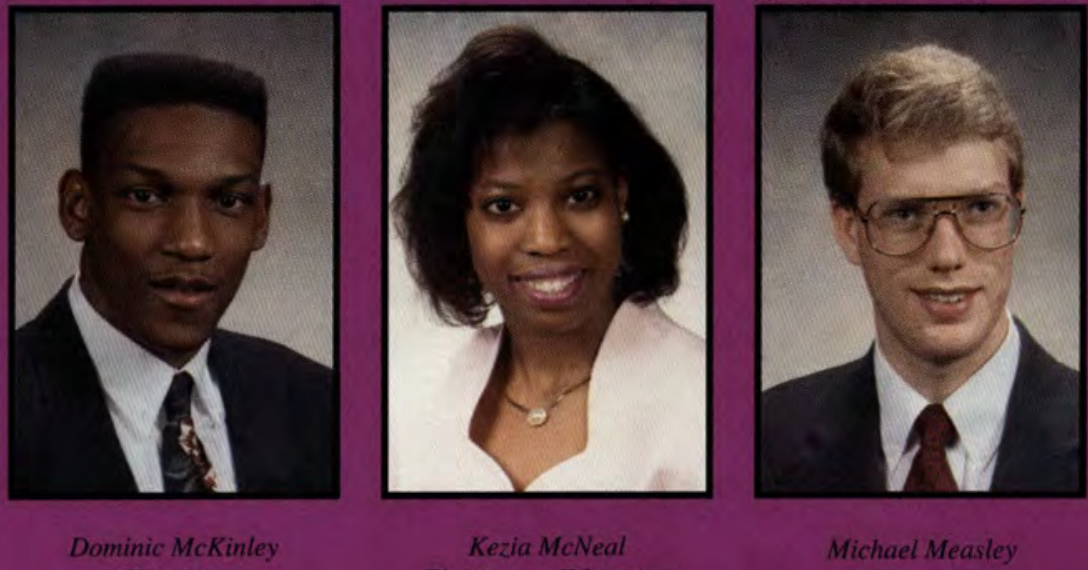

Chemistry
Portsmouth. $O F$
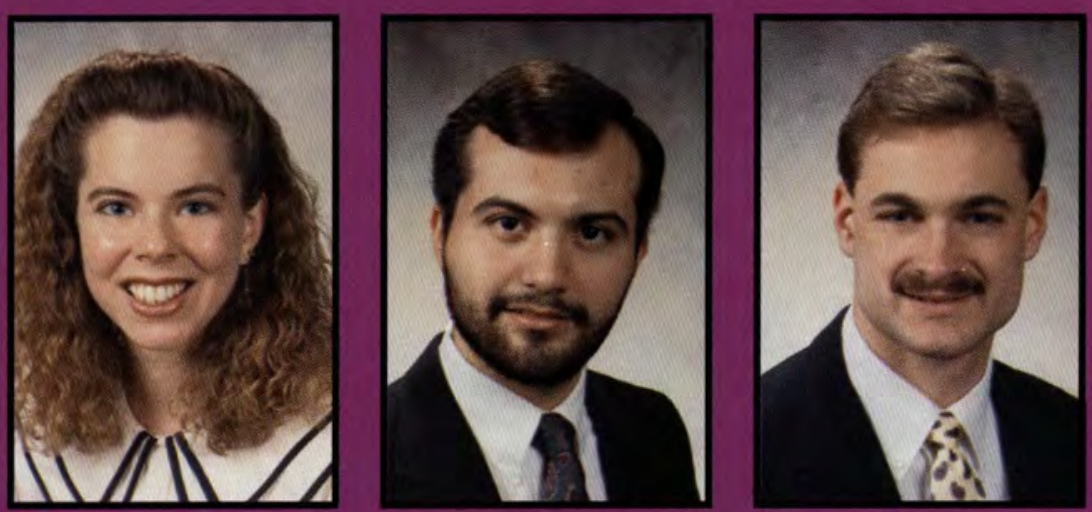

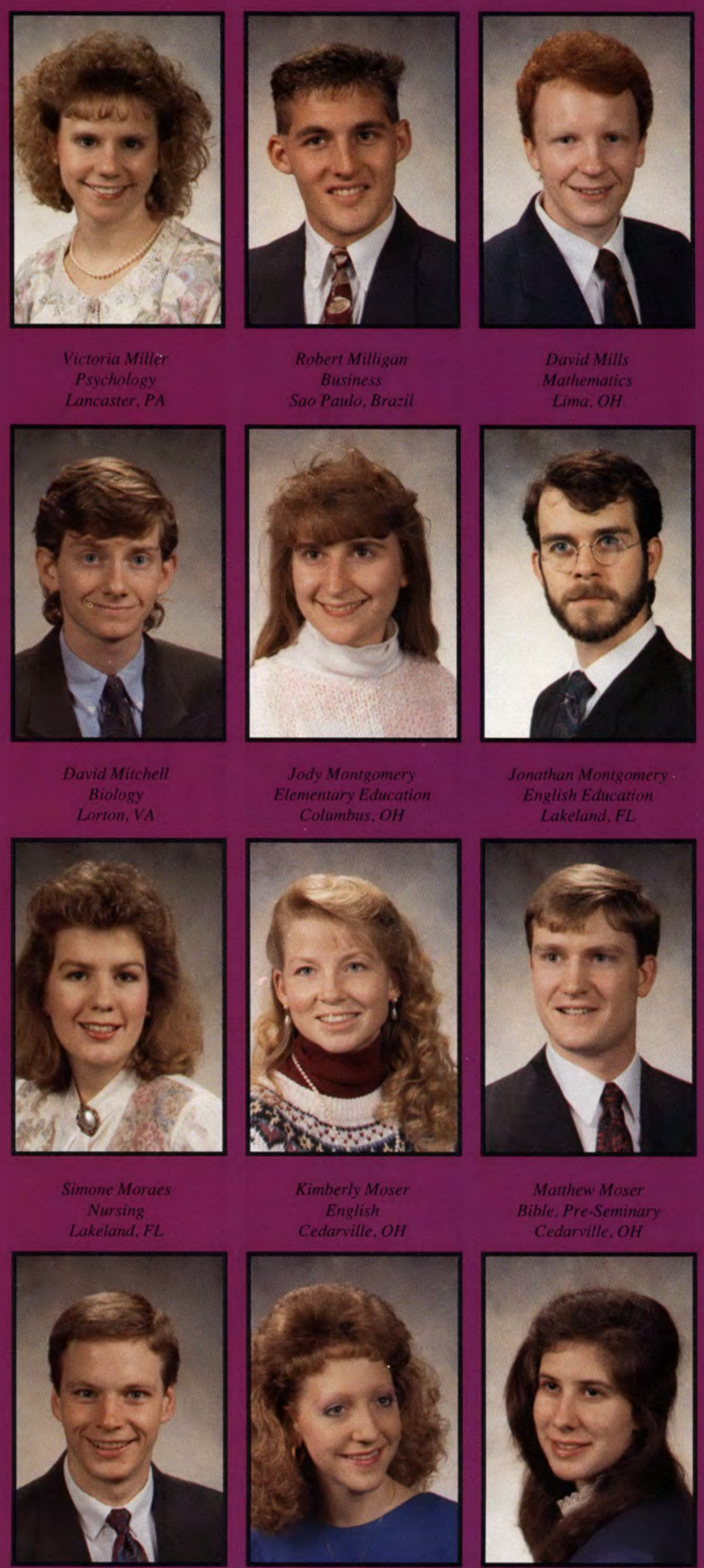
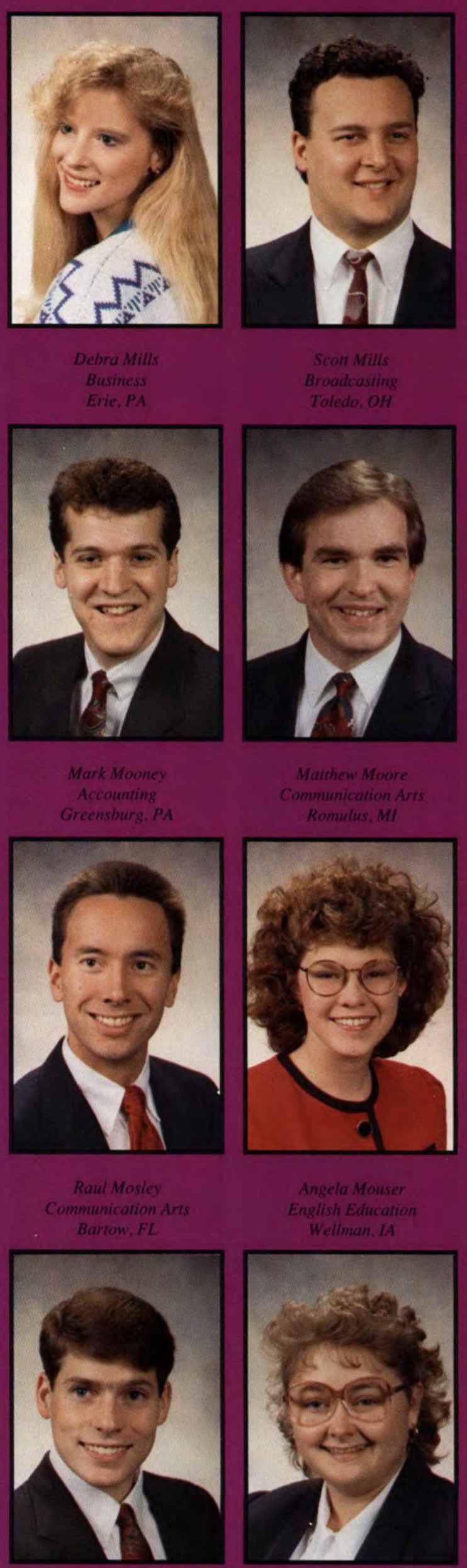


\section{Standing On Her Own}

Through her teacher's patient love and guidance in children's church, Jennifer Libby accepted gesus Christ as her personal Savior. Week after week this willing servant acted out and lived the gospel. And as a result, gennifer followed after her teacher's example and allowed Jesus to become a significant part of her life.

Leaving her precious family in Oregon and moving to continue her education at Cedarville College was what God had in mind for Iennifer. Before coming to Cedarville, she expected college to mirror whiat she had been exposed to at home. But as time passed, she reafized that she had to re-examine her beliefs and make those befiefs her own. That was the biggest challenge she faced here : finding out what she really believed and why and dealing with people who felt differently. She appreciates the fact that many diverse befiefs are represented and spread all over campus, yet we remain one in Christ.

Her ministry teams, Swordbearers and Heathergreene, fiave opened her eyes tremendously. When she was younger, the brevity of life was not an issue. But as a result of Heathergreene, she understands and witnesses the shortness of life and the need for real compassion and love to be shown.

$\mathcal{A}$ s a result of Cedarville, gennifer now feels braver and confident in what she believes and in herself as a person.

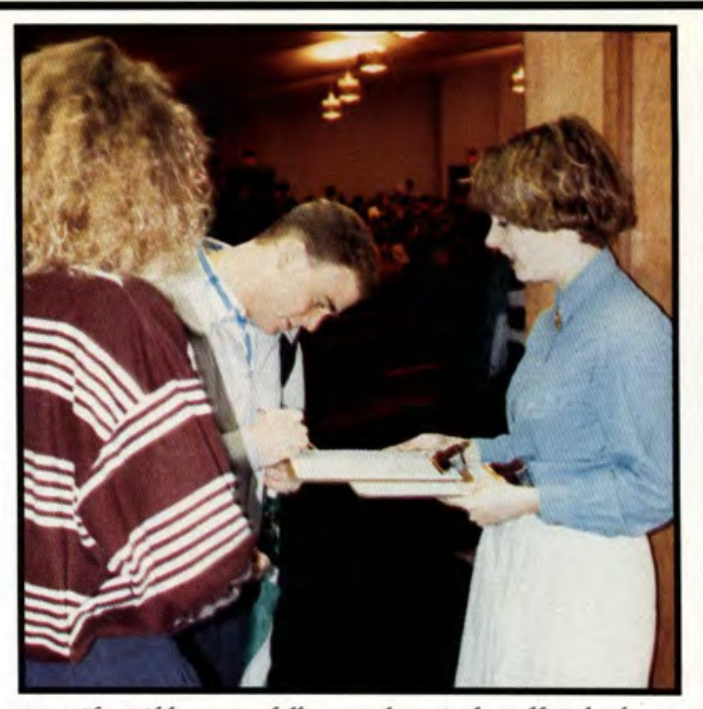

Jennifer Libby greets fellow students in fier official role as a "chapel checker."
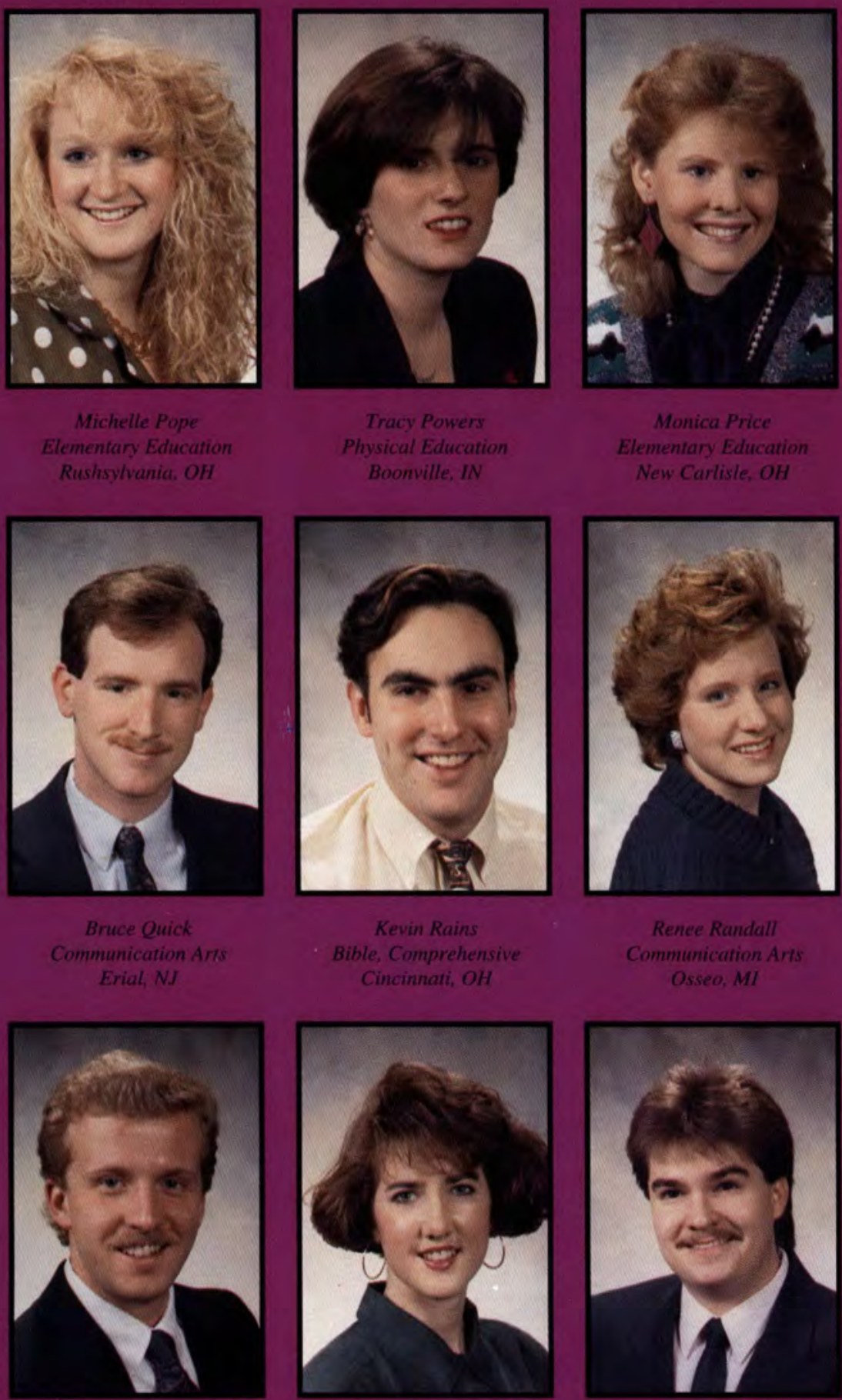
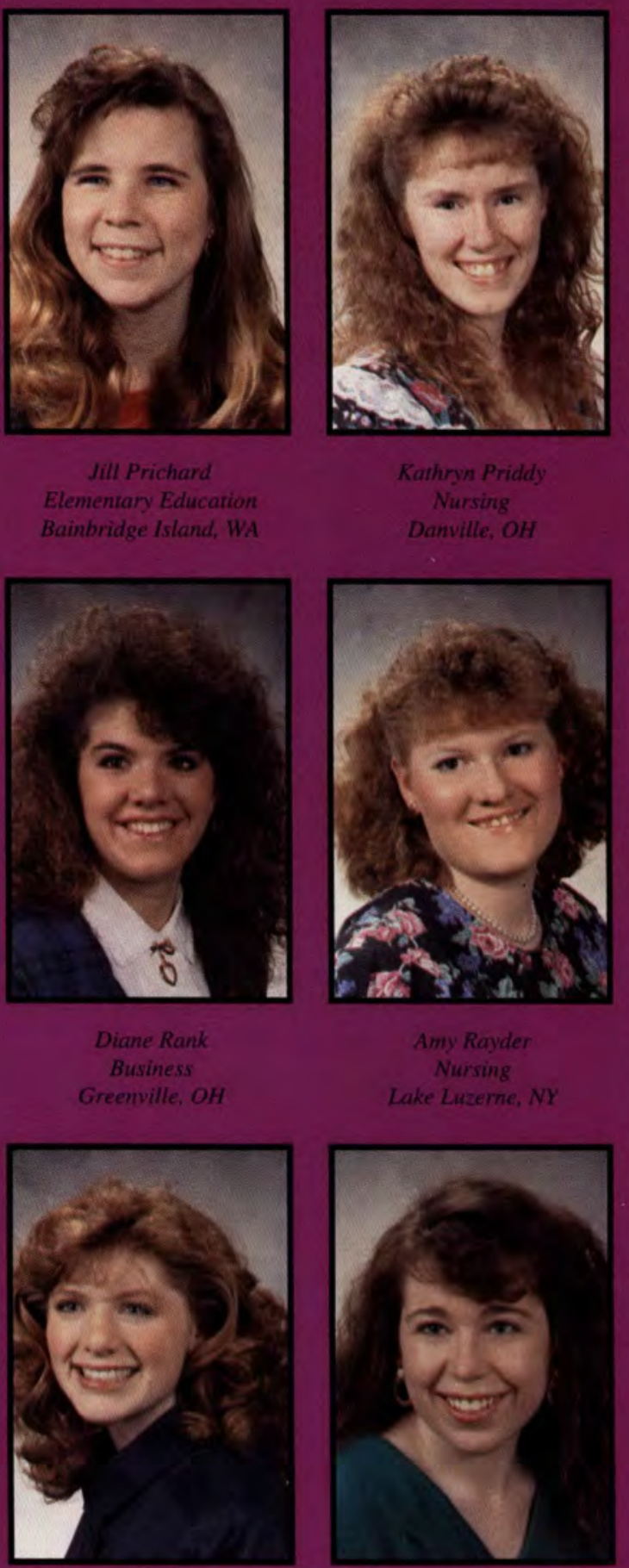

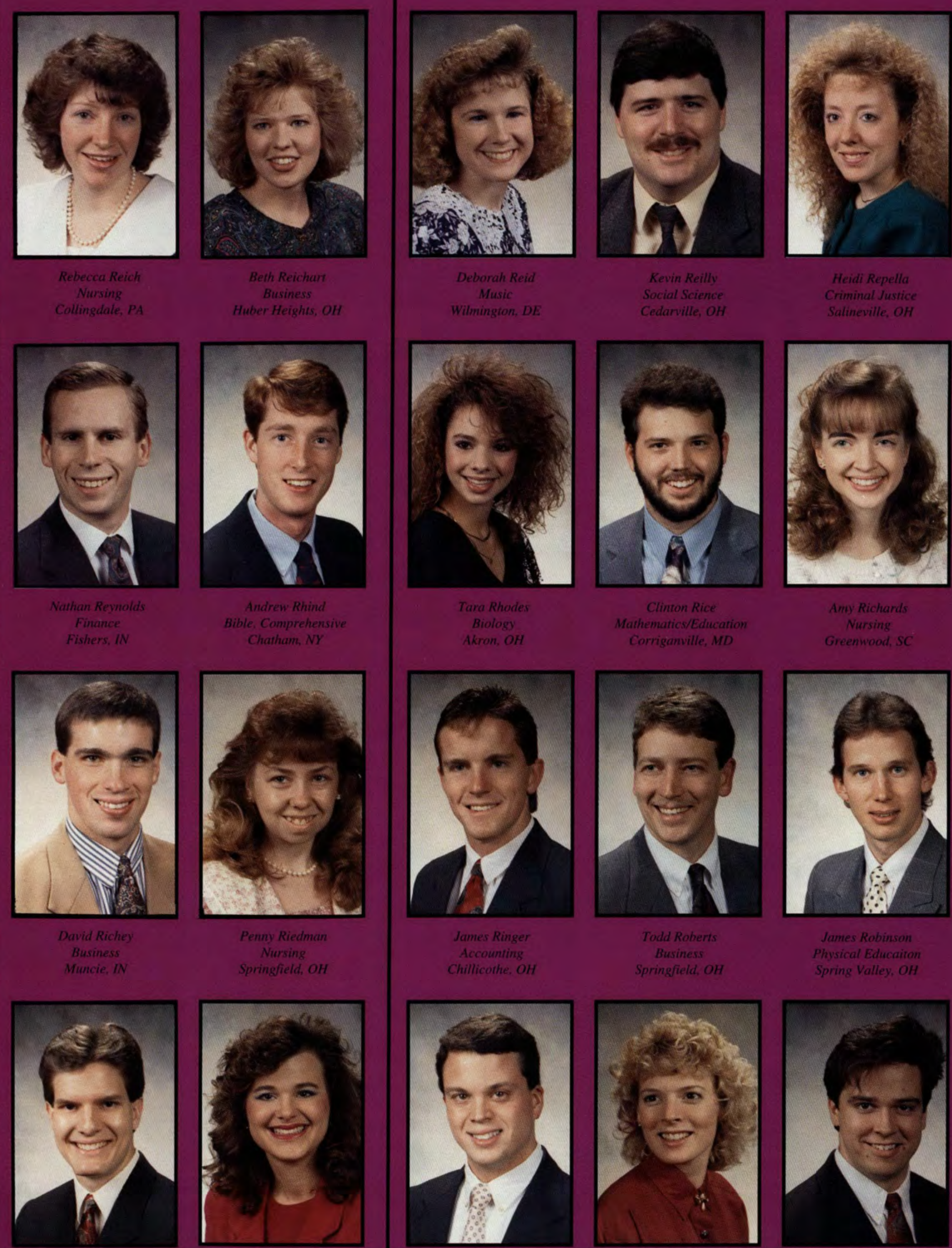
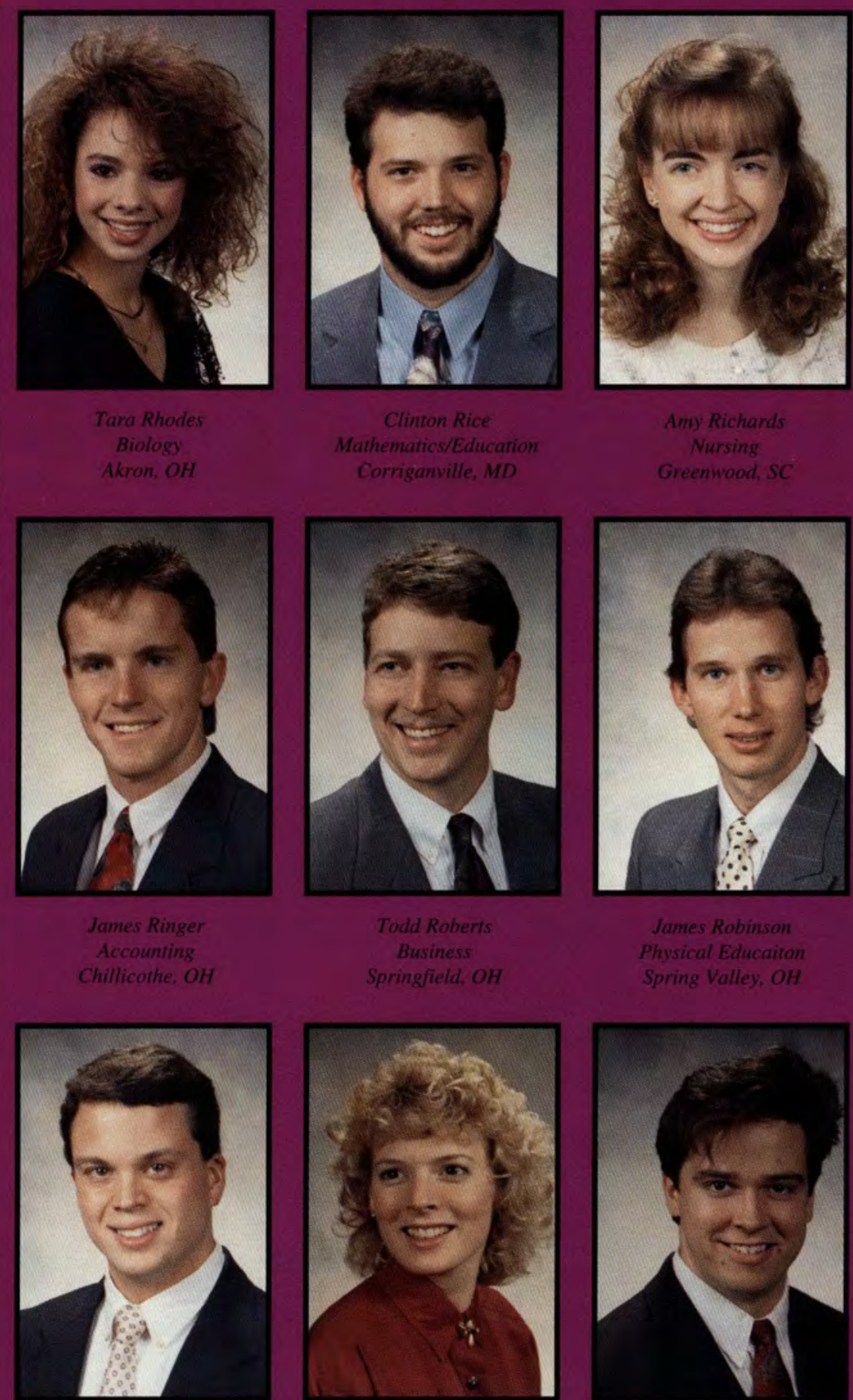

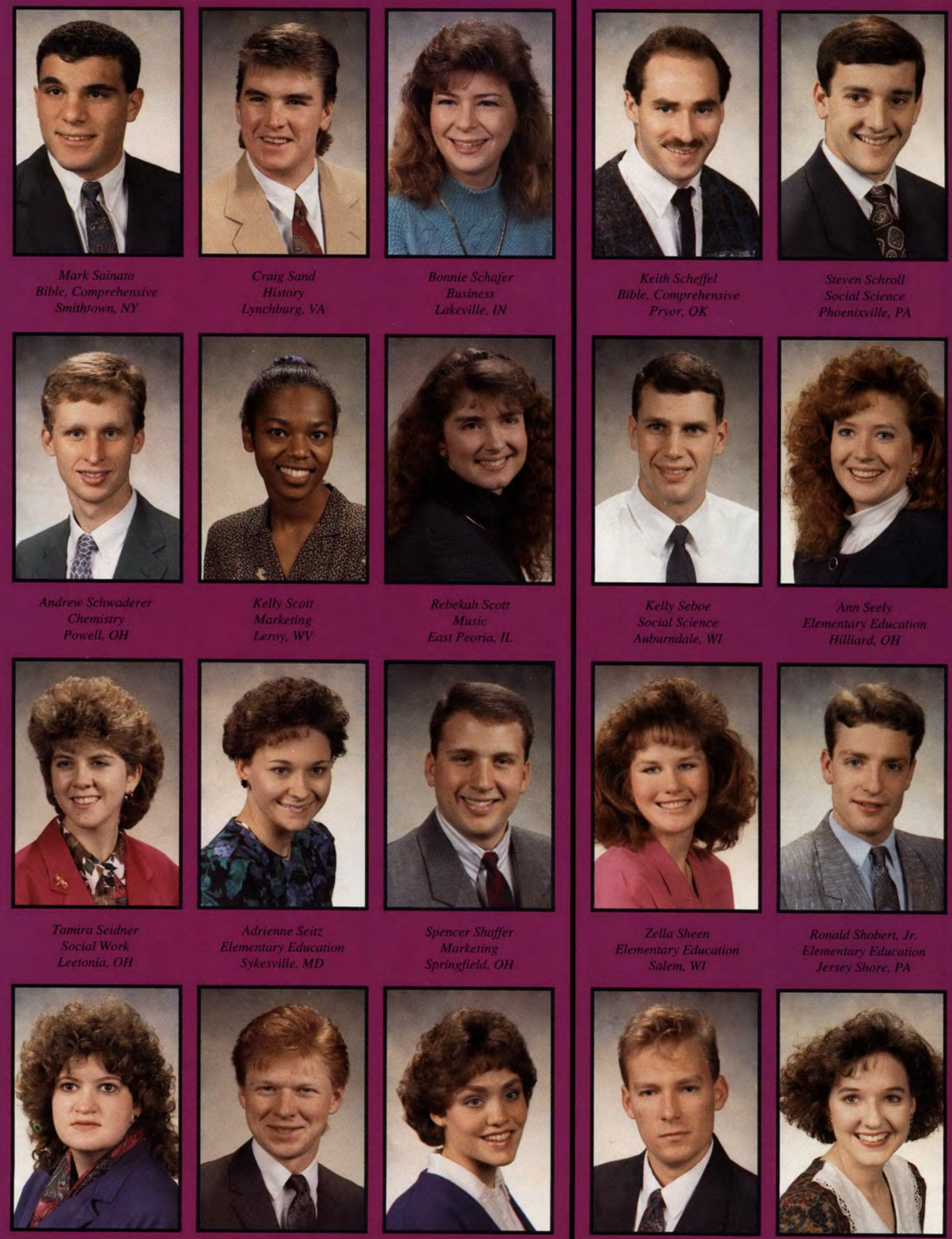

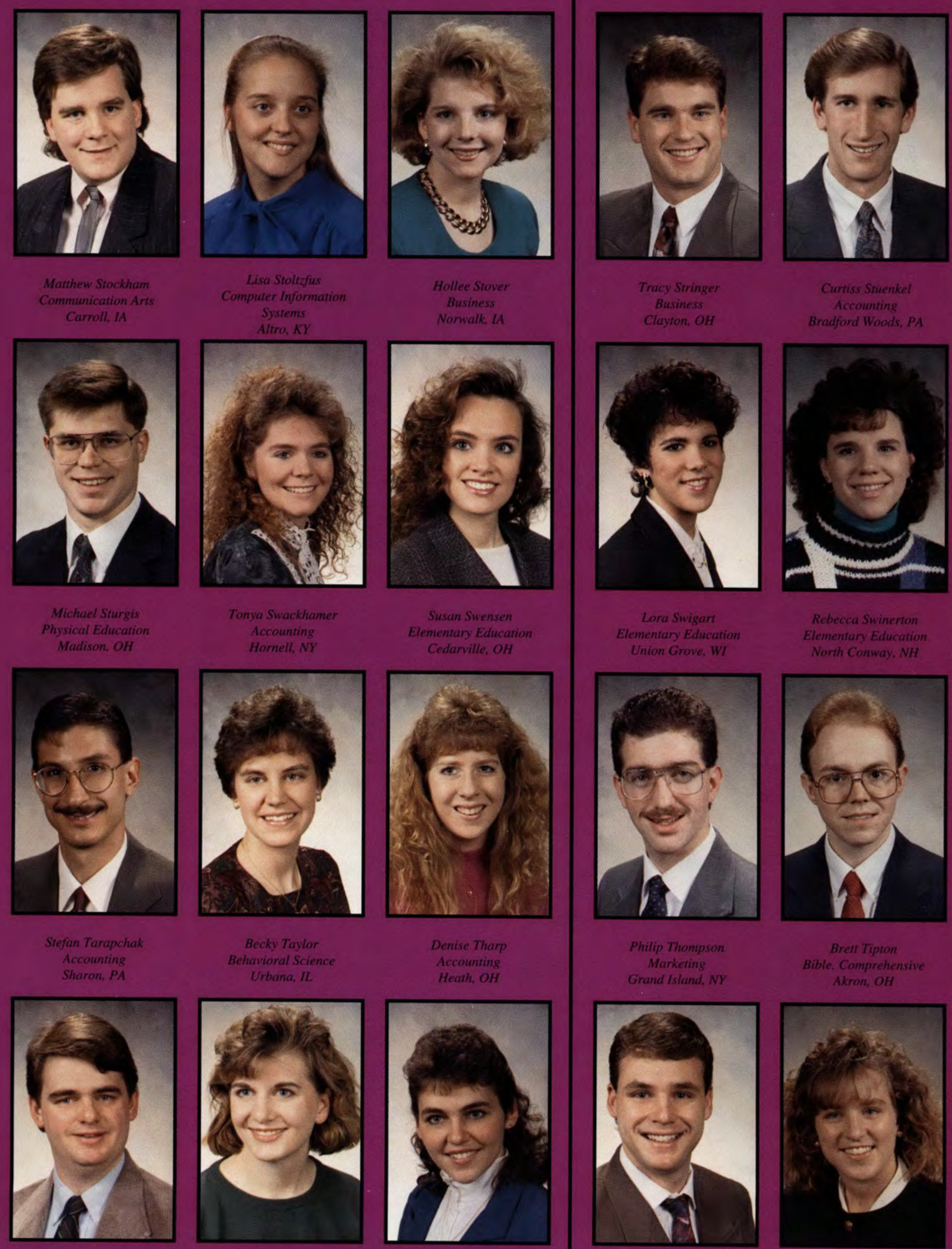


\section{The Best Dears?}

Often, the final year of college can be a time of reflection. If a group of seniors were asked to name their favorite years of college, most likely a variety of answers would come up. "MYy freshman year," some may respond, "because I made new friends and had fun!" Others may insist, "My sophomore year was my favorite because I was comfortable here and no longer a 'lowly freshman.'" Surprisingly, several may agree that the senior year is the best because, "we are almost done, and Spring Quarter will be a breeze!" Senior Cindy De Clark happily declares that her junior year proved to be fier best year.

$\mathcal{A}$ s a returning student, Cindy was not only familiar with the campus, but the people as well. She was quite pleased with her dormitory life, for her roommate was a long-time friend from home. In addition, Cindy finally began to take the higherlevel courses for her Elementary Education major. It turned out to be a challenging yet enjoyable experience for her. The single aspect that caused her junior year to be her best was her brother unit. Around Christmas, Cindy and her unit-mates met their brother unit. From then on, they became inseparable, and Cindy and her friends continually "beat the Winter Quarter 6lahs" by participating in enjoyable activities with eight guys from their brother unit, excursions including Iofn Bryan and a Michael W. Smith concert.

Adults often encourage college students to enjoy their college years, for they will be the best years of their lives. During financial struggles, academic pressures, and home-sickness, students often question the truth of that statement. Many find that statement to be true though; because college is the place where lifetime friendships are made.

- Karla Warnken
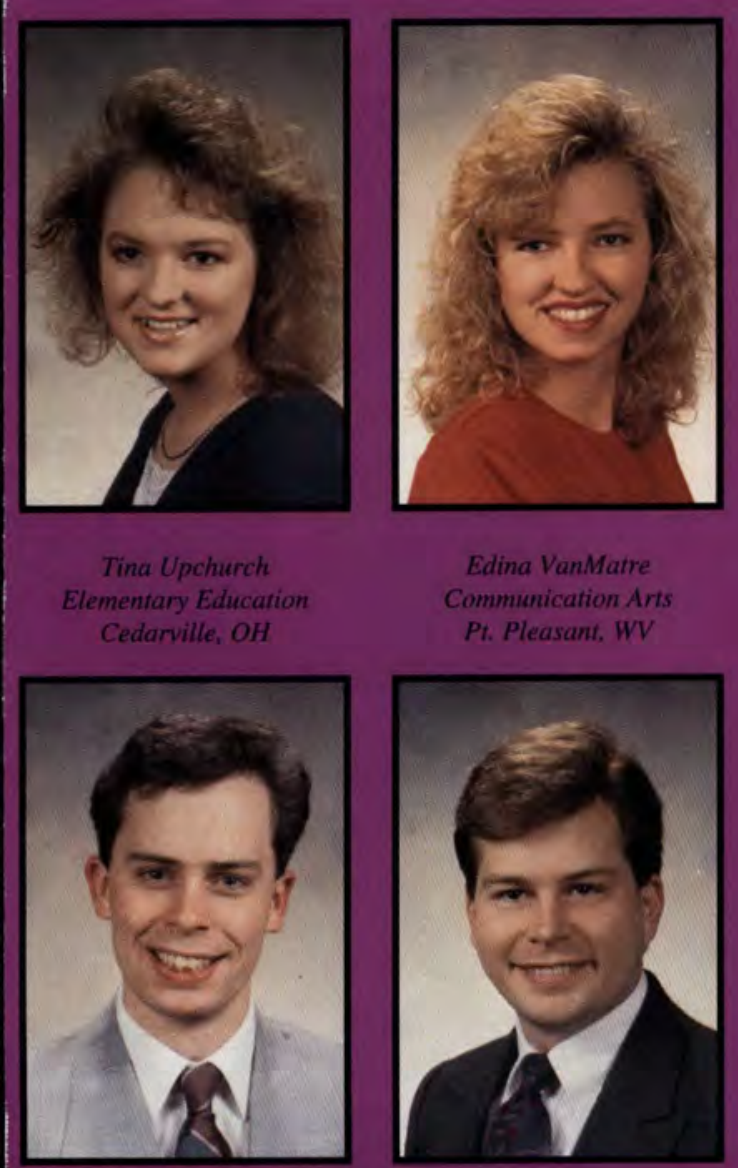
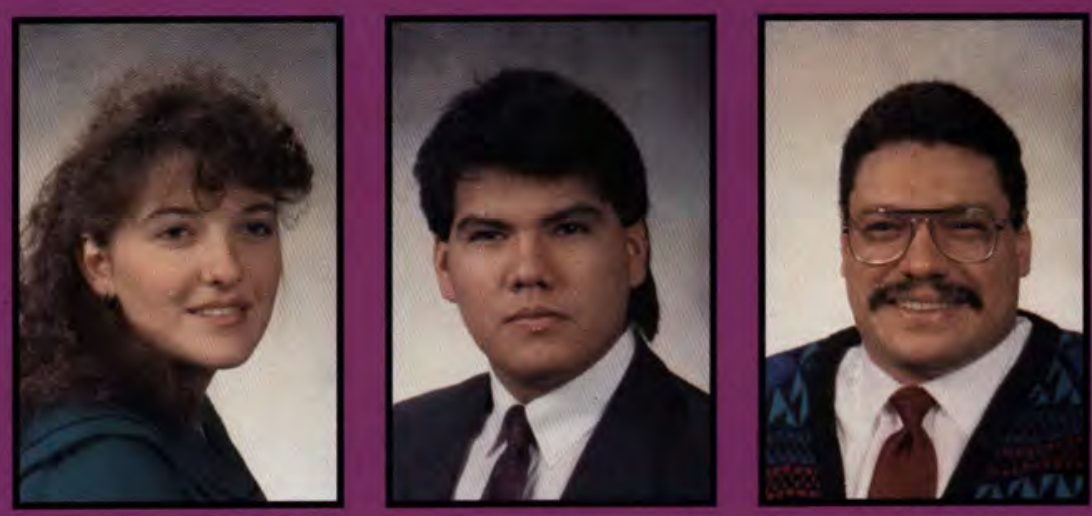
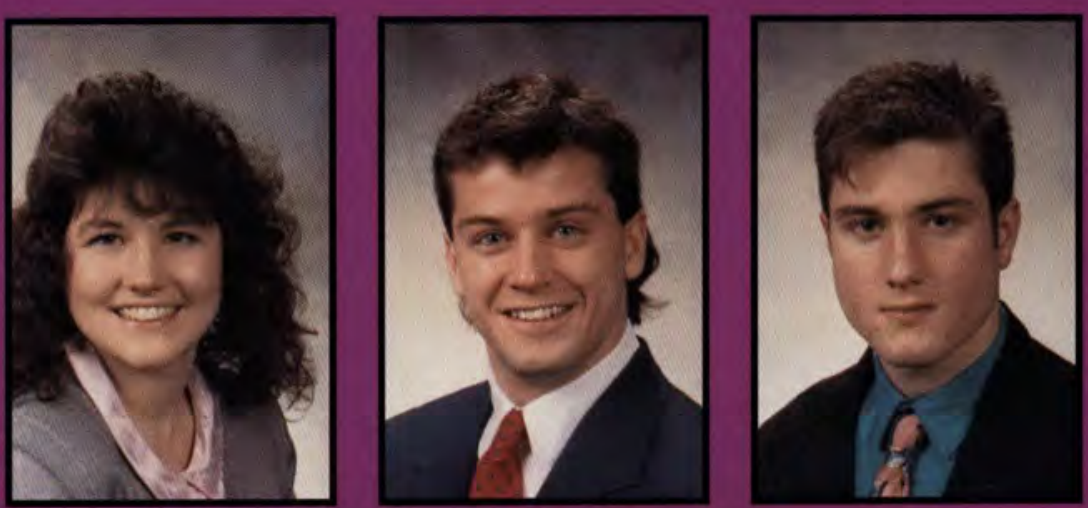

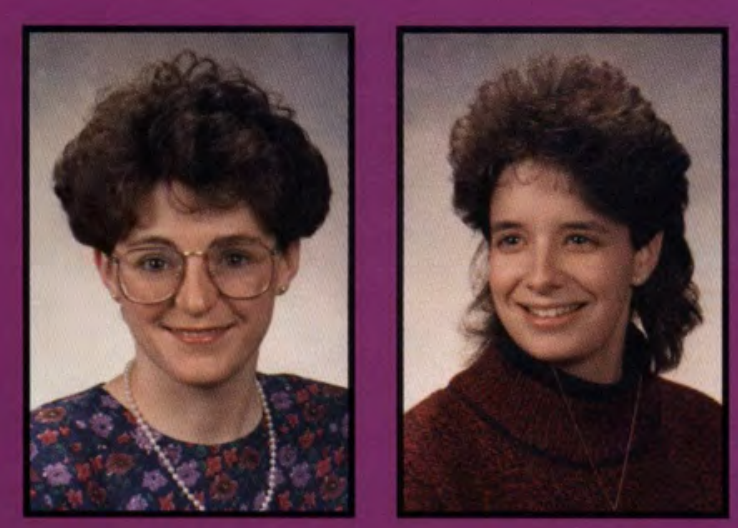

Paula Webe

Meadville. PA

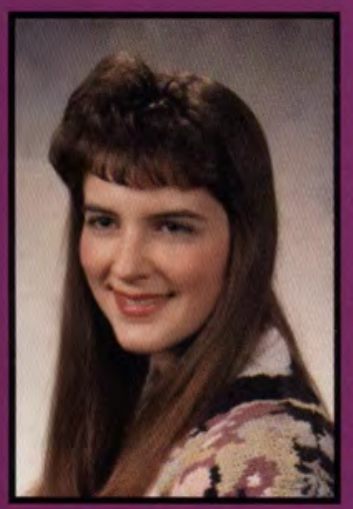

Cedarville. $\mathrm{OH}$

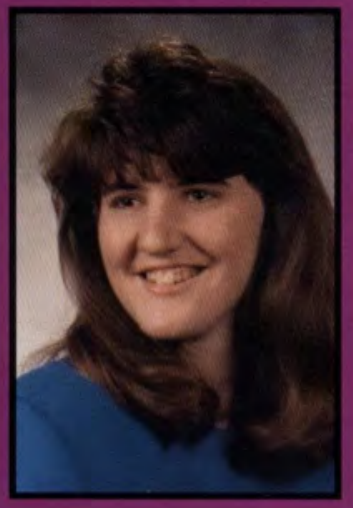

Heidi William.

Athens, $O F$

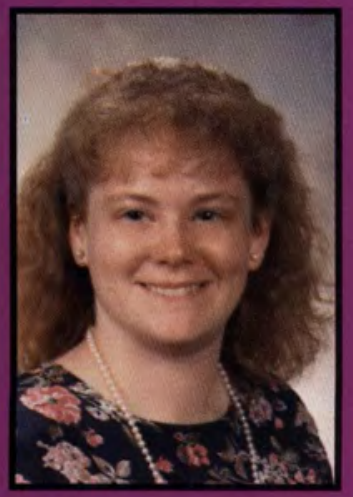

Rhonda Willsi

Randolph. NY
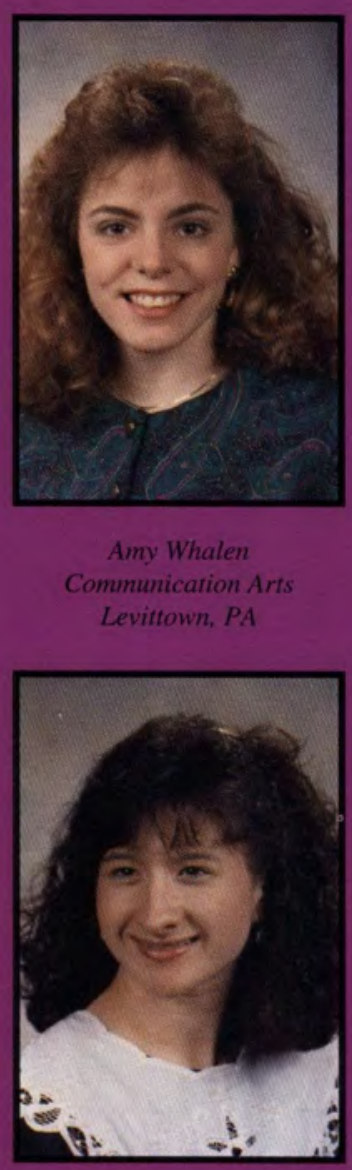

Theresa Webster

Physical Education

Binghamton, NY

Amv Whalen

Comumunication Art

Karen Williams

Ementary Educatio

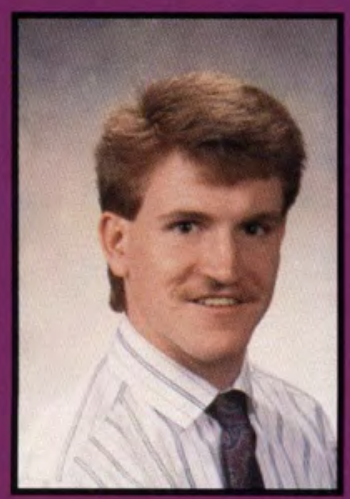

Craig Winsor

Physical Educatio

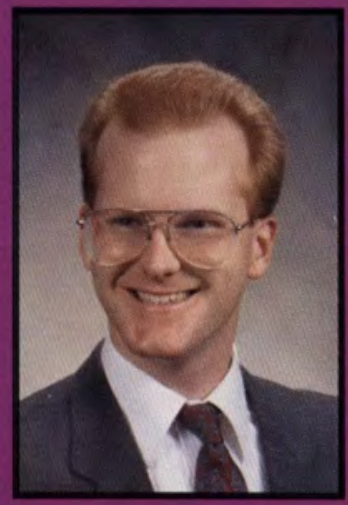

Scott Weenum

Holland MI

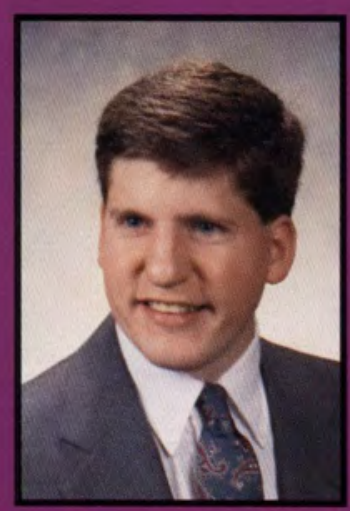

Matthew White

Elementary Education

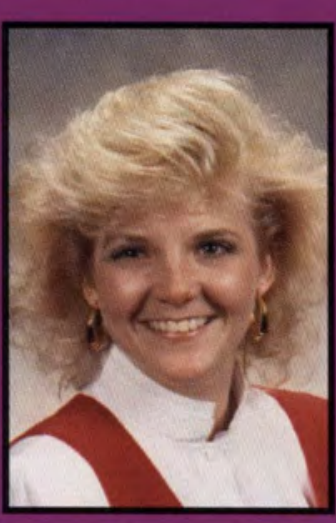

Kendra Williams

Elementary Educati

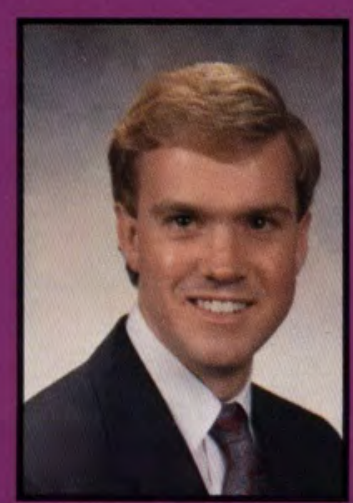

Matthew Wolf

Cambertville, MI
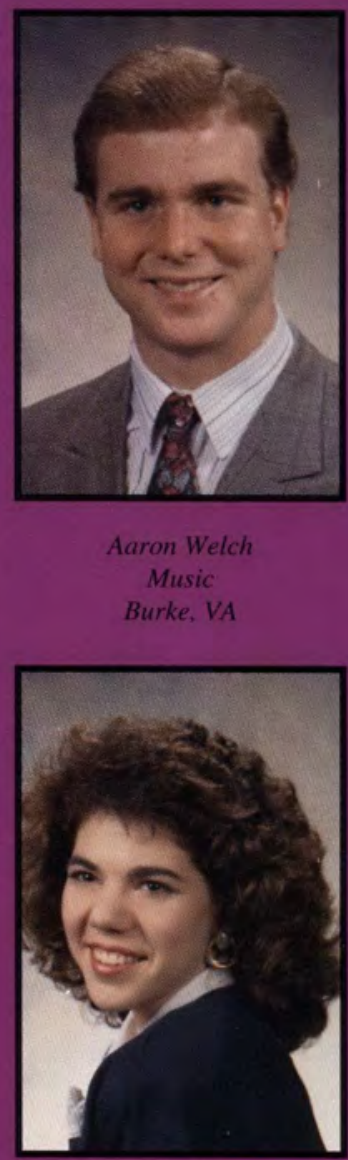

Wendi White

Biology
Chesapeake, VA

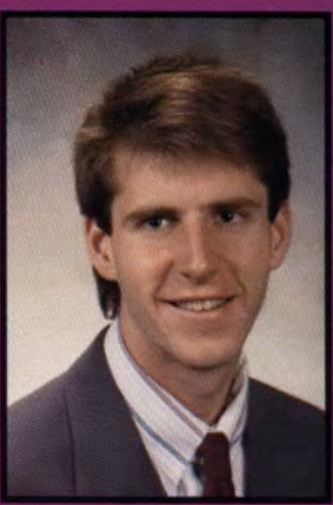

Kristian Williams

Physical Educat:

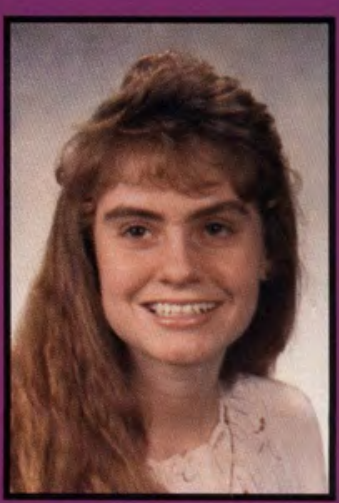

Melanie Wol

Lambertville, MI

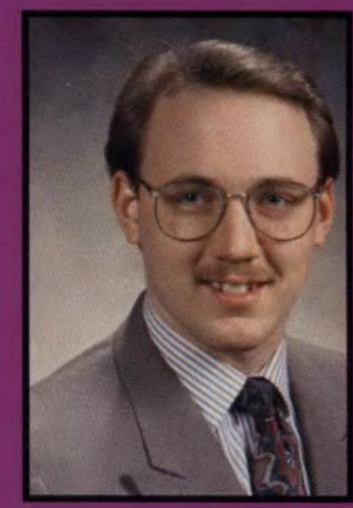

Jesse Wesselin

Bible, Preseminar

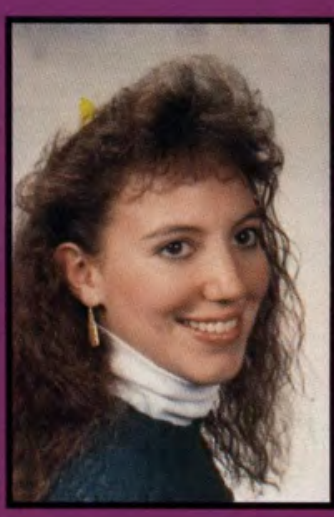

Deanna Wilco

Psychology
Binghamton, NY

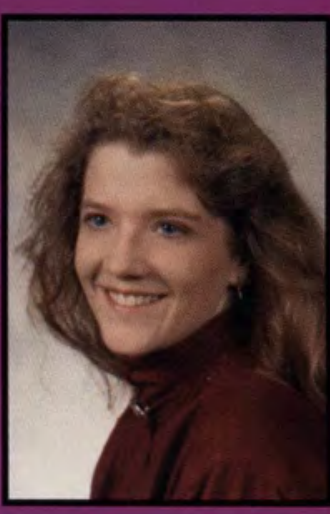

Aileen Willsie

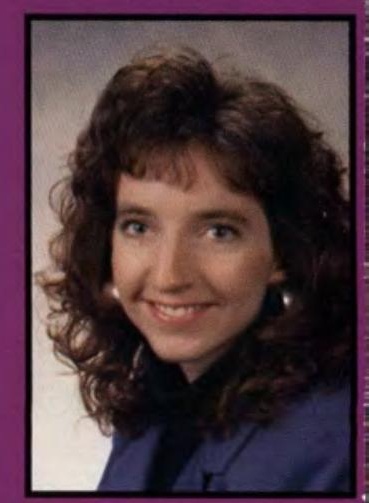

Rachel Wolford

Des Moines, IA 

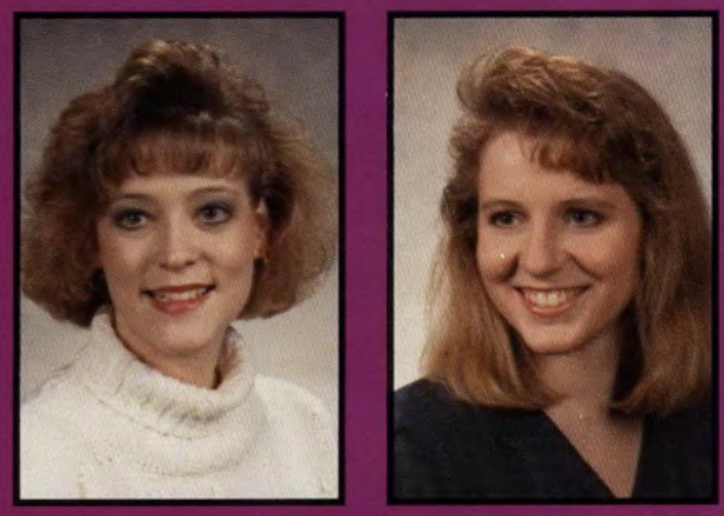

Gia Wooc

English
Battle Creet M

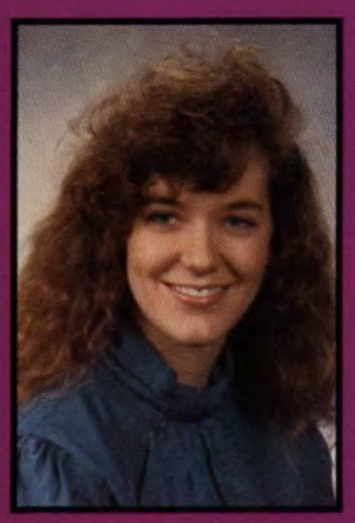

Gwendolyn Workman

Elementary Educa
Burton, $\mathrm{OH}$

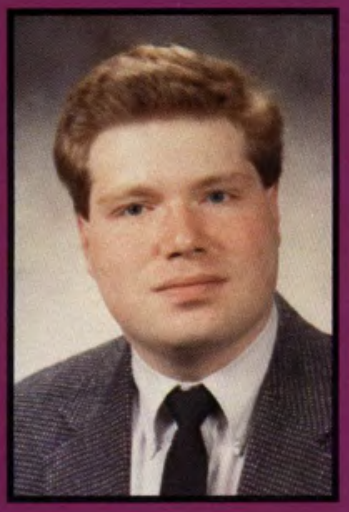

Alan Yate.

Bolivar N

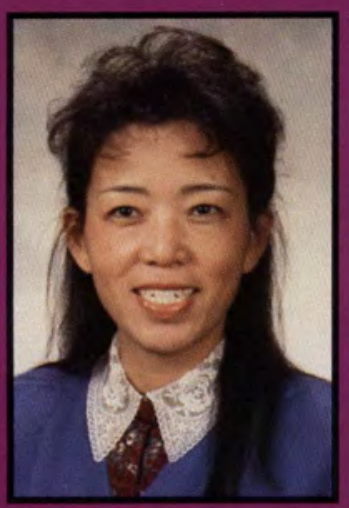

Joan Zhuang

Cedarville, $O H$
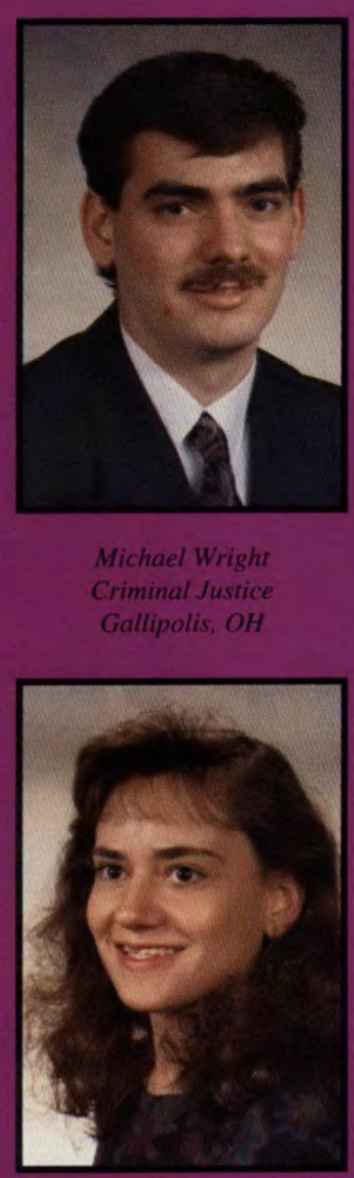

Michael Wright

Criminal Justice

Gallipolis, $O H$

Baton Roupe IA

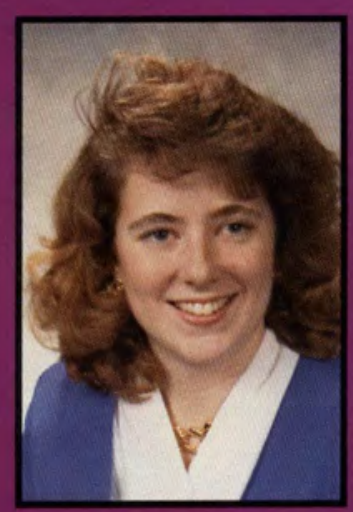

Lisa Zimunerman Blue Ball, PA
Blutary Educa

(0) free

Techerabagy

Loup City, NE

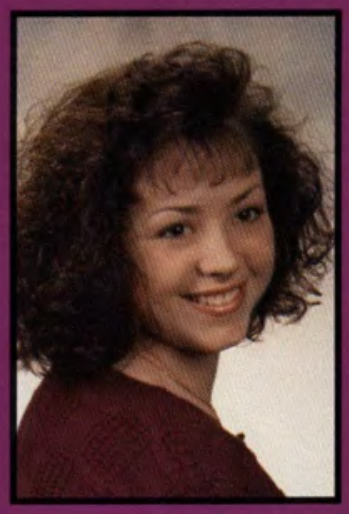

Pam Constable

Toronto, Ontario
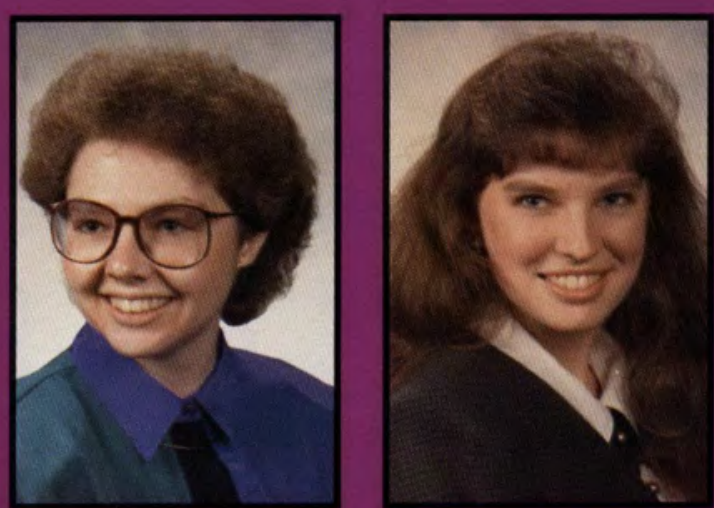

Melissa Byrom

Beavercreek, $\mathrm{OH}$

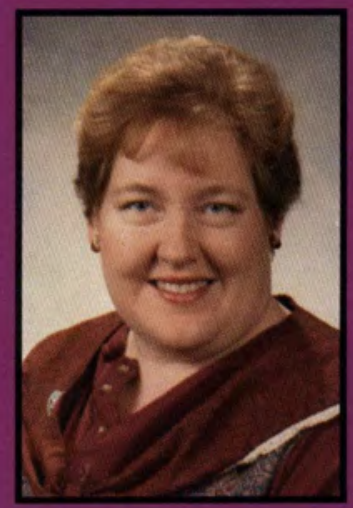

Sylvia Frazier

Cedarville, $\mathrm{OH}$

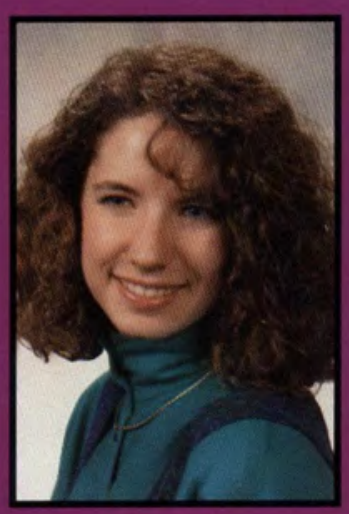

Denise Maronn

Oshkosh, WI

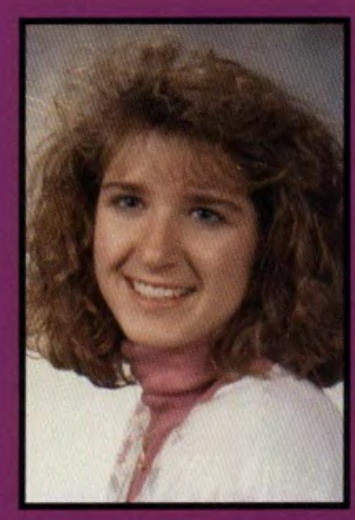

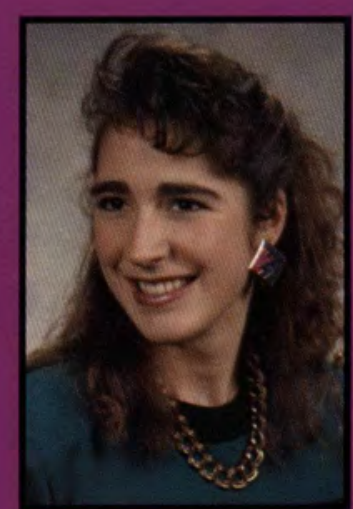

Tana Castelor

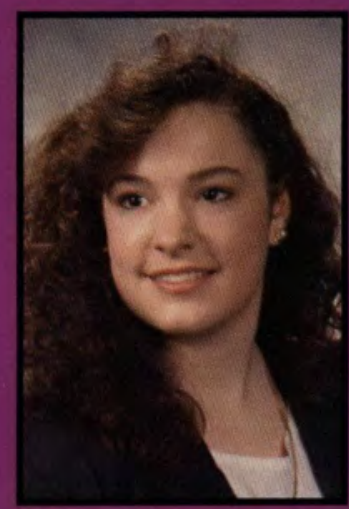

Tina Heyins

Pasadena, MD 


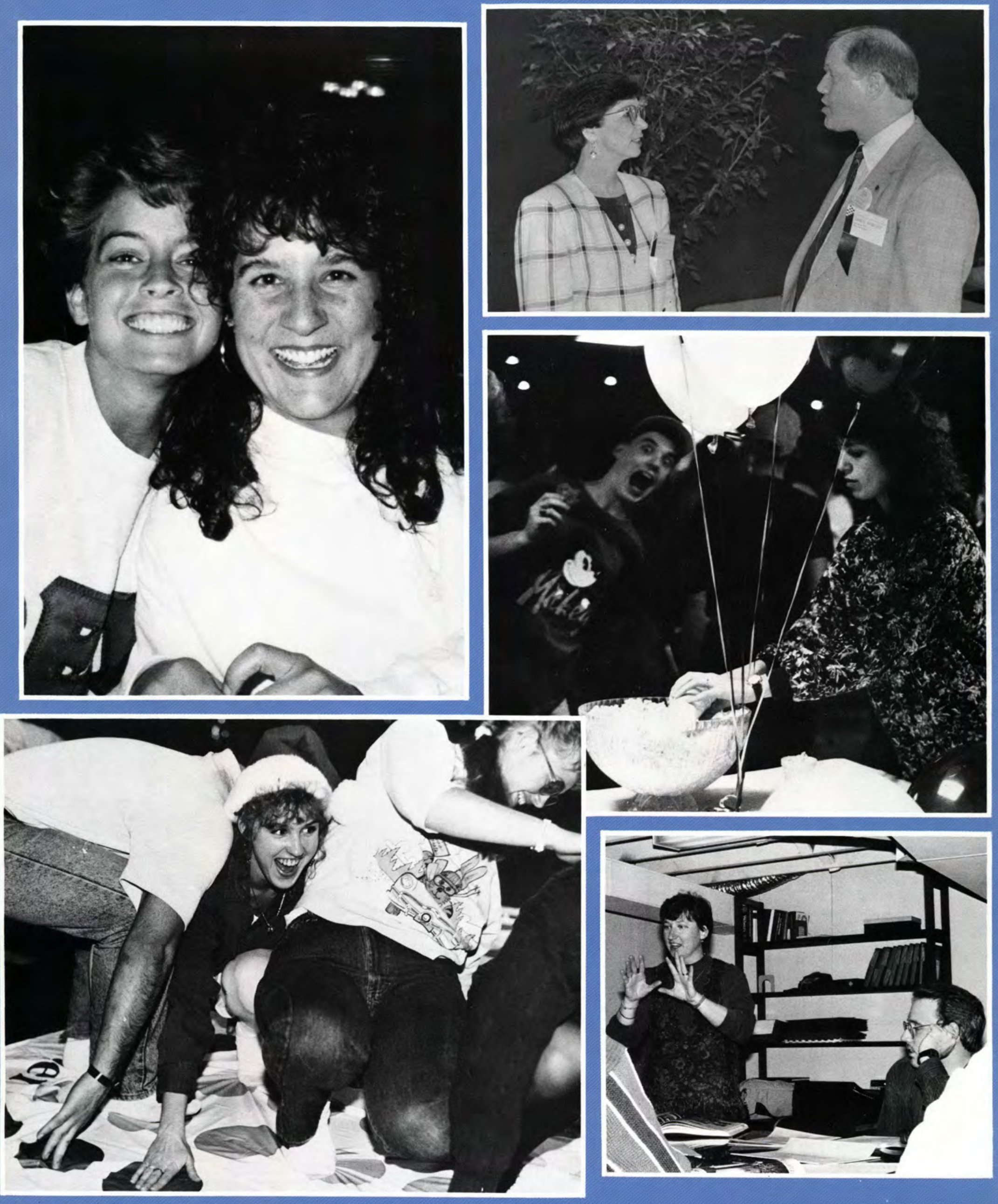

$4 \sqrt{196)}$ Organizations 


\section{Sacrifices for Success}

Table of Contents:
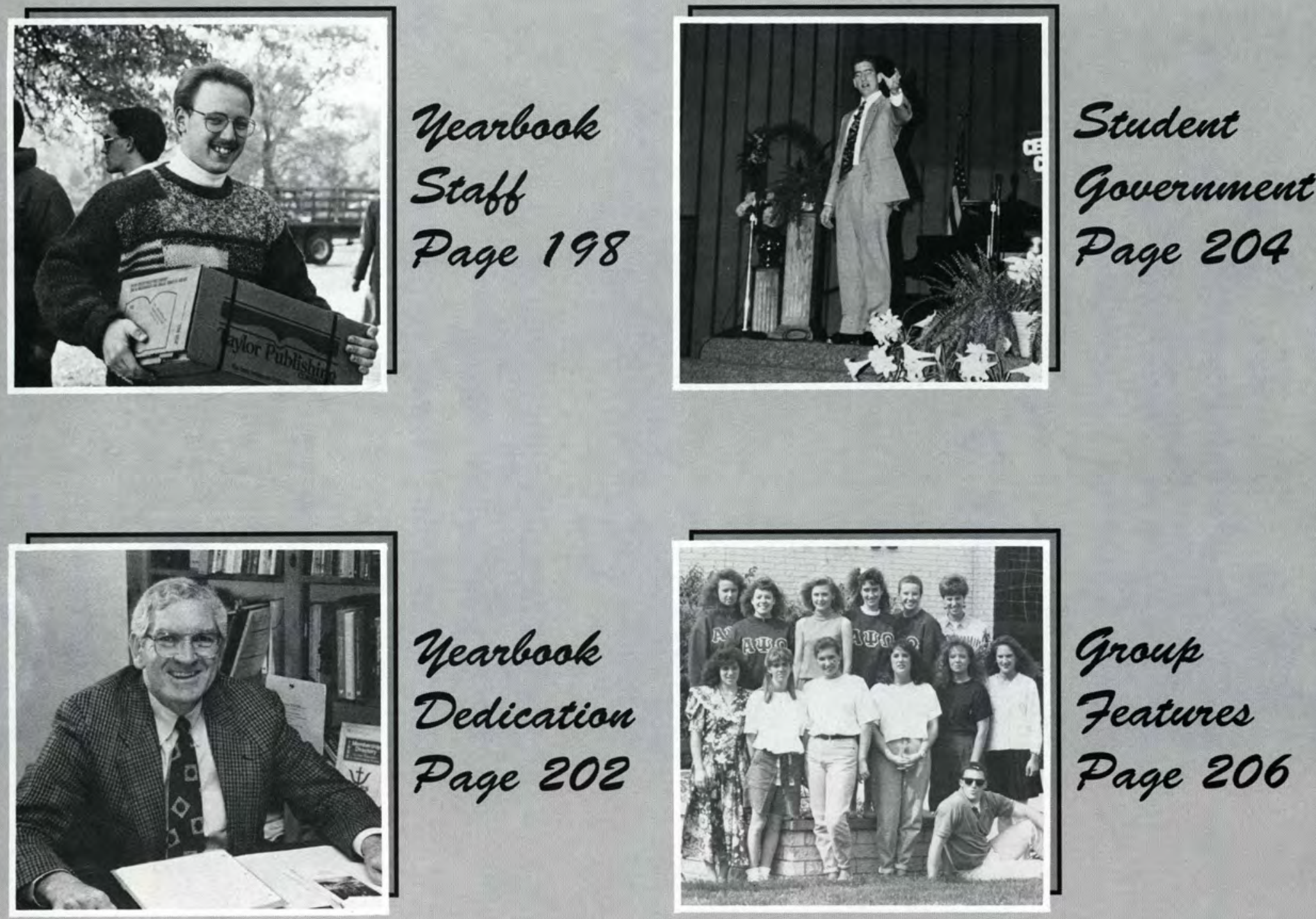

Yearbook

Stabf

Page 198

Yearbook

Dedication

Page 202

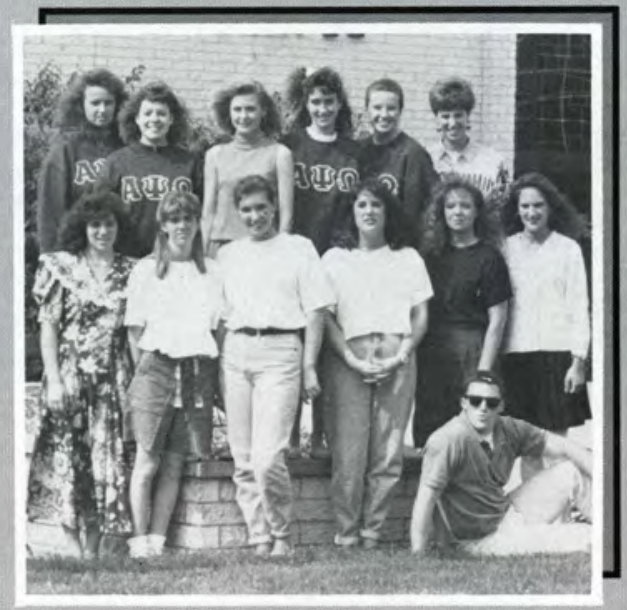

Group

Features

Page 206 


\section{Miracle Staff: Minds at Work}

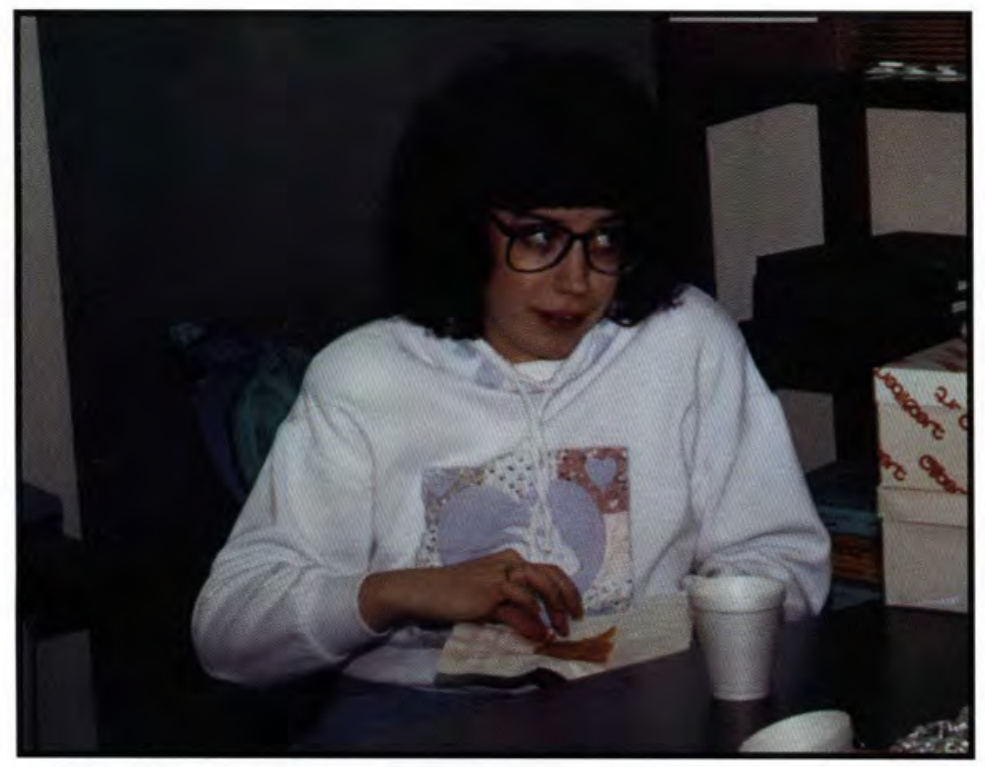

AN INSPIRING MOMENT Jim Foster writes another innovative article.

SANITY BREAK Secretary Susan O'Leary pauses from stuffing envelopes with patron letters and enjoys a slice of pizza.

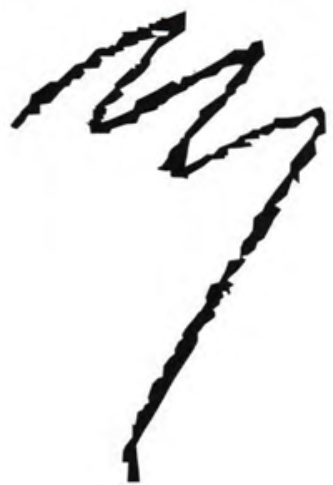

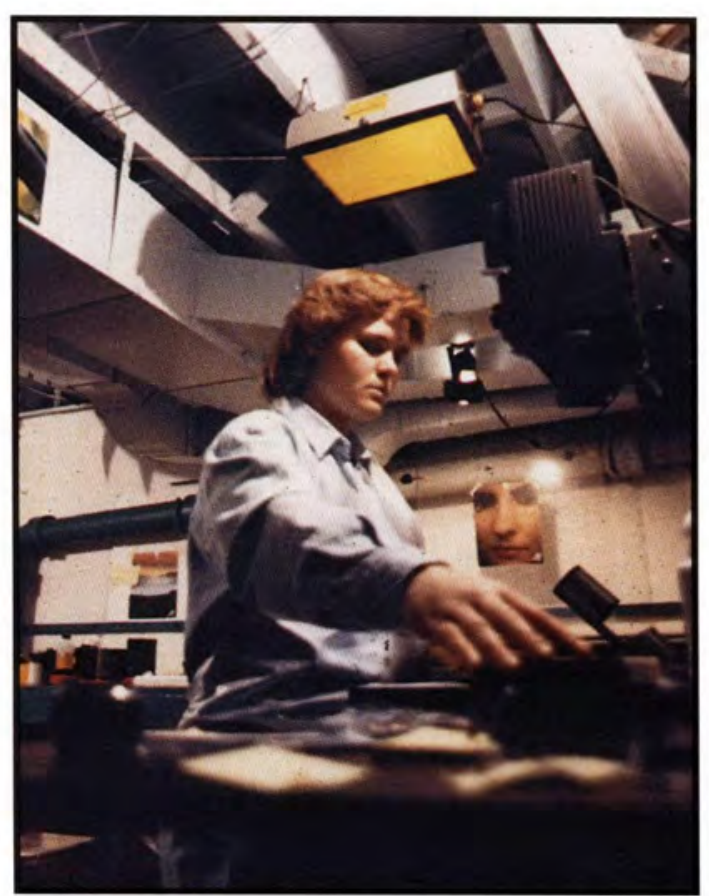

PICTURE PERFECT Photography Editor Marsha Olsen prints another yearbook photograph.

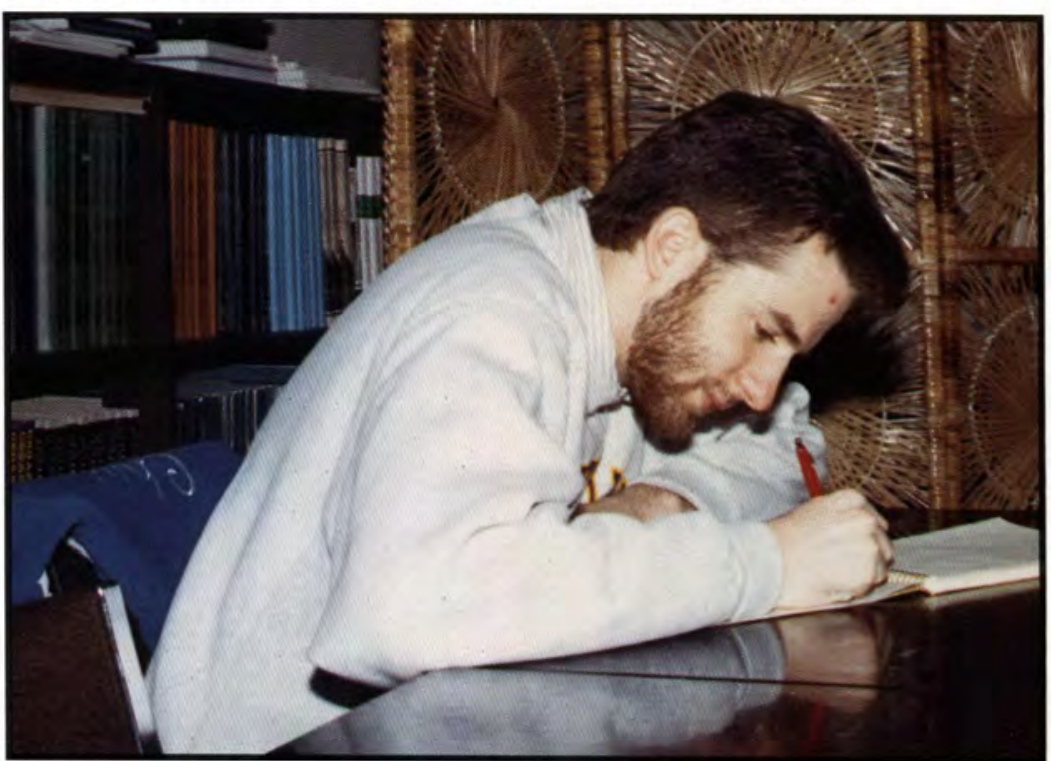

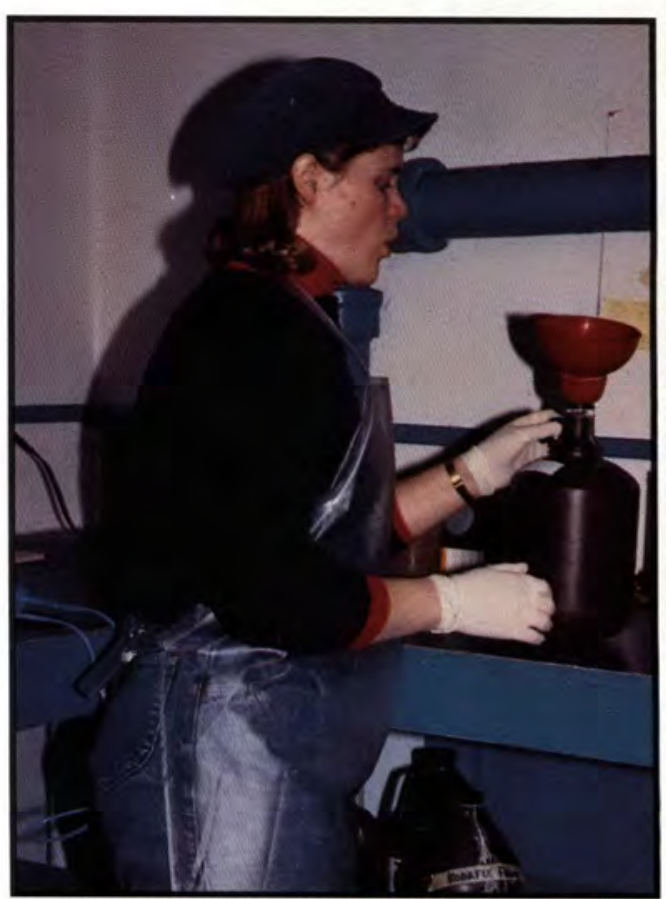

WHISTLING WHILE SHE WORKS Marsha Olsen mixes chemicals in the yearbook darkroom. 
SHOWING OFF A MASTERPIECE Layout designer J.J. Stevens thanks photographer Steve Cook for a shot well taken.
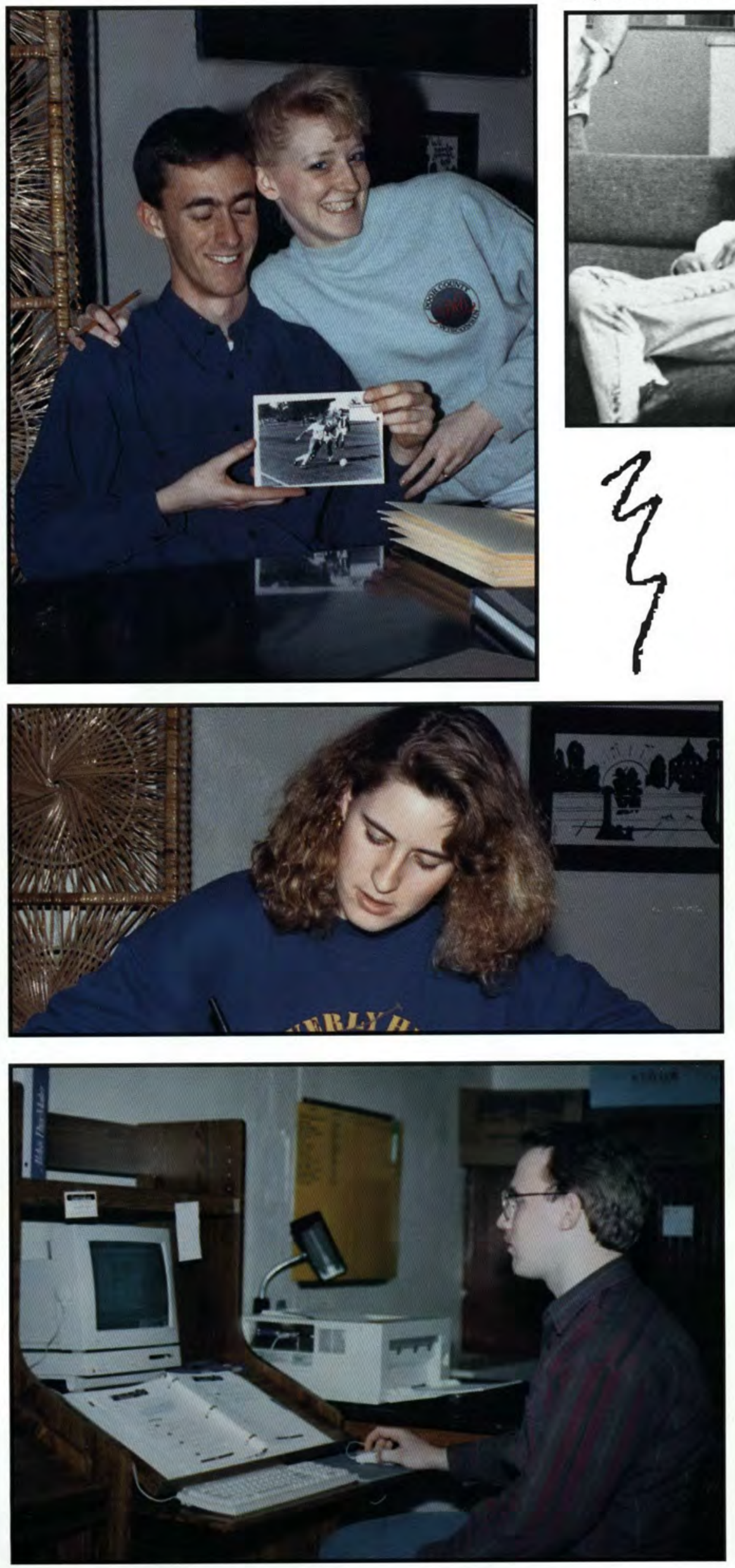

(middle) CALLING THE SHOTS Copy Editor Meredith Clements hands out the weekly writing assignments.

(bottom) A HIGH-TECH TOUCH Editor-in-chief Jesse Wesselink designs a yearbook page using the new desktop publishing program.

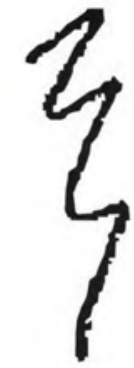

TAKING TIME OUT Tammy Wittkamper and Debbie Koch enjoy time away from classes at the yearbook staff retreat.
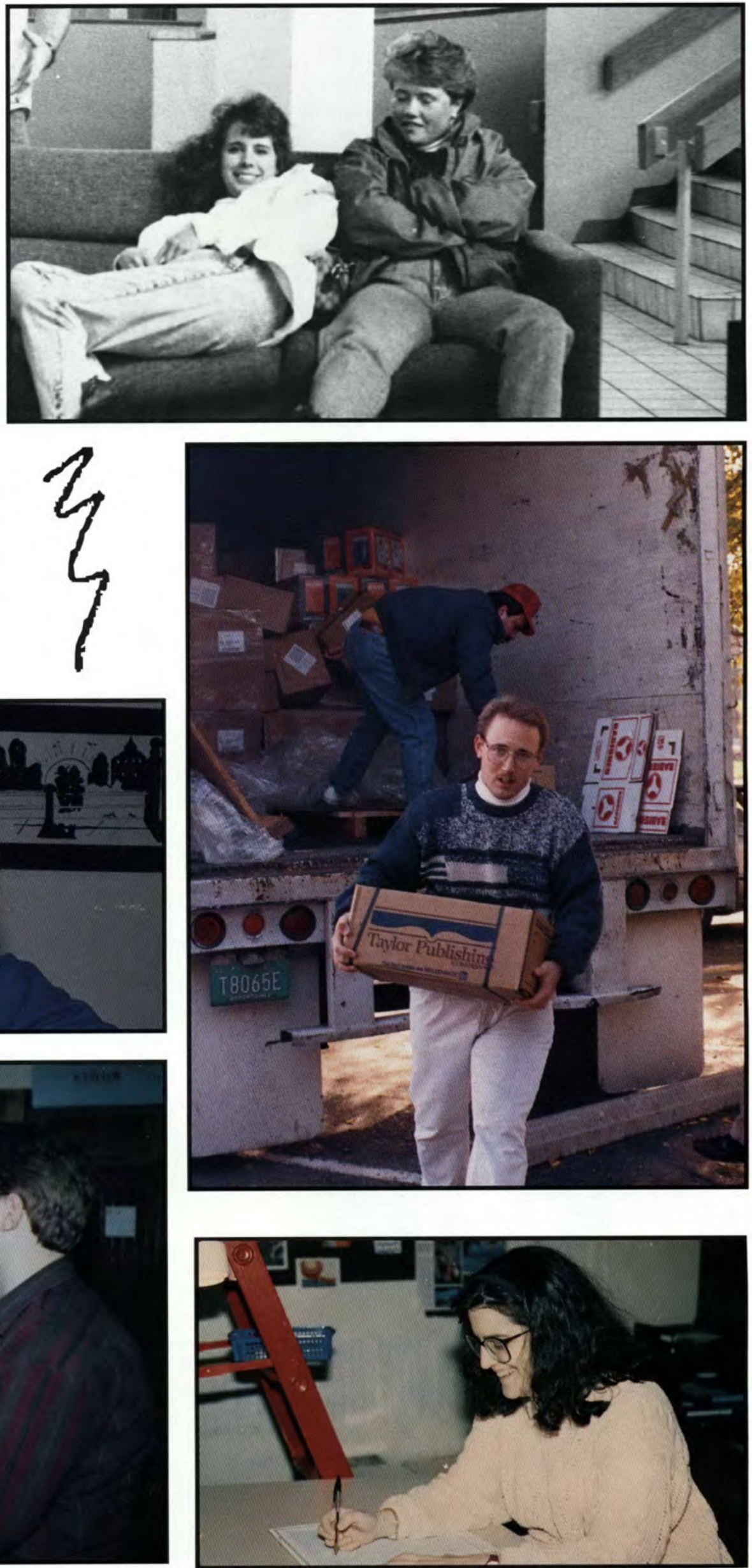

(middle) THEY'RE FINALLY HERE! Jesse Wesselink unloads the 1991 yearbooks off the truck.

(bottom) SERVICE WITH A SMILE Layout editor Mary Ellen Fogg begins designing yet another yearbook page. Organizations 1996) 

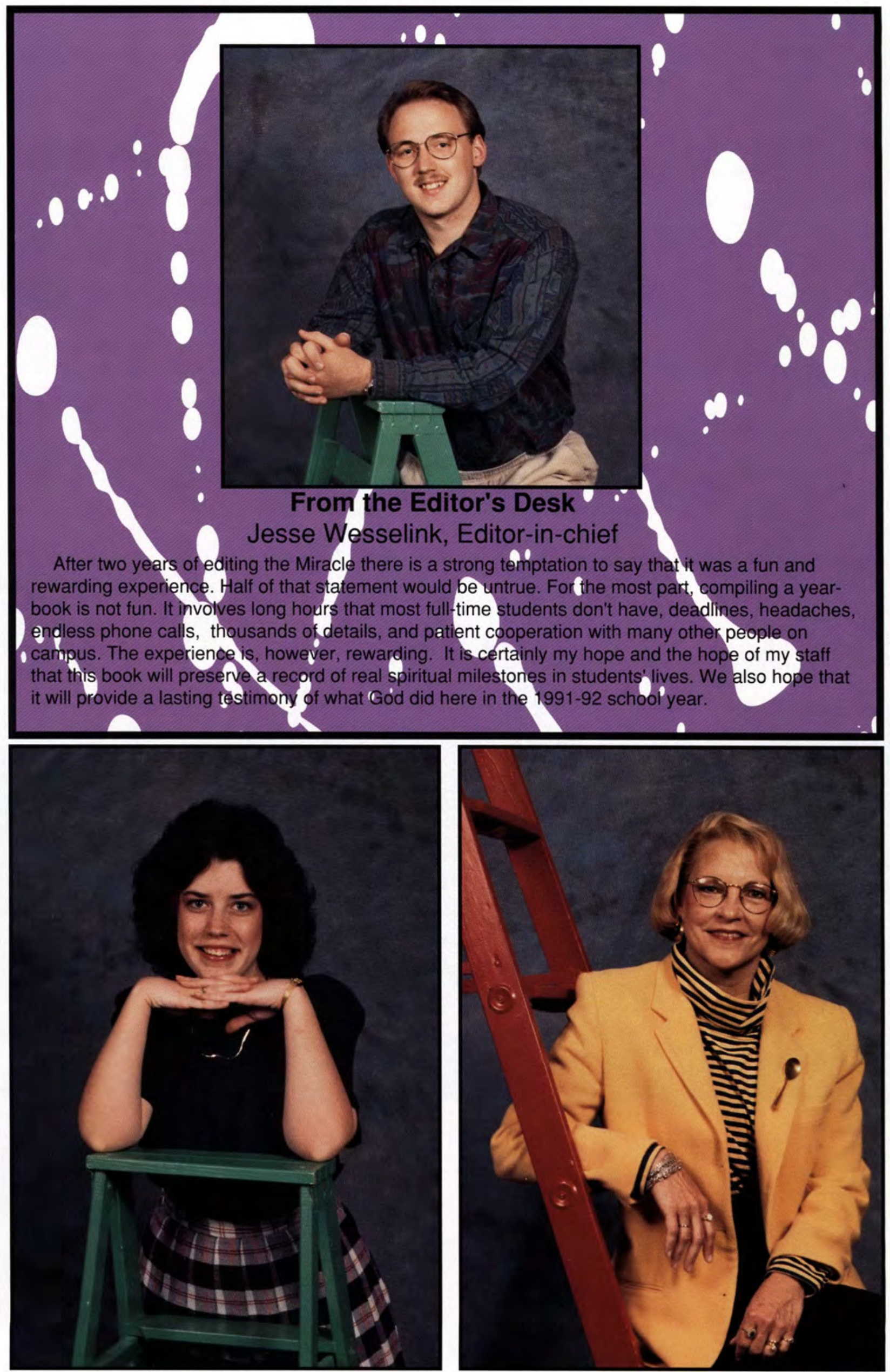

Secretary

Susan O'Leary

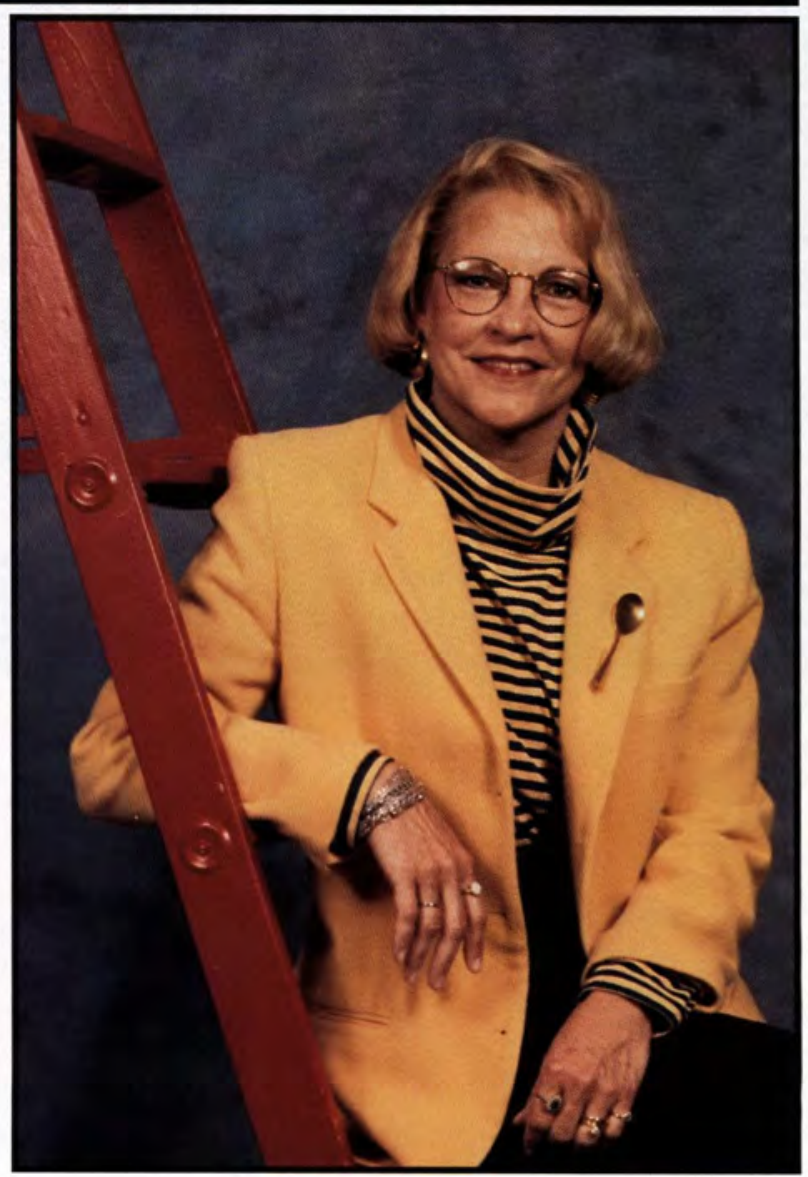

ADVISOR

Pat Dixon 

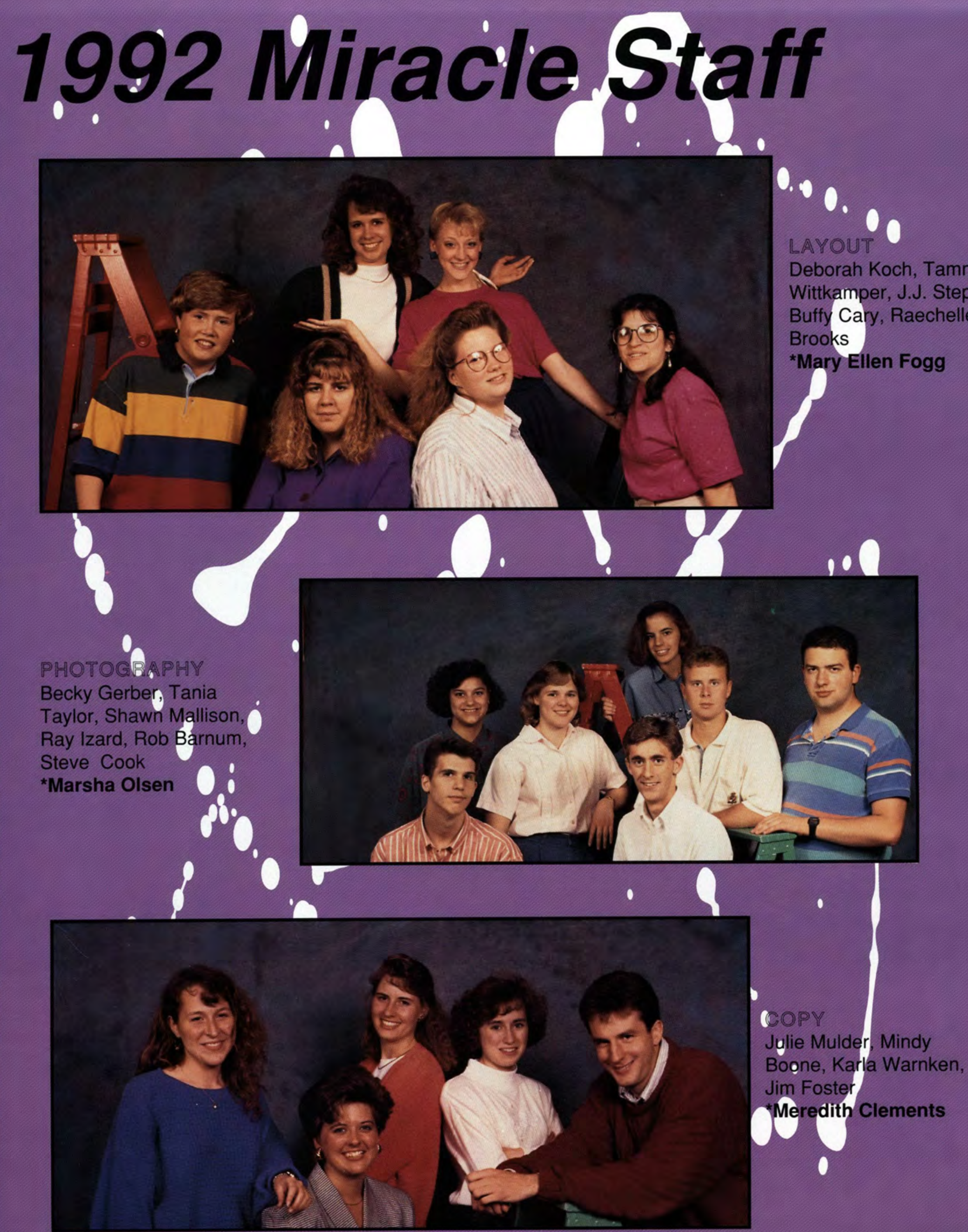

* Editors in Section 


\section{Dedicated To Working Beyond the Call of Duty}

FREE ADVICE Dr. Ballard advises a Cedarville student.

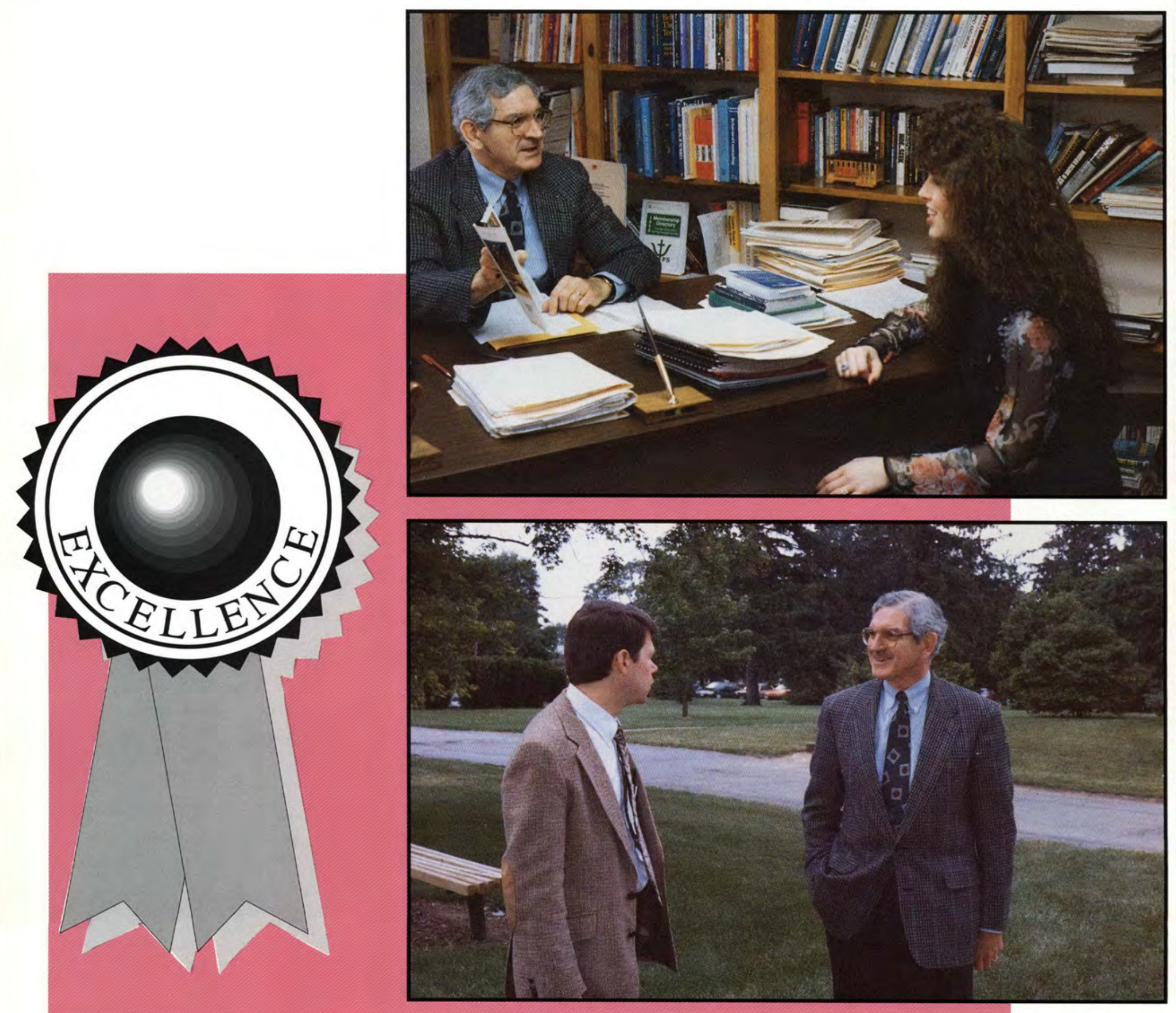




\section{Dr. Stanley Ballard}

Cedarville College is built upon the lives of committed people who have faithfully and quietly dedicated the majority of their lives to the college's ideals. Most of their work goes on behind the scenes. Some professors have highly visible ministries in large general education and introductory courses, but many work primarily with students within their department in upper level courses. These professors have the privilege of mentoring their students and leading them through their personal example.

Dr. Stanley Ballard is an excellent example of a man who quietly and behind the scenes has dedicated 27 years of his life to Cedarville College. He has served as Dean of Men, Bible Professor, Psychology Professor, and Chairman of the Psychology Department. He has chaired and served repeatedly on most of the important committees which, although little recognized, have been crucial to Cedarville College's stability, growth, and vitality. Dr. Ballard has also been the driving force behind the Psychology Department for 20 years, building it into a program which has been the prototype for other Christian colleges and which has through its alumni supplied the professors for some of those programs.

Dr. Ballard is known as a demanding teacher with an extraordinary vocabulary who assigns lots of papers. He has been very effective in motivating and preparing his students for graduate school. His students usually return in a few years saying graduate school was easy compared to Cedarville. He is dedicated to the integration of psychology and theology. He is one of the few psychologists who is as conversant with theology as psychology. His classes challenge students to approach psychology from a biblical perspective and from a Christian world and life view. He has produced a generation of students who teach and counsel for Christ across the United States.

One of Dr. Ballard's most powerful influences on Cedarville College has also been one of the least visible. Dr. Ballard is a mentor. He has a life long commitment to his students. It is not uncommon for his former advisees and students to visit or correspond with him for advice and guidance many years after graduation. He has had a continuous mentoring relationship with some students for twenty years in which he taught them, helped them into graduate school, encouraged them through it, helped them with career plans after graduate school, supervised them for licensure, helped them get established in practice, and welcomed them as colleagues. Through years of mentoring, $\mathrm{Dr}$. Ballard has influenced his students, who have affected the world.

Dr. Ballard, like Cedarville College, is known for his depth, his commitment to individual students and his spiritual balance. These are the Cedarville College treasures which lie beyond face value.

GETTING THE POINT ACROSS Dr. Ballard leads an informal class discussion. 


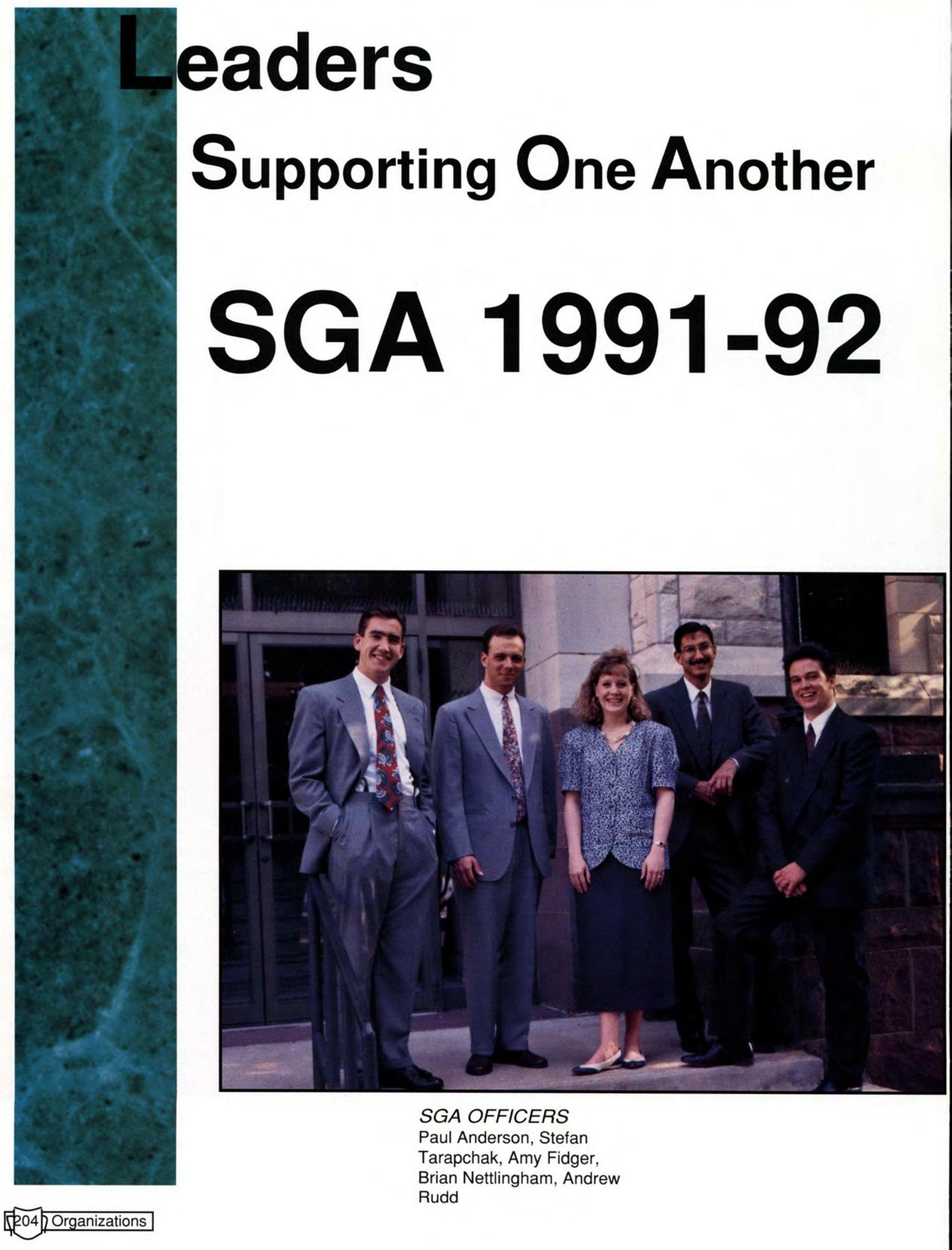



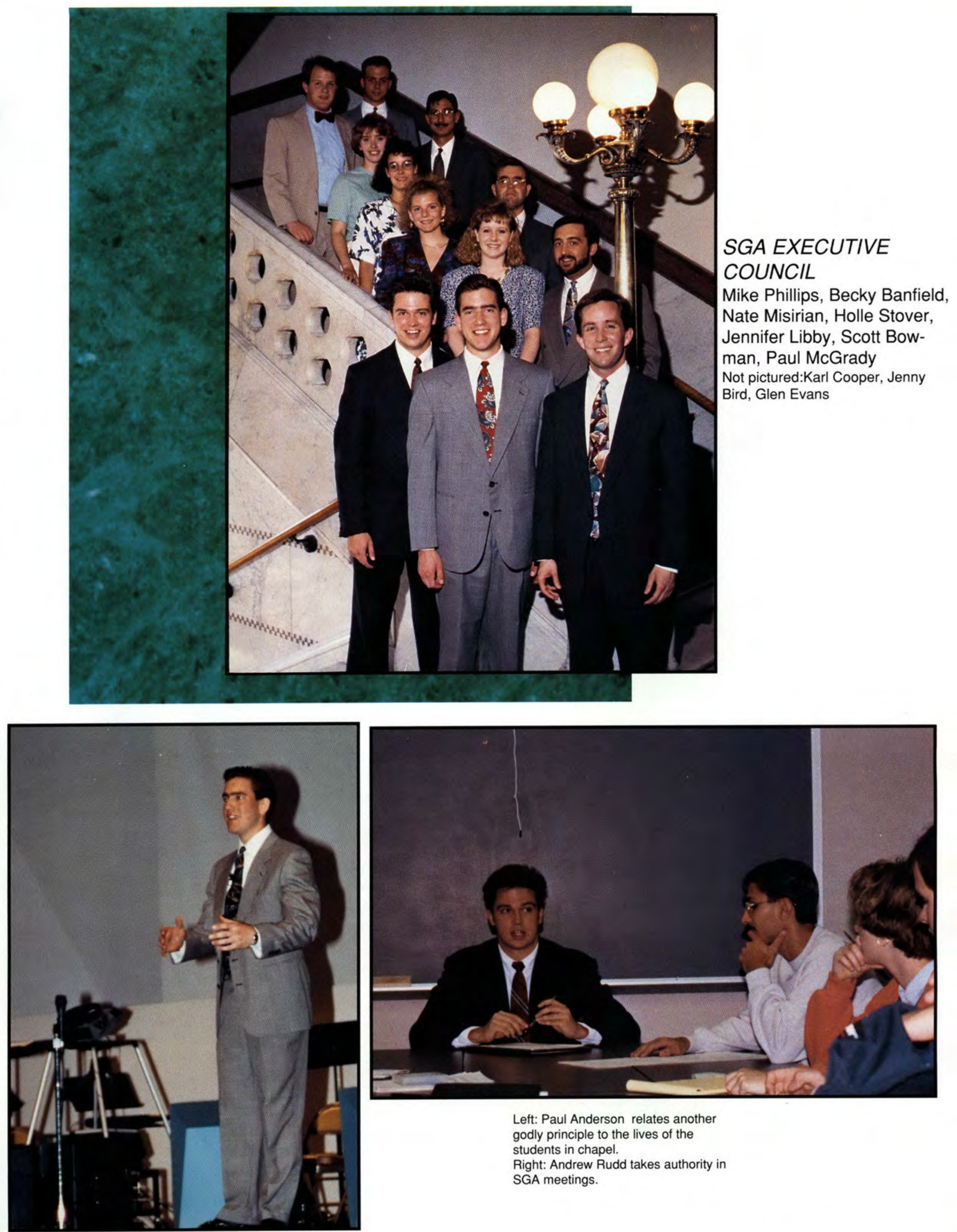

Left: Paul Anderson relates another

godly principle to the lives of the

students in chapel.

Right: Andrew Rudd takes authority in

SGA meetings. 


\section{By the Students And}

\section{For the Students: Class Officers}

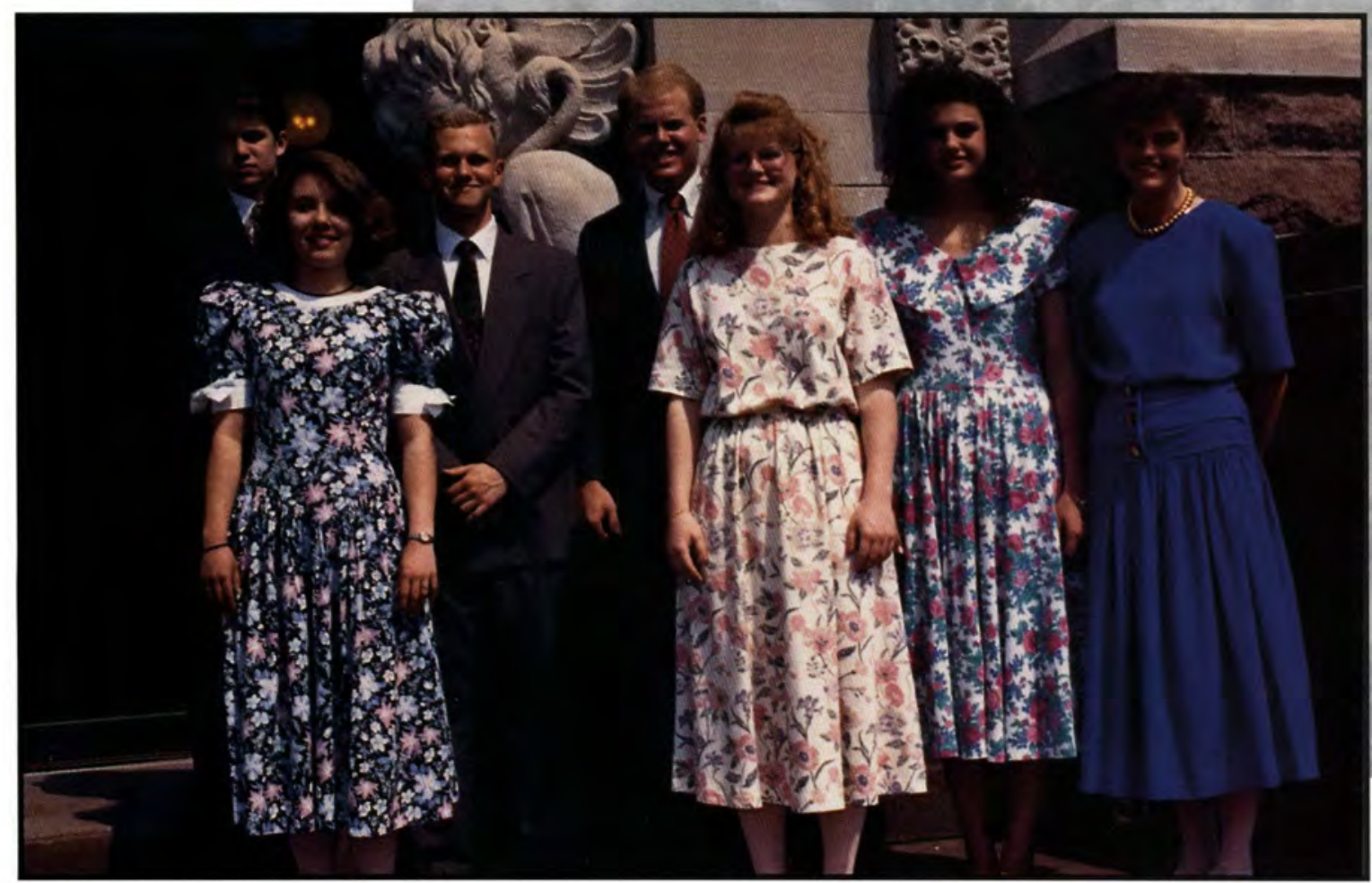

Freshman Officers Amy Barnes, Laurie Bell, Kathy Bond, Nicole Grizenko, David Rudd, Patrick Hanes, Chuck LeMaster
Sophomore Officers Tim Hoy, Dana Gosser, Joe Slavens, Cheryl Philipps, Greg Milentis, Ryan Linnehan, Robin Sheldahl

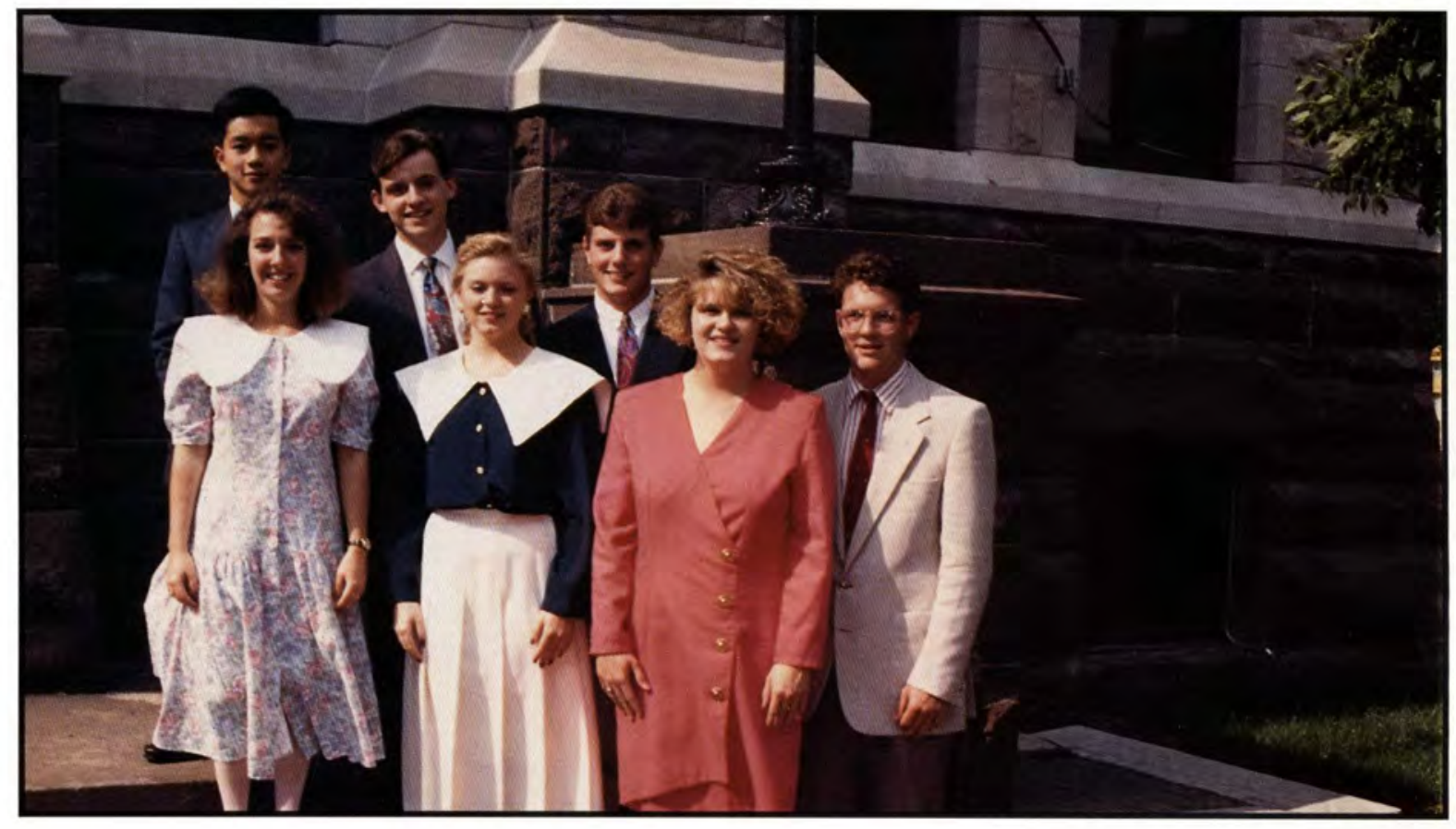



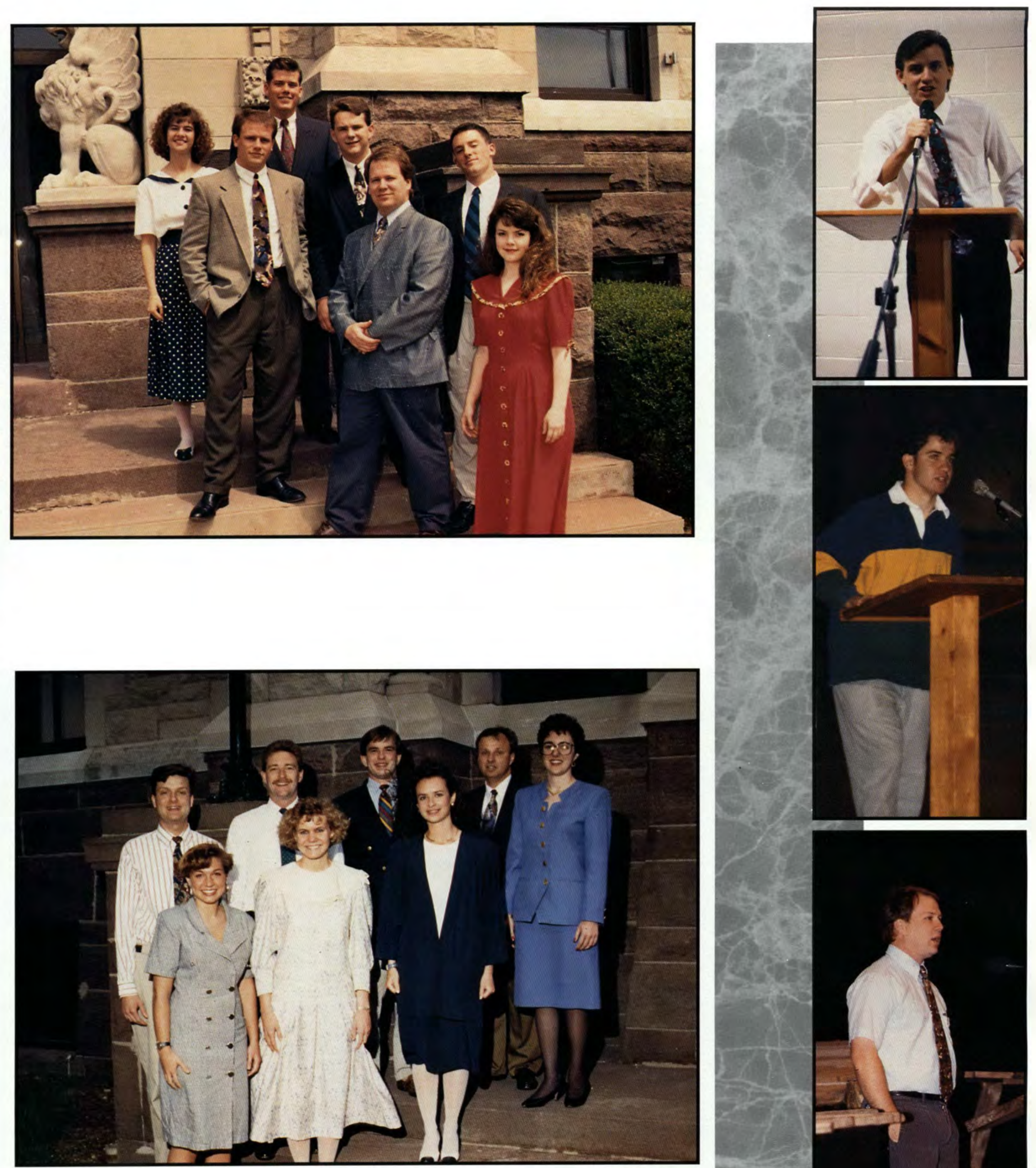

Senior Officers

Brendon Cleary, Matt Moore,

Renee Maxwell, Jim DeVine,

Michelle Polish, Allyson

Graham, Laura Farnsworth

Advisor-Tim Heaton

Officers in Class Chapel:

Joe Slavens

David Rudd

Rob Fogg 


\section{organizations}

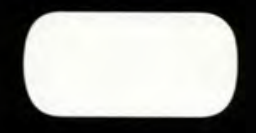

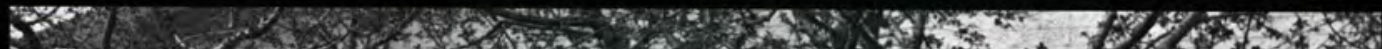

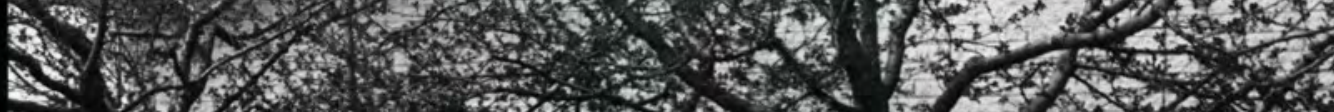
Til

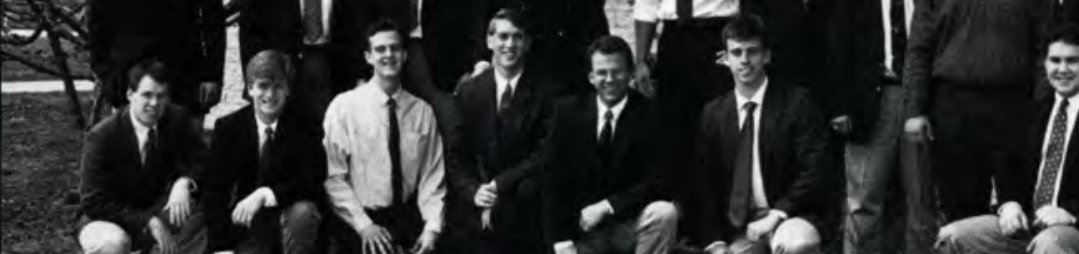

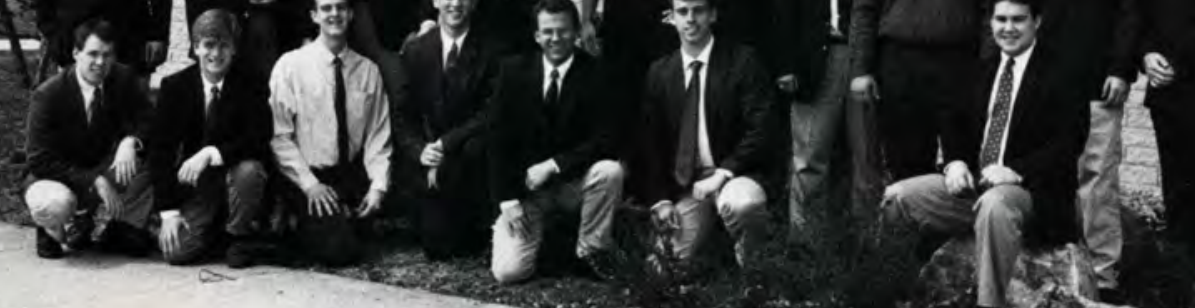
62
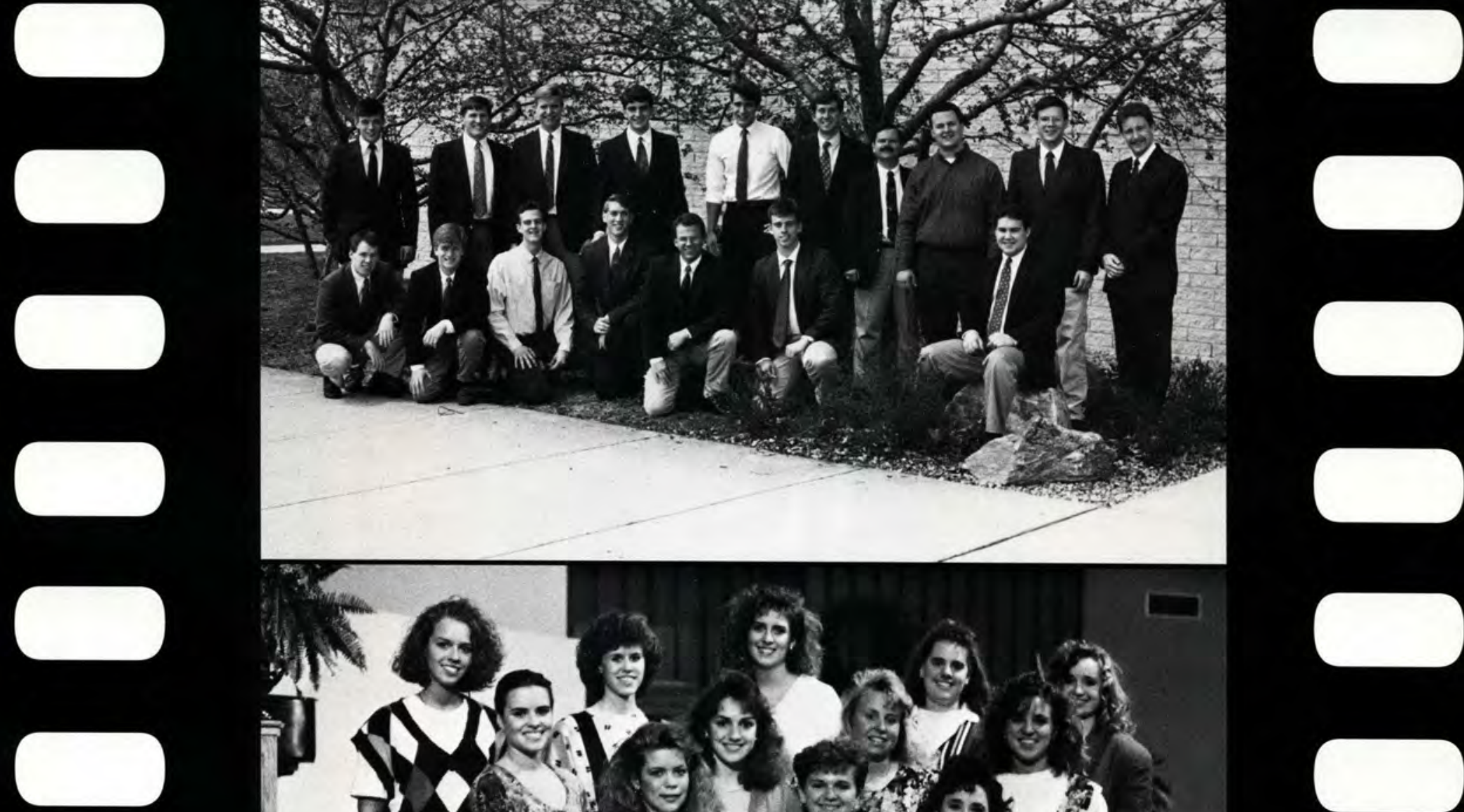

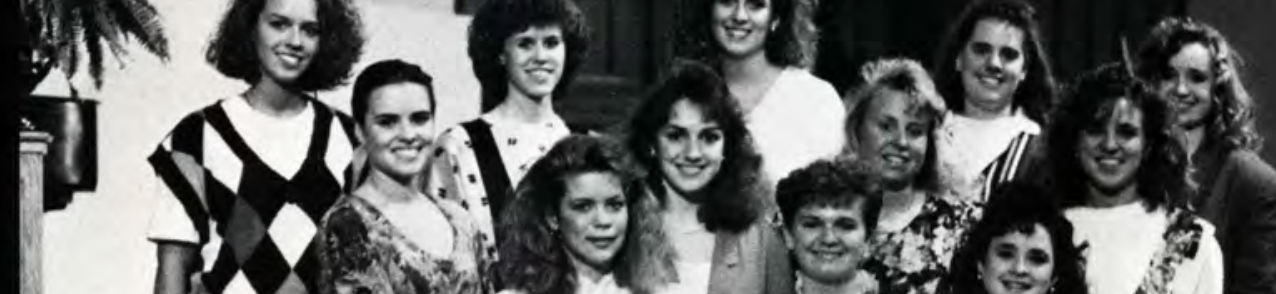
8. 1 a - cu ran
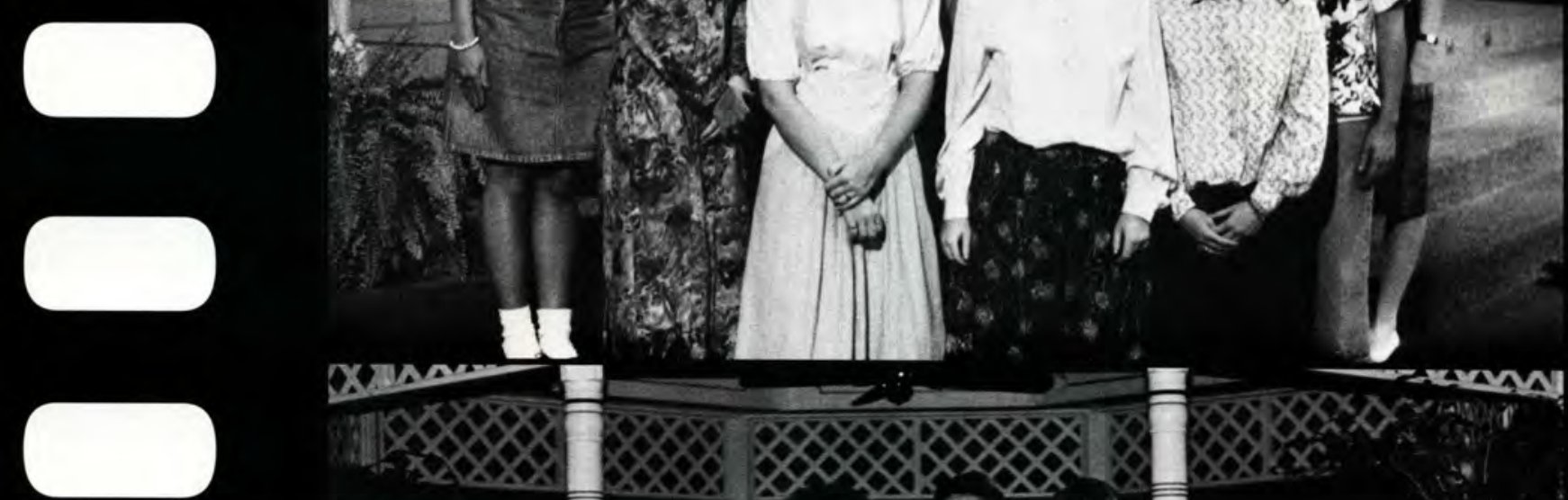

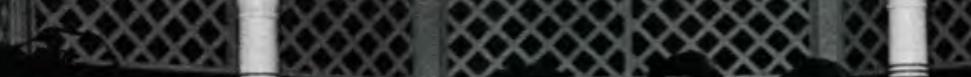



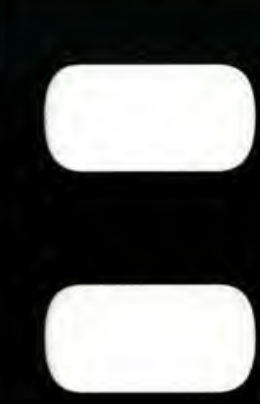

ALPHA CHI

ALPHA CHI is an organization with a heart for serving others in the school and surrounding community. They demonstrate this by helping older staff members with yard work and moving in new staff members. On campus they are active with their assistance in setting up concerts and involvement with Project Angel Tree. Alpha Chi is responsible for the Annual Talent Night held during winter quarter. Their organization puts much time and effort into making The Talent Night a success. Alpha Chi is already looking forward to next year when they sponsor the campus wide CEDAR WHAT, an in - depth, mock election created by Alphi Chi years ago. We appreciate Alphi Chi's ministry to Cedarville College.

\section{- Julie Mulder}

First row: David Shumaker, Grege Riddle, John Wambold, Nathan Boitler, Devin Cheek, Randy Southwell, Steve Mathwin. Second row: Tom Bockmann, Jeff Burr, Chris Wilson, Scott Michael, Mike Carroll, Dr. Kevin Sims, Scotty Mills, Rob Reed, Joe Piscopo.

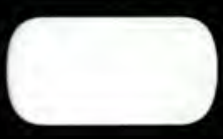

ALPHA DELTA OMEGA

The purpose of ADO is to be a service and social organization for the women of Cedarville. Under the leadership of their current president, Kara

Underwood, they focus on the aspect of serving in two ways: first, to those within ADO and then to those in the college and community.

Alpha Delta Omega is committed to putting God first in every aspect of their lives. The Alpha and Omega, which stands for the beginning and the end, surround the Delta triangle, which represents the three areas of our lives as Christians: spiritual, emotional, and physical. ADO's purpose is to work together to fulfill these goals.

ADO is responsible for many service oriented projects: Project Angel Tree, The Battle of the 'Ville, and Barney's Week. ADO also helps AX with the fall Halloween Party and DOE with the Cupid's Bash on Little Sib's weekend. - Julie Mulder

First row: Michelle Yates, Susan Beach, Stacy Smith. Second row: Amy McDonald, Diane Hannay, Kathleen Belmont, Kera Underwood. Third row: Shelly Souza, Jenine Hyten, Dana Thompson, Tammy Clark, Carrie Grayson. Not pictured: Shelly Baessen. Kathleen Gasparro, Angie Smith, Zella Sheen, Beth Brendle

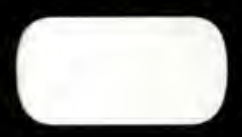

\section{ALPHA PHI LAMBDA}

ALPHA PHI LAMBDA is an organization that was founded four years ago and "seeks to fill the need for cultivation of the appreciation of Fine Arts at Cedarville College. Its members desire to provide an outlet for the artistic efforts of students." Although in past years Alpha Phi Lambda has not been very well known, John Varner, the newly elected president of the organization, has future plans to change that. Alpha Phi Lambda meets weekly to share poetry, short stories and compositions that its members originated or discovered in their own reading of poetry books and magazines. The shared material is then discussed with the hope of fulfilling the stated purpose of gaining a better appreciation of the fine arts. Each year this group publishes a book called "Book of Ashes" containing the various original works of Alpha Phi Lambda members as well as Cedarville students.

- Julie Mulder

First row: Phil Huber, Susan Clark, Abby Boone, Philip Graves. Second row: Necia Fanton, Sue DeMan, Jonathan Varner, Brenda Sinnamon.
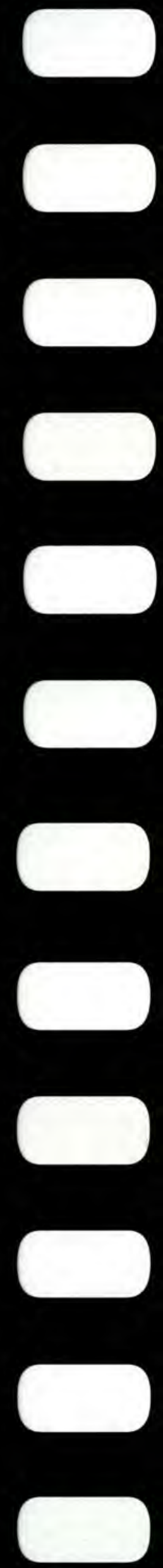





\section{$\mathrm{CSI}$}

The members of CSI seek to gain experience in the secretarial field and build friendships with those of similar interests. Not only do they provide a laser printing service and sponsor computer workshops, but also they use their bookkeeping skills at the Crisis Pregnancy Center. For Secretary's Day, all the secretaries on campus are honored by a CSI sponsored dinner at which there is a film or guest speaker which is beneficial to the secretaries. The organization also tries to attend at least one national or regional conference a year. This year's conference was in St. Louis, Missouri.

-Mindy Boone
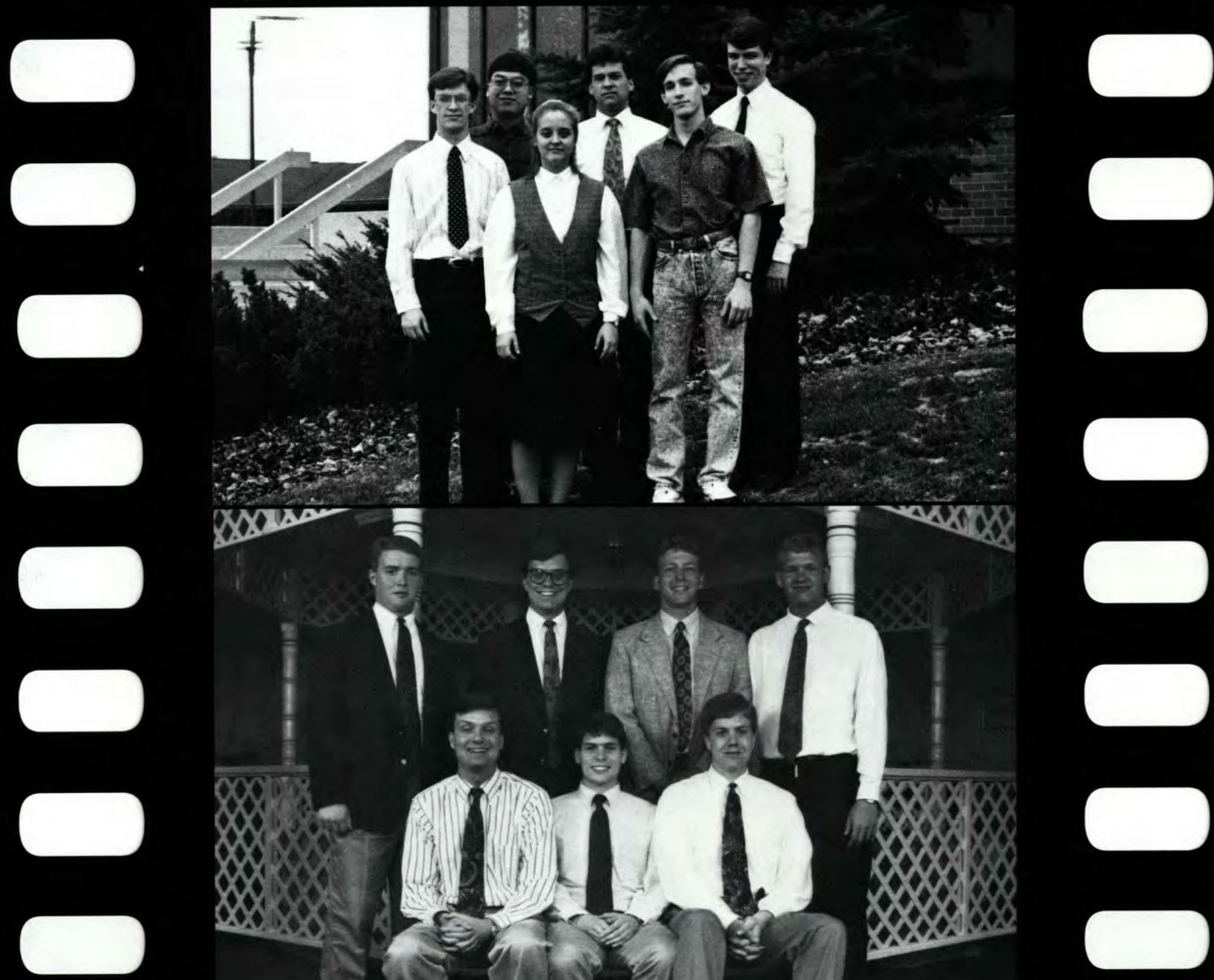


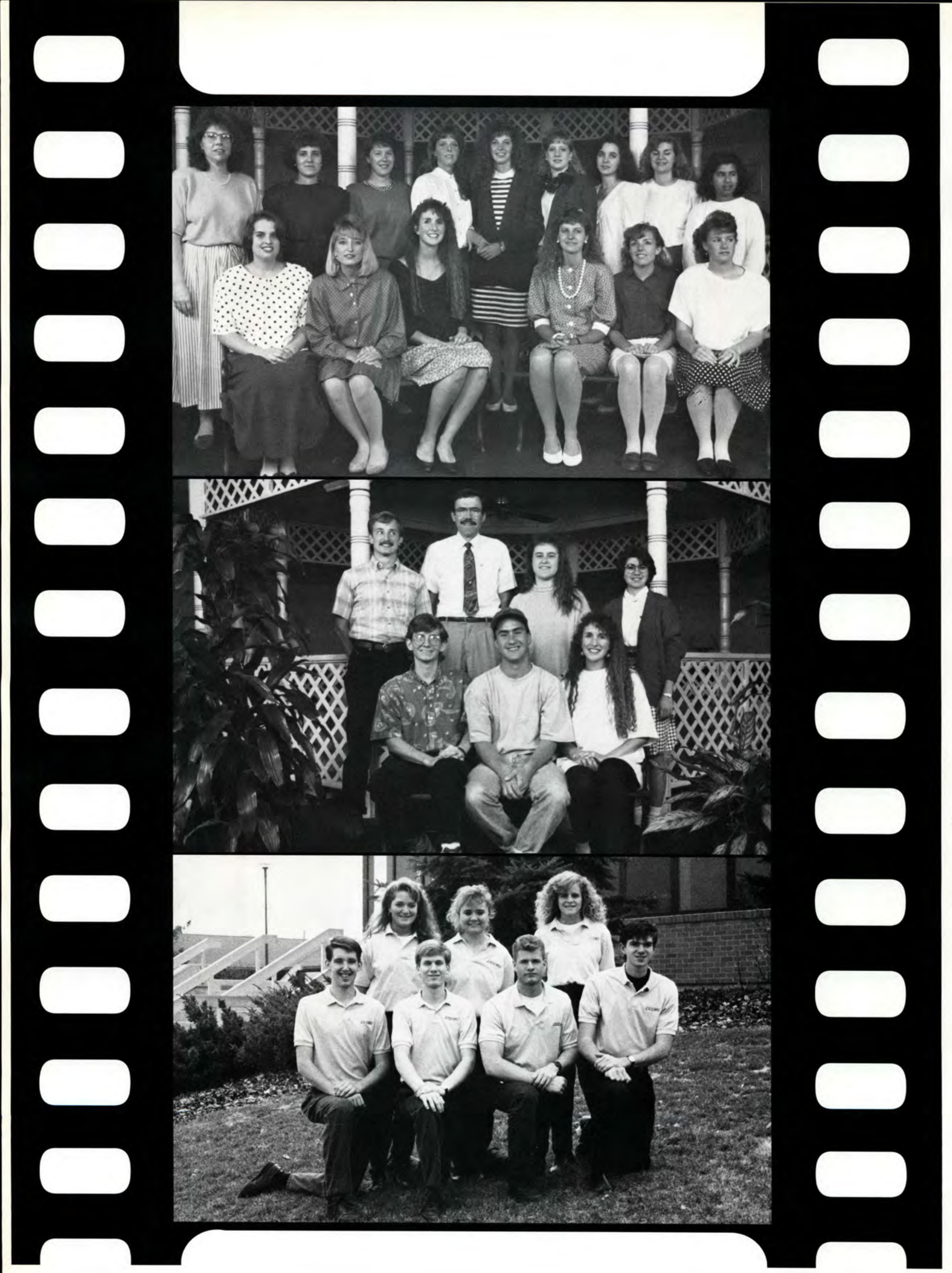


DELTA PI SIGMA

"Okay, ma'am! We will bring your kids back in about half an hour," shouts the comfortably-dressed college student. "Thanks! Have fun at the park, kids!" replies the over-worked mom, eager to experience some piece and quiet.

Taking the Maple Street children to the park is just one of the many outreach and service activities done by Delta Pi Sigma. According to leader Gale Nocella, the women's organization is dedicated to Christ and strives to serve others. Along with spending time with local children, the women initiate other service activities, such as housecleaning and sponsoring needy children worldwide.

To grow closer to the Lord, as well as each other, Delta Pi Sigma is divided into discipleship groups. Each year, the group sponsors late night skates and enjoys several retreats and dinners together.

Indeed, Cedarville, Ohio, is a small community. Yet even the smallest communities abound with service opportunities. They spread God's love to the lives they touch.

-Karla Warnken

First row: Lisa Gillett, Gale Nocella, Chandra Mann, Kim Lloyd, Nikki Starr, Julie Seaman. Last row: Jane Adams Smith, Joy Haworth, Wendy Weyand, Dawn Czerniak, Sharon Hill, Amy Fidger, Ann Guest, Lori Bishop, Sylvia Faragalla.

\section{EARTH STEWARDSHIP}

The Bible states that "...God created the heavens and the earth," yet how many of us fail to recognize the awesomeness of His Creation? A small, unofficial, relatively new organization called Earth Stewardship seeks to promote an understanding and appreciation of this beautiful world in which we live.

Earth Stewardship had several activities this year which were open to anyone from the college family. A guest speaker from Antioch College led a forum entitled "Economic and Social Injustices in the Rainforest." Also, the organization sponsored several nature hikes at local places of interest. Finally, the organization presented several interesting slide shows about places such as Yellowstone National Park.

Indeed, even in the flatlands and cornfields of Cedarville, Ohio, the wonders of God's Creation can be seen and appreciated. Earth Stewardship attempts to accomplish that, while "broadening its horizons' in the process.

First row: David Mitchell, Zack Pappas, Chandra Mann. Last row: John McCutcheon, Dr. John Silvius, Sara Taylor, Holly Glenzer. -Karla Warnken
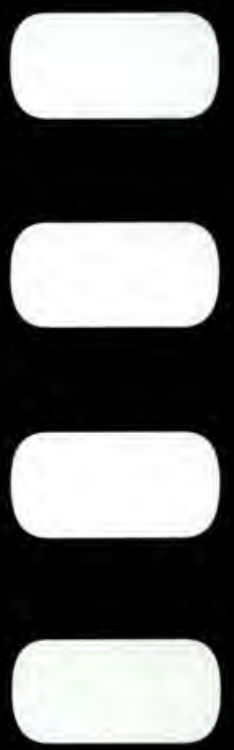

\section{EMERGENCY MEDICAL SERVICE}

This organization is composed of students who successfully complete the EMT classes held quarterly. According to Chief Bill Hauter, EMS does more than provide medical care to the college family; it also allows its members to develop medical skills and maintain a Christian testimony in the process.

This year, EMS has had its share of gains and losses. The organization was pleased to complete its payment of the brand-new ambulance purchased last year. Unfortunately, EMS was saddened to lose its long-time medical director, Betty Bertschinger, but continued to meet with her for training meetings and parties.

"Calm down. You're going to be just fine," the EMS member gently reassures an ailing student. The ambulance doors slam, as it leaves the dorm for its destination. Another day in the life of an EMS member has just begun.

-Karla Warnken

First row: George Goodwin, Bill Hauter, Jeff Rinehart, Jeff Lidaberry. Last row: Michelle Zehr, Tracy Swackhamer, Katrina Parlin. Not pictured: Brian Blind, Shelly Kincaid, Darren Young.
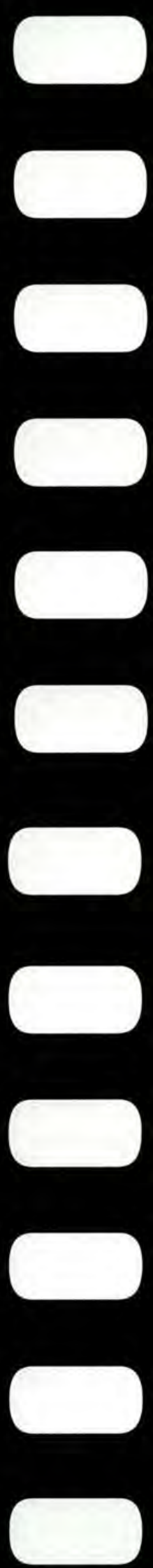



\section{IOTA CHI}

"We are one in Christ." Often, many people do not realize the full meaning of that statement. As believers, though, we are one in Christ: whether black or white, Chinese or Cuban, and so on. lota Chi seeks to promote oneness in the body of Christ by informing its members and creating an awareness of different cultures. Among this year's activities was the first lota Chi Chapel, in which several members of the organization were granted the opportunity to address the student body. The group also met several times throughout the year for fellowship and fun, as well as thoughtful interaction. According to leader Kelly Scott, the most important aspect of lota Chi is the fact that members learn from one another. How can we learn unless we love fellow believers?

Percy Day, Kelly Scott, Kim Dirtrich, Shandra Randolph.

\section{KAPPA EPSILON ALPHA}

The name Kappa Epsilon Alpha means "proclaiming the free market." But far beyond the name is the true meaning of this organization. In this fast-paced society where the rude and ruthless seem to make it to the top so easily, KEA seeks to promote Biblical principles in the business world.

Among this year's activities were quarterly pizza parties, dinner with Dave Thomas, president of Wendy's, Inc., the annual Organizational Fair, and a late Night Skate sponsored by the organization. In the spring, Kappa Epsilon Alpha held a golf tournament in which students played against local business figures.

Most importantly, KEA sponsored its annual trip to Chicago from February 20 to February 22. A group of forty-five students had the opportunity to visit such places as the Chicago Mercantile Center, McDonald's Hamburger University, and Moody Bible Institute.

-Karla Warnken
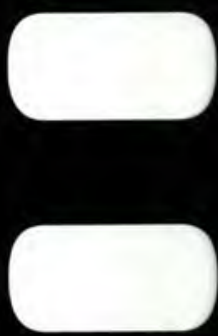

\section{SPANISH CLUB}

The Spanish Club, under the leadership of Kristi Van Dyke, is an

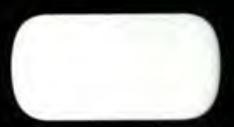
organization that exists to provide students with an opportunity to practice and enhance their Spanish as well as to promote Spanish cultural awareness in the group members.

Together, Drs. Jones and Loach advise this unique organization which meets regularly for meals where English is the forbidden tongue.

The Spanish Club held a cookout during the fall quarter in which they hosted the Argentine Puppet Team; after dinner the puppet team presented a show in Spanish for the club. 


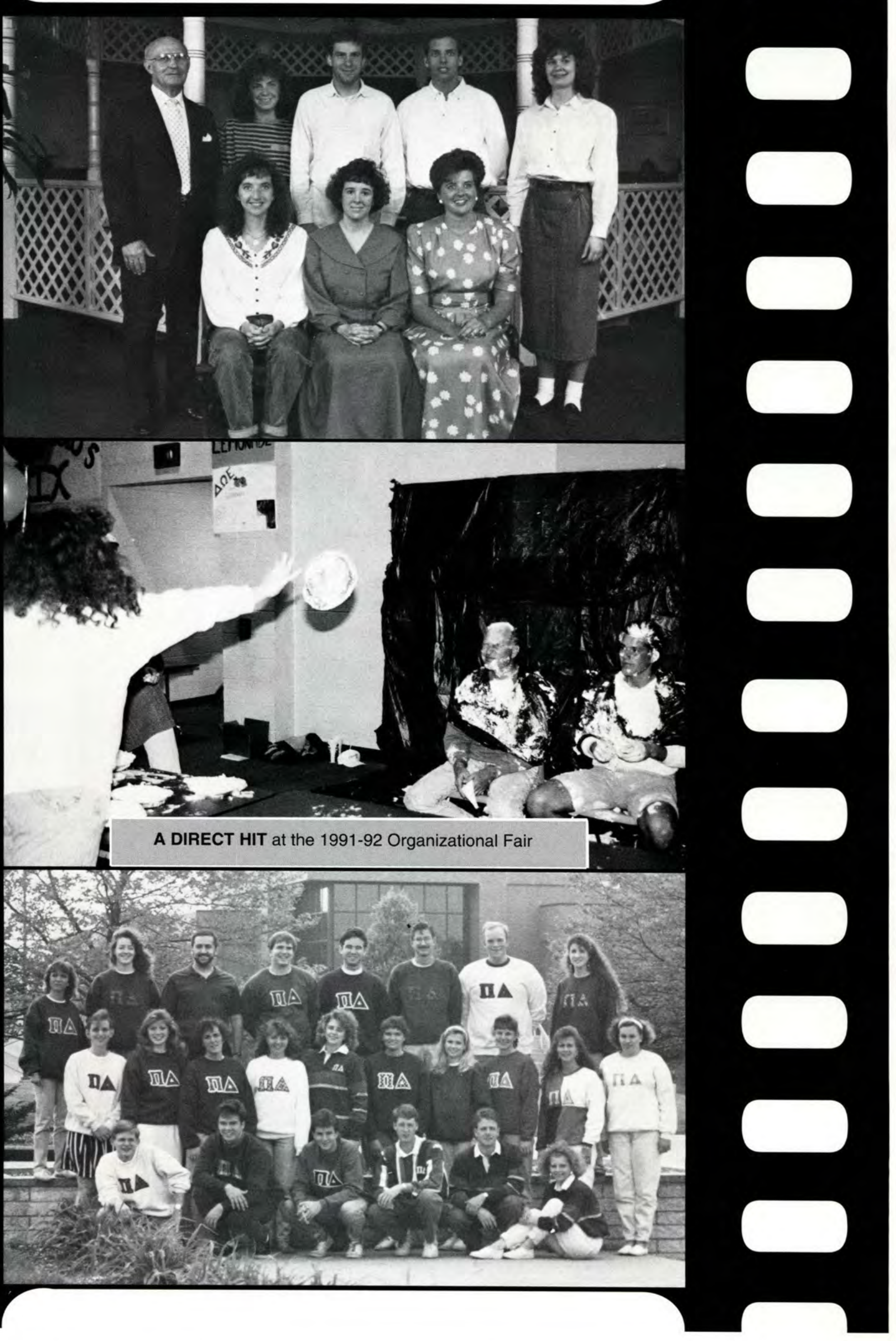




\section{LITERATI}

What organization provides social opportunities related to literature and the arts? Literati, under the leadership of president Jim Foster, holds this preceding statement as their central purpose for being.

As an outgrowth of Alpha Chi, Literati not only provides social opportunities within the group but also has attempted to reach out as an organization and take part in a Christian ministry. Literati believes that their Christian ministry is equally important as their social encounters.

Literati has spent many enjoyable evenings in the home of their advisor, Mr. Ed Spencer, watching and discussing various literary productions. Along with their parties, they are also planning trips to see CATS in Columbus, Ohio and Kurt Vonnegut at Wittenberg University.

First row: Rachel Wolford, Cheryl Davis, Mindy Boone. Last row: Mr. Edward E. Spencer, Brenda Furman, Jim Foster, Chad P. Davis, Ruth Pfahler.

\section{MENC}

MENC, under the direction of Keith Watson, was formed to provide increased awareness in music education. MENC is a campus chapter of a national organization that strives to make the transition from college to the professional world easier for music educators.

MENC holds forums on music education and sponsors concerts to benefit the student body of Cedarville College. Within the group the members meet each quarter for social events such as operas and marching band competitions.

\section{PI DELTA}

On a regular basis, groups of prospective students, youth leaders, and parents can be seen moving around campus from chapel to the cafeteria to the bookstore. Leading these groups is a fearless member of Pi Delta, who takes time out of his or her busy schedule to show off Cedarville College.

This volunteer organization, under the direction of president Nate Misirian, serves as the official host to campus guests. Pi Delta is not only a volunteer group but also an honorary one in which members must hold a G.P.A. of 3.0 or better. Only students with enthusiasm for the college, excellent communication skills, and professionalism are chosen as members of Pi Delta.
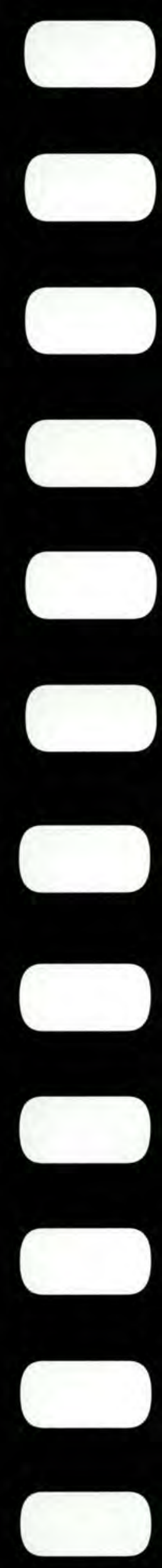


\section{PHI EPSILON BETA}

Phi Epsilon Beta is a women's organization that focuses on service to the community. Phi Epsilon Beta has dedicated themselves to serving the elderly of Cedarville as well as volunteering at the Xenia Crisis Pregnancy Center. IEB provided the campus-wide "Great Pumpkin Fest" and sold the infamous 2.0 mugs, a new 'Ville tradition. Under the leadership of Heather Hidalgo, Phi Epsilon Beta participated in a lock-In at advisor Debbie Haffey's house and the yearly Lock-Out at John Bryan State Park. Phi Epsilon Beta is truly a Cedarville trend-setter.

First row: Laura Farnsworth, Amy Hurst, Monica James, Sara Norder, Lori Garrigan, Sharyn Norder. Last row: Molly Ward, Kathy House, Katie Stull, Meredith Clements, Nicki Beecher, Heather Hunsberger, Heather Hidalgo.

\section{PHI GAMMA PSI}

Phi Gamma Psi, under the leadership of Lori Lindner, is a relatively new women's organization on the campus of Cedarville. This organization promotes social interaction by way of dinners and parties, and enhances the spiritual growth among the women in Phi Gamma Psi.

\section{-Meredith Clements}

First row: Sandra Waddell, Beth Radcliff, Michelle Gaffner, Tracy Quinn, Michelle Ferrigno. Row 2: Allie Smith, Jennifer Benefield, Adrienne Butterfield, Allison Knowles, Kim Higginbotham. Row 3: Deborah Richard, Jenny Rotroff, Jennifer Battosiewicz, Dana Gosser. Last row: Dawn Ambrose, Tami Haberstich, Susanni "Bif" Justia, Shelly Heldreth, Abbe "Stu" Beach.

\section{PI SIGMA NU}

"Pi Sig" is a social fraternity which seeks to develop a devoted camaraderie among its members, who commonly refer to each other as brothers. Pi Sig accomplishes this brotherhood by holding weekly meetings, Bible studies, social outings each quarter, camping and white water rafting trips, and, of course, pledging. This year officers are Tim Neubert (President), Sean Kaiser (Vice President), Seth Kinley (Secretary), Jim Hanssen (Treasurer), and John Keenan (Student Government Representative). 


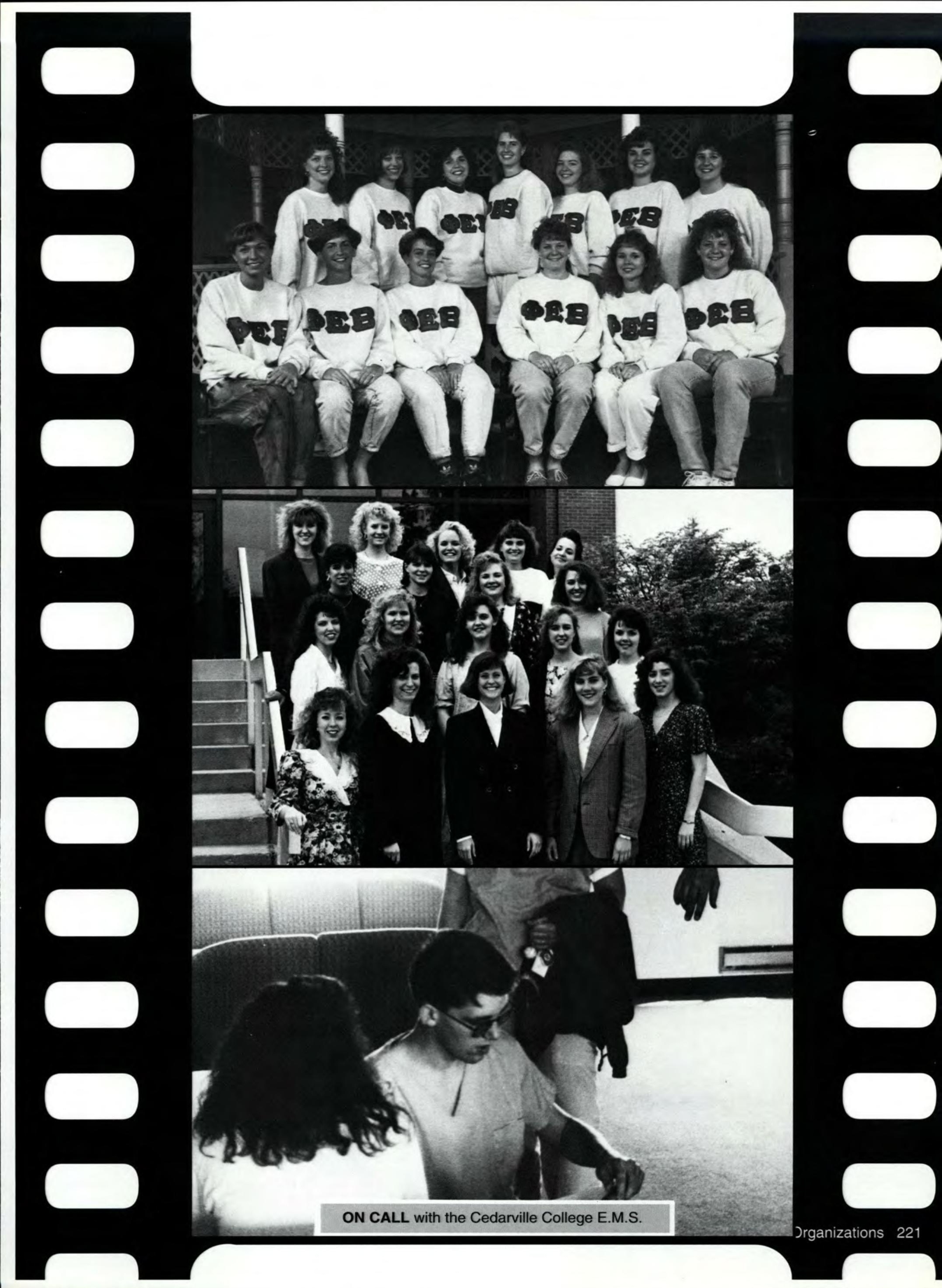




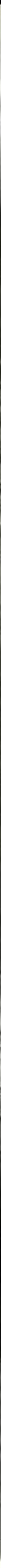




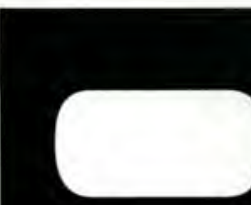

\section{SOCIETY FOR HUMAN RESOURCE MANAGEMENT}

The Society for Human Resource Management is part of a national professional and student organization designed to get students involved with professionals in the field of human resource management. Activities include tours of plants, dinners, and programs with people in the field. The organization has about twenty members, including officers Jodi Culp (President), Dave Hoffiditz (Vice-President), Mark Miller (Treasurer), Norm Byers (PR-Recruiting), Hollee Stover (Student Government Representative).

\section{- Jim Foster}

William Davis, David Hoffeditz, Renee Randall, Jim Edgerton, Lisa Barnitz, Jodi Culp, Kurt Moreland. Not pictured: Michele Abramowitz, Jason Bishop, Jim Bell, Julie Buentello, Norm Byers, Melissa Byrom, Angela Davis, Jim Devine, Laury Hackney, Mitch Hall, Jennifer McGillivray, Mark Miller, Darryl Peary, Michelle Plunkitt, Todd Roberts, Kelly Scott, Hollee Stover.

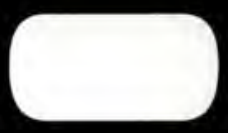

\section{SOCIETY FOR TECHNICAL COMMUNICATION}

Cedarville's branch of the Society for Technical Communication (STC) is part of an international organization which sponsors conferences and attempts to establish a network of professionals within the field. Students have opportunity to gain further knowledge in the area of professional writing and develop contacts with professionals in their field, while at the same time promoting Cedarville's contribution to this area. Cedarville College's branch of STC has hosted a regional conference, attended an international conference in Atlanta, and provided fellow students at school with newsletters and a resume service. This year's officers were Nikki Beecher (President), Amy Edwards (Vice-President), Ruth Bartholomew (Vice-President), Nanci Woodard (SGA Rep.), Holly Leadbeater (Treasurer), and Kim Averitt (Secretary).

First row: Dave Bates, Ruth Bartholomew, Gennifer Geviston, Marsha Olsen. Last row: Dave Kimmel, Victoria Johnson, Joy Haworth.

\section{STUDENT NURSES}

The Student Nursing Organization is service oriented and focuses on community health. Through education, which includes screenings, newsletters, and flyers, the college family will become more aware of health issues, both in society, and as they relate to individuals. The officers for the 91-92 school year are Elizabeth Foster (President), Amy Rayder (Vice-President), Amy Tapp (Treasurer), and Elsa Estenor (Secretary).

First row: Rebekah L. Searcy. Last row: Jennifer Johnson, Shelli Drew, Keri Christner, Ann Weise. 


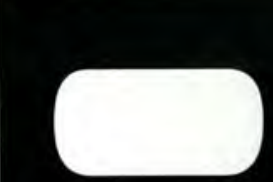

TAU DELTA KAPPA

TDK is a campus organization that provides an opportunity for fellowship, exchange of ideas, and support of those students involved in the Honors program. Just this year led by Michelle Nelson, they began publishing their own newsletter, "The Republic." TDK meets monthly to discuss anything from classes to philosophical and intellectual topics.

During fall quarter they started out the new year picnicking at John Bryan State Park. While celebrating, they held an orientation time for new members. They also attended The Nutcracker in December. A party at Dr. Percesepe's house is planned for February.

TDK members motivate each other to pursue an excellent academic career here at Cedarville and encourage this pursuit to be centered around Christ.

- Janet Payne

\section{VARSITY C}

Varsity $C$ is an organization set up to serve students of Cedarville College in various capacities: selling food, candy, and soft drinks at basketball games. They also attempt to exemplify Christ both as an athlete and as a warrior for Christ. The president is Johnny Milligan and the vice-president is Dan Ambrose.

-Janet Payne

First row: Deanne Hauser, Angela Hartman, Debbie Henry, Lynette Cruz, Sara Norder, Sharyn Norder. Last row: Peter J. Casaletto, Todd Roberts, Dan Ambrose, John Neill.
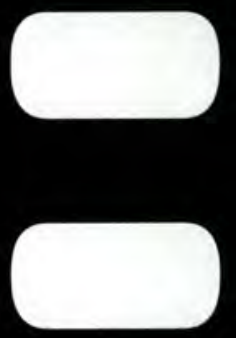

The Cedarville College newspaper, "Cedars," is produced regularly to inform accurately and faithfully the students of Cedarville College everything that transpires on the Cedarville campus. It is vital in keeping the students freshly aware of events and allowing them to freely voice their opinions. They include such things as senior and faculty recitals, play productions, important weekends, such as Parents Weekend and Li'l Sibs Weekend, and even who recently decided to walk the aisle in marriage. "Cedars" should be commended for their thorough and complete report on the new computer system that is being installed this fall.

-Janet Payne 


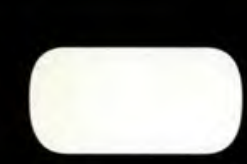

\section{WSRN}

The Student Radio Network strives to edify and minister to the student body through broadcasting daily. Their main goal is to honor and glorify the Lord Jesus Christ. With two years of experience and history behind it, WSRN hopes to continue effectively to broadcast for many years to come.

A special advantage that WSRN has is that it is student oriented, and that it evolved totally around the student. That is their focus: glorifying God through serving the student body.

First row: Tom Mathisen, Alex Todd, Jennifer Jones, Brent Apperson, Bill Montgomery. Second row: Scott Mills, Rich Doese, Mary Sweetland, Amy Smith, Buffy Cary, Steve Kinsey. Third row: Lara McGovern, Gywne Davies, Eric Johnson, Shelly Sutton, Steve Kellogg. Forth row: Mr. Jim Leightenheimer, Leah Roseryold, Mark Zuiderveen, Ken Nichols. Fifth row: Derran Reebal, Chris Pincket, Ed Huff, Ray Izard, Anna Marie Kulin, Justin VanEaton, Matt Stockham, Alan Yates. Last row:Brad, Iten, Todd Stach, Chris Green.

\section{STUDENTS FOR SOCIAL JUSTICE}

According to the Students for Social Justice's constitution, the purpose of the organization is "To follow Christ's compassionate example by promoting social justice (Matt. 22:37-40, 25:31-46, James 2:14-26)." Social Justice is defined as "The right of all mankind to live and operate in moderate and life encouraging circumstances." This is accomplished by providing needy families with food and clothing, being involved with Habitat for Humanity, and helping care for the elderly around Cedarville. The officers this year were Holly Glenzer (President), Mark Irving (Secretary), Beth Irving (Treasurer), and Don Erickson (Student Government Representative).

- Jim Foster

\section{UNDERGRADUATE ALUMNI ASSOCIATION}

The purpose of Undergraduate Alumni Association is to assist the CC Alumni Association and office with the activities, represent the student body in the Alumni Association, and to give opportunity for students to gain knowledge of the A.A. by networking with alumni.

- Jane Adams Smith

First row: Bruce Quick, Kathy House, Jerri Cook, Kezia McNeil, Julie Buentello, Mrs. Jane Adams Smith. Last row: Allyson Graham-Pres., Sherri Leeds, Matt Brown, Brandon Cearley, Lori Newell, Butch Davis. Not pictured: Jennifer Benefield and Kim Higginbotham. 


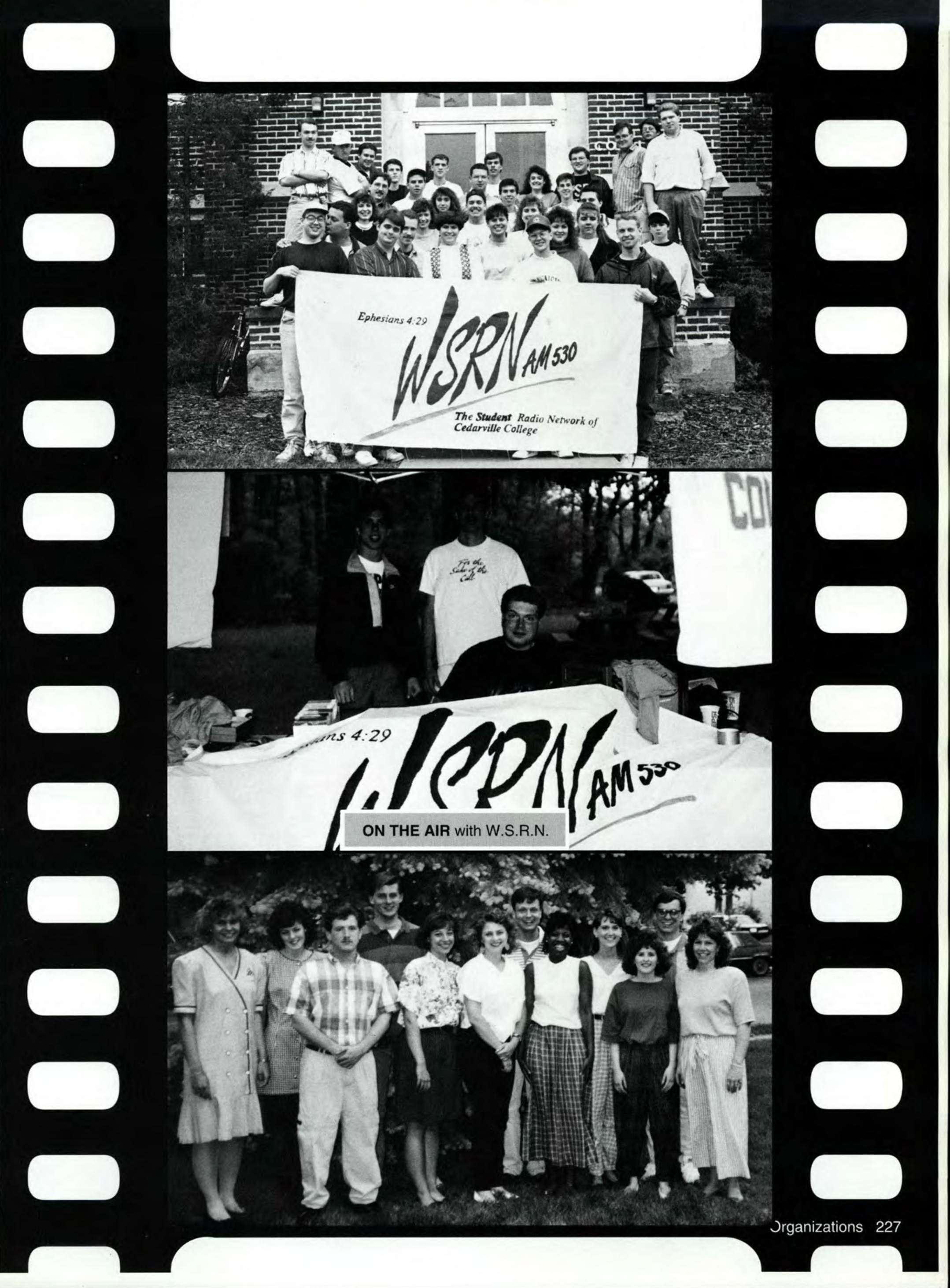




\section{Parent Patrons}

Mr. \& Mrs. Alfred Abramowitz Freeport, IL

Dr. \& Mrs. Eugene Armour

Rochester, NY

Mr. \& Mrs. David Baier

Gates Mills, $\mathrm{OH}$

Mr. \& Mrs. David Bauer Akron, $\mathrm{OH}$

Mr. \& Mrs. William Belh Woodstown, NJ

Mr. \& Mrs. James Bishop Pennellville, NY

Dr. \& Mrs. Peter Bletzinger Fairborn, $\mathrm{OH}$

Mr. \& Mrs. Russell Blew Windsor, PA

Mr. \& Mrs. Wayne Blind Columbus, $\mathrm{OH}$
The 1992 Miracle staff offers a special thank you to all of those parents and churches who through their generous gifts made this Miracle possible. Without their help many special elements of this yearbook such as extra color pages, photography or design elements would be greatly reduced or eliminated.

Rev. \& Mrs.

Thomas Bonifield

Plainville, MA

Dr. \& Mrs. Randy

Bork

Lapeer, MI

Mr. \& Mrs. Mark Brandon Mansfield, $\mathrm{OH}$

Mr. \& Mrs. Kenneth Broadhead Mt. Vernon, IN

Mrs. Beatrice Brown Johnstown, NY

Mr. \& Mrs. David H. Brown Sylvania, $\mathrm{OH}$

Mr. \& Mrs. David Brown Easthampton, MA Mr. \& Mrs. Robert Bruckner Londonderry, NH
Mr. \& Mrs. Melvin Burkley Flushing, MI

Mr. \& Mrs. Richard Burns East Rochester, $\mathrm{OH}$ Mr. \& Mrs. Paul Casaletto Andover, MA Mr. \& Mrs. John Christner Goshen, IN Mr. \& Mrs. Gary Coe Wyoming, MI Mr. \& Mrs. Thomas Cooper Champaign, IL

Mr. \& Mrs. Samuel De Man Grand Rapids, MI
Mr. \& Mrs. Louis Dinelli, II Dale City, VA

Mr. \& Mrs. Charles Donaldson Pitman, NJ

Mr. \& Mrs. Thomas Driscoll Yardley, PA

Mr. \& Mrs. Robert Eckart Harleysville, PA

Mr. \& Mrs. Russell Edwards Sleepy Hollow, IL

Mr. \& Mrs. Charles Feldman Rochester, IN Mr. \& Mrs. Dean Fox Pekin, IL Mr. \& Mrs. Kenneth Gadd Sterling, VA

Mr. \& Mrs. Albert Garrigan Wappingers Falls, NY 
Rev. \& Mrs. Fred Gerhardt Lansing, MI

Mr. \& Mrs. Eddie Gill Newark, $\mathrm{OH}$

Mr. \& Mrs. Donald Gilson Marion, $\mathrm{OH}$

Mr. \& Mrs. David Gosman Madison, IN

Mr. \& Mrs. Randal Gosser Indianapolis, IN Mr. \& Mrs. G. Riley Griffiths Franklin, $\mathrm{OH}$

Mr. \& Mrs. William Gross Harrisburg, PA Mr. Bruce A. Grove Perkasie, PA

Mr. \& Mrs. Alfred Hahnenstein

Canton, NY

Mr. \& Mrs. Joseph

Hanssen Ankeny, IA
Mr. \& Mrs. James Hetherington Rock Falls, IL

Mr. \& Mrs. Dennis Higley Troy, $\mathrm{OH}$

Mr. \& Mrs.

Norman Hochstettler Harrod, $\mathrm{OH}$

Mr. \& Mrs. Charles Horr Portsmouth, $\mathrm{OH}$

Mr. \& Mrs. Gerry Horton Mattituck, NY

Mr. \& Mrs. Daniel Irving Littleton, CO

Dr. \& Mrs. Thomas Jagger

Corning, NY

Mr. \& Mrs. Roger Jensen Kettering, $\mathrm{OH}$

Mr. \& Mrs. Marvin Jones Marine City, MI

Mr. \& Mrs. David Jordan Schaumburg, IL
Mr. \& Mrs. Michael Kadlecik Binghamton, NY Mr. \& Mrs. James Kohlmeyer Wheaton, IL Mr. \& Mrs. Ralph Kuivinen Fairview Park, $\mathrm{OH}$ Mr. \& Mrs. Robert F. Landrum Ypsilanti, MI Mr. \& Mrs. John Le Blanc Frankfort, IN Mr. \& Mrs. George Leshan Cleveland, $\mathrm{OH}$ Mr. \& Mrs. Richard Linak Sylvania, $\mathrm{OH}$ Mr. \& Mrs. Philip Lindner West Des Moines, IA Mr. \& Mrs. John Linnehan, Jr. Ellsworth, ME
Mr. \& Mrs. Alexander Lombardo Arlington Hts., IL Mr. \& Mrs. Frank Longo Sykesville, MD

Mr. \& Mrs. Robert Lunn Ft. Fairfield, ME Mr. \& Mrs. Thomas Mann Lodi, CA

Mr. \& Mrs. James Marihugh Delphos, $\mathrm{OH}$ Mr. \& Mrs. Roger Marland Plattsburgh, NY Mr. \& Mrs. Arne Michael, Sr. Fremont, $\mathrm{OH}$ Mr. \& Mrs. Russell Miller Laurel, MD Mr. \& Mrs. Joel Miller Freeport, IL 
Mr. \& Mrs. Howard Mills, Sr. Erie, PA

Mr. \& Mrs. Charles Mitchell Lorton, VA

Mr. \& Mrs. James Nast

Farmington Hills, $\mathrm{MI}$

Mr. \& Mrs. Earl Nickelson St. Charles, IL

Dr. \& Mrs. James O'Leary Pittsburgh, PA

Mr. \& Mrs. Bobby Oliver Blanchester, $\mathrm{OH}$

Rev. \& Mrs. Douglas Parlin Astatula, FL

Mr. \& Mrs. Cecil Paulhamus Linden, PA

Mr. \& Mrs. Garold Paxson Kokomo, IN
Mr. \& Mrs. Levi

Pence

Newton, IA

Mr. \& Mrs. Joseph Perkins Poland, $\mathrm{OH}$

Mr. \& Mrs. Al Polish Fraser, MI

Mr. \& Mrs. Richard Rodebaugh Ayden, NC

Mr. \& Mrs. Clifford Roop Columbia, $\mathrm{OH}$ Mr. \& Mrs. Glenn Rudicil Westerville, $\mathrm{OH}$

Mr. \& Mrs. Richard Sand Lynchburg, VA Mr. \& Mrs. Ken Scheffel Pryor, OK

Mr. \& Mrs. Roger Schoolar Mission Viejo, CA Mr. \& Mrs. Robert W. Scott Marlton, NJ
Mr. \& Mrs. Samuel Shaffer Springfield, $\mathrm{OH}$

Dr. \& Mrs. William Sherman Watertown, NY

Mr. \& Mrs. Ronald Shobert, Sr. Jersey Shore, PA

Dr. \& Mrs. Charles Shook Mansfield, $\mathrm{OH}$ Mr. \& Mrs. Roger St. John Xenia, $\mathrm{OH}$ Mr. \& Mrs. Alvin Stamper Columbus, $\mathrm{OH}$ Mr. \& Mrs. William K. Stanley Herndon, VA

Mr. \& Mrs. Steve Starr Doylestown, $\mathrm{OH}$

Mr. \& Mrs. Leroy Stephenson Tacoma, WA

Rev. \& Mrs. Richard Stitzel Burlington, $\mathrm{CO}$
Mr. \& Mrs. Henry Stone Birmingham, AL

Mr. \& Mrs. Robert Strong Chelsea, MI

Mr. \& Mrs. Alvin B. Terry Sellersville, PA Mr. \& Mrs. Kent Underwood Dublin, $\mathrm{OH}$

Mr. \& Mrs. Frank Vroegop Schoolcraft, MI Mr. \& Mrs. Galen Weber Edgerton, $\mathrm{OH}$

Mr. \& Mrs. Lawrence Weber Wauseon, $\mathrm{OH}$

Dr. \& Mrs. Ronald White Sarasota, FL

Mr. \& Mrs. David Wilcox Binghamton, NY Mr. \& Mrs. Kenneth Williams Downers Grove, IL 
Mr. \& Mrs. Henry Winters, Jr. Elizabethtown, PA

Anthony Baptist Church Jersey Shore, PA

Berean Baptist Church Grand Rapids, MI

Bible Baptist Church Bedford, $\mathrm{OH}$

Calvary Bible Church Derry, NH

Cornerstone Baptist Church Cumberland, MD

Emmanuel Baptist Church Dayton, $\mathrm{OH}$

Faith Baptist Church Winfield, IL

First Baptist Church Argos, IN
Mr. \& Mrs. David Wong Parma, ID
Mr. \& Mrs. Doug Woodhams Allegan, MI

\section{Church Patrons}

First Baptist Church Butler, PA

First Baptist Church Hackensack, NJ

First Baptist Church Johnson City, NY

First Baptist Church of University Place Tacoma, WA

Fox Valley Bible Church St. Charles, IL Grace Baptist Church Cedarville, $\mathrm{OH}$ Grand Avenue Baptist Church Fairborn, $\mathrm{OH}$

Greater Emmanuel Church Portsmouth, $\mathrm{OH}$
Heritage Baptist

Church

Lakeland, FL

Indianola Regular Baptist Church Indianola, IA

Lincroft Bible Church Lincroft, NJ Merson Bible Church Gobles, MI

North Hills C\&MA Church Pittsburgh, PA Church Northfield, $\mathrm{OH}$

Pleasant Grove Miss. Church Yellow Springs,
Northfield Baptist
Pleasant View Bible Church Warsaw, IN

Regular Baptist Church Loup City, NE Shawnee Hills Baptist Church Jamestown, $\mathrm{OH}$

Southgate Baptist Church Springfield, $\mathrm{OH}$ Tabernacle Baptist Church Ithaca, NY

The Chapel in Marlboro Hartville, $\mathrm{OH}$

Wheelersburg Baptist Church Wheelersburg, $\mathrm{OH}$ 
Bartholomew, Raymond , 10, 21 Bartholomew, Ruth ........95, 223 Bartley, Mary.

Barton, Alesia .

46

Barton, Jeremy .............95, 154

125,220

Bass, Marla

Bassett, Philip

..... 95

Abbas, Robert ........................210

bramowitz, Michele ....172, 223

Abrams, Melinda ............. 53, 78

Adams, Laun

Ademeit, Donna $\ldots . . . . \ldots \ldots . . .52,95$

Adler, Nathan ..................... 172

Ager, Merlin

Aiken, William:

Alexander, Stephanie .......53, 87

Alexander, Stephen …...........172

Allen, Denise

Allen, Jennifer ........................... 30, 78

Allen, Patricia

Alley. Timothy

Alsdort, Jared .....................25, 134, 14

Alyn. Irene ............... 18, 21, 170

.95, 225

Ambrose, Dawn ……...........2, 220

Anderson, Heather ................ 172

Anderson, Kerry

Anderson, Lyle ...................

Anderson, Paul 60, 95, 204, 205

Anderson, Ray ..... 146, 147, 172

Anderson, Todd

Andrews, France

Bates, David ........ 95, 123, 223

Battin, Phillip

Bauer, Marnie

Baughey, Kristen

Baumann Donald

Beabout, Victoria ......................... 78

Beach, Abbe ..............95, 220
Beach, Susan ...38, 60, 95, 210

Bean, Jennifer …...................78

Beasley, Renee …...........30, 87

Beck, Karen

Beck, Kristine

Beckelhymer, Kyle

95

Beebe, Gwendolyn …............ 95

Beecher, Nicole ....90, 173, 220 ,

223

Beecher, Robert …........... 52, 78

Beheler, Tiffany …...........31, 78

Beikert, Grace $\ldots . . . \ldots \ldots . . . \ldots \ldots . . .23$

Beiler, Jeffrey ……....................87

Beitter, Nathan ..................... 78

Belh, Brian

Bell, Andrew _............... 44, 87
Bell, James Jr. .......... 173, 223

Bell, Laurie ......... 42, 43, 78, 206

Bellew, Michelle ............ 78

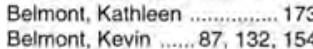

Bender, Lorynda .................. 95

Benefiel, Jennifer .. 95, 166, 220,

226

Benim, James ...................... 87

Benim, Shari ........................... 87

Bennett, Alicia ..................52, 78

Benson, Erik ........................ 175

Berkheiser, Rebecca _.............78

Bernhard, William ….................. 15

Beroth, David ................... 32

Beroth, Edward

Berry, Christina $\ldots \ldots \ldots \ldots \ldots \ldots \ldots . . .87$
Berry, Devon …............ 5, 53, 78

Bertschinger, Betty ,.......23, 215

Beshaw, Harold …............53, 87

Besosa, Robert

Beste, Jeff ........

Biddle, Agnes

Biddle, Benjamin .......53, 87, 146

Bierly, Cinnamon ........... 78, 148

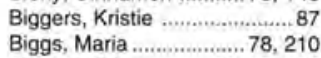

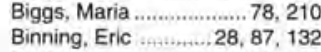

Bird, Jenny ................. 173, 205

Bird, Jonathan ............ 7, 28, 173

Bird, Melissa

Bishop, Aaron

36,174

Bishop, David …......... 95, 212

Bishop, Jason ................174, 223

Bishop, Lorí,

Bishop, Mary ..................... 174
Blackburn, Brian …....94, 154

Blackburn, Brian ............94, 154
Blackburn, Christy .........52, 174

Blair, Brian ..

Blanton, Scott ..............124, 125

Blaylock, Shawn

Blenis, Darcey

......................... 174

Blew, Amanda …................ 78

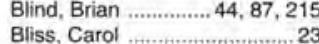

Bliss, Carol
Blumenstock, Helen .................23

Blumenstock, Richard ...........20

Bockmann, Thomas ........87, 209

Boitler, Nathan .......... 42, 43, 78

Bolender, Jeff .............146, 14

Bolender, Sharie - 135, 136, 148

Bolger, Brian …................53, 87
Bond, Jennifer ……........174

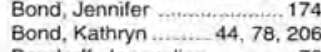

Bondorff, Jacqueline ..............78
Bonga, Janet .......................78

Bonga, Janet ....

Boone, Abby ... 31, 87, 112, 113

209

Boone, Mindy 13, 44, 45, 62, 83 .

$86,112,169,174,180,201$.

$210,212,219$

Bork, Jenifer

Borkholder, Misty
Calvert, Becky .......87, 124, 125

Campell, Fran ................ 44, 79

Campbell, Jack …....................23

Campbell, Julie _.................87

Canine, Michelle ..............53, 175

Canine, Michelle ….........53, 175

Canton, Steven .......................... 89
Carlson, Betsy ...................

Carlson, Carolyn ………….... 22

Carlson, Ruth .............................175

Carnahan, Brian …................. 88

Carraher, James ……............... 15
Carrick, David

Carrick, David ….......... 142, 175

Carrington, Jim ................78

Carson, Angela .......... 36, 53, 96

Carson, Cynthia ...............40, 79

Carsten, Laura …_.................... 79

Carter, Olivia
Cary, Buffy ........ $40,79,201,226$

Cary, Buffy ....... 40, 79, 201, 226

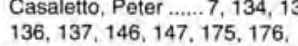

225

Case, April

Case, Eric ....

Castelow, Tana

Caton, Steve .

Cearley, Brendon . 175, 212, 226

Cesal, Nathan

Chamberlain, Curtis $88,113,123$

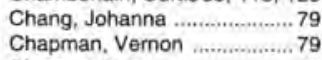

Charette, Erica.

Chase, Margaret …...................175

Chasnov, Robert ......,...t.......... 21

Cheek, Devin ………......96, 209

Chezik, Janet ....................53, 88

Childers, Gary .........96, 120, 121

Childers, Rebecca ………...79

Chisholm, Doug ….................. 3

Christman, Robert _........... 88

Clark, Brian ....................150, 151

Clark, Martin ….................1 14

Clark, Tammy ...............44, 62, 88

Cleary, Brendon …................. 207

Clements, Meredith .. 12, 30,31,
$66,72,159,161,166,173,175$,

$66,72,159,161,16$
$199,201,220,224$

199, 201, 220, 224
Clemons, Vivian

Clemons, Vivian ........ 79

Clidence, Lisa

Clifford, Daniel ……........40, 88

Cline, Jack.

Cline, Kelly

Clow, Alexander

Clow, Andrew ..................... 175
Clymer, Lisa ................... 53, 79

Cochran. Eric .......... 8, 9, 96, 166

Coe, Chad ............., 46, 96, 166

Coffelt, Joy

Colangelo, Joyce ……...... 45, 88

Colbert, Bruce $\ldots \ldots \ldots . . .32,88$

Coleman, Melissa ............. 32, 79

Collins, Michael …............ 88

Colman, James ...............21, 114

Combs, Mark.

Combs, Susan ......

Comegys, Mir
Comers, Jill

Commons, Willian

....... 88

Burns, April

Burns, JulieLynn

Burns, Robert ………..................... 87

$\begin{array}{lr}\text { Burns, Tara } & 95,210 \\ \text { Burr, Jeft } & 52,95,209\end{array}$

Burrichter, Margaret 52, 95, 209

Bush, Jonathan .60, 70, 71, 132 ,

133

Bush, Sharon

53,87

Butler, Jennifer .......79, 124, 125

Butterfield, Adrienne .... 175, 220

Byers. Norm .......... 158, 175, 223

Byler, Clyde

Byler, Kendra

$.7,175$
$.52,87$

Byrom. Melissa .............195, 223

.

Cone, Jeff

Cone, Julie ..._.......... 43, 49

Conkel, Kevin 88, 134, 135, 136

Conley, Bobbi

Conner, Kimberly

Conrad, Robert ......

Cook. Elise

Cook, Jerni 7, 64, 122, 123, 176

226

Cook, Steve ... 5, 60, 64, 65, 96

$112,123,129,151,199,201$

Cooley, John

Cooper, Gary ………..................... 17

Cooper, Karl .......49, 88, 94, 205

Cooper, Kristin ..................176
Copeland, Christine ......79, 131

Copeland, Christine .......79, 131
Copeland, Stephen .........96
Cordier, Jackie .........36, 96, 210

Cordier, Jackie .........36, 96, 210

Corey, Mary

Cornett, Jennifer ......................., B8

Cornwell, Chad ………............... 45,79

Cossairt. Thomas ………..... 176

Costello, Sandra ............................ 79

Cowdery, Jason

Cowley, Timothy

Coy, Ronal

Coy, Sherry

Crace, Michae

Crandall, Anna

Crandall, David

Crapo, Jeanette

Crary, Jason .

Crawtord, Jennifer

Crider, Jonathan

Cripe, Laura

Cross, James

Crouthamel, Scoll

Crow, Jennifer

Crum, Kristin

Cruver, Deborah ……..... 41,79

153,225

Cudney, Jerilynn ...........170, 176

Cuerca, Sue .........................
Culp, Jodi $7,124,125,163,177$.

223

Cunningham, Amy ..................88 88

Cunningham, Bob ..........96, 154
Cunningham, Dawn . 44, 96, 210

Cunningham, Jeff ...................23

Currall, Gail

Currie, Paul

Curry, George

Curtis, Melody ..

Cushman, Karen

Cutler, Matthew

Czerniak, Dawn

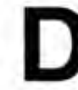

Dady, Kenneth

Dail, Gregory

Dail, Kim ..............

Dalton, Jeanette

Damon, Gail

Damiels, Dana

Danube, Tim

Daugherty, Matthew $\quad 144,145$

Davidson, Lisa .....................21

Davies, Gwynne

60,177
$+\ldots+, 226$

Davis, Angela …...........177, 223

Davis, Beth

Davis, Brent

Davis, Butch

Davis, Chad

Davis, Chery!

Davis, Cynthi

Davis, Kelly ...

Davis, Kimberli

Davis, Rachel

Davis, Todd

Davis, William

on ……............ 80

Dawson, Matthew ……........ 96

Day. Christy

Day, Persephone .......... 177, 217 


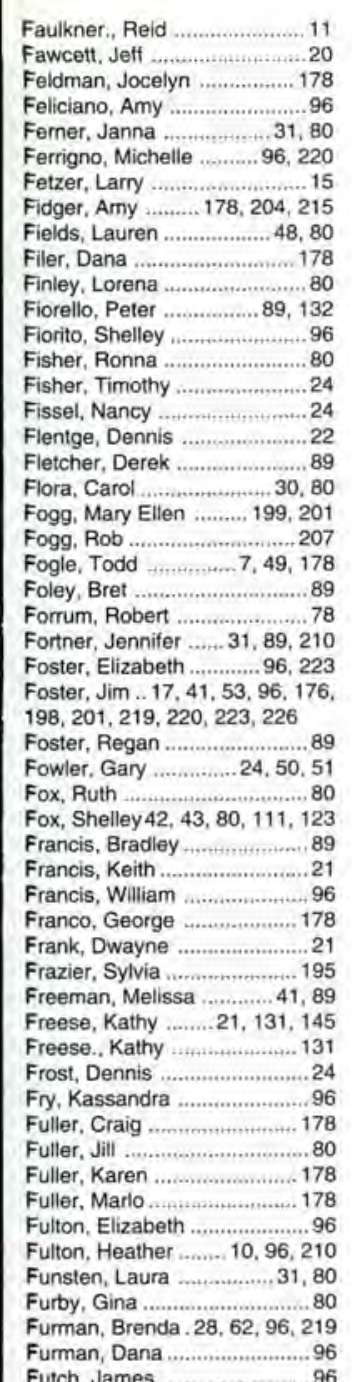

Futch, James ..........................96

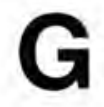

Gadd, Sleve.

Gadell, Nicole Gaffner, David ....................... 24

Gaffner, Michelle .....7, 179, 220 Gaglio, Stephen .................. 179 Gaither, Chris ..................... 53 Gall, Darin ........................ 89

Gannon, Cindy ..................152 132

Gardner, Krista .................30, 89

Gardner, Timothy ............... 44, 80

Garland, Samuel ..............30. 80

Garmany, Stacey … $\quad 179,210$

Garn, Jamie ….............179, 210

Gasparro, Kathleen ...............96

Gathany, Jacquie $\ldots . . . \ldots \ldots . . . . . .24$

Gathany, Paul ..........................24

\begin{tabular}{l} 
Gathany, Todd \\
Gavitt, Sherry $\ldots . . . . . . . . . . .24$ \\
\hline
\end{tabular}

Geelhood, Philip ….............. 80

Geiger, Amy ….................4 40, 96

Geiger, David .......................80

Geise, Michele $\ldots . . . . . . . . . . . .8$
Geist, Alan ……………......... 24

Gentry, Douglas …............. 80

Gentry, Lance
Gentry, Lynn ............................ 89

George, Andrea …….............8 80

Gerber, Becky 39, 64, 74, 75, 80 ,

Gerber, Becky $39,64,74,75,80$,
$130,141,201$
. . . 39, 96

Gerber, Gabrielle .............39, 96
Geremia, Kimberly ..........32, 89

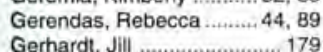

Gerhardt, Jill ...

Gess, Kathleen

Geviston, Gennifer ……........... 223

Geyer, Steve .......................60 60 Glauthier, Renee
Gibbs, Kirsten ….................................

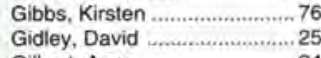
Gilbert, Amy ........................... 24
Giles. Catherine _...........53, 96 Gill, Nathan .. .19
.179

Gillam, Rebecca _.......... 44, 89

Gillett, Lisa ............96, 210, 215

Gillies, Leigh Ann .....................96

Hansley Richard 24, 146, 148

Gilson, Matthew …_..............96 96

Gingerich, Eric ...................... 179

Glenzer, Holly ............215, 226

Godden, Sean ……................ 89

Godwin, Joseph ......................15

Goetsch, Jeremy ............53, 80

Goldbourn, Kimberly ........31, 89

Good, Brian .......................... 89

Good, Christopher …........48, 89

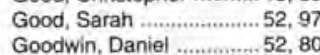

Goodwin, George .... 7, 179, 210

215

Gordon, Andrea …........... 49, 97

Gosman, David

Gosser, Dana ...53, 89, 206, 220

Gottwals, Diane ..................... 24

Gozdan, Jennifer ................35, 80

Grab, Nina _................ 97

Grabbe, Susan $\ldots . \ldots . . . . . . . . . . .89$

Graham, Aaron …1........ 80

Graham, Allyson ... 179, 207, 226
Graham. David ............... 15

Graham, Rob .......................74

Graves, Philip ..........52, 89, 209

Grayson, Carrie
Grayson, Chad …................ 31,89
53,80

Grayson, Chad $\ldots \ldots \ldots \ldots . . .53,80$

Green. Chris ....80, 141, 226

Green, Harold ..............4, 14, 55

Hayden, Yvonne....97.215,223

Hayes, Eric A. ....................... 180

97 Hayes, Eric W.

Greenly, Jack

Greentree, Annette .................89 89

Greentree, Carla ….............53, 80

Greenwood, Chris ..............145

Greist, Elizabeth

Griffith, Corey

Griffiths, Shannon ................ 97

Grinnell, Jeremy ...89, 123, 124,

125

Grissom, Joanna …................. 80

Gritsavage, Reid $\ldots \ldots \ldots \ldots . . .52,89$

Grizenko, Nicole .......40, 80, 206

Gromacki, Robert .... 11, 20, 154
Gromko, Eliza $\ldots \ldots \ldots . . . . . . .31,89$

31,89

Grove, Cory ............... 99, 151

Grygiel, Charline ...................8 179

Gudeman, Jonathon $\ldots \ldots \ldots \ldots . .31$

Guenin, Glenn

Guess, Paul

Guest. Ann.

Guider, Donna .......................... 97

Guinther, Brian …................... 179

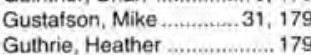

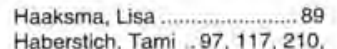

220

Hackney, Lauralyn ........ 179, 223

Haffey, Debbie ........................220

Hagan, Kathryn .................53, 80

Hague, Andrea

Hague, Keith ......................... 24

Hahnenstein, Cathleen ....31.89

Hahnenstein, Christine .....31, 89

Haines, George

Hale, Sarah........

Halk, Marsha

Hall, Jennifer .

Hall, Mitchell

Hall. Shane ..................223

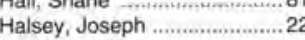

Halsey, Leah .............................
Halsted, Thomas

Halsted, Thomas
Hamblen, Elta .................... 179
Hamel, Lindsay

Hamilton, Craig .................. 81
Hamilton, Lori $138,139,179$

Hamilton, Troy ............40, 52, 81

Hammock, Darryl ...89, 146, 147

180

Hamstra, Katrina ..................81 81

Han, Nathan .......... 89, 210
Handel, Christopher ... 46, 72, 81

Hoewing, Steph
Herring, Christian ................. 97
Hertzler, Jill $\ldots \ldots \ldots \ldots . . . .97,145$

Hess, Beth ..........................97
Hetherington. Scott $\ldots . . . . .181$

Hetherington. Scott $\ldots . .181$

Hewson, Ryan ……........... 89
Heyd, Ruth
Heying, Tina

Hezlitt, Rebecca ..................8

Holley, Rachel …...........53, 89

Holliday, Kimberly

..... 22

Holloway, Thile

Holmes, David

Holmes, Janet

$\begin{array}{lr}\text { Holmes, Timothy } & 181 \\ \text { Holsinger, Mark _...................... } \\ \text { Holtz Amy }\end{array}$

Honeywell. Melissa a......... 40,81

Hook, Adarn ....

Hoover, Apryl

Hoover, Elaine

Hopkins, Brenda

Horine, Benjamin

Hombuckle, Steven .................. 99

Horst, Fern.

Horst, Vonda .

Horton, Jennifer

Horton Jr., Gerry

House, Kathy 72, 159, 181, 220,

226

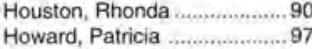

Howard, Rachel .....90, 130, 131

Howard, Trisha ..... 90, 130, 131

Howard, Trisha ......................... 82

Howell, Tilfany
Hoy, Timothy ……........90, 906

Hoyt. Jeffery

Hubbard, Kimberly ............44, 97

Huber, Pearl ..................... 90
Huber, Phil ......29, 52, 90, 209

Huber, Trish

Huck, Scott

...................... 24

Hudson, Julie ................ 52, 90

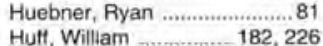

Hutf, William $\ldots .182 .226$
Hughes, Lisa ....................... 182

Hughes, Mindy.. 36, 53, 97, 152 .

153

Hughes, Philip II .................182

Hull, Dana .................30, 49, 90
Humble, Mindy ..........131, 145

Hundley, April ...................33,81

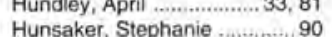

Hunsberger, Angela ...............81
Hunsberger, Heather ....182, 220

Hunsberger, Heather ... 182, 220

Hunsberger, Jill
Hunt, Carmen ...................53, 59,90

Hunt, Jeffirey

Hunter, Jeffrey ....4.................97 97

Hurst, Amy …..............182, 220

Hurt, Keith .................32, 33, 81

Hyback, Chery

Hyten, Jenine

......... 81
97

Hickox, Sandra 40,81

Hidalgo, Heather .......... 181, 220

Hiebert, Aaron .
Higginbotham. Kim 97. 220, 226
Higley, Ann

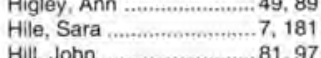

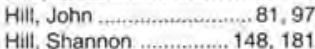

Hill, Sharon.....

Hill, Stephen

Hille, Anna

Hines, Randa

Hinman, Kathlen.........38, 97

Hintz, Marcy

Ho, Nathan

Hochstettler, John ….................. 181

Hodson, Carolyn

Hoewing, Rodney

Hoffeditz, David 7, 165, 181, 223

Hoffeditz, Kimberly ………... 89

Holfeditz, Kimberly …................29

Hofheinz, Karl .................53, 181

Hotmann, Margret ................81
Hohmann, Sherene

Hohmann, Sherene
Holcomb, Michelle .................. 89
Holden, Steven ….....97, 212

Holden, Steven …....... 97, 212
Hollander, Laura
H............ 181

Hollaway, Mary …....................... 97

IIjes, Kristine

Imhoff, Ruth

Ingalls, Margaret

Irish, Kathleen.

.............. 97

Irving. Elizabeth .........210, 226

Irving. Mark ........40, 49, 97, 226

Iten. Bradford 90

Izard, Ray ….......81, 201, 226

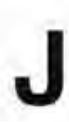

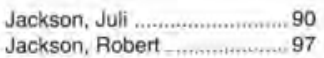

Jackson, Robert _................. 97
Jacobs, Jack .................... 182

Jacobson, John ..............60, 182
Jagger, Emily .........................81

Jagger, Emily .........................81
James, Monica

Jameson, Peter ............. 182
Jamieson, Andy ....97, 134, 136,

137

Jamora, Gina $\begin{array}{r}97 \\ \text { Jariga, Carol _................. 97, } 110\end{array}$

97.710
.+.90

Jariga, William

Jeffers, Patricia
Jeffries, Clark

Jeffries, Skip

Jenks, Stephen

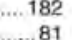

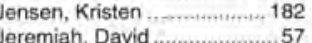

Jeremiah. James

Johnson, Andrew

Johnson. Cliff

Jonson, Erik .................81, 226

Johnson, Jefle
Johnson, Jeftrey.................97
Johnson, Jennifer ….....90, 223
Johnson. Judy

Johnson, Marcy

Johnson, Robert

Johnson, Shirley

Johnson. Timothy

Johnson, Victoria

Johnston, Faith

Joiner, Randall

Jones, Barry

Jones, Christian

Jones, Christin

Jones, Diane....

Jones, Lori .

Jones, Mark ..

Jones, Matthew

Jones, Philip .........

Jones, Susan

Jones, Susan ..................... 29

Jones, Thomas .... 132, 133, 182

Jones, Tonya

Justice, Susanne ...97, 120, 220

Justice, Tracy ….29, 23, 90

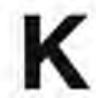

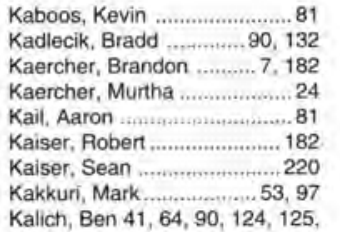

146

Kamauf, Julie .

Karrels, Tom ...

Katrinak, Carrie

Kaufman, Deidre

Kaufman, Devin

Keefe, Edward III

Keefer, Heidi...

Keenan, John

Kelb, Tim -

Keiser, Andre

Keller, Julie

Kellogg, Heidi

Kellogg. Steph

Kelly, Anne.

Kelly, Steven .........

Kendig, Gina

Kennedy, Brian

Kennedy, Darla

Kosman, Thomas $\quad 91,132$

Koziol, Kimberly ..................... 82
Kreider, Christen .............45, 82 
Lunn, Rebecca …...................91

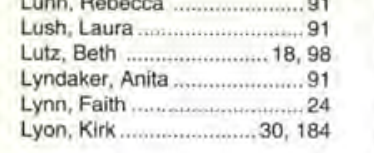

Messer, Jason

Meyer, Jennette.

Michael, Scott

Minalko, David _...209

Milentis, Greg ...........32, 91, 206

Miller, Aimee ……..... 32, 82, 138

Miller, Anita

$32,82,138$

M

Ma Gee, Rebecca ... 30, 91, 210 Mac Farquhar, Jennifer 82, 210 Mac Leod, Kenneth ......120, 184 Mach, Julie

Madding, Danielle .................. 32, 82 Magallon, Victor III .................. 82 Magnuson, Heather …....... 82 Majeski, David

Mallison, Shawn74, 75, 184, 201 Malone, David ....................... 184 Malone, David .......................... 184
Mann, Carrie
Mann, Chandra ..................... 184, 215 Mann, Chandra ......37, 184, 215
Manning, Patricia ...91, 148, 149 Manning, Patricia ,..91, 148, 149
Marihugh, John .... 184 Marland, Christopher ..............82 82 Marner, Dorothy $\ldots . . . . . . . . . . . . . . . .82$
Maronn, Denise $. . . . \ldots . . .49,195$ Marsdale, Marc …....................... 82 Marshall, Laura ..................... 98 Marshall, Robert .....................98
Martens, Matthew ..................98 Martin, Lee
Martin, Ruth Martin, Ruth
Martinez, Melanie …........ 30,184 Marzano, Dennis ................. 132 Mascari, Jason …................... 91
Mascari, Tonya ................... 184 Mathews, Mark …..... 24 Mathisen, Thomas .... 46, 76, 98 ,
226

Mathwin, Steven .....5 53, 98, 209
Matson, David .. 21, 60, 114, 168 Matson, David ..21, 60, 114, 168
Matson, Sandra

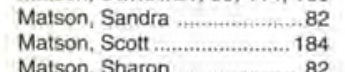
Matson, Sharon ........................82 Maust, Audrey
Maxwell. Renee ............. 168,184 Mazelin, Mark …….............82 82 Mc Chesney, David ....................98 Mc Chesney, David ...............998 98 Mc Colm, Rosanne .................. 82
Mc Comb, Beverly …............98

Mc Conkey, Tracy
Mc Coy, Kimberly ., 98, 131, 145 Mc Coy. Molly ……….............98 Mc Cullough, Shelly Mc Cutcheon, John 98, 184, 215 Mc Donald, Amy ................. 184 Mc Donald, Amy ................. 184
Mc Donald, Jeremy ................ 82 Me Donald, Rachel ............... 98
Mc Elroy, James 7, $55,134,135$ 136, 185

Mc Fadden, Colynn _...53, 91 Mc Fadden, Julie .....52, 91, 210 Mc Fadden, Paul ….............82 Mc Gillivray, John ..21, 132, 148 Mc Gillivray, Scott ............. 185 Mc Gillivray, Scott .................. 185
Mc Gillvary, Suzanne ............91 Mc Ginnis, Stephen ........... 185
Mc Govern, Lara .... 53, 185, 226 Mc Govern, Lara ....53, 185, 226
Mc Grady. Paul ............. 98, 205 Mc Graw, Angela ................. 82 Mc Graw, Angie ...........

Mc Guire, Christina

Mc Guire, Larry

Mc Intosh, Paul ........................ 98

Mc Kanna, Bruce ........10, 46, 98 Mc Kinley, Dominic ....... 129, 185 Mc Laughlin, Amy …...... 98, 148
Mc Mahon. Amy ......31, 82, 210 Mc Mahon. Amy .......31, 82, 210
Mc Millen, Mark ........... 98
Mc Millen, Matthew 98 Mc Millen, Matthew ….............. 98
Mc Nabney, Melia Mc Namee, Jennifer 44, 82, 210 Mc Neal, Kezia . 7, 76, 160, 161. 169, 171, 185

\section{Mc Neil, Kezia}

Mc Pherson, Melinda $\ldots . . .82,113$ Mc Pherson, Sherilyn ...... 53, 98
Mc Oueen, Todd ............ 31, 98 Mc Queen, Todd …........... 31, 98
Mc Vey, Diana $\ldots . . \ldots \ldots \ldots \ldots . . . . .82$ Measley. Michael .....52, 53, 185 Meeder, Jon ...

Megilligan, Brian

Meigs, Stephen

Menendez, Anthony ................. 185

234 Index Munk, James ……....... 98, 212
Miller, Brian .....91, 134, 146, 147 Miller, Charlene _.................. 185 Miller, Cheryl $24 . . .24$ Miller, Elizabeth ﹎........82, 138 Miller, Eric ................... 91, 146 Miller, Eugene ......................... 15 Miller, Jeff _......53, 91, 123, 146

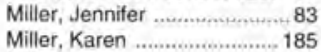
Miller, Karen ….......................... 185 Miller, Mark 6, 83, 144, 145, 185 , 223

Miller, Michelle..

Miller, Regina .

Miller, Rhonda

Miller, Shawn

Miller, Victoria

Miller, Wendy .

Milligan. Johnny

Milligan, William

Mills, David ........

Mills, Debra.......

Mills, Scott 46, 64, 76, 101, 186

226

Mills, Scotty

Milner, Kristin

Miner, Kelly .

Minor, Terrance

Misere, Jonathon

Misirian, Jonathan

Misirian, Jonath

Misirian, Nathan

Misian, Nathan ................

Mitchell, Amy
Mitchell, David ..............52, 186, 91

Mitchell, Matthew .....53, 98, 146

Mitchell, Micah .......98, 134, 146

Moffett, Susan …….......... 43, 83

Mohr, Holly

Moles, Dennis .................t.t.t..... 83

Monroe, Allen ….................... 154

Montgomery, Bill _.... 76, 98, 167 . 226

Montgomery, Jody ...13, 53, 186 Montgomery, Jonathan 53,186 Moodie, Cynthia

Mooney, Mark _......... 186

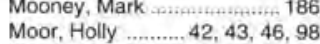
Moore, Bruce ....................98, 15

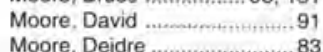

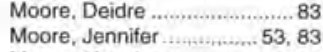
Moore, MaryAnn ……..... 28, 98 Moore, Matt 7, 10, 60, 122, 123 $124,125,160,161,163,169$, $171,186,207$

Moraes, Simone ................... 186 Morales, Jennifer ....................98 98 More, Thomas $\ldots . . .138$
Moreland, Kurt …........... 20, 223 Morgan. Brian _.................... 83
Morgan, Jeff _............. 98 Morgan, Jeff _............... 53, 98
Morgan, Kristine ......... 92,210 Morgan, Tera

Morris, Dee .

Morse, Hope ......

Moseley,

Moser, Kimberly .................... 186

Moser, Matthew ......tent, 186

Mosley. Raul ...7, 124, 125, 170 186

Most, Aaron ....................... 83
Mott, Cynthia Mouser, Angela ... 7, 11, 60, 186 Mouser, Julie ….....................99

Mulder, Julie .28, 34, 35, 36, 98 , $121,185,201,209,212$

Pagnard, Charles ....11, 21, 110 , Mullins, Ondrea …................... 83

Mummey, Julie …......................98 Murdoch, Murray $=10,22,150$. 151

Murphy, Dale .

Murphy. James

Murphy, Kara

Murphy, Kelly

Murray, Holly …….............41, 92

Nast, Kristen …..............39, 186

Nearmyer, Lisa $\ldots 186$
Neil, Daniel
N.

Neill, John $6,32,132,186,212$.

Nelson, Benita
…….......... 186

Nelson, Jeff ..._._.......83, 151
Nelson, Karen _..............83

Nelson, Michelle .40, 42, 43, 98 ,

225

Nettleingham, Brian .53, 98, 204

Neubert, Tanya _............92, 131

Neubert, Tim …_.........187, 220

Neudeck, Jeffrey ..................83
Neudeck, Jennifer
46, 92

Neudeck, Jennifer .......... 46, 92
Neumann, Celeste .........53, 187

New, Brent ............... 83

Newcomb, Aar
122, 124, 125

Newell, Kimberly _..................92
Newell, Lori ................ 187, 226

Newton, Lorraine …...............92

Nicholas, Luann
Nichols, Kenneth ..................... 52,83

Nichols, Kenneth ............52, 83

Nickel, Chris .... 52, 83, 134, 146

Nickelson, Dawn …......... 38, 92

Nordaas, Kristi _.......... 187, 215

Norder, Sara 144, 145, 187, 220 ,

225

220, 225

Norman, Christopher ............. 92
Noss, David ........................ 92

O'Bryon, George

O'Keete, Kayley …................... 98

O'Leary, Susan 53, 92, 198, 200

Neal, Christine

Oberholtzer, Jody

Ohnmeiss, Jonathan

Olachea, Devin

Olah, Heidi .........

Olsen, Marsha $3,10,11,17.98$

$19,56,57,64,66,69,71,74$.
.

$75,98,109,115,116,117,118$

$119,128,130,131,133,134$

$135,136,138,139,140,141$
$142,143,153,158,159,161$

$168,170,171,198,201,223$

Olson, Christina

Olson, Irwin

Olson. Lisa .

Orms, Bradley

Ormsbee, David

Orser. William

Ortlieb, Michael

Ortiof, Wayner, Dean

Dean .............................5 57

Osbom, Deanna …......... 53, 92

Overcash, Rebekah ..................83 83

Overmoyer, Julie .......... 99, 123
Oxford, Heather .............. 38, 99

Pakson, Gary

Myers, Buffie

Myers, David.

Parsell, Ali. .

Pasquale, Michael $52,83,210$

Passineau, Michael …............ 92

Patterson, Rory .............. 83, 120

Paul, Angela Paulhamus, Brenda .... 135, 136

Paulhamus, Brenda ....

Pawluk, Laurie

Paxson, Gary ......... _ 53

Payne, Janet ..... 53, 78, 99, 188

Payne, Rose Marie …..................99

Pearson, Kelvin ….......................... 89

Peary. Darryl ......

Peary, Jt., Darryl _............ 187
Peet, Terri ........................... 99

Pence, Jeff .................... 49, 187

Perkey, Amy .................. 99

Perkins, Deborah .......33, 35, 92

Perler, Stacey .......................... 92

Perry, Heather …................ 187,152

Persons, Chad .................... 134

Pelek, Gregory …............... 99
Petek, Thomas 99

Peteres, Heather

Peters, Heather

Pfahler. Puth $17,53,99.187$

Phillips, Cheryl ............. 92, 206

Phillips, Edmond .......................24

Phillips, Eric …....... 41, 94, 99

Phillips, Michael .7 7, 52, 53, 187

205

Phipps, Brian ……....6, 6, 11, 187

Phipps, James …_......... 10, 20

Pierce, Alex

, 92

Pierce, Chanda ..................... 84

Pierce, Douglas …….......32, 92

Pike, Gretchen ................99, 113

Pincket, Chris ..............94, 226
Pinkerton. Cheryl ............37, 99

Piper. Sharon ........................84

Piscopo, Joe ......

Petcher, Rosemary

Plough, Barbar

Plough. Heidi

Plunkitt, Michelle

Plush, Jonathon .....92, 146, 147

Poiesz, Mildred _.................. 182

Polish, Monica …………..... 32

Pool, Charlene ................84

Pope, Melissa ........................... 84

Pope, Michelle …………...... 188

Popp, Pamela

Porter, John _................ 134
Post, Kristine …........ 42, 43, 92

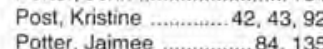

Potter, Jaimee ................84, 135
Potts, Brannon ......92, 150, 151

Potts, Matthew

Powell, Kirk.....

Powers, Laura

Prall, Michael.

Pratt, Sandra

Prentis, Tara

Price,

Prichard, Jill ......... 7, 42, 43, 188

Priddy, Deanna ...................... 99

Priddy. Kathryn ................... 188 148, 149

Profant, Michelle .............44, 84

Prusinowski, Maureen ......52, 92
Purple, Jon ...............20,94 
Siert, Melinda ........... 85, 210 Silber, Shelley .......................... 190
Silvera, Nicole ............... 52,93 Silvera, Nicole ................ 52, 93
Silvius, Bradley ..................... 190 Silvius, Bradley ….................. 190
Silvius, John ................22, 215 Silvius, John ................22, 215
Simmons, Jennifer ...53, 85, 210 Simons, Jack ………............. 21 Simons, Kathryn ........ 49, 85
Simons, Peter $85,134,136,137$ 146

Sims, Kevin ...................22, 209 Singer, Penny ……............. 100 Sinnamon, Brenda .......... 85, 209
Sipes, Aichard .............85, 146 Sipes, Richard ............... 85, 146
Sissom, Jolie ...................... 100 Sissom, Jolie ...................... 100
Sissom, Joy _........ 170, 190 Sizemore, Amanda ….............. 85 Skaggs, Shea ……r... 93 Skiles, Jenifer .....................31, 93
Skillman, Jon ......................... 24 Skillman, Katy …................23, 24 Skinner, Lynn ................48, 93 Slav

207
Sloan, John IV _................... 100 Sloan, John IV ................... 100
Sloan, Kathlene ...........29, 191 Smart, Kathy ............... 85

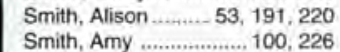
Smith, Amy ................... 100, 226
Smith, Angela ..................191 Smith, Benjamin ……........... 24 Smith, Bill ...........................15 Smith, Brady _................... 85 Smith, Brock ............................ 93 Smith, Bryan ............................ 93 Smith, Bryan ........................ 93 Smith, Douglas ...................... 100 Smith. Galen _.............20, 212 Smith, Jane ............25, 215, 226 Smith, Jeff .................53, 85, 123 Smith, Jennifer ......152, 153, 191 Smith, Laura ........................ 100 Smith, Loretta …..................... 100 Smith, Loretta …t.1, Smith, Lynne ........................... 85 Smith, Maria ............ntintitn, 100 Smith, Martin ….................. 100 Smith, Michael ……_... 93 Smith, Michelle ..................... 191 Smith, Sara Smith, Shawna ….................. 191 Smith, Stacy ……................ 93

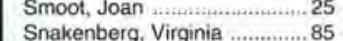
Snakenberg, Virginia ...............8 85
Snell, Randal Snodgrass, Amber …....... 44, 93 Snodgrass, Scott $64,65,66,67$. 100, 109, 114, 116, 119, 143

Snow, Kevin ........................10 Snowden, James ..................21 Snyder, Phillip .............................. 85 Solomon, Mark _...............52, 53 Solomon, Mark $\ldots+\ldots+. .52,53$
Solum, Lisa ........................ 191 Somerville, Cherith .................... 85 Sommerfeld, Cynthia ............. 191 Sommerfeld, Cynthia …..... 191 Sommerfeld, Scott .................
Sorensen. Eric ..................... 32 Sorg, Pamela ,...................44, 93 Souder, Donette …............... 100 Southwell, Christina ... 132, 209 Southwell, Randy. 100, 132, 209 Souza, Shelly ..........................93 Sowards, Jennifer ............ 191
Spaulding, James IV .............. 85 Spaulding, James IV ................ 85 Spencer, Dorthy ................25 219 Spieth, Jeremy .......................85 Spurr, Jonathan .................... 191 Stach, Todd .................93, 226 Stamm, Sally ............................85 Stamper, Cynthia .............. 100 Stanley, Leah ..........85, 124, 125 Stanley, Leah ..........85, 124, 93 Stanton, Kendra Stanton, Mark ................... 191
Staples, Jennifer ........ 43, 52, 85

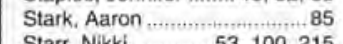
Starr, Nikki .............53, 100, 215 \begin{tabular}{lr} 
Starr. Traci _.. 162, 191 \\
\hline
\end{tabular} Steenwyk, Michelle ........ 85, 140

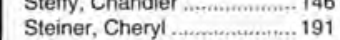
Steininger, Gretchen ................93 93 Stephen, Deana $\ldots$ Stephen, Loretta .....................85 85 Stephen, Loretta ..................85 Stephenson, Martin .......30, 100 Stevens, Albert .............. 15 Stevens, Becky ... 42, 43, 52, 53, 93

Stevenson, Virginia ............... 100 Stewart, Andrew ......... 85, 132 Stewart. John ….................. 191 Stickley, Gary ..........................93 Stiles, Sarah Stitchman, Michele n.............. 191
Stitzel, Kimberly

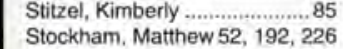
Stockham. Matthew 52, 192, 226
Stolar, Allison .................. 52, 93

Synnette ……….............85 William III …………........93 Stoltzfus, Lisa ..........192, 212 Stone, Stephen ...........................93 Stonehouse, Hans ................... 12 Stoppel, Patricia ……........ 32, 85 Stove, Byan …………..... 132
Stover, Byron Stover, Hollee ...... 192, 205, 223 Strayer, Shanda .....37, 100, 210 Street, Joan _..................... 25 Stringer, Tracy ............129, 192 Strong, Luman 31, 100, 146, 147 Stroop, David ............................8 85 Stroop, David ….......................85 Stull, Katherine ….....40, 93, 220 Stumbo, Gary …................... 100 Sturgis, Michael $\ldots \ldots . . .192$
Sturgis, Tim ……...8 120,122 Sturrock, Rebecca 40, 42, 43, 93 Stutes, Chris ….................30, 85 Stutes, Patty .............................25 Sutter, Cindy ............................. 19 Sutter, Cynthia ......................... 22 Sutton, Shelly . $35,60,100,120$ Sutton,

Swackhamer, Teresa ............ 100 Swackhamer, Tonya ............. 192 Swackhamer, Tracy ............ 215 Swackhammer, Tracy ............53 Swartzentruber, Rita .........32, 93 Sweetland, Mary ............85, 226 Sweetland, Mary ............85, 226 Swensen, Susan _.................... 192
Swigart, James .................... 85 Swigart, Lora $\ldots . . . . . . . . . . . . . . . . .192$
Swinehart, Kristal Swinerton, Rebecca .... 100, 192

Tackett, Laura .93
.100 Tague, Arian

Tait, Elizabeth

Tapp, Amy Tarapchak, Stefan $\ldots$ 6, 192, 204 Tassell, Paul _......................15 Tassell, Paul ........................... 15 Tate, Cynthia ...................... 85 Taylor, Eleanor .....................152 Taylor, Janna Taylor, Tania 12, 62, 63, 77, 100 $129,132,133,144,145,158$,

201

Taylor, Virginia ....................... 25 Templeman, Tonya ….....31, 100 Tennant, Cindy …................. 100 Terkelsen, Susan .................... 25 Terpstra, John ….................93 Terry, Chris ..................... 40, 8 Thacker, Steven …...............25 Tharp, Catherine ............85, 148 Thigpen, David ……………....... 85 Thomas, Christy …............... 93 Thomas, Joel $\quad 100$ Thompson, Dana ................... 100 Thompson, Dana …….......... 93 Thompson, Jill ....................... 93 Thompson, Philip ................... 192 Thompson, Tyler .................... 100 Thomson, Jacqueline .............85 Thorsen, Charles .................. 100 Thorsen, Kristine ...................85 Threlfall, Christine ....................99 Tipton, Brett .................28, 192 Titus, Sheryn ........................ 100 Tocknell, John ...................25
Todd, Alex _......... 13, 192, 226 Todd, Faith ........37, 42, 43, 192 olsma, Erin ........ 85 Tomlinson, Tonya .................. 100 Tonelli, Robert ……...............93 Tourinsky, Laura ................5 53 Tramel, Maribeth ...60, 100,210 Traucht, Andra ............... 93, 131 Traucht, Andra .......................100 Treier, Daniel ....................... 100 Trimble, Tiffany ..................40,85 Triplett, Paula .........85, 152, 153 Trow, Tim _........... 53, 93, 129 Trowsdale, Joshua ..........41, 93 Troyer, Les …........................25 schanz, Gina .................... Tuorinsky, Laura .................... 100 Turner, Cooley …......................25

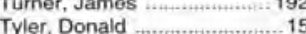
Tyler, Donald ....................... 85

Uhl, Denise …..........52, 53, 100 Ulery, Adam ………............. 100 Umbaugh, Earl ............................. 15 Underwood, Brent ,..................41 41 Underwood, Kara ... 41, 192, 209

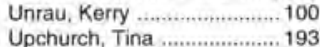
$\begin{array}{lr}\text { Usita, Lemuel } & 49,74,85 \\ \text { Utz, Mark } & 49 .\end{array}$

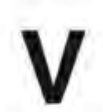

Van Dyke, Kristi ....... 53, 93, 217 Van Eaton, Justin .................226 Van Gorp, Traci ...................... Van Matre, Edina ........... 46, 193 Van Wert, Sonja ............ 93, 120 Vancise, Sallianne ...................85 Vande Guchte, Timothy ........100 Vande Gutche, Todd .............. 93 Vandenberg, Timothy ....41, 100 Vanderbilt, Jennifer ..............85 Vanderwest, Ken - 100, 124, 125 Vannest, Stephen …..............101 Varner, Jonathan ........31, 209 Veelman, John ........................75 Veelman, William ....................101 Velazco, Ivo …….............. 1901 Velazco, Karyn ......................193 193 Veneberg. Kimberlee ................85 Vernier, Paul ........................ 15 Vickman, Bonnie .....................2.25 Viera, Pablo Viera, Poblo ...................... 165 Vine, Allan ..............................25 Vine, Kitty Sue .........................25 Virgilio, Annette ….................. 93 Vitarelli, Chad

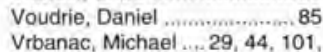
140

Vroegop, Mark _....46, 101, 166

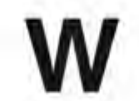

Waddell, Sandra _. 101, 123, 220 Wagenaar, Tara _.. 85 Wagner, Trudee .......................25 Wakefield, Michael …........... 193 Walborn, Josette ............93, 158 Walborn, Kristy .................161 161 Walborn. Timothy 161,193
Walker, Julie ................... 32,93

Walker, Kristi

Walker, Ronald 20

Wall, Melissa ….............29, 101

Wallace, Debra

Wallace, Heather

Wallace, Melinda

Wallenbeck, Kevin …......... 85

Wallis, Joe

Walls, Jeffrey .............................. 101

Walter, Lynn …............40, 45, 94

Walter, Melan

Walter, Rebecca .................85

Walters, Tim 146, 147, 148, 149 Waltz, Brandon …....................... 40 Wambold, John ……..... 85, 209 Wandell, Brenda .................. 94 Wandell, Brenda …................ 94
Ward, Erin Ward, Erin

Ward, Molly

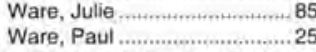

Warnken, Karla ... 13, 18, 33, 35.

$101,193,201,215,217$

Warnshuis, James .................86

Warnshuis, John ...........52, 101

Warren, David _............20, 101

Warren, Pat ..................... 135

Warren Sr., David .................... 135

Warren Sr. , David ................. 134

Waters, Cassandra , 42, 43, 101

Watson, Keith ......101, 163, 219

Wawro, Erin .

Weaver, Doris

Weaver, Erin $\quad 46,86$

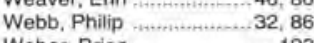
Weber, Brian ................ 193 Weber, David .......146, 147, 193 Weber, Paula ....................... 194

Webster, James _._..........94

Webster, Theresa …............. 194

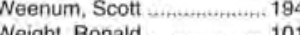
Weise, Ann …….....86, 210, 223 Weise, Ann ........... 86, 210, 223 Wenger, Ruth ..................86, 152 Wenger, Shannon . 94, 131, 14 Wesselink, Jesse . 4, 5, 8, 9, 10 $11,12,54,55,56,111,114$. $115,116,117,119,141,142$, $144,145,155,164,165,194$ 199,200

West, Troy …..................28, 28, 101 Westbeld, Heidi .................48, 94 Westlake, Leanne $\ldots . . . . .48,94$ Westlake, Leanne ...............94 Wetzel, Daniel .................19, 22 Wetzel, Jacqueline ……........ 194
Wetzel, Phyllis 

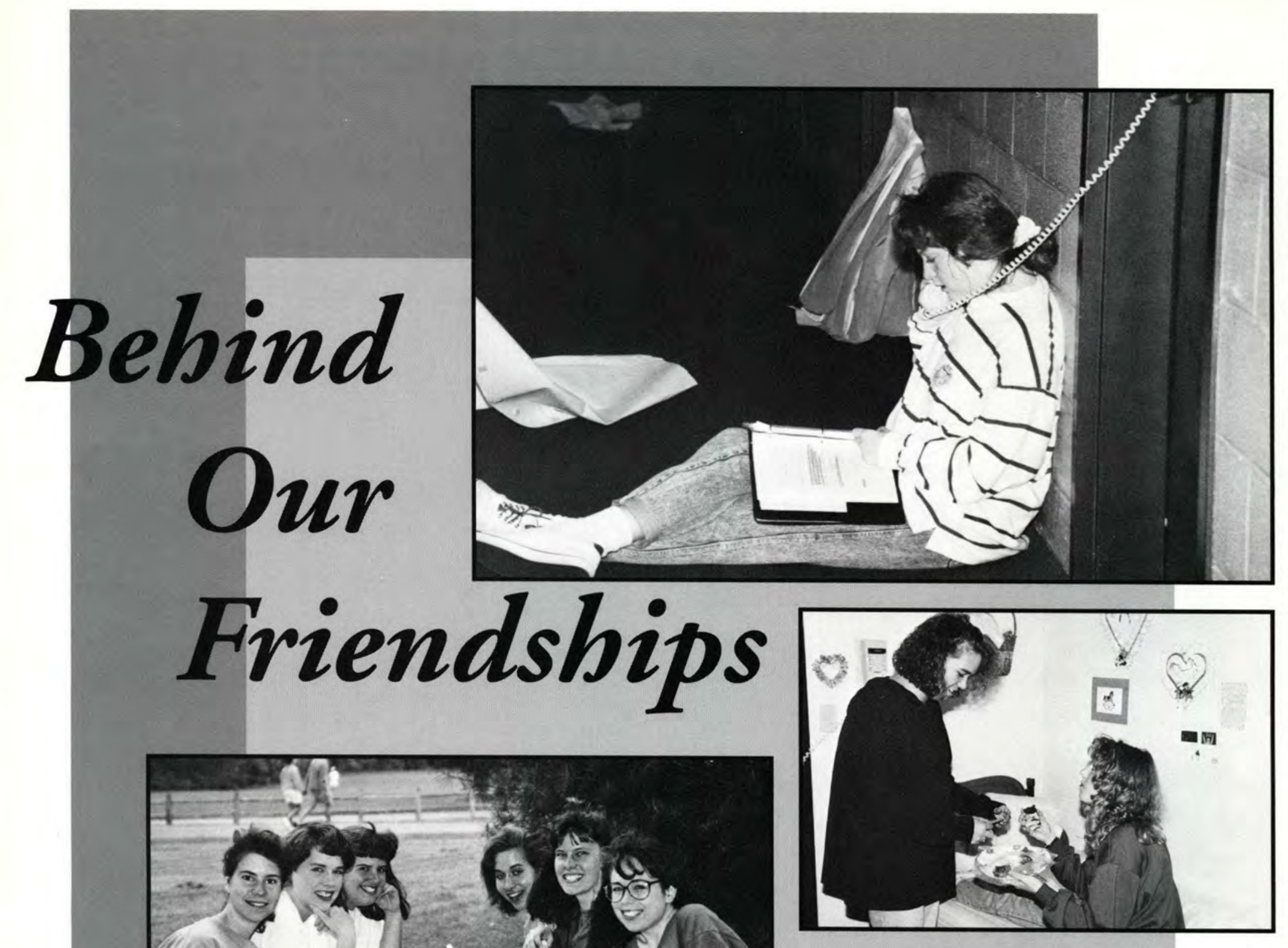

速 $3 6 \longdiv { \text { Closing } }$
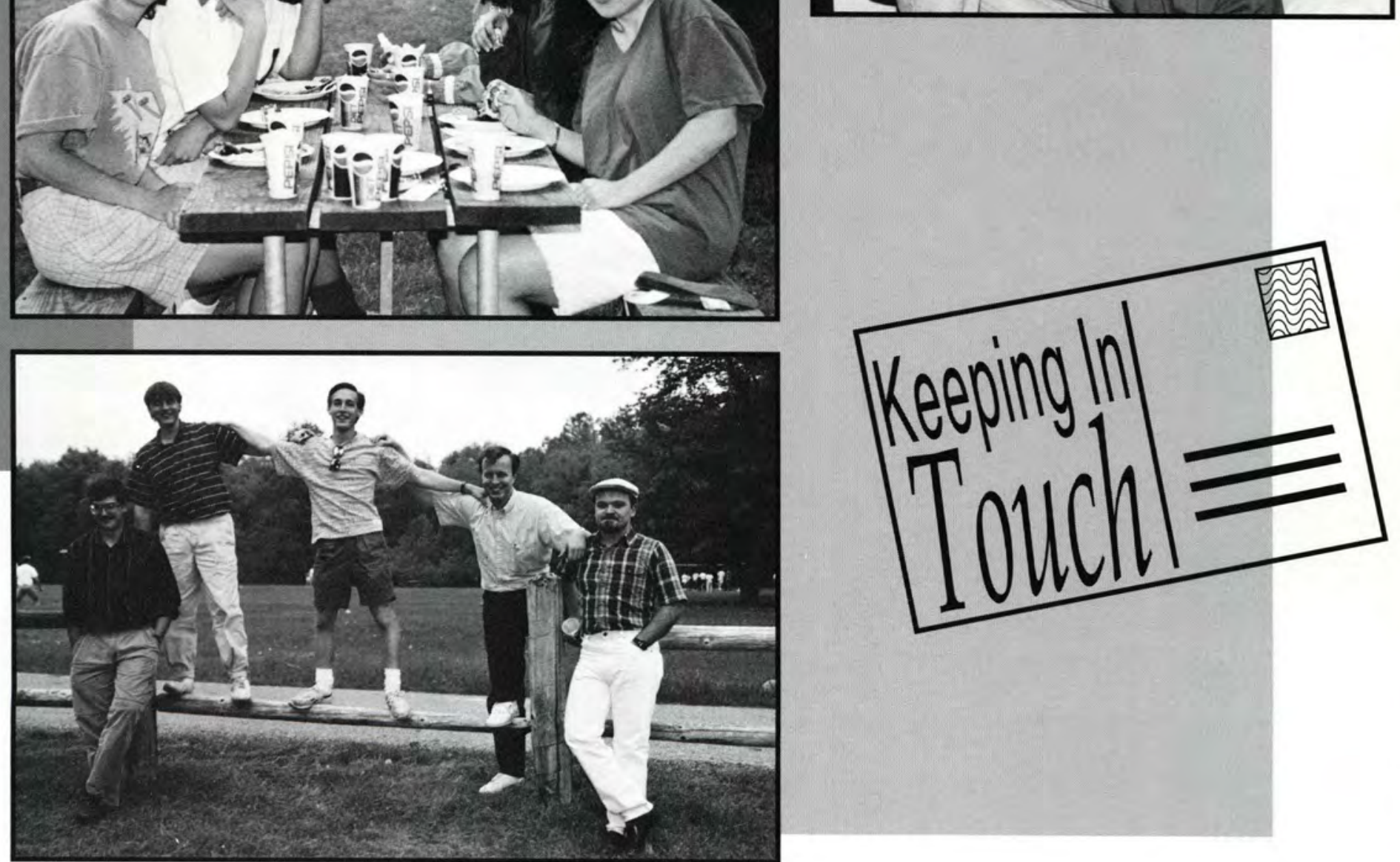

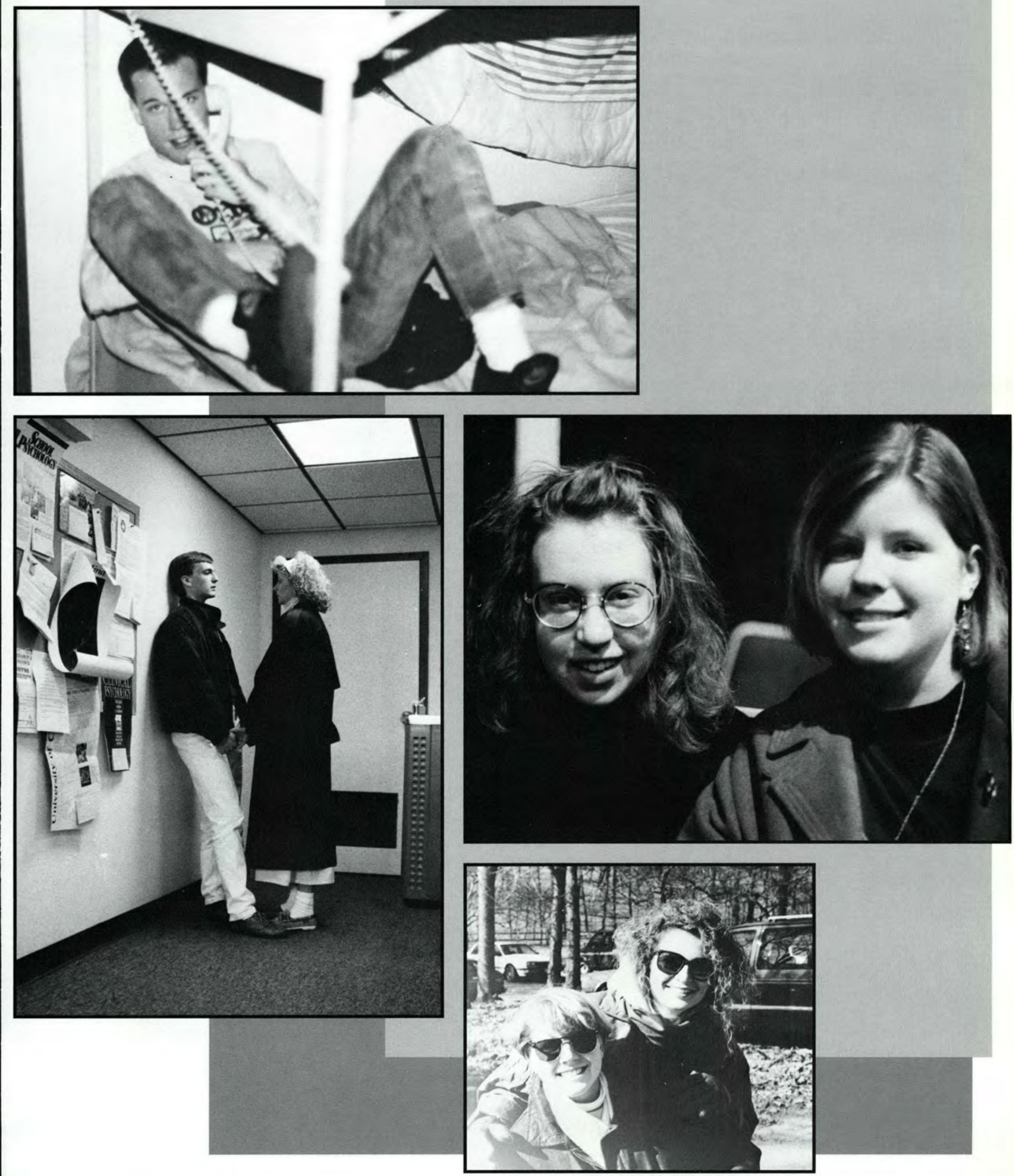


\section{Bebind}

\section{Our}

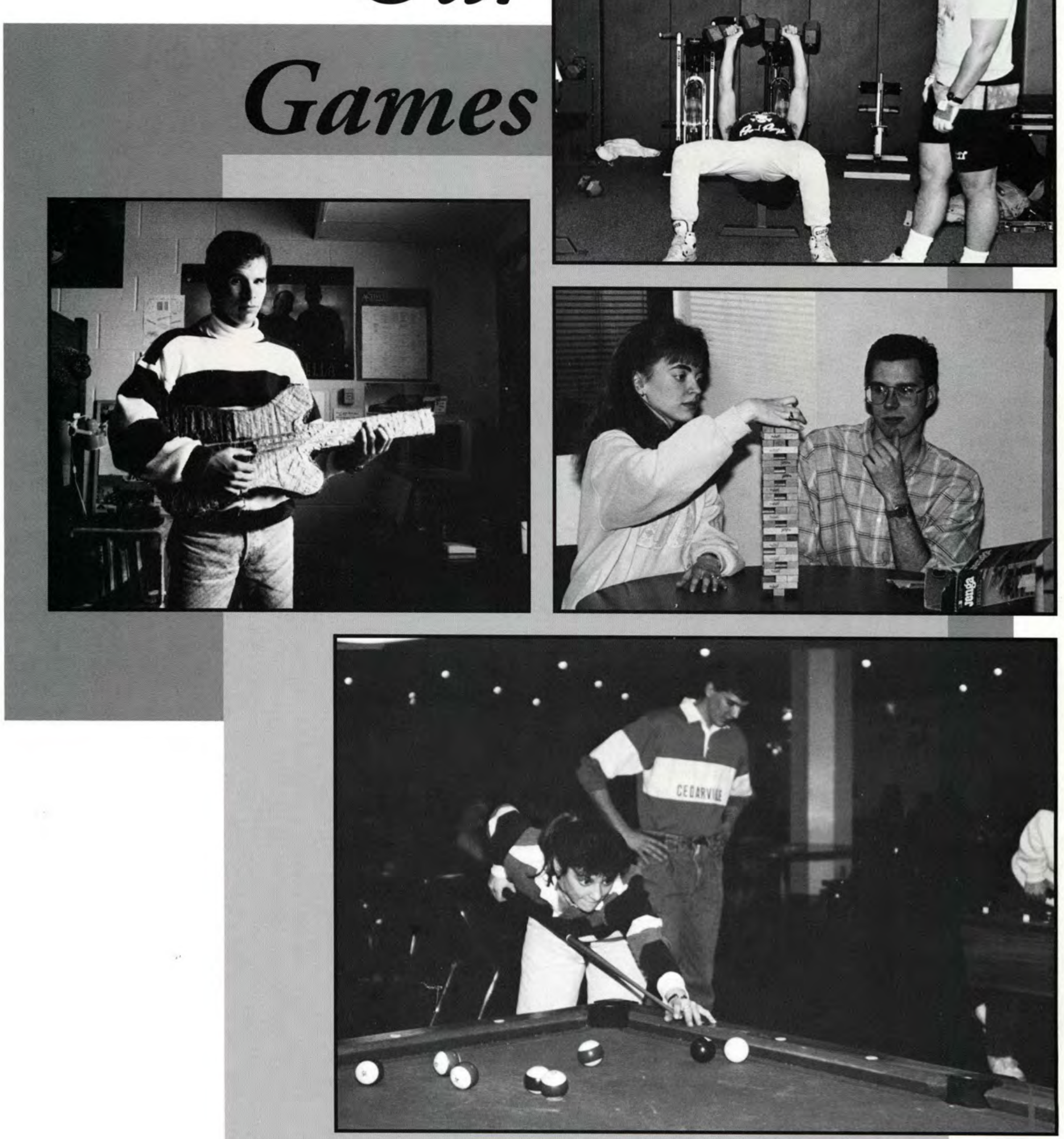

1038 Closing 

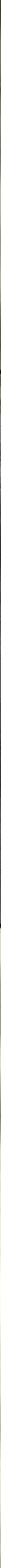
Bebind Our Labors...
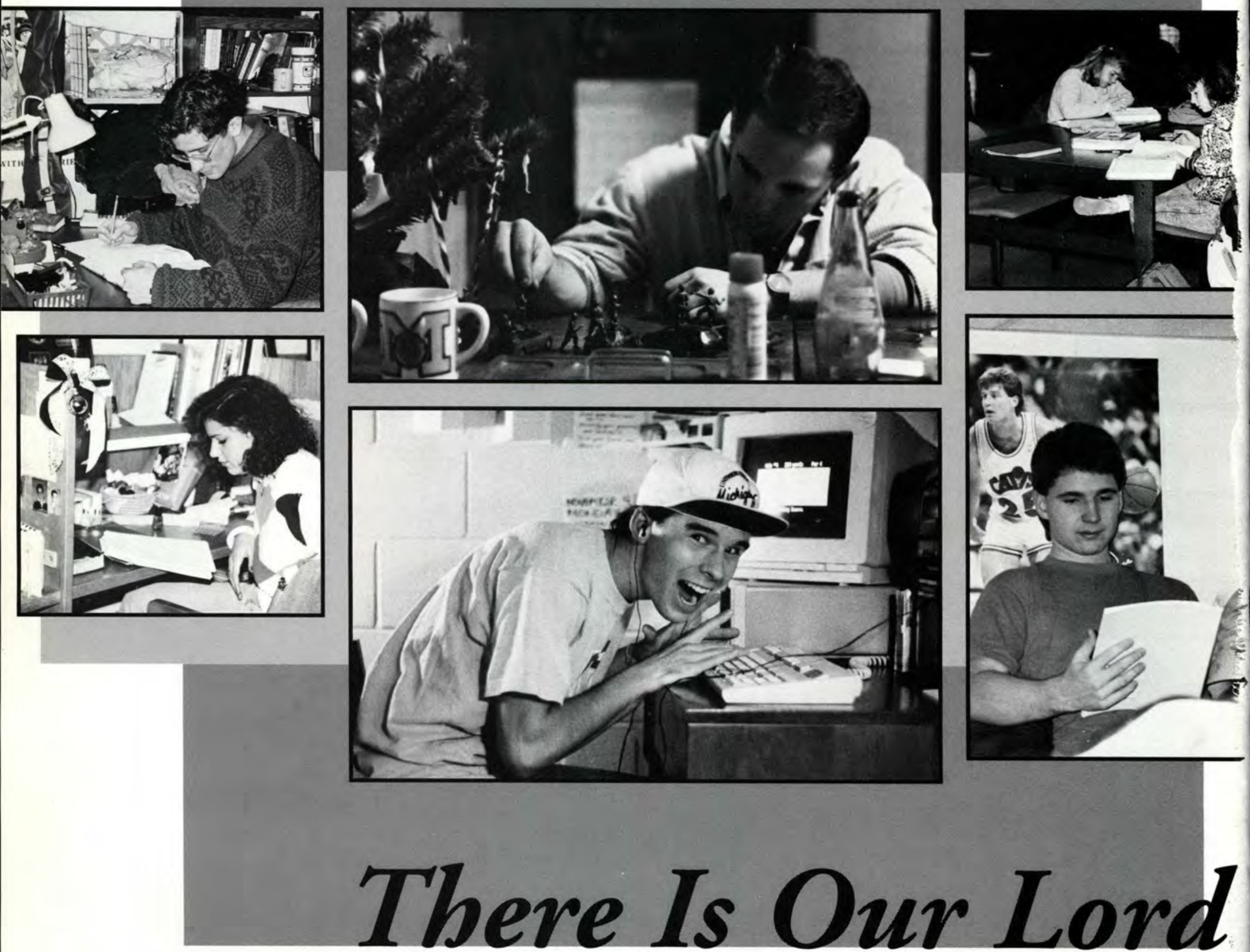

"For I know the plans I have for you," declares the LORD,

"plans to prosper you and not to harm you, plans to give you bope and a future." 




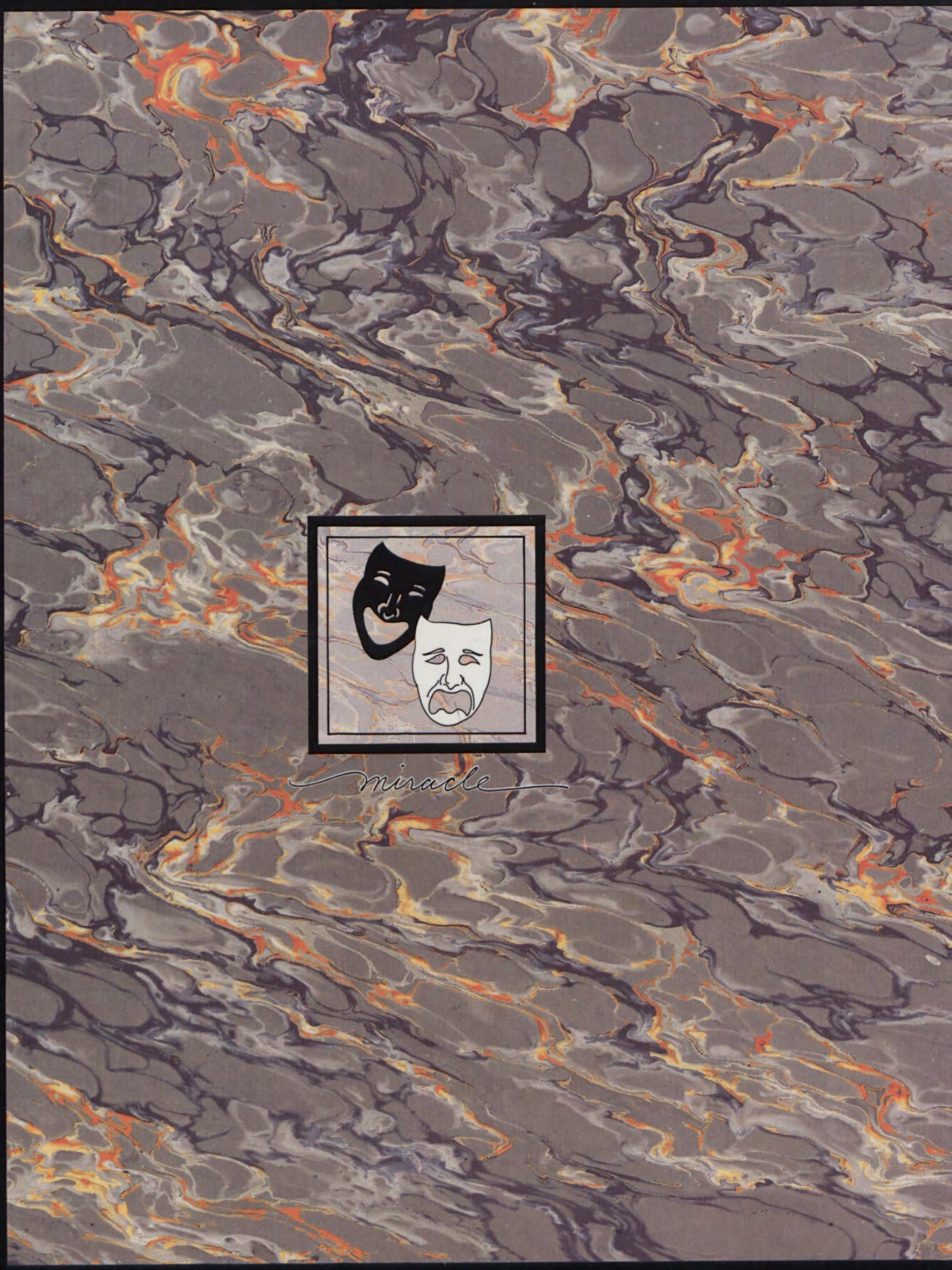

